Guilherme Setoguti Julio Pereira

\title{
CONTEÚDO DO PROVIMENTO E LIMITES OBJETIVOS E SUBJETIVOS DO PROVIMENTO E DA COISA JULGADA NA IMPUGNAÇÃO DE DELIBERAÇÕES DE ASSEMBLEIAS DE SOCIEDADES POR AÇÕES
}

\author{
DisSERTAÇÃo DE MESTRADO \\ Orientador: Prof. Titular Flávio Luiz YARShell
}

FACUldade de Direito da Universidade de SÃo PaUlo

São Paulo

2013 
Guilherme Setoguti Julio Pereira

\title{
CONTEÚDO DO PROVIMENTO E LIMITES OBJETIVOS E SUBJETIVOS DO PROVIMENTO E DA COISA JULGADA NA IMPUGNAÇÃO DE DELIBERAÇÕES DE ASSEMBLEIAS DE SOCIEDADES POR AÇÕES
}

\begin{abstract}
Dissertação apresentada como exigência parcial à obtenção do título de Mestre em Direito, no âmbito do Programa de Pós-Graduação da Faculdade de Direito da Universidade de São Paulo, sob orientação do Professor Titular Dr. Flávio Luiz Yarshell.
\end{abstract}

Faculdade de Direito da Universidade de São Paulo

São PaUlo 
BANCA EXAMINADORA:

Orientador:

Professor Titular Dr. Flávio Luiz Yarshell

Professor Arguidor:

Professor Arguidor: 
Aos meus queridos pais, José Flávio e Ruth, com meu amor incondicional e eterna gratidão por terem me ensinado o valor do estudo e por tudo o que representam para mim.

Ao Professor Flávio Luiz Yarshell, por todas as oportunidades e portas que me abriu e por ser um exemplo de acadêmico, advogado e, sobretudo, pessoa.

"I was getting ready to consider my next plan of attack

I think I'm gonna sack the whole board of trustees All those Don Quixote's on their B-17s

And I swear this time, yeah this time They'll blow us back to the 70's"

(Andrew Bird - Sovay)

"So drunk in the August sun

And you're the kind of girl I like

Because you're empty and I'm empty

And you can never quarantine the past"

(Pavement - Gold soundz) 


\section{AgradeCimentos}

Não são poucas as pessoas a quem devo agradecer após o término deste trabalho. Registro, antes de tudo, sincera gratidão ao meu orientador, Professor Flávio Luiz Yarshell, que desde os bancos do primeiro ano da graduação me cooptou para os terrenos do processo civil.

Agradeço aos Professores Erasmo Valladão Azevedo e Novaes França e Paulo Henrique dos Santos Lucon, que integraram a banca de qualificação e cujas observações e abertura para o debate franco foram fundamentais para as conclusões a que aqui cheguei. Devo agradecer também aos Professores Kazuo Watanabe, Humberto Ávila, Cássio Scarpinella Bueno, Eduardo Talamini e Antonio do Passo Cabral, os quais, muito gentilmente, discutiram comigo alguns dos temas da dissertação. $\mathrm{O}$ mesmo agradecimento vai para os Professores José Rogério Cruz e Tucci, José Alexandre Tavares Guerreiro e Rodrigo Barioni, que, quando eu não encontrava obras nem mesmo em livrarias e sebos do exterior, me abriram as portas de suas bibliotecas. Sou grato, ainda, aos amigos e igualmente Professores Heitor Sica, Walfrido Warde Jr., Marcelo von Adamek, Marcelo Guedes Nunes e Helena Najjar Abdo, que, cada qual ao seu modo, seja lendo o trabalho, discutindo-o comigo, emprestando livros ou apenas dando conselhos sobre como conciliar a atividade acadêmica com a advocacia, contribuíram decisivamente para que este trabalho nascesse.

Meu carinho e gratidão a Thaís Ricci Conesa, Rafael Setoguti, Gabriel Vituri, Luis Gustavo Meneguetti e Pedro Vituri, ex-moradores, moradores ou frequentadores do apartamento da Alameda Ribeirão Preto, que testemunharam a ranzinzice, a falta de tempo para os compromissos sociais e a necessidade de silêncio que vieram juntos com esta dissertação. Agradeço, também, aos amigos de Graduação e Pós-Graduação da São Francisco Gustavo Vasen, João Eduardo Gomide de Paula, Marcelo Golfetti Pacheco, João Nassif, Bruno Salles Ribeiro, Guilherme Suguimori Santos, Gabriel Nascimento Pinto, Adriano Scalzaretto, Bruno Rizzi, Ayrton Freire Jr., Celso Araújo Santos, Ataide Rodrigues Neto, Benito Pereira da Silva Filho, Daniel Menezes, Danilo Cymrot, Igor Bimkowski Rossoni, Newton Marzagão, Guilherme Cardoso Sanchez e Sérgio Seleme pela amizade, companheirismo e momentos de farra. 
Não poderia deixar de agradecer, também, a todos os colegas de escritório, em especial Gustavo Pacífico, grande advogado, chefe e amigo. Agradeço, ainda, a Felipe Nassar Cury, pelo auxílio com a pesquisa de jurisprudência, aos amigos do Comitê Societário do CESA - Centro de Estudos das Sociedades de Advogados e aos amigos do IDSA - Instituto de Direito Societário Aplicado, estes últimos por terem me convidado para inúmeras das suas reuniões de 2012.

Meus inaudíveis mas verdadeiros agradecimentos a Velvet Underground, Rolling Stones, Belle and Sebastian, Cat Power, Caetano Veloso, Strokes, Roberto Carlos, Silver Jews, Black Keys, Air, Erasmo Carlos e Miles Davis, que, nos intervalos entre um estudo e outro, mantiveram minha sanidade mental e constantemente lembraram que a vida, felizmente, é muito mais do que o Direito.

Por fim, meu muito obrigado a meus pais, por todo seu amor, carinho e dedicação. 


\section{RESUMO}

Este trabalho propôs-se a estudar, mediante abordagem crítica e mutidisciplinar, questões processuais que surgem na impugnação de deliberações de assembleias de sociedades por ações, procurando não só comprovar a ideia de que o direito processual civil deve responder a especificidades vindas do direito material, mas tecer conclusões a respeito de qual maneira o processo civil, neste âmbito específico do direito material, atende a essas peculiaridades. Por entendermos que existe um fio condutor lógico que une conteúdo do provimento, objeto do provimento e limites objetivos e subjetivos da coisa julgada, foram eleitas algumas questões processuais como objeto principal da pesquisa, sintetizadas nas seguintes indagações: (i) qual o conteúdo do provimento jurisdicional que desconstitui deliberações de assembleias gerais de sociedades por ações?; (ii) quais os limites objetivos desse provimento e da coisa julgada que sobre ele incide?; e (iii) quais os limites subjetivos desse mesmo provimento e da coisa julgada que o acoberta? O escopo principal desta dissertação, assim, foi responder a essas perguntas, embora, para que se atingisse esse intuito, outras indagações também tenham sido respondidas.

Palavras-chaves: deliberações assembleares - invalidade - nulidade - anulabilidade ação declaratória de nulidade - ação anulatória - limites objetivos da sentença e da coisa julgada - limites objetivos da sentença e da coisa julgada - atos conexos - modulação de invalidades - ações concorrentes - coisa julgada erga omnes. 


\begin{abstract}
This work aims at studying, through a critical and multidisciplinary approach, procedural matters arising out of claims that request the annulment of shareholder meeting's resolutions, seeking not only to evidence the idea that the civil procedural law should correspond to specific issues of the substantive law, but also draw conclusions on how the civil procedure, within the specific ambit of the substantive law, answers to these peculiarities. Since we understand there is a logical guiding thread that links the judgment, its subject matter and the objective and subjective limits of the judgement and of the res judicata, we have chosen a few procedural issues as main object of our research, summarized in the following questions: (i) what is the content of the judgement that annuls the shareholder meetings' deliberations?; (ii) what are the objective limits of this judgement and of the res judicata, which affect such deliberations?; and (iii) what are the subjective limits of this same judgement and of the res judicata, which restrict their interference in said deliberations? The main scope of this dissertation was, therefore, to answer these questions, although, in doing so, other questions have ended being answered.
\end{abstract}

Key-words: shareholders meeting's resolutions - invalidity - nullity - annulability - suit for declaratory judgment of nullity - suit for annulment - objective limits of the judgement and of the res judicata - objective limits of the judgement and of the res judicata connected acts - modulation of invalidities - concurrent actions - res judicata erga omnes. 


\section{SUMÁRIO}

\section{CONSIDERAÇÕES INTRODUTÓRIAS}

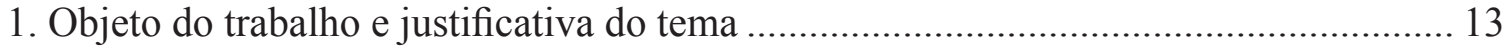

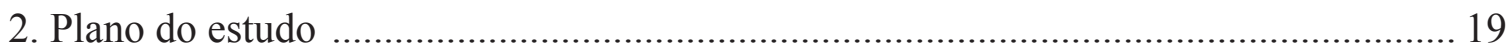

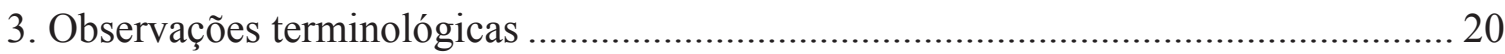

\section{Capítulo I}

\section{Noções Fundamentais Sobre Vícios das Deliberações Assembleares}

4. Deliberação assemblear: conceito e natureza jurídica .................................................. 22

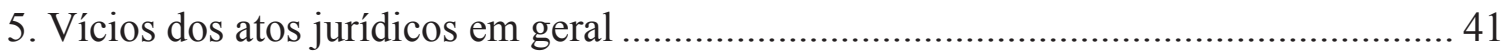

6. Vícios do conclave, do voto e da deliberação .................................................................. 46

7. Invalidades no direito societário brasileiro (LSA, arts. $115, \S 4^{\circ}$ e 286$)$....................... 49

7.1. Existem deliberações nulas no ordenamento brasileiro? ....................................... 55

7.2. Inexistência, nulidade, anulabilidade e ineficácia das deliberações ...................... 63

8. A posição dos administradores perante deliberações inválidas...................................... 71

9. Interesse tutelado nas demandas de impugnação: interesse

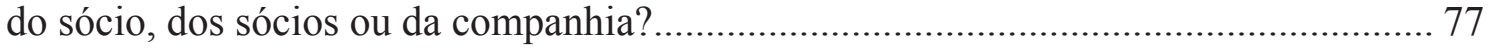

\section{Capítulo II}

\section{Tutela Jurisdicional e Deliberações Assembleares Inválidas}

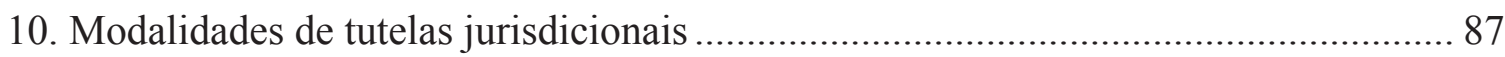

10.1. Critérios classificativos. Considerações críticas sobre

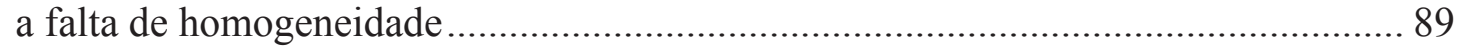

10.1.2. Tutela cognitiva, executiva e cautelar: escopo ou finalidade ........................ 93

10.1.2.1. Tutela cautelar como tertium genus: acerto do critério ........................... 95

10.1.3. Tutela meramente declaratória, tutela constitutiva

e tutela condenatória: estrutura processual........................................................... 100

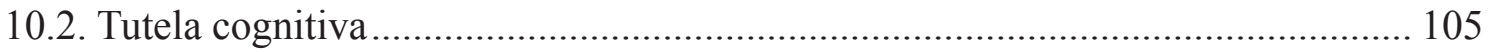

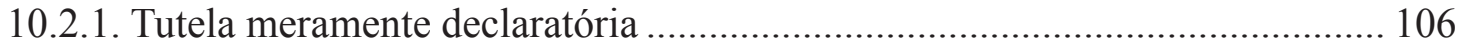

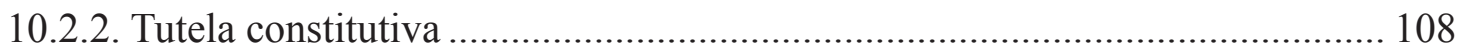


11. Momento de eficácia. Relevância da tutela cautelar nos provimentos constitutivos e declaratórios

11.1. Crítica da distinção entre efeitos principais e efeitos

práticos. Defesa da constituição e declaração provisórias

12. Vícios de deliberações assembleares e conteúdo do provimento

\section{Capítulo III}

\section{Limites Objetivos do Provimento e da Coisa Julgada}

13. O eixo lógico entre objeto litigioso do processo, objeto

do provimento e limites objetivos da coisa julgada 163

14. Objeto litigioso do processo. 164

14.1. Demanda declaratória de nulidade e demanda

anulatória: distinção quanto ao objeto litigioso do processo?..... 171

15. Correlação entre demanda e provimento 173

15. 1. Infidelidades objetivas 176

15.2. Nulidade relativa ou absoluta? 185

16. Alcance temporal do provimento na desconstituição de

deliberações assembleares: ex nunc, ex tunc ou modulação de efeitos?..... 186

16.1. Modulação de efeitos na invalidação: admissibilidade no direito brasileiro 192

16.2. Critérios decisionais

17. Impugnação de deliberações e atos conexos.

17. 1. A sentença pode determinar a desconstituição de ato cuja invalidação não foi pedida?

17. 2. A sentença desconstitui ato cuja invalidação não foi expressamente determinada, mas que guarda relação de dependência com a deliberação anulada (efeito expansivo)?

17.2.1. Título desconstitutivo e decisões implícitas

17.2.2. Efeitos secundários? 
17.2.3.1. Deliberação que afeta o processo formativo da deliberação posterior ..... 224

17.2.3.2. Deliberação que afeta o conteúdo da deliberação posterior 228

17.2.3.3. Nossa posição sobre o chamado efeito expansivo: admissão

de ineficácia derivada e negação de desconstituição como efeito direto do provimento

17.2.3.4. Alternativas para que os atos subsequentes sejam

desconstituídos pela eficácia direta do provimento

(não apenas reputados ineficazes por eficácia reflexa) 241

18. Efeito inibitório?

19. Fato superveniente: confirmação, renovação e revogação da deliberação

20. Causa de pedir em demandas declaratórias positivas, negativas e desconstitutivas

\section{Capítulo IV}

\section{LIMITES SUBJETIVOS DO PROVIMENTO E DA COISA JULGADA}

21. Correlação entre demanda e provimento e eficácia natural do provimento: efeitos diretos e efeitos reflexos 257

22. Incindibilidade da deliberação assemblear e eficácia constitutiva erga omnes 261

22.1. Direito potestativo concorrente: irrelevância do pólo ativo. 263

22.2. Legitimação passiva: a importância do conceito de "ato colegial". 264

23. Partes e terceiros: a condição de parte como critério geral para a fixação dos limites subjetivos da coisa julgada 264

24. Pluralidade de legitimados para impugnação de ato incindível: a insuficiência do art. 472 do CPC 267

24.1. Ações subjetivamente concorrentes e a teoria de Liebman. 271

24.2. Litisconsórcio unitário: necessário ou facultativo?. 274

24.3. Substituição processual 279

24.4. Coisa julgada secundum eventum litis. 281

24.5. Teorias que defendem a coisa julgada erga omnes em decorrência da natureza da relação jurídica material 283

24.6. Direito comparado: tendência ao alargamento da coisa julgada. 295

25. Direito e processo: a influência do direito material nos limites subjetivos da coisa julgada 
25. 1. Unitariedade da relação jurídica: demandas

"individuais de alcance coletivo" e demandas "pseudoindividuais" 299

26. Coisa julgada erga omnes: admissibilidade no direito

brasileiro (unitariedade de relações jurídicas plurissubjetivas

e impossibilidade de conflitos de julgados)

26.1. A proteção aos terceiros: (i) mecanismos de reação,

(ii) informação efetiva e (iii) conluio e atos de

disposição do processo e do direito material. 309

26.1.1. Mecanismos de reação

26.1.1.1. Assistência litisconsorcial ou intervenção litisconsorcial voluntária?...... 311

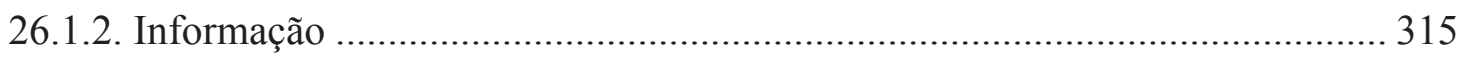

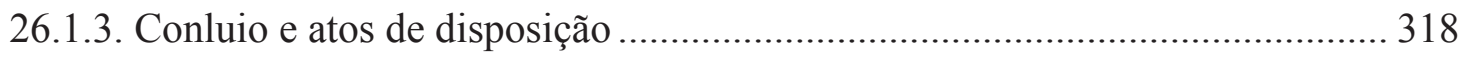

26.1.4. Controle de ingresso em juízo (representatividade adequada)? ................... 322

27. Sucessão, substituição e representação processuais..................................................... 323

27.1. Cessão de ações por ato inter vivos (alienação do direito litigioso) ..................... 324

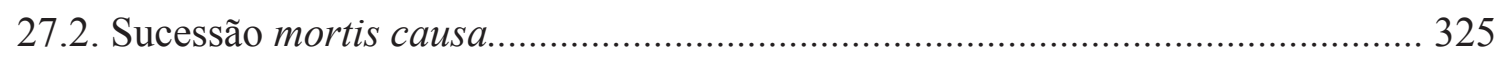

27.3. Incorporação, fusão e cisão da sociedade (LSA, arts. 227/229) ......................... 325

27.4. Representação processual: a hipótese do art. 68

da LSA (agente fiduciário e comunhão de debenturistas) ........................................ 327

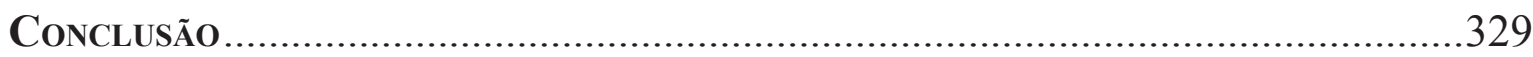

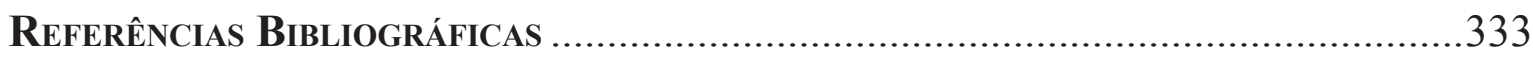




\section{CONSIDERAÇÕES INTRODUTÓRIAS}

\section{Objeto do trabalho e justificativa do tema}

O tema deste estudo é conteúdo do provimento e limites objetivos e subjetivos do provimento e da coisa julgada na impugnação de deliberações assembleares de sociedades por ações e o seu propósito é, mediante abordagem crítica e multidisciplinar, responder a três perguntas: (i) qual o conteúdo do provimento jurisdicional que desconstitui deliberações de assembleias gerais de sociedades por ações?; (ii) quais os limites objetivos desse provimento e da coisa julgada que sobre ele incide?; e (iii) quais os limites subjetivos desse mesmo provimento e da coisa julgada que o acoberta?. ${ }^{1}$ E, na busca por essas respostas, serão respondidas também outras indagações, que, embora não constituam objeto do trabalho, são peças necessárias no iter lógico que se pretende percorrer ao longo da pesquisa.

Como aponta a doutrina que se debruçou sobre o assunto da invalidade das deliberações societárias, existe - ainda que não em decorrência do direito posto brasileiro uma disciplina própria das invalidades no direito societário, com caracteres diversos do regime das invalidades do direito civil e marcada pelo princípio da estabilidade, o qual, por sua vez, busca possibilitar a continuidade da atividade empresarial diante de vícios nos processos de constituição das sociedades e de formação da vontade social. Essa especificidade do direito material contamina o processo e gera intrincadas questões processuais, dentre as quais figuram as enunciadas no parágrafo precedente.

O tema foi escolhido não só para que sejam estudadas essas questões processuais diretamente relacionadas a um campo bastante restrito do direito material, mas também por ser um útil pano de fundo metodológico para a análise de debates doutrinários que há muito são travados entre os processualistas civis. O estudo de institutos de direito processual com específica referência a um tema de direito material, como afirmou doutrina

\footnotetext{
${ }^{1}$ Tal qual ensinado por José Reinaldo de Lima Lopes, "el trabajo jurídico responde a una indagación, una duda, una cuestión jurídica" (cf. "Regla y compás, o metodologia para un trabajo jurídico sensato", in Christian Courtis (org.), Observar la ley, p. 53).
} 
de peso, é um excelente banco de prova para a aferição da correção das posições assumidas pelo cultor do direito processual. ${ }^{2}$

O tema, nessa medida, insere-se em um contexto mais amplo, qual seja, o da invalidação de atos jurídicos privados por meio do processo civil. E apesar de não se ter a pretensão de analisar assunto tão amplo como esse, o tema ora proposto pode, ao atuar como verdadeiro hard case, fornecer respostas que contribuam para outros debates, inclusive o há pouco mencionado.

Com efeito, a análise do tema das deliberações assembleares inválidas com olhos de processualista faz com que despontem dúvidas acerca das modalidades de tutelas jurisdicionais prestadas na pronúncia desses vícios, especialmente a respeito das associações que se costuma fazer entre nulidade/tutela meramente declaratória e anulabilidade/tutela desconstitutiva, que se fundamentam, basicamente, na premissa de que os atos nulos são absolutamente ineficazes e, os anuláveis, precariamente eficazes.

O tema é, ainda, um excelente laboratório para a análise de debates doutrinários que existem a respeito da relação entre demanda, objeto litigioso do processo e limites objetivos da sentença e da coisa julgada. Dentre inúmeras outras questões processuais que podem ser abordadas ao seu ensejo, questiona-se, por exemplo, (i) quais os limites temporais da decisão que se pronuncia sobre o ato societário viciado; (ii) se existe uma eficácia expansiva que abarque também atos jurídicos que não estejam incluídos no objeto litigioso do processo mas que extraiam seu fundamento de validade do ato desconstituído, assunto diretamente relacionado ao tema das deliberações sociais conexas; e (iii) se é possível cogitar de uma eficácia inibitória de emissão de posteriores atos de conteúdo idêntico. Especificamente em relação a esse último aspecto, o tema ora escolhido é relevante por tratar da invalidação de atos de poder, resultantes do exercício de um direito potestativo, pelo qual é dado a um sujeito intervir unilateralmente na esfera jurídica alheia. Surgem questões, nessa medida, enfrentadas com perplexidade pela dogmática processual

\footnotetext{
${ }^{2}$ Cf. Dinamarco, Prefácio a André de Albuquerque Cavalcanti Abbud, Execução específica de acordo de acionistas, p. 9: “O exame de um instituto processual com específica referência a um tema de direito substancial constitui um dos mais confiáveis bancos de prova das posições assumidas pelo processualista, porque vale como excelente oportunidade para questionar o acerto e conveniência de seus conceitos e pressupostos à luz de fenômenos da vida comum que no processo se projetam".
} 
civil, sobretudo no que diz respeito à renovação de atos potestativos de conteúdo idêntico a um anteriormente anulado. ${ }^{3}$

O assunto é rico também para a análise dos limites subjetivos do provimento e da coisa julgada. Prova disso é que um exemplo frequentemente utilizado em livros e salas de aula para ilustrar as chamadas ações subjetivamente concorrentes - desde Chiovenda, ${ }^{4}$ passando por Liebman ${ }^{5}$ e culminando em atual e prestigiosa doutrina nacional ${ }^{6}-$ é o da demanda de impugnação de deliberação assemblear, pela circunstância de que, embora ela possa ser individualmente movida por apenas um sócio, a decisão que a aprecia, em decorrência do caráter incindível que a deliberação ostenta, projeta efeitos na esfera de todos os demais sócios; o que demonstra a insuficiência do art. 472 do Código de Processo Civil (CPC) para reger situações como essa.

Como bem observado por Edoardo Ricci, ademais, o exame da impugnação de deliberações assembleares, como estudo da tutela dos interesses de grupo, coloca-se em um patamar intermediário entre o estudo da tutela jurisdicional dos interesses meramente individuais - objeto tradicional do direito processual - e o da tutela jurisdicional dos interesses difusos e coletivos, fronteira do direito processual civil contemporâneo. ${ }^{7} \mathrm{O}$ aprofundamento no tema, nessa medida, pode render soluções e argumentos para o enfrentamento de questões que nasçam do confronto entre esses dois ramos do direito processual civil.

A pretensão deste trabalho, ressalva-se, não é meramente examinar questões de direito material sob uma ótica processual, como se este trabalho fosse um adendo

\footnotetext{
${ }^{3}$ Cf. Stefano Villata, Impugnazioni di delibere assembleari e cosa giudicata, p. 1.

${ }^{4}$ Cf. "Sul litisconsorzio necessario", in Saggi di diritto processuale civile, v. II, p. 444.

${ }^{5}$ Cf. "Ações concorrentes" e "Pluralidade de partes legítimas à impugnação de um único ato", in Eficácia e autoridade da sentença e outros escritos sobre a coisa julgada, pp. 218 e 222, respectivamente.

${ }^{6}$ Cf. José Rogério Cruz e Tucci, Limites subjetivos da eficácia da sentença e da coisa julgada civil, n. 24.4.2, p. 247; Ada Pellegrini Grinover, Notas a Enrico Liebman, "Eficácia e autoridade da sentença" in Eficácia e autoridade da sentença e outros escritos sobre a coisa julgada, p. 231; e Eduardo Talamini, Coisa julgada e sua revisão, n. 2.5.2, p. 99, para citar apenas alguns autores. Aliás, para abordar o tema dos efeitos da sentença e da coisa julgada diante da pluralidade de legitimados para impugnação de ato único, esse último autor justifica que "usará como exemplo aquele que é o mais frequentemente considerado - inclusive em vista das complicações adicionais que ele envolve", que é o da "possibilidade que qualquer sócio tem de, individualmente, impugnar as deliberações da assembléia geral da sociedade anônima" (cf. Coisa julgada..., n. 2.5.2, p. 99).

${ }^{7}$ Cf. "Gli effetti delle sentenze sulle impugnazioni di deliberazioni assembleari", in Processo civile e società commerciali, p. 14.
} 
processual de uma obra de direito comercial. Ainda que seja necessária uma breve incursão pelos campos do direito substancial, a fim de assentarmos as premissas sobre as quais será traçada a linha de raciocínio proposta, o direito substancial será abordado na medida do estritamente necessário. $\mathrm{O}$ tema é puramente processual.

Também motiva este trabalho o laconismo da legislação do anonimato em regrar a invalidade das deliberações assembleares, ${ }^{8}$ uma vez os únicos dispositivos que tratam especificamente do assunto são os arts. 286 e 115, § $4^{\circ}$ da Lei 6.404/76 (LSA). Referida escassez justifica o esforço da doutrina em fazer construções que, de alguma forma, supram a omissão do legislador. ${ }^{9}$

\footnotetext{
${ }^{8}$ Houve um descompasso de orientação entre o legislador do Código de Processo Civil de 1973 e a Lei 6.404/76 no que diz respeito aos aspectos processuais da legislação do anonimato. A Exposição de Motivos ao CPC enviada pelo então Ministro da Justiça Alfredo Buzaid ao Presidente da República estabeleceu, em seu item 24, que as novas leis especiais deveriam contar com disposições processuais relativas aos assuntos por ela regulados. E, por isso, o legislador do CPC manteve em vigor, no art. 1.218, uma série de disposições especiais que deveriam permanecer em vigor enquanto não viessem as novas leis especiais. Exemplo disso é o processo de dissolução e liquidação de sociedades (CPC, art. 1.218, VII). Esperava-se, assim, que a Lei 6.404/76 trouxesse disposições que regulamentassem, sob uma perspectiva processual, os seus aspectos materiais, o que, contudo, não foi feito ou, quando muito, feito insuficientemente, causando problemas para a atuação processual dos direitos previstos naquela legislação. Exemplo disso é o já referido processo de dissolução e liquidação de sociedades: o art. 209, parágrafo da Lei 6.404/76 diz que a liquidação judicial da sociedade deverá observar o disposto na lei processual. O CPC/73, contudo, remete ao CPC/39, o que evidencia o descompasso entre o legislador do CPC/73 e o da Lei 6.404/76 (cf. Araújo Cintra, "Atuação por via processual dos direitos decorrentes da nova lei das sociedades anônimas" (palestra proferida na AASP), in A nova Lei das Sociedades Anônimas, p. 66; e Paulo Cézar Aragão. "Aspectos processuais da legislação societária", in $R T$, v. 641, p. 51). A mesma insuficiência pode ser vista no que diz respeito à demanda de impugnação de deliberação assemblear, uma vez que, a despeito da complexidade material e processual que o tema das invalidades das deliberações societárias possui - e cujas especificidades exigem um tratamento processual que fuja do regime ordinário do CPC - não há, com exceção dos arts. 286 e 115, § 4º nenhuma disposição na Lei 6.404/76 que trate do assunto. Sintomática disso é a circunstância de que, em sua redação original, o Anteprojeto Buzaid de Código de Processo Civil, no art. 889, dispunha que "Qualquer sócio pode requerer a suspensão de deliberação social, quando esta violar a lei, o estatuto ou o contrato". Em sua forma definitiva, encaminhada pelo Presidente da República ao Congresso Nacional, contudo, o Projeto já não contou mais com essa disposição - por força de exclusão promovida pela Comissão Ministerial -, que previa a medida de suspensão de deliberação social como um procedimento cautelar específico (cf. Ovídio Baptista da Silva, A ação cautelar inominada no direito brasileiro, n. 54, p. 410). E, de fato, apontando a insuficiência das disposições processuais da LSA, Paulo Cézar Aragão escreveu que: "Outro ponto bastante relevante decorre de uma curiosa e inexplicável diferença entre o texto do anteprojeto do Código de Processo Civil preparado pelo Ministro e Professor Alfredo Buzaid e o teor finalmente aprovado pelo Congresso Nacional. De fato, dispunha o anteprojeto original, elaborado por determinação do então Presidente Jânio Quadros, que entre as medidas cautelares típicas incluía-se a suspensão da eficácia das deliberações sociais, o que não se repetiu no texto da lei, sendo silente a tal respeito o Livro III do Código de 1973" (cf. "Aspectos processuais da legislação societária", $R T$, v. 641, p. 63).

${ }^{9}$ Sobre a relação que existe entre, de um lado, produção legislativa, e, de outro, produção doutrinária no âmbito das deliberações inválidas, Vasco da Gama Lobo Xavier fez as seguintes observações: "Quem tem com a prática um mínimo de convívio pode apercerber-se de que poucos ou nenhuns dos temas do domínio comercial se impõem, entre nós, à atenção dos juristas como o da invalidade e ineficácia das deliberações dos sócios (...). E se na literatura jurídica alemã o tema parece algum tanto fora de moda, depois do imenso interesse que despertou noutros tempos, a culminar nos anos vinte e trinta, isso deve-se à clarificação operada na matéria pela primeira Aktiengesetz, que fez rarear o contencioso e distraiu os cuidados dos comercialistas,
} 
Assim exposto o objeto do trabalho, cabe restringi-lo.

Em primeiro lugar, existem inúmeras outras questões processuais relevantes no trato do assunto da invalidade de deliberações, como, por exemplo, as relativas à legitimidade ad causam, à tutela de urgência e à arbitragem. Estas questões são deliberadamente deixadas de fora do objeto de trabalho, por se entender que existe um fio condutor lógico que une conteúdo do provimento, objeto do provimento e limites objetivos e subjetivos da coisa julgada.

Em segundo lugar, o trabalho tratará apenas da impugnação de deliberações de sócios tomadas em assembleias gerais de sociedades por ações. ${ }^{10}$ Não serão abordadas as invalidades de deliberações de outros órgãos sociais que não a assembleia geral, como conselho de administração, diretoria ou conselho fiscal. Tais órgãos possuem especificidades que alargariam em demasia o objeto do trabalho, de modo que não se tratasse de nada em profundidade. ${ }^{11}$ Tampouco serão examinadas deliberações de outros tipos societários, que também possuem peculiaridades próprias que também alargariam por demais o objeto do estudo. ${ }^{12}$ E mais. Ainda que se tratando de deliberações de assembleias

entretanto solicitados por novas e novíssimas questões. Já, por exemplo, na Itália, onde se revelaram menos felizes os textos legais referentes às deliberações inválidas, estas têm continuado até aos nossos dias a ser objecto de uma casuística inestancável e de uma polêmica doutrina incessantemente renovada" (cf. Anulação de deliberação social e deliberações conexas, p. 9). No Brasil, contudo, ressalvados alguns excelentes e até hoje atuais trabalhos (encontrados, por exemplo, na produção de Ascarelli, Erasmo Valladão França e Priscila Corrêa da Fonseca), no Brasil pouco foi escrito, de forma aprofundada, sobre o tema.

${ }^{10}$ Por sociedades por ações entenda-se o que a doutrina chamava de sociedades anônimas, que, em conjunto com as sociedades em comandita por ações, seriam espécies das quais sociedades por ações é gênero (cf. Waldemar Ferreira, Tratado de direito comercial, v. 4, n. 602, pp. 26/27). Com a extinção das ações ao portador no direito brasileiro, há hoje apenas ações nominativas, de modo que nos parece incorreto falar em sociedades anônimas. Assim, parece que o correto é considerar como gênero as sociedades por ações stricto sensu, e como espécies as sociedades em comandita por ações e as sociedades por ações stricto sensu. É destas últimas que iremos tratar.

${ }^{11} \mathrm{Na}$ doutrina portuguesa, Vasco da Gama Lobo Xavier, com indicação de vasta literatura estrangeira sobre o assunto, afirma que as deliberações das assembleias gerais possuem distinções relevantes em relação às deliberações de outros órgãos sociais e às deliberações de outros tipos de sociedades (cf. Anulação de deliberação social e deliberações conexas, pp. 33/38, nota 1).

12 Embora, como apontado com propriedade por José Rogério Cruz e Tucci, boa parte das considerações que aqui serão feitas acabe também podendo sera ser aplicada a outras hipóteses de deliberação colegiada, como as tomadas por sócios de sociedade empresária limitada, associações, fundações, condomínios etc. (cf. Limites subjetivos..., p. 247). De forma similar, ao comentar o art 2.377 do Codice Civile italiano, após a alteração legislativa ocorrida em 6.2.04, Corrado Ferri afirma que, embora tal dispositivo diga respeito à sociedade por ações, aplica-se também à impugnação de outros atos jurídicos, como deliberações de sócios de "società a responsabilità limitata" ou do "consiglio di amministrazione" (Cf. "Le impugnazioni...", n. 1, p. 51). O que une esses entes associativos é a circunstância de que a sua manifestação de vontade é regida pela regra majoritária, e não pelo consenso entre os integrantes do grupo (cf. Andrea Proto Pisani, "Appunti sulla 
gerais de sociedades por ações, não serão abordados os vícios de deliberações constituintes das companhias. Deliberações assembleares, portanto, serão utilizadas com o significado de deliberações de sócios tomadas em assembleia geral.

A pesquisa será basicamente teórica, calcada na legislação nacional, na doutrina e na jurisprudência que enfrentou o tema. $\mathrm{O}$ número relativamente reduzido de trabalhos nacionais destinados ao tema justifica, também, o recurso a obras estrangeiras.

Por fim, a maioria dos estudos de direito substancial que versam sobre o tema da invalidade de deliberações assembleares possuem capítulos que o abordam sob uma ótica processual. Tais capítulos costumam ser divididos em dois objetos de pesquisa claramente delimitados: o da demanda declaratória de nulidade e o da demanda anulatória de deliberações assembleares, que, como já visto, são geralmente reputadas como os meios processuais adequados para o reconhecimento judicial das invalidades de atos jurídicos privados. Esses trabalhos opõem os dois tipos de demandas, cotejando as suas diferenças e semelhanças, inclusive no que diz respeito ao objeto litigioso do processo, ao conteúdo da tutela jurisdicional e aos limites objetivos e subjetivos da coisa julgada - ainda que essas associações não sejam feitas de modo explícito e, talvez, nem mesmo consciente. Mesmo que este trabalho pretenda superar a oposição entre as duas demandas, por entendermos que elas, neste contexto, apresentam menos diferenças do que se costuma sustentar, ele partirá dessa dicotomia, por acreditarmos que é um interessante polo metodológico para o alcance da resposta às questões processuais enunciadas acima.

tutela c.d. costitutiva (e sulle techniche di produzione degli effetti sostanziali)", in Rivista di diritto processuale, v. 46, p. 67). Carpi afirmou que embora situações em que se cogita da anulação de um ato colegial mediante iniciativa de um ou mais dos participantes de uma organização (como, por exemplo, anulação de deliberação de assembleia de sociedade por ações, de condomínio ou de associação civil) geralmente venha examinadas conjuntamente, isso nem sempre é correto ("a me non sembra che sia lecito fare di tutta l'erba un fascio"), porque do ponto de vista substancial essas fatispécies são diversas em vários aspectos. Contudo, diz Carpi, essas situações podem ser analisadas unitariamente sob a perspectiva processual. $\mathrm{O}$ art. 2.377 do Código Civil italiano, assim, que estabelece a coisa julgada ultra partes na anulação de deliberação societária, assume um significado paradigmático para outras situações análogas (cf. L'efficacia 'ultra partes' della sentenza civile, nn. 33/36, pp. 145/146 e 155/156). Sobre o assunto, v., ainda, Redenti, Il giudizio civile con pluralità di parti, cap. II, n. 50, p. 67, obra clássica em que demonstrou o acerto da tese de que o processo civil pode constituir-se com mais de duas partes sem deixar de ser uma única entidade jurídica. Cite-se, por exemplo, a afirmativa de Comparato de que a estruturação em órgãos é justamente uma das diferenças fundamentais entre a sociedade anônima e as demais sociedades, "em que falta essa estruturação orgânica" (cf. O poder de controle na sociedade anônima, n. 3, p. 18). Essa diferença fundamental com certeza acarreta diferenças no tratamento processual das demandas de impugnação de deliberações assembleares nos diferentes tipos societários. 


\section{Plano do estudo}

Primeiro, aborda-se o tema da invalidade das deliberações assembleares, procurando-se assentar noções fundamentais sobre vícios desses atos jurídicos (Capítulo I). O intuito é firmar premissas sobre as quais serão problematizadas, nos capítulos seguintes, as questões processuais objeto da pesquisa. O direito material será abordado apenas nos estritos limites do essencial.

Examina-se em seguida (Capítulo II) a relação entre vícios de deliberações assembleares inválidas e tutela jurisdicional, com especial enfoque para as já referidas associações entre nulidade/tutela meramente declaratória e anulabilidade/tutela desconstitutiva. O objetivo é chegar a uma conclusão a respeito de qual o conteúdo do provimento que atua na certificação e remoção de tais vícios. Além da tomada de posição quanto a essa questão ser um dos propósitos desta pesquisa, ela servirá, também, de base para os capítulos subsequentes.

No terceiro capítulo (Capítulo III), passa-se ao estudo dos limites objetivos do provimento e da coisa julgada na impugnação das deliberações assembleares, ocasião em que serão feitas considerações a respeito do objeto litigioso do processo, do alcance temporal do provimento na desconstituição de deliberações assembleares e da eventual existência de um efeito expansivo na impugnação de deliberações e atos conexos, dentre outros assuntos.

O Capítulo IV destina-se a abordar os limites subjetivos da sentença e da coisa julgada na impugnação de deliberações, exame que parte da tensão que existe entre, de um lado, o caráter incindível da deliberação, e, de outro, da circunstância de que tal ato diz respeito a uma pluralidade de pessoas, que, nas grandes companhias de capital aberto, pode representar um número não só elevado como também a cada instante mutável.

Ao final (Conclusões) são sistematizadas as conclusões parciais feitas no decorrer do estudo. 


\section{Observações terminológicas}

É importante, por fim, estabelecer algumas premissas terminológicas, para que, em atenção ao caráter científico que se quer imprimir ao trabalho, lide-se com conceitos precisos e definidos.

A primeira delas diz com a escolha do termo impugnação para o título da dissertação. De início, cogitou-se de vocábulos como invalidação, anulação e desconstituição. Os três, contudo, possuem significados que não refletem com exatidão o objeto da pesquisa, pois todos eles em regra são empregados para refletir as consequências que recaem sobre os vícios de anulabilidade. Tais termos poderiam transparecer a ideia de que o objeto de estudo são apenas os provimentos constitutivos negativos, que seriam os que incidem, ao menos de acordo com a doutrina predominante, sobre os atos anuláveis. É dizer, se poderia dar a entender que os atos nulos, que para a doutrina prevalente devem ser atacados por provimentos meramente declaratórios, estariam fora do objeto da investigação; o que não é o caso, como alertado.

Estes três termos, ademais, poderiam indicar que a pesquisa limitar-se-ia ao estudo dos provimentos que julgam procedentes as demandas mencionadas acima e que estariam excluídos os provimentos que as julgam improcedentes. Embora a primeira espécie de provimentos constitua o objeto maior da dissertação, a decisão de improcedência também o compõe.

Por esses dois motivos optou-se pelo vocábulo impugnação, termo genérico que indica a possibilidade de provocação da jurisdição com vistas a eliminar efeitos de uma situação jurídica anterior, a que se atribuem tais efeitos, independentemente da natureza do vício. $^{13}$

\footnotetext{
${ }^{13}$ Nesse sentido, Angeles Alcala Diaz defende que "se utilizará el término de impugnación en el sentido de ejercicio de acciones judiciales frente al acuerdo viciado de un órgano social, con independencia de la calificación jurídica del vicio que afecta el acuerdo, es decir, tanto si el acuerdo es nulo como anulabile" (cf. La impugnacion de acuerdos del consejo de administracion de sociedades anonimas, pp. 77/78, nota. 1). Em reforço dessa ideia, veja-se que a doutrina utiliza o termo impugnação para fazer menção às ações declaratórias de nulidade e anulatórias de deliberação social (cf. Barbosa Moreira, "Coisa julgada: extensão subjetiva. Litispendência, Ação de nulidade de patente", in Direito processual civil, p. 275; Eduardo Talamini, Coisa julgada..., p. 98; Liebman, "Pluralidade de partes...", p. 221; e José Rogério Cruz e Tucci, Limites subjetivos..., p. 245. Na doutrina italiana, usa-se azione impugnativa (cf. Tullio Ascarelli, Appunti...,
} 
De toda forma, além da utilização do vocábulo impugnação com o sentido acima enunciado, desconstituição será empregada também como termo genérico para o reconhecimento judicial dos vícios dos atos jurídicos e a imposição das consequências jurídicas decorrentes desse acertamento. Apesar do inconveniente antes levantado - de que o termo pode dar a entender que se estaria fazendo menção apenas às hipóteses de anulabilidade -, esse é o mais amplo dentre os considerados ${ }^{14}$ e que se coaduna, inclusive, com a ideia que se quer defender de que o provimento constitutivo é o adequado também para a desconstituição de deliberações nulas (v. item 12). Fique claro, portanto, que aqui desconstituição abarca todas as formas e meios judiciais pelos quais se reconhecem os vícios dos atos jurídicos e se impõem as consequências jurídicas daí decorrentes.

Por fim, o termo conteúdo do provimento deve ser também explicado. Como será exposto à frente, vigora certa confusão terminológica no emprego da expressão conteúdo do provimento pela doutrina processual. Aqui, quando se empregar a expressão, se estará significando estrutura processual, isto é, modo em que o provimento é estruturado (v. item 10.1.3).

p. 272). Erasmo Valladão França e Vasco da Gama Lobo Xavier, contudo, associam impugnação à anulabilidade (cf., respectivamente, Invalidade..., n. 16, p. 71, nota 9 e Anulação..., n. 1, pp. 39/40, nota 5).

${ }^{14}$ Analisando os termos rescisão, revisão, revogação, cassação, anulação e desconstituição, Flávio Yarshell também conclui que o último é "consideravelmente mais amplo" (cf. Ação rescisória - juízos rescindente e rescisório, n. 2, p. 27). 


\section{CAPÍTUlo II - NoÇõeS FUNDAMENTAIS SOBRE VÍCIOS DAS DELIBERAÇõeS} ASSEMBLEARES

\section{Deliberação assemblear: conceito e natureza jurídica}

Embora esta dissertação seja um trabalho de direito processual civil, o seu tema é interdisciplinar e, pois, exige uma breve passagem pelos domínios do direito civil e do direito comercial. O objetivo desta empreitada - confessadamente árida para o autor - é fixar as bases teóricas de direito substancial sobre as quais serão problematizadas as questões processuais objeto da pesquisa. ${ }^{15}$

A palavra deliberar deriva do latim (libra, $\alpha=$ balança) e transmite a noção de pesar, sopesar, ponderar. Ostenta dois significados: o processo formativo de um juízo (a ponderação) ou o resultado final desse processo (a resolução ou decisão). No direito espanhol, o primeiro fenômeno é chamado de deliberación, ao passo que o segundo é nomeado acuerdo. Já os direitos francês (déliberation), italiano (deliberazione ou delibere) e português (deliberação) utilizam o termo apenas para designar o ato final do referido processo criativo. $^{16}$

Também no direito brasileiro o vocábulo deliberação apresenta essa dualidade significativa, ${ }^{17}$ como bem demonstra a definição contida no dicionário: "ato ou efeito de deliberar". ${ }^{18} \mathrm{O}$ verbo deliberar, assim, pode assumir dois sentidos: um que indica a

\footnotetext{
${ }^{15}$ É impossível afirmar, por exemplo, o conteúdo do provimento que se pronuncia sobre um ato inválido sem o exame de qual maneira a causa de invalidade atua, no plano material, sobre a eficácia do ato (cf. Ilaria Pagni, Le azioni di impugnativa negoziale - contributo allo studio della tutela costitutiva, cap. I, n. 1, p. 7). Daí a necessidade deste capítulo.

${ }^{16}$ Cf. Jorge Henrique Pinto Furtado, Deliberações de sociedades comerciais, n . 1, I, p. 20 e Curso de direito das sociedades, n. 59, p. 391; Stefano Villata, Impugnazioni di delibere assembleari, cap. I, n. 4, p. 42; e Priscila Corrêa da Fonseca, Suspensão de deliberações sociais, p. 72. Pontes de Miranda, por sua vez, ressaltou que "A deliberação é o ato de pôr em nível, acertar a balança, o ato de reflexão e de solução (Nada tem com o liberare, fazer livre, cujo étimo é outro). Quem delibera resolve, afasta ou acerta o peso" (cf. Tratado de direito privado, t. 50, n. 5.322, p. 277).

${ }^{17}$ Cf. Bulhões Pedreira, "Deliberação de sócios quotistas de transformar limitada em S.A.", in A Lei das S/A, p. 656; e Ricardo Tepedino, Direito das companhias (coord. Lamy Filho-Bulhões Pedreira), v. I, n. 256, p. 940.

${ }^{18}$ Cf. Dicionário Houaiss da Língua Portuguesa, p. 931. Lamy Filho-Bulhões Pedreira também apontaram referida dualidade (cf. "Acordo de acionistas sobre exercício do direito de voto", in A Lei das S/A, v. II, p. $550)$.
} 
ponderação (discutir); outro, a decisão (decidir). ${ }^{19}$ Em nosso direito comercial, porém, quando se alude a uma deliberação social se está exprimindo a declaração de vontade, ciência ou sentimento da sociedade, ${ }^{20}$ formada mediante um procedimento organizacional regido pelo princípio majoritário ${ }^{21}$, no qual convergem e se compensam as vontades individuais de seus sócios. Em sentido técnico-jurídico, portanto, deliberação social é o ato final, ${ }^{22}$ não o procedimento que culminou naquele.

${ }^{19}$ Cf. Dicionário Houaiss - Sinônimos e Antônimos, p. 240. No campo da teoria geral do direito, Carnelutti atrelou o ato de deliberar à realização de um juízo crítico ou juízo de valor (cf. Teoría general del derecho, $\mathrm{n}$. 126, p. 339). E embora Menezes Cordeiro afirme que "A deliberação é uma proposição imputada à decisão de um conjunto de pessoas singulares ou seres humanos" (cf. SA: Assembleia geral e deliberações sociais, $\mathrm{n}$. 69, p. 149), ligando as deliberações apenas aos agrupamentos de pessoas, parece-nos que o processo e o ato de formação da vontade de um sujeito individual também podem ser vistos, leigamente, como deliberação. Não é raro que se fale, por exemplo, que eu deliberei tomar certa atitude. É, contudo, no âmbito dos entes coletivos que, de fato, as deliberações assumem maior relevo.

${ }^{20}$ Há três tipos de deliberações: a que forma a vontade social com eficácia puramente interna; a que forma e declara a vontade social com eficácia externa; e a que forma a vontade social, mas que deverá ser declarada pelos administradores. Embora Ascarelli tenha afirmado que a deliberação diga respeito à formação da vontade da sociedade, e não à sua declaração, pois "não são diretamente manifestadas a terceiros", uma vez que "os seus destinatários imediatos são os diretores, ou seja, o órgão executivo da sociedade", os quais, "por sua vez, comunicam a declaração aos terceiros" (cf. "Vícios das deliberações assembleais - direitos individuais dos acionistas - prescrição", in Problemas das sociedades anônimas e direito comparado, n. 2, p. 371; no mesmo sentido, v. Marcelo von Adamek, Responsabilidade civil dos administradores de S/A, n. 7.3.1.4.2.2, p. 355), parece-nos que a deliberação representa sim uma declaração de vontade da sociedade. Como essa declaração de vontade será transmitida a terceiros, depende da estrutura organizacional da sociedade. Mas essa é outra questão. Em hipótese alguma, contudo, se poderá dizer que a deliberação não é declaração apenas pela circunstância de que é dirigida aos administradores. Mesmo nessas hipóteses ela é uma declaração: da sociedade a um de seus órgãos (a administração). O próprio Ascarelli, na passagem citada acima, reconhece que as deliberações "podem, no entanto, visar, diretamente, as relações para com terceiros" (p. 372). Todavia, reitera-se: entendemos que mesmo nas hipóteses em que a deliberação volta-se apenas aos administradores estaremos diante de uma declaração da sociedade.

${ }^{21}$ Cf. Galgano, La societá per azioni, cap. 7, n. 6, p. 212. E, realmente, como apontou Carnelutti, o domínio da maioria é um instrumento jurídico indispensável para a vida da sociedade comercial (cf. "Eccesso di potere nelle deliberazioni dell'assemblea delle anonime", Rivista del diritto commerciale e del diritto generale delle obbligazioni, v. XXIV, $1^{\mathrm{a}}$ parte, p. 181). Assim também Comparato, para quem nas sociedades que contam com muitos sócios "seria totalmente desarrazoado aceitar a regra contratual do consentimento unânime, nas deliberações sociais". Daí porque "em todas as legislações, estabeleceu-se o princípio majoritário, notadamente em matéria de sociedades por ações". Ainda de acordo com Comparato, a razão de ser do chamado princípio majoritário está, na lição de Kelsen, em que "o ordenamento social deve estar de acordo com o maior número possível de sujeitos, e em desacordo com o menor número possível". E isso não significa oprimir a minoria, pois a regra da maioria exige, ao menos uma vez, a unanimidade: no momento da constituição da sociedade (cf. O poder de controle na sociedade anônima, n. 12, pp. 43/44). Na mesma direção, Romano-Pavoni vê na vinculação da deliberação uma necessidade imprescindível da estrutura societária (cf. Le deliberazioni delle assemblee delle società, n. 30, p. 113).

${ }^{22}$ Com esse sentido é que Romano-Pavoni diz que a deliberação é a conclusão de um procedimento (cf. Le deliberazioni..., n. 8, p. 24) e que Francesco Terrusi a define "come sintesi finale di un procedimento che si sviluppa in coerenza con le refole organizzative" (cf. L'invalidità delle delibere assembleari della SPA, n. 1.2., p. 15). Também Comparato afirmou que o vocábulo "deliberações" contido no art. 286 da LSA "só pode ser interpretado no sentido de resoluções ou decisões" (cf. "Da imprescritibilidade da ação direta de nulidade de norma estatutária", in Novos ensaios e pareceres de direito empresarial, p. 216). 
Trata-se de mecanismo de expressão do grupo e que, por isso, apresenta raiz coletiva. ${ }^{23}$ É uma forma de expressão grupal que historicamente surge no campo do direito público, mais precisamente nas grandes assembleias políticas da Antiguidade. ${ }^{24}$ No direito comercial - inicialmente marcado pela figura do comerciante individual -, a deliberação surge, de forma incipiente, apenas com as grandes companhias coloniais dos séculos XVI e XVII. E é só com a codificação do século XIX, quando ganham corpo as sociedades comerciais plurissubjetivas, que o instituto assenta-se na dogmática jurídica comercialista. $^{25}$

É um truísmo a afirmação de que as deliberações são peças-chave para o funcionamento de entes coletivos, como as sociedades por ações. Enquanto sujeitos de direito que não dispõem de vontade própria, essas dependem de seus órgãos para que possam formular e emitir suas manifestações volitivas. ${ }^{26}$ Daí já se ter dito que a

${ }^{23}$ Tanto é isso verdade que ao classificar os atos administrativos no direito português Marcello Caetano afirma que "se o acto provém de um órgão singular, é decisão, se provém de um órgão colegial, é deliberação" (cf. Manual de direito administrativo, v. I, n. 184, p. 443).

${ }^{24}$ Cf. Galgano, La società..., cap. 7, n. 6, p. 211. De fato, de acordo com Comparato, as deliberações da assembléia geral - "órgão soberano" - "obedecem a uma disciplina jurídica análoga à das eleições populares" (cf. O poder de controle..., n. 4, p. 23). Também Nelson Eizirik apontou que "As sociedades anônimas foram originalmente concebidas nos moldes de um Estado Democrático, segundo os dogmas da Revolução Francesa, de forma que todo o poder emanaria do acionista e em seu nome deveria ser exercido. (...) (Ou seja, a sociedade anônima foi idealizada à semelhança de um modelo democrático parlamentarista: os diretores, como delegados dos acionistas para o exercício de administração ordinária, responderiam perante a assembléia geral, da mesma forma que o gabinete de ministros responde perante o Parlamento, como delegado para o exercício do Poder Executivo" (cf. "Interpretação dos $\S \S 8^{\circ}$ e $9^{\circ}$ do art. 118 da Lei das S/A", in Revista de direito mercantil, n. 139, p. 155).

${ }^{25}$ Pinto Furtado dá nota de que a deliberação "surge, historicamente, no campo do Direito público: foram as grandes assembleias políticas instituídas desde os tempos mais antigos que constituíram o seu caldo de cultura e agro de eleição" e que no direito comercial a figura ganhou corpo apenas com o movimento codificador do século XIX, no qual foram talhadas de forma mais estruturada as sociedades comerciais de nossos dias (cf. Deliberações... n . 1, II, p. 21). Por essa razão, aliás, que muitos teóricos que tratam das deliberações das sociedades recorrem às construções dos estudiosos do direito público na tentativa de suprir lacunas da legislação societária. Nesse sentido Stefano Villata, para quem o fenômeno deliberativo é parcialmente contíguo a fenômenos que ocorrem no âmbito tipicamente privado (negócio jurídico, por exemplo) e mais propriamente assimilável a fenômenos do direito administrativo (cf. Impugnazioni..., n. cap. I, n. 4, p. 41). Também Aurelio Candian traçou esse paralelo, sob o fundamento de que a estrutura, a repartição de poderes em zonas de competência e o modo de constituição e funcionamento dos órgãos individuais e colegiais apresentam aspectos comuns no âmbito de uma sociedade anônima e de um ente de público (cf. Nullità e annullabilità di delibere di assemblea delle società per azione, n. 15, p. 38).

${ }^{26}$ Cf. Teófilo de Castro Duarte, O abuso do direito e as deliberações sociais, n. XI, p. 81. De acordo com Stefano Villata, "lungi dall'essere um soggeto in grado di volere", a sociedade "costituisce una categoria utilizzata per assoggettare una determinata colletività organizzata ad una specifica disciplina giuridica" (cf. Impugnazioni..., cap. I, n. 4, p. 47). E isso porque, na linha do que ensina Menezes Cordeiro, "A vontade é, em si, um fenômeno psicológico puramente humano e individual. Uma colectividade não tem 'vontade' própria: apenas esquemas que permitam imputar-lhe uma proposição a qual, na origem, deverá ter vontades humanas". Daí concluir o jurista luso que "a deliberação social acaba por ser uma criação jurídico-cultural destinada a atribuir, a um grupo, uma determinada decisão" (cf. SA: Assembleia geral e deliberações sociais, n. 69, p. 150). Indo na mesma direção, Ascarelli apontou que o fenômeno deliberativo estará presente sempre 
deliberação é a fala institucional e uma forma de expressão grupal, ${ }^{27}$ que a sociedade por ações moderna possui uma constituição tipicamente democrática ${ }^{28}$ e que a assembleia geral é o órgão propulsor da vida social. ${ }^{29}$ A deliberação, portanto, apresenta função e valor organizativos. E ainda que não possa ser apenas uma expressão de vontade - pois, como será visto, pode consistir também em uma declaração de ciência ou de sentimento -, no mais das vezes a deliberação será um ato de vontade, isto é, uma manifestação volitiva de um grupo organizado. Por esses motivos é que, nos dizeres de Waldemar Ferreira, ela constitui declaração de vontade coletiva ${ }^{30}$ e que Lamy Filho e Bulhões Pedreira afirmaram ser uma expressão da vontade coletiva. ${ }^{31}$

Todas as deliberações tomadas pela sociedade ou por algum de seus órgãos, quer como declaração imputável àquela, quer como declaração atribuível unicamente ao órgão individualmente considerado, são deliberações sociais. Quando representam apenas a vontade de algum órgão social, são deliberações setorizadas, como, por exemplo, do conselho de administração, da diretoria, do conselho fiscal, da assembleia geral etc.

A assembleia geral é o órgão de maior poder na sociedade anônima e exerce, por excelência, a função - ou, de acordo com Comparato, o poder-função - de deliberar e expressar um juízo da companhia. ${ }^{32-33}$ Por esse motivo, em regra as deliberações da

que "manifestações psicológicas de vontade de mais pessoas sejam encaradas juridicamente como vontade de "uma' parte" (cf. "Vícios das deliberações...", n. 2, pp. 370/371, nota 2). Sobre o assunto, v., ainda, a crítica feita por Walfrido Warde Filho à noção de vontade social como violadora da lei e/ou do estatuto social (cf. Responsabilidade dos sócios - a crise da limitação e a teoria da desconsideração da personalidade jurídica, n. 5.2.1, pp. 299/300), no sentido de quem viola a lei ou o estatuto não é a sociedade, mas sim seus sócios ou administradores. A respeito dos fenômenos associativos complexos, como é o caso da sociedade anônima, e da necessidade de "distribuição de podêres através de centros volitivos determinados", v. Luiz Gastão Paes de Barros Leães, "Diretoria de conselho de administração na sociedade anônima", in Direito comercial textos e pretextos, pp. 60 e seguintes.

${ }^{27}$ Cf. Pinto Furtado, Deliberações..., n. 1, II, pp. 21/22. Também atrelando a assembleia geral à formação da vontade social, v. Elena Ricci Armani, "Le delibere di rigetto adottate dalla maggioranza assembleare in conflito d'interessi", in Rivista del diritto commerciale, v. 95, n. 1-2, p. 81.

${ }^{28}$ Cf. Haroldo Malheiros Verçosa, Curso de direito comercial, v. 2, 1.14.1.2, p. 180.

${ }^{29} \mathrm{Cf}$. Antigono Donati, L'invadilità della deliberazione di assemblea delle società anonime, p. 3.

${ }^{30}$ Cf. Tratado de direito comercial, v. 4, n. 777, p. 307.

${ }^{31}$ Cf. "Acordo de acionistas sobre exercício do direito de voto", in A Lei das S.A., v. II, p. 291. Ainda, v. Fernando Antonio Maia da Cunha e Walfrido Jorge Warde Júnior, "A arbitragem e os limites à atuação do Judiciário nos litígios societários”, in Flávio Luiz Yarshell e Guilherme Setoguti J. Pereira (coords), Processo societário, p. 748.

${ }^{32}$ Em obra obrigatória para o estudioso do direito comercial brasileiro, Comparato anotou que "ao contrário do que sucede nos demais tipos societários, a economia interna da sociedade anônima não é deixada à livre decisão dos seus fundadores ou acionistas. O legislador discriminou poderes-funções considerados fundamentais, atribuindo-os a órgãos próprios, insuprimíveis e inconfundíveis: o poder-função deliberante à 
assembleia geral representarão a vontade social. ${ }^{34}$ Pode ser que haja deliberações setorizadas e que não sejam uma forma de representação orgânica de toda a sociedade. Nada impede, contudo, que a sociedade seja representada por uma deliberação de outro órgão se, por exemplo, houver disposição estatutária nesse sentido. ${ }^{35}$ Portanto, embora em regra a deliberação assemblear seja deliberação social, esta é gênero do que deliberações assembleares e demais formas de deliberações setorizadas são espécie. ${ }^{36} \mathrm{O}$ objeto deste

assembleia geral, o poder-função administrativo à diretoria e o poder-função sindicante ao conselho fiscal. A liberdade negocial dos particulares, na organização de uma companhia, é, pois, limitada pelo respeito devido a essa estrutura básica" (cf. O poder de controle..., n. 2, p. 16). V., ainda, Luiz Gastão Paes de Barros Leães, "Diretoria e conselho...", p. 63.

${ }^{33}$ L. P. Moitinho de Almeida, Anulação e suspensão de deliberações sociais, p. 9. De origem francesa, assembleia é termo que, assim como deliberação, também apresenta dualidade significativa. De um lado, assembleia pode ser encarada sob o ponto de vista organizacional, como sendo a reunião de acionistas cuja finalidade é discutir e decidir sobre os negócios de interesse da sociedade. Sob o ponto de vista orgânico, é um órgão social, que se encontra inserido no organismo que é a sociedade e que neste desempenha, primordialmente, função deliberante. Invocando-se novamente a lição de Comparato, a estruturação em órgãos é justamente uma das diferenças fundamentais entre a sociedade anônima e as demais sociedades, "em que falta essa estruturação orgânica" (cf. O poder de controle..., n. 3, p. 18).

${ }^{34}$ Lacerda Teixeira-Tavares Guerreiro ensinam que no modelo clássico da sociedade anônima a reunião dos acionistas ostentava a característica de soberania absoluta: cabia à assembleia, com exclusividade, a função de deliberar, aos demais órgãos administrativos funções meramente executórias e ao conselho fiscal a função de controle. Transformações econômicas, contudo, impactaram esse modelo e passaram a exigir das empresas "um ritmo decisório mais ágil e mais rápido, incompatível com o ritual das assembléias". Houve, então, uma "hipertrofia dos órgãos da administração" e o fenômeno que nomearam de "declínio das assembléias" (cf. Das sociedades anônimas no direito brasileiro, v. 1, n. 131, pp. 383/384). Tanto é isso verdade que Von Gierke chegou a dizer que a assembleia já não é mais órgão supremo (cf. Derecho comercial y de la navegación (trad. de Juan Semon), v. 1, p. 450). Contudo, na mesma passagem referida, Lacera Teixeira-Tavares Guerreiro alertam que, nada obstante esses fenômenos, diante da expressa disposição do art. 121 da LSA continua a ser inegável a soberania da assembleia na decisão de todos os assuntos da vida social. Na mesma direção Luiz Gastão Paes de Barros Leães, para quem "Sem embargo da hipertrofia dos órgãos da administração, apontada por vários estudiosos, remanesce ainda em mãos da Assembléia-Geral o núcleo decisório da companhia" (cf. "Vícios em assembleia geral ordinária", in Estudos e pareceres sobre sociedades anônimas, n. 7, p. 157). E, de fato, conforme Bulhões Pedreira, embora a partir do segundo quartel do século XX a legislação de alguns países tenha passado a questionar o princípio da soberania da assembleia, "Na legislação brasileira, diferentemente, o órgão supremo sempre foi e continua a ser a assembleia" (cf. "Acordo de acionistas sobre controle de grupo de sociedades", Revista de direito bancário, do mercado de capitais e da arbitragem, n. 15, n. 2.1.2, pp. 229/230). A respeito da concepção clássica, que enxerga na assembleia geral o órgão supremo, e da concepção moderna, pela qual referida supremacia ocorre apenas na medida em que os seus poderes não derivam dos outros órgãos sociais, v. Vasco da Gama Lobo Xavier, Anulação de deliberação social e deliberações conexas, n. 20, pp. 350/352, nota 101.

${ }^{35}$ Como exemplo de deliberação que não seja de assembleia, podem ser citadas as deliberações do conselho de administração: "O conselho de administração da sociedade anônima é um órgão colegial, assim como a assembléia geral. Quer isso dizer (...) que esse órgão age por meio de deliberações, que são manifestações coletivas de vontade" (cf. Comparato, "Eleição de diretores em companhia aberta. Validade e eficácia de reuniões do conselho de administração de sociedade anônima. 'Quorum' deliberativo em assembléias gerais de companhia aberta", in Direito empresarial, n. 10, p. 189).

36 Essa é, com alguns temperamentos, a classificação adotada por Pinto Furtado, que, ao justificar as deliberações da sociedade como seu objeto de estudo, ressaltou que "Fora de nosso campo de análise ficarão, assim, as declarações colectivas simplesmente sectoriais, imputáveis a órgãos societários que não representem a síntese unitária da própria sociedade globalmente considerada como um todo" (cf. Deliberações..., n. 5, p. 5). Priscila Corrêa da Fonseca igualmente entende que, embora a assembleia geral seja o órgão deliberante por excelência, também o conselho de administração e a diretoria exercem função deliberante e, portanto, emitem deliberações sociais (cf. Suspensão de deliberações sociais, pp. 75/76). 
trabalho, porém, são as deliberações das assembleias das sociedades por ações, isto é, as deliberações assembleares.

A deliberação é composta pelos votos ${ }^{37}$ e em regra não se exige a manifestação unânime dos sócios, apenas a vontade da maioria (princípio majoritário). Ela é constituída em uma reunião, chamada de assembleia, e mediante um procedimento, com vistas a possibilitar o contraditório. ${ }^{38} \mathrm{O}$ método assemblear, assim, opera como instrumento de proteção da minoria, pois exige que essa seja previamente informada do objeto da deliberação e permite que ela participe das discussões e manifeste sua opinião. ${ }^{39} \mathrm{O}$ poder exercido pela assembleia encontra limites na lei e no estatuto ${ }^{40}$ e é justamente nessa relação de tensão entre lei/estatuto e deliberação que surgem as invalidades das deliberações. ${ }^{41}$

No que diz respeito ao conteúdo, embora sejam as mais comuns, as deliberações assembleares não se limitam às declarações de vontade, como é o caso da eleição de membros do conselho de administração, da aprovação da fusão da sociedade ou da alteração do estatuto social. Nessas hipóteses exprime-se um querer, manifesta-se uma

Ovídio Baptista da Silva rejeita que no conceito de "deliberações sociais" incluam-se apenas as deliberações de assembleias gerais (cf. A ação cautelar inominada no direito brasileiro, n. 54, p. 414). Lobo Xavier utiliza a expressão deliberações sociais como sinônimo de deliberações de sócios tomadas em assembleia geral, porém ressalvando que essa restrição ao conceito de deliberação social é feita apenas por comodidade (cf. Anulação..., n. 2, p. 45, nota 16).

${ }^{37}$ Cf. Galgano, La società per azioni - Trattato di diritto commerciale e di diritto pubblico dell'economia, $v$. $7^{o}$, cap. 7, n. 6, p. 211. O voto é "a célula cujo conjunto agregado compõe e entretece o tecido deliberativo" (cf. Pinto Furtado, Delberações..., n. 22, p. 133). No mesmo sentido, v. Comparato, "Da imprescritibilidade...”, pp. 217/218; e Romano-Pavoni, Le deliberazioni..., n. 24, p. 87.

${ }^{38}$ Cf. Lobo Xavier, "Invalidade e ineficácia das deliberações sociais no direito português, constituido e constituendo; confronto com o direito espanhol", Boletim da Faculdade de Direito, v. LXI, 1981, pp. 2/4. Sobre a relação entre deliberação e procedimento, Erasmo Valladão Azevedo e Novaes França, ao referir-se à competência da assembleia geral, bem apontou que "o exercício desse poder-função está sujeito a um determinado procedimento, minuciosamente regulado pela lei, consistente na prévia convocação da assembleia, com indicação da ordem do dia a ser discutida, e no cumprimento de uma série de formalidades durante o conclave (cf., basicamente, arts. 86, 87 e 123 a 136, da Lei n. 6.404/76)" (cf. Invalidade..., n. 10, p. 37). V., também, Haroldo Malheiros Verçosa, Curso..., v. 2, n. 1.14.1.2., p. 180).

${ }^{39}$ Cf. Galgano, La società..., cap. 7, n. 6, p. 213.

${ }^{40}$ Cf. Luiz Gastão Paes de Barros Leães, "Vícios em assembleia-geral ordinária”, in Estudos e pareceres sobre sociedades anônimas, p. 156.

${ }^{41}$ Cf. Waldirio Bulgarelli, “Anulação de assembléia geral de sociedade anônima”, $R T$ 514, pp. 58/59: "Os choques normais, decorrentes das várias posições e, mesmo, das opinões sobre a melhor política a ser seguida pela sociedade devem efetuar-se como é norma, por força da sua disciplina jurídica, no seio das assembléias gerais, órgão soberano para ditar as deliberações sobre a vida societária”. Sobre os diferentes interesses congregados e os conflitos que podem surgir na moderna sociedade anônima, v. Aldo Maisano, L'eccesso di potere nelle deliberazioni assembleari di società per azioni, cap. I, n. 1, pp. 1/3; e Celso Barbi Filho, "Acordo de acionistas: panorama do instituto no direito brasileiro e proposta para a reforma de sua disciplina legal”, Revista Forense, v. 354, n. 2, pp. 103/104. 
vontade. Há casos, porém, em que a deliberação assume as vestes de uma declaração de ciência ou sentimento. Exemplo da primeira são a aprovação das demonstrações financeiras anuais e da segunda o voto de confiança ou a manifestação de pesar ou cortesia. $^{42}$

Discutiu-se e ainda discute-se muito acerca da natureza jurídica da deliberação assemblear. ${ }^{43}$ Falou-se em ato simples, ato coletivo, ato complexo, ato colegial, ato sui generis, ato unilateral, ato coletivo, ato jurídico, negócio jurídico, ato de hierarquia etc. E ainda que natureza jurídica não seja mais do que uma abstração, ${ }^{44}$ é essencial tomar posição nesse debate pois, como bem anotou Antigo Donati, ele possui não apenas valor terminológico, mas também substancial, ${ }^{45}$ na medida em que é a partir dessa tomada de partido que são solucionadas inúmeras questões, como, por exemplo, a relativa à legitimidade ad causam passiva nas demandas desconstitutivas desses atos jurídicos (item 22.1).

A deliberação assemblear é um ato jurídico em sentido lato, isto é, um fato que decorre de uma ação humana (ato, portanto) ${ }^{46}$ e que produz efeitos jurídicos (jurídico, portanto). Mas afirmar só isso não basta. É preciso ir mais fundo.

\footnotetext{
${ }^{42}$ Cf. Romano-Pavoni, Le deliberazioni..., n. 9, p. 30; Mario Vaselli, Deliberazioni nulle e annullabili delle società per azioni, n. 2, p. 10; e Pinto Furtado, Deliberações..., n. 23, pp. 155/158.

${ }^{43}$ Tanto é que, em obra de 2007, Francesco Terrusi anotou que "Con riguardo alla definizione della natura dell'atto-delibera, la dottrina tradizionale se è peraltro espressa in modo non univoco" (cf. L'invalidità..., n. 1.2 , p. 14). No mesmo sentido, em sua tese excelente de doutoramento apresentada em 2004 e publicada comercialmente em 2005, Pinto Furtado afirmou que "O enquadramento dogmático das deliberações de sociedades comerciais tem sido objecto de um grande subjetivismo, com a carga de imprecisão que, naturalmente, este acarreta para a definição do recorte e alcance do conceito" (cf. Deliberaçães..., n. 23, p. 134).

${ }^{44}$ V., nesse sentido, a crítica tecida por Comparato, que chama atenção para o artificialismo do conceito de natureza jurídica como sendo algo essencial. Para o ilustre jurista, não devemos trabalhar com conceitos jurídicos puros e imutáveis, mas sim com "definições aproximativas, em cada época histórica" (cf. $O$ poder de controle..., n. 22, pp. 83/84). Permeado por tal ideia é que, nessa mesma obra, Comparato afirma que a classificação dos bens pelo direito não é uma mera tarefa de raciocínio lógico e não atende a exigências inalteráveis da natureza, "como as classificações botânicas ou zoológicas". É preciso, continua, "atentar, constantemente para os interesses sociais e os valores históricos que as suscitam, sob pena de se frustrar qualquer esforço de compreensão da vida jurídica, em sua perpétua evolução" (n. 29, p. 94). Mesmo feita essa ressalva, porém, parece-nos útil trabalhar com um conceito de deliberação assemblear, com a consciência e a preocupação evidenciadas por Comparato de que a ciência jurídica é fruto e reflexo de um momento histórico.

${ }^{45}$ Cf. L'invalidità..., n. 11, p. 33.

${ }^{46}$ Aliás, etimologicamente, ato deriva de ação. Nesse sentido, Carnelutti aduziu que "Acto es un hecho debido a la fuerza del hombre más bien que a la fuerza de la naturaleza, recibiendo essa fuerza el nombre, precisamente, de acción" (cf. Teoría general..., n. 88, p. 273). Sobre o assunto, v., ainda, Von Tuhr, Derecho civil (trad. de Tito Ravá), v. II, n. 48, pp. 95 e seguintes.
} 
Fatos jurídicos são acontecimentos que geram consequências jurídicas, é dizer, acontecimentos aos quais a ordem normativa atribui relevância jurídica ao ponto de que a partir deles comecem, modifiquem-se ou extingam-se relações jurídicas. ${ }^{47}$ Podem ser acontecimentos naturais (desvio do curso de um rio, decurso do tempo) ou derivados da ação humana. Os últimos dividem-se em involuntários (o nascimento de uma pessoa) e voluntários (o arremesso de uma pedra em uma vidraça). Estes, ao seu turno, podem-ser atos jurídicos lato sensu (lícitos) e atos ilícitos. Os primeiros, por fim, classificam-se em atos jurídicos stricto sensu e negócios jurídicos. ${ }^{48-49}$

Atos jurídicos lato sensu são, melhor explicando, aqueles nos quais a vontade consciente atua como elemento central de seu suporte fático ${ }^{50}$ e aos quais a lei assegura relevância jurídica. Podem ser atos jurídicos stricto sensu ou negócios jurídicos. ${ }^{51}$ Os primeiros são os praticados pelo homem sem que lhe seja possível, deliberadamente, delinear o conteúdo do efeito jurídico pretendido: a prática do ato decorre de um ato

\footnotetext{
${ }^{47}$ Conceituando fatos jurídicos, Betti afirmou que "Hechos jurídicos son, por tanto, los hechos a los que el Derecho atribuye trascendencia jurídica para cambiar las situaciones preexistentes a ellos y configurar situaciones nuevas, a las que corresponden nuevas calificaciones jurídicas" (cf. Teoría general del negocio jurídico, n. 1, p. 6).

${ }^{48}$ Cf. Clovis Bevilacqua, Theoria geral do direito civil, n. 48, pp. 269/270; Vicente Ráo, Ato jurídico, nn. 4/7, pp. 28/39; Orlando Gomes, Introdução ao direito civil, nn. 152/154, pp. 237/240; Caio Mário da Silva Pereira, Instituições de direito civil, v. 1, pp. 391/393; e Silvio Venosa, Direito civil, v. I, p. 378. As classificações desses autores possuem algumas singularidades, sobretudo de nomenclatura, mas substancialmente se equivalem. Para uma análise mais profunda, v. Betti, Teoría general..., nn. 1/3, pp. 3/21; e Carnelutti, Teoría general..., nn. 82/99, pp. 255/293.

${ }^{49}$ Com razão, Antonio Junqueira de Azevedo discordou de que todo ato jurídico em sentido estrito e negócio jurídico sejam categorias do gênero ato lícito, pois é perfeitamente possível que o ato ou negócio seja ilícito. Ser ilícito ou não é uma qualificação que se dá ao ato, o que não faz parte de sua estrutura (cf. Negócio jurídico - existência, validade e eficácia, cap. I, n. 3, pp. 19/20). Também assim Marcos Bernardes de Mello, para quem embora o Código Civil de 2002 distinga ato jurídico stricto sensu de negócio jurídico, errou ao nomear este último de ato jurídico lícito (Título II do Livro III da Parte Geral), pois o ato jurídico lícito é gênero do qual são espécies o negócio jurídico e o ato jurídico stricto sensu. Da maneira como está no Código, tem-se a impressão de que o negócio jurídico não é um ato jurídico lícito (cf. Teoria do fato jurídico - plano da validade, p. 33, nota 1). Os renomados civilistas estão certos mas, como não é nosso intuito aprofundar a matéria, adotamos a classificação tradicional.

${ }^{50}$ Cf. Von Tuhr, Derecho civil, v. II, n. 48, p. 95. Daí ter Silvio Rodrigues, em conhecida monografia, afirmado: "Ponto de partida: o ato jurídico é ato de vontade" (cf. Dos vícios do consentimento, n. 5, p. 9).

${ }^{51} \mathrm{O}$ que a doutrina contemporânea nomeia negócio jurídico a doutrina clássica intitulava ato jurídico em sentido estrito. Veja-se, por exemplo, o art. 81 do Código Civil de 1916. Em razão disso, por exemplo, que a clássica e ainda atual obra de Vicente Ráo chama-se Ato jurídico mas, em realidade, o seu principal objeto é o hoje chamado negócio jurídico. Ressalte-se, porém, que ainda na vigência do Código Civil de 1916 parte da doutrina nacional, inspirada em autores alemães, já utilizava a expressão negócio jurídico (cf. Orlando Gomes, Introdução..., n. 172, p. 263).
} 
volitivo, mas deste não decorre a sua eficácia ou seu conteúdo, ${ }^{52}$ ao agente não é outorgado poder negocial. Exemplos dessa modalidade são o pagamento, o reconhecimento da paternidade, a transferência de domicílio e os atos processuais. ${ }^{53} \mathrm{O}$ negócio jurídico é o campo por excelência da autonomia privada e do direito de autorregulamentação: o agente, por meio de declaração de vontade, persegue um dado e particular efeito jurídico, por ele especificado, enquanto que no ato jurídico stricto sensu também existe manifestação volitiva, mas os efeitos são pré-fixados pelo ordenamento. ${ }^{54}$ Por isso é que, em feliz conceituação, Menezes Cordeiro escreveu ser o negócio jurídico marcado pela liberdade de celebração e pela liberdade de estipulação, ${ }^{55}$ diferentemente do ato jurídico stricto sensu, que embora seja livremente praticado, possui efeitos ex lege, e não ex volutate.

Em qual dessas categorias encaixa-se a deliberação assemblear?

\footnotetext{
${ }^{52}$ Como ensinou Calmon de Passos, nesses atos "a conseqüência da conduta é posta pelo direito objetivo, descartando-se, para a imputação, o real direcionamento da vontade do agente para essa conseqüência. (...) exige-se, para a imputação, esteja o agente na plena posse de suas faculdades volitivas e que, em função delas, tenha agido, ainda que perseguindo objetivo diverso daquele que resultou de sua atividade. (...) O que é irrelevante para a imputação é a correspondência entre o objetivo consciente e voluntariamente perseguido pelo agente e o que de sua conduta efetivamente resultou. Prescinde-se, aqui, da correspondência entre o objetivo perseguido pelo agente e o resultado objetivamente imputável" (cf. Esboço de uma teoria das nulidades aplicadas às nulidades processuais, n. 18, pp. 28/29).

53 Os atos processuais são atos jurídicos stricto sensu, pois as consequências jurídicas deles derivadas independe do conteúdo da vontade de quem os praticou. É irrelevante o objetivo perseguido pelo agente, já que a consequência é a prevista no ordenamento (cf. José Roberto dos Santos Bedaque, Efetividade do processo e técnica processual, pp. 418/419). Embora critique o que chama de dogma da irrelevância da vontade nos atos processuais, a professora portuguesa Paula Costa e Silva bem explica essa relação em Acto e processo, n. 1, pp. 19/20.

${ }^{54}$ Cf. Orlando Gomes, Introdução..., n. 172/173, pp. 263/273; Caio Mário da Silva Pereira, Instituições..., v. 1, pp. 407/408, com indicação de vasta bibliografia nesse sentido; Silvio Venosa, Direito civil, v. I, p. 381; Antigono Donati, L'invalidità..., n. 14, p. 51; e Comparato, "Notas sobre parte e legitimação nos negócios jurídicos", in Ensaios e pareceres de direito empresarial, n. 1, p. 513. Escrevendo sobre os negócios jurídicos, Calmon de Passos observou que "a ordem jurídica abdica de definir a consequiência imputável à conduta, deixando essa definição à vontade dos próprios sujeitos envolvidos na situação qualificada como suposto normativo. Cuida-se da vasta área reservada ao que se denomina de autonomia privada. (...) Nesse particular, exige-se não só a existência de uma vontade lvre e mentalmente sã, mas também se torna um imperativo a correspondência entre a consequiência pretendida e a que foi objeto da vontade manifestada pelo sujeito, no exercício de sua autonomia. (...) Faz-se imprescindível, nessa hipótese, não só a vontade do ato (inicial) com o a vontade do resultado (final)" (cf. Esboço de uma teoria das nulidades aplicadas às nulidades processuais, n. 19, pp. 29/20). A seguinte distinção traçada por Antigo Donati é bastante elucidativa: "negozi giuridici sarebbero soltanto quelle dichiarazioni di volontà che, nei limiti posti dall'ordinamento giuridico, sono fonte immediata di effetti giuridici conforme agli scopi pratici che il soggetto si propone e non quelle dichiarazioni di volontà - qualificate come meri atti giuridici - dalle quali dipende il sorge di un effeto, il quale è determinato direttamente dalla lege e può quindi essere non conforme, anzi talora perfino contrario a quello che il soggetto si propone" (cf. L'invalidità..., n. 14, p. 51). Antonio Junqueira de Azevedo teceu várias críticas à teoria dominante, que enxerga o negócio jurídico sob a ótica da vontade. Criticou também a teoria que analisa o negócio sob a perspectiva da função e, ao final, defendeu teoria que parte da estrutura. Para uma análise de sua teoria, v. Negócio jurídico..., especialmente, cap. I, pp. $1 / 22$.

${ }^{55}$ Cf. SA: Assembleia geral..., n. 70, p. 152. V., ainda, Von Tuhr, Derecho civil, t. II, n. 50, pp. 131 e seguintes.
} 
Boa parte da doutrina, em especial a alemã, a vê como negócio jurídico, amparada principalmente pela ideia de que a vontade de seu emitente (a sociedade) é quem dita os seus efeitos, os quais, portanto, decorrem do particular, e não da lei. ${ }^{56}$ Essa doutrina é criticada, sobretudo por autores italianos, ${ }^{57}$ sob o fundamento de que nem todo ato de vontade que permite ao seu emissor alcançar os efeitos por ele pretendidos é um negócio jurídico. ${ }^{58}$ Além disso, tais críticos dizem que, em realidade, a deliberação não é negócio jurídico porque consiste em um provimento, uma declaração, um ato unilateral da sociedade, o que seria incompatível com aquela figura, que demanda mais de uma parte para que se perfaça.

Veja-se, por exemplo, Antigono Donati, que criticou a visão contratualista ao fundamento de que no contrato as partes miram a satisfação de interesses contrastantes e instalam vínculo jurídico recíproco mediante o consenso, ao passo em que na deliberação os sócios não almejam interesses contrastantes, não instalam um vínculo recíproco e, em regra, não se exige a unanimidade. ${ }^{59}$ Também Mario Vaselli criticou a doutrina que enxerga a deliberação como contrato ao fundamento de que esta consideraria apenas o processo de formação da deliberação, desconhecendo que a vontade da maioria atua como vontade da sociedade no âmbito externo, e que isso é incompatível com a ideia de contrato. ${ }^{60}$ Stefano Villata, por sua vez, embora afirme que existam elementos que sem dúvida aproximam a deliberação da figura do negócio jurídico, entende que no direito

\footnotetext{
${ }^{56}$ Cf. Kübler, Derecho de sociedades (trad. Michèle Klein), p. 342; Von Tuhr, Derecho civil, v. II, n. 53, p. 211; Teófilo de Castro Duarte, $O$ abuso do direito..., n. XI, p. 80; e Ricardo Tepedino, Direito das companhias (coords. Alfredo Lamy Filho e José Luiz Bulhões Pedreira), v. I, n. 257, p. 946. Com vasta indicação de bibliografia, Lobo Xavier afirma que "parece-nos seguro que a generalidade das deliberações sociais apresenta as notas do conceito de negócio jurídico, na medida em que se trata aqui de actos a que devem atribuir-se efeitos de direito em conformidade com a vontade dos seus autores" (cf. Anulação..., n. 45, p. 554/556, nota 14). Também Carvalhosa afirma serem as deliberações sociais negócios jurídicos (cf. Acordo de acionistas, n. 7.3, pp. 147/148), enquanto que Fernando Antonio Maia da Cunha e Walfrido Jorge Warde Júnior traçam o paralelo entre as deliberações e os negócios jurídicos, valendo-se da expressão "negócios deliberativos" (cf. "A arbitragem e os limites...", pp. 748/749). V., ainda, Aurelio Candian, que compara o negócio jurídico privado e o ato administrativo como sendo ambos manifestações de vontade que regulam um caso individual e concreto. Contudo, ressalva Candian que a teoria do negócio jurídico apresenta vários "spazi in bianco" na solução de questões das deliberações, o que justifica a utilização de construções do direito administrativo (cf. Nullità..., n. 15, pp. 33/37).

${ }^{57}$ Veja-se, porém, as menções que Stefano Villata faz a autores italianos que adotam a teoria da deliberação como negócio jurídico (cf. Impugnazioni..., cap. I, n. 4, p. 50, nota 104).

${ }^{58}$ Cf. Pinto Furtado, Deliberações..., n.23, p. 163. Para uma análise aprofundada da doutrina que defende a teoria do negócio jurídico, v. pp. 159 e ss. dessa mesma obra, inclusive a nota 190.

${ }^{59}$ Cf. L'invalidità..., n. 12, pp. 39/40.

${ }^{60}$ Cf. Deliberazioni nulle..., n. 2, pp. 11/12.
} 
societário a categoria do negócio jurídico corre o risco de perder as suas características devido aos princípios do direito societário que se distanciam dos que regem a prática contratual, citando como exemplo a circunstância de que o contrato exige o consenso e a deliberação supera o dissenso. Daí porque defende, ao invés de uma aplicação automática dos cânones do negócio jurídico à deliberação assemblear, deve ser analisado cada caso, para que se conclua qual o campo do direito cujas normas deverão ser invocadas para solucionar problemas relativos à invalidade das deliberações. ${ }^{61}$

Essas objeções, contudo, são facilmente desconstruídas pela figura do negócio jurídico unilateral, que é aquele em que a vontade de apenas uma parte - e não apenas um sujeito, pois a parte é um centro de interesses, isto é um sujeito ou conjunto deles que atuam em prol do mesmo interesse próprio - é suficiente para a produção de consequências jurídicas a que se destina (exemplo: testamento, denúncia do arrendamento, renúncia à servidão etc.). De outro lado existem os negócios jurídicos plurilaterais, que exigem não só concurso de vontades de mais de uma parte como também consenso entre elas. A classificação entre negócios jurídicos uni e bilaterais é colhida na mais autorizada doutrina, como Von Tuhr, ${ }^{62}$ Enneccurus-Kipp-Wolff, ${ }^{63}$ Coviello $^{64}$, Betti ${ }^{65}$, Vicente Ráo ${ }^{66}$, Serpa Lopes, ${ }^{67}$ Caio Mário da Silva Pereira ${ }^{68}$ e Hörster. ${ }^{69}$

${ }^{61}$ Cf. Impugnazioni..., cap. I, n. 4, pp. 51/53. Para Villata, existem inúmeras diferenças estruturais entre a deliberação e o contrato. E, de fato, tais diferenças existem e não iremos nos deter detalhadamente sobre as idéias de Villata. Chama a atenção, contudo, a assertiva de que a deliberação pode ser vista como um procedimento, ao contrário do contrato. A primeira observação que fazemos sobre essa afirmativa é a de que, como apontamos, a deliberação pode ser vista como o procedimento assemblear e como o ato resultando desse procedimento. Portanto, com esse último significado - que é o utilizado quando falamos em anular/desconstituir uma deliberação -, ela deriva de um procedimento, mas não é um procedimento. Uma segunda observação é que, tal qual defendido em clássica obra de Clóvis do Couto e Silva, qualquer obrigação assume as vestes de um processo/procedimento. A relação obrigacional, escreveu esse civilista, é algo que "se encadeia e se desdobra em direção ao adimplemento, à satisfação dos interesses do credor" (cf. A obrigação como processo, p. 17). Portanto, embora Villata esteja rigorosamente correto em afirmar que a deliberação afasta-se estruturalmente do contrato, a afirmação de que o contrato não é um procedimento deve ser vista com um grão de sal.

${ }^{62}$ Cf. Derecho civil, v. II, n. 53, pp. 185 e seguintes.

${ }^{63}$ Cf. Tratado de derecho civil (trad. de Blas Pérez González e José Alguer), t. I, v. II, n. 137, pp. 69 e seguintes.

${ }^{64}$ Cf. Doctrina general..., n. 102, p. 345.

${ }^{65}$ Cf. Teoría general..., cap. V, n. 38, p. 223.

${ }^{66}$ Cf. Ato jurídico, n. 20, p. 65.

${ }^{67}$ Cf. Curso de direito civil, v. I, n. 248, p. 423.

${ }^{68} \mathrm{Cf}$. Instituições..., v. 1, n. 85, p. 425.

${ }^{69}$ Cf. A Parte Geral do Código Civil Português, n. 679, p. 427, 
E, de fato, como bem observou Antigono Donati, o ato unilateral não é aquele que decorre de uma única manifestação de vontade, mas sim da declaração de apenas uma parte. Já o ato plurilateral não é o que decorre de várias manifestações de vontade, mas das manifestações de vontade de mais de uma parte. ${ }^{70}$ Nos negócios bilaterais (contratos), as vontades se defrontam, isto é, estão contrapostas; nos negócios jurídicos complexos, marcham paralelas, como ensinou Serpa Lopes, dando como exemplo desta última categoria o vínculo de sociedade. ${ }^{71}$ A deliberação é um negócio jurídico unilateral, já que derivada da vontade um único indivíduo, a sociedade. ${ }^{72}$

Uma segunda crítica dirigida à teoria do negócio jurídico ampara-se na correta afirmação de que a deliberação não é fruto do consenso: não haveria autonomia privada e não se exigiria unanimidade entre os acionistas, pois a maioria dobra a minoria e faz valer a sua vontade. De acordo com tal crítica, poder-se-ia falar em negócio jurídico apenas nas votações unânimes, já que, ao contrário dos contratos, pelos quais as partes só se comprometem na medida de suas emissões de vontade, as deliberações sujeitam todos os acionistas, ainda que ausentes ou dissidentes. ${ }^{73-74}$

Mas, novamente, a objeção não procede. O negócio jurídico unilateral não exige consenso por uma questão de lógica: ele é emitido por apenas uma parte, sendo um contrasenso demandar-se unanimidade pelo simples fato de que não se pode exigir consenso da parte com si mesma. O consenso só faz sentido quando há confluência de

${ }^{70}$ Cf. Antigono Donati, L'invalidità..., n. 11, pp. 38/39. Também Von Tuhr parece ter qualificado a deliberação como negócio jurídico unilateral (cf. Derecho civil, v. II, n. 53, p. 211).

${ }^{71}$ Cf. Curso de direito civil, v. 1, n. 249, p. 424.

${ }^{72}$ Cf. Teófilo de Castro Duarte, $O$ abuso..., n. XI, pp. 80/81.

${ }^{73}$ Cf. Erasmo Valladão França, "Ilegitimidade de parte e falta de interesse processual da companhia para requerer a anulação das próprias deliberações", in Temas de direito societário, falimentar e teoria da empresa, pp. 380/381; e Invalidade..., p. 41. Do mesmo jeito, Antigono Donati sustentou que "la deliberazione di assemblea, quale volontà di un organo unico, diversa dalla volontà delle persone da esso investite, non può essere quindi che un atto giuridicamente semplice; e tanto nell'interno della persona giuridica, quanto all'esterno, la deliberazione formata si presenta come un atto rigorosamente unilaterale, che può però divenire, direttamente o mediante la dichiarazione degli amministratori, elemento (offerta, accettazione) di un contratto o di altro negozio giuridico bi o pluraterale concluso con terzi. In ogni caso, non vi è nulla di male a precisare col Gierke che la deliberazione è un atto giuridico sociale, o meglio, collegiale dato che il processo di formazione dell'atto collegiale presenta, come abbiamo visto, caratteristiche diverse dal processo formativo del negozio giuridico individuale" (cf. L'invadilità..., n. 13, pp. 48/49).

${ }^{74}$ Já Pietro Trimarchi define deliberação como a proposição normativa que forma o conteúdo da maioria de votos. Em sua concepção, conteúdo do voto da maioria e deliberação coicidem: "la propozione che esprime il voto di maggioranza e quella che esprime la deliberazione sono identiche" (cf. Invalidità delle deliberazioni di assemblea di società per azioni, cap. II, n. 3, pp. 17 e 19). 
vontades, isto é, quando há mais de uma parte, o que não é o caso da deliberação, pois nela não há convergência de vontades sob a perspectiva da parte emissora (a sociedade): o emissor é um só. Sob a perspectiva da parte emissora da deliberação - discrímen utilizado na divisão dos negócios jurídicos em unilaterais e bilaterais - não há a menor razão para se falar em e exigir consenso.

Os que criticam a ideia da deliberação como negócio jurídico sob o fundamento acima desconsideram por completo a categoria do negócio jurídico unilateral, que, como visto, é assentada na melhor doutrina. A crítica confunde negócio jurídico unilateral com negócio jurídico bilateral (contrato), sem atentar para o fato de que ambos são espécies do qual negócio jurídico é gênero. De fato, há diferenças rigorosas entre as deliberações e os contratos, pois as duas categorias (i) possuem diferentes processos formativos, (ii) a vontade da assembleia não é a soma da vontade dos sócios votantes e (iii) a deliberação é um ato de poder da maioria, ao passo em que o contrato é um ato que se constitui como decorrência da paridade de situações jurídicas. ${ }^{75}$ Mas os negócios jurídicos, repita-se, não se limitam aos contratos. A deliberação assemblear não é um contrato - pois lhe falta o concurso de vontades de mais de um emitente e para ela não se exige o consenso -, mas pode ser enquadrada na categoria de negócio jurídico unilateral, ${ }^{76}$ principalmente pelo seguinte motivo: a assembleia ostenta autonomia para estipular o conteúdo e os efeitos que o ato terá.

Uma terceira crítica é encontrada em Mario Vaselli, que rejeitou tratar-se a deliberação de um negócio jurídico porque aquela nem sempre terá por conteúdo criar, regular ou extinguir um direito. ${ }^{77}$ Pode ser, como visto, que ela manifeste uma declaração de ciência ou sentimento. Todavia, mesmo nessas duas hipóteses haverá intuito negocial, pois a assembleia é livre para estabelecer o conteúdo e os efeitos de sua declaração, que é o cerne do conceito de negócio jurídico. Mesmo nessas hipóteses, parece-nos, estaremos diante de um negócio jurídico.

\footnotetext{
${ }^{75}$ Cf. Stefano Villata, Impugnazioni..., cap. I, n. 4, pp. 51/52,

${ }^{76}$ Também defendendo que 'a deliberação social é sempre negócio jurídico unilateral", Priscila Corrêa da Fonseca, Suspensão..., p. 74

${ }^{77}$ Cf. Deliberazioni nulle..., cap. II, n. 2, p. 10.
} 
Outra distinção que existiria entre a deliberação e o negócio jurídico é que, ao contrário deste, que pressupõe uma vontade destinada a operar externamente, aquela, como aponta Von Tuhr, em regra possui eficácia puramente interna (nomeação de administrador, por exemplo). ${ }^{78}$ De fato, como decorrência da regra - que, como tal, apresenta exceções de que a assembleia é o órgão deliberativo e a administração, o executivo, as deliberações podem ser de três tipos: a que forma a declaração social com eficácia puramente interna, a que cria e declara a manifestação social com eficácia externa e a que constitui a declaração social, mas é manifestada externamente por meio de seus administradores. ${ }^{79}$ Porém, não vemos por qual razão isso teria o condão de desnaturar a deliberação como negócio jurídico. Este caracteriza-se, basicamente, pela liberdade conferida pelo ordenamento para que o agente discipline os efeitos que persegue, sendo irrelevante que tais efeitos produzam-se interna ou externa corporis.

A deliberação assemblear, portanto, é um negócio jurídico unilateral. Mas, é preciso depurar ainda mais o conceito.

A doutrina que se debruçou sobre o tema parte da distinção entre atos simples, constituídos pela declaração de vontade de apenas um sujeito, e, do outro lado, atos compostos ou complexos lato sensu, formados por várias manifestações de vontade. Estes últimos podem resultar da ação concursal de vários sujeitos ou do comportamento reiterado de um único deles, caso em que se tratará de um ato continuado. ${ }^{80}$ Sendo um ato resultante da vontade de vários sujeitos, estaremos diante de duas categorias: atos convencionais ou contratos, formados pela junção das vontades de partes distintas, e os atos unilaterais, isto é, constituídos pela vontade de um sujeito único ou de uma parte única formada por vários

\footnotetext{
${ }^{78}$ Cf. Derecho civil, t. II, n. 53, p. 213. Nesse sentido foi Mario Vaselli, embora ele próprio tenha ressalvado que essa deliberação diz respeito também a terceiros, mas preponderantemente produz efeitos internos à sociedade (cf. Deliberazioni nulle..., cap. II, n. 2, pp. 10/11). Realmente, como bem apontado por Fernando Antonio Maia da Cunha e Walfrido Jorge Warde Júnior, "O direito societário (...) disciplina apenas relações internas (excepcionalmente externas com eficácia interna (...)" (cf. "A arbitragem e os limites...", p. 739). Sobre o tema, v. Romano-Pavoni, Le deliberazioni..., n. 5, pp. 56/59.

${ }^{79}$ Cf. Antigono Donati, L'invalidità..., nn. 6 e 10, pp. 24 e 32.

${ }^{80} \mathrm{O}$ ato composto, na definição de Carnelutti - que utiliza a nomenclatura ato complexo -, seria, assim, "una unificación o universitas de actos, cuya pluralidad se combina, en diversa medida, com la unidad" (cf. Teoría general..., n. 184, p. 449).
} 
sujeitos. Estes últimos, por fim, dividem-se em outras três subcategorias: (i) ato coletivo, (ii) ato complexo e (iii) ato colegial. ${ }^{81}$

O ato coletivo é composto por declarações que, embora tenham conteúdo e finalidade idênticos, são juridicamente autônomas. Mas, por serem manifestadas simultaneamente, merecem tratamento unitário. Há mera justaposição de partes idênticas, sem que estas se unam ou se fundam, e não se persegue um único escopo, pois cada declarante possui sua própria esfera de interesses. Os declarantes possuem poderes distintos, mas unidos para a satisfação de interesses paralelos. Um exemplo são as denúncias manifestadas por dois coarrendatários do mesmo imóvel.

Já no ato complexo as declarações são convergentes e homogêneas, isto é, visam ao mesmo fim, e se fundem em um só ato, formando uma declaração grupal. Há um fim unitário, analogia de interesses, atividade homogênea e exercício de um mesmo poder. ${ }^{82}$ Um exemplo é o diploma legal promulgado pelo chefe de estado e referendado pelo primeiro ministro, ou a lei, formada pela vontade do congresso e do chefe de estado. ${ }^{83}$

O ato coletivo é constituído por elementos que existem cada um por si, ainda que sua coexistência seja necessária para que se atinja certo efeito jurídico, enquanto que o complexo é formado por elementos com alto grau de dependência, de modo que cada um refira-se ao outro e sem que possa ser concebido singularmente. ${ }^{84}$ Por isso que naquele os elementos se unem e neste se fundem. $\mathrm{O}$ ato complexo é o resultante da fusão de várias manifestações de vontade, direcionadas a um único fim e no exercício de um único poder; o ato coletivo é formado da união de diversas manifestações de vontade, só que emanadas do exercício de poderes distintos e unidos para a satisfação de interesses paralelos. ${ }^{85}$

\footnotetext{
${ }^{81}$ Cf. Pinto Furtado, Deliberações..., n. 23, pp. 137/138. A qualificação e a classificação dos atos compostos, contudo, como alertou Vicente Ráo, com apoio em Carnelutti, é incerta e divergente (cf. Ato jurídico, n. 18, p. 58).

${ }^{82}$ Cf. Priscila Corrêa da Fonseca, Suspensão..., p. 73; e Antigono Donati, L'invalidità..., n. 11, p. 35.

83 A definição e o primeiro exemplo são de Jorge Henrique Pinto Furtado (cf. Deliberações..., n. 23, pp. 145/146), ao passo em que o segundo exemplo é de Mario Vaselli (cf. Deliberazioni nulle..., n. 3, p. 13). Sobre o assunto, v., ainda, Ricardo Tepedino, Direito das companhias, v. I, n. 257, p. 943.

${ }^{84}$ Cf. Carnelutti, Teoría general..., n. 192, p. 465.

${ }^{85}$ Cf. Antigo Donati, L'invalidità..., n. 11, p. 35. Também entendendo haver incongruência entre interesses contrapostos e atos complexos, Ascarelli, "Vícios das deliberações...”, n. 2, p. 371, nota 2.
} 
Aquele é constituído por todos homogêneos, este pode ser formado por todos não só heterogênos como antagônicos. ${ }^{86}$

Como no ato coletivo as manifestações de vontade são autônomas e não se fundem, os efeitos jurídicos referem-se a cada um dos sujeitos individuais. Como no ato complexo as vontades se fundem, os efeitos jurídicos referem-se à coletividade vista como um todo orgânico. ${ }^{87}$

Por fim, o ato colegial, visto por alguns como uma espécie de ato complexo, de fato assemelha-se a esse, mas distingue-se pelas seguintes razões: embora em ambos haja a intervenção conjunta de uma pluralidade de sujeitos que, mediante atos individuais, cooperam como um só sujeito na formação de um ato unitário, no ato complexo os sujeitos dispõem de poderes diversos e estão ligados a interesses distintos, mas paralelos e convergentes, enquanto que no ato colegial os sujeitos não titularizam poderes individuais, mas apenas um poder coletivo e único, indivisível e atribuível a todos, de participar da realização do ato final, que, pelas regras da maioria, representará a coletividade. ${ }^{88}$ No ato complexo as vontades se fundem, perdendo a sua individualidade, ao passo em que no ato colegial elas se unem, permanecendo distintas e discerníveis. ${ }^{89}$ As vontades unem-se e formam um todo unitário, mas sem perder a sua individualidade. E, vale ressaltar,

\footnotetext{
${ }^{86}$ Esse último aspecto é, todavia, questionado por Von Tuhr (cf. Derecho civil, v. II, n. 53, p. 212).

${ }^{87}$ Cf. Antigono Donati, L'invalidità..., n. 11, pp. 35/36.

${ }^{88}$ Cf. Pinto Furtado, Deliberações..., n. 23, p. 149; e Romano Pavoni, Le deliberazioni..., nn. 8/9, pp. 24/31.

${ }^{89}$ Cf. Priscila Corrêa da Fonseca, Suspensão..., p. 74. Também Stefano Villata rejeitou ser a deliberação uma fusão dos votos. Para ele a deliberação é uma abstração e o voto assume relevo apenas na medida em que influi o procedimento formativo da deliberação. Ele influencia referido procedimento, mas não constitui a deliberação (cf. Impugnazioni..., cap. I, n. 4, pp. 43/44 e 52). Essa distinção entre fusão e união, contudo, não é muito clara. Há doutrinadores que dizem que no ato colegial as vontades se fundem, como é o caso de Mario Vasselli: "L'atto collegiale è un atto unico formato dalla fusione delle dichiarazioni dei membri di uno stesso organo" (cf. Deliberazioni nulle..., n. 3, p. 17). Essa é também a posição de juristas brasileiros de peso, como Comparato (cf. "Da imprescritibilidade...", pp. 216/218), Erasmo Valladão França (cf. Invalidade..., n. 11, p. 42) e Ricardo Tepedino (cf. Direito das companhias, v. I, n. 257, p. 943), que escreveram que as declarações de vontade fundem-se para formar um ato único. Todavia, parece-nos que a primeira corrente é que está com a razão, basicamente pela idéia de que, mesmo após perfazer-se a deliberação, os votos permanecem como atos individualizáveis. Não há fusão, pois os votos não se tornam um amálgama só (nem mesmo os votos da maioria). Os votos são elementos essenciais ao procedimento formativo, mas o ato final (deliberação) é um ato unitário que foi constituído mediante o citado procedimento; a deliberação é um ato unitário, mas não pode ser decomposta em vários pequenos-atos (votos). Por isso, parece-nos que o correto é considerar que os votos concorrem para a deliberação, a qual nasce como um novo ato, resultado do procedimento assemblear. De qualquer modo, a questão é mais conceitual do que prática, visto que, sob qualquer ótica, a desconstituição do voto irá influenciar a deliberação apenas quando desmantelar a maioria. E a essa conclusão se chega quer se entenda que os votos se fundiram, que se uniram ou, ainda, que concorreram para a formação da deliberação.
} 
conforme ensinaram Galgano e Lamy Filho-Bulhões Pedreira, o que distingue a deliberação do agregado de atos individuais é a organização por efeito do procedimento deliberativo. ${ }^{90}$

É justamente nessa última categoria que se encaixa a deliberação assemblear.

Sob a perspectiva formativa, a deliberação é um ato colegial, ${ }^{91}$ pois nela há a atuação de uma pluralidade de sujeitos. Mas, sob a perspectiva estrutural, trata-se de ato unitário, simples, imputável ao colégio. ${ }^{92}$ Além disso, o ato colegial diverge do negócio jurídico bilateral (contrato) porque neste há duas partes, contrapostas entre si, enquanto que naquele há vários sujeitos atuando perante a mesma parte; no contrato há vontades que se entrecruzam, enquanto que na deliberação há vontades paralelas; nesta as declarações se unem, naquele forma-se um vínculo jurídico, mas sem unificação. Por fim, ao contrário do que ocorre nos contratos, nas deliberações as partes não pretendem obrigar-se reciprocamente, mas sim produzir um único efeito jurídico, em especial perante terceiros. ${ }^{93}$

E nada obstante se defenda que a deliberação seja formada apenas pela união dos votos da maioria, desprezando-se os votos vencidos, ${ }^{94}$ não concordamos com essa posição. As deliberações são formadas por todos os votos manifestados validamente na assembleia,

\footnotetext{
${ }^{90}$ Respectivamente, cf., La società..., cap. 7, n. 6, p. 211; e "Acordo de acionistas sobre exercício do direito de voto", in A Lei das S/A, v. II, p. 550. O seguinte exemplo, também colhido na mesma passagem dos dois autores do anteprojeto que resultou na Lei 6.404/76, é bastante útil: "se um pesquisador de opiniões pergunta a todos os sócios de sociedade qual deva ser a decisão social sobre determinada questão, o conjunto das respostas que recebe é um agregado de atos individuais, não uma deliberação coletiva; ainda que todos se manifestem no mesmo sentido, essas manifestações não exprimem a vontade social - não são imputáveis ao grupo, como um todo. (...) Para que exista deliberação social é necessário que os sócios se manifestem sobre proposta de deliberação na qualidade de membros do grupo e com o fim de definir a vontade social, o que pressupõe um procedimento que organize seus atos". O mesmo exemplo é colhido em outro parecer de Bulhões Pedreira (cf. "Deliberação de sócios...”, p. 656).

${ }^{91}$ Cf. Bulgarelli, Comentários à Lei das S.A., v. 4, p. 161.

92 Cf. Redenti, Il giudizio civile con pluralità di parti, cap. II, n. 50, p. 68, nota 62; Antigono Donati, L'invalidità..., n. 13, p. 49; e Lamy Filho-Bulhões Pedreira, “Acordo de acionistas...", in A Lei das S/A, v. II, pp. 550/551.

${ }^{93}$ Cf. Coviello, Doctrina general..., n. 102, p. 346. Citando Coviello, Vicente Ráo também expõe essa diferenciação (cf. Ato jurídico, n. 15, p. 57).

${ }^{94}$ Essa é a opinião de Galgano, La società..., cap. 7, n. 6, p. 211, segundo quem tal ideia teria a função de ocultar o dissenso e justificar o princípio majoritário, e de Pinto Furtado, Deliberações..., n. 23, p. 150. Aparentemente é também a de Erasmo Valladão França, pois afirma que "as deliberações de assembléia se formam por manifestações de vontade convergentes" (cf. Invalidade..., n. 11, p. 42); de Comparato, que escreveu que as deliberações formam-se pela "idêntica manifestação de vontade de vários sujeitos" (cf. "Da imprescritibilidade...", p. 216); e de Ascarelli, para quem "Le deliberazioni si formano col concorso della maggioranza dei voti" (cf. Appunti di dirito commerciale - società e associazioni commerciale, p. 256).
} 
inclusive os vencidos, mas a sua orientação é definida pelos votos da maioria. Os votos da minoria constituem, integram, compõem a deliberação, mas não têm o condão de definir o seu sentido. Adotar esse entendimento é a única forma de legitimar o ato, reconhecendo o direito de participação dos sócios e o exercício do contraditório. ${ }^{95}$ Tanto é isso verdade que os votos da minoria compõem a deliberação que pode ser que, anulados alguns votos, $a$ minoria se torne maioria. Se a deliberação não fosse composta pelos votos vencidos, esses nunca poderiam, em caso de desconstituição de votos, prevalecer. Essa é, parece-nos, a prova cabal de que a deliberação não é composta apenas pelas declarações da maioria vencedora.

Para arrematar, digna de nota é a quase sempre polêmica posição de Pontes de Miranda. Para ele, é errônea qualquer classificação global dos atos da assembleia geral, na medida em que a natureza desses varia de acordo com os seus respectivos conteúdos. A nomeação de administradores, por exemplo, depende da aceitação dos eleitos e, logo, tem caráter negocial; a deliberação que aprova ou desaprova o balanço é mera declaração de conhecimento e, portanto, ato jurídico em sentido estrito; a deliberação que tenha por objeto a incorporação, a fusão, cisão ou a dissolução de sociedade é negócio jurídico plurilateral, assim como a modificação do objeto social etc. ${ }^{96}$

95 Embora Pinto Furtado defenda que os votos minoritários são excluídos do resultado final do processo formativo, isto é, da deliberação vista como ato, pois são só eles que "lhe integram o output, fundidos numa declaração unitária da vontade colectiva", reconhece que "não pode ignorar-se portanto que, na formação e estrutura da deliberação entram também, conjuntamente com os maioritários, os votos minoritários, os quais, deste modo, participam, por assim dizer, do seu input". Há, para ele, uma pluralidade formativa, mas não uma pluralidade de resultado (cf. Deliberações..., n. 23, p. 151). Na mesma direção, embora não adotem expressamente a posição por nós defendida, Lamy Filho-Bulhões Pedreira também afirmam que a deliberação social tem "o conteúdo determinado pela maioria dos votos" (cf. "Acordo de acionistas...", p. 551), de onde se pode extrair que apenas o conteúdo, mas não a própria deliberação, é determinado pela maioria, pois, caso contrário, não haveria sentido em terem aqueles ilustres juristas optado pelo vocábulo "conteúdo". E, de fato, os mesmos autores afirmam que "o princípio majoritário diz respeito à determinação do conteúdo do ato coletivo, mas não modifica a unidade do ato. Por isso, o ato coletivo criado pelo procedimento de deliberação - com o conteúdo determinado pela maioria dos votos - é ato de todo o grupo". Embora não chegue à conclusão ora defendida, também Walfrido Warde Jr. sinaliza para o seu acerto, ao afirmar que "a deliberação é fruto de uma comunhão de vontades, nem sempre convergentes" (cf. "Qual o modelo de governança corporativa que exsurge da disciplina das reorganizações societárias no Brasil", in Walfrido Warde Jr. (coord.), Fusão, cisão, incorporação e temas correlatos", n. 2.2.2, p. 136).

${ }^{96}$ Cf. Tratado de direito privado, t. 50, n. 5.322, pp. 277/282. Com apoio em Antonio Junqueira de Azevedo, Erasmo Valladão França defende que, em que pese à classificação de Pontes de Miranda, no mais das vezes as deliberações serão atos de hierarquia, por dirigirem-se em regra aos administradores, seus naturais destinatários (cf. Invalidade..., n. 12, pp. 51/52). E, realmente, Donati parece concordar com essa posição, ao afirmar que as deliberações que formam e manifestam a vontade com eficácia interna ou externa são negócios jurídicos, embora não o sejam as que formam a vontade social, mas determinam que essa seja manifestada por seus administradores. Nesse último caso, a vontade que emanou da deliberação é apenas um 
Não se pode concordar com a objeção de que a "deliberação" de constituição da sociedade é um negócio jurídico plurilateral e, portanto, essa seria uma exceção à ideia de que a deliberação é um negócio jurídico unilateral, ${ }^{97}$ por uma simples razão: nesse momento, ainda não há sociedade e, consequentemente, tampouco órgãos sociais, de modo que não se pode falar em deliberação social ou deliberação assemblear. A deliberação é de subscritores, não de acionistas, de modo que as manifestações de vontade estão em um momento anterior à própria constituição do ente grupal e, portanto, não formam manifestação de vontade coletiva. De fato, o negócio jurídico, aí, é plurilateral, mas não é deliberação e, portanto, não infirma a tese ora defendida. Ascarelli teceu aguda crítica à posição de Pontes de Miranda, embora sem lhe direcioná-la. ${ }^{98}$ Tampouco é negócio jurídico plurilateral a deliberação que tem por objeto a incorporação, a fusão, cisão ou a dissolução de sociedade. A deliberação com esse objeto é, como qualquer outra, um ato unitário da sociedade; quais serão os seus desdobramentos no mundo exterior (por exemplo, a fusão com outra sociedade), pouco importa.

Também não é correto sustentar que a deliberação que aprova ou desaprova as contas apresentadas pelos administradores é ato jurídico em sentido estrito, sob o fundamento de que os seus efeitos estariam vinculados pela lei, já que a assembleia poderia apenas rejeitá-las ou aprová-las. A incorreção deve-se a um erro de premissa: nessa votação não existem apenas duas condutas possíveis, pois a assembleia pode aprovar as contas e, por exemplo, fazer uma ressalva; desaprovar mas assinalar prazo para que o administrador corrija o equívoco; e daí por diante. Franqueia-se à assembleia um semnúmero de condutas, de modo que também nesses casos há certa margem de liberdade para que a sociedade estipule os efeitos da deliberação.

elemento do negócio jurídico. E até que a vontade seja declarada pelo adminsitrador, o negócio jurídico não existe (cf. L'invalidità..., n. 14, pp. 53/54).

${ }^{97}$ Cf. Pontes de Miranda, Tratado de direito privado, t. 50, n. 5.322, p. 278; e Ricardo Tepedino, Direito das companhias, v. I, n. 257, p. 946.

${ }^{98}$ Para Ascarelli, era óbvia a distinção entre deliberação social (manifestação de uma parte: a sociedade) e a constituição da sociedade, "em que cada subscritor é encarado como 'uma' parte distinta, justamente pelo fato de não haver ainda sociedade. Na constituição da sociedade há, a meu ver, um 'contrato' plurilateral, à vista da contraposição de interêsses entre os sócios, que obsta a possibilidade de falar em ato complexo no sentido técnico da expressão; na deliberação, um ato colegial, manifestação única de vontade, embora resultante, por seu turno, das declarações de mais pessoas, sendo, por isso, também nesta hipótese, inapropriada a classificação do ato complexo, no sentido técnico do têrmo" (cf. "Vícios das deliberações...", n.2, p. 371, nota 2 ). 
A questão é tormentosa e, embora Pinto Furtado tenha certa dose de razão ao conceituar a deliberação como ato jurídico sui generis, ${ }^{99}$ pois possui tantas peculiaridades que é difícil enquadrá-la nas categorias tradicionais de atos jurídicos, cremos que ela pode ser vista como negócio jurídico unilateral colegial. ${ }^{100}$ Negócio jurídico bilateral (contrato) ela nunca será porque lhe faltam os dois principais elementos essenciais desses atos jurídicos: (i) concurso de vontades de partes diversas (e não sujeitos diversos) e (ii) consenso. Ela será sempre negócio jurídico unilateral, pois fruto da declaração de uma única parte: a sociedade. Por fim, não se trata de negócio jurídico simples, pois não é formada pela declaração de um só agente ou vários agentes constituídos em partes contrapostas; trata-se de negócio complexo, resultante de várias vontades paralelas, que se unem e que são emitidas por sujeitos de uma mesma parte - a sociedade -, regidas pelo princípio majoritário.

\section{Vícios dos atos jurídicos em geral}

Embora o regime de invalidades do direito societário seja autônomo e distanciese do regime das nulidades do direito civil (v. item 7 a seguir), aquele emana deste ${ }^{101}$ e, assim, nosso estudo deve partir deste.

Não existe uniformidade quanto à classificação dos vícios dos atos jurídicos, ${ }^{102}$ mas é possível traçar, com certa segurança, os elementos comuns às várias teorias sobre o assunto. Existente é o ato que ostenta todos os elementos nucleares que juridicamente o

\footnotetext{
${ }^{99}$ Cf. Deliberações ..., n. 23, p. 166.

100 Apesar de não conceder essa definição, Betti defendia que o ato colegial é uma espécie de negócio unilateral, caracterizado por ser emitido pó por pessoas componentes de um mesmo órgão. E como exemplos de "órganos colegiales, colegialmente deliberantes", cita como exemplo os supremos Conselhos de Estados, os colégios judiciais e os órgãos de administração das sociedades por ações, como a assembleia geral e o conselho de administração (cf. Teoría general..., n. 38, p. 224).

${ }^{101}$ Cf. Angeles Alcala Diaz, La impugnacion..., p. 78.

${ }^{102}$ Para se ter uma ideia, Caio Mário da Silva Pereira chega a afirmar que "a matéria é muito obscurecida, carece de boa exposição dogmática, e alimenta acentuada desarmonia entre os escritores, não somente no que se refere à fixação dos conceitos, como ainda no que diz respeito à terminologia, que é algo desencontrada e imprecisa" (cf. Instituições..., v. I, p. 537). Da mesma forma Antônio Junqueira de Azevedo, para quem a doutrina vem há muito fazendo alusão a negócios inexistentes, inválidos e ineficazes, mas "não se tem conseguido fixar, com precisão, em que cada situação se distingue da outra". Ainda de acordo com o eminente civilista, a teoria das nulidades é reconhecida pela doutrina como das mais difíceis do direito, a ponto de "Sobre ela, pode-se dizer, sem blogue, que o único ponto em que todos estão de acordo é que não há acordo a seu respeito" (cf. Negócio jurídico..., p. 25). Veja-se a resenha da doutrina feita por Junqueira de Azevedo, que demonstra o caos não só terminológico/conceitual como também classificatório que impera na doutrina das invalidades dos atos jurídicos (pp. 27/29).
} 
constituem como tal. Além de existir no mundo fático - pois seria um contrasenso falar-se de um não ato -, existe também no mundo jurídico. Se estão presentes todos os elementos nucleares mas o ato é inquinado por outro vício, o suporte fático concretiza-se no mundo jurídico, porém de forma deficiente: ele existe, mas pode ser inválido ou ineficaz. ${ }^{103}$ Válido é o ato perfeito, isto é, de acordo com os requisitos do suporte fático previsto pela norma que o prevê ou que, embora em desacordo com essa moldura, possua defeitos que o sistema repute irrelevantes a ponto de não lhe impor sanções como a ausência de eficácia. ${ }^{104}$ Eficaz, por fim, é o ato que possui todos os fatores necessários para produzir os efeitos a que se destina. ${ }^{105}$

Invalidade é a sanção imposta ao ato que, embora existente, foi praticado em desobediência aos seus requisitos legais, isto é, que não possui os requisitos necessários para a sua configuração objetiva. ${ }^{106}$ A validade do ato, portanto, depende de sua sujeição às exigências legais, variando o grau da sanção de ineficácia proporcionalmente à relevância que o ordenamento atribui aos requisitos desatendidos. Em regra, um ato válido será também eficaz e, um inválido, ineficaz.

Em uma acepção lata, ineficácia é empregada para todos os casos em que o ato jurídico não produz efeitos e, portanto, trata-se de gênero do qual invalidade é espécie, pois o ato inválido, em regra, será inapto a produzir os efeitos a que se destina. Em uma acepção estrita, ineficácia se opõe a invalidade e diz respeito ao ato que, embora possua todos os seus elementos essenciais - isto é, seja válido -, não produz efeitos por conta de

\footnotetext{
${ }^{103}$ Cf. Marcos Bernardes de Mello, Teoria do fato jurídico - plano da validade, pp. 41/42. O autor cita como exemplo o contrato de compra e venda, que possui como elementos nucleares o acordo de vontades, o objeto (a coisa) e o preço. Faltando algum desses elementos, o contrato será inexistente; mas estando todos eles presentes, pode ser que incida algum vício sobre eles, como, por exemplo, o acordo de vontades não seja manifestado por pessoas capazes, o objeto seja impossível ou o preço seja fixado em moeda que não a nacional. Nesses casos, em decorrência da deficiência em elemento nuclear o ato é inválido (p. 42, nota 17).

${ }^{104}$ Cf. Marcos Bernardes de Mello, Teoria do fato..., p. 34. No sistema do Código Civil, o negócio jurídico é válido desde que preencha certos requisitos relacionados à pessoa do agente, ao objeto da relação e à forma da emissão de vontade. O art. 104 do CC alude a agente capaz, objeto lícito, possível, determinado ou determinável, e forma adequada.

${ }^{105}$ Essa é a classificação de Antônio Junqueira de Azevedo, que faz menção a elementos de existência, requisitos de validade e fatores de eficácia (cf. Negócio jurídico, p. 30).

${ }^{106}$ Cf. Pontes de Miranda, Tratado de direito privado, t. IV, n. 362, p. 28; Zeno Veloso, Invalidade do negócio jurídico - nulidade e anulabilidade, n. 25, p. 146; e José de Oliveira Ascensão, Direito civil: parte geral, v. II, n. 204, p. 314.
} 
algum elemento externo, como o não implemento de termo ou de condição. ${ }^{107}$ Nessa última perspectiva, existem quatro categorias de atos viciados, em uma escala crescente de ineficácia: ${ }^{108}$ ineficazes stricto sensu, anuláveis, nulos e inexistentes. ${ }^{109}$

A ineficácia stricto sensu aplica-se ao ato para o qual, embora válido, não concorre algum elemento que lhe é alheio e do qual dependem os seus efeitos. ${ }^{110}$ Já a inexistência - categoria originalmente concebida para fundamentar a ineficácia absoluta de atos praticados no âmbito do direito de família, como, por exemplo, o casamento de pessoas do mesmo sexo, ${ }^{111}$ quando este ainda era repelido - está ligada à falta de elemento essencial do ato, sem o qual este sequer se perfaz juridicamente. $\mathrm{O}$ ato foi praticado e existe faticamente, mas não possui existência jurídica. ${ }^{112}$ Trata-se de categoria polêmica e que até hoje não é completamente aceita pela doutrina. ${ }^{113}$

${ }^{107}$ Cf. Orlando Gomes, Introdução..., n. 276, p. 471. Também atrelando a invalidade a uma circunstância interna e a ineficácia a uma circunstância externa, v. Mario Vaselli, Deliberazioni nulle..., cap. III, n. 2, pp. $27 / 28$.

${ }^{108}$ Antonio Junqueira de Azevedo criticou essa classificação, que coloca os atos inexistente e ineficaz ao lado do nulo e do anulável: "Não é lógico que se continue a colocar, ao lado do nulo e do anulável, o negócio dito inexistente, como se tratasse de um tertium genus de invalidade. Não há uma gradação de invalidade entre o ato inexistente, o nulo e o anulável. Ao negócio inexistente opõe-se o ato existente (este é que pode ser nulo, anulável, ou válido). A dicotomia 'negócio existente - negócio inexistente', de um lado, e a tricomotia 'negócio válido - negócio nulo - negócio anulável', de outro, estão em planos diferentes. (...) Da mesma forma, o negócio ineficaz em sentido estrito também não é, ao lado do nulo e do anulável, um tertium genus (ou quartum genus, para os que admitem também a inexistência). Ao negócio ineficaz se opõe o negócio eficaz" (cf. Negócio jurídico..., cap. 2, n. 5, p. 63).

109 O Código Civil de 2002, assim como já o fazia o Código Civil de 1916, adotou os termos nulidade e anulabilidade, abandonando a antiga divisão da nulidade em absoluta e relativa, que fora acolhida pelo Regulamento $\mathrm{n}^{\mathrm{o}} 737 / 1850$.

${ }^{110}$ Cf. Angeles Alcala Diaz, La impugnacion ..., pp. 78/79. No mesmo sentido, Caio Mário da Silva Pereira conceitua ineficácia stricto sensu como "a recusa de efeitos quando, observados embora os requisitos legais, intercorre obstáculo extrínseco, que impede se complete o ciclo de perfeição do ato" (cf. Instituições..., v. I, p. 539).

${ }^{111}$ De acordo com Roque Komatsu, a noção de ato inexistente teria surgido no começo do século XIX, no campo do direito matrimonial francês, no qual, em razão de vigorar regra de que não há nulidade sem expressa cominação legal, forjou-se uma saída jurídica para tornar ineficazes certos casamentos que feririam a moral da época, como, por exemplo, aqueles entre pessoas do mesmo sexo (cf. Da invalidade no processo civil, pp. 154/157).

${ }^{112}$ Diferentemente do ato nulo, que "reúne os elementos necessários à sua constituição, mas apresenta defeito que a lei considera bastante grave para lhe recusar validade", o ato inexistente sequer chega a se formar, "porque lhe falta requisito indispensável à sua existência jurídica" (cf. Orlando Gomes, Introdução..., n. 275, p. 469). Para uma análise da categoria da inexistência e da sua evolução histórica, não apenas no direito processual, é consulta obrigatória a obra La sentenza civile inesistente, de Chiara Besso. V., ainda, o nosso É possível a chamada relativização da coisa julgada?, n. 5, p. 62, onde analisamos a doutrina que tratou do assunto.

${ }^{113}$ No direito processual, apontou Flávio Yarshell que "a doutrina é consideravelmente incerta a propósito do tema e, de forma não pouco freqüente, a referência à categoria peca pela falta de critérios objetivos e envereda para o casuísmo" (cf. Ação rescisória - juízos rescindente e rescisório, n. 78, p. 24 1). Ainda sobre o tema, v. a resenha doutrinária sucinta, mas elucidativa, feita por Eduardo Talamini sobre as principais posições sobre o assunto (cf. Coisa julgada e sua revisão, n. 5.4, pp. 294 e ss.) 
Invalidade é considerada gênero do qual nulidade e anulabilidade são espécies. ${ }^{114-}$ ${ }^{115}$ Essa posição é adotada pelo Código Civil, que intitula o Capítulo V do Título I do Livro III da Parte Geral com a frase "Da invalidade do negócio jurídico" e distingue, nos artigos nele contidos, nulidade de anulabilidade (arts. 166/184).

A nulidade é a sanção imposta ao ato contra legem, isto é, àquele que infringe uma proibição que, embora não necessariamente legal, tutela um interesse público ou que suplanta a esfera das partes envolvidas. Costuma-se atrelá-la ao desrespeito à ordem pública, ao interesse geral, à moral e aos bons costumes ${ }^{116-117-118}$ - por mais fluidos que sejam tais conceitos. O regime da nulidade caracteriza-se, por isso, afirma a doutrina tradicional, por demandas cujo exercício não é submetido a prazos e legitimidades específicas, na medida em que há um interesse geral na identificação dos vícios. Para essa espécie de vício vigoram os seguintes preceitos: (i) a nulidade se opera de pleno direito; (ii) a nulidade pode ser invocada por qualquer interessado, pelo Ministério Público e de

${ }^{114}$ Cf. Pontes de Miranda, Tratado..., t. IV, n. 362, p. 29; Marcos Bernardes de Mello, Teoria do fato jurídico - plano da validade, p. 35, nota 4; Zeno Veloso, Invalidade..., n. 14, pp. 26/29; e José de Oliveira Ascensão, Direito civil..., n. 205, p. 315 .

${ }^{115}$ Nulidade é o termo utilizado nos mais variados ordenamentos (nullitè, nulità, nichtigkeit etc). Já o termo anulabilidade sofre variações. No direito italiano se diz anulabilidade, ao passo em que no francês se prefere a denominação nulidade relativa e no alemão impugnável (cf. Angeles Alcala Diaz, La impugnacion..., p. 78). No Brasil, utilizam-se os termos nulidade e anulabilidade e, em menor grau, nulidade absoluta e nulidade relativa. Na doutrina francesa, como aponta Heitor Sica, prefere-se falar em nulidades absolutas e relativas (cf. "Contribuição ao estudo da teoria das nulidades: comparação entre o sistema de invalidades no novo Código Civil e no direito processual civil", in Impactos processuais do direito civil (coord. Cassio Scarpinella Bueno), p. 184).

${ }^{116}$ Cf. Enneccurus-Kipp-Wolff, Tratado..., t. I, v. II, n. 189, pp. 354 e seguintes; Von Tuhr, Derecho civil, v. II, n. 55, pp. 247 e seguintes; Zeno Veloso, Invalidade..., n. 16, p. 35; e Mario Vaselli, Deliberazioni nulle..., cap. III, n. 5, p. 31. Caio Mário da Silva Pereira apontou que o legislador brasileiro desprezou o critério do prejuízo, desconsiderando o velho princípio francês de que não há nulidade sem prejuízo ("pas de nullité sans grief"). Preferiu o legislador pátrio o princípio do respeito à ordem pública, assentando a nulidade na infração de normas que contenham esse caráter (cf. Instituições..., v. I, p. 540).

${ }^{117}$ Não se deve confundir a ligação da nulidade com violação ao interesse geral com a violação a uma norma cogente, imperativa. Pode haver violação a uma norma dessa espécie sem que haja nulidade. O critério é o interesse tutelado. Nesse sentido, segue a seguinte passagem de Antigono Donati: "non tutte le violazioni di norme cogenti (proibitive) danno luogo a nullità, ma quelle soltanto delle norme proibitive poste nell'interesse generale" (Cf. L'invalidità..., n. 24, p. 99).

${ }^{118}$ Há, contudo, quem defenda a divisão da nulidade em absoluta e relativa: embora a nulidade seja tipicamente entendida como aquela em que está em jogo um interesse geral, e não particular, "examinando algumas figuras básicas de nulidade, verificamos que há um interesse particular que é contemplado em primeira linha". Exemplo disso seria, no direito português, a simulação: embora o ato simulado seja nulo por expressa disposição legal, a anulação do ato simulado tutela, antes de tudo, os particulares interessados. Por isso que "a nulidade relativa é assim aquela em que não há prioritariamente um sujeito que é tutelado; na nulidade absoluta pode pelo contrário haver vários interessados particulares, mas a tutela é em primeira linha de um interesse geral". Por conta dessa subdivisão, fica de certa forma afetada a distinção entre nulidade e anulabilidade (cf. José de Oliveira Ascensão, Direito civil..., nn. 207/209, pp. 318/319 e 322/323). 
ofício pelo juiz (CC, art. 168); e (iii) o negócio nulo não é passível de confirmação e, em regra, não convalesce pelo decurso do tempo (CC, art. 169). ${ }^{119}$ Ademais, diferentemente do anulável, o ato nulo não pode ser ratificado (CC, arts. 169 e 172): se as partes querem obter os efeitos jurídicos que pretenderam com o ato, devem praticá-lo novamente. Nessa hipótese, haverá o perfazimento do ato - não a sua ratificação - e os efeitos derivarão do segundo. $^{120}$

Já a anulabilidade é a sanção à violação a normas ditadas em proteção de interesses de pessoas ou grupos específicos. Existe imperfeição não tão grave que a lei franqueia ao interessado a opção entre pleitear o reconhecimento de sua ineficácia ou deixar que seus efeitos transcorram normalmente, convalidando-se pelo decurso do tempo. ${ }^{121}$ De tal sorte, as medidas judiciais destinadas ao reconhecimento do vício em regra sujeitam-se a prazos decadenciais breves e só podem ser adotadas pelos sujeitos a favor de quem as normas foram estabelecidas. ${ }^{122}$ Só os interessados podem alegar a anulabilidade, não cabendo iniciativa do Ministério Público e tampouco pronúncia de ofício (CC, art. 177). O ato anulável, ainda, pode ser confirmado (CC, art. 172) e é sanado pelo decurso do tempo.

Uma das distinções entre o ato nulo e o anulável, como visto, é que, ab initio e de pleno direito, aquele não produz os efeitos a que se destina (quod nullum est, nullum producit effectum), ${ }^{123}$ ao passo em que o segundo produz efeitos provisórios que, se não impugnados adequada e tempestivamente, trasmudam-se em definitivos. Em razão disso,

\footnotetext{
${ }^{119}$ No sistema do Código Civil, ato nulo é, alternativamente, o praticado por pessoa absolutamente incapaz, que possui objeto ilícito, impossível ou indeterminável, que desrespeita a forma cominada para a sua prática ou que é simulado (CC, arts. 166/167).

${ }^{120}$ Cf. Silvio Venosa, Direito civil, v. I, p. 594.

${ }^{121}$ Existem três formas pelas quais convalesce o ato anulável: decurso do tempo, que extingue o direito à anulação (decadência); confirmação (CC, arts. 172 e 173); e suprimento da autorização, nas hipóteses em que a ausência deste torna o ato anulável (CC, art. 176) (cf. Caio Mário da Silva Pereira, Instituições..., v. I, pp. 546/548). Mais genericamente, Silvio Venosa alude apenas ao decurso do tempo e à ratificação (cf. Direito civil, v. I, p. 601). E, de fato, a terceira hipótese indicada pelo primeiro autor é particular a alguns vícios.

${ }^{122}$ Cf. Angeles Alcala Diaz, La impugnacion..., pp. 80 e 82; e José de Oliveira Ascensão, Direito civil..., n. 206, p. 316. Também atrelando a nulidade ao interesse social e a anulabilidade ao privado, Silvio Venosa, Direito civil, v. I, pp. 588 e 591: "Devemos ter em mente que a nulidade repousa sempre em causas de ordem pública, enquanto a anulabilidade tem em vista mais acentuadamente o interesse privado". Da mesma forma Orlando Gomes, Introdução..., n. 279, p. 474.

${ }^{123}$ De acordo com Zeno Veloso, "normalmente, como regra geral, o negócio nulo não produz quaisquer efeitos jurídicos" (cf. Invalidade..., n. 25, p. 146). Sobre o assunto, v., ainda, Coviello, Doctrina general..., n. 106, p. 359; José de Oliveira Ascensão, Direito civil..., nn. 205/206, pp. 316/317; e Hörster, A Parte Geral..., n. 347 , p. 212.
} 
para alguns autores o decreto judicial da nulidade gera efeitos ex tunc, pois apenas limitarse-ia a declarar um estado jurídico que, desde o momento em que constituído o ato viciado, já era marcado pela ineficácia, ao passo em que a pronúncia sobre a anulabilidade geraria efeitos ex nunc, pois os seus efeitos provisórios foram produzidos e só são extirpados do mundo jurídico a partir do momento em que sobrevenha uma mudança na ordem jurídica.

Em suma, no regime geral do direito privado, a principal diferença entre nulidade e anulabilidade é que aquela está a serviço do "interesse social" - por mais que esse conceito indeterminado seja, repita-se, fluido e difícil de ser definido - e esta diz respeito a interesses privados. Em decorrência disso, possui legitimidade para suscitar a nulidade qualquer interessado ou o Ministério Público; pelos mesmos motivos, ela deve ser pronunciada de ofício. A anulabilidade depende de alegação de interessados e deve ser necessariamente decretada por provimento judicial, ao passo em que a nulidade opera-se pleno direito e não requer decisão judicial. O que justificaria a necessidade de pronunciamento sobre a nulidade é a insegurança que a dúvida sobre a validade do ato gera. Os atos anuláveis podem ser ratificados (ou confirmados, para usar a terminologia do Código Civil), ao contrário dos nulos.

De toda forma, deve ser considerada a afirmação de Marcos Bernardes de Mello de que não é possível falar, rigorosamente, em características da nulidade, na medida em que as características que a ela são comumemente imputadas (imprescritibilidade, alegabilidade por qualquer interessado, ineficácia do ato etc.) não são encontradas em todos os atos nulos. Isso porque os sistemas jurídicos, procurando atender a situações especiais e particulares, criam exceções que impedem sejam feitos enunciados genéricos. $^{124}$

\section{Vícios do conclave, do voto e da deliberação}

O art. 286 da LSA dispõe que "a ação para anular as deliberações tomadas em assembléia-geral ou especial, irregularmente convocada ou instalada, violadoras da lei ou

\footnotetext{
${ }^{124}$ Cf. Teoria do fato jurídico - plano da validade, n. 65, p. 261: "Por isso é necessário destacar, bem claramente, que nenhuma daquelas características integra essencialmente, de modo absoluto, o conceito de nulidade, em face das exceções. Daí não ser cientificamente correto afirmar-se que sejam características essenciais da nulidade, mas, sim, que em geral lhe são pertinentes".
} 
do estatuto, ou eivadas de erro, dolo, fraude ou simulação prescreve em 2 (dois) anos, contados da deliberação", ${ }^{125}$ ao passo que o $\S 4^{\circ}$ do art. 115 da LSA preceitua que "a deliberação tomada em decorrência do voto de acionista que tem interesse conflitante com o da companhia é anulável". Logo se vê que o legislador misturou três espécies diferentes de vícios: (i) do conclave (irregularidades relativas ao procedimento assemblear, como de convocação e instalação); (ii) da deliberação (irregularidades materiais, de infração à lei ou ao estatuto social, ou de conflito de interesse); e (iii) do voto (irregularidades nas manifestações de vontade individuais dos sócios). Não obstante tenha havido essa confusão, não só esses defeitos são diversos como importam em consequências e disciplinas diversas, como, por exemplo, a legitimidade ad causam para a impugnação. ${ }^{126}$

${ }^{125}$ Embora o referido dispositivo - no que é seguido por quase toda a doutrina - aluda a um prazo prescricional, trata-se, na verdade, de prazo decadencial. Com efeito, em tese de cátedra para a cadeira de Direito Civil da Faculdade de Direito da Universidade de São Paulo, Câmara Leal bem explicou que, embora haja semelhanças entre decadência e prescrição (ambas são causas extintivas, baseam-se na inércia do titular do direito e têm o tempo como fator operante), são institutos diversos por basicamente três fatores. $\mathrm{O}$ primeiro é que a decadência extingue o direito, ao passo em que a prescrição extingue a ação (ou, mais propriamente, a pretensão, pensamos). A prescrição, portanto, extingue o direito apenas indiretamente. $\mathrm{O}$ segundo traço distintitivo é que o prazo decadencial nasce no mesmo momento em que nasce o direito, ao passo em que a prescrição pressupõe um direito já existente e só passa a correr em que este é ameaçado ou violado "porque nesse momento é que nasce a ação, contra a qual a prescrição se dirige". O terceiro e último traço diz respeito à natureza do direito violado: a decadência opera-se sobre um direito que, "embora nascido, não se tornou efetivo pela falta de exercício", enquanto que a prescrição "supõe um direito nascido e efetivo, mas que pereceu pela falta de proteção pela ação, contra a violação sofrida" (cf. Da prescrição e da decadência, nn. 72 e 318/323, pp. 100/102 e 397/401). No mesmo sentido, Agnelo Amorim Filho afirmou que, como os direitos potestativos (dando o exemplo o direito à anulação do contrato) são direitos sem pretensão ou sem prestação, "só as ações condenatórias podem prescrever". Prosseguindo, concluiu que "os potestativos são os únicos direitos que podem estar subordinados a prazos de decadência, uma vez que o objeto e efeito desta é, precisamente, a extinção dos direitos não exercitados dentro dos prazos fixados". E arrematou ao aludir à "manifesta impropriedade da expressão ações imprescritíveis" para designar as ações constitutivas não sujeitas à decadência, defendendo que se utilize a locução ações perpétuas em substituição àquela expressão (cf. "Critério científico para distinguir a prescrição da decadência e para identificar as ações imprescritíveis", $R T$, v. 744, pp. 735/736, 738 e 746/747). Firmados estes critérios, parece ser evidente que o prazo firmado no art. 286 da LSA é decadencial, pois o direito à impugnação da deliberação só surge a partir do momento em que ela própria surge, isto é, a partir do momento em que o ato é praticado, e, portanto, o prazo para o exercício do direito de ação começa a correr no mesmo momento em que surgiu o direito que vai embasar o pedido de tutela jurisdicional. Como reforço do ora defendido, ressalte-se ainda que Câmara Leal arrolava dentre decadenciais o prazo de a minoria anular a modificação do estatuto social das fundações (nn. 291/292, pp. 374/375). Para uma análise de teorias que procuram diferenciar os dois institutos, v. Serpa Lopes, Curso de direito civil, v. I, n. 405, pp. 563/566. Diga-se, por fim, que também Erasmo Valladão França afirmou se tratar de prazo decadencial (cf. Invalidade..., n. 16, p. 71, nota 9).

${ }^{126}$ Ascarelli atentou para que o fato de que o art. 156 do Decreto $n^{\circ} 2.627 / 40$ - cuja redação foi praticamente replicada pelo art. 286 da LSA - disciplinava diferentes tipos de vícios (cf. "Vícios das deliberações...", nn. 2 e 3, pp. 371 e 382/385). No mesmo sentido, v. Comparato, "Da imprescritibilidade...", p. 218; Erasmo Valladão França, "Ilegitimidade de parte...", p. 387, Invalidade..., p. 85 e "Invalidade de deliberações conexas da companhia", in Temas..., nn. 2/3, pp. 409/410; e Erasmo Valladão França e Marcelo von Adamek, "Algumas notas sobre o exercício abusivo da ação de invalidação de deliberação assemblear", in Flávio Luiz Yarshell e Guilherme Setoguti J. Pereira (coords.), Processo societário, p. 157, nota 2. Renato Ventura Ribeiro corrobora essa classificação (cf. Direito de voto nas sociedades anônimas, p. 261). Diferenciando os vícios na convocação e na instalação e os vícios das deliberações, Modesto Carvalhosa anota que os primeiros dizem respeito a "formalidades preliminares, necessárias e suficientes à instalação e 
Quando se tratar de vício do conclave, isto é, que diga respeito à própria assembleia, todas as deliberações nela tomadas também serão maculadas, pois há relação de prejudicialidade: se a deliberação resulta da convergência de vontades manifestadas em uma reunião procedimental, viciado esse procedimento igualmente viciado será, por via de estrita consequência, como anotou Comparato, o seu resultado. ${ }^{127}$ Os vícios dessa espécie mais comuns são os que resultam de desrespeito às formalidades estabelecidas para a convocação e instalação da assembleia (LSA, arts. 123/125), mas Erasmo Valladão França confere outros exemplos: desrespeito à ordem do dia (LSA, art. 124, caput); recusa de participação ao acionista ou a seu representante (LSA, art. 126, $\S 1$ e $4^{\circ}$ ); inexistência de quórum legal ou estatutário de deliberações (LSA, arts. 129 e 136); falta de lavratura da ata; ausência de prévia publicação de documentos da administração (LSA, art. 133); desrespeito ao procedimento e aos demais requisitos firmados no art. 134 da LSA. ${ }^{128}$

Quando houver vício de voto, a deliberação só será afetada se, excluído o cômputo desse voto, altere-se a maioria exigida em lei. A deliberação será válida, portanto, desde que os votos válidos sejam suficientes para se mantê-la. ${ }^{129}$ Exemplos de vícios que

deliberação das assembléias gerais", ao passo em que os últimos referem-se ao "mérito dessas mesmas deliberações". Os primeiros vícios dizem respeito ao procedimento e os segundos ao conteúdo (cf. Comentários..., $4^{\circ}$ v., t. II, p. 480). Também evidenciando a distinção entre vícios do voto ou da deliberação, Pontes de Miranda anotou que "a nulidade pode resultar da manifestação de vontade de um, ou do órgão" (cf. Tratado de direito privado, t. 50, n. 5.322, p. 282).

${ }^{127} \mathrm{O}$ referido autor atenta para "a necessidade lógica de se distinguirem as deliberações das reuniões ou assembléias durante as quais elas são tomadas", pois "a reunião aparece como o quadro jurídico, que constitui o pressuposto necessário (condicionio juris) à validade e eficácia das deliberações". E completa: "Nula uma reunião (por falta de regular convocação, p. ex.), nulas são, por via de estrita conseqüência, todas as deliberações nelas tomadas" (cf. "Eleição de diretores em companhia aberta. Validade e eficácia de reuniões do conselho de administração de sociedade anônima. 'Quorum' deliberativo em assembléias gerais de companhia aberta", in Direito empresarial, n. 11, pp. 189/190). No mesmo sentido, Erasmo Valladão França, Invalidade..., n. 19.1., p. 88; e Modesto Carvalhosa, Comentários..., v. 4, t. II, p. 488 . Colhe-se o entendimento também na jurisprudência: "se a assembléia realizada estava inquinada de nulidade, todos os atos por ela aprovados são nulos, pois o que é nuclearmente nulo, resulta sem possibilidade de repercussões efetivas, sendo de antiga sabença que quod nullum est non producit effectus" (TJSP, Apelação 144.1601/4, Rel. Antonio Carlos Munhoz Soares, 2a Câmara Civil, j. 10.03.1992).

${ }^{128}$ Cf. Invalidade..., n. 19.1, pp. 91/97.

${ }^{129}$ Cf. Ascarelli, "Vícios das deliberações...", n. 3, p. 385; Erasmo Valladão França, Invalidade..., n. 19.3., pp. 113/114; e Nelson Eizirik, A Lei das S/A comentada, v. III, p. 597. É por isso, aliás, que Comparato escreveu que a decretação da ineficácia de votos proferidos em violação a acordo de acionistas "acarretará, por via de consequência, a ineficácia das deliberações tomadas em assembléia com aqueles votos, infirmando-se todos os atos ulteriores praticados pela companhia com base nelas" (cf. "Validade e eficácia de acordos de acionistas. Execução específica de suas obrigações", in Novos ensaios e pareceres de direito empresarial, p. 71). E mesmo que os votos viciados não interfiram no resultado do conclave, não se pode falar que o acionista não teria interesse na anulação, uma vez que referido interesse pode repousar na isenção de responsabilidade e no exercício de direitos como o de recesso (cf. Renato Ventura Ribeiro, Direito de 
maculem os votos: incapacidade; vício de consentimento (erro, dolo, simulação); voto em conflito de interesses (LSA, art. 115, $\S 1^{\circ}$ ); voto de administrador a respeito dos documentos listados no art. 133 da LSA (LSA, art. 134, $\S 1^{\circ}$ ); e voto do acionista que, na fusão, pronuncia-se sobre o laudo de avaliação do patrimônio líquido de sociedade de que faz parte (LSA, art. $228, \S 2^{\circ}$ ).

Há quem discorde dessa diferenciação, defendendo que todos os vícios previstos pelo art. 286 da LSA são da deliberação, sob o argumento de que esta é um ato complexo ou procedimental, isto é, um ato final resultando de vários outros atos intermediários e autônomos, praticados ao longo de um iter procedimental. ${ }^{130}$ Referida discordância não procede, porém. O voto é uma declaração de vontade do acionista, ao passo em que a deliberação resulta dos votos manifestados na assembleia, que, por sua vez, é, ao mesmo tempo, uma reunião e um órgão da sociedade. São, pois, coisas diversas, cujos vícios importam em consequências igualmente diversas.

\section{Invalidades no direito societário brasileiro (LSA, arts. 115, § $4^{\circ}$ e 286)}

Como apontam autorizadas vozes, é necessária e existe - ainda que não em decorrência do direito posto brasileiro - uma disciplina própria das invalidades no direito societário, com caracteres diversos do regime das invalidades do direito civil, ${ }^{131}$ marcada

voto..., p. 262). No direito português, Pinto Furtado chega a conclusão diversa, ao sustentar que se o voto não for essencial para a deliberação, "não seria ele impugnável em si mesmo". A isso o jurista lusitano chama de prova de resistência, "pois não faria sentido alimentar um contencioso judicial relativamente a um voto que, viciado embora, ao descontar-se à maioria por que foi aprovada a deliberação, apenas reduziria a dimensão do seu voto, sem a eliminar" (cf. Deliberações..., n. 96, p. 712). Também aludindo à prova de resistência, Menezes Cordeiro, SA: assembleia geral..., n. 104, p. 228. A jurisprudência também acolhe essa relação existente entre votos e deliberação: TJSP, Câmara Reservada de Direito Empresarial, Ap. 000765410.2010.8.26.0286, Rel. Romeu Ricupero, j. 07.02.2012.

${ }^{130}$ Cf. Luiz Gastão Paes de Barros Leães, "Vícios ...”, p. 164.

${ }^{131}$ Em regra, são estudiosos de direito privado que chegam a essa conclusão, como Antigono Donati, que defendeu a abordagem do tema com a comunhão de princípios do direito privado, do direito administrativo e do direito processual (cf. L'invalidità..., n. 3, pp. 13/14). Nesse sentido, v., ainda, Erasmo Valladão França, Invalidade..., nn. 5 e 6, pp. 21/27, e "Anulação de assembléia de transformação de S/A”, in Temas..., nn. 6/9, pp. 265/263; Andrea Pisani Massarmormile, "Invalidità delle delibere assembleari. Stabilità ed effetti", Rivista del diritto commerciale e del diritto generale delle obligazioni, v. 102, n. 1/3, pp. 55 e 57; Angeles Alcala Diaz, La impugnacion ..., p. 106; Lobo Xavier, Anulação..., pp. 12/13; Francesco Terrusi, L'invalidità..., nn. 1.2. e 2.1, pp. 16 e 61/63; Waldirio Bulgarelli, "Anulação de assembléia geral de sociedade anônima", $R T$, v. 514, p. 60 e "Questão referente a livros societários e documentos relativos à presença e às deliberações das assembléias gerais”, RDM, n. 114, p. 255; Carvalho de Mendonça. Tratado..., v. III, n. 1.002, pp. 372/374; Moitinho de Almeida, Anulação..., p. 1; Bulhões Pedreira, "Regime especial de invalidade dos atos societários", in A Lei das S/A, v. II, 697/699; Lamy Filho, "Mudança de objeto social e incorporação de subsidiária", in A Lei das S/A, pp. 545/546; José Edwaldo Tavares Borba, Direito 
pelo princípio da estabilidade dos atos e que busca permitir a continuidade da atividade empresarial diante de defeitos nos processos de constituição das sociedades e de formação da vontade social. ${ }^{132}$

Defende-se a existência de um regime que se afasta do regime comum de nulidades do direito civil - e, de fato, diferentes ramos apresentam diferentes disciplinas de invalidades $^{133}$ - e que é marcado por (i) maior tolerância às transgressões aos requisitos

societário, pp. 484/485 Modesto Carvalhosa, Comentários..., v. 4, t. II, pp. 475/476; Luiz Gastão Paes de Barros Leães, "Vícios...", pp. 162/163; Nelson Eizirik, A Lei das S/A..., v. III, pp. 580/581 e 591; e Ricardo Tepedino, Direito das companhias, v. I, n. 261, p. 975. Mas também há processualistas que defendem a existência do regime especial de nulidades societárias: Corrado Ferri, "Le impugnazioni di delibere assembleari. Profili processuali”, in Rivista trimestrale di diritto e procedura civile, v. 59, n.1, p. 52; Ada Pellegrini Grinover, "Realização de assembléia sob o regime da execução provisória e posterior anulação", in Ernane Fidélis dos Santos e outros (coords.), Execução civil: Estudos em homenagem ao Professor Humberto Theodoro Júnior, p. 393; José Rogério Cruz e Tucci, "Impugnação judicial da deliberação de assembleia societária e projeções da coisa julgada", in Flávio Luiz Yarshell e Guilherme Setoguti J. Pereira (coords.), Processo societário, p. 471; Luiz Fernando C. Pereira, Medidas urgentes no direito societário, p. 164; e Francesco Carnelutti, "Eccesso di potere...", p. 176, embora esse último autor tenha tido produção doutrinária profícua também fora do direito processual. Esse entendimento ecoa também na jurisprudência: STJ, $4^{\mathrm{a}}$ Turma, RESP n ${ }^{\circ}$ 35.230-0, relator Sálvio de Figueiredo Teixeira, DJ 20.11.95; e STJ, REsp 1.046.497/RJ, Rel. João Otavio de Noronha, DJe 09.11.2010. Ainda, reflexo da especialidade do regime de nulidades do direito societário, é a defesa da professora espanhola Sonia Calaza López de um regime especial de limites subjetivos da coisa julgada com base na necessidade de celeridade do tráfego processual (cf. La cosa juzgada, cap. IV, n. 7.1.3, p. 175).

${ }^{132}$ De acordo com Andrea Pisani Massarmormile, esse princípio fundamenta-se nas necessidades de rapidez do tráfego mercantil, eficiência das organizações e governo eficaz das empresas (cf. "Invalidità delle...", pp. 57 e 64), o que é corroborado por Franceso Terrusi, L'invalidità..., n. 2.1., p. 63. De acordo com esse último autor, "la ragione della specialità del regime veniva correlata all'esigenza di garantire la stabilità degli atti societari, in considerazione del novero dei soggetti potenzialmente coinvolti: i soci, ma anche, sebbene indirettamente, i terzi" (cf. L'invalidità..., n. 2.1., pp. 61/62). Também aludindo a tal princípio, Erasmo Valladão Azevedo e Novaes França, "Apontamentos sobre a invalidade das deliberações conexas das companhias", in Temas de direito societário, falimentar e teoria da empresa, pp. 69 e seguintes.

${ }^{133}$ Exemplo disso são as profundas diferenças existentes entre as nulidades processuais civis e as do direito civil, decorrentes principalmente do caráter privado deste e do público daquele. O grande exemplo disso é que em processo não existem nulidades de pleno direito, uma vez que, conforme apontado por Dinamarco, fazendo referência ao direito processual civil, "não há nulidades de pleno direito em nosso campo, porque os atos do juiz são provimentos, atos estatais imperativos, repugnando ao sistema que possa o particular, mediante seu próprio juízo, refutar a eficácia do comando recebido" (cf. "Os institutos fundamentais do direito processual", Fundamentos do processo civil moderno, t. I, p. 246). Na mesma linha, ainda na vigência do Código de Processo Civil de 1939, Luis Eulálio de Bueno Vidigal já alertava para as diferenças entre os regimentos de nulidades do Código Civil e do Código de Processo Civil (cf. Da ação rescisória dos julgados, p. 25). De fato, é incorreta a transposição do regime de invalidades do direito civil para o direito processual civil, que não só pertence ao direito público, como se trata de ramo autônomo do direito, com princípios, regras e diretrizes próprios. Nesse sentido, v. a crítica tecida por Roque Komatsu, Da invalidade..., pp. 26/28. Remete-se, ainda, a texto de Heitor Sica, em que o professor das Arcadas compara os sistemas de invalidades do Código Civil de 2002 e do direito processual civil, inclusive afirmando que ainda que hoje se tenha consciência de que a divisão da ciência jurídica em "ramos" é fruto de uma conformação histórica distante e que possui valor menor do que já se pensou, é inegável que quando se analisam alguns assuntos, como a "teoria das nulidades", tal divisão apresenta-se induvidosa (cf. "Contribuição ao estudo...", pp.183/202). 
para a prática dos atos, (ii) relativização à regra de contaminação das nulidades, ${ }^{134}$

prazos decadenciais mais curtos, (iv) limitação do rol de legitimados para demandas de impugnação e (v) preservação de efeitos. Exemplificativa disso é a afirmação de Waldemar Ferreira de que, mesmo portadora de vício congênito em seu ato constitutivo, a sociedade empresária, em especial a anônima, organiza-se e age no mundo jurídico como se regular fosse, na plenitude de sua capacidade de contrair deveres e adquirir direitos. ${ }^{135}$

À base desse pensamento está o dinamismo exigido pela vida societária, ${ }^{136}$ incompatível com a insegurança e a instabilidade que o sistema tradicional de invalidades propicia, ${ }^{137}$ ou, como disse Galgano, a exigência de eficiência do aparato produtivo e de

134 Entende-se que, sendo anulada uma deliberação assemblear, não necessariamente devem ser reputados inválidos as deliberações e os atos praticados com base nela. Nesse sentido L. P. Moitinho de Almeida, que inclusive indica doutrina em sentido inverso (cf. Anulação e suspensão..., p. 15).

${ }^{135}$ Cf. Tratado..., v. 4, n. 980, p. 632.

${ }^{136} \mathrm{E}$, de fato, os modelos de "processos societários" de países da União Européia apresentam em comum aspectos que estão diretamente relacionados com a necessidade de ser conferida resposta jurisdicional rápida, como sumarização procedimental, sumarização cognitiva e economia processual (cf. Remo Caponi, "La tutela sommaria nel processo societario in prospettiva europea", Rivista trimestrale di diritto e procedura civile, v. 58, n. 4, p. 1.376). Sobre o processo societário italiano, v. Andrea Proto Pisani, "I lineamenti del nuovo processo societario", Rivista di diritto civile, v. 49, n. 5, pp. 547 e seguintes; Roberta Tiscini, "Il procedimento di cognizione nelle liti societarie", Rivista trimestrale di diritto e procedura civile, v. 58, n. 1, pp. 261 e seguintes; Diego Volpino, "Cognizione e decisione nel procedimento societario", Rivista trimestrale di diritto e procedura civile, v. 61, n. 1, pp. 67 e seguintes; Giuseppe Tarzia, "Interrogativi sul nuovo processo societario", Rivista di diritto processuale, v. 58, n. 3, pp. 641 e seguintes; Sergio Menchini, "Il giudizio sommario per le controversie societarie, finanziarie e bancarie", in Studi di diritto processuale civile in onore di Giuseppe Tarzia, t. II, pp. 1.767 e seguintes; e Bruno Sassani, "Sulla riforma del processo societario", in Studi di diritto processuale civile in onore di Giuseppe Tarzia, t. II, pp. 1.811 e seguintes.

${ }^{137}$ Como apontou Ada Pellegrini Grinover, “a aplicação ao direito das sociedades dos princípios da nulidade clássica ou civil pode, sem maiores cautelas, produzir efeitos certamente indesejáveis. Nesse ramo específico, em nome da preservação da dinâmica da vida empresarial, constata-se uma certa e justificada tolerância com transgressões talvez impensáveis para um civilista, mas que são próprias e necessárias para a efetividade e utilidade do direito comercial. O processo, como instrumento que é, deve estar pronto a aceitar e implementar essas diferenças, tornando-se igualmente mais flexível e dinâmico" (cf. "Realização de assembléia...", p. 393). Chamando a atenção para o descompasso entre as regras societárias e as processuais, José Alexandre Tavares Guerreiro, ao tratar do art. 118, § $3^{\circ}$ da LSA, escreveu: "A complexidade processual inerente à consecução do objetivo desejado pelo legislador de 1976 revela o descompasso entre a lei acionária e o ordenamento processual, a sugerir e recomendar, além de esforços da doutrina e da jurisprudência, providências legislativas capazes de colocar em consonância os preceitos da lei do anonimato e as disposições de ordem processual destinadas a torná-los efetivos, numa perspectiva de praticidade e objetividade" (cf. "Execução específica do acordo de acionistas", RDM, v. 41, 1981, p. 68). A necessidade de um regime especial de nulidades no direito societário é bem resumida em conhecida e ácida crítica que Carvalho de Mendonça dirigiu ao sistema de nulidades da constituição de sociedades: "O systema legal quanto á nullidade da constituição das sociedades anonymas não resiste á mais benigna censura. Derramaram-se profusamente os casos de nullidade para afungentar a fraude. A preoccupação tornou-se obsecção. (...) A sociedade exerce a sua actividade e explora o seu objecto por longos annos. Celebra contractos que tiveram execução, cria relações jurídicas; de repende se vê ameaçada pela acção de nullidade. Anima-se o appetite dos deshonestos; dá-se foros de cidade à profissão indecorosa de demandista. O portador de uma acção que seja, sem ter soffrido prejuizo directo, desacredita a mais forte sociedade com a demanda perversa, baseada, não raro, em futilidades, como esta: 'eu não assignei os estatutos, não obstante ter participado da assembléa constituinte, que os approvou, ter recebido dividendos e vendido com agio as 
expansão econômica. ${ }^{138}$ Além disso, como para as sociedades por ações vige a regra de livre transferência das ações, ${ }^{139}$ já que típicas sociedades de capitais, ${ }^{140}$ as suas deliberações afetam não só um quadro social a cada instante mutável, mas também, sobretudo nas grandes companhias de capital aberto, uma esfera muito vasta de terceiros. A aplicação do regime de invalidades do direito civil, pois, traria prejuízos não só à própria companhia $^{141}$ como a terceiros. ${ }^{142}$

Por esses motivos, Giorgio Meo noticia haver tendência de o sistema normativo italiano salvaguardar situações substanciais instauradas com base na deliberação inválida. ${ }^{143}$ Da mesma forma, Lucas Enriques e Andrea Zorzi anotam que no direito italiano, sobretudo após a reforma do direito societário de 2003, passou-se a oferecer com maior vigor a tutela ressarcitória como uma alternativa à tutela específica (desconstituição

acções que subscrevi. Comprei-as de novo na baixa e pretendo annullar a sociedade'! (...) A nullidade resolve-se na dissolução da sociedade e responsabilidade dos fundadores. Todos os actos praticados pela sociedade não deviam ter, em rigor, existencia jurídica, porque foram praticados por quem não existia; torcem-se, porém, todas as consequencias, emprestando-se vida ao nada, contrapondo o facto ao direito. (...) Para que esse rigor se temos instituido o registo do commercio, no qual as sociedades depositam os seus documentos legaes para poderem funccionar? Porque se não dá aos encarregados deste registo o direito de verificar a legalidade dos documentos fundamentaes da organização da sociedade., isto é, se o acto constitutivo está conforme á lei e se as condições exigidas da sociedade foram cumprida? (...) Porque a lei não se limita a estabelecer sérias responsabilidaes civis e penaes contra os fundadores que a infringirem?". Por isso que o ilustre comercialista recomendava que "as nullidades devem ser reduzidas ás estrictamente necessarias e em todos o caso sujeitas ás seguintes regras: $1^{\mathrm{a}}$, a prescripção da acção dentro do anno da constituição da sociedade; $2^{\mathrm{a}}$, ratificação pelas assembléas, funccionando com dois terços. As infracções da lei, ás quaes não fosse comminada a pena de nullidade, teriam como sancção a responsabilidade directa e solidaria dos fundadores para serem os interessados pelos prejuizos, perdas e damnos que este soffressem" (cf. Tratado..., v. III, livro 2, n. 1.002, pp. 372/374). V., ainda, Ilaria Pagni, Le azioni..., p. 594.

${ }^{138}$ Cf. La società..., cap. 7, n. 8, p. 224.b

139 Cf. Waldirio Bulgarelli, Regime jurídico da proteção às minorias das S/A, cap. II, n. 29: “A transmissibilidade das ações tem sido admitida pacificamente pela doutrina, como um direito irrevogável, considerada como da essência das sociedades anônimas".

${ }^{140}$ Conquanto criticada por comercialistas de peso - v., por exemplo, a crítica feita por Waldemar Ferreira em Tratado de direito comercial, v. 3, pp. 217/218; mais recentemente, v. Erasmo Valladão França e Marcelo Vieira Von Adamek, ao tecerem críticas ao conceito de affectio societatis em 'Affectio societatis' e conceito de 'fim social', in Erasmo Valladão Azevedo e Novaes França, Temas de Direito Societário, Falimentar e Teoria da Empresa, pp. 27 e ss. -, a distinção entre sociedades de capital e sociedades de pessoas continua válida para diferenciar características das sociedades empresariais e para solucionar importantes problemas que surgem no dia a dia desses entes jurídicos.

${ }^{141}$ Cf. José Rogério Cruz e Tucci, "Impugnação judicial...”, p. 471: "É até intuitivo que o interesse na estabilidade das deliberações sociais não se deve apenas ao fato de tais atos poderem repercutir na esfera de direitos de um círculo considerável de pessoas e, sobretudo, nas sociedades anônimas de capital aberto, a todo tempo mutável, mas, de modo particular, aos danos que poderiam ser experimentados pela própria gestão da empresa, se sujeitos à impugnação em prazo muito amplo".

${ }^{142}$ Cf. Vasco da Gama Lobo Xavier, Anulação..., n. 7, p. 99.

${ }^{143}$ Cf. Gli effetti..., cap. III, n. 20, pp. 201/203. 
da deliberação), procurando-se privilegiar a estabilidade dos atos societários. ${ }^{144}$ Também por isso é que no campo societário existe tendência de diminuir o radicalismo da nulidade absoluta, atribuindo-se efeitos aos atos nulos e inexistentes, de modo que se impeça a sua retroatividade e permita-se a sua retificação. ${ }^{145}$ Parte da doutrina diz, ainda, que outra particularidade da nulidade da deliberação assemblear é que o ato não é ineficaz $a b$ ovo. Nesse sentido Bulhões Pedreira, para quem no regime especial de invalidade dos atos societários não prevalece o enunciado de que o ato nulo não produz nenhum efeito. ${ }^{146}$ Ademais, prazos decadenciais mais curtos do que os da lei civil caracterizam o regime em análise e encontram fundamento na dinamicidade da atividade empresarial. ${ }^{147}$

No Brasil não há nenhuma regra ou princípio positivados que acolham expressamente referido regime. Embora disponhamos de uma lei de sociedade por ações reconhecidamente moderna, ${ }^{148}$ ela quase nada estabelece a respeito da invalidade de deliberações societárias. Tanto é que os arts. $115, \S 4^{\circ}$ e 286 da LSA - únicos dispositivos que versam sobre o assunto - não contêm sequer uma palavra sobre um regime especial de nulidades. E mesmo o Projeto de Lei no 1.572/11 - que tramita na Câmara dos Deputados e que, baseado em minuta elaborada por Fábio Ulhoa Coelho, objetiva instituir novo Código Comercial brasileiro ${ }^{149}$ - não traz qualquer regra a respeito de invalidades de deliberações.

\footnotetext{
${ }^{144}$ Cf. "Spunti in tema di rimedi risarcitori contro l'invalidità delle deliberazioni assembleari", in Rivista del diritto commerciale, v. 104, p. 1.

${ }^{145}$ Cf. Waldirio Bulgarelli, "Anulação de assembléia...", p. 62.

${ }^{146}$ Cf. "Regime especial...", p. 697.

${ }^{147}$ Cf. Modesto Carvalhosa, Comentários..., t. v. 4, t. II, p. 475. O art. 286 da Lei 6.404/76 reduziu o prazo do art. 156 do DL 2.627/40, que estipulava a prescrição (rectius: decadência) em três anos. Além disso, esclarece Carvalhosa que, apesar de a atual lei do anonimato não mais estipular que o lapso inicia-se com a publicação da ata que instrumentaliza a deliberação, como fazia o art. 156 do diploma de 1940, essa regra continua em vigor, "pelo simples fato de a eficácia do mesmo [ato societário] somente se produzir a partir do seu arquivamento e publicação" (pp. 476/475). No mesmo sentido, Nelson Eizirik, A Lei das S/A..., v. III, pp. 588 e 593; Marcelo Vieira Von Adamek, Responsabilidade civil dos administradores de S/A e as ações correlatas, n. 7.3.3.2.1., p. 371; e Fran Martins, que inclusive dá notícia histórica do trâmite legislativo do projeto que redundaria na lei 6.404 e afirma que a menção do dispositivo ao prazo contado "da deliberação" deve ser tratada como erro legislativo (cf. Comentários à Lei das S.A., v. 3, n. 1.175, p. 530). Isso se deve ao fato de que a publicação possui função declarativa e constitutiva da deliberação (cf. Romano-Pavoni, Le deliberazioni..., n. 31, p. 114).

${ }^{148}$ Prova disso é que, referindo-se a esse diploma legal, Manoel de Queiroz Pereira Calças disse que existe "o reconhecimento geral da excelência do mesmo e da grande importância que ele teve na consolidação de um capitalismo saudável" (cf. "A reforma da Lei das Sociedades por Ações", Revista do instituto de pesquisas e estudos, n. 25, p. 17).

${ }^{149}$ A minuta foi levada a público pelo professor da Pontifícia Universidade Católica de São Paulo no livro $O$ futuro do direito empresarial, publicado em 2010 (cf. Fábio Ulhoa Coelho, Princípios do direito comercial, parte I, n. 9, p. 22).
} 
Doutrina e jurisprudência, porém, extraem esse regime do art. 286 da LSA embora a associação também deva ser feita com o art. 115, § $4^{\circ}$ da LSA -, argumentando que ele estabelece apenas a anulabilidade das deliberações e, pois, silencia sobre a nulidade. Nesse sentido é a lição de Luiz Gastão Paes de Barros Leães, para quem a confirmação da existência de um regime de invalidades societárias sui generis adviria de que a legislação do anonimato não prevê casos de nulidade e, pois, teria reduzido todas as invalidades à anulabilidade, evitando a ineficácia completa do ato e a restituição das coisas ao estado anterior. ${ }^{150}$

Com efeito, comentando o art. 155 do DL 2.627/40 - que tratava da invalidade da constituição de companhia e é hoje reproduzido, com algumas alterações, ${ }^{151}$ pelo art. 285 da LSA -, Trajano de Miranda Valverde anotou que o regime comum das nulidades não se aplica às sociedades, ao menos não sem graves desvios, pois como é possível, indagou o autor do anteprojeto que culminou naquele Decreto-lei, sustentar que o nulo não produz efeito algum se com base nele surgiram e motivaram-se transformações jurídicas várias, muitas vezes impossíveis de serem retroativamente desfeitas? A regra de que as partes envolvidas por um negócio nulo devem ser repostas ao status quo ante encontra sérios obstáculos no contexto das sociedades comerciais, em especial as por ações. ${ }^{152}$ Daí porque, ainda conforme Miranda Valverde, a lei societária optou por um regramento particular, pautado por (i) prazos prescricionais mais curtos, (ii) irretroatividade dos efeitos da invalidação e (iii) possibilidade de convalidação e ratificação do ato. Pelos mesmos

\footnotetext{
${ }^{150}$ Luiz Gastão Paes de Barros Leães, "Vícios em assembleia-geral ordinária", in Estudos e pareceres sobre sociedades anônimas, n. 20, pp. 162/163. A particularidade desse regime é bem exemplificada na seguinte passagem de Bulhões Pedreira: "A ineficácia do negócio jurídico de sociedade e dos atos dos órgãos societários não está sujeita ao regime comum do direito civil, mas a regime especial no qual (a) não prevalece o princípio de que 'o que é nulo não produz nenhum efeito'; (b) os prazos de prescrição da ação de anulação dos atos viciados ou defeituosos são curtos; e (c) os vícios ou defeitos podem ser corrigidos a qualquer tempo, mesmo depois de proposta a ação de anulação do ato" (cf. "Regime especial...", p. 697).

${ }^{151}$ Modesto Carvalhosa critica a redação do art. 286 da Lei 6.404/76, que teria empobrecido a redação do art. 156 do diploma de 1940: "O artigo ora comentado apresenta-se empobrecido quanto à sua redação, vis-à-vis do referido art. 156 do diploma de 1940. Usando linguagem telegráfica, suprimiu-se a conjunção alternativa 'ou' entre 'assembléia irregularmente convocada ou instalada' e 'violadoras da lei ou do estatuto'. Essa supressão gramatical, ainda que irrelevante sob o ponto de vista interpretativo, demonstra a singeleza de linguagem do legislador de 1976, que trouxe perplexidade à doutrina sobre o real sentido do texto legal" (cf. Comentários..., $4^{\circ}$ v., t. II, p. 474).

${ }^{152}$ Vejam-se as seguintes passagens: "O regime comum das nulidades dos atos jurídicos não se ajusta, sem graves desvios, aos organismos que, sob a denominação de sociedades, associações, corporações, fundações, surgem por obra de energia dos homens e atuam, como sujeitos de direito, na vida social. (...) A afirmação de que o ato jurídico nulo não existe, é um nada - nihil actum est - soçobra no mar agitado da vida econômica. (...) Frágil é a máxima de que o ato nulo não produz efeitos - 'quod nullum est, nullum producit effectum"” (cf. Sociedades por ações, v. III, nn. 811, 812 e 815, pp. 97, 99, 100 e 103).
} 
motivos é que, não obstante ter dirigido a Valverde críticas veementes, Pontes de Miranda asseverou ser esse regime fruto de uma técnica legislativa protetiva, cujo escopo é evitar danos a terceiros e acionistas e, assim, atender à função social que as sociedades por ações desempenham na sociedade. ${ }^{153} \mathrm{E}$ apesar de todas essas considerações terem sido feitas a respeito do art. 155 do DL 2.627/40, que tratava da invalidade da constituição da companhia, aplicam-se também às invalidades das deliberações em geral.

A própria opção legislativa por um regime de mera anulabilidade, como visto, é um claro sinal da instituição de um regime particularizado. ${ }^{154}$ Mas, realmente, o ordenamento brasileiro conta apenas com a figura da anulabilidade das deliberações assembleares?

\section{1. Existem deliberações nulas no ordenamento brasileiro?}

Não é só a legislação brasileira que prevê apenas a anulabilidade das deliberações societárias. O ordenamento português - que trata do tema nos arts. $56^{\circ} / 62^{\circ}$ do Código das Sociedades Comerciais, de 1986, que se aplica às sociedades anônimas, e no art. $46^{\circ}, \S 1^{\circ}$ da Lei de 11 de abril de 1901, que se aplica às sociedades por quotas - hoje alude a deliberações nulas e anuláveis, mas o revogado art. 146 do Código Comercial, de 1882, versava apenas sobre a anulabilidade. No direito alemão, até 1937, data da edição da Aktiengesetz (AktG, Lei de Sociedades por Ações alemã), não havia previsão de nulidade das deliberações, pois a Aktiennovelle, de 1884, preceituava apenas a anulabilidade. O mesmo ocorreu com o direito italiano, que antes da edição do Código Civil de 1942, isto é, na vigência do Codice di Commercio de 1882, estatuía apenas a anulabilidade das deliberações (art. 163). ${ }^{155}$ Hoje o Codice Civile italiano estabelece também a nulidade

\footnotetext{
${ }^{153}$ Embora tenha criticado a interpretação dada por Trajano de Miranda Valverde (cf. Tratado de direito privado, t. LI, n. 5.358, p. 95).

${ }^{154}$ A peculiaridade desse regime decorre das vicissitudes das normas de direito societário. Para que se afirme a existência de um tal regime particular, não é sequer necessário invocar-se o chamado princípio da conservação, que, de acordo com Antonio Junqueira de Azevedo, “consiste, pois, em se procurar salvar tudo que é possível num negócio jurídico concreto, tanto no plano da existência, quanto da validade, quanto da eficácia" (cf. Negócio jurídico..., cap. 2, n. 5, p. 66). Sobre o princípio da conservação, Marcos Bernardes de Mello, Teoria do fato jurídico - plano da validade, n. 66, p. 262. Ainda, tratando especificamente da aplicação desse princípio às deliberações assembleares, Gianluca Guerrieri, La nullità..., cap. III, n. 8, pp. 194/195.

${ }^{155}$ Cf. Antigono Donati, L’invadlità..., n. 15, p. 59; e Lobo Xavier, Anulação..., pp. 108/109. Este último, que defende a categoria das deliberações nulas, atribui a falta de previsão do regime de nulidade a uma deficiência daqueles sistemas legistativos, que logo foi suprida pela doutrina e pela jurisprudência, porém (p.
} 
(arts. 2.377 e 2.379), embora as duas figuras sejam próximas em inúmeros aspectos. ${ }^{156}$ Também as legislações suíça, venezuelana, mexicana, peruana e argentina não prevêem a nulidade das deliberações. ${ }^{157}$

Porém, apesar da opção do legislador de seu país por um regime de mera anulabilidade, Lobo Xavier defende que a tipologia das deliberações inválidas não pode esgotar-se na disciplina dos dispositivos referidos. Para comprovar essa assertiva, emprega argumento ad absurdum: se a impugnação do vício só pudesse ocorrer por meio de demanda anulatória a ser proposta por acionista - que no direito português deve fazê-lo dentro do exíguo prazo de 30 dias $^{158}$-, estaria nas mãos dos sócios a escolha de estabilizar todo e qualquer efeito contrário ao estatuto ou à lei. O mesmo ocorreria em caso de renúncia pelos acionistas do direito à anulação ou, para os que defendem a ilegitimidade do sócio para anular deliberação para a qual proferiu voto favorável, de deliberação aprovada por todos os acionistas. ${ }^{159}$ Além disso, não sendo a deliberação nula passível de confirmação, também não se poderia permitir que ela se convalide pelo tempo, pois o que não é concedido aos sócios diretamente (confirmação) também não pode ser dado pela via

111). Esse mesmo trabalho teria sido, ainda de acordo com Lobo Xavier, desenvolvido pelas doutrinas e jurisprudências suíça, mexicana, austríaca e venezuelana, países onde também faltaria a expressa menção a deliberações nulas. Afirma Lobo Xavier, ainda, que "já no Brasil, a distinção entre deliberações nulas e deliberações anuláveis é geralmente omitida pelos autores. Entre os nacionais, a vemos mencionada apenas por Aloysio Lopes Pontes, II, p. 113 e ss. - que, porém, parece não atribuir a estas duas categorias a fisionomia que normalmente se lhes assinala; e, por seu turno, Waldemar Ferreira, Instituições de Direito Comercial, I, $3^{\text {a }}$ ed., Rio de Janeiro-S. Paulo, 1951, p. 365, fala de 'nulidade absoluta' de deliberações sociais, mas apenas a propósito de uma hipótese particular. Não obteve aparentemente grande ressonância, no meio a que era destinado, o claro e breve estudo que Ascarelli publicou durante o seu exílio brasileiro (cf. Problemas das sociedades anônimas, cit., p. 375 e ss.), onde sustentava serem compatíveis com o direito local as categorias das deliberações nulas, ineficazes e inexistentes - para além das deliberações impugnáveis nos termos do art. 156. ' do Dec.-Lei n. ${ }^{\circ} 2672$ de 26 de setembro de 1940" (cf. Anulação..., p. 113). Vale dizer que Lobo Xavier fez suas considerações à luz do revogado art. $146^{\circ}$ do Código Comercial Português, de 1882. Hoje, quem rege a matéria é, como dito, o Código das Sociedades Comerciais, de 1986, em seu art. $59^{\circ}$.

156 Em 2003, os arts. 2.377, 2.378 e, especialmente, 2.379 do Código Civil italiano sofreram reforma substancial, mediante a Lei 366, de 3.10.01 e do Decreto Legislativo 6, de 17.1.03 - que alteraram diversos aspectos do Código Civil a respeito de sociedades de capitais e cooperativas. Para uma análise aprofundada da reforma do direito societário italiano a respeito de deliberações assembleares, v. Erasmo Valladão Franca, "Lineamentos da reforma do direito societário italiano em matéria de invalidade das deliberações assembleares", in Temas de direito societário, falimentar e teoria da empresa, pp. 99/118.

${ }^{157}$ Cf. Lobo Xavier, Anulação..., n. 7, p. 109, nota 18. A edição dessa obra é de 1998 e, portanto, podem ter havido alterações legislativas depois dela.

${ }^{158}$ Conforme o art. 56 do Código das Sociedades Comerciais, de 1986, antes do qual vigorava o prazo de 20 dias, previsto pelo revogado art. 146 do Código Comercial, de 1882. Lobo Xavier faz menção ao prazo do Código Comercial, uma vez que apresentou sua tese em 1973 e a publicou em 1976.

${ }^{159}$ Cf. Anulação..., nn. 8 e 9, pp. 123/127, 143 e 146. 
oblíqua. ${ }^{160}$ Admitir a inexistência da nulidade, assim, significaria permitir que os sócios regrassem a vida social ao completo arrepio da ordem jurídica, razão pela qual defendeu Lobo Xavier que os tipos de deliberações inválidas extrapolam a previsão legal e podem ser também de nulidade e ineficácia. ${ }^{161}$

De forma análoga, Erasmo Valladão França escreveu que o argumento decisivo contra a adoção de um regime de mera anulabilidade no direito brasileiro é o de que, se todo e qualquer vício importasse unicamente em sanção com os caracteres próprios da anulabilidade, seria permitido aos acionistas que produzissem e cristalizassem os efeitos jurídicos que bem entendessem: passados os dois anos do prazo decadencial do art. 286 da LSA ou havendo renúncia ao direito de impugnação, convalidar-se-iam todos os vícios, gerando-se a absurda situação de que deliberações ilegais fossem acobertadas pelo manto da imutabilidade. Por isso, de acordo com o comercialista é inegável que não há como afastar do terreno das deliberações a aplicação do regime das nulidades do Código Civil, de tal sorte que a nulidade da deliberação pode ser alegada por qualquer interessado ou pelo Ministério Público e deve ser pronunciada de ofício, ${ }^{162}$ além de ser vedada a sua ratificação. ${ }^{163}$ No direito brasileiro há quem, contudo, negue as deliberações nulas ${ }^{164}$ ou as restrinja a hipóteses muito específicas. ${ }^{165}$

Apesar dessa última opinião, cremos que as deliberações assembleares nulas convivam entre nós. Mas discordamos de que não se sujeitam à decadência e que podem ser impugnadas sem limite de prazo. Ou seja, as deliberações nulas existem, mas a elas não se aplica o cânone de que podem ser desconstituídas a qualquer momento. Compartilhamos

\footnotetext{
${ }^{160}$ Cf. Lobo Xavier, Anulação..., n. 9, p. 146. Embora esse autor utilize a palavra convalidação como algo que os sócios não podem fazer diante de uma deliberação nula, cremos que queria se referir à confirmação.

${ }^{161}$ Cf. Anulação..., n. 8, pp. 126/129.

${ }^{162}$ Em sentido contrário, o seguinte julgado: "não pode o juiz, de ofício, mesmo nos casos em que ainda não atingido o termo 'ad quem' do lapso prescricional, reconhecer a ilegalidade da deliberação e declará-la nula" (STJ, 4ª Turma, RESP n 35.230-0, relator Sálvio de Figueiredo Teixeira, DJ 20.11.95).

${ }^{163}$ Cf. Invalidade..., n. 16, pp. 73/75. Também Ascarelli (cf. "Vícios das deliberações...", n. 3, pp. 374/375 e 385/386), Pontes de Miranda (cf. Tratado de direito privado, t. 50, n. 5.322, pp. 288/295) e Ricardo Tepedino (cf. Direito das companhias, v. I, n. 261, p. 974), para citar alguns, adotaram o mesmo entendimento.

${ }^{164}$ Cf. Luiz Gastão Paes de Barros Leães, "Vícios em assembleia-geral...", n. 20, pp. 162/163; Trajano de Miranda Valverde; Sociedades por ações, v. III, nn. 811, 812 e 815, pp. 97, 99, 100 e 103; e Eduardo Talamini, "Legitimidade, interesse, possibilidade jurídica e coisa julgada nas ações de impugnação de deliberação societária", in Flávio Luiz Yarshell e Guilherme Setoguti J. Pereira (coords.), Processo societário, p. 114.

${ }^{165}$ Para Nelson Eirizik, só se pode cogitar de nulidade absoluta diante de disposição estatutária contrária à lei (cf. A Lei das S/A..., v. III, pp. 591/592 e 598).
} 
do entendimento de que a deliberação nula deveria estar submetida a um prazo decadencial mais alongado do que a anulabilidade (embora nunca a prazo algum), mas diante da redação do art. 286 da Lei das S.A. esta é uma posição defensável apenas de lege ferenda. Na nossa realidade legislativa - que, repita-se, não pode ser desconsiderada -, pouco importa o vício que inquina a deliberação; o direito de impugná-lo estará sempre sujeito ao prazo decadencial bienal.

$\mathrm{O}$ art. 286 da LSA expressamente estabelece que o direito à desconstituição da deliberação inválida esvai-se em dois anos e, apesar de, ao interpretarmos o texto legal, não estarmos atados à sua literalidade, não podemos simplesmente desconsiderar as palavras da lei. ${ }^{166}$ Se esta estabelece $X$, não podemos dela extrair Y; quem sabe $\mathrm{X}$ com algum temperamento, mas não Y. Quando menos, portanto, o art. 286 da LSA sinaliza para dizer pouco - na direção de que o ordenamento quer que, independentemente da natureza do vício que o inquina, o ato se convalide em dois anos.

Verdade que vai contra o senso de justiça a ideia de que deliberações ilegais tornem-se imutáveis porque não impugnadas dentro de certo prazo. Por outro lado, igualmente injusto seria que elas fossem indefinidamente precárias, à eterna espera de que algum interessado pedisse a sua invalidação. Mesmo os ilícitos penais, salvo poucas exceções, sujeitam-se à prescrição, por mais graves que sejam. É correto que os prazos prescricionais para a pretensão punitiva de crimes graves são bem mais alongados que o prazo bienal do art. 286 da LSA, mas é também verdade que o direito penal é a ultima ratio e, assim, os bens jurídicos por ele tutelados são, em tese, mais relevantes do que os que podem ser violados por uma deliberação inválida.

\footnotetext{
${ }^{166}$ A respeito disso, ver nosso É possível a chamada "relativização" da coisa julgada?, no qual, analisando a questão da desconsideração da coisa julgada, apontamos que "embora não se negue aqui que o ato de interpretação seja ele também um ato de criação normativa (...), está sendo paulatinamente esquecido - e ninguém parece com isso se importar - que há limites na atividade interpretativa e, mais ainda, que esses limites têm uma razão de ser, que é a de resguardar a sociedade do arbítrio e das subjetividades do julgador". $\mathrm{Na}$ mesma ocasião, tivemos a oportunidade de apontar que "o que me parece importante é atentar para o fato de que deve haver um mínimo de conformidade ao texto legal, pois, do caso contrário, seria o mesmo que reputar inúteis a Constituição, os Códigos e os demais diplomas jurídicos. É dizer, na medida em que, a pretexto de se estar fazendo interpretação extensiva, sistemática, conforme a Constituição etc. se desprenda completamente do texto legal, esvazia-se por completo a noção de ordenamento jurídico enquanto conjunto ordenado de normas" (cap. 6.7, pp. 89/90).
} 
Note-se, ademais, que há outros ordenamentos que não só contam com prazos para a impugnação de deliberação anulável muito mais curtos do que os nossos dois anos, como também fixam prazo para a impugnação de deliberação nula. É o caso, por exemplo, da Itália, que prevê 30 dias para a primeira demanda e três anos para a segunda, ressalvada apenas a deliberação nula que institua objeto social ilícito ou impossível, hipótese em que não há prazo para o exercício da pretensão (arts. 2.377 e 2.379). ${ }^{167}$

E mais. Apesar de o art. 169 do Código Civil fixar que o nulo não convalesce pelo decurso do tempo e, assim, acolher o que afirmou a doutrina tradicional (quod nullum est nullo lapsu temporis convalescere potest, ou, o que é nulo não pode ganhar força com o decurso do tempo), há nomes de autoridade que, com razão, afirmam que o nulo está sujeito à decadência. Buzaid, com efeito, alertou que o enunciado de que as demandas meramente declaratórias - geralmente associadas à impugnação dos atos nulos - não estão sujeitas a lapso temporal é uma regra, que, como tal, comporta exceções. ${ }^{168}$ Caio Mário da Silva Pereira, por sua vez, defendeu que a paz social, a favor da qual milita a prescrição e a decadência, deve prevalecer sobre o resguardo da ordem jurídica, de maneira que não haveriam direitos imprescritíveis. ${ }^{169}$ Também Agnelo Amorim Filho, em trabalho ainda hoje fundamental para o estudo da prescrição e da decadência, afirmou que existem demandas que, como a de nulidade de ato jurídico, seriam apenas aparentemente declaratórias, já que na realidade são constitutivas negativas, pois extirpam o ato do mundo jurídico. Em reforço desse entendimento, invocou os atos nulos que produzem

\footnotetext{
167 Embora também haja ordenamentos que disciplinam a questão de forma diversa. Em Portugal, por exemplo, o Código das Sociedades Comerciais firma o prazo de 30 dias para o ajuizamento da demanda de anulação de deliberação (art. $59^{\circ}$ ), mas silencia a respeito do prazo para a demanda de nulidade, o que leva a doutrina a defender que esta não está sujeita a prazo algum (cf. Paulo Olavo Cunha, Direito das sociedades comerciais, n. 30.6.3, p. 708).

${ }^{168}$ Sob a vigência do Código Civil de 1916, Buzaid deu os exemplos da ação de contestação de legitimidade da filiação (art. 178, $\S 3^{\circ}$ ); ação dos herdeiros do filho para prova da legitimidade da filiação (art. 178, $\S 6^{\circ}$, XII); e ação do filho natural para impunar o reconhecimento (art. 178, § 9, VI) (cf. "A ação declaratória no direito brasileiro", pp. 162/166).

169 Nesse sentido: "Estão, pois, um contra o outro, dois princípios de igual relevância social: o nãoconvalescimento do ato nulo tractu temporis e o perpétuo silêncio que se estende sobre os efeitos do negócio jurídico, também tracto temporis. E, do confronto entre estas duas normas, igualmente apoiadas no interesse da ordem pública, continuo sustentando que não há direitos imprescritíveis e, portanto, perante o novo Código, a declaração de nulidade prescreve em dez anos (art. 206)" (cf. "Instituições...”, v. I p. 542). Silvio de Salvo Venosa, que partilhava dessa posição no CC/16, defende que, diante do art. 169 do CC/02, o ato nulo é sim imprescritível (cf. Direito civil, v. I, p. 595). No direito italiano, Betti já apontara que a invalidação do matrimônio era sujeita a uma particular forma de caducidade em períodos breves (um ou três meses) (cf. Teoría general..., n. 587, p. 356), em razão das já tantas vezes referidas particularidades de tratamento que o direito material dos mais variados dispensava ao casamento. O mesmo raciocínio aplica-se às invalidades societárias.
} 
efeitos permanentes e que inclusive chegam a se convalidar, como é o caso do casamento putativo. ${ }^{170} \mathrm{E}$, pela leitura de seu artigo, parece-nos que, se indagado sobre a demanda de anulação ou de nulidade de deliberação assemblear, ele diria que ambas estão sujeitas à decadência, pois, como visto anteriormente, em sua teoria as demandas de nulidade de atos jurídicos são constitutivas (e não declaratórias). Com pensamento análogo, Humberto Theodoro Jr. defende que a teoria moderna distingue entre negócios nulos que produziram efeitos concretos e os que não os produziram. Se o ato inválido não foi efetivado, isto é, não produziu efeitos, poderá ser objetada a sua invalidade a qualquer momento, sem que se cogite de decadência. Se, contudo, apesar do seu defeito, produziu seus efeitos naturais e criou situações para as partes envolvidas, está sujeito à decadência, pois a segurança jurídica não pode ficar indefinidamente em xeque. ${ }^{171}$

Se o nulo não está a salvo da decadência nem no direito civil, o que dirá no direito societário. E, de fato, já entendeu o STJ que "a teoria das nulidades de Direito comum não se aplica, de ordinário, em matéria de sociedades anônimas, de modo que os atos societários nulos prescrevem nos prazos previstos na lei societária"172 e que "o direito de impugnar as deliberações tomadas em assembléia, mesmo aquelas contrárias à ordem legal ou estatutária, sujeita-se à prescrição, somente podendo ser exercido no exíguo prazo previsto na Lei das Sociedades por Ações". 173

A despeito de a lei referir-se apenas a deliberações anuláveis, portanto, as deliberações nulas convivem entre nós, mas também elas estão sujeitas ao prazo decadencial do art. 286 da LSA. Essa regra geral, porém, apresenta duas exceções, pois há dois casos em que, embora não se possa dizer que não se aplica o prazo do art. 286 da LSA - porque ele se aplica indistintamente a qualquer situação -, em termos práticos é obtido o mesmo resultado como se aquele não se aplicasse. Tais hipóteses são: (i) norma estatutária nula e (ii) deliberação nula que viole a lei e cujos efeitos sejam constantemente produzidos.

A primeira hipótese é a de modificação do estatuto social por deliberação nula, da qual são exemplos a fixação da "comercialização de drogas" ou da "prestação de

\footnotetext{
${ }^{170}$ Cf. "Critério científico....", pp. 742/743 e 747/748.

${ }^{171}$ Cf. Notas a Orlando Gomes, Introdução ao direito civil, n. 286, p. 485.

172 REsp 1.046.497/RJ, Rel. João Otávio de Noronha, DJe 09.11.2010.

${ }^{173}$ STJ, $4^{\mathrm{a}}$ Turma, RESP no 35.230-0, Rel. Sálvio de Figueiredo Teixeira, DJ 20.11.95.
} 
serviços de assassinato" como objeto social. ${ }^{174}$ A deliberação que alterou o estatuto continua sujeita ao prazo decadencial de dois anos, mas a norma estatutária poderá ser impugnada sem limite de tempo. Nada impede que se peça também a desconstituição da deliberação; mas, para tanto, a pretensão está sujeita ao prazo do art. 286. Mas, de toda forma, para que se atinja o fim pretendido no mais das vezes bastará anular a norma estatutária, mesmo que não se anule deliberação que lhe deu origem.

A norma estatutária é um efeito da deliberação, que se destaca desta. Existe, nos dizeres de Comparato, uma separação objetiva entre elas, que são ontológica e cronologicamente diversas. Da mesma forma, como ocorre com a lei, que após o regular trâmite legislativo passa a ter existência jurídica autônoma, também a norma estatutária desprende-se da deliberação que a criou. Além de haver diferença ontológica entre as duas figuras - pois a norma é um comando geral e abstrato, dirigido a todos, ao passo que a deliberação é um ato pontual e emitido por determinado sujeito -, há também diferença cronológica: enquanto a deliberação é um fato jurídico pontual, a norma se protrai no tempo. ${ }^{175}$ E essa diversidade gera diferença também no tratamento das invalidades. ${ }^{176}$

Quando se pede a desconstituição de uma norma estatutária, o objeto do provimento não será um ato ou relação jurídica em particular, mas sim um enunciado abstrato e geral. A norma inválida insere-se em uma hierarquia normativa e, assim, é como se a violação seja constantemente renovada. Por isso é que para o reconhecimento da invalidade de norma estatutária não há que se falar em decadência. ${ }^{177}$ Mas, repita-se, para toda e qualquer deliberação, aplica-se o prazo bienal do art. 286 da LSA.

\footnotetext{
${ }^{174}$ Também Ascarelli defendeu que a nulidade do contrato social pode ser sempre invocada (cf. "Os vícios de constituição...”, n. 15, p. 367).

${ }^{175}$ Cf. "Da imprescritibilidade...”, p. 219. Também Nelson Eizirik entende que a única hipótese de nulidade absoluta é a da disposição estatutária contrária à lei, de modo que, em razão da estrutura escalonada das normas, "o estatuto integra o ordenamento jurídico societário de determinada companhia e suas regras retiram o seu fundamento de validade das normas superiores contidas na Lei das S.A. Assim, uma disposição estatutária conflitante com a Lei das S.A. não existe como norma jurídica, podendo ser declarada a sua nulidade a qualquer tempo" (cf. A Lei das S/A..., v. III, pp. 587/588 e 592).

${ }^{176}$ Mais uma vez invocando-se Comparato, "como direito objetivo que é, como sistema normativo, o estatuto está submetido a regras de validade bem diferentes das que disciplinam os atos jurídicos" (cf. "Da imprescritibilidade...”, pp. 222/223).

${ }^{177}$ Embora chegue à mesma conclusão, Comparato o faz por outros fundamentos: a imprescritibilidade da demanda que visa ao reconhecimento de invalidade da norma estatutária decorre de que, nesse caso, o que está em jogo não são interesses pessoais, mas sim da "comunidade para a qual a norma foi editada" (cf. "Da imprescritibilidade...”, pp. 224/225).
} 
A segunda e última hipótese em que a deliberação nula pode ser impugnada a qualquer momento é a da deliberação nula que viole a lei e cujos efeitos sejam constantemente renovados no tempo. É o caso, por exemplo, da deliberação que eleja um estrangeiro para administrar empresa jornalística, em violação ao art. 222 da $\mathrm{CF}:{ }^{178}$ os efeitos da deliberação não se esgotam no momento em que cumprida, mas perduram por todo o período em que o estrangeiro permanecer no cargo. Também nesta situação não é que o prazo do art. 286 da LSA não se aplique; ele se aplica, mas como a violação é constante e contínua, o termo a quo para o exercício da pretensão desconstitutiva é também constantemente renovado.

Essas duas exceções conciliam o art. 286 da LSA com a impossibilidade de que se convalidade norma estatutária nula ou deliberação nula violadora de lei e cujos efeitos sejam produzidos constantemente.

Outra saída talvez seja aceitar e alargar a categoria das deliberações juridicamente inexistentes. Em um breve artigo escrito em réplica a Carnelutti, Ascarelli disse que, embora as consequências da inexistência e da nulidade possam coincidir, a distinção entre as duas figuras é também prática e se evidencia em situações em que a lei alude apenas à anulabilidade e o intérprete não vê como encaixar nessa categoria uma hipótese concreta, ou em situações em que a lei também regula casos de nulidade mas a letra da lei não permite encaixar o caso concreto. ${ }^{179}$ Caso este caminho seja trilhado, desde logo deve-se alertar que a inexistência está, como disse Vivante, ligada a uma existência aparente ou à falta de elementos essenciais do ato jurídico ${ }^{180}$ - que, em regra, diz respeito ao trinômio sujeito, objeto e forma. ${ }^{181}$ Fora dessas hipóteses, não é correto falar em inexistência, sobretudo pragmaticamente, com o único intuito de afastar a decadência.

Vale lembrar, por fim, que, fechada a porta da tutela específica, restará sempre a via da tutela ressarcitória. Essa é, aliás, uma tendência do direito italiano, sobretudo após a

\footnotetext{
${ }^{178}$ Exemplo colhido em Erasmo Valladão França, Invalidade..., n. 16, p. 73.

${ }^{179}$ Cf. "Inesistenza e nullità", in Problemi giuridici, t. I, pp. 227/228.

${ }^{180}$ Cf. Trattato di diritto comerciale, v. II, n. 521, p. 253. A respeito do núcleo essencial da deliberação, v. Valentino Sanna, "L'inesistenza delle deliberazioni assembleari e delle decisioni assembleari: un problema ancora aperto", Rivista di diritto civile, v. 53, n. 2, p. 205.

${ }^{181}$ Vem a calhar a ponderação de Flávio Yarshell, para quem, no direito processual civil, "mesmo em relação aos três elementos já mencionados - sujeito, objeto e forma -, não é qualquer vício que será apto a gerar uma decisão qualificável como inexistente" (cf. Ação rescisória..., n. 78, p. 245).
} 
reforma de 2003, pela qual, procurando privilegiar a estabilidade dos atos societários, o legislador evidenciou a tutela ressarcitória como uma alternativa à tutela específica. ${ }^{182}$ Por isso, nem se diga que a posição ora defendida seria restritiva do direito de acesso à justiça. É como se o legislador optasse por, em se tratando de litígios societários, restringir a tutela desconstitutiva e dar prevalência à tutela condenatória (indenizatória), na premissa de que o custo econômico que a posição contrária representaria é muito grande. Opta-se por restringir direitos em prol do caminhar da vida societária. ${ }^{183}$

\subsection{Inexistência, nulidade, anulabilidade e ineficácia das deliberações}

A tipologia dos vícios das deliberações assembleares, assim como a dos atos jurídicos em geral, obedece, antes de tudo, à vontade da lei. Trata-se, portanto, de questão de política legislativa. ${ }^{184}$ Mas, independente disso, também como ocorre com os atos

${ }^{182}$ Luca Enriques e Andrea Zorzi, com efeito, apontam que "la riforma del diritto societario del 2003 ha confermato, accentuando, la tendenza dell'ordinamento settoriale delle società a cercare in rimedi diversi da quelle invalidativi (o 'reali') gli strumenti di tutela delle posizioni soggetive degli attori giuridici, in ossequio a una costante ricerca di 'stabilitá' degli atti sociali. In questo quadro, lo strumento alternativo privilegiato (...) è la tutela risarcitoria. (...) Si è parlato di 'sostituzione' della tutela invalidatoria con quella rissarcitoria. Il chiaro intento di politica legislativa é quello di evitare che l'azione sociale sai intralciata da soci di minoranza titolari di partecipazioni inferior a una soglia ritenuta critica; il legislatore ritiene più consona alla tutela degli interessi di tali soggetti la tutela, appunto, risarcitoria, che garantisce (dovrebbe garantire) il diritto della parte lesa 'senza compromettere interessi dimensionalmente sproprozionati all'entità della lesione', dato che tale forma di tutela può essere di 'precisione chirurgica"” (cf. "Spunti in tema...", n. 1, pp. 1 e 3).

${ }^{183}$ Dúvida existe sobre a possibilidade de que o estatuto altere o prazo decadencial do art. 286 da LSA. O Código Civil vigente, inovando em relação ao de 1916, prevê expressamente a hipótese de decadência convencional, em seu artigo 211: "Se a decadência for convencional, a parte a quem aproveita pode alegá-la em qualquer grau de jurisdição, mas o juiz não pode suprir a alegação". Também o Código de Defesa do Consumidor traz disposição nesse sentido, ao permitir a ampliação e a redução do prazo para o consumidor, diante de responsabilidade por vício do produto e do serviço, optar pela substituição do produto por outro, devolução da quantia paga ou redução do preço (art. 18, § $2^{\circ}$ ): "Poderão as partes convencionar a redução ou ampliação do prazo previsto no parágrafo anterior, não podendo ser inferior a sete nem superior a cento e oitenta dias". Não só a decadência convencional existe em nosso sistema como está prevista justamente no microssistema do CDC. Diante disso, talvez fosse possível a inserção de cláusula estatutária alterando o prazo do art. 286 da LSA. O prazo, assim, poderia apenas ser apenas aumentado, mas não diminuído, pois assim estar-se ia restringindo o direito de ação de modo mais gravoso do que estabeleceu o legislador. Contudo, em que pese a esse raciocínio, cremos que o prazo do art. 286 não pode ser alterado, por se tratar de regra imperativa.

${ }^{184}$ Exemplo disso é que, ao analisar os arts. 2.377 e 2.379 do Codice Civile italiano, Corrado Ferri observa que, enquanto no direito civil italiano a demanda de nulidade é geral e construída com base na circunstância de que o ato seja contrário a normas imperativas e a demanda de anulação é especial e exercida apenas nos casos previstos em lei, com a disciplina da invalidação de deliberações sociais ocorre o contrário: é geral a demanda de anulação e especial a de nulidade. Isso porque o art. 2.379, que disciplina os casos de nulidade, possui rol taxativo, ao passo em que o art 2.377, que disciplina os casos de anulabilidade, apresenta uma moldura legislativa subsidiária, para os demais casos de violação à lei ou ao estatuto. Daí por que a violação a uma norma imperativa pode gerar a mera anulabilidade da deliberação (cf. "Le impugnazioni...”, n. 1, p. 52). Isso, aponta Ferri, decorre da necessidade de se eliminar, quando possível, as incertezas quanto à estabilidade das deliberações societárias, o que tutela não só a sociedade, mas inclusive terceiros que com 
jurídicos em geral - v. item 5 acima -, o critério adotado na classificação das invalidades das deliberações é o do interesse violado. Se a norma infringida tutela um interesse geral, que extravasa a órbita societária ou que pode prejudicar terceiros, o futuro quadro de acionistas ou o interesse público em sentido estrito, haverá nulidade; se a violação é de norma que resguarda interesse particular, restrito a um sócio em específico ou mesmo a todos os sócios que, naquele momento, integram a sociedade, haverá anulabilidade. ${ }^{185}$

Um primeiro aviso que deve ser feito é: o que se chama de "nulidade" em matéria de deliberação assemblear não tem nenhuma relação com a nulidade do direito civil. São vícios radicalmente diversos, ${ }^{186}$ inclusive porque, como será visto a seguir, entendemos

esta contratam (p. 53). Também anotando que no regime do Código Civil italiano a anulabilidade pode estar relacionada a violação de qualquer norma legal ou estatutária, Stefania Pacchi Pesucci, "Impugnazione di delibere assembleari: legitimazione ed interesse ad agire", Rivista del diritto commerciale, v. 88, n. 1-2, p. 45. Como aponta Raffaele Lener, o regime dos arts. 2.377 e 2.379 do Código Civil italiano prevê a nulidade apenas quando há ausência de convocação da assembleia, ausência de manifestação de vontade ou ilicitude ou impossibilidade do objeto. Todos os outros vícios implicam apenas anulabilidade (cf. "Invalidità delle delibere assembleari di società per azioni”, Rivista del diritto commerciale, v. 102, n. 1/3, p. 79).

185 Cf. Ascarelli, "Vícios das deliberações...", n. 3, p. 385 e Appunti di diritto commerciale - società e associazioni commerciali, p. 280; Erasmo Valladão França, Invalidade..., cap. III, pp. 65/118; RomanoPavoni, Le deliberazioni..., n. 35, p. 131; Mario Vaselli, Deliberazioni nulle..., cap. III, nn. 5/6, pp. 31/36; Antigono Donati, L'invadlità..., nn. 25, 26 e 31, pp. 101, 105 e 121; Lacerda Teixeira-Tavares Guerreiro, Das sociedades anônimas..., v. II, n. 282, p. 821; Wilson de Souza Campos Batalha, Sociedades anônimas e mercado de capitais, n. 321, pp. 803/804; e Priscila Corrêa da Fonseca, Suspensão..., p. 152. Com algumas peculiaridades, esse é o critério adotado também por Aurelio Candian (cf. Nullità e annullabilità..., n. 70, p. 134). O mesmo critério é utilizado pela doutrina também na classificação dos vícios das deliberações das assembleias de condôminos (cf. João Batista Lopes, Condomínio, p. 108). Contudo, há casos, ressalta Ascarelli, que "embora se trate de violação de norma que tutela os terceiros, a deliberação é 'anulável', e não 'nula'", dando como exemplo a deliberação em fraude aos credores, que, segundo ele, também estaria sujeita à disciplina do art. 156 do DL 2.627/40 e, portanto, acarretaria a anulabilidade (cf. "Vícios das deliberações...", n. 3, pp. 385/386, notas 54 e 55). Pontes de Miranda e Moitinho de Almeida apreciam o assunto de forma casuísta, sem externar qual o critério classificatório por eles empregado (respectivamente, cf. Tratado de direito privado, t. 50, n. 5.322, p. 287/295 e Anulação e suspensão, parte I, n. 4, pp. 50 e seguintes.).

${ }^{186}$ Por exemplo, no direito italiano a nulidade do direito civil comum é imprescritível, enquanto que a nulidade prevista pelo art. 2.379 do CC daquele país submete-se ao prazo decadencial de três anos, salvo uma única hipótese. A nulidade da deliberação também é conhecível de ofício pelo juiz, mas apenas dentro do prazo em que a parte pode impugná-la e suscitá-la. Se escoado o lapso prescrional trienal, o poder-dever do juiz esvai-se. Além disso, a nulidade comum é insanável, ao passo que a de deliberação nula é expressamente sanável e substituível por nova deliberação. Por fim, costuma-se dizer que a nulidade do direito civil opera $e x$ tunc, atingindo os atos subsequentes que guardem relação com aquele ato viciado inicial: quod nullum est, nullum producit effectum. O mesmo não ocorre com as deliberações assembleares. Em alguns casos, a nulidade da deliberação gera apenas a sanção de ressarcimento em favor de quem se sagrou vitorioso na ação judicial (cf. Andrea Pissani Massamormile, "Invalidità delle delibere assembleari. Stabilità ed effetti", Rivista del diritto commerciale e del diritto generale delle obligazioni, n. 102, pp. 55/57). Também Ascarelli apontou que "Nullità e annullabilità della deliberazione non costituiscono a loro volta trasposizione delle norme genelerali del negozio giuridico" (cf. "L'interesse sociale dell'art. 2441 Cod. Civile. La teoria dei diritti individuali e il sistema dei vizi delle deliberazioni assembleari”, in Problemi giuridici, t. II, p. 533). V, ainda, Corrado Ferri, "Le impugnazioni di delibere assembleari. Profili processuali", Rivista trimestrale di diritto e procedura civile, LIX, p. 52; e Francesco Terrusi, L’invalidità..., n. 5.1, p. 220. E embora essas 
que no direito societário são bastante reduzidas as diferenças entre nulidade e anulabilidade. Também válida é a observação de Comparato de que é preciso ter em mente que a LSA estabelece uma verdadeira distinção de natureza entre sociedades abertas e fechadas. Naquelas predomina o aspecto institucional, pautado por um número maior de disposições inderrogáveis pelos acionistas, ao passo que nestas predomina caráter contratual, marcado por maior liberdade conferida aos acionistas na regulação dos interesses da companhia. Por isso, ao analisar a hipótese concreta procurando concluir quanto ao tipo da mácula que contamina a deliberação, o intérprete deve verificar se tratase de sociedade de capital aberto ou fechado. ${ }^{187}$

Partindo da distinção entre os três tipos de vícios que a confusa redação do art. 286 da LSA misturou, Erasmo Valladão França sustenta que no direito brasileiro o vício no conclave é sancionado com a anulabilidade. Embora as normas relativas à convocação, à instalação e às demais formalidades da assembleia sejam imperativas, como a lei expressamente dispõe que o conclave é anulável, assim deve ser. Provavelmente porque o legislador entendeu que esses vícios violam apenas uma assembleia em concreto e, consequentemente, apenas os direitos dos que compõem o quadro acionário naquele momento, que, se quiserem, deverão tomar a iniciativa de propor a demanda anulatória. ${ }^{188}$

observações tenham sido claramente feitas com base nas peculiaridades do direito italiano, aplicam-se, de certa forma, também à nossa realidade.

${ }^{187}$ Cf. "A natureza da sociedade anônima e a questão da derrogabilidade das regras legais de quorum nas assembleias gerais e reuniões do conselho de administração", in Novos ensaios e pareceres de direito empresarial, n. 3, p. 119. Citando esse artigo, Erasmo Valladão França, Conflito de interesses nas assembléia de S.A., cap. II, n. 4, p. 48; e Invalidade..., n. 19, p. 87, embora o referido autor ressalve que "é óbvio que a 'ampla liberdade de estipulação', a que se refere Comparato, é muito relativa, pois existem inúmeras disposições de caráter cogente que se aplicam indistintamente a ambos os tipos de sociedades, notadamente no tocante à sua estrutura”. A consideração entre a natureza aberta ou fechada da companhia é defendida também por Carvalhosa na aferição da conduta do administrador para fins da responsabilização prevista pelo art. 158 da LSA, opinião segundo a qual em se tratando de companhias com capital disperso e sem controlador definido, exige-se ainda maior rigor na conduta dos seus administradores, pois estes exercem a dupla função de gestores e condutores da política empresarial (policy makers), já que não é possível identificar um controlador (cf. Comentários..., $3^{\circ}$ v., pp. 436/438 e 426). De modo similar, Jaeger apontou haver radical diferença entre a sociedade em que os sócios constituem um grupo delimitado e a sociedade de "grandissime dimensioni", que apresenta quadro acionário numeroso e flutuante, o que, contudo, não justifica um tratamento diferenciado a respeito da tutela do interesse social (cf. L'interesse sociale, cap. IV, n. 14, p. 163).

${ }^{188}$ Cf. Erasmo Valladão França, Invalidade..., n. 19.1., pp. 88/97. Esse mesmo autor, porém, ressalva duas hipóteses: ausência de convocação e ausência de quórum de instalação. A primeira seria caso de nulidade, pois se o art. 286 dirige a anulabilidade à assembléia irregularmente convocada, a não convocada só pode ser nula. Já a assembléia irregularmente instalada seria apenas anulável. Além disso, Erasmo Valladão França aponta outros casos de vícios da assembléia ou do conclave: inobservância da ordem do dia (LSA, art. 124, caput), recusa de participação ao acionista (LSA, art. 126, par. $1^{\circ}$ e $4^{\circ}$ ), inexistência do quórum para as votações (LSA, art. 129 e 136), ausência de lavratura da ata (LSA, art. 130), ausência de publicação dos documentos da administração (LSA, art. 133) e inobservância do procedimento e demais formalidades 
Portanto, não importa se a violação foi de norma legal (LSA, arts. 123/128) ou estatutária, ou de norma cogente ou não cogente: sendo o desrespeito a formalidades procedimentais de uma assembleia em concreto (principal, mas não exclusivamente, problemas em convocação e instalação), haverá anulabilidade da assembleia e, consequentemente, de todas as deliberações nela tomadas.

No que diz respeito ao vício da deliberação, muda-se de figura. Quando se pretende alterar ilicitamente o estatuto de modo a se estabelecer uma disciplina permanentemente contrária à lei, as deliberações são nulas, pois violam não só os direitos dos componentes do quadro societário naquele momento, mas também direitos de eventuais futuros acionistas. Mas há ainda um segundo motivo para esse entendimento: enquanto normas jurídicas, as regras estatutárias submetem-se ao brocardo lex superior derogat lex inferiori, de modo que, conflitando com as normas legais, devem prevalecer estas. Não existem normas anuláveis, mas apenas nulas. ${ }^{189}$ Por isso, se uma assembleia ou deliberação viola o direito de um acionista ou mesmo de todos os acionistas em um dado momento, será caso de anulabilidade; se, porém, se pretender estabelecer uma disciplina que viole continuamente a lei, estaremos diante de nulidade. Exemplificando: uma deliberação que desrespeite o direito de preferência de um acionista em concreto é anulável, enquanto que a que excluir permanentemente o direito de preferência de todos os acionistas é nula.

Também nulas são as deliberações que atentem contra a ordem pública ou os bons costumes, em decorrência de impossibilidade ou ilicitude do objeto (exemplo: deliberações que obriguem administradores a praticarem atos fraudulentos ou ilícitos de modo geral, como crimes, simulação, fraude contra credores etc.), bem como as que infrinjam disposições legais que salvaguardem direitos de terceiros (como, por exemplo, normas que asseguram a integridade do capital social ou a veracidade das demonstrações financeiras). ${ }^{190}$ Por fim, são nulas as deliberações que violam o interesse público em

estabelecidas no art. 134 da LSA (pp. 91/96). Também Trajano Miranda Valverde ressalvou que as normas relativas à convocação da assembléia são "preceitos destinados à proteção do interêsse público", mas disse que esses vícios acarretam a anulabilidade, e não a nulidade. O comercialista não justificou por que se trataria de causa de anulabilidade mas, pensamos, isso decorre do seu particular pensamento, que entendia que todos os vícios de deliberações geravam a anulabilidade (cf. Sociedades..., v. III, n. 828, p. 113).

${ }^{189}$ Cf. Erasmo Valladão França, Invalidade..., n. 19.2, pp. 98/100.

${ }^{190}$ Cf. Ascarelli, Appunti di diritto commerciale - società e associazioni commerciali, p. 281; e Erasmo Valladão França, Invalidade..., n. 19.2, pp. 106/108. Nesse último caso, contudo, pensamos que a disciplina 
sentido estrito, como, para citar algumas, as que infrinjam disposições que exigem participação majoritária de brasileiros em determinadas companhias (por exemplo, art. 222 da CF) ou autorização estatal para funcionar. ${ }^{191}$

Se uma deliberação, por seu conteúdo, violar uma disposição estatutária, ela será anulável, pois, novamente conforme Valladão França, terão sido desrespeitados os direitos dos próprios acionistas, aos quais é facultado renunciar às normas estatutárias. ${ }^{192}$

A ineficácia de deliberação, por sua vez, está relacionada à presença ou à falta de um elemento extrínseco, que impede a produção de efeitos. ${ }^{193}$ No direito brasileiro, tratamse deliberações que, sem o consentimento dos acionistas, estabeleçam disciplina violadora de seus direitos especiais. É o caso da alteração nas preferências ou vantagens conferidas a determinada classe de ações preferenciais, que, para ser eficaz, deve ser aprovada ou ratificada dentro de um ano, "por titulares de mais da metade de cada classe de ações preferenciais, reunidos em assembleia especial convocada pelos administradores" (LSA, art. 136, $\S 1^{\circ}$ e incisos I e II). A ineficácia é imposta também em caso de mudanças estatutárias atinentes à diversidade de classes (LSA, art. 16, par. único) ou das que estejam sujeitas à prévia aprovação de titulares de uma ou mais classes de ações preferenciais (LSA, art. 18, par. único). Aqui, novamente, é importante distinguir entre uma violação em concreto e o estabelecimento de uma disciplina que viole os referidos direitos especiais: a

da nulidade já estaria abarcada pela simples violação à norma legal. Também associando a nulidade à violação a direito de terceiros, Lobo Xavier, Anulação..., n. 8, pp. 140/142.

191 Cf. Erasmo Valladão França, Invalidade..., n. 19.2., pp. 110/111. Também assim Lobo Xavier, Anulação..., n. 8, pp. 135/138.

${ }^{192}$ Cf. Erasmo Valladão França, Invalidade..., n. 19.2, p. 105: "resta dizer serem meramente anuláveis (...) as deliberações que violarem os estatutos. Nesta hipótese não se acham em questão senão os interesses dos próprios acionistas, que podem livremente renunciar à aplicação das regras estatutárias, normas meramente internas da corporação, nos casos concretos, inexistindo, outrossim, interesses outros (de 'futuros acionistas', relativos a direitos irrenunciáveis e inderrogáveis, etc.) que justifiquem a sanação de nulidade a tais atos. $\mathrm{O}$ campo da nulidade absoluta das deliberações, portanto, restringe-se à violação à lei e não dos estatutos". Diversamente, Trajano Miranda Valverde sustentou que, quer em caso de violação à lei, quer em caso de violação ao estauto, a deliberação poderia ser anulada (cf. Sociedades..., n. 830, p. 114). Isso decorre da já mais de uma vez mencionada posição desse autor, que reduzia todas as invalidades de deliberações à hipótese de anulabilidade). De acordo com Moitinho de Almeida, no direito português a violação à lei ou ao estatuto pode redundar em nulidade ou anulabilidade, a depender do vício concreto (art. 56 do Código das Sociedades Comerciais) (cf. Anulação e suspensão..., parte, I, n. 4, p. 59). Contudo, com indicação de vasta doutrina estrangeira, Lobo Xavier expressamente afirma que "o vício de que enferma a deliberação que simplesmente contraria estipulações do pacto social nunca se traduzirá na nulidade, mas tão-só na anulabilidade - ou, em certos casos, na ineficácia até ao assentimento de determinado sócio ou categoria de sócios" (cf. Anulação..., n. 9, pp. 148/149).

${ }^{193}$ Cf. Romano-Pavoni, Le deliberazioni..., n. 36, p. 134. 
primeira hipótese leva à ineficácia; a segunda, à anulabilidade, na forma do art. 286 da LSA. ${ }^{194}$

Os vícios nos votos são relevantes para a desconstituição da deliberação apenas quando, excluídos, a maioria não esteja mais presente (v. item 6). Os vícios dos votos enunciados no art. 286 são erro, dolo, fraude ou simulação, mas nada impede que a coação também seja invocada como fundamento para o pedido de desconstituição. ${ }^{195}$ Diante de deficiências desse tipo, o voto e, se este tiver sido essencial para a formação da maioria, também a deliberação serão anuláveis, não só porque o art. 286 da LSA assim dispõe, mas também porque assim o faz o Código Civil (arts. 148 e seguintes). Igualmente anulável é a deliberação que tenha sido constituída com voto proferido em conflito de interesse (LSA, art. $115, \S 4^{\circ}$ ). Mais uma vez conforme a lição de Erasmo Valladão França, todos esses casos representam hipóteses de anulabilidade (LSA, art. 286 e 115, $\S 4^{\circ}$ ) porque se encontram em jogo apenas interesses dos acionistas. Contudo, em se tratando de voto proferido por absolutamente incapaz, será caso de nulidade; e em caso de contrariedade a acordo de voto arquivado na sede da companhia, o voto será ineficaz (LSA, art. 118). ${ }^{196}$

Resta, por fim, analisar a inexistência de deliberação, categoria que, como visto no item 7.1, é controversa. Tanto é que Ascarelli, que entendia haver deliberações inexistentes, disse não haver critérios precisos para diferenciá-las das nulas e anuláveis. ${ }^{197}$ Por outro lado, a categoria é rejeitada por Erasmo Valladão França ao fundamento de que

${ }^{194}$ Cf. Erasmo Valladão França, Invalidade..., n. 19.2, pp. 111/113. Também ineficazes são, ainda de acordo com esse autor, as deliberações que alteram o estatuto de maneira a atingir os direitos dos credores de partes beneficiárias, de debêntures conversíveis em ações ou de debêntures simples (LSA, art. 51, 57, par. $2^{\circ}, 174$ e 231), assim como as deliberações, em relação a terceiros, que reformem o estatuto, enquanto não fore arquivadas e publicadas (LSA, art. 135, $\S 1^{\circ}$ ). No direito português, apontam Vasco da Gama Lobo Xavier e L. P. Moitinho de Almeida, a ineficácia também está ligada a deliberações às quais falta algum requisito exterior do ato, em regra o consentimento de determinado sujeito, para que o ato produza efeitos (cf., respectivamente, Anulação..., n. 7, p. 106, nota 10; e Anulação e suspensão..., parte 1, n. 4, p. 52).

195 Cf. Trajano Miranda Valverde, Sociedades..., v. III, n. 831, pp. 114/115; e Modesto Carvalhosa, Comentários..., v. 4, t. II, p. 287. Como exemplo de erro ou dolo, Erasmo Valladão França aponta ser comum o caso de votação sobre a situação financeira da empresa ser viciada por conta de balanço irregular. Já como exemplo de simulação esse mesmo autor alude aos casos em que administradores, proibidos de votar as própras contas, transferem suas ações para testas-de-ferro, para que estes votem e aprovem as contas em seus lugares (cf. Invalidade..., n. 19.3., pp. 113/117).

196 Cf. Invalidade..., n. 19.3, pp. 116/117.

${ }^{197}$ Um exemplo dado pelo mestre é a deliberação tomada em assembleia cuja convocação não foi realizada regularmente, havendo prejuízo à publicidade e ao direito de participação dos sócios. Uma assembleia como essa seria inexistente, assim como inexistente as deliberações nela tomadas, e o vício poderia ser reconhecido judicialmente mediante demanda meramente declaratória, não sujeita a termo decadencial (cf. Appunti di diritto commerciale - societè e assoziacioni commerciali, p. 279). Romano-Pavoni, por sua vez, entendeu ser útil a distinção entre invalidade e inexistência (cf. Le deliberazioni..., n. 34, p. 129). 
os chamados vícios de inexistência estão englobados pelos vícios de nulidade e que o regime da anulabilidade confere adequada solução à questão. ${ }^{198}$ Com efeito, embora tenha atrelado a inexistência à ausência completa de um requisito do ato e a nulidade ao ato que, embora apresente todos os seus requisitos, em seu conteúdo viola normas postas a serviço do interesse geral, Antigono Donati pontuou ser essa distinção exclusivamente terminológica, inútil e sem importância prática, pois ambas as categorias levariam à ineficácia completa. ${ }^{199} \mathrm{E}$, de fato, o principal motivo para a criação dessa categoria é a ideia de que ela é completamente ineficaz e, portanto, em caso de dúvida seria adequada a tutela meramente declaratória. Mas no caso das deliberações mesmo a deliberação juridicamente inexistente, especialmente após registro e publicação, ostenta uma aparência de legalidade que vai além da mera incerteza jurídica e, em certos casos, pode exigir a remoção por tutela constitutiva.

A verdade é que há grande inexatidão a respeito do que leva à inexistência e, por isso, parecem estar com razão aqueles que afirmam que, ainda que fosse possível trabalhar com essa categoria, isso não seria recomendável. Caso se opte por empregar referida categoria, vale o alerta de Donati: a inexistência deve ser extendida a todas as hipóteses em que falta um requisito essencial da deliberação, e não só aos casos de falta de assembleia, falta de declaração de vontade ou violação a direitos de terceiros. ${ }^{200}$

Resumindo a classificação que acaba de ser exposta, e que neste trabalho é acolhida, tanto os vícios de voto como os de assembleia levam à anulabilidade, pois aqueles maculam apenas os direitos dos acionistas emissores dos votos e estes, os dos acionistas que compõem a sociedade naquele dado momento. Havendo vício na deliberação, a violação de interesse extra-societário (direitos de terceiros, ordem pública, bons costumes, interesse público, interesses de futuros acionistas) leva à nulidade, ressalvados os casos em que a lei autoriza a prática do ato mas a condiciona à aquiescência dos interessados, hipóteses em que haverá ineficácia. Se a deliberação violar a lei de forma

\footnotetext{
${ }^{198}$ Cf. Invalidade..., p. 84. Nesse sentido também Aurelio Candian, que iguala a deliberação nula à nãodeliberação e dá como exemplo daquela a hipótese de "quando manca un requisito d'esistenza della assemblea", que é o que ocorre, por exemplo, se os participantes do conclave não são sócios (cf. Nullità..., n. 17, p. 49).

${ }^{199}$ Cf. L'invalidità..., nn. 24 e 26, pp. 99 e 104. Para um apanhado da doutrina que escreveu sobre o tema, v. n. 24 , pp. 93 e seguintes.

${ }^{200}$ Cf. L'invalidità..., nn. 24 e 26, pp. 99 e 104. Sobre a inexistência de deliberação, v., ainda, Waldirio Bulgarelli, “Deliberar não deliberar é deliberar?”, in Questões de direito societário, pp. 83/93.
} 
duradoura, será caso de nulidade; se violá-la em um caso concreto, de anulabilidade; e, se violar o estatuto, também será caso de anulabilidade. Por fim, as hipóteses de ineficácia estão, grosso modo, relacionadas à criação de disciplina que, sem o consentimento dos acionistas, viole direitos especiais seus. ${ }^{201}$ Basicamente, portanto, o intérprete deve avaliar, no caso concreto, qual o interesse transgredido, fazendo a seguinte pergunta: a quem este vício afeta? Se perturbar apenas a esfera de um acionista, ou mesmo de todos os acionistas em um dado momento da vida societária, haverá anulabilidade; se o derespeito ultrapassar essa órbita, será caso de nulidade.

Embora esta classificação seja feita pela mais autorizada doutrina e, repita-se, seja por nós seguida, ela é confusa, pouco prática e possui relevância muito inferior ao que se costuma pensar. A nosso ver, ela serve principalmente para estabelecer a legitimidade ativa para a impugnação: no caso de nulidade e, para os que a admitem, inexistência, a legitimidade é atribuída a qualquer interessado, isto é, a qualquer um que tenha recebido prejuízo jurídico da deliberação. Inclusive o acionista que votou a favor da deliberação, administradores e terceiros prejudicados têm legitimidade para suscitar os vícios. Já para a anulabilidade prevalece a opinião de que o sócio dissidente, ausente, abstinente ou sem direito a voto possui legitimidade para impugná-la, mas não o acionista que votou favoravelmente, os administradores e, na medida em que as deliberações via de regra produzem apenas efeitos interna corporis, tampouco credores e terceiros. Em se tratando de ineficácia, a legitimidade é daqueles cujo consentimento foi desconsiderado. ${ }^{202-203}$

Dizemos que essa é a principal - e talvez a única - relevância da distinção entre deliberações nulas e anuláveis porque nos parece que no direito societário tal diferenciação

\footnotetext{
${ }^{201}$ Cf. Erasmo Valladão França, Invalidade..., n. 19.4, pp. 117/118.

${ }^{202}$ A respeito da legitimidade, v. Erasmo Valladão França, Invalidade..., n. 20.1, pp. 119 e seguintes; Erasmo Valladão França e Marcelo von Adamek, "Algumas notas...”, p. 162; e Eduardo Talamini, "Legitimidade, interesse...", pp. 104 e seguintes. Embora a temática da legitimidade para a demanda de impugnação de deliberação assemblear não seja objeto deste trabalho, faz-se remissão a um caso bem específico em que surge essa questão, analisada em parecer de Erasmo Valladão França, qual seja, o de sócio de sociedade controladora pleitear a anulação de deliberação da controlada subsidiária integral (cf. "Legitimaçao do sócio da sociedade controladora para pleitear a anulação de assembleia da controlada subsidiária integral", in Temas..., pp. 424/431).

203 E mesmo essa classificação é criticável, na medida em que há doutrina de peso, como Eduardo Talamini, que, partindo da premissa de que a LSA quis igualar nulidade à anulabilidade, defende que não há na lei brasileira, diferentemente do que ocorre na Espanha, Itália e Portugal, distinção entre deliberações nulas e anuláveis sequer quanto à legitimidade ativa ad causam (cf. "Legitimidade, interesse...", p. 114).
} 
é bastante diluída. ${ }^{204}$ Isso porque as duas categorias (i) exigem desconstituição judicial (v. item 12); (ii) são removidas em princípio com efeito ex tunc (v. item 16); e (iii) estão sujeitas à decadência e, portanto, convalescem pelo decurso do tempo (v. item 7.1). E embora haja quem entenda que apenas a deliberação anulável é passível de ratificação e confirmação, ${ }^{205}$ há, de outro lado, quem defenda que, por conta dos imperativos de ampla sanação e convalidação dos atos viciados que vigoram no direito societário, também a nula pode ser ratificada e confirmada. ${ }^{206}$ Mesmo que não seja possível equivaler os dois vícios, eles estão muito mais próximos do que se costuma defender.

Em suma, por um lado, embora a divisão que expusemos entre deliberações nulas e anuláveis seja complexa e até mesmo confusa, ela é acolhida neste trabalho. Mas, por outro, parece-nos que o único aspecto relevante em que se distinguem as deliberações nulas e anuláveis diz com a legitimidade ativa ad causam. Todos os demais aspectos que costumam ser apontados pela doutrina ao diferenciar atos civis nulos e anuláveis não se aplicam, salvo reflexão mais amadurecida, no terreno das deliberações inválidas.

De toda forma, não convém aprofundar o assunto. Para os fins deste trabalho, o importante é reconhecer que, no que diz respeito ao conteúdo do provimento e aos limites objetivos e subjetivos do provimento e da coisa julgada na demanda de impugnação de deliberação assemblear, não há rigorosamente nenhuma diferença entre deliberações nulas e anuláveis. É o que basta para prosseguirmos.

\section{A posição dos administradores perante deliberações inválidas}

Não só porque o administrador deve agir no interesse da companhia e, assim, evitar a prática de ato ilegal, mas também porque pode ser pessoalmente responsável pelo cumprimento de deliberação ilícita, predomina a ideia de que a administração deve dar

\footnotetext{
${ }^{204}$ Nesse sentido, v. Luiz Fernando C. Pereira, Medidas urgentes..., n. 3.7, p. 164; e, no direito italiano, Elena Zucconi Galli Fonseca, "La compromettibilità delle impugnative di delibere assembleari dopo la riforma", Rivista trimestrale di diritto e procedura civile, v. 59, n. 2, p. 456.

${ }^{205}$ Cf. Ricardo Tepedino, Direito das companhias, v. I, n. 261, p. 988.

${ }^{206}$ Cf. Trajano de Miranda Valverde, Sociedades..., v. III, n. 832, pp. 115/116; Lamy Filho, "Mudança do objeto...", pp. 545/546; Nelson Eizirik, A Lei das S/A..., v. II, pp. 582 e 591/593.
} 
cumprimento à deliberação anulável, mas negar-se a fazê-lo se o ato for nulo. ${ }^{207}$ À base dessa diferenciação está a tantas vezes referida noção de que as deliberações nulas são desprovidas de efeito e as anuláveis produzem efeitos provisórios, cuja remoção dependeria da iniciativa de alguns poucos interessados. ${ }^{208}$

Há quem tenha defendido, porém, que a administração não está cegamente atrelada nem mesmo à deliberação anulável e que por isso tem o dever de recusar-se a concretizá-la. ${ }^{209}$ Nesse sentido Ascarelli, para quem os administradores não devem seguir as deliberações viciadas, ainda aquelas cujo reconhecimento do vício dependesse de iniciativa do acionista, ${ }^{210}$ e Lobo Xavier, que disse haver hipóteses em que os administradores, sopesando os ganhos e prejuízos do cumprimento e do descumprimento da deliberação anulável, devem optar por este último. ${ }^{211} \mathrm{Na}$ mesma direção foi Erasmo Valladão França, para quem os administradores não estão adstritos a seguir deliberações nulas, sob pena, inclusive, de serem responsabilizados pessoalmente (LSA, arts. 201, $\S 1^{\circ}$ c/c art. 190 e art. 138), embora, tenha reconhecido aquele teórico, as deliberações anuláveis devam em princípio ser cumpridas. ${ }^{212}$

Contudo, a deliberação inválida - mesmo a nula, como se demonstrará no item 12 - em princípio produz efeitos e, em razão das exigências de estabilidade da atividade empresarial, somente um ato formal, como uma sentença ou uma deliberação que revogue a deliberação anterior, é que pode contrabalançar a existência desta perante os sócios, os terceiros e a própria companhia: é um procedimento que dá vida à deliberação e é apenas

\footnotetext{
${ }^{207}$ Cf. Antigono Donati, L'invalidità..., n. 72, p. 221. Nelson Eizirik entende que os administradores têm o poder-dever de não acatar as deliberações contrárias à lei e aos estatutos, embora sem diferenciar as nulas das anuláveis (cf. A Lei das $S / A$..., p. 595).

208 O que, conforme se procurará demonstrar no item 12, não nos parece correto, pois ambos os vícios não impedem a eficácia do ato assemblear.

${ }^{209}$ Cf. Aurelio Candian, Delibere..., n. 72, p. 141; e Romano-Pavoni, Le deliberazioni..., n. 94, p. 362.

210 Cf. “Appunti...", nn. 9 e 11, pp. 277 e 285: “indipendentemente dall'azione del socio, le deliberazioni viziate non debbono essere eseguite dagli ammiistratori”. Aparentemente é essa a posição também de Gianluca Guerrieri (cf. La nullità..., cap. V, n. 15, p. 356).

${ }^{211}$ Ou seja, o administrador tem o poder-dever de, considerando as razoáveis probabilidades de uma futura anulação da deliberação, não cumprir uma deliberação anulável: "muito embora a deliberação anulável se dirija a vincular a actividade dos titulares do órgão administrativo, naquele domínio em que isto se considere admissível, será lícito àqueles absterem-se de a executar, quando, ponderadas as circunstâncias que referimos - ou seja, as probabilidades de uma futura anulação e os inconvenientes da execução em tal hipótese -, este caminho lhes apareça indicado pelo interesse da sociedade e dos sócios" (cf. Anulação..., n. 20, pp. 347/366).

${ }^{212}$ Cf. Invalidade..., n. 15, p. 64, inclusive nota 107. Também defendendo que não há como constranger os administradores a cumprirem deliberações contrárias à lei ou ao estatuto social, Priscila Corrêa da Fonseca (cf. Suspensão..., pp. 96/97) e Marcelo von Adamek (cf. Responsabilidade civil..., n. 6.2.2, p. 275).
} 
um ato igualmente formal que pode extirpá-lo do mundo jurídico. Não apenas o nascimento mas também a eliminação da deliberação é construída com vistas a assegurar o desenvolvimento da organização societária. Também para a sua desconstiuição, logo, exige-se o percurso de um iter previamente estabelecido. ${ }^{213}$

\section{É com esse espírito que em Portugal o art. $57^{\circ}$ do Código das Sociedades} Comerciais investe o órgão de fiscalização do dever de denunciar as deliberações nulas à assembleia geral. Uma vez promovida a denúncia, abrem-se ao colégio de sócios três opções: renovar a deliberação, se possível; promover a demanda declaratória de nulidade; ou não fazer nada. Cabe aos sócios, assim, e não ao administrador, o juízo sobre a licitude do ato. $^{214}$

${ }^{213}$ Cf. Ilaria Pagni, Le impugnazione..., pp. 592/595. Nesse sentido é que Pagni diz que "la materia è permeata da esigenze di certezza dei trafici, che rendono necessaria l'adozione di opportune forme di pubblicità dell'operare degli organi sociali, e la stessa delibera viene ad esistenza rispettando regole procedimentali che ne garantiscono la conoscibilità. Per questo solo un atto parimenti formale (com'è la sentenza) è in grado di bilanciare l'emanazione dell'ato invalido agli occhi dei soci e dei terzi e ad evitare in consolidarsi di situazioni di apparenza sorrette dall'autosufficienza del negocio di attuazione corrispondente o dall'autosufficienza dell'elemento pubblicitario" (p. 594). Para ilustrar, aquela autora fornece o exemplo do art. 2.504 quater do Código Civil Italiano, que estabelece que, após ser inscrita no registro de empresa, a deliberação de fusão não pode ter sua nulidade decretada, o que revela que, por razões internas ao sistema societário, pretendeu-se evitar gravíssimas dificuldades que adviriam da invalidação de uma fusão já consolidada (p. 593).

${ }^{214}$ Artigo 57.

(Iniciativa do órgão de fiscalização quanto a deliberações nulas)

1 - O órgão de fiscalização da sociedade deve dar a conhecer aos sócios, em assembleia geral, a nulidade de qualquer deliberação anterior, a fim de eles a renovarem, sendo possível, ou de promoverem, querendo, a respectiva declaração judicial.

2 - Se os sócios não renovarem a deliberação ou a sociedade não for citada para a referida acção dentro do prazo de dois meses, deve o órgão de fiscalização promover sem demora a declaração judicial de nulidade da mesma deliberação.

3 - O órgão de fiscalização que instaurar a referida acção judicial deve propor logo ao tribunal a nomeação de um sócio para representar a sociedade.

4 - Nas sociedades que não tenham órgão de fiscalização, o disposto nos números anteriores aplica-se a qualquer gerente.

Sobre esse dispositivo, Pinto Furtado anotou que "o nosso Código, por seu turno, começa por apresentar, no referido art. 57, a particularidade de impor ao órgão de fiscalização um especial dever prévio de apurar a existência de deliberações nulas e fazer a sua denúncia perante a assembléia geral, com vista à imediata reposição da legalidade, prontamente lhe reconhecendo legitimidade para a propositura da acção declarativa da nulidade, se isso não tiver sido feito". E mais: "Não se trata, pois, apenas, de denunciar a nulidade da deliberação 'anterior', mas de um dever de comunicação, na primeira reunião da assembleia geral posterior ao apuramento do vício, podendo imputar-se-lhe negligência, se deixar passar essa reunião sem the dar cumprimento". Na eventualidade da assembleia entender que, de fato, o ato é nulo, explica Pinto Furtado, será necessário recorrer ao Judiciário apenas em casos especiais, pois se a deliberação não estiver sujeita a registro e se não teve aplicação prática, bastará "o acertamento deliberativo da nulidade". Caso a assembleia queira confirmar a validade da deliberação, deverá rechaçar a denúncia e produzir "uma deliberação assertória da validade da deliberação anterior que, decerto, jamais poderá ser vista como uma renovação" (cf. Deliberações..., nn. 110/111, pp. 752/753). Também defendendo a compulsoriedade da deliberação nula 
Embora entre nós não haja disposição legal semelhante, cremos que solução como essa é a que melhor se ajusta ao direito brasileiro. As deliberações nulas e anuláveis são eficazes, e enquanto não desconstituídas vinculam a administração, razão pela qual caso se entenda que a deliberação é nula ou anulável cabe ao conselho de administração, se houver, à diretoria ou mesmo aos acionistas detentores de mais de 5\% do capital social convocar a assembleia geral para deliberar sobre a invalidade do ato (LSA, art. 123, caput e parágrafo único, “b”). A assembleia poderá revogar a deliberação, renová-la, se possível for, ou simplesmente mantê-la hígida. ${ }^{215}$ Caso adote a última alternativa, deverão os legitimados ajuizar as demandas cabíveis; ou, no caso do administrador, restará ainda a possibilidade de renunciar (LSA, art. 151). Até que haja revogação ou ordem judicial suspendendo os efeitos do ato, ele é eficaz e deve, em princípio, ser seguido.

A menos que tenha sido fixado um prazo exíguo para que a deliberação seja cumprida, a posição ora defendida não compele o administrador a cometer ilegalidades, pois no dia-a-dia da companhia existe certa maleabilidade no prazo para realizar a deliberação. A administração pode, dentro do razoável, deixar de efetivar a deliberação que entende inválida e aguardar a apreciação da questão pela assembleia. Imagine-se, por exemplo, deliberação que determine aos administradores que pratiquem um ato que reputem ilícito, sem contudo fixar um prazo certo para que o façam. Neste caso, haverá tempo para apreciação da dúvida em posterior conclave. Se a própria deliberação tiver fixado um prazo muito exíguo para o seu cumprimento e, assim não houver tempo para a convocação da assembleia, poderá o administrador ou o acionista valer-se de demanda de suspensão dos efeitos da deliberação. ${ }^{216}$ Aliás, a prova cabal de que mesmo a deliberação

ou anulável no direito português, Paulo Olavo Cunha escreveu que "a deliberação social é executável enquanto não for anulada ou declarada nula" e que "enquanto não for colocada em causa, a deliberação social inválida produz os efeitos para que tende" (cf. Direito das sociedades..., nn. 30.6.1 e 30.7.3, pp. 706 e 714).

215 Pois "a companhia sempre pode revogar as deliberações de suas assembleias" (cf. Erasmo Valladão França, "Ilegitimidade de parte...", n. 5, p. 383). No mesmo sentido, Trajano de Miranda Valverde: "A assembléia geral pode sempre rever as suas próprias deliberações. Pode, assim, cancelar ou anular deliberação anterior e ratificar todos os atos que interessam à sociedade" (cf. Sociedades..., v. III, n. 832, p. 115); e Waldemar Ferreira: a assembleia geral tem "poderes para a retificação e ratificação dos vícios e defeitos de assembléia anteriormente realizada" (cf. Tratado..., t. 4, n. 985, p. 637).

${ }^{216}$ Discorda-se da afirmação de Luiz Fernando C. Pereira no sentido de que, na hipótese de deliberação que determine que "dentro de dois anos, contra o que prescreve o estatuto, o pro-labore dos administradores será multiplicado por vinte", só poderá ser determinada a sua suspensão quando inicado o prazo ou na iminência de que se inicie, pois até então não haveria periculum in mora (cf. Medidas urgentes..., n. 3.4.2, pp. 138/139). $\mathrm{Na}$ verdade, o perigo de demora existe desde que a deliberação é tomada, pois ela pode ser efetivada a qualquer momento. Não é necessário que se aproxime o fim do prazo para que nasça o periculum. 
nula deve ser cumprida pelos administradores é, de um lado, o cabimento da demanda de suspensão dos efeitos da deliberação inquinada por vício dessa natureza, e, de outro, a legitimidade ativa dos administradores para essa demanda. ${ }^{217}$ Se (i) é necessária ordem judicial para que sejam suspensos os efeitos da deliberação nula e se (ii) essa demanda pode ser ajuizada pelo próprio administrador da companhia, é porque, em princípio, esse administrador não pode, de pleno direito, recusar eficácia ao ato assemblear.

Portanto, é sempre preferível que, ao invés de negar-se a cumprir a deliberação em razão de um juízo pessoal seu, o administrador submeta a questão à assembleia ou a outras instâncias adequadas, como, por exemplo, eventual comitê/conselho jurídico instituído com base no art. 160 da LSA. Em casos extremos, o administrador pode negarse a cumprir a deliberação que reputa inválida. Mas, ao assim agir, estará assumindo o risco de sua avaliação ser equivocada. É verdade que, como o caput e o inciso II do art. 158 da LSA dispõem que o administrador é pessoalmente responsável pelos atos que causar com violação da lei ou do estatuto, o administrador tem o dever de negar-se a cumprir deliberação inválida. E, de fato, não se pode questionar que, com base em tal dispositivo, esse deve, reputando inválida a deliberação, abster-se de cumpri-la. Ele, todavia, não possui poderes para desconstituir a deliberação e, caso deixe de cumprir ato jurídico que na realidade seja válido, também responderá pela violação da lei ou do estatuto. Por isso, a melhor solução é, sempre que possível, submeter a questão à assembleia antes do descumprimento. Embora discipline hipótese diversa, a parte final do $\S 1^{\circ}$ do art. 158 da LSA ("O administrador não é responsável por atos ilícitos de outros administradores, salvo se com eles for conivente, se negligenciar em descobri-los ou se, deles tendo conhecimento, deixar de agir para impedir a sua prática. Exime-se de responsabilidade o administrador dissidente que faça consignar sua divergência em ata de reunião do órgão de administração ou, não sendo possível, dela dê ciência imediata e por escrito ao órgão da administração, no conselho fiscal, se em funcionamento, ou à assembléia-geral") pode ser invocada por analogia para a posição ora defendida, ${ }^{218}$ uma

217 Reconhecendo que a deliberação nula pode produzir efeitos, Priscila Corrêa da Fonseca defende expressamente o cabimento da medida de urgência diante de deliberações nulas e a legitimidade ativa dos administradores para a medida (cf. Suspensão..., pp. 154 e 94). Também pensa assim Luiz Fernando C. Pereira, que inclusive admite a suspensão de deliberação inexistente (cf. Medidas urgentes..., nn. 3.7 e 3.5.1, pp. 163/164 e 143/144).

${ }^{218}$ Apesar de negar legitimidade ao administrador para impugnar as deliberações, Eduardo Talamini diz que "não se nega que o administrador tem o dever de zelar pela validade dos atos societários. Mas sua atuação há de fazer-se no âmbito interno da sociedade. A instância última a quem ele deve apontar ilicitudes, defeitos de 
vez que, como visto, um dos fundamentos para que se defenda que o administrador deixe de cumprir deliberação inválida é justamente a possibilidade de que ele seja responsabilizado pela prática de ato ilícito (LSA, 158, I). Caso não haja tempo hábil ou seja por demais onerosa a convocação de assembleia geral extraordinária apenas para a apreciação dessa matéria, o administrador poderá descumprir a deliberação, mas também deverá, assim que possível, submetê-la à apreciação dos sócios no próximo conclave.

É como uma lei inconstitucional: embora exista o dever de ser cumprida enquanto não for extirpada do ordenamento, é possível que o cidadão faça um juízo de que ela o será, de que ninguém irá exigir a sua observância ou de que, caso alguém o faça, o Judiciário, em última instância, reconhecerá a licitude de sua conduta. Caso não ocorra nenhuma dessas hipóteses, contudo, a atitude do cidadão terá sido ilícita. Igualmente, sempre que descumprir a deliberação o administrador estará agindo por conta própria e de acordo com um juízo pessoal, que poderá ou não ser confirmado por quem tem competência para tanto (assembleia e, em uma instância final, o Judiciário ou o árbitro). Se não for confirmado e houver prejuízo à companhia, poderá ser responsabilizado (LSA, art. 158 , II). ${ }^{219}$ Daí porque, quando menos por cautela, a administração deve sempre submeter a questão à assembleia.

Em suma, os administradores devem cumprir todas as deliberações da assembleia. Caso entendam que há nulidade ou anulabilidade, devem submetê-la aos

validade e abusos é a própria assembleia geral - órgão máximo da companhia. Se ele reporta-se à assembleia, não há como ele pretender controlar-lhe os atos externamente ao âmbito societário. A solução pode ser buscado na parte final do $\S 1^{\circ}$ do art. 158 da Lei 6.404", que dispõe que "Exime-se de responsabilidade o administrador dissidente que faça consignar sua divergência em ata de reunião do órgão de administração ou, não sendo possível, dela dê ciência imediata e por escrito ao órgão da administração, no conselho fiscal, se em funcionamento, ou à assembléia-geral". E, continua Talamini, "tal regra é aplicável por analogia à hipótese em exame. Basta ao administrador, para eximir-se de responsabilidade, adotar as condutas indicadas nessa norma. Se reputar o vício grave a ponto de não poder com ele compactuar, resta-lhe renunciar" (cf. "Legitimidade, interesse...", p. 119).

${ }^{219}$ A responsabilidade do administrador pela violação à lei e ao estatuto (LSA, art. 158, parágrafo único, II) é, aliás, subjetiva e, pois, não prescinde de culpa (cf. Marcelo von Adamek, Responsabilidade civil..., n. 5.2.3, p. 215). Por isso, não seria demais sustentar que, ainda que reputando inválida a deliberação, se o administrador submete o seu juízo à assembleia e esta referenda a deliberação, ele estaria eximido da culpa por executá-la. O juízo sobre a licitude de um ato é sempre subjetivo e, logo, ainda que tenha a convicção pessoal de que existe uma ilegalidade, se a assembleia ratificou o entendimento de que o ato é válido, cabe ao administrador executá-lo (em sentido contrário, v. Marcelo von Adamek, Responsabilidade civil..., n. 6.2.2, p. 275). Caso ainda assim entenda pela ilegalidade, o administrador é legitimado para a demanda de impugnação (e de suspensão dos efeitos) e pode seguir esse caminho, que, contudo, reconheça-se, não deixa de gerar perplexidade, pois equivale a uma espécie de motim societário. Por isso, ao invés do ajuizamento da demanda, talvez a atitude mais razoável seja a renúncia ao cargo. 
sócios (LSA, art. 123). Se houver premência, podem negar-se a efetivar o ato nulo e também o anulável (LSA, art. 158, II), mas tão logo quanto possível deverão submeter a questão ao colégio de sócios, a quem caberá a palavra final sobre o assunto. Se a assembleia mantiver a deliberação e ainda assim o administrador entender pela invalidade, caberá a ele tomar medida judicial visando à suspensão e à posterior desconstituição do ato; ou, em último caso, renunciar ao cargo.

\section{Interesse tutelado nas demandas de impugnação: interesse do sócio, dos sócios ou da companhia?}

De grande relevância para os fins deste trabalho é saber se, ao ajuizar uma demanda de impugnação de deliberação, o sócio ${ }^{220}$ está defendendo interesse próprio, da coletividade de sócios ou da companhia. Trata-se, é dizer, de demanda individual, demanda coletiva ou demanda social? ${ }^{221}$

A doutrina italiana anterior ao Codice Civile de 1941 considerava que o acionista atuava como órgão social, em defesa do interesse social, ${ }^{222-223}$ de forma análoga à posição desempenhada pelo autor da ação popular. ${ }^{224}$ Nesse sentido Vivante, para quem são órgãos

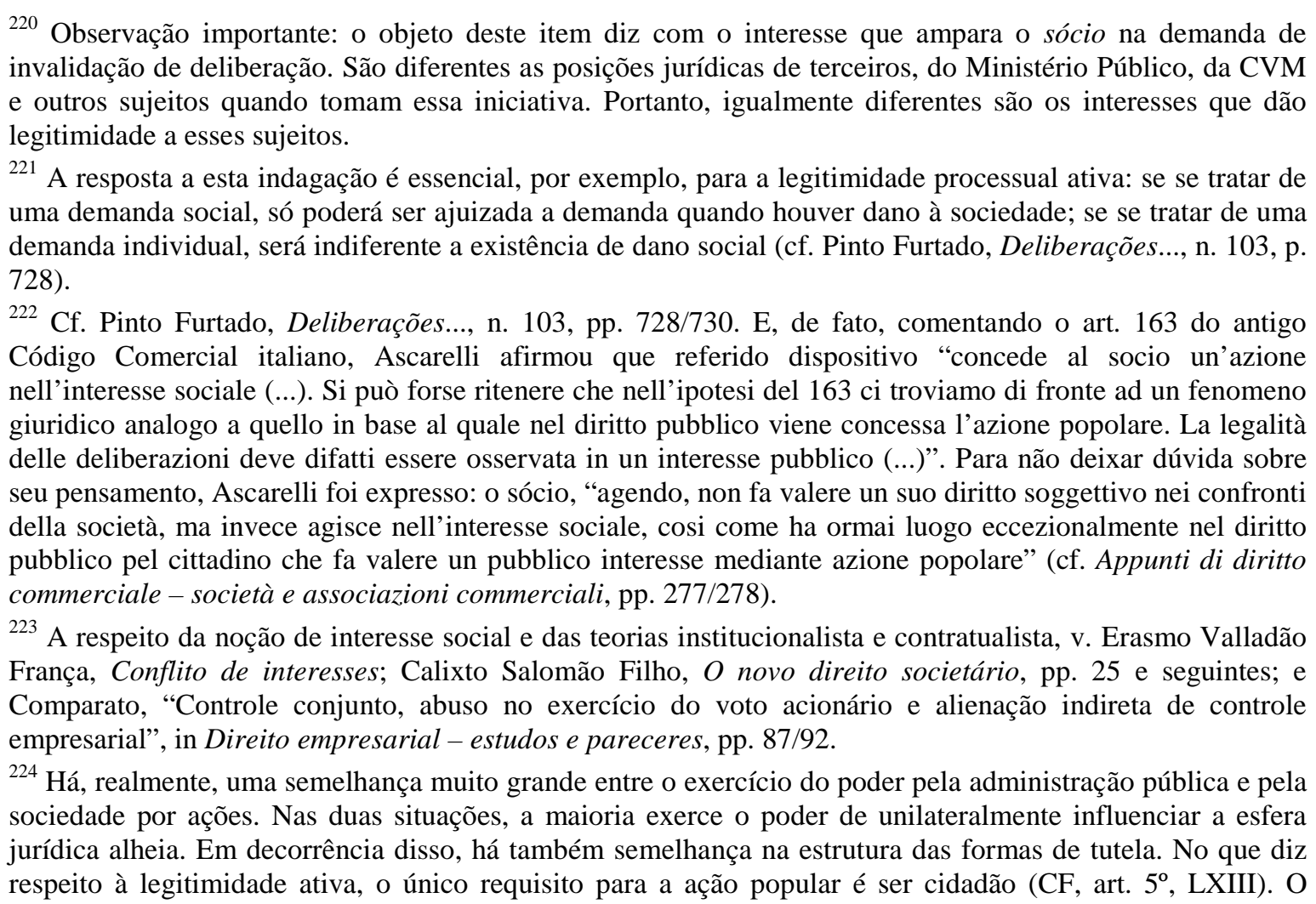


extraordinários da companhia a minoria e os sócios, que, nessa condição, têm a função de, agindo em prol do interesse social, remediar as deficiências dos órgãos ordinários. ${ }^{225}$ Já antes daquele diploma, porém, parte dos autores peninsulares passou a sustentar que o sócio age em defesa de direito subjetivo próprio. ${ }^{226}$

Após realizar exaustiva resenha doutrinária, Lobo Xavier concluiu que o direito de impugnação é exercido pelo sócio em seu interesse e por sua conta, ${ }^{227}$ no que foi seguido por Armando Manuel Triunfante. ${ }^{228}$ No mesmo sentido Liebman, conforme o qual

cidadão age em nome próprio, mas em defesa de um interesse transindividual. A ideia originária da ação popular, no direito romano, estava relacionada a uma demanda intentada em defesa de um direito indiviso de uma comunidade. Ao mesmo tempo em que exercia seu próprio direito, o autor da demanda representava o interesse dos demais membros da coletividade. Contudo, o fundamento de sua demanda residia no seu próprio direito, e o fato de que sua ação beneficiava os demais não lhe conferia, de maneira alguma, o caráter de representante (cf. Buzaid, Considerações sobre o mandado de segurança coletivo, n. 30, p. 38). Também José Afonso da Silva entende que o autor popular age em defesa de direito próprio, qual seja, o de participar na vida pública, embora imediatamente defenda um interesse que é da coletividade ou da pessoa jurídica lesada. Para o constitucionalista, não é caso de substituição processual, na medida em que é também titular do direito lesado: a lide se instaurou entre cada cidadão e os produtores do ato impugnado (cf. Ação popular constitucional, nn. 4.4. e 10, pp. 185 e 259). Veja-se a seguinte passagem: "sustentamos que o autor popular ingressa em juízo na defesa de direito próprio, embora o interesse defendido seja ut universis, de toda a comunidade. Todos os cidadãos dessa comunidade são titulares do mesmo direito de ir a juízo, mediante a demanda popular, para defender a probidade administrativa. (...) a res in iudicium deducta é a mesma que poderia ser apresentada por todos os cidadãos, tanto que, em princípio, todos eles poderiam integrar a relação processual concreta decorrente do ajuizamento da ação. Por outro lado, o autor popular, defendendo direito seu, ao mesmo tempo, assume a qualidade de defensor do direito dos demais cidadãos e o interesse geral da comunidade. Ora, o julgamento da demanda, no caso, significa que o Estado, naquele caso concreto, relativamente àquela res, já concedeu prestação jurisdicional. A lide, com suas circunstâncias objetivas e subjetivas, ficou decidida - completa e definitivamente decidida - com a coisa julgada. Isso basta para explicar a extensão erga omnes da eficácia e autoridade da sentença que resolve a lide popular, nos limites previstos no art. 18 da Lei n. 4.717/1965".

${ }^{225}$ Cf. Trattato..., v. II, nn. 486 e 521, pp. 215, 253 e 256.

${ }^{226}$ Cf. Pinto Furtado, Deliberações..., n. 103, p. 729. Nesse sentido, em 1937 Antigono Donati criticou a ideia de ação social ou de ação popular, dirigindo suas críticas a Vivante, Ascarelli, Vitta, Ferri, Lehmann, Fischer, Müller-Erzbach e Gierke. Afirmou que o sócio age contra a sociedade, de modo que entre o sócio e ela instaura-se uma relação processual de natureza contenciosa. Por essa razão, ficaria desde logo descartada a ideia de que o sócio atua como órgão social, pois seria inconcebível que a sociedade agisse contra si mesma. Igualmente rechaçada ficaria a ideia de que a sociedade é a titular do direito à impugnação e o sócio age como substituto processual daquela, pois seria igualmente inconcebível uma relação processual contenciosa entre o titular do direito subjetivo e seu substituto processual. Por essa mesma razão Donati rejeitou a analogia com a ação popular. O sócio, disse esse autor, possuiria um direito próprio e uma consequente ação contra a sociedade; o que, contudo, não autoriza concluir que o sócio defende um interesse pessoal. De acordo com Donati, a circunstância de que o art. 163 do antigo Codice Commerciale atribuía legitimidade a todos os sócios, e não só aos quais tiveram interesses pessoais violados, e até mesmo a terceiros, autorizava concluir que ao propor ação de impugnação o sócio agia em defesa do ordenamento jurídico da sociedade (cf. L'invalidità..., n. 22, pp. 85/93).

${ }^{227}$ Cf. Anulação..., n. 16, pp. 287/291, nota 38. No mesmo sentido, v. Carneiro da Frada, Renovação de deliberações sociais, n. 2.3, p. 14.

${ }^{228}$ Cf. A tutela das minorias nas sociedades anônimas - direitos indviduais, n. 69, p. 173. 
cada um dos sócios é titular de um direito próprio de impugnação, reconhecido em seu interesse individual, ${ }^{229}$ lição à qual aderiu Edoardo Ricci. ${ }^{230}$

Realmente, não há dúvida de que quando vai a juízo pedir a invalidação de uma deliberação o acionista não se ampara em interesse da sociedade ou dos demais sócios, mas sim seu. Tanto é que até na demanda de nulidade a legitimidade ativa é outorgada não a qualquer pessoa, mas sim a qualquer interessado, ${ }^{231}$ isto é, somente àqueles que tenham, de alguma forma, interesse na invalidação. Outra prova do caráter individual desse direito é que o demandante pode desistir do processo ou mesmo transacionar, sem que, por exemplo, como ocorre com a ação popular estejam o Ministério Público ou outros cidadãos autorizados a assumirem o polo ativo e prosseguirem com a ação (Lei 4.717/65, art. $9^{\circ}$ ). Da mesma forma, é também ponto pacífico que o acionista não é substituto processual dos demais sócios: a sua legitimação é ordinária. ${ }^{232}$

Mas tal direito apresenta uma primeira peculiaridade, bem apontada por Aurelio Candian: ainda que o interesse do acionista seja o propulsor da demanda, a sua satisfação importa também em benefício de interesses de outros sócios e da companhia. ${ }^{233}$ Por essa mesma razão é que Luiz Fernando C. Pereira aduz que o interesse tutelado na demanda de suspensão de deliberação é do sócio individual, o que, contudo, não impede que esteja atrelado ao interesse social. $^{234}$

Embora o acionista seja legitimado ordinário - e, portanto, definitivamente não aja como substituto processual dos demais interessados -, inegável que, como está inserido em uma relação de direito material que diz respeito a uma pluralidade de pessoas, ${ }^{235} \mathrm{o}$ tratamento processual que deve ser dado ao litígio que nasça dessa relação deve guardar alguma singularidade frente ao tratamento de um litígio entre Pedro e Maria. Por isso,

\footnotetext{
229 Cf. "Eficácia e autoridade...", n. 30, p. 97: "a qualidade de sócio é o título que confere à pessoa a legitimação para agir pela anulação, mas todos os que têm esta qualidade são pessoalmente titulares de uma ação própria de impugnação outorgada em seu interesse individual".

${ }^{230}$ Cf. "Sugli effetti...", Rivista di diritto processuale, v. 50, n. 1, p. 58.

${ }^{231}$ Sobre esse último aspecto, v. Erasmo Valladão França, Invalidade..., n. 20.1.1., p. 119.

${ }^{232}$ Cf. Dinamarco, Litisconsórcio, n. 92, p. 223.

${ }^{233}$ Cf. Delibere..., nn. 76 e 78, pp. 146/147 e 152: “Alla base dell'azione c’è sempre, inderogabilmente, un interesse del socio, perchè solo questo è il propulsore di essa".

${ }^{234}$ Cf. Medidas urgentes..., n. 3.3., p. 129.

${ }^{235}$ Cf. Dinamarco, Litisconsórcio..., n. 92, p. 223.
} 
apenas afirmar que o autor da demanda vai a juízo defender um interesse seu não revela o fenômeno em sua integralidade. Quem impugna uma deliberação assemblear age em proteção de um interesse que, embora próprio, se atendido importará na satisfação também de outros interesses que com aquele se alinham. Trata-se, nessa medida, de um direito concorrente, uma vez que outros membros do grupo possuem direitos idênticos, voltados para a mesma direção. $\mathrm{O}$ acionista, portanto, age em defesa de um direito próprio mas não exclusivo, e, por isso, o acolhimento da sua demanda satisfaz a posição de outros que se encontram na mesma situação. ${ }^{236}$

Em razão do caráter incindível da deliberação assemblear e da projeção de seus efeitos a uma pluralidade de pessoas, o direito à sua anulação é o típico exemplo do que se chama de direito potestativo concorrente: entre o direito da parte e o do terceiro existe um nexo de concorrência tal que a satisfação daquele implica imediata satisfação deste. A mutação jurídica decorrente da decisão exorbita a esfera jurídica de quem tomou a iniciativa de pleitear proteção. Tudo isso, ressalva Allorio, não permite concluir que o cotitular age como órgão no interesse na massa dos demais co-titulares; ele age em seu próprio e individual interesse, mas a especial estrutura do direito cotitularizado impõe que o resultado da sua iniciativa reverbere também na esfera dos demais. A atuação prática do direito do sócio representa a realização do direito dos demais que se encontram na mesma situação. $^{237}$

Vem a calhar, nesse sentido, a lição de Carnelutti de que ao lado de interesses cuja defesa é atribuída ao seu titular e de interesses cuja defesa é relegada a um terceiro existe um tertium genus: o direito subjetivo coletivo. Este caracteriza-se pela circunstância de que a sua tutela não é atribuída a um terceiro e nem a alguém que o titula integralmente, mas sim a cada um ou a um dentre os seus vários titulares. Há, pois, dois elementos essenciais para o conceito: o interesse deve ser coletivo (isto é, pertencer a um agrupamento de pessoas) e a sua defesa deve ser confiada a algum (uns) desses titulares, que agirá (ão) em nome próprio. O titular defende o direito não como um representante de

\footnotetext{
${ }^{236}$ Cf. Carpi, L'efficacia 'ultra partes' della sentenza civile, nn. 17, 35 e 36, pp. 67, 151 e 155.

${ }^{237}$ Cf. Cosa giudicata rispeto ai terzi, nn. 72 e 159, pp. 127 e 273/274.
} 
todos os demais cotitulares, mas sim como um titular qualquer. ${ }^{238}$ E parece-nos que é exatamente o enquadramento do direito do sócio à anulação da deliberação assemblear. ${ }^{239}$

Mas há ainda outra idiossincrasia do direito em análise: trata-se de direito de fiscalização da vida societária. Tanto é isso verdade que não há necessidade de comprovação de prejuízo $^{240}$ ou, mais propriamente, que o autor da demanda tenha, em concreto, sofrido prejuízo. Basta que tenha havido violação da lei ou do estatuto e, assim, a sociedade tenha sofrido o prejuízo que, embora deva ser jurídico, não precisa ser pecuniário. E é desse prejuízo que nascerá o interesse do acionista. Daí ter Trajano de Miranda Valverde dito que em certos casos a demanda objetivará apenas restabelecer a ordem jurídica da sociedade, ${ }^{241}$ lição a que aderiu Carvalhosa. ${ }^{242}$ A entendimento semelhante chegou Pinto Furtado, para quem o poder de impugnação é titularizado tão-só pelo fato de ser sócio, sem que se exija deste ter ocorrido dano para si ou para a sociedade. ${ }^{243}$ A legitimidade para a propositura da demanda decorre, portanto, da mera condição de sócio.

\footnotetext{
${ }^{238}$ Cf. Teoría general..., n. 67, pp. 207/209. Em outra passagem, Carnelutti afirma também que a titularidade do direito coletivo pode ser atribuída igualmente a pessoa jurídica resultante do grupo a que é comum o interesse (p. 210). Deve haver, portanto, um interesse coletivo envolvido. Além disso, é preciso que a tutela do interesse seja atribuída a algum de seus titulares, que o tutela em nome próprio, e não em nome de todos os outros interessados, "o sea, como un ciudadano qualquiera, y no como representante de todos los ciudadanos" (cf. Teoría general..., 2. 67, p. 209). Essa lição foi acolhida por Romano-Pavoni (cf. Le deliberazioni..., n. 23, p. 84).

${ }^{239}$ Cf. Teoría general..., n. 67, p. 209: "Los técnicos del derecho de la sociedad mercantil saben, de modo especial, que hay algunos interesses sociales cuya tutela se actua más bien que mediante un poder concedido a la Junta, y por tanto a los socii uti universi, mediante un poder atribuído a cada uno de ellos, es decir, al particular uti socius". Ainda de acordo com Carnelutti, "los derechos de los socios se distinguen en derechos individuales y derechos colectivos".

${ }^{240}$ Cf. Erasmo Valladão França e Marcelo von Adamek, "Algumas notas...”, p. 163.

${ }^{241}$ Nesse sentido Trajano de Miranda Valverde, que embora afirme que "a prova do prejuízo não é, pois, um requisito essencial na anulatória", se bem analisado, quis dizer que "casos haverá em que a ação visará, exclusivamente, a restabelecer a ordem jurídica na sociedade anônima, turbada por uma deliberação violadora da lei ou dos estatutos". Ora, essa violação gera inegavelmente um prejuízo jurídico.

${ }^{242}$ Nessas hipóteses, diz o ilustre comercialista, o autor age no interesse da própria companhia, embora não ostente legitimação extraordinária (cf. Comentários..., $4^{\circ}$ v., t. II, p. 481).

${ }^{243}$ Cf. Deliberações..., n. 103, p. 732. Nesse sentido é a lição de Comparato: "o interesse social não é redutível a qualquer interesse dos sócios e sim, unicamente, ao seu interesse comum, de realização do escopo social. (...) Os sócios reúnem-se para a realização de um objetivo comum. O interesse social consiste, pois, no interesse dos sócios à realização desse escopo. Daí a possibilidade de existência de um conflito entre sócio e sociedade, na medida em que aquele persegue, enquanto sócio, objetivos diversos desse escopo comum" (cf. O poder de controle..., n. 117, p. 303). V., também, Erasmo Valladão França, Conflito..., cap. II, n. 4, pp. $51 / 53$.
} 
No mesmo sentido, apesar de concordar que o sócio possui um verdadeiro direito subjetivo de pleitear a anulação de uma deliberação, Romano-Pavoni afirmou que referido direito refere-se à posição jurídica de poder exigir do ente respeito às normas legais e estatutárias. $^{244}$ Em reforço dessa tese, diga-se que até mesmo Pinto Furtado, que nega expressamente que o autor da demanda aja como órgão social em defesa do interesse comum, sustenta que o seu direito de sócio, que está à base da demanda, traduz-se na fiscalização da legalidade objectiva da actividade deliberativa. Trata-se, é dizer, de um direito de controle ou de fiscalização, ${ }^{245}$ faceta evidenciada também por Erasmo Valladão França e Marcelo Vieira von Adamek. ${ }^{246}$

Diretamente ligado a isso está outro aspecto apontado pela doutrina: a tutela prestada na desconstituição de deliberações reveste-se de certo caráter objetivo. Na literatura jurídica italiana recente, com efeito, Stefano Villata defendeu que na atuação desses direitos a tutela do seu titular fica em segundo plano, pois em primeiro está a legalidade do ato. Daí porque o objeto do processo de impugnação seria a questão de ilegitimidade da deliberação, ${ }^{247}$ ideia, aliás, defendida já por Redenti. ${ }^{248}$ Ao fundamentar sua tese, Villata vale-se de construções de administrativistas, mais especificamente da categoria do chamado interesse legítimo, previsto nos arts. 24, 103 e 113 da Constituição Italiana para hipóteses de controle de legalidade de atos da administração pública, especialmente no âmbito do contencioso administrativo. ${ }^{249}$

\footnotetext{
${ }^{244}$ Cf. Le deliberazioni..., n. 23, p. 82.

${ }^{245}$ Cf. Deliberações..., n. 103, p. 732.

${ }^{246}$ Cf. “Algumas notas...”, p. 163.

${ }^{247}$ Cf. Impugnazioni..., cap. III, n. 11, p. 408.

${ }^{248}$ Cf. Il giudizio..., cap. I, n. 46, pp. 63/64, inclusive nota 55: "Si badi bene che anche secondo la mia opinione il giudice dovrà sempre verificare se la legge leggitima l'attore a chiedere l'annullamento o modificazione od altro mutamento. Ma io sostengo che, accertato questo, al giudice non resta che esaminare se l'atto in sè deve essere annullato o modificato ecc., e pronunciares su questo punto. Invece secondo l'opinione che combatto, il giudice, verificata la legittimazione, deve pronunciare che esiste il diritto all'annullamento, modificazione ecc., e poi annullare".

${ }^{249}$ Art. 24 Tutti possono agire in giudizio per la tutela dei propri diritti e interessi legittimi.
}

Art. 103 Il Consiglio di Stato e gli altri organi di giustizia amministrativa hanno giurisdizione per la tutela nei confronti della pubblica amministrazione degli interessi legittimi e, in particolari materie indicate dalla legge,anche dei diritti soggettivi.

Art. 113 Contro gli atti della pubblica amministrazione è sempre ammessa la tutela giurisdizionale dei diritti e degli interessi legittimi dinanzi agli organi di giurisdizione ordinaria o amministrativa. 
O interesse legítimo é uma situação jurídica que surge quando a um sujeito é atribuído poder de governo sobre a coletividade. Submetido a tal poder, o particular ostenta não um direito subjetivo clássico, mas um interesse de que o poder seja exercido legitimamente. Embora também tenha como contrapartida um dever, o interesse legítimo é uma situação jurídica diversa do direito subjetivo individual: existe um dever de quem exerce a autoridade/poder, mas a ele não corresponde um verdadeiro e próprio direito individual. ${ }^{250} \mathrm{O}$ desenvolvimento do interesse legítimo justifica-se na existência de um interesse público ou supraindividual, pertencente a uma coletividade, que implica a perda do monopólio da ação, em favor da ordem jurídica objetiva e da pluralidade de interessados. $^{251}$

E embora essa construção tenha surgido no direito administrativo, não há razão, diz Villata, para não aplicá-la no direito privado, especialmente no âmbito do controle dos atos societários. A categoria, da mesma forma, não seria particular do direito italiano, antes instituto de teoria geral, e por isso está presente em outros países sempre que um sujeito, público ou privado, é titular de uma posição de poder sobre uma coletividade. ${ }^{252}$ Teses $^{2}$ similares foram defendidas por Satta, para quem a categoria é plenamente aplicável às sociedades por ações, ${ }^{253}$ e por Aurelio Candian, que sustentou um paralelismo entre a

${ }^{250}$ Cf. Stefano Villata, Impugnazioni..., cap. III, n. 3, pp. 285, 287/288, 289, 296 e 298. Sobre a noção de interesse legítimo, v. Bruno Sassani, Impugnativa dell'atto e disciplina del rapporto, cap. I, n. 3, pp. 63 e ss; Ilaria Pagni, Le azioni..., pp. 614/615; e Carpi, L'efficacia..., n. 13, pp. 52 e seguintes.

${ }^{251}$ Cf. Monteleone, I limiti soggettivi del giudicato civile, n. 11, p. 126. A noção de interesse legítimo, assim, surgiu no direito administrativo porque nesse âmbito a posição do administrador relaciona-se a uma atividade que, embora se desenvolva para um fim que institucionalmente transcende sua pessoa, ainda assim incide em sua esfera de interesse (cf. Satta, "La responsabilità per lesione di interessi legitimi", Rivista del diritto commerciale, v. 61-I , 1963, p. 327). O interesse legítimo, ademais, é inativo: como só pode ser satisfeito mediante conduta do ente que exerce o poder, enquanto não houver violação ao dever o reconhecimento judicial do interesse não traz nenhuma vantagem para seu titular, ao contrário da declaração judicial de um direito subjetivo, que imediatamente beneficia-o com situações jurídicas de vantagem. $\mathrm{O}$ acertamento do interesse legítimo não acarreta ao seu titular nenhum bem da vida, que só poderá ser fruído mediante um exercício legítimo do poder pelo ente coletivo. A tutela desses interesses, pois, assume uma conotação negativa e impugnatória: como o juiz não pode satisfazer o interesse do sujeito, só pode protegê-lo pela via negativa, anulando o ato lesivo (cf. Stefano Villata, Impugnazioni..., cap. III, n. 5, pp. 306/308).

${ }^{252}$ Cf. Impugnazioni..., cap. III, n. 3, p. 285; e Romano-Pavoni, Le deliberazioni..., n. 23, p. 84. Em sentido contrário, Monteleone defende que a categoria é indossociável à presença do poder supremo da Administração Público (cf. I limiti..., n. 11, p. 127).

${ }^{253}$ Cf. "La responsabilità...", p. 327: "Senonché questa posizione che ha dato luogo alla identificazione degli interessi legittimi è tutt'altro che esclusiva del diritto amministrativo o pubblico in genere. Oso dire che se l'osservazione fosse stata estesa alle altre branche del diritto e in specie al diritto privato, forse molte cose si sarebbere chiarite, anche in ordine alla questione che qui si tratta. Si considere per es. quel che avviene in materia di società per azioni. Qui c’è um'amministrrazione in senso ampio (consiglio di amministrazione, assemblea, ecc) della società e c'è il socio. Non c'è dubbio che la attività di questi organi di amministrazione si svolge nell'interesse generale della società (così come quella degli organi amministrativi si svolge nell generale interesse) e non c'è dubbio che tale attività incide nella sfera di interessi del socio, anche se è 
posição do cidadão perante a administração pública e a do acionista perante a sociedade por ações. ${ }^{254}$ Com base nessa construção, defende Villata que, assim como ocorre no processo administrativo, a impugnação de uma deliberação não sustenta a violação de uma obrigação pontual, mas sim a violação a regras de conduta, a respeito das quais o sócio possui apenas um interesse instrumental. ${ }^{255}$

Essa a razão de ser da chamada referida conotação objetiva a que alude a doutrina. Não no sentido de que se procura tutelar a observância da lei, mas sim no de que o juízo de qualificação normativa dos fatos é promovido sem a intermediação de uma situação subjetiva. O que interessa é verificar a conformidade do comportamento do ente coletivo (Poder Público ou sociedade por ações) às normas que disciplinam seus poderes, sem que sequer seja necessário reconhecer a existência de uma situação subjetiva lesada. Com esse espírito, aliás, é que já se aludiu ao acertamento de uma situação jurídica objetiva. $^{256}$

Mais detalhadamente, conforme a teoria ora analisada, o interesse do acionista não é objeto do acertamento, mas, na verdade, mera situação legitimante, que é objeto de cognição apenas para resolver a questão processual de legitimidade ativa ad causam. A qualidade de ser acionista - e de ter votado favorável ou contrariamente à deliberação - é relevante apenas para aferir a legitimidade do autor da demanda. ${ }^{257-258}$ Sendo positivo o

istituzionalmente legittima; la pregiudica o può pregiudicare, può essere, per le sue particolari ed egoistiche speranze, rovinosa. Orbene, che cosa fa la legge? Essa non lascia abbandonato a se stesso il socio, ma stabilisce regole giuridiche per l'attività amministrativa, che ne condizionano la validità (...); e al socio atribuisce l'azione di impugnativa (...). Che cosa è questo se non il perfetto corrispondente dell'interesse leggitimo del diritto amministrativo?".

${ }^{254}$ Cf. Delibere..., nn. 77/78/, pp. 147/152. Também Alessandro Lolli traçou analogia entre o direito do acionista impugnar a deliberação e o chamado interesse legítimo (cf. I limiti soggettivi del giudicato amministrativo - stabilità del giudicato e difesa del terzo nel processo amministrativo, cap. IV, n. 3, p. 121).

255 À base da impugnação estaria um interesse do autor a um diverso conteúdo de deliberação, que só poderia ser satisfeito mediante uma deliberação que esteja de acordo com a lei e o estatuto social. Daí, portanto, o caráter negativo da tutela prestada na desconstituição, como decorrência da infungibilidade da atividade do órgão assemblear, que, da mesma forma como sucede com a administração pública, não pode ser substituído pelo órgão jurisdicional (cf. Impugnazioni..., cap. III, n. 3, pp. 300/302).

${ }^{256}$ Cf. Impugnazioni..., cap. III, nn. 5, 8 e 10, pp. 306, 348/349 e 381.

${ }^{257}$ A única situação substancial presente na fatispécie considerada seria o interesse legítimo do acionista, que, embora cumpra uma função legitimante, não é objeto do acertamento. Não há tutela abstrata do direito objetivo. Isso seria confirmado pela circunstância de que o sujeito impugnante pode invocar qualquer violação da lei ou do estatuto, independente do interesse protegido pela norma que se alega violada. Importa menos, portanto, a lesão a uma posição subjetiva, e mais a violação objetiva (cf. Impugnazioni..., cap. III, n. 10, pp. 381/382). Em outra passagem, Villata afirma "appare evidente come pure il processo di impugnazione delle deliberazioni assembleari sia stato strutturato dal legislatore secondo caratteristiche oggettive. Seppur il fine dell'azione è sempre quello della tutela di posizioni giuridiche soggettive, queste 
juízo, o magistrado passa a julgar o mérito, que se desprende do autor da demanda ${ }^{259}$ e passa a dizer respeito unicamente à conformidade do ato com as normas legais e estatutárias. $^{260}$ É como se o julgador apenas verificasse se o autor é um legítimo contraditor, isto é, se possui legitimidade para deduzir aquele pleito. Se for, o que importa é o confronto entre a deliberação e as normas a que submete a sociedade, e não a situação pessoal do acionista. Apesar de tutelado, o direito individual do acionista não é objeto do acertamento. Este, na verdade, é a legalidade da deliberação. ${ }^{261}$

O caráter objetivo da tutela prestada nessa hipótese foi ressaltado também por Chiovenda, que afirmou que a pessoa que suscita a invalidade em juízo fica em segundo plano. O direito do autor é que motivaria, justificaria e fundamentaria a demanda. E é ele que seria satisfeito, mas em via mediata. ${ }^{262}$

rimangano fuori dell'oggeto dell'accertamento per svolgere una funzione prettamente legittimante" (cf. cap. III, n. 11, p. 408).

${ }^{258}$ Como visto, a posição predominante da doutrina pátria é de que, em caso de anulabilidade, quem votou favoravelmente à deliberação não pode pleitear a sua anulação, ao passo que, em caso de nulidade, é irrelevante o conteúdo do voto.

${ }^{259}$ A esse respeito, disse Satta que sempre que há uma organização o sujeito nela inserido pode invocar a lei de regência da organização para negar valor a algo que contrariou referida lei (cf. "La responsabilità...", p. 328).

${ }^{260}$ Cf. Impugnazioni..., cap. III, n. 5, pp. 308/309: "la qualità di socio assenziente o dissenziente o astenuto, lungi dall'entrare nell'oggeto dell'accertamento, viene conosciuta ai soli fini di consentiri un giudizio sul merito".

${ }^{261}$ Cf. Impugnazioni..., cap. III, n. 11, pp. 409/410. E, de fato, já Aurelio Candian havia defendido que à base da demanda de impugnação está sempre a violação a uma norma. Quando a norma tutelar interesse da sociedade, o sócio faria valer um interesse legítimo, ao passo que quando a norma tutela um interesse do sócio, ele faria valer um direito subjetivo. No primeiro caso, o objeto imediato da tutela é o interesse da sociedade e o mediato, o interesse do sócio. No segundo, o contrário: tutela-se imediatamente o interesse do sócio e mediatamente o da sociedade (cf. Delibere..., n. 78, p. 153).

${ }^{262}$ Cf. "Sul litisconsorzio...", n. 6, p. 451: "può dirsi che ciò che è in giudizio sia veramente l'atto giuridico che si tratta riformare e che le persone qualificate a trarlo in giudizio passino in seconda linea, così che il loro mutarsi non abbia importanza. Il concetto della Cassazione di Roma che la identità della qualità sostituisca qui la identità della persona sembra quindi sostanzialmente esatto". Essa posição foi severamente atacada por Allorio, que negou haver no processo administrativo uma jurisdição de direito objetivo. Para ele, o interesse legítimo seria nada mais do que uma posição jurídica do sujeito frente à administração, de que esta se porte de uma determinada maneira. Havendo o descumprimento, o interesse converter-se-ia em direito (subjetivo e potestativo) à anulação do ato. Esse direito subjetivo e potestativo, portanto, é que seria objeto do acertamento judicial no processo de anulação. O processo, assim, se resolve no debate sobre a existência ou a inexistência do direito do recorrente à anulação (cf. El ordenamiento jurídico en el prisma de la declaración judicial, n. 29, pp. 180/181). Assim também Edoardo Ricci, para quem o direito do autor da demanda é objeto do acertamento pelo julgador (cf. "Gli effetti...", n. 4, p. 16). Os argumentos de Allorio foram refutados por Stefano Villata (cf. Impugnazioni..., cap. III, n. 5, p. 304). 
Há, como visto, grande variedade de opiniões a respeito do assunto. ${ }^{263}$ Apesar disso, parece-nos seguro afirmar que o acionista age amparado em direito próprio. E é esse direito, unicamente resultante da sua condição de sócio, que fundamenta a sua pretensão e lhe dá interesse processual. É inegável, por outro lado, que tal direito, ainda que próprio, apresenta algumas singularidades. Quer se qualifique como interesse legítimo, direito subjetivo coletivo, direito potestativo concorrente ou mero direito de fiscalização/observância da ordem normativa, o fato é que sua efetivação processual, por conta de sua conformação jurídica, foge e deve mesmo fugir do esquema de atuação do direito propriamente individual.

$\mathrm{O}$ acionista age fundamentado por um direito seu, mas a estrutura concorrente desse direito e a unitariedade da relação jurídica em que está inserido fazem com que a tutela suplante a sua esfera individual. Salvo casos em que a demanda tenha por fundamento violação à esfera jurídica de um único acionista - hipótese em que, por exemplo, a deliberação desrespeitou a opção/direito de preferência de um sócio -, estaremos diante de algo que não pode ser qualificado como uma demanda individual ordinária, nem mesmo como coletiva. Daí a afirmação de Edoardo Ricci, já referida neste trabalho, de que o estudo da invalidação das deliberações societárias situa-se em um patamar intermediário entre o processo coletivo e o individual. ${ }^{264}$

\footnotetext{
${ }^{263}$ Além dos textos citados ao longo da exposição, v., a esse respeito, Fabio Filocamo, "I c.d. diritti individuali dell'azionista, i poteri degli amministratori e la non impugnabilità delle delibere consiliari da parte del socio", in Rivista del diritto commerciale e del diritto generale delle obbligazioni, v. 98, n. 1, pp. $41 / 44$.

${ }^{264}$ Cf. "Gli effetti...”, p. 14.
} 


\section{Capítulo III - Tutela JURisdicional E DELIberações ASSEMbleares INVÁLIDAS}

\section{Modalidades de tutelas jurisdicionais}

Tutela jurisdicional é a proteção conferida pelo órgão jurisdicional à parte amparada pelo direito material, ou, mais simplificadamente, à parte que tem razão à luz do ordenamento jurídico. ${ }^{265}$ É conceito diretamente ligado ao direito material. ${ }^{266}$ Embora já se tenha proposto, com autoridade, a conceituação de tutela jurisdicional não só pela perspectiva do resultado do processo mas também sob o ângulo dos meios processuais empregados, ${ }^{267}$ é aquele primeiro significado que prevalece em doutrina. ${ }^{268}$

A tutela jurisdicional comporta um sem-número de classificações. Há espécies e espécies de tutelas, a depender do critério eleito: preventiva e reparatória, individual e coletiva, antecipada e final, sumária e exauriente, específica e genérica, ordinária e diferenciada etc. Sendo infinitos os critérios, igualmente infinitas são as classificações. ${ }^{269}$ Uma delas, chamada de tradicional ou clássica, divide a tutela em cognitiva, executiva e cautelar, e aquela primeira em outras três subcategorias, quais sejam, tutelas meramente declaratória, constitutiva e condenatória. ${ }^{270-271}$

${ }^{265}$ O processo tutela pessoas, e não direitos (cf. Dinamarco, A instrumentalidade do processo, n. 27, p. 210,
nota 5).
${ }^{266}$ Embora autônomo em relação ao direito material, o direito processual guarda com aquele relação de
instrumentalidade. Por isso, a boa dogmática processual moderna já assentou que os institutos processuais
são, em muitas das vezes, talhados à luz das características e especificidades do direito material (cf.
Dinamarco, "Momento de eficácia da sentença constitutiva", in Fundamentos do processo civil moderno, t. I,
p. 950 ). Um dos terrenos em que as coisas se dão desta maneira é o das modalidades de tutelas jurisdicionais.
${ }^{267}$ Cf. Flávio Yarshell, Tutela jurisdicional, n. 2.4, pp. 32/34. E, dentro das premissas traçadas pelo autor, essa conclusão é rigorosamente correta.

${ }^{268}$ Cf. José Roberto dos Santos Bedaque, Direito e processo, p. 32 e Efetividade do processo e técnica processual, p. 519; Dinamarco, Instituições de direito processual civil, v. II, n. 725, p. 633; Flávio Yarshell, Tutela jurisdicional, cap. 2, pp. 23/34; Cássio Scarpinella Bueno, Curso sistematizado de direito processual civil, v. 1, pp. 260/261; e Eduardo Talamini, Tutela relativa aos direitos de fazer e de não fazer, n. 5, p. 165.

${ }^{269}$ A observação é de Satta, Direito processual civil, v. 1, n. 74, p. 166. No mesmo sentido, v. Alfredo Rocco, La sentencia civil, n. 61, p. 227; Chiovenda, Instituições de direito processual civil, v. I, n. 10, p. 33; Flávio Yarshell, Tutela jurisdicional, n. 5.7, p. 150; e José Roberto dos Santos Bedaque, Efetividade..., p. 532.

${ }^{270}$ Cf. Jauernig, Direito processual civil (trad. de F. Silveira Ramos), n. 59, p. 308; Zanzucchi, Diritto processuale civile, I, pp. 121/122; Shönke, Derecho procesal civil (trad. de Prieto Castro), n. 43, pp. 151/152; Giovanni Verdi, Profili del processo civile, v. 1, cap. 5, n. 3, p. 172; Attardi, Diritto processuale civile, v. I, pp. 5 e 93 e seguintes; e Lebre de Freitas, Introdução ao processo civili, cap. I, n. 3.1, pp.23/26. De acordo com Barbosa Moreira, essa classificação é fruto dos trabalhos da doutrina processual de fins do século XIX e 
Basicamente, a tutela cognitiva ou de conhecimento é a tendente à declaração da norma jurídica que regerá um caso em concreto. O julgador é chamado a dizer qual das partes tem razão em um litígio em específico e qual o regramento que a lei reserva para a contenda. A tutela executiva, por sua vez, é a que atua a norma jurídica concreta. O Estado pratica atos materiais subrogatórios sobre o patrimônio do devedor (execução direta) ou atos de pressão psicológica e financeira sobre o devedor (execução indireta), satisfazendo o direito do credor. Já a tutela cautelar tem por escopo assegurar a eficácia prática do provimento final, por meio da neutralização ou minimização dos efeitos deletérios que o tempo de duração do processo possa causar aos direitos disputados. ${ }^{272}$

No que diz respeito às subcategorias da tutela de conhecimento, a primeira delas, tutela meramente declaratória, é estruturada de forma a unicamente conferir certeza a uma situação jurídica. Mais nada. A tutela constitutiva, ao seu turno, é a que produz uma alteração na ordem jurídica por meio da criação, modificação ou extinção de situações jurídicas. A tutela condenatória, por fim, é a que autoriza o credor de uma obrigação (rectius, o Estado, em favor do credor $^{273}$ ) a promover o cumprimento forçado dessa obrigação quando o devedor não o faz de modo espontâneo. São essas, grosso modo, as características de cada uma dessas tutelas, contidas na referida classificação tradicional.

Embora essa divisão seja antiga e consagrada em doutrina, paradoxalmente não há consenso sobre qual o critério por ela empregado. O que não é à toa, na medida em que

começo do século XX (cf. "Questões velhas e novas em matéria de classificação das sentenças", in Temas de direito processual, $8^{a}$ Série, p. 125). Na mesma passagem, v., também, a evolução traçada por esse autor a respeito das doutrinas alemãs, italiana e brasileira que se dedicaram ao tema.

${ }^{271}$ É comum que se fale em classificação dos processos ou das ações. O mais adequado, contudo, é a classificação em tutelas ou provimentos, pois esses é que ostentam as características de que se costuma tratar. Por esse motivo é que Calamandrei optou pela classificação em providências (provimentos) jurisdicionais (cf. Introducción al estudio sistemático de las providencias cautelares (trad. de Marino Ayerra Merín), n. 1., p. 32).

${ }^{272}$ Exemplo interessante de medida cautelar que pode ser empregado no âmbito do direito societário é o protesto judicial. Sobre o assunto, v. Manoel de Queiroz Pereira Calças, "Protesto judicial contra alienação de bens, ações e quotas em conflitos societários", in Flávio Luiz Yarshell e Guilherme Setoguti J. Pereira (coords.), Processo societário, pp. 475 e seguintes.

${ }^{273}$ Sendo a ação um poder (ou direito, para alguns) que tem como titular o cidadão e o Estado no polo oposto, é incorreto dizer-se que a ação é exercida contra o réu. A ação é exercida contra o Estado e o réu fica sujeito à autoridade deste. Por tal razão é que no direito italiano se diz que a ação é exercida "nei confronti" do réu (cf. Dinamarco, Direito processual civil, n. 22, p. 62). No Brasil usa-se a expressão propor a demanda em face do réu. 
ela utiliza critérios não homogêneos. E em que pese a sua falta de rigor classificatório, ela é aqui tomada como ponto de partida metodológico para se estudar a maneira pela qual a jurisdição - um dos institutos fundamentais do processo $^{274}$ - atua na impugnação das deliberações assembleares.

\subsection{Critérios classificativos. Considerações críticas sobre a falta de homogeneidade}

Alguns autores afirmam que a classificação acima exposta toma como pedra de toque a natureza do provimento pleiteado. ${ }^{275}$ Há, porém, evidente indefinição em se dizer que a tutela é classificada de acordo com sua natureza. Natureza é termo equívoco, de significado impreciso, que pode indicar muitas noções. Para ilustrar, não significa absolutamente nada afirmar-se que a classificação das cores leva em conta as suas naturezas e que o azul se diferencia do vermelho por terem naturezas diversas. Isso e nada é a mesma coisa. É preciso definir, com maior precisão, pois, o que se entende por natureza.

Procurando dar essa definição, Flávio Yarshell anota que quando se faz menção à natureza do provimento se está querendo significar eficácia da decisão. ${ }^{276} \mathrm{Com}$ efeito, para parte da doutrina, o que distingue as tutelas jurisdicionais é a sua aptidão à produção de efeitos (eficácia): provimentos são atos estatais imperativos destinados à produção de efeitos, e seria com base nessa propensão que se distinguiriam as modalidades de tutelas. ${ }^{277}$

${ }^{274}$ Cf. Dinamarco, “Os institutos fundamentais do direito processual”, in Fundamentos..., t. I, n. 146, p. 286.

${ }^{275}$ Nesse sentido Liebman, para quem essa seria a única legítima e importante classificação das "ações” (cf. Manual de direito processual civil, v. 1, n. 76, p. 213). Chiovenda e Satta também aludem à natureza do pronunciamento judicial (cf., respectivamente, Instituições..., v. I, n. 10, p. 34 e Direito processual civil, v. 1, n. 74, p. 166. Cintra-Grinover-Dinamarco esclarecem que, quando fazem menção à natureza do provimento, estão significando "natureza peculiar da prestação jurisdicional invocada" (cf. Teoria geral do processo, nn. 161 e 192, pp. 273 e 309/310). Dinamarco fala em "natureza processual do provimento postulado" (cf. $A$ instrumentalidade... n. 7, p.74; e Direito processual civil, n. 23, p. 62). Agnelo Amorim Filho utiliza o critério da natureza do provimento judicial, equivalendo-a à carga de eficácia pontiana (cf. "As ações constitutivas e os direitos potestativos", Revista Forense, v. 216, p. 28). Flávio Yarshell faz alusão à "natureza do provimento" ou à "natureza dos efeitos processuais daí decorrentes" como sendo o critério da classificação ternária (cf. Tutela jurisdicional, n. 5.7, p. 150). De acordo com Paulo Lucon, o critério da teoria ternária leva em consideração "a natureza e a eficácia do provimento" (cf. Eficácia das decisões e execução provisória, n. 44, pp. 151/152), acrescentando que, além disso, referida classificação leva em conta também "a cognição realizada" (cf. Embargos à execução, n. 37, p. 37). Tudo isso, contudo, continua a ser obscuro.

${ }^{276}$ Cf. Tutela jurisdicional específica nas obrigações de declaração de vontade, n. 2.3, p. 20.

277 Nesse sentido, v. Liebman, Manual..., v. 1, n. 76, p. 213; e Arruda Alvim, Manual de direito processual civil, n. 299, p. 1.086. Para José Roberto dos Santos Bedaque, é "o tipo de crise de direito material que indica a espécie de tutela adequada a solucioná-la", uma vez que "tanto a tutela cognitiva, nas suas três espécies, 
Alude-se também à forma de atuação da lei no processo. ${ }^{278}$ Para outros, o caráter distintivo é a atividade exercida pela autoridade judiciária ao cumprir o ofício jurisdicional $^{279}$ ou os resultados que o processo oferece em face das situações substanciais trazidas a juízo, ${ }^{280}$ corrente que parece poder ser reconduzida à da eficácia.

Uma sexta corrente defende a classificação por meio do conteúdo do provimento, ${ }^{281}$ alguns de seus integrantes frisando que conteúdo não é o mesmo que efeitos da decisão. ${ }^{282}$ À suposta confusão feita entre conteúdo e efeitos, Barbosa Moreira dirigiu crítica, como de costume, contundente. Para ele, todo ato jurídico possui um conteúdo e é ele que deve definir a essência do ato. Por outro lado, todo ato jurídico é, em tese, apto a produzir efeitos no mundo jurídico, e os efeitos podem ser considerados potencialmente (passíveis de serem produzidos) ou em forma de ato (efetivamente produzidos). Os efeitos potenciais fazem parte das características dos atos e, por isso, a inaptidão para a potencial

como a executiva levam em conta os efeitos do pronunciamento judicial na própria relação jurídica material" (cf. Tutela cautelar e tutela antecipada: tutelas sumária e de urgência. Tentativa de sistematização, p. 194). Calamandrei faz menção aos efeitos substanciais que derivam do provimento (cf. Introducción..., n. 1, p. 32). Cássio Scarpinella Bueno também adota o critério dos efeitos, ressalvando que esse é o critério correto, e não o da eficácia, pois "o que distingue cada uma dessas classes de tutela jurisdicional é a produção concreta de seus efeitos, e não sua mera aptidão de produzir quaisquer efeitos" (cf. Curso..., v. 1, n. 8.5, pp. 293/294). Mesmo a famosa e igualmente polêmica classificação das "ações" de Pontes de Miranda leva em consideração a eficácia preponderante, como resultado do sopesamento entre as diversas cargas de eficácia do provimento (cf. Tratado das ações, t. I, n. 25, p. 9). Embora alerte que a posição doutrinária que adota a divisão ternária esconda equívocos gravíssimos, Ovídio Baptista da Silva afirma que ela leva em consideração as eficácias das decisões (cf. Sentença e coisa julgada, p. 98).

${ }^{278}$ Cf. Celso Agrícola Barbi, Comentários ao Código de Processo Civil, v. 1, t. I, n. 40, p. 67.

${ }^{279}$ Embora aluda a conteúdo do provimento, Bedaque também afirma que a classificação das tutelas é "feita à luz de aspectos inerentes à atividade preponderante exercida pelo juiz no processo e à natureza da controvérsia reproduzida na inicial" (cf. Efetividade..., p. 519). Liebman também se referiu à atividade desenvolvida pelo juiz, mesclando-a com o critério da natureza e o dos efeitos do provimento: "A essas categorias de ações correspondem tantas categorias de processos, cada um destes com características formais diferentes, adequadas aos diferentes tipos de provimento pedido por quem propõe a demanda e à diferente função que o órgão judiciário é chamado a desempenhar. O estudo das ações implica, por isso, o das diversas formas através das quais a autoridade judiciária pode exercer suas funções e o das diversas configurações e dos diversos efeitos que seus provimentos podem ter" (cf. Manual..., v. 1, n. 76, p. 213). Na oposição entre execução e cognição, contudo, ele adota o critério da atividade: cognição (atividade prevalentemente lógica, de declaração da regra concreta) e execução (atividade prática e material) (cf. "Execução e ação executiva", in Estudos sobre o processo civil brasileiro, n. 3, p. 33).

${ }^{280}$ Cf. Dinamarco, Instituições..., v. I, n. 58, p. 156.

${ }^{281}$ Cf. Andrea Proto Pisani, Lezioni di diritto processuale civile, cap. IV, n. 1, p. 149; e Elio Fazzalari, Istituzioni diritto processuale, cap. VI, n. 1, pp. 351 e ss. Também Schwab fez alusão a conteúdo (cf. El objeto litigioso en el proceso civil, n. 16, p. 242).

${ }^{282}$ Cf. Tomás Pará Filho, Estudo sobre a sentença constitutiva, p. 28; e Junior Alexandre Moreira Pinto, Conteúdos e efeitos das decisões judiciais, n. 1.3, p. 76. Este último autor, contudo, contraditoriamente afirma que "caminhou a doutrina no sentido de criar uma classificação da tutela, à luz de seu conteúdo e do efeito pretendido pelo litigante". 
produção de efeitos típicos desnatura o ato como tal. Já os efeitos considerados em ato podem faltar, eventual e temporariamente, sem que aquele seja descaracterizado. $\mathrm{O}$ exemplo é a compra e venda nula, que, conquanto ineficaz, continua sendo uma compra e venda: possui conteúdo, mas não efeitos desse contrato. ${ }^{283}$ Embora seja natural a correlação entre conteúdo e efeitos, explica Barbosa Moreira, eles não se confundem. Por definição, o efeito é necessariamente exterior ao ato; ao contrário do conteúdo, que está contido naquele, de tal sorte que seria uma contradição a ideia de um efeito incluso no ato jurídico. Tudo que está dentro do ato são os elementos de seu conteúdo. ${ }^{284}$ E é a partir deste que deveriam ser definidos e classificados os atos. ${ }^{285}$

Ainda de acordo com esse processualista, tal construção aplicar-se-ia também às decisões judiciais, já que são espécies do gênero ato jurídico: os efeitos do provimento variam, em regra, de acordo com o seu conteúdo, mas com este não se confundem. Por isso, partindo da ideia de que é incorreto classificar o objeto por algo que lhe é exterior, Barbosa Moreira defende ser errôneo qualificar as decisões judiciais por seus efeitos ${ }^{286}$ erro em que, de acordo com ele, incorreria a maior parte da doutrina.

Em que pese as precisas e afiadas observações do ilustre processualista, a mesma crítica aqui feita à corrente que defende o critério da natureza do provimento cabe à que

${ }^{283}$ Cf. "Conteúdo e efeitos da sentença: variações sobre o tema", in Temas de direito processual, $4^{\mathrm{a}}$ série, $\mathrm{p}$. 175 .

${ }^{284}$ Cf. "Notas sobre el contenido, los efectos y la inmutabilidad de la sentencia", in Temas de direito processual, $5^{\mathrm{a}}$ Série, p. 105; "Reflexões críticas sobre uma teoria de condenação civil", Temas de direito processual, $1^{\text {a }}$ Série, p. 77; e "Conteúdo e efeitos ...", p. 176. Citando Barbosa Moreira, Paulo Lucon adere a essa diferenciação, mas afirma que "a eficácia, em sentido jurídico, refere-se ao conteúdo do ato jurídico, designando a qualidade ou o atributo do ato idôneo a gerar efeitos" (cf. Eficácia das decisões..., n. 42, p. 147). Não nos parece, contudo, que essa seja a leitura correta do texto de Barbosa Moreira, pois o professor carioca, como já visto, equivale eficácia a efeitos, diferenciando estes do conteúdo. Nesse sentido, v., além das passagens já mencionadas acima, "Notas sobre el contenido...", n. 2, p. 105.

285 Embora em contexto diverso, também Dinamarco afirmou que "não é metodologicamente correto, em ciência alguma, definir um fenômeno pelos sues efeitos - senão por seus próprios elementos constitutivos" (cf. "O conceito de mérito em processo civil", in Fundamentos do processo civil moderno, t. I, n. 170, p. 345). Igualmente em contexto diverso, Agnelo Amorim Filho criticou a distinção entre decadência e prescrição pelo critério de que aquela extingue o direito e esta a ação, pois tal critério parte dos efeitos ou das consequências dos institutos, ainda que esses sejam, realmente, os seus principais efeitos (cf. "Critério científico...", p. 727).

${ }^{286}$ Como exemplo, cita-se a sentença condenatória. Para alguns, o seu principal efeito é o de ensejar a execução. Mas obviamente essa característica não se localizaria em seu interior e, portanto, afirma Barbosa Moreira, certamente não é o elemento definidor do conteúdo do provimento condenatório (cf. "Conteúdo e efeitos...”, p. 177). Em sentido contrário, Eduardo Talamini afirma que "não há outra perspectiva para identificar a condenação senão a da sua 'função processual'. Sentença condenatória é a que possibilita a execução forçada" (cf. Tutela relativa..., n. 6.1, p. 188). 
preconiza o critério do conteúdo. A menos que se defina o que se entende por conteúdo, asseverar-se que os provimentos classificam-se por esse critério também é cair no vazio. E mesmo Barbosa Moreira não expõe claramente o que entende por conteúdo. Traça alguns aspectos característicos de efeitos e conteúdos - principalmente o de que aqueles são externos e estes internos ao ato -, mas não fornece, precisamente, os seus conceitos dessas categorias. $^{287}$

A verdade é que há uma tremenda confusão em todas essas classificações ${ }^{288}$ e a grande maioria dos autores analisados mistura, em uma mesma classificação, critérios diversos. É frequente que se tome partido por um critério e, no mesmo trabalho, passe-se a adotar outro.

Na realidade, a classificação em tutela cognitiva, executiva e cautelar utiliza um critério diverso (finalidade) do utilizado pela divisão das tutelas de conhecimento em meramente declaratória, constitutiva e condenatória (estrutura processual). Como será visto a seguir, a adoção do critério da finalidade para a primeira dessas categorizações é a única maneira para que a tutela cautelar seja considerada um terceiro gênero e não seja absorvida pelas tutelas cognitiva e executiva. E mais: o único critério que é integralmente baseado em (i) elementos internos ao provimento e (ii) elementos processuais - isto é, que não se fundamenta em elementos externos ao ato e/ou encontrados no direito material - é o da estrutura processual, naseado na compleição processual do provimento.

\footnotetext{
${ }^{287}$ Da mesma forma Junior Alexandre Moreira Pinto, que no livro intitulado Conteúdo e efeitos das decisões judiciais não confere, em momento algum, conceito do que seria conteúdo. Exemplificativa é a seguinte passagem: "Os efeitos das decisões também foram objeto de análise. Partindo-se da premissa de que não se confundem os conteúdos com os efeitos das decisões, foi anotado que a aptidão para as transformações no plano material representa os efeito do decisum. Sob este prisma, inconfundíveis os institutos do conteúdo e do efeito das decisões" (p. 2). O autor, como se vê, conceitua, de maneira acertada, efeito, mas não conteúdo. Em passagem anterior, ao explicar que procurou tratar dos conteúdos das decisões, afirma que "houve a análise detida de cada elemento do decisum, à luz da crise surgida no âmbito do direito material. Nessa linha, foram definidas as características das tutelas meramente declaratórias, constitutivas e condenatórias" (p. 1). Contudo, mais uma vez, dizer que o critério classificatório são as características ou os elementos da decisão também não significa nada. É preciso definir, repita-se, o que se entende por conteúdo.

${ }^{288}$ Mesmo Barbosa Moreira reconhece que em matéria de classificação de sentenças possui mais perguntas do que respostas e que não possui um critério claro fazer essa separação (cf. "Questões novas e velhas em matéria de classificação das sentenças", in Temas de direito processual, $8^{a}$ Série, p. 141). E alerta que "podemos classificar as sentenças de acordo com o conteúdo, ou de acordo com os efeitos. O que decididamente não podemos é passar, no meio do caminho, de um critério a outro". São também comuns argumentos circulares: "Tendo em vista os diferentes tipos de sentença a que visa o autor, as ações de conhecimento classificam-se em ações condenatórias, ações declaratórias e ações constitutivas, segundo a sentença pretendida seja condenatória, declaratória ou constitutiva" (cf. Celso Agrícola Barbi, Comentários..., v. 1, t. I, n. 40, p. 68).
} 
A única maneira de viabilizar-se a classificação tradicional da tutelas jurisdicionais é entender que a divisão em cognição, execução e cautelaridade parte do critério da finalidade, e que a divisão em tutelas meramente declaratória, constitutiva e condenatória parte do critério da estrutura processual. E a adoção dessa perspectiva tem consequências. É do que se passa a tratar.

\subsubsection{Tutelas cognitiva, executiva e cautelar: critério do escopo ou da finalidade}

Os critérios que dividem a tutela em executiva, cautelar e cognitiva e o que separa esta última em meramente declaratória, constitutiva e condenatória claramente não são os mesmos. O primeiro deles não considera a eficácia, tampouco o conteúdo da tutela jurisdicional ou qualquer outro dos critérios analisados acima, como atividade desenvolvida pelo juiz, modo de aplicação da lei no processo ou resultado oferecido frente ao direito material. A adoção de qualquer desses discrímens leva à desestruturação da classificação em tutela cognitiva, executiva e cautelar.

Com efeito, entre cognição, execução e cautela não há diferença de eficácia porque os potenciais efeitos jurídicos e fáticos (ou efeitos principais e práticos, na terminologia de parte da doutrina) decorrentes de um provimento cautelar são os mesmos de uma decisão cognitiva ou executiva, na medida em que a tutela cautelar atua por meio de cognição e/ou execução. É verdade que são intrinsecamente provisórios os efeitos da tutela cautelar e definitivos os das demais formas de tutela. Mas o posicionamento aqui assumido não é alterado por isso, na medida em que a definitividade e a provisoriedade são apenas atributos dos efeitos, que em seu âmago continuam a ostentar seus traços característicos (cognição ou execução).

Da mesma forma com relação ao suposto conteúdo. Em que pese a indefinição terminológica sobre o que se deve entender por conteúdo, partindo-se da premissa de que é sinônimo de estrutura processual - definição que é por nós concebida, mas que, repita-se, não é dada pelos que defendem o critério do conteúdo -, a tutela cautelar também possui ora a estrutura da tutela cognitiva, ora a da tutela executiva, e, no mais das vezes, representa um amálgama dessas duas espécies de tutela, declarando (cognição) e atuando 
(execução) a norma concreta. A decisão cautelar não é estruturalmente diversa daquelas outras duas modalidades de decisão. ${ }^{289}$

Outro critério que poderia amparar a divisão em tutela cognitiva, executiva e cautelar é o da atividade do juiz. Mas a adoção dele também leva à conclusão de que não haveria por que se falar em divisão tripartite, na medida em que a atividade desenvolvida pelo juiz na tutela cautelar é, como visto, ora de cognição, ora de execução. Não há uma atividade cautelar propriamente dita.

O único critério que diferencia essas três modalidades de tutela é o que leva em consideração as suas finalidades. Embora a relação jurídica processual seja autônoma ao direito material em decorrência de seus sujeitos, pressupostos e objetos, ${ }^{290}$ o processo é um instrumento posto a serviço da realização do direito material ${ }^{291}$ e da pacificação social e, nessa medida, possui conotação eminentemente teleológica. ${ }^{292}$

O processo é um método de trabalho utilizado pelo Estado na solução de insatisfações dos jurisdicionados, que possui escopos jurídicos sociais, jurídicos e políticos como nortes. ${ }^{293}$ Quando se fala em finalidade dos provimentos, não se está fazendo alusão aos escopos da jurisdição. Optou-se pelo termo finalidade para que não se fizesse tal confusão. A divisão aqui proposta não é, como pode transparecer, entre provimentos de escopos sociais, jurídicos e políticos - seria um absurdo sustentar tal posição. Esses três

\footnotetext{
${ }^{289}$ Isso levou respeitadas vozes a negar o caráter de tertium genus da tutela cautelar, conforme será visto à seguir.

${ }^{290} \mathrm{Cf}$. Oskar Bülow, La teoria de las excepciones procesales y los presupuestos procesales (trad. de Miguel Angel Rosas Lichtschein), n. 1, pp. 10/12. Como é notório, esse autor foi o responsável pela sistematização da ideia de processo como relação jurídica de natureza pública, que se desenvolve gradativamente e é mantida entre o juiz e as partes.

${ }^{291}$ Daí a noção de direito processual como direito instrumental, o que não se confunde com direito adjetivo, locução esta que, já em 1977, representava para Alcides de Mendonça Lima "um atraso de mais de cem anos" (cf. Direito processual civil, cap. XIV, n. 1, p. 289).

${ }^{292}$ Essa é a concepção positiva de instrumentalidade do processo (cf. Dinamarco, A instrumentalidade..., n. 36, p. 319). Em seu aspecto negativo, a instrumentalidade serve de alerta de que o processo não é um fim em si mesmo e que à aplicação das regras de direito processual não deve ser dada tanta importância a ponto de se desconsiderar o direito material e o mandamento constitucional de acesso à ordem jurídica justa. Nesse sentido, a instrumentalidade é um fator de controle a exageros e distorções, que expurga o culto ao processo.

${ }^{293}$ Como já se apontou com autoridade, é vaga a afirmação de que algo é um instrumento se não acompanhada da indicação de quais são os objetivos que se quer atingir mediante o seu emprego: "Todo instrumento, como tal, é meio; e todo meio só é tal e se legitima, em função dos fins a que se destina. $\mathrm{O}$ raciocínio teleológico há de incluir então, necessariamente, a fixação dos escopos do processo, ou seja, dos propósitos norteadores da sua instituição e das condutas dos agentes estatais que o utilizam" (cf. Dinamarco, A instrumentalidade..., n. 18, p. 177).
} 
escopos aglutinam-se e determinam ao Estado que, sempre que exercer a jurisdição, norteie-se por eles. Esse é o objeto final do processo: aplicar o direito material (escopo jurídico), pacificar com justiça (escopos sociais) e legitimar o exercício do poder (escopos políticos). Mas, na perseguição desses escopos, ele deve valer-se dos provimentos jurisdicionais, que, de acordo com as suas finalidades, podem ser classificados em cognitivos, executivos e cautelares. Daí porque se pode falar, também, em funções cognitiva, executiva e cautelar: a depender da finalidade do provimento, este terá uma ou outra função. ${ }^{294}$

O escopo mediato da jurisdição é um amálgama dos escopos jurídicos, sociais e políticos, ao passo que o escopo imediato são as finalidades da jurisdição: declaração da regra jurídica concreta, efetivação da regra jurídica concreta e asseguração. ${ }^{295}$ Cada uma dessas espécies de tutelas tem um intuito, e é partir deles que são classificadas daquela forma. É somente assim que se pode trabalhar com uma divisão tripartite.

\subsubsection{Tutela cautelar como tertium genus: acerto do critério da finalidade}

A prova de que o critério correto na classificação em tutelas cognitiva, executiva e cautelar é o da finalidade é a adoção dessa última como terceiro gênero de tutela. Caso sejam adotados os demais critérios pregados por parte da doutrina (eficácia, conteúdo,

\footnotetext{
${ }^{294}$ A própria Exposição de Motivos do CPC de 1973 alude "à função jurisdicional de conhecimento, de execução e cautelar" (Cap. VI, n. 11). Fredie Didier Jr. adota a ideia de "função jurisdicional que se busca", que equivale ao que se está afirmando aqui (cf. Curso de direito processual civil,v. 1, n. 5.3, p. 200). Dinamarco compara a jurisdição a um serviço prestado pelo Estado, em oposição às demais funções estatais, como a executiva e a legislativa. A distinção entre elas se dá em razão dos objetivos por ela perseguidos (cf. A instrumentalidade..., n. 15, pp. 136/139); ou seja, de suas finalidades. Em outra passagem, o ilustre processualista alude às funções dos processos cognitivo e executivo (n. 28.2, p. 224). Negando poderem ser as sentenças classificadas por sua função, Alfredo Rocco afirmou que esta é a mesma em toda a sentença, pois "toda sentencia como tal no es ni puede ser otra cosa que un juicio sobre la existencia o no existencia de una relación o de un conjunto de relaciones jurídicas" (cf. La sentencia civil (trad. de Mariano Ovejero), n. 61, pp. 227/228). Essa ponderação, contudo, merece duas objeções. A primeira delas é que trata apenas da sentença, ato praticado por excelência no processo de cognição. Tal consideração, portanto, não afeta a classificação em provimentos cognitivo, executivo e cautelar. A segunda objeção é a de que, embora seja verdadeiro que toda sentença (cognitiva) contenha o elemento declaratório sobre a existência ou inexistência de um direito, elas não se limitam a isso. Daí por que mesmo na classificação das decisões de conhecimento seria aplicável o critério da função - apesar de que, como se verá a seguir, prefiramos o da estrutura processual. Também aludindo às funções das tutelas, v. Chiovenda, "Azione di mero accertamento", in Saggi di diritto processuale civile, v. III, p. 51, e Ferri-Comoglio-Taruffo, Lezioni sul processo civile, v. 1, cap. XXI, n. 7, p. 625.

${ }^{295}$ Dinamarco dá notícia de outra divisão, feita por Zanzucchi, em escopos mediato (reintegração do direito objetivo) e imediato (realização de interesses), que não equivale à aqui proposta (cf. A instrumentalidade..., n. 19, p. 182).
} 
atividade do julgador etc.), a tutela cautelar perde autonomia e é reconduzida àquelas outras duas.

Prevalece o entendimento de que a cautelar é uma terceira espécie de tutela jurisdicional, ao lado da cognitiva e da executiva, ${ }^{296}$ posição encampada pelo CPC de 1973, que dedica ao processo cautelar um dos cinco livros em que ele é dividido (Livro III). A Exposição de Motivos do Código justifica essa opção ao assentar que "a dogmática do processo civil moderno sanciona esta classificação. O processo cautelar foi regulado no Livro III, porque é um tertium genus, que contém a um tempo as funções do processo de conhecimento e de execução. O seu elemento específico é a prevenção". Para referendar este posicionamento, a Exposição de Motivos faz remissão à mais autorizada doutrina processual, como Carnelutti, Liebman, Rosenberg e Alcalá-Zamora y Castillo.

Por essa concepção, embora seja instrumental ao processo principal, o processo cautelar não é considerado um mero acessório daquele ou, como a doutrina e as legislações alemãs e austríacas clássicas preconizam, um apêndice do processo de execução. ${ }^{297} \mathrm{~A}$ tutela cautelar goza de autonomia, e não se confunde com a cognitiva e a executiva.

Negando ser a cautelar um terceiro gênero de tutela, Calamandrei sustentou que os provimentos cautelares possuem qualitativamente os mesmos efeitos dos cognitivo e executivo. O que distinguiria a tutela cautelar não é a qualidade de seus efeitos - pois eles também são declarativos ou executivos -, mas sim o seu caráter de provisoriedade subordinada ao provimento principal (instrumentalidade hipotética), em contraposição à definitividade dos demais provimentos. ${ }^{298}$ Daí ter falado em provimentos cognitivos e executivos definitivos e provimentos cognitivos e executivos cautelares.

\footnotetext{
296 Nesse sentido, Liebman: “À cognição e à execução, com que a jurisdição realiza todo o ciclo de suas principais funções, acrescenta-se uma terceira atividade, que tem um objetivo auxiliar e subsidiário, e que é a atividade cautelar" (Cf. Manual..., v. 1, p. 278).

${ }^{297}$ Essa comparação é feita por Galeno Lacerda, Comentários ao Código de Processo Civil, v. VIII, t. I, p. 4.

${ }^{298}$ Cf. Instituciones del derecho procesal civil (trad. de Santiago Sentís Melendo), v. 1, n. 27, pp. 219/220; e Introducción..., nn. 1 e 2, pp. 33/36. Embora utilize o termo definitividade para designar as tutelas que se contrapõem à cautelar, Calamandrei faz ressalvas ao termo definitividade, que seria uma qualificação atribuída a algumas sentenças, que não teria nada que ver com o conteúdo do provimento jurisdicional, mas sim com um elemento externo e formal relacionado ao momento cronológico em que inserida no iter procedimental. Assim, haveria decisões definitivas e decisões interlocutórias. Na verdade, o que Calamandrei quis opor foi decisões interlocutórias e decisões finais (ou sentenças), o que, em princípio, afastaria a impropriedade da utilização do termo definitivas, até porque, no caso de provimentos cautelares proferidos em via não incidental, eles são finais. Mas o termo é mesmo impróprio, pois definitividade está relacionada,
} 
As decisões podem ser classificadas com base nos efeitos que o provimento projetará sobre o direito material. De acordo com esse critério, haveria apenas a atividade jurisdicional cognitiva e a executiva, às quais a atividade cautelar seria conduzida. ${ }^{299}$ Uma segunda classificação levaria em conta a definitividade do provimento. Há providências cautelares (ou não definitivas) e providências definitivas (ou principais). ${ }^{300}$ Assim, o que definiria a tutela cautelar não seria a atividade desenvolvida pelo juiz ou os efeitos do provimento final, mas a sua aptidão (ou, melhor dizendo, inaptidão) em tornar-se definitiva e a sua finalidade de afastar o dano marginal do processo. Por essas razões que incluir a tutela cautelar ao lado da de cognição e execução não atenderia a critério homogêneo de classificação. $^{301}$

De fato, sob o ângulo da atividade desenvolvida pelo juiz, a tutela cautelar não se distingue das tutelas de conhecimento e de execução. ${ }^{302}$ Da mesma forma quanto aos

em sentido técnico-processual, às sentenças de mérito acobertadas pela coisa julgada material. E isso demonstraria o desacerto de se qualificar os provimentos não cautelares como definitivos. Contudo, firmada a premissa de que por definitivos se entendem os provimentos que bastem a si mesmos, isto é, que não guardem relação de instrumentalidade com outro, não há problema em se opor os provimentos provisórios (cautelares) aos provimentos definitivos (cognitivo e executivo). Mas o próprio Calamandrei afirma preferir os termos provimentos cautelares e provimentos principais (ao invés de definitivos) (cf. Introducción..., n. 10, p. 47).

${ }^{299}$ Cf. Instituciones..., v. 1, n. 27, pp. 209/212.

${ }^{300}$ Cf. Instituciones..., v. 1, n. 27, p. 219. Os provimentos cautelares se diferenciam dos sumários porque aqueles sempre estão relacionados a um perigo de dano jurídico derivado do retardo da prestação da tutela jurisdicional definitiva. É necessário que haja urgência para se falar em tutela cautelar (periculum in mora) (cf. Introducción..., nn. 5 e 6, pp. 40/41).

${ }^{301}$ Cf. Instituciones..., v. 1, n. 18, p. 156. Nessa passagem, aliás, embora utilize a expressão tertium genus, Calamandrei afirma que a cautelar não pode ser considerada um quartum genus e colocado ao lado das outras três espécies de tutela: constitutiva, declaratória e contra a transgressão de preceito (condenatória). Essas três tutelas, como visto, são subespécies da tutela cognitiva. No mesmo sentido, v. Introducción..., n. 2, p. 35. Escorado nessa lição, José Roberto dos Santos Bedaque também sustenta que a afirmação da autonomia da tutela cautelar e a sua colocação ao lado das demais tutelas jurisdicionais pecam por não aplicarem critério homogêneo de classificação (cf. Tutela cautelar..., p. 194). Igualmente afastando a cautelar como tertium genus, Cássio Scarpinella Bueno dá conta de que, sob o ângulo da atividade desenvolvida pelo juiz, a tutela jurisdicional é dividida em cognitiva e executiva e que o critério empregado pela doutrina para incluir a tutela cautelar como terceiro gênero peca pelo critério de classificação (cf. Curso..., v. 1, p. 288, e v. 4, p. 150).

${ }^{302}$ Tanto é isso verdade que vários dos que defendem a autonomia da ação cautelar assumem que no processo cautelar são exercidas atividades cognitivas e executivas, no mais das vezes de maneira integrada: "No processo cautelar existe um único procedimento, em que o conhecimento e a execução se aglutinam, em razão do objetivo da tutela específica invocada; não se podem sequer distinguir uma fase de conhecimento e uma fase de execução, de vez que o procedimento é unitário e indivisível, ficando o conhecimento e a execução unidos, sem solução de continuidade e sem possibilidade de separação" (cf. Cintra-GrinoverDinamarco, Teoria geral..., pp. 326/327). V., também, Liebman, Manual.., p. 279. Da mesma forma, Crisanto Mandrioli ensina que a tutela cautelar é composta de atividade de cognição em um primeiro momento e de atividade de execução em momento seguinte: "Con riguardo alle caratteristiche dell'attività cautelare, basterà qui richiamare i rilievi compiuti in sede di nozioni introduttive circa la funzione non autônoma, ma strumentale di questo tipo di attività giurisdizionale rispetto alla funzione (...) della cognizione 
efeitos. ${ }^{303}$ Sob esses dois enfoques, o processo cautelar de fato não traz características diferentes do processo cognitivo e executivo, mas antes representa a aglutinação desses dois últimos. ${ }^{304}$ Parece ser correta, pois, a negação da cautelar como gênero autônomo de tutela jurisdicional.

Essas considerações, contudo, pecam pelo seguinte: levam em conta critérios diversos do da finalidade.

O primeiro grande passo em direção à autonomia da tutela cautelar foi dado por Chiovenda. ${ }^{305}$ Deve-se, contudo, a Liebman e, principalmente, a Carnelutti, a ideia de que o processo cautelar é autônomo. De acordo com Liebman, embora de fato a demanda cautelar seja ligada por uma relação de complementação à demanda principal, aquela é autônoma e pode ser acolhida ou rejeitada independentemente do resultado que vá ter esta. Por essa razão, apesar de também ter enxergado a unitariedade do procedimento cautelar, ao reconhecer que na tutela cautelar são realizadas atividades de cognição e execução e que os efeitos daquela são os mesmos dessas duas últimas, o professor de Milão defendeu ser aquela um tertium genus. ${ }^{306}$

Nada obstante a tutela cautelar se equivalha às de cognição e execução quanto aos seus efeitos e à atividade desenvolvida pelo julgador, ela se apresenta como uma terceira finalidade da jurisdição. Por isso que o que justificaria a categorização da tutela cautelar

o dell'esecuzione; nonché, correlativamente, circa il difetto di caratteri strutturali especifici di questo tipo de attività, che presenta in un primo momento caratteri paragonabili a quelli della cognizione ed in un ulteriore momento caratteri paragonabili a quelli delle'esecuzione" (Cf. Diritto processuale civile, v. III, p. 261).

${ }^{303}$ Nesse sentido Carnelutti, que embora não tenha negado o caráter autônomo da tutela cautelar, assentou que, quanto aos seus efeitos, ostenta os mesmos das tutelas de cognição ou de execução: "Para la constitución de la cautela basta a veces la cognición, a veces, em cambio, hay que agregar la ejecución procesal (...). (...) Por tanto, debiendo el proceso cautelar operar a través de la cognición o de la ejecución, sus effectos son naturalmente análogos a los definidos em los dos títulos anteriores" (cf. Instituciones del processo civil (trad. de Santiago Sentís Melendo), v. I, n. 90, p. 157).

${ }^{304}$ Liebman afirma que "na tutela cautelar não se pode, por isso, distinguir uma fase de cognição e uma outra de execução; ela se realiza em todos os caso através de um procedimento unitário, em que se encontram juntas e eventualmente misturadas as atividades de índole diferentes que, caso a caso, concorrerão para a plena atuação da cautela" (cf. Manual..., v. 1, n. 96, p. 279).

${ }^{305}$ Cf. Galeno Lacerda, Comentários..., p. 4. De fato, fazendo menção à demanda cautelar, o processualista italiano defendeu que "o poder jurídico de obter uma dessas medidas é, por si próprio, uma forma de ação (ação assecuratória); e é mera ação, que não se pode considerar como acessório do direito acautelado porque existe como poder atual quando ainda não se sabe se o direito acautelado existe" (cf. Instituições..., p. 273).

${ }^{306}$ Cf. Manual ..., v. 1, n. 96, pp. 278/279. 
como um terceiro gênero é, para alguns, a sua função de prevenção. ${ }^{307}$ Mesmo Calamandrei, que, como visto, defende que qualitativamente os efeitos do provimento cautelar não se diferenciam dos efeitos dos provimentos cognitivo e executivo, reconhece uma finalidade sui generis naquele provimento, qual seja, a de assegurar a eficácia prática da providência definitiva que, essa sim, efetivará o direito material. ${ }^{308}$

No Brasil, como já dito, tal posição é ratificada pela maioria da doutrina e inclusive pelo CPC de 1973. Afirma-se que, embora quando se conceda tutela cautelar a atividade jurisdicional seja tanto de conhecimento como de execução (unitariedade do procedimento), na cautelar há o escopo da prevenção. ${ }^{309}$ Esse seria o seu elemento definidor, que a caracterizaria como terceira modalidade de tutela jurisdicional.

Atrelar-se a tutela cautelar à noção de prevenção, contudo, não é correto na medida em que a prevenção é exercida também pelas demais modalidades de tutela, nas hipóteses em que o direito ainda não foi lesionado. Fala-se, assim em tutela preventiva, em oposição à tutela repressiva: naquela o interesse de invocar a intervenção estatal deriva

\footnotetext{
${ }^{307}$ Essa é a posição de Carnelutti, que defendeu que, embora a estrutura da tutela cautelar equivalha às das tutelas cognitiva e executiva, o mesmo não ocorre quanto ao seu escopo, critério a partir do qual aquela ela é terceiro gênero de tutela. O provimento cautelar tem o seu relevo justificado em conta da sua função, mas não da sua estrutura. Confira-se: "Se così il processo cautelare si contrappone, quanto allo scopo, al processo giurisdizionale e al processo esecutivo, è da notare invece fin d'ora come, quanto ai mezzi, si identifichi ora con l'uno ora con l'altro nel senso che gli atti del proceso cautelare sono, secondo i casi, o i medesimi atti dei quali si giova la giurisdizione o quelli stessi che servono all'esecuzione (...). Ciò vuol dire che la figura del processo cautelare ha un suo proprio rilievo dal lato della funzione del processo ma non dal lato della struttura". Da mesma forma: "Così, accanto alla giurisdizione e alla esecuzione, la prevenzione (dei danni della lite) si presenta come un terzo scopo del processo" (Cf. Sistema di diritto processuale civile, v. I, pp. 205/206). Na doutrina italiana mais recente, Francesco P. Luiso chega a afirmar que "terza forma di intervento giurisdizionale è la tutela cautelar" e que "la tutela cautelare è una forma di intervento giurisdizionale ancillare, subordinato (ma non nel senso di importanza), strumentale rispetto alle altre forme di intervento giurisdizionale, e quindi destinata ad essere in esse riassorbita", dando a entender que considera a cautela como terceiro gênero de tutela (cf. Diritto processuale civile, v. IV, pp. 19 e 21).

${ }^{308}$ Cf. Introducción..., n. 9, p. 45.

${ }^{309}$ Cf. Cintra-Grinover-Dinamarco, Teoria geral..., pp. 326/327. José Frederico Marques também asseverou que a cautelar estaria ao lado das tutelas de conhecimento e executiva, perfazendo, assim, um terceiro gênero, marcado pela instrumentalidade ao processo cognitivo ou de execução (cf. Manual de direito processual civil, v. 1, p. 159). Galeno Lacerda, por sua vez, elogia Alfredo Buzaid, autor do anteprojeto do CPC de 1973, por ter colocado a tutela cautelar no mesmo nível das cognitiva e executiva (cf. Comentários..., pp. 3/4). Na lição de Humberto Theodoro Jr., a cautelar é um tertium genus, embora ele também reconheça que ela desempenha as funções de cognição e execução. Tal processualista defende que a autonomia do processo cautelar está na função desempenhada no ordenamento, qual seja, a função de assegurar a eficácia prática do provimento final (cf. Processo cautelar, pp. 41 e 69).
} 
não de um dano ocorrido, mas do perigo de dano futuro. A prevenção não é exclusiva da tutela cautelar e, portanto, não pode ser invocada como seu caráter definidor. ${ }^{310}$

Não é qualquer perigo que caracteriza o interesse para a tutela cautelar, mas um perigo qualificado pela demora do processo (periculum in mora). A mora que autoriza o provimento cautelar é a que decorre do percurso do iter procedimental ordinário exigido para a outorga da tutela jurisdicional. A finalidade da tutela cautelar é afastar o dano marginal do processo e, assim, assegurar a eficácia prática da tutela principal (cognitiva ou executiva). Apenas nessa medida é que a cautelar deve ser um terceiro gênero de tutela.

Esse raciocínio demonstra o acerto da adoção do critério da finalidade na classificação das tutelas em cognitiva, executiva e cautelar. Nada impede, como dito, que aquelas sejam classificadas de acordo com seus efeitos ou qualquer outro critério. Mas, para manter a divisão tripartite, a única opção é reconhecer o critério da finalidade.

\subsubsection{Tutela meramente declaratória, tutela constitutiva e tutela condenatória: estrutura processual}

Diverso é o critério utilizado na chamada classificação ternária das tutelas jurisdicionais de conhecimento. Se, como reconhece a doutrina, o que move essa classificação é a natureza da crise de direito material - sendo esse o único ponto em que praticamente todos concordam ${ }^{311}$-, e a superação dessa crise se dá mediante os provimentos jurisdicionais, que, por sua vez, atuam projetando efeitos sobre o plano do

${ }^{310}$ Cf. Calamandrei, Introducción..., n. 6-a, pp. 40/41. Isso também foi percebido por Cássio Scarpinella Bueno, que apontou que não apenas o processo cautelar seria marcado pela prevenção, uma vez que esta qualidade pode ser encontrada na "ação declaratória" prevista pelo art. $4^{\circ}$ do CPC; no art. 558 do CPC, que permite que o relator conceda efeito suspensivo ao recurso; e no art. 615, III do CPC, que autoriza o exequente a "pleitear medidas acautelatórias urgentes". Por isso, o autor preconiza que "melhor do que entender a preventividade como algo inerente a um 'processo' (o 'cautelar'), portanto, é entendê-la como inerente ao próprio exercício da função jurisdicional” (cf. Curso..., v. 4, p. 151).

${ }^{311}$ São as situações de insatisfação de interesses que determinam o provimento adequado à superação da crise e, consequentemente, os efeitos que se esperam do provimento pretendido. $\mathrm{Ou}$, melhor dizendo, são as crises jurídicas que ditarão o tipo de tutela jurisdicional, entendidas tais crises como as situações de insatisfação que existem à luz do direito material (cf. Dinamarco, Instituições..., v. 1, ns. 56 e 58, pp. 151 e 153/156; Flávio Yarshell, Tutela jurisdicional, p. 150; Tomás Pará Filho, Estudo..., p. 28; Satta, Direito processual..., v. 1, n. 147, p. 276; José Roberto Bedaque, Efetividade do processo.., p. 532; e Paulo Lucon, Eficácia das decisões..., n. 44, p. 151). Eduardo Talamini alude à "íntima relação entre situações de direito material tuteladas e a eficácia preponderante do provimento empregado" (cf. Tutela relativa..., n. 6.3, p. 197). Como bem apontou Dinamarco, "a variedade de meios processuais constitui, assim, espelho da variedade das soluções ditadas no direito substancial” (cf. Instituições..., v. I, n. 57, p. 151). 
direito material, a classificação mais correta é, aparentemente, a que leva em consideração a eficácia da tutela. A depender da crise jurídica de direito material, haverá uma tutela processual adequada a debelá-la. É o mesmo que dizer que são as características da doença que ditarão a espécie de remédio: diante de uma inflamação, o médico deve ministrar um anti-inflamatório, que terá o efeito potencial de erradicar a inflamação; diante de uma alergia, deverá ser empregado um anti-histamínico, cujo efeito será curar a crise alérgica, e assim por diante. O que diferenciaria as diversas formas de tutela jurisdicional seriam, portanto, os seus efeitos jurídicos.

Conteúdo e efeitos do provimento estão imbricados. ${ }^{312}$ Ainda que não se confundam, estes decorrem daquele ${ }^{313}$ e entre eles há, portanto, inegável relação de causalidade. ${ }^{314} \mathrm{O}$ provimento só é condenatório porque autoriza a realização de atos de execução, ou seja, por algo que, embora lhe seja exterior (o efeito de dar ensejo à execução), deriva do seu conteúdo. Da mesma forma a decisão constitutiva: só se caracteriza como tal por gerar o efeito de modificar uma situação jurídica. O efeito modificação jurídica emana do seu conteúdo. ${ }^{315}$

Há quem sustente, como visto, a incorreção de utilizar-se a eficácia das tutelas de conhecimento como critério classificativo. Seria tautológico catalogar um fenômeno com base nos seus resultados. ${ }^{316}$ Com todo o respeito, não se vê por que razão haveria tautologia nisso. Todo fenômeno comporta tantas classificações quantos forem os critérios eleitos, ${ }^{317}$ de maneira que é perfeitamente possível catalogar um fenômeno por seus efeitos. Pode-se até considerar que este não seja o critério adotado na classificação ternária, mas

\footnotetext{
312 Apesar de afirmar que o critério para classificação das "ações" deve levar em conta a natureza do provimento, Satta esclarece que "é justo proceder à análise dessa tutela pelos reflexos que tem acerca do conteúdo e sobre a eficácia da sentença", deixando evidente que conteúdo e efeitos estão interligados (cf. Direito processual..., v. 1, n. 74, p. 166).

${ }^{313}$ Cf. "Conteúdo e efeitos...", pp. 176/177: "Esses efeitos variam segundo o conteúdo, são determinados por ele, mas nem por isso com ele se confudem". Contudo, ressalva o mestre ser possível que "eventualmente, se atribuam efeitos iguais a atos de diferentes conteúdos, ou vice-versa".

${ }^{314}$ Nessa direção, Eduardo Talamini afirma que a eficácia está, ela própria, dentro do conteúdo (cf. Tutela relativa..., n. 6.6, p. 203). Ainda que discordemos da inclusão da eficácia no conteúdo, valendo-nos da distinção feita por Barbosa Moreira, parece que Talamini tem razão em demonstrar essa relação umbilical entre o conteúdo e os efeitos do provimento. Da mesma forma, embora adote a distinção feita por Barbosa Moreira, Paulo Henrique dos Santos Lucon afirma que "não há, portanto, como negar a estreita relação entre o conteúdo e os efeitos do ato jurídico" (cf. Eficácia das decisões..., n. 42, p. 148, nota 11.).

${ }^{315}$ Cf. Eduardo Talamini, Tutela relativa..., n. 6.6, p. 204.

${ }^{316}$ Cf. José Roberto dos Santos Bedaque, Efetividade do processo..., pp. 519 e 533, nota 24.

${ }^{317} \mathrm{E}$ com isso até mesmo Bedaque concorda (cf. Efetividade do processo..., p. 532).
} 
isso não permite dizer que o critério seja tautológico. Em suma, qualquer critério classificativo é válido; o que não pode é, em uma mesma classificação, serem misturados discrímens.

Mas, além das críticas feitas por Barbosa Moreira no sentido de que é inadequado classificar um ato por seus efeitos - com o que não se pode concordar, ao menos não sem as ressalvas feitas no parágrafo precedente -, a rejeição do critério que leva em consideração a eficácia do provimento justifica-se pela necessidade de se buscar um critério processual, isto é, que esteja integralmente contido no direito processual. Há evidente relação de funcionalidade e instrumentalidade entre tutela jurisdicional e crises de direito material, mas isso não significa que o critério classificativo das tutelas deva ser procurado no direito material. Nessa premissa, o critério que deve ser empregado na divisão das tutelas de conhecimento é o que leva em conta o modo dessas agirem dentro do processo. Ou seja, o critério da sua estrutura processual.

O critério da estrutura processual é encontrado integralmente no provimento, e não em aspectos exteriores a ele (efeitos, por exemplo), o que afasta a crítica dos que sem razão, a nosso ver - sustentam a tautologia de se efetuar a classificação dos provimentos com base em seus efeitos. Nessa medida, a ideia de estrutura processual é uma depuração da de conteúdo, na medida em que aquela transmite a ideia de algo intrínseco e contido no provimento. Como exposto, o problema do critério do conteúdo é a equivocidade desse termo e a falta de definição com que a doutrina o aplica. Assim como natureza, conteúdo podem ser tantas coisas que, se não especificado o seu significado, não se saberá do que se está falando. Por isso, desde que se defina que por conteúdo ou natureza se está significando estrutura processual, pode ser dito que o critério da divisão das tutelas de conhecimento é o do conteúdo ou da natureza. ${ }^{318}$ Mas, como essa definição não é dada e para que não se abra margem para equívocos, insiste-se aqui na ideia de estrutura processual.

\footnotetext{
${ }^{318}$ Embora sem maior aprofundamento, Flávio Yarshell parece empregar ao conceito de conteúdo o sentido de estrutura (Cf. Tutela jurisdicional específica..., n. 2.3., p.24, nota 31). Da mesma forma Barbosa Moreira, que, ao defender a autonomia da tutela constitutiva sob a ótica do conteúdo, alude à sua estrutura inteligível, composta por dois elementos ou momentos (cf. "Reflexões críticas...", p. 78). No mesmo texto, esse autor afirma que, na sentença constitutiva, "ao estabelecimento da nova situação jurídica (efeito) corresponde, na estrutura da sentença, um elemento identificável como causa: a modificação operada pela pronúncia judicial" (n. 8, p. 79).
} 
O critério da estrutura processual é adequado, ainda, por um segundo motivo. O discrímen é integralmente processual, isto é, prescinde de elementos do direito material. Ele é construído a partir das crises de direito material, mas não é, estruturalmente, composto por elementos do direito substancial.

Ademais, esse critério afasta algumas situações de perplexidade. Por exemplo, costuma-se dizer que a crise de certeza deve ser sanada pela tutela declaratória, a crise de situação jurídica pela tutela constitutiva e a crise de adimplemento pela tutela condenatória. Da mesma forma, costuma-se afirmar que a um direito prestativo corresponde a tutela condenatória; e a um direito potestativo, a tutela constitutiva. ${ }^{319}$

Mas apenas a natureza do direito violado - isto é, da crise jurídica que surgirá dessa violação - não é suficiente para determinar a tutela jurisdicional adequada. Afirmase isso por conta de um tipo de obrigação: a de prestar declaração de vontade. Referida obrigação, como o próprio nome diz, tem como contraparte positiva um direito prestativo, consistente em poder-se exigir determinada prestação do sujeito passivo. A essa categoria de direitos se opõe a de direitos potestativos, os quais, ao invés de franquear ao seu titular a posição jurídica de vantagem de exigir do sujeito passivo uma prestação, conferem-lhe o poder de, unilateralmente, efetuar uma mudança jurídica que afetará a esfera jurídica de outro sujeito. Como defende a doutrina fortemente predominante, aos direitos potestativos corresponderia a tutela constitutiva (crise de situação jurídica - tutela constitutiva); e aos direitos prestativos, a condenatória (crise de adimplemento - tutela condenatória). ${ }^{320}$

O direito a uma declaração de vontade é prestativo e, portanto, em tese deveria ser protegido pela tutela condenatória. Inadimplida a obrigação de prestar declaração de vontade, caberia ao credor ajuizar demanda de cunho condenatório, objetivando a imposição ao réu de dever de prestar determinada conduta. Essa, aliás, é a opção do

\footnotetext{
319 Assim, Agnelo Amorim Filho: "tôdas as ações condenatórias e tôdas as ações constitutivas são, respectivamente, instrumentos de exercício de direitos subjetivos de prestação (reais ou pessoais) e direitos subjetivos potestativos" (cf. "As ações constitutivas...", p. 29). Por sua vez, Giovanni Verdi diz que à base da demanda constitutiva está uma situação ativa de poder e uma situação passiva de sujeição (cf. Profili del processo civil, v. 1 , cap. 5 , n. 3, p. 182).

${ }^{320}$ Nesse sentido, Chiovenda, Instituições..., v. I, nn. 4,10 e 42, pp. 11, 14/15, 35 e 182/183 e "Sul litisconsorzio necessario", in Saggi di diritto processuale civile, v. II, p. 400; e Satta, Direito processual..., v. 1, n. 146, p. 27. Denominando a demanda condenatória de "ação de prestação", v. Arruda Alvim, Manual..., n. 302, p. 1.091. Sobre os direitos potestativos, v., ainda, Heinrich Ewald Hörster, A Parte Geral.., n. 396, pp. $243 / 245$.
} 
Código de Processo Civil, ao estabelecer que "condenado o devedor a emitir declaração de vontade, a sentença, uma vez transitada em julgado, produzirá todos os efeitos da declaração não emitida" (art. 466-A). Contudo, em que pese à equivocada redação desse dispositivo transmitir a noção de que a tutela prestada na efetivação dessas obrigações seja condenatória, tal provimento é constitutivo, e não condenatório. ${ }^{321}$

Se essa constatação não infirma a relação entre natureza da crise de direito material e tutela jurisdicional, ao menos a estremece, ao questionar o entendimento de que uma crise de adimplemento deve inexoravelmente levar à tutela condenatória. No exemplo utilizado, a crise é de adimplemento, mas a natureza sui generis do direito violado torna adequada à sua proteção a tutela constitutiva, e não a condenatória. ${ }^{322}$

Não há problema em que, de um lado, a classificação entre tutelas de conhecimento, executiva e cautelar, e, de outro, em tutelas meramente declaratória,

${ }^{321}$ Cf. Flávio Yarshell, Tutela jurisdicional específica nas obrigações de declaração de vontade, nn. 2.6/2.7, pp. 44/55; Barbosa Moreira, O novo processo civil brasileiro, pp. 223/224; Marcelo Bonício, Comentários à execução civil - título judicial e extrajudicial (artigo por artigo), p. 25; e Paulo Lucon, Código de Processo Civil Interpretado (coord. Antonio Carlos Marcato), pp. 1.515/1.516. Aderindo a essa corrente, Dinamarco chega a falar em "falsas 'condenações' a prestar declaração de vontade" (cf. Instituições..., v. III, n. 922, p. 253), enquanto José Maria Tesheiner diz que referidas sentenças são constitutivas ou mandamentais (cf. Elementos para uma teoria geral do processo, cap. VII, n. 8, p. 150). Sobre o assunto, v., ainda, o nosso "Cumprimento de acordo de acionistas em arbitragem”, in Flávio Luiz Yarshell e Guilherme Setoguti J. Pereira (coords.), Processo societário, pp. 278/279. Há, contudo, autores de peso que sustentam o caráter condenatório dessas decisões, associando os efeitos por ela produzidos à noção de execução forçada (cf. Alfredo Rocco, La sentencia..., n. 60, p. 222). Para análise da divergência doutrinária sobre a natureza jurídica desse provimento, v. Barbosa Moreira, “Aspectos da 'execução' em matéria de obrigação de emitir declaração de vontade", in Temas de direito processual, 6a série, pp. 229 e seguintes; e Flávio Yarshell, Tutela jurisdicional específica..., n. 26, pp. 44/55, este último com farta indicação de bibliografia. Em sentido inverso do aqui defendido, José Roberto dos Santos Bedaque entende que essa é modalidade de provimento condenatório e o invoca justamente para comprovar a ideia de que é possível condenação sem execução (cf. Efetividade..., cap. VI, n. 12, p. 555).

${ }^{322}$ Conforme foi por nós exposto em outro trabalho, a obrigação de prestar declaração de vontade é sui generis. Embora se enquadre na categoria de obrigações de fazer, que são normalmente infungíveis, possui uma especificidade: a sua infungibilidade é apenas fática, e não jurídica. Ao acolher pedido que pretende sanar o inadimplemento de uma obrigação dessa espécie, o juiz não emite a declaração de vontade em nome do devedor, já que não pode substituí-lo (infungibilidade fática), mas o provimento produz os efeitos jurídicos idênticos aos que adviriam do adimplemento da obrigação (fungibilidade jurídica). Daí por que o correto é falar em substituição dos efeitos da declaração de vontade, e não substituição da própria declaração de vontade. A prestação em si é infungível, de modo que o provimento não pode implementar a própria prestação, mas apenas os efeitos que dela decorreriam. Por isso, a obrigação distancia-se das obrigações infungíveis ordinárias, onde a obtenção da tutela específica é possível apenas por meio do emprego de meios coercitivos sobre a vontade do devedor (cf. Guilherme Setoguti J. Pereira, "Cumprimento de acordo de acionistas...", p. 278). Sobre o assunto, v. Dinamarco, "Sentença substitutiva da vontade do devedor e execução por obrigações específicas”, in Fundamentos do processo civil moderno, t. I, p. 989; e Luis Eulálio de Bueno Vidigal, Da execução direta das obrigações de prestar declaração de vontade, p. 78. 
constitutiva e condenatória, levem em consideração critérios diversos. Afinal são classificações diversas. Mas é preciso que isso seja dito claramente.

\subsection{Tutela cognitiva}

A tutela cognitiva ou de conhecimento é a que tem por escopo a declaração da regra jurídica concreta ou, como defendeu Chiovenda, a declaração da vontade concreta da $l e i{ }^{323} \mathrm{O}$ juiz não apenas afirma qual parte está com a razão, pois, para que pusessem fim à divergência de opiniões, bastaria que as partes questionassem qualquer pessoa. Investido do poder jurisdicional, o magistrado julga e manda, declarando imperativamente qual a relação jurídica existente entre as partes. ${ }^{324} \mathrm{O}$ órgão julgador é chamado a, por meio de uma sentença de mérito, apreciar a pretensão deduzida na demanda e declarar qual a prescrição legal para aquela situação e qual das partes tem razão à luz do direito material. ${ }^{325}$ Por isso é que a proteção concedida por meio do processo de conhecimento é chamada de tutela declaratória lato sensu. ${ }^{326} \mathrm{O}$ juiz não cria o direito, enunciando um novo 323 Cf. Instituições..., v. I, nn. 10 e 33 , pp. 34 e $157 / 158$. A identificação da jurisdição com a declaração de
direitos e obrigações já existentes é um desdobramento da teoria dualista do ordenamento jurídico, que
sustenta a divisão deste em duas ordens (a do direito substancial e a do direito processual) e a suficiência
daquele para a criação de direitos e obrigações. Por essa teoria, as relações jurídicas surgem, modificam-se e
extinguem-se, no mais das vezes, independente do processo, sendo necessário recorrer a este apenas na
hipótese de litígio ou em casos em que o próprio ordenamento condiciona a efetivação de determinado direito
à atuação jurisdicional (caso das chamadas açôes constitutivas necessárias, por exemplo). Mesmo nessas
hipóteses, contudo, sustentam os adeptos dessa corrente que o juiz não está criando o direito, mas apenas
declarando qual a normatizaçãa que o ordenamento possuía para os fatos que compõem aquela situação
específica. Por isso que Dinamarco, combatente da teoria unitária, afirmou que a jurisdição não cria o
direito, pois "a regra do caso concreto já existia antes, perfeita e acabada, interessando agora dar-lhe
efetividade, ou seja, promover a sua atuação" (cf. A instrumentalidade..., n. 29, p. 246).

${ }^{324}$ Cf. Calamandrei, Instituciones..., v. 1, n. 19, p. 164; e Carnelutti, Instituciones..., v. 1, n. 30, pp. 63/64. Nessa mesma passagem, Carnelutti anota que historicamente apenas o processo de conhecimento esteve englobado pelo conceito de jurisdição, em contraposição à execução. Apenas no processo de conhecimento é que o juiz seria chamado a exercer jurisdição (isto é, dizer o direito), ao passo em que no de execução apenas realizaria atos práticos. Mas mesmo Carnelutti explica que, no decorrer de sua produção, abandonou tal contraposição entre jurisdição e execução, de modo que aquela passou a englobar não só o processo de conhecimento mas também o de execução. Hoje não há dissenso na doutrina acerca do caráter jurisdicional da execução. A respeito disso, Calamandrei apontou que, embora etimologicamente jurisdição significasse iuris dictio - isto é, dizer o direito -, fazendo alusão ao "procedimiento lógico que más arriba hemos analizado, acerca de cuál es el mandato individualizado que regula el caso concreto", o que é fruto de um tempo em que se ensinava que a jurisdição se esgotava em "julgar", com o passar do tempo essa ideia foi superada, passando a considerar a execução como função igualmente jurisdicional (cf. Instituciones..., v. 1, n. 20, p. 165). Sobre a evolução do conceito de jurisdição, v. Ovídio Baptista da Silva, Teoria geral do direito civil, pp. 57/69 e 302.

${ }^{325}$ Cf. Couture, Fundamentos del derecho procesal civil, n. 47, p. 67; Cintra-Grinover-Dinamarco, Teoria geral..., p. 310; e Flávio Yarshell, Tutela jurisdicional específica..., n. 2.3., p. 22. A sentença é o ato pelo qual se realiza a tutela de conhecimento (cf. Alfredo Rocco, La sentencia ..., n. 12, p. 57).

${ }^{326}$ Daí ter dito Calamandrei que na cognição a função do juiz é a de "declarar oficialmente la certeza del derecho incierto o controvertido" (cf. Instituciones..., v. 1, n. 19, p. 161). Como decorrência do seu peculiar 
regramento; ele declara qual a qualificação que o ordenamento jurídico reserva para a situação submetida a julgamento. Daí se ter comparado a atividade do magistrado à atividade do técnico fotográfico, que, por meio do processo químico de revelação, traz à luz imagens que já existiam previamente, mas não eram visíveis. ${ }^{327}$

A tutela cognitiva, por sua vez, levando-se em consideração a sua estrutura (ou conteúdo, como visto anteriormente) - ou seja, o seu modo de atuação processual -, divide-se em meramente declaratória, constitutiva e condenatória.

\subsubsection{Tutela meramente declaratória}

A tutela cognitiva é também chamada de declaratória lato sensu porque declara a regra jurídica concreta. Contudo, uma de suas subespécies tem em vista unicamente esse mister. Garante-se por meio dela o direito à certificação jurídica. ${ }^{328} \mathrm{O}$ provimento jurisdicional exaure-se na declaração, debelando uma crise de certeza. O que se quer é, única e tão-somente, a certificação da existência ou inexistência de uma situação jurídica. ${ }^{329}$ Tal é a tutela meramente declaratória (ou tutela declaratória stricto sensu).

entendimento sobre a jurisdição, Carnelutti entendia haver duas formas de tutela: a dispositiva e a declaratória. Aquela se dá quando se confere ao juiz certa discricionariedade e lhe autoriza a decidir com base na equidade, e não em uma regra contida no ordenamento. A relação jurídica é constituída ao invés de declarada. Essa espécie de tutela é raramente aplicada no âmbito contencioso. A tutela declaratória, contudo, ocorre quando a atuação do juiz está vinculada e atua por meio da verificação de fatos e direitos, de modo que, ao final do raciocínio desenvolvido pelo juiz, este declare que a situação jurídica controvertida existe ou não. Assim, a antítese do processo dispositivo seria o processo declaratório: aquele constitui a relação jurídica, este apenas a declara. A tutela declaratória, por sua vez, se dividiria em tutela meramente declaratória, declaratória constitutiva e condenatória (cf. Instituciones..., v. 1, nn. 31/32, pp. 65/69).

${ }^{327}$ Cf. Dinamarco, A instrumentalidade..., n. 28.2, p. 228.

${ }^{328}$ Cf. Celso Agrícola Barbi, Comentários..., v. 1, t. I, n. 46, p. 72; Liebman, Processo de execução, n. 4, p. 15; e Flávio Yarshell, Tutela jurisdicional, p. 152. De acordo com Ovídio Baptista da Silva, "O bem da vida, neste caso, na terminologia chiovendiana, é justamente, e apenas, a obtenção de uma sentença com força de coisa julgada que torne absolutamente indiscutível, num eventual processo futuro, a existência, ou a inexistência, daquela relação jurídica que o juiz declarou existir ou não existir" (cf. Teoria geral..., p. 229). João Batista Lopes, por sua vez, defende que por trás da tutela declaratória está o valor segurança e que ele é o seu traço marcante e distintivo (cf. Ação declaratória, n. 3.8, p. 93).

${ }^{329}$ Cf. Pontes de Miranda, Tratado das ações, t. I, n. 25, p. 118; e Andrea Proto Pisani, “Appunti sulla tutela di mero accertamento", Rivista trimestrale di diritto e procedura civile, v. 33, n. 2, p. 621. Segundo Fredie Didier Jr., a demanda declaratória tem por objetivo certificar a existência ou inexistência de uma situação jurídica, gênero do qual relação jurídica é espécie. Isso porque é possível pedir seja certificado um direito ou um dever, que são situações jurídicas (cf. Curso ..., v. 1, p. 205). Portanto, embora comumente se faça alusão às relações jurídicas como objeto do provimento meramente declaratório, parece-nos que o correto é considerar as situações jurídicas. 
O provimento é meramente declaratório quando a existência da situação objeto dele é completamente independente deste, isto é, quando o provimento é irrelevante para os rumos da existência da situação jurídica sobre a qual versa e apenas põe fim à incerteza que reina sobre esta. Por exemplo, se existe dúvida sobre a propriedade de um dado bem e concede-se tutela meramente declaratória, esta apenas declarará a existência da propriedade, não a alterando em nada. ${ }^{330}$

Diz-se tutela meramente declaratória porque todas as formas de tutela jurisdicional de conhecimento são preliminarmente declaratórias. A decisão sobre o mérito que qualquer provimento cognitivo representa é, antes de tudo, a declaração sobre a situação jurídica deduzida em juízo. Essa declaração é a premissa em que se assentará qualquer outro provimento cognitivo (constitutivo ou condenatório), na medida em que a condenação e a constituição sempre derivam de uma prévia verificação da existência ou inexistência da relação jurídica afirmada pelas partes. ${ }^{331} \mathrm{O}$ que define o provimento meramente declaratório, portanto, não é que ele declare a existência ou inexistência de situação jurídica, mas sim que, estruturalmente, seja composto apenas por esse momento lógico declarativo. ${ }^{332}$

\footnotetext{
${ }^{330} \mathrm{O}$ exemplo é dado por Carnelutti (cf. Instituciones..., v. 1, n. 33, p. 70).

${ }^{331}$ Cf. Chiovenda, "Azioni e sentenze di mero accertamento" e "Azione di mero accertamento", in Saggi di diritto processuale civile, v. III, pp. 19 e 51); Goldschmidt, Derecho procesal civil (trad. de Leonardo Priesto Castro), §§ 13, 14 e 15, pp. 103, 105 e 111; Tomás Pará Filho, Estudo sobre..., p. 58; Buzaid, A ação declaratória no direito brasileiro, p. 95; Carnelutti, Instituciones..., v. 1, n. 32, p. 69; Liebman, Manual..., v. I, n. 83, p. 233; Couture, Fundamentos..., n. 199, p. 258; e Andrea Proto Pisani, Lezioni..., cap. IV, n. 1, p. 149. Alfredo Rocco chegou a dizer que a declaração do direito no caso concreto é a função essencial das sentenças (cf. La sentencia..., n. 53, p. 206). Pelos mesmos motivos Calamandrei escreveu que, antes de realizar qualquer medida para reintegrar o direito violado, o Estado exige que se obtenha a declaração de certeza oficial acerca da violação. A coação jurisdicional não pode ser exercida antes de prévia declaração de que a violação de fato houve (cf. Instituciones..., v. 1, n. 15, p. 141). Como afirma Barbosa Moreira, tratando da sentença condenatória e da declaratória, "a declaração do direito litigioso é o traço comum a ambas as classes de sentenças". Posteriormente, diz que também a sentença constitutiva possui dois elementos: um declaratório, outro propriamente constitutivo ("Reflexões críticas....", pp. 72 e 78). Flávio Yarshell aponta que o sentido etimológico da palavra jurisdição confirma que a função declaratória está presente em todas as modalidades de provimento cognitivo (cf. Tutela jurisdicional, p. 152).

332 Ordinariamente, o objeto da demanda declaratória é uma relação jurídica (ou, mais propriamente, uma situação jurídica, como visto). Exclui-se do alcance da tutela declaratória os fatos que não se revistam da forma de relação jurídica. Um simples fato, mesmo que juridicamente relevante, não pode ser objeto de uma demanda declaratória (cf. Chiovenda, "Azione di mero accertamento", p. 72; e Buzaid, A ação declaratória..., p. 97). Contudo, no sistema do Código de Processo Civil vigente pode haver pronúncia judicial sobre a existência ou inexistência de meros fatos. Trata-se da declaração sobre a autenticidade ou a falsidade de um documento (CPC, art. $4^{\circ}$ ) (cf. Buzaid, A ação declaratória..., p. 73). A título de curiosidade, registre-se que, ao contrário de ordenamentos como o brasileiro (CPC, art. $4^{\circ}$ ) ou o alemão (ZPO, § 256), o italiano não possui previsão genérica de ação declaratória. Há nele apenas ações declaratórias típicas, mas doutrina e jurisprudência mitigam o rigor legal e admitem a tutela declaratória atípica (cf. Andrea Proto Pisani, Lezioni..., pp. 133/134; Comoglio-Ferri-Taruffo, Lezioni..., p. 651; e Flávio Yarshell, Tutela jurisdicional, p. 153, nota 52).
} 
A tutela declaratória exaure-se com o pronunciamento judicial. Ao contrário da tutela condenatória, ela não exige cumprimento espontâneo ou prática de atos de invasão patrimonial para que se efetive. É tutela com alto grau de efetividade, já que prescinde de providências ulteriores para que seja assegurada a satisfação da pretensão reclamada e reconhecida no provimento. ${ }^{333}$ Se além da declaração pretende a satisfação do direito que o provimento tornou certo, o autor terá que se valer de nova demanda, com pedido condenatório. Mas essa é outra questão. Na premissa de que o objeto da demanda declaratória é apenas a obtenção da certeza jurídica - como reconhecido pela doutrina clássica $^{334}$ - e que o autor da demanda entende que a certeza lhe bastará, é inegável que esse bem jurídico seja fornecido apenas pelo provimento.

A tutela meramente declaratória, portanto, é caracterizada por estruturalmente contar apenas com a declaração da regra jurídica concreta.

\subsubsection{Tutela constitutiva}

Quando se pleiteia constituição, modificação ou extinção de uma situação jurídica, o que se está pedindo é tutela constitutiva. ${ }^{335}$ À declaração da regra jurídica concreta, inerente a todos os provimentos de conhecimento, o provimento constitutivo acrescenta a alteração da situação jurídica preexistente. Por isso é que se afirmou ser clara a diferença entre o provimento meramente declaratório e o constitutivo: enquanto aquele mantém o estado de direito existente, limitando-se a constatar a existência de algo que lhe é anterior, no provimento constitutivo a alteração decorre da intervenção do juiz. ${ }^{336}$ Enquanto nas tutelas declaratória e condenatória o que se quer sanar são, respectivamente,

\footnotetext{
${ }^{333}$ Diz Andrea Proto Pisani que a necessidade de tutela jurisdicional é satisfeita unicamente mediante a imutabilidade do acertamento contido no provimento (cf. "Appunti sulla tutela di mero accertamento", p. 621), mesma razão pela qual José Roberto dos Santos Bedaque afirmou que em termos de efetividade do processo a tutela declaratória "é plena" (cf. Direito e processo, p. 42).

${ }^{334}$ Cf. Celso Agrícola Barbi, Comentários..., v. 1, t. 1, p. 68; e João Batista Lopes, Ação declaratória, n. 3.8, p. 93, embora pensemos haver fortes razões para se questionar isso.

${ }^{335}$ A observação é de Ilaria Pagni, que indica farta bibliografia sobre o assunto nas doutrinas alemã e italiana (cf. Le azioni..., cap. I, n. 1, pp. 1/2 e nota 1). Exemplo de tutela constitutiva é a prestada na ação rescisória julgada procedente, pois esta desconstitui a sentença viciada (cf. Luis Eulálio de Bueno Vidigal, Comentários ao Código de Processo Civil, v. VI, n. 29, p. 39). Veja-se, também, Câmara Leal, que inclusive disse ter defendido ser prescricional o aludido prazo e posteriormento ter chegado à conclusão oposta (cf. $D a$ prescrição e da decadência, n. 315, p. 392).

${ }^{336}$ Cf. Ilaria Pagni, Le azioni..., cap. I, n. 1, p. 2.
} 
crises de certeza e de adimplemento, aqui o que se procura debelar é uma crise de situação jurídica. $^{337}$

\section{É impossível falar em tutela constitutiva sem tratar dos chamados direitos} potestativos. Categoria de direitos concebida pela doutrina alemã do final do século $\mathrm{XIX},{ }^{338}$ agrega direitos subjetivos que prescindem de dever correspondente para que sejam fruídos. Ao contrário de direitos prestativos (pessoais e reais), que conduzem a uma prestação de outrem, os direitos potestativos dispensam conduta alheia para que sejam efetivados. São situações jurídicas subjetivas de vantagem que têm por conteúdo o poder de produzir, unilateralmente, mediante simples manifestação de vontade de seu titular ou verificação do órgão jurisdicional, uma modificação jurídica na esfera de outrem sem que este possa se insurgir contra isso. O exercício desses direitos não visa ao cumprimento de um dever. ${ }^{339}$ Daí por que os terceiros encontram-se em estado de sujeição em relação ao titular do direito. ${ }^{340}$

${ }^{337}$ A expresssão é de Dinamarco (cf. Instituições..., I, p. 155).
${ }^{338}$ Embora a primeira referência à sentença constitutiva tenha constado de uma obra de Wach de 1885
chamada Handbuch des deutschen Civilprozessrecht (cf. Stefano Villata, Impugnazioni..., p. 268), Rocco
afirma que o mérito de haver elaborado uma construção clara e precisa dessa categoria de sentença foi de
Hellwig (cf. La sentencia..., n. 54, p. 207). Agnelo Amorim Filho também atribuiu à doutrina alemã de fins
do século XIX a gênese da noção de direito potestativo (Hasse, Bekker, Zitelmann, Thon, Seckel e Hellwig),
afirmando ser de Chiovenda, contudo, a criação da locução direito potestativo (cf. "As ações constitutivas...", pp. 23/24). Nesse sentido, Corrado Ferri, Profili dell'accertamento costitutivo, n. 1, pp. 4 e 7.

${ }^{339}$ Cf. Chiovenda, "L'azione nel sistema dei diritti", in Saggi di diritto processuale civile, t. I, p. 21; Luis Eulalio de Bueno Vidigal, Da execução direta das obrigações de prestar declaração de vontade, p. 86; Stefano Villata, Impugnazioni..., p. 268; e Guilherme Setoguti J. Pereira, "Cumprimento de acordo de acionistas...", p. 277. Por isso disse Agnelo Amorim Filho que "a principal característica dos direitos potestativos - e que os distingue substancialmente dos direitos de prestação (os pessoais e os reais) - é o seu completo desvinculamento da noção de dever". Como exemplo de direitos potestativos esse autor cita os direitos "exercitáveis por meio das denominadas 'ações de estado'; direito de anular o casamento: direito que tem o cônjuge de promover o desquite; direito de promover a interdição de determinadas pessoas; direito que tem o marido de contestar a legitimidade do filho nascido de sua mulher etc." e "o direito que tem o mandante de revogar o mandato; o direito que tem cada contratante de rescindir o contrato nos casos previstos em lei; o direito de escolha nas obrigações alternativas e nas obrigações de dar coisa incerta; o direito de dissolver a sociedade por tempo indeterminado; o direito de alegar as exceções substanciais (compensação, retenção, prescrição, anulação, inadimpleti contractus); o direito de dar vida a um contrato mediante a aceitação da oferta; o direito de promover a rescisão das sentenças transitadas em julgado; o direito que tem o filho de desobrigar os imóveis de sua propriedade alienados ou gravados pelo pai fora dos casos permitidos em lei" etc. (cf. "As ações constitutivas...", pp. 24/26). Corrado Ferri, por sua vez, afirmou que o direito à anulação da deliberação assemblear é potestativo ("Le impugnazioni...", p. 58). Segundo Eros Grau, seria também potestativo o poder de controle (cf. "Parecer - acordo de acionistas", in Direito público: Revista da Procuradoria Geral do Estado de Minas, v. 1, n. 2, 2009, p. 61).

${ }^{340}$ Essa a razão pela qual Chiovenda afirmou que "il lato praticamente importante di queste figure giuridiche, è la soggezione delle persone di fronte a cui il potere spetta: la soggezione della loro volontà, in quanto non può volere che l'effetto non si produca". Ainda de acordo com esse autor, o direito de ação é o direito potestativo por excelência (cf. "L'azione...", p. 21). Isso foi apontado por Tomás Pará Filho, que ensinou que a "potestatividade" do direito de ação resulta de que a lei condiciona a atuação da ação apenas à vontade do 
Quando houver resistência ao reconhecimento do direito potestativo - o que não é incongruente com a assertiva de que tais direitos prescindem de prestação - ou quando o ordenamento vedar a atuação espontânea daquele, será necessário recorrer ao Estado, que, na defesa dessa classe de direitos, deverá ofertar tutela constitutiva. ${ }^{341-342}$

Em lição clássica, Chiovenda defendeu que essa categoria de provimentos atua por meio da certificação de direitos potestativos, dos quais decorreriam os tais efeitos jurídicos. O direito que ampara a mudança preexistiria ao provimento e este viria apenas para certificá-lo, declarando-o como existente. O próprio direito é que promoveria a alteração na ordem jurídica. A função exercida pelo julgador seria a mesma exercida na tutela meramente declaratória, ${ }^{343}$ e o que as distinguiria seria apenas o direito objeto do provimento, que da tutela constitutiva seria um direito potestativo. Nesse pensamento, o

particular, independendo de obrigação ou consentimento do adversário (cf. Estudo sobre..., p. 80). Nesse sentido, também Arruda Alvim, Manual..., n. 119, p. 398.

${ }^{341}$ Cf. José Roberto dos Santos Bedaque, Efetividade..., p. 534. Analisando a questão sobre haver na origem da tutela constitutiva um direito potestativo ou um poder substancial, v. Corrado Ferri, Profili..., cap. I, n. 2, pp. 13/14. Criticando o atrelamento entre direito potestativo e tutela constitutiva, v. Adolfo di Majo, La tutela civile dei diritti, v. 3, cap. IV, n. 1, pp. 339/343.

${ }^{342}$ Disso decorre a distinção entre tutela constitutiva não necessária (a modificação jurídica é passível de ser obtida pela via extrajudicial, mediante manifestação de vontade do sujeito, sendo necessário o provimento apenas em caso de não reconhecimento por outros sujeitos envolvidos) e tutela constitutiva necessária (a modificação jurídica só ocorre mediante atuação judicial) (cf. Ilaria Pagni, Le azioni..., cap. I, n. 1, p. 3). De acordo com essa autora, as demandas que impugnam negócios jurídicos são demandas necessárias apenas quando não há cooperação dos demais sujeitos envolvidos em promover a modificação jurídica pretendida ou quando, em algumas hipóteses excepcionais (desconstituição de casamento, por exemplo), a lei exige a pronúncia judicial (p. 5). Assim, embora possam as partes promover a modificação do ato jurídico negocial sem intervenção judicial (tutela constitutiva não necessária), havendo resistência referida tutela transmuda-se em necessária. Devem ser distinguidas duas hipóteses de exercício dos direitos potestativos, portanto. A primeira é aquela na qual os direitos podem ser exercidos extrajudicialmente, mas, não havendo acordo entre os interessados, deve-se recorrer à via judicial (caráter subsidiário da jurisdição). É o caso, por exemplo, da cláusula resolutória de contrato, do direito de condômino de dividir a coisa comum, do direito de sócio promover a dissolução litigiosa da sociedade etc.: a alteração na ordem jurídica se dá por meio de simples declaração de vontade do titular do direito. A segunda é aquela em que o direito potestativo só pode ser exercitado mediante ação, ou seja, por meio de provimento que certifique a existência do direito potestativo à modificação jurídica. Nesse caso, fala-se em ações constitutivas necessárias (cf. Chiovenda, "L'azione...", p. 24; Tomás Pará Filho, Estudo sobre..., pp. 40 e 81; e Stefano Villata, Impugnazioni..., p. 269). Agnelo Amorim Filho acresce a essa classificação ainda duas categorias: direitos potestativos exercitáveis mediante exceção substancial (direito de compensar a dívida, direito de retenção, direito de obter a pronúncia da prescrição etc.) e direitos potestativos que não comportam em hipótese algum exercício pela via judicial, só podendo ser exercido mediante ato jurídico unilateral seu (direito de revogar o mandato, direito de escolha nas obrigações alternativas, direito de arrependimento contratual" etc. (cf. "As ações constitutivas...", pp. $30 / 31)$.

343 "Também aquelas são sentenças, como as demais, declarativas; sua particularidade depende exclusivamente da natureza especial do direito que the constitui o objeto" (cf. Chiovenda, Instituições..., v. I, n. 51, p. 195). Ainda, v. Chiovenda, "Azioni e sentenze di mero accertamento", p. 20; e Principii di diritto processuale civile, p. 182. Analisando a teoria chiovendiana, v. Corrado Ferri, Profili..., cap. I, n. 1, pp. 7/8. 
provimento tem como pressuposto o direito à situação jurídica nova (direito potestativo) e, de outro lado, é a própria causa da novidade jurídica. Daí se ter dito que a sentença constitutiva se situa entre o direito potestativo, do qual depende, e a situação jurídica nova, da qual atua como causa eficiente. ${ }^{344}$ A tutela constitutiva, assim, atuaria certificando a existência de um direito postestativo e a mutação jurídica derivaria não do plano processual, mas sim do próprio direito material reconhecido judicialmente. A alteração jurídica viria ope legis, por meio do direito potestativo reconhecido. ${ }^{345} \mathrm{O}$ provimento é pressuposto da modificação - pois o direito precisa ser reconhecido -, mas a causa da modificação é o próprio direito. ${ }^{346}$

O provimento constitutivo, logo, possuiria a mesma estrutura processual do meramente declaratório. ${ }^{347}$ Não é difícil compreender, pois, porque parte da doutrina italiana emprega a expressão accertamento costitutivo (declaração constitutiva) para designar essa modalidade de provimento.

Opondo-se a essa ideia, Liebman negou que a atividade do juiz na tutela constitutiva seja a mesma realizada na meramente declaratória - ou, de acordo com a posição por nós defendida, que a estrutura processual do provimento constitutivo seja a mesma do meramente declaratório. ${ }^{348}$ De acordo com o mestre, a alteração jurídica deriva não do direito declarado, mas sim da própria decisão judicial. Melhor explicando, Liebman desenvolveu a noção chiovendiana de provimento constitutivo e defendeu que este é

\footnotetext{
${ }^{344}$ Cf. Cândido Dinamarco, "Momento de eficácia...", n. 533, p. 958.

${ }^{345}$ Seriam sentenças "nas quais essa eficácia constitutiva depende do próprio direito que elas declaram" (cf. Chiovenda, Instituições..., v. I, n. 51, p. 194). Em sentido similar, Stefano Villata, Impugnazioni..., p. 270 e nota 11. Cintra-Grinover-Dinamarco parecem concordar com essa posição ao afirmarem que o provimento constitutivo na realidade apenas declara o direito preexistente, emanando desse direito declarado os efeitos constitutivos, já previstos na norma geral e abstrata (cf. Teoria geral..., n. 196, p. 313.). Igualmente digna de nota é a posição de Alfredo Rocco, que embora negue veementemente a categoria dos direitos potestativos, afirma que a decisão constitutiva é uma espécie de decisão meramente declaratória que se distingue das demais espécies apenas em decorrência de seu objeto (cf. La sentencia..., nn. 58 e 63, pp. 217 e 236).

${ }^{346}$ Embora tenha se oposto à categoria chiovendiana de direitos potestativos, Carnelutti acabou por integrar a mesma corrente que Chiovenda (cf. Instituciones..., n. 34, pp. 71/72). Daí ter Tomás Pará Filho dito que, "por vias diferentes, Chiovenda e Carnelutti chegam ao mesmo resultado", pois "ambas as concepções ressaltam que o efeito constitutivo é independente da vontade do juiz, o qual apenas verifica os pressupostos necessários, segundo a lei, para o reconhecimento do efeito alterativo. Mas, acrescentam, a sentença é, nesses casos, e isso também por força de lei, pressuposto da própria inovação, eis quem sem ela, o efeito alterativo não se poderá projetar, validamente" (cf. Estudo sobre..., pp. 88/89).

${ }^{347}$ Cf. Ferruccio Tommaseo, I provvedimenti d'urgenza - struttura i limiti della tutela anticipatoria, p. 262.

${ }^{348}$ De acordo com o processualista italiano, a lei é que dirá se os efeitos constitutivos decorrem do ato da parte ou do acertamento constitutivo. Na ausência de lei atribuindo eficácia constitutiva ao ato da parte, não se pode defender tal posição (cf. Profili..., cap. I, pp. 67/69).
} 
estruturado em dois bem definidos momentos lógicos: declaração e modificação de situações jurídicas. ${ }^{349}$ Ao invés de conter apenas o momento declarativo, como entendia Chiovenda, o provimento constitutivo ostentaria uma estrutura mista, marcada por aqueles dois bem definidos momentos lógicos. Pretende-se, em um primeiro momento, a certificação do direito à modificação jurídica por ele alegado - como em toda demanda de conhecimento. Por isso, quer no provimento de procedência, quer no de improcedência, haverá eficácia declaratória: no primeiro caso, o direito do autor é declarado como existente; no segundo, como inexistente. ${ }^{350}$ No momento seguinte, caso o direito alegado tenha sido reconhecido, ele é satisfeito mediante alteração da preexistente situação jurídica substancial. É esse segundo elemento que caracteriza a tutela constitutiva, estruturada de modo a corresponder a esses dois momentos. A produção dos efeitos que alterarão o estado anterior ou criarão o novo estado decorre do provimento judicial. ${ }^{351}$ É ele, provimento, que atua como causa da modificação jurídica; ${ }^{352}$ os efeitos constitutivos decorrem da sentença. Assim, antes de uma negação da teoria chiovendiana, a ideia de Liebman representa o desenvolvimento daquela.

E, de fato, parece estar com a razão Liebman. A vingar a ideia chiovendiana, a tutela constitutiva não seria autônoma em relação à tutela declaratória, pois ambas possuiriam a mesma estrutura processual: mera declaração de direitos. Elas não se

\footnotetext{
${ }^{349}$ Assim, "é necessário admitir na sentença constitutiva, unidas no mesmo ato, uma declaração e, conjuntamente, uma atividade tendente a produzir mudança na situação jurídica deduzida em juízo" (cf. "Eficácia e autoridade...", n. 6, p. 29). Também repudiando a doutrina chiovendiana sobre o provimento constitutivo, Tomás Pará Filho defendeu que "na sentença constitutiva, outro é o conteúdo, porque ela realiza, por si mesma, a constituição, modificação ou extinção de uma relação ou estado jurídico. (...) $\mathrm{O}$ conteúdo da sentença constitutiva, conforme Goldschmidt, assim se pode decompor: a) - uma declaração de existir o direito à ação constitutiva (direito de exigir a constituição judicial de uma situação jurídica); b) - um ato constitutivo de caráter judicial, com força de coisa julgada formal, isto é, de um ato pelo qual se constitui, modifica ou extingue uma relação de direito" (cf. Estudo sobre..., p. 29). Citando Calamandrei, Barbosa Moreira também rejeita a ideia de que a sentença constitutiva não faria nada diferente do que declarar o direito à modificação jurídica (cf. "Reflexões críticas...", n. 7, p. 78, nota 20). Embora utilize a nomenclatura "processo de declaração de certeza constitutiva" para designar o processo em que se confere a tutela constitutiva, Carnelutti também entende que nessa modalidade de tutela o provimento atua como causa da modificação jurídica, em oposição à tutela declaratória, que, de acordo com ele, se caracterizaria justamente porque em nada altera a situação anterior (cf. Instituciones..., v. 1, n. 34, p. 71).

${ }^{350}$ Cf. Edoardo Ricci, "Gli effetti delle sentenze sulle impugnazioni di deliberazioni assembleari", in Processo civile e società commerciali, p. 16; e Ricardo Arcoverde Credie, Adjudicação compulsória, p. 22.

${ }^{351}$ Cf. Buzaid, A ação declaratória..., p. 88.

352 "Portanto, mais uma vez se verifica ser o próprio ordenamento jurídico a condicionar o advento de um determinado efeito jurídico à sentença. $\mathrm{O}$ efeito não existia antes da norma, mas estava nela previsto; em outras palavras, não é a sentença que cria o direito, pois se limita a declarar o direito preexistente, do qual derivam efeitos constitutivos, previstos no ordenamento jurídico" (Cf. Cintra-Grinover-Dinamarco, Teoria geral..., p. 313).
} 
diferenciariam nem por conta de seus efeitos, uma vez que a mudança jurídica, na teoria de Chiovenda, adviria do plano do direito material, e não da decisão.

É correto, por isso, o pensamento de que a tutela constitutiva caracteriza-se por estar estruturada em dois momentos lógicos bem definidos: declaração do direito à modificação jurídico-substancial e efetivação de tal modificação. ${ }^{353}$ Por essa mesma razão, aliás, que Betti disse que a sentença que anula um ato jurídico tem eficácia declaratória e constitutiva. ${ }^{354}$ É verdade que, ao transformar o mundo jurídico com a emissão do provimento, o juiz deve atender aos pressupostos do direito material. Mas a sentença é que realiza a mutação. ${ }^{355}$

Tais efeitos modificativos operam diretamente no mundo jurídico, e não no dos fatos, como ocorre com a tutela condenatória, que exige a prática de atos materiais para que se produzam os efeitos do direito certificado. Por serem fenômenos exclusivamente jurídicos, a alteração, criação ou extinção de direitos ocorrem por meio do próprio provimento, sem a necessidade da prática de atos incidentes sobre a realidade fática. ${ }^{356}$ Não sendo necessária a execução do direito reconhecido, a tutela constitutiva aproxima-se

\footnotetext{
${ }^{353}$ Além dos pensamentos representados por Chiovenda e Liebman, Tomás Pará Filho alude ainda a duas outras correntes. De acordo com ele, haveria quatro correntes sobre a tutela constitutiva: "a) - doutrinas que vêm, nesse tipo de provimento, efeito inovativo ou constitutivo, decorrente da própria força da lei material; b) - doutrinas para as quais a sentença constitutiva não se reduz à declaração dos pressupostos da mudança jurídica, pois a realização da mudança, em si mesma, é o seu característico fundamental; c) - doutrinas que vêm na sentença constitutiva duplo conteúdo, isto é, nela exergam tanto a declaração de uma situação preexistente como a produção do efeito inovativo; e d) - doutrinas que negam autonomia à sentença constitutiva" (cf. Estudo sobre..., cap. VII, n. 2, p. 77). Para uma análise das várias teorias sobre o provimento constitutivo, consulte-se a obra de Pará Filho, seguramente a mais completa e profunda sobre o tema na doutrina nacional. A corrente a que se filia Chiovenda é a representada pela letra "a" e a que se filia Liebman a representada pela letra "c". Dentre os integrantes da corrente representada pela letra "b" pode ser citado Satta (cf. Direito processual..., n. 147, p. 278), e da corrrente representada pela letra "d", Alfredo Rocco (cf. La sentencia..., n. 55, p. 210). Segundo este último, pelos mesmos motivos que "hemos rechazado por su impropiedad técnica el concepto de una categoria de derechos, consistente en la pura facultad de producir un efecto jurídico (derechos del poder judicial o derechos potestativos), rechazamos también por improprio e infructuoso el concepto de una categoria de sentencias, cuya función no consiste en la declaración del derecho, sino en el cambio de las relaciones jurídicas existentes (sentencias constitutivas)" (n. 55, pp. 209/219). Embora Rocco negasse a autonomia da tutela constitutiva e, portanto, possa ser enquadrado na quarta categoria referida por Pará Filho, na verdade pode, de certa forma, ser reconduzido à ideia chiovendiana de que a sentença constitutiva possui a mesma estrutura que a declaratória, pois limitar-se-ia a declarar um direito preexistente: "No es, pues, a la sentencia a lo que en estos casos se refiere el nacimiento de la relación o del conjunto de relaciones jurídica; éstas preexistían ya, si bien latentes, ya la sentencia, aun en este caso, no llena más función que la simplesmente declarativa” (n. 55, pp. 211/212). A diferença para o pensamento de Chiovenda é que Rocco, sob o argumento de que o efeito constitutivo deriva do direito, e não da sua declaração judicial, nega completamente autonomia ao provimento declaratório.

${ }^{354}$ Cf. Trattato dei limiti soggettivi della cosa giudicata in diritto romano, cap. II, n. 3-D, pp. 285/286.

${ }^{355}$ Cf. Arruda Alvim, Manual..., n. 301, pp. 1.089/1.090.

${ }^{356}$ Cf. Fredie Didier, Curso..., v. 1, n. 5.4.2, p. 204.
} 
da meramente declaratória e distancia-se da condenatória, na qual a realização do direito certificado depende da vontade do devedor ou da execução forçada. Daí se dizer serem aquelas auto-satisfativas: por si só atendem à pretensão do demandante e extirpam a crise jurídica que instaurou o litígio. ${ }^{357}$ Como bem anotou Dinamarco, o objeto litigioso do processo em demanda que persegue essa classe de provimento esgota-se na própria modificação jurídica, a qual independe de ulterior conduta do réu. ${ }^{358}$

Já se reconheceu, por essa razão, certo caráter executivo no provimento constitutivo, com base na ideia de que ele possuiria os resultados da soma de cognição $e$ execução ${ }^{359}$ - embora essa execução ocorra apenas no mundo jurídico, sem a prática de atos materiais, como ocorre com a execução forçada. ${ }^{360} \mathrm{Em}$ certos casos, são necessários

${ }^{357}$ Cf. Chiovenda, "Azione di mero accertamento”, p. 65; Ferri-Comoglio-Taruffo, Lezioni, p. 654; Tomás Pará Filho, Estudo sobre..., p. 29; Eduardo Talamini, Tutela relativa..., n. 6.1, p. 187; Cândido Dinamarco, Instituições..., v. 1, n. 58, p. 155; e Flávio Yarshell, "Antecipação de tutela...", in Teresa Arruda Alvim Wambier (coord.), Aspectos polêmicos da antecipação de tutela, n. 3, p. 176. De modo geral, costuma-se dizer que a auto-satisfatividade é comum apenas ao provimento constitutivo. Acontece que esse entendimento aplica-se também ao provimento declaratório, que, como visto, é igualmente modalidade de tutela auto-satisfativa, já que o bem perseguido em uma demanda declaratória é a certeza jurídica e esta se produz única e diretamente por meio do pronunciamento jurisdicional. Nesse sentido, Barbosa Moreira apontou que "o que existe de comum a ambas as classes é a circunstância de que não lhes sobrevive qualquer necessidade de determinado comportamento, por parte do vencido, para a satisfação do vencedor" (cf. "Tendências na execução de sentenças e ordens judiciais", in Temas de direito processual, $4^{\mathrm{a}}$ série, n. 2, p. 217). Flávio Yarshell chega a conclusão semelhante, diferenciando declaração positiva e declaração negativa: "Quando se presta simplesmente a estabelecer certeza sobre a existência de uma relação jurídica de que resulte uma prestação (fazer, não-fazer ou dar) - tutela positiva -, de fato, a tutela meramente declaratória distancia-se daquela aludida 'auto-suficiência' da tutela constitutiva e o respectivo grau de efetividade reduzse substancialmente. Mas, quando dita tutela estabelece certeza sobre a inexistência de uma relação jurídica tutela negativa -, o grau de efetividade atingido aumenta substancialmente, de sorte a dispensar nova atuação jurisdicional" (cf. "Tutela jurisdicional meramente declaratória", n. 4, pp. 51/52). Em decorrência dessa oposição entre, de um lado, provimento condenatório, e, de outro, provimentos constitutivo e meramente declaratório, é que Marcelo Lima Guerra classificou as sentenças em auto-suficientes (meramente declaratória e constitutiva) e instrumentais (condenatória) (cf. Direitos fundamentais e a proteção do credor na execução civil, n. 1.3, p. 27).

${ }^{358}$ Cf. "Momento de eficácia...", n. 533, p. 959.

${ }^{359}$ Cf. Tomás Pará Filho, Estudo sobre..., pp. 67/68. De acordo com o citado autor, o segundo momento lógico da sentença constitutiva, consistente na constituição propriamente dita, "em sentido lato, é atividade executória". Melhor explicando: "Pode-se afirmar que a sentença constitutiva, realizando o seu próprio comando, isto é, exaurindo aquilo que dispôs, é, em sentido genérico, ato executório. Não se trata, porém, de execução forçada, senão de executividade de índole especial, entranhada na própria sentença, e que, projetando os seus efeitos, dá ao provimento caráter constitutivo" (cf. Estudo sobre..., p. 70). Andrea Proto Pisani também apontou que alguns provimentos constitutivos (que suprem manifestações de vontade) possuem estrutura cognitiva mas funções cognitiva e executiva (cf. "Appunti sulla tutela c.d. costitutiva...", pp. 87/88).

${ }^{360}$ Cf. Flávio Yarshell, Tutela jurisdicional específica..., n. 2.3, p. 27 e “Antecipação de tutela...”, n, 4, p. 176; e Dinamarco, "Momento de eficácia...", n. 533, p. 961. Este último, contudo, esclarece que "não é lícito afirmar sem ressalvas esse caráter executivo das sentenças condenatórias [rectius: constitutivas], pois isso teria o mal de estabelecer mal-entendidos terminológicos em uma ciência que pretende ser precisa em seus conceitos". Como exemplo de autores que entreveram na sentença constitutiva típico ato de execução, podem ser citados Calamandrei e Luis Eulálio de Bueno Vidigal (cf. Bueno Vidigal, Da execução direta..., n. 70). 
atos formais para que os provimentos constitutivos e declaratórios operem-se, como é o caso, por exemplo, da averbação no registro público da sentença translativa da propriedade imóvel ou da sentença de anulação do casamento. Mas essas medidas - achamadas de execução imprópria ${ }^{361}$ - não podem ser consideradas atos de execução no sentido clássico de execução forçada e, portanto, não afastam essas considerações.

\subsubsection{Tutela condenatória}

A tutela condenatória é, em regra, o meio de efetivação de norma que impõe a alguém uma prestação (direito prestativo). ${ }^{362}$ Daí se afirmar que com essa classe de tutela procura-se sanar uma crise de adimplemento. Aqui também o acolhimento do pedido passa pela declaração de existência do direito alegado pelo autor, de modo que também essa modalidade de tutela é preliminarmente declaratória. ${ }^{363}$

De acordo com Liebman, a sentença condenatória declara a existência do direito e a sua violação - até aqui, função unicamente declaratória - e, na etapa seguinte, acrescenta uma sanção em decorrência da inobservância da norma geral e abstrata. O caráter distintivo desse provimento seria o plus representado pela possibilidade de acesso à via processual da execução forçada, na hipótese de não haver cumprimento espontâneo da regra certificada na decisão. O elemento diferenciador da decisão condenatória seria, pois, a imposição de uma sanção prevista pela lei para o ato ilícito praticado pelo réu: sujeição do devedor às medidas executivas previstas em lei. ${ }^{364} \mathrm{~A}$ sentença condenatória, assim,

\footnotetext{
${ }^{361}$ Cf. Dinamarco, Execução civil, n. 54, p. 102.

${ }^{362}$ Disso resulta a afirmação de que "correlativo ao conceito de condenação é o conceito de prestação" (cf. Chiovenda, Instituições..., v. 1, n. 43, p. 184). Chiovenda, aliás, dividiu os direitos prestativos em, de um lado, absolutos (dirigem mandamentos legais de fazer ou não fazer a toda a coletividade; por exemplo: propriedade, servidão, direitos da personalidade etc.) e relativos (apenas determinadas pessoas figuram como obrigadas; por exemplo, direitos obrigacionais), e, de outro, em reais (direitos absolutos que garantem o gozo de coisa exterior e que, por isso, podem ser atribuídos a uma e a outras pessoas, bem como serem transferidos entre elas; exemplo: propriedade) e pessoais (derivam desde sua origem entre duas ou mais pessoas determinadas, obrigadas a uma determinada prestação; exemplo: mandato) (cf. Instituições..., v. I, n. 4, pp. 11 a 13). Ainda, v., Fredie Didier Jr., Curso..., v. 1, n. 5.4.1, p. 200, relacionando os direitos prestativos à tutela condenatória, mandamental e executiva lato sensu.

${ }^{363}$ Cf. Chiovenda, “Azioni e sentenze...", p. 21.

${ }^{364}$ Cf. Manual..., v. 1, n. 84, p. 237. De acordo com o processualista peninsular, "a atividade desenvolvida pelos órgãos judiciários para dar atuação à sanção recebe o nome de execução" e "a execução consiste na realização de certas medidas que em conjunto representam a sanção para a falta de observância do direito material" (cf. Processo de execução, nn. 2 e 7, pp. 4 e 17/18). De forma similar, Cintra-Grinover-Dinamarco conceituam sanção como a possibilidade de "acesso à via processual da execução forçada" (cf. Teoria geral..., n. 195, p. 312).
} 
possuiria duplicidade de elementos e de funções: declaração do direito existente e aplicação da sanção, pela qual concretizaria as forças repressoras que se encontravam latentes na ordem jurídica. ${ }^{365}$

Embora prevalente na doutrina brasileira, ${ }^{366}$ essa doutrina não ficou imune a críticas.

Barbosa Moreira criticou o atrelamento lógico feito por Liebman entre condenação e sanção, partindo da premissa de que o processualista italiano teria defendido que só haveria sentença condenatória quando houvesse sanção e que, por outro lado, sempre que houvesse sanção haveria condenação. Para aquele, seria possível haver condenação, com efeito executório, sem que houvesse comportamento antijurídico - ou seja, condenação sem ilicitude. ${ }^{367}$ De fato, adotado conceito amplo de sanção como consequência prevista para a inobservância de um preceito, a observação parece correta. Mas não foi esse o significado empregado por Liebman: para ele, sanção é, especificamente no campo da tutela condenatória, a autorização de submeter-se o devedor às medidas executivas previstas em lei. É o que possibilita a instauração de execução. Embora em algumas passagens de sua obra Liebman tenha nomeado sanção como as próprias medidas executivas, parece-nos que aquele primeiro conceito é que é o mais adequado à sua teoria: a sanção possibilita a instauração das medidas executivas, não se confundindo com estas. ${ }^{368}$

${ }^{365}$ Cf. Flávio Yarshell, Tutela jurisdicional específica..., p. 23. O seguinte trecho da obra de Liebman é bastante elucidativo: "as regras sancionadoras abstratas, quer expressas (como as do direito penal), quer latentes na estrutura orgânica da ordem jurídica (como as que prescrevem a execução civil para o caso de falta do cumprimento da obrigação), não se tornam automaticamente concretas pela simples ocorrência de ato ilícito. Seja este um crime ou um ilícito civil, o autor do fato não é só por isso submetido à atuação da sanção: esta deve ser-lhe aplicada, imposta, determinada para o caso concreto que lhe foi imputado. A condenação representa exatamente o ato do juiz que transforma a regra sancionadora de abstrata e latente em concreta, viva, eficiente. Em outras palavras, a condenação é o ato que o transgressor deverá sofrer pelo ato cometido" (cf. Processo de execução, n. 7, p. 18). Para uma explicação da teoria de Liebman sobre a mecânica pela qual atuam as sanções cominadas pelo ordenamento contra os atos desconformes às suas prescrições, v. Barbosa Moreira, "Reflexões críticas...", pp. 73/74.

${ }^{366}$ Cf. Frederico Marques, Manual..., v. I, n. 110, p. 208; Cintra-Grinover-Dinamarco, Teoria geral..., n. 195, p. 312; Arruda Alvim, Manual..., n. 302, p. 1.090; e Paulo Lucon, Eficácia das decisões..., n. 48, p. 158. Na doutrina italiana, Carnelutti também vinculou a tutela condenatória à aplicação de sanção, embora com algumas diferenças em relação a Liebman (cf. Instituciones..., v. 1, nn. 32 e 35, pp. 69 e 72).

${ }^{367}$ Cf. "Reflexões críticas...", n. 4, p. 74.

368 Parecem estar com a razão, nesse sentido, Cintra-Grinover-Dinamarco, ao afirmarem que a sanção "consiste em possibilitar o acesso à via processual da execução forçada" (cf. Teoria geral..., n. 195, p. 312). Ou seja, a sanção possibilita a execução, não se equivalendo a esta. O mesmo não parece entender Barbosa Moreira: "importa não confundir a atuação da sanção - que só no processo executório se consumará - com a 
É contraditório defender, aliás, que a sanção consista nas próprias medidas executivas, pois ela decorre de processo cognitivo-condenatório, distinto do processo de execução. Advogar a ideia de que a essa consista nas próprias atividades subrogatórias é defender que a execução está contida na cognição. A sanção enseja, possibilita, autoriza as atividades práticas satisfativas; com elas não se confunde.

Feito esse esclarecimento, logo se vê que a objeção levantada por Barbosa Moreira não se sustenta porque ele mesmo reconhece que em toda e qualquer condenação haverá sanção (no conceito de Liebman). O que Barbosa Moreira afirma poder não haver em determinados casos é ilicitude, isto é, comportamento antijurídico, dando como exemplo a condenação do litigante vencido ao pagamento das despesas processuais e dos honorários advocatícios. ${ }^{369}$ Mas, repita-se, sanção não se confunde com ilicitude; antes, guarda com esta relação de causa e efeito.

Adotado o conceito liebmaniano, é inegável que, na condenação ao pagamento das despesas processuais e dos honorários advocatícios da parte contrária, há aplicação de sanção à parte derrotada. Tanto é que, não havendo cumprimento espontâneo do vencido em pagar tais verbas, ele se sujeitará à execução direta. Quanto a não haver antijuridicidade, também discordamos de Barbosa Moreira. É verdade que, excluídas as hipóteses de abuso do processo, os atos de propor uma demanda ou de opor-se à pretensão nela contida não pode ser reputado ilícito, já que estão contidos nos poderes de ação e de

pronúncia judicial que constitui o título para a execução, e por conseguinte é pressuposto da sanção, mas ainda não é a sanção mesma (cf. "Reflexões críticas...", n. 6, p. 76). Na verdade, Barbosa Moreira faz essa distinção com base em frase de Liebman que afirma que sanção verdadeira é apenas a execução forçada ("sanzione vera e ultima può dirsi dunque solo l'esecuzione forzata"). Mas, como visto, Liebman ora conceitua sanção como o título da execução, isto é, como o que possibilita a execução, ora como o conjunto de medidas executivas. E, analisando sistematicamente a sua tese, parece-nos que o primeiro conceito é o que melhor se adapta ao seu entendimento. Exatamente nesse sentido é a seguinte passagem de Calamandrei, que comprova que também para ele sanção e execução não são a mesma coisa e que aquela na verdade apenas possibilita esta: "Esta ulterior actividad jurisdiccional, que debe seguir a la condena a fin de que la sanción individualizada en la decisión pueda ser prácticamente puesta en obra en el mundo sensible, es la ejecución forzada" (cf. Instituciones..., v. I, n. 20, p. 169). Em sentido contrário, v. Dinamarco, que também conceita a sanção liebmaniana como o "conjunto de atos de agressão patrimonial" (cf. Execução civil, n. 63, p. 115; e Instituições..., v. IV, n. 1.326, p. 31).

369 A seguinte passagem é cabal nesse sentido: "Ora, em mais de um caso se reconhece pacificamente a ocorrência de condenação, com o seu típico efeito executório, em decisões judiciais sem qualquer correspondência com atos ou comportamentos antijurídicos" (cf. "Reflexões críticas...", n. 4, p. 74). Ao tratar de típico efeito executório, o mestre carioca está a reconhecer que em toda e qualquer condenação haverá efeito executório e, portanto, sanção liebmaniana. A essa mesma conclusão sobre o equívoco conceitual de Barbosa Moreira chegou Flávio Yarshell (cf. Tutela jurisdicional específica..., n. 2.3, p. 24). 
defesa (CF, art. 5 $\left.5^{\circ}, \mathrm{XXXV}\right)$. Contudo, a condenação no pagamento daquelas verbas decorre da regra da causalidade e é imposta à parte que ou pediu algo a que não tinha direito ou se opôs a algo a que estava obrigada. Por serem antijurídicas, essas condutas devem ser apenadas. ${ }^{370}$ Daí porque na hipótese da condenação ao pagamento da sucumbência sempre haverá ilicitude e sanção.

Outro exemplo dado por Barbosa Moreira com o intuito de infirmar a tese de Liebman é o da condenação para o futuro, na qual o julgador, antes de vencida a obrigação, confere ao credor título executivo. ${ }^{371}$ Nessa hipótese, além das considerações feitas logo acima sobre a confusão feita por Barbosa Moreira acerca do conceito de sanção, cabe também ressaltar que há sim a imposição de sanção e o reconhecimento de conduta antijurídica, ainda que sujeitas ao implemento de condição. Tanto que, para o ajuizamento da demanda executiva, exige-se a comprovação de que a condição se aperfeiçoou (CPC, arts. 572 e 614, III), o que, no caso, é a demonstração de que o devedor não cumpriu a sua obrigação e, portanto, agiu ilicitamente.

Mesmo Liebman já havia reconhecido a possibilidade de excepcionalmente haver provimentos condenatórios sem a função declaratória - isto é, sem o acertamento da ilicitude do réu -, fornecendo o exemplo de condenação para o futuro, ${ }^{372}$ bem como entendido que não há declaração de inadimplemento na condenação da parte sucumbente ao pagamento das despesas judiciais e aos honorários advocatícios (isto é, que não há ato ilícito). ${ }^{373}$

Além de ser possível condenação sem sanção, Barbosa Moreira entende ser possível também sanção sem condenação, citando o exemplo dos atos jurídicos nulos ou anuláveis, para os quais o sistema atribuiria a sanção de ineficácia, sem que houvesse condenação, uma vez que a sentença que impõe essa sanção é declaratória ou constitutiva. $^{374}$ Aqui, mais uma vez, o eminente jurista carioca empregou conceito de

\footnotetext{
${ }^{370}$ Em sentido inverso, negando haver ilicitude, v. Dinamarco, Instituições..., v. III, n. 748, p. 666.

${ }^{371}$ Cf. "Reflexões críticas...", p. 75.

${ }^{372}$ Cf. Processo de execução, n. 7, p. 19.

${ }^{373}$ Cf. Manual... v. 1, n., 84, p. 239.

${ }^{374}$ Cf. "Reflexões críticas...", pp. 75/76.
} 
sanção diverso do de Liebman, pois na anulação de atos jurídicos não há aplicação de sanção com o sentido específico empregado na execução forçada. ${ }^{375}$

Barbosa Moreira critica a noção de Liebman, ainda, porque ela confundiria conteúdo com efeitos da sentença condenatória. A aplicação da sanção - isto é, a possibilidade de utilização dos meios executivos - seria um efeito da decisão condenatória, e não seria possível definir algo por elementos a ele exteriores, como seus efeitos. ${ }^{376}$ Essa crítica também não procede na medida em que a sanção consiste na autorização de utilização dos meios executórios, e não nos próprios meios executórios.

Enfim, em que pesem as judiciosas críticas de Barbosa Moreira, permanece válida a tese de que a tutela condenatória se diferencia pela imposição da sanção (ou seja, por seu conteúdo contar com a imposição de uma sanção). Dessa forma, a tutela condenatória tem por conteúdo a declaração da norma jurídica concreta e, na etapa seguinte, a imposição da sanção. Essa é a sua estrutura processual.

Mas o que é sanção?

Sanção é conceito equívoco ${ }^{377}$ e problemático. Basta ver as inúmeras objeções levantadas acima. Em nosso sentir, trata-se da autorização de utilização dos meios de exigência coativa do direito declarado ${ }^{378}$ Adotado esse conceito, não se tem mais o inconveniente de que a sanção seja associada ao ato ilícito, e tampouco o de atrelar-se a tutela condenatória apenas à execução direta. Passa-se a abarcar também a execução indireta (meios de pressão psicológica) e também as chamadas tutelas mandamental e executiva lato sensu (para aqueles que as admitem). A sanção executiva, portanto, autoriza a prática de atos de invasão patrimonial ou de pressão sobre a vontade do devedor.

\footnotetext{
${ }^{375}$ O que também foi notado por Flávio Yarshell (cf. Tutela jurisdicional específica..., n. 2.3, p. 24).

${ }^{376}$ Cf. "Reflexões críticas...", n. 8, p. 79.

377 A respeito, v. Calamandrei, Instituciones..., v. I, n. 13, p. 138.

${ }^{378}$ Embora não defenda essa mesma posição, Calamandrei aparentemente pensava de modo semelhante, ao conceituar execução como "empleo por parte del Estado de la fuerza física, para traducir en realidad el mandato declarado cierto por meio de la decisión” (cf. Instituciones..., v. I, n. 20, p. 169).
} 
Já se disse que, se o plus da sentença condenatória é a aplicação da sanção e se esta consiste em "declará-la aplicável”, o provimento condenatório e o meramente declaratório se equivaleriam. ${ }^{379}$ Duas objeções mostram que o raciocínio não está correto.

A primeira é a de que, mesmo firmada a premissa de que a decisão condenatória tem uma segunda etapa consistente na declaração de que a sanção é aplicável - do que discordamos -, apenas por isso ela seria diferente da meramente declaratória, pois esta possui somente a primeira etapa, consistente na declaração da regra jurídica concreta. ${ }^{380} \mathrm{~A}$ decisão condenatória possuiria duas declarações, uma seguida da outra, por relação de causa e efeito, e isso já seria suficiente para diferenciá-la daquela outra classe.

A segunda objeção é a de que, na realidade, a segunda etapa da decisão condenatória, que representa o seu elemento diferencial, consiste não na declaração de aplicabilidade da sanção, mas sim na constituição de uma situação jurídica, que autorizará a exigência do cumprimento coativo do direito. Por vedar a autotutela, o sistema exige que a conduta antijurídica seja judicialmente reconhecida e, consequentemente, aplicada a sanção correspondente, isto é, autorizado ao credor que pleiteie o cumprimento coativo do dever. Essa situação jurídica (poder de exigir que o Estado exija o cumprimento coativo do direito) não existia antes - ou estava latente, como disse Liebman. Por isso, esse segundo momento lógico é constitutivo. ${ }^{381} \mathrm{O}$ efeito é a nova situação jurídica: ela resulta do provimento. $\mathrm{O}$ conteúdo é a emissão desse efeito. ${ }^{382}$

\footnotetext{
379 'Aplicar a 'sanção' reduzir-se-ia, pois, na fórmula proposta, a 'declará-la aplicável', com a óbvia consequência de tornar indispensável a procura de outro critério para a diferenciação conceptual entre a sentença condenatória e a meramente declaratória" e "que restaria como conteúdo da sentença? Apenas a declaração de que a sanção é aplicável - declaração pura e simples, sem nenhuma diferença essencial em relação à do direito controvertido" (cf. Barbosa Moreira, "Reflexões críticas..., p. 77). Junior Alexandre Moreira Pinto também entende que Liebman teria defendido que aplicação da sanção se dá por meio de uma segunda declaração (cf. Conteúdo e efeitos..., n. 4.3, p. 167).

${ }^{380}$ De certa forma, nesse sentido é que Chiovenda disse que a diferença entre a decisão meramente declaratória e a condenatória é que nesta o acertamento possui duas funções, a de declarar a vontade concreta da lei e a de preparar a execução (cf. "Azione di mero accertamento", p. 64).

${ }^{381}$ Mesmo Liebman reconheceu expressamente que a função sancionadora é uma novidade produzida pela sentença condenatória (cf. Processo de execução..., n. 7, p. 18). A seguinte passagem é ainda mais clara: "do ponto de vista processual, a condenação é constitutiva da sujeição do devedor à execução e do correspondente poder conferido ao credor. Neste sentido, a sentença condenatória cria realmente qualquer coisa de novo, que antes não existia" (cf. "Execução e ação executiva", pp. 31/32). Embora chegue a conclusão diversa, Barbosa Moreira também enxergou esse aspecto constitutivo na sentença condenatória, afirmando, contudo, que a diferença entre o provimento condenatório e o constitutivo é que neste a mudança jurídica é satisfativa, por se exaurir na tutela jurisdicional outorgada, e naquele é instrumental, pois apenas concede ao vencedor o poder de executar o vencido. E, de acordo com tal autor, essa diferenciação se coloca na ordem de efeitos, e não do conteúdo (cf. "Reflexões críticas..., pp. 77/78). Dinamarco sustentou que, sob a
} 
O plus da sentença condenatória é possibilitar ao credor exigir coativamente o cumprimento do dever. O comando normativo já existe, mas como o Estado arroga para si o monopólio do uso da força é vedada a autotutela. Por isso, o jurisdicionado que entenda ter tido sua esfera jurídica violada recorre ao Estado para que lhe seja franqueado exigir coativamente o cumprimento das obrigações, pelos meios e nos limites previstos em lei. Esse conceito de sanção é menos polêmico do que o liebmaniano e não tem o inconveniente de estar ligado apenas à execução forçada.

A sentença condenatória, portanto, se analisada por sua estrutura, não deixa de ser constitutiva, pois o seu segundo momento lógico também consiste na constituição de uma nova situação jurídica. ${ }^{383}$

Outra questão controversa é aquela relativa à existência de ordem no provimento constitutivo. Nele não existe ordem para o devedor cumprir a obrigação na medida em que o mandamento - isto é, o dever de prestação - já existe na lei e o juiz nada mais faz do que declará-lo. A própria sentença meramente declaratória, ao declarar como existente uma relação jurídica, declara e formula uma regra jurídica concreta que, a depender da relação, exige delas o cumprimento de uma prestação. Toda sentença atua como ato imperativo de

ótica da situação criada pelo provimento condenatório, este é constitutivo, pois cria uma situação nova, consistente na ação executiva. Mas a situação criada localiza-se apenas no plano do processo e limita-se a facilitar a atuação do direito material, sem chegar a promover tal atuação - no que o pensamento de Dinamarco se aproximaria de Barbosa Moreira, ao ter este sustentado o caráter instrumental da constituição na sentença condenatória (cf. A instrumentalidade..., n. 29, p. 247). Para Francesco Terrusi, qualquer sentença (meramente declaratória, constitutiva ou condenatória) é, de certo modo, constitutiva, pois incide na esfera substancial das partes por meio da criação de uma situação jurídica nova (Cf. L'invalidità..., n. 5.2, p. 227). Igualmente reconhecendo que o provimento condenatório cria uma nova situação substancial, embora em senso um pouco diverso do aqui defendido, Elio Fazzalari, Istituzioni di diritto processuale, cap. VI, n. 1, p. 352. Fazzalari também entende que qualquer provimento cognitivo "è sempre di natura costitutiva, nel senso che incide nella sfera sostanziale dei litiganti creando una nuova situazione. La quale, come detto, sarà di contenuto uguale alla situazione sostanziale preesistente al processo, e già creata dalla lege sostanziale" (cf. Istituzioni..., cap. VI, n. 1, p. 356). E mesmo em hipóteses como as dos provimentos meramente declaratório e condenatório, em que o provimento "replica" o comando contido na lei, aquele possuiria uma funcionalidade autônoma em razão de atributos que acompanham a vontade emitida pelo julgador e que a qualificam como comando (pp. 359/361).

382 Embora concluindo de forma diversa, Barbosa Moreira adota a mesma premissa: "a execução é evidentemente exterior à sentença; o poder de promovê-la, que surge para o vencedor, é efeito da sentença, e por conseguinte também se situa fora dela" (cf. "Reflexões críticas...”, p. 77).

${ }^{383}$ Ela diferencia-se da constitutiva stricto sensu por conta dos seus efeitos: na constitutiva os efeitos atuam apenas no plano jurídico e, por isso, trata-se de tutela com alto grau de efetivade. A condenatória apenas constitui o direito de exigir o cumprimento coativo do direito violado, para o qual será necessária a prática de atos materiais. E não há problema em, nesta subclassificação, utilizar critério diverso (efeitos). O que é logicamente incorreto é utilizar-se de critérios diversos dentro da mesma classificação. 
vontade, formulando (declarando) uma preexistente vontade da lei, de tal sorte que, quanto a esse aspecto, a decisão condenatória não se diferenciaria das demais classes de provimentos. ${ }^{384}$ Devido ao caráter subrogatório da execução - ao menos quando se fala em execução direta - a vontade do devedor é irrelevante. O que difere a sentença condenatória das demais tutelas de conhecimento é a imposição de uma sanção executiva. ${ }^{385}$

\subsubsection{Tutela executiva lato sensu e tutela mandamental?}

Firmado o critério de diferenciação das tutelas de conhecimento aqui proposto (estrutura processual), logo se conclui que as chamadas tutelas executiva lato sensu e mandamental são modalidades de tutelas condenatórias, pois a sua estrutura processual também é marcada por dois momentos lógicos: declaração e constituição de uma situação jurídica nova, autorizadora de se exigir o cumprimento coativo do direito prestativo. A

${ }^{384}$ Cf. Chiovenda, Instituições..., v. 1, n. 43, p. 185. De acordo com Chiovenda, a decisão condenatória, sob certo aspecto, gera nova ordem, dirigida aos órgãos encarregados da execução, isto é, ordem de que devem ser praticados atos executivos.

${ }^{385}$ Cf. Liebman, Processo de execução, n. 7, p. 15; e Manual..., v. 1, n. 84, p. 236. Sobre não veicular a decisão condenatória um mandamento ao réu, v. Eduardo Talamini, inclusive com indicação de bibliografia sobre o assunto (cf. Tutela relativa..., nn. 6.1 e 6.2, pp. 187 e 193); e Barbosa Moreira, "Questões novas...", p. 134. Em sentido contrário, Paulo Lucon, embora adote a ideia liebmaniana de sanção, afirma também que "destina-se a ação condenatória a obter um provimento que obrigue o réu a cumprir determinado ato comissivo ou omissivo" e que "o juiz ordena alguém a dar, fazer ou não fazer" (cf. Eficácia das decisões..., n. 48, p. 157), o que, salvo melhor juízo, é contraditório. Em que pese ao acerto desse raciocínio, não existe mesmo ordem? Dinamarco alude a "ordem para entregar o bem ao credor na execução" e, na premissa de que a execução efetiva a condenação, forçoso concluir que a condenação é ordem (cf. Instituições..., v. 1, n. 57, p. 151). Afirma também que a sentença condenatória chama o obrigado a suprir a crise de adimplemento, sob pena de suportar futura execução (Cf. Instituições..., v. 1, nn. 57/58, pp. 154 e 157). Ora, parece-nos que o chamar equivale a uma ordem, um comando. Couture, a seu turno, afirma que a decisão condenatória é aquela que impõe o cumprimento de uma prestação e a atrela a uma cominação (cf. Fundamentos..., n. 200, p. 259). Agnelo Amorim Filho também identifica o provimento condenatório a uma prestação do réu (cf. "As ações constitutivas...", p. 28). Bedaque, por sua vez, aduz que "toda sentença condenatória é dotada de comando dirigido ao réu, impondo-lhe um comportamento previsto pelo direito material" (cf. Efetividade do processo..., p. 536). Comoglio-Ferri-Taruffo afirmam que com uma sentença de condenação emitida a seu favor a parte obtém um provimento que prescreve ao sujeito passivo "un certo comportamento consistente nel compimento di una prestazione" (cf. Lezioni..., cap. XXI, n. 9, p. 628). Para Junior Alexandre Moreira Pinto, "quando o autor submete ao Poder Judiciário uma crise de adimplemento, buscando ao réu uma sentença que imponha ao réu a obrigação de prestar alguma coisa, deve pleitear a obtenção de uma sentença condenatória", e essa modalidade de tutela impõe "ao réu o cumprimento de determinado ato comissivo ou omissivo" (cf. Conteúdo e efeitos..., n. 1.3.1.3, pp. 91/92). Esse autor, aliás, um dos adeptos da tese de que o conteúdo das tutelas é o critério que as diferencia, defende que o conteúdo específico da sentença condenatória é a eliminação do inadimplemento da obrigação (p. 92). Não é possível concordar com isso porque a tutela condenatória, por si só, não satisfaz a obrigação. A menos que haja cumprimento espontâneo por parte do devedor. Não o havendo, será necessária a sua efetivação, por meio de execução direta ou indireta. Por esta tutela jurisdicional, procura-se solucionar uma crise de adimplemento. Após a emissão do provimento condenatório e persistindo o inadimplemento, deverá o demandante recorrer à tutela executiva para que obtenha tutela efetiva. 
diferença está apenas na forma de se pedir tal efetivação. ${ }^{386}$ As duas tutelas podem ser reconduzidas à tutela condenatória, pois diferenciam-se da tutela condenatória "ordinária" apenas pelos respectivos modos de efetivação: a tutela mandamental em decorrência da ordem emitida, a tutela executiva lato sensu por dispensar processo de execução autônomo - o que, após as reformas legislativas que desde meados das década de 1990 vêm alterando o regime do processo de execução, passou a ser a regra em nosso ordenamento.

Outro sinal distintivo da tutela mandamental seria a especial qualidade do destinatário do provimento (servidor público). Por isso, o que a distinguiria das demais modalidades de tutelas seria não a natureza do provimento jurisdicional ou os efeitos desta decorrente, mas sim a qualidade do seu destinatário. ${ }^{387}$ Por trás dessa concepção está a ideia de que o Estado não pode sofrer execução direta. Porém ela acabou sendo superada para enxergar como característica dessa tutela não a especial qualidade de seu destinatário - já que ela passou a ser admitida também dirigida a particulares -, mas sim pelo fato de que conterem ordem dirigida ao réu. ${ }^{388}$ Tal crítica, portanto, está superada.

Essas tutelas, de qualquer modo, podem ser reconduzidas à condenatória, pois apresentam a mesma estrutura processual: declaração do direito e imposição de uma sanção executiva, que consiste na autorização de utilização dos meios de exigência coativa do direito declarado.

\subsection{Tutela executiva}

Este trabalho adota a ideia de que a distinção entre tutelas cognitiva, executiva e cautelar reside nas suas respectivas finalidades. Enquanto a tutela cognitiva tem por fim declarar a norma jurídica concreta, a executiva - atividade verdadeiramente jurisdicional -

\footnotetext{
${ }^{386}$ Nesse sentido, afirma Arruda Alvim que os efeitos dessas modalidades de tutela não lhes são intrínsecos, "senão que dizem respeito à forma de realização do direito" (cf. Manual..., n. 303, p 1.092). Para uma análise dessas teorias, por meio das obras de seus maiores adeptos, v. Ovídio Baptista da Silva, Sentença e coisa julgada, especialmente pp. 11/92, e Teoria geral do processo (em coautoria com Fábio Luiz Gomes), especialmente pp. 236/246; Pontes de Miranda, Tratado das ações, t. I, pp. 211/212; e José Maria Tesheiner, Elementos..., cap. VII, nn. 8/9, pp. 150/154. Combatendo essas modalidades de provimento, v. Barbosa Moreira, "Sentença executiva?", in Flávio Luiz Yarshell e Maurício Zanoide de Moraes (orgs.), Estudos em homenagem à Professora Ada Pellegrini Grinover; e José Roberto dos Santos Bedaque, pp. 524/531. Note, por fim, que mesmo na doutrina alemã há quem rejeite a autonomia da sentença mandamental (cf. Schönke, Derecho procesal..., n. 44, p. 153)

${ }^{387}$ Cf. Flávio Yarshell, Tutela jurisdicional específica..., n. 2.3, p. 21.

${ }^{388}$ Cf. Eduardo Talamini, Tutela relativa..., n. 6.2, pp. 190/191.
} 
procura efetivar a norma jurídica condenatória por meio da prática de atos materiais de invasão patrimonial ou de pressão sobre a vontade do obrigado. A jurisdição não cumpriria integralmente sua função se, para certas espécies de crises jurídicas, limitasse-se ao processo cognitivo.

Para crises jurídicas passíveis de serem debeladas por tutela meramente declaratória ou constitutiva, não é necessário execução porque, como visto, referidas tutelas atuam no plano jurídico e, portanto, os efeitos por elas produzidos dependem apenas do próprio provimento. Prescindem, portanto, de execução. ${ }^{389}$ Mas, para algumas crises jurídicas, não basta enunciar a regra jurídica especial. Não havendo cumprimento espontâneo por parte do devedor, é necessário atuá-la, modificando a realidade fenomênica por meio da invasão do patrimônio do devedor ou da pressão psicológica sobre esse. ${ }^{390}$ É nesse mister que atua a tutela executiva, dando efetividade ${ }^{391}$ ao direito reconhecido no título judicial ou extrajudicial.

A tutela executiva também visa a debelar crises de adimplemento e está umbilicalmente ligada à condenatória. É por isso que Liebman conceituou execução como o conjunto de atos desenvolvidos pelos órgãos judiciários com a finalidade de dar cumprimento à sanção, a qual, como visto, é o caráter diferenciador da tutela condenatória. ${ }^{392}$ Execução, portanto, está ligada unicamente à sentença condenatória ou a

\footnotetext{
${ }^{389}$ Essa diferenciação entre as tutelas de conhecimento e a relação delas com a execução foi muito bem exposta por Calamandrei: "Se puede, desde luego, observar, que, para alcanzar los fines de la jurisdicción, no es necesario que a toda declaración de certeza siga la ejecución forzada". Aludindo às tutelas meramente declaratória e constitutiva, o autor ainda apontou que "en estos dos últimos casos la garantía jurisdiccional es completa y se agota en la decisión: basta la decisión para garantizar la observancia del derecho (...). en cambio, como ya se ha dicho, la decisión, la llamada 'condena', no basta ella sola (salvo que el obligado, para evitar la sanción con que la misma le amenaza, se determine, sin más, a cumplir voluntariamente la obligación declarada cierta en la condena) para alcanzar los fines de la jurisdicción, y hay necesidad, a fin de que la observancia del derecho que restablecida, de una ulterior actividad jurisdiccional, de la cual la condena, que mira al futuro, es, por decirlo así, el anunci y la legitimación" (cf. Instituciones..., v. 1, n. 20, p. 169). Em sentido análogo, Buzaid, A ação declaratória..., n. 206, p. 340.

${ }^{390}$ Como corretamente observou Dinamarco, "na execução forçada a busca dos escopos da jurisdição é feita diretamente pelo Estado, o qual já não cogita de aclarar preceitos postos em dúvida, nem de colocar motivos sérios para forçar a determinação do obrigado, mas invade ele próprio a esfera de autonomia deste e produz o resultado que a lei quer" (cf. Execução civil, n. 57, p. 109). No mesmo sentido, v. Paulo Lucon, Embargos à ехесис̧а̃o, n. 38 , p. 84.

391 É por isso que Dinamarco disse que "executar é dar efetividade e execução é efetivação" (cf. Instituições..., v. IV, n. 1.326, p. 31).

${ }^{392}$ Cf. Processo de execução, n. 2, p. 4. Marcelo Lima Guerra e Leonardo Greco também evidenciaram a relação de dependência entre condenação e execução (cf., respectivamente, Direitos fundamentais..., n. 1.3, pp. 23/27 e $O$ processo de execução, v. 1, n. 3.2, p. 164). Dito isto, não é difícil compreender por que Chiovenda afirmou que os provimentos declaratórios compreendem todos os casos em que à sentença não se
} 
outro título executivo, pois é só neles que há aplicação da sanção com esse conceito (sanção executiva).

Na decisão condenatória, à declaração acresce-se a sanção: constitui-se, assim, o título executivo, do qual se partirá para que seja concretamente realizada a norma nele contida. Como as sentenças meramente declaratória e constitutiva atuam no plano jurídico, a execução é adequada apenas para as decisões condenatórias. ${ }^{393}$ É por isso que a execução não se relaciona àquelas duas espécies de decisão: elas não exigem execução, por serem tutelas auto-satisfativas.

O processo de cognição visa a um julgamento; o de execução busca resultados práticos. Por isso é que se diz que, enquanto na cognição se busca descobrir qual é o direito que deverá reger a contenda, na execução o direito é um ponto de partida. A principal distinção entre as tutelas de conhecimento e de execução é teleológica: enquanto na primeira a atividade é desenvolvida convergindo para o ato de acertamento, que declarará a norma concreta (sentença), na segunda os atos buscam preparar o ato material que satisfará o direito do demandante. ${ }^{394}$

Tudo o que se falou até agora aplica-se ao que se convencionou chamar de execução forçada ou execução em sentido estrito. Com esse sentido, apenas as sentenças condenatórias são passíveis de execução. Mas execução é termo equívoco e empregado com outras acepções. Em um sentido amplíssimo, pode-se falar em execução para designar a simples realização das obrigações. Executar uma obrigação equivaleria a cumprir uma obrigação. Pode-se aludir também ao caráter executivo do provimento constitutivo: ao modificar situações jurídicas, o provimento atinge integralmente o seu escopo de eliminação de conflitos e, assim, atua a vontade concreta da lei, executando-a. É possível falar em execução, ainda, para indicar medidas de pressão psicológica exercidas sobre o obrigado, como multas, astreintes e prisão civil. Este último caso é o que se nomeia

\footnotetext{
segue a execução forçada (cf. "Azione di mero accertamento", in Saggi di diritto processuale civile, v. III, p. 51), pois entendendo o provimento constitutivo como uma espécie de provimento declaratório (accertamento costitutivo), com aquela observação quis o mestre atrelar a execução apenas à tutela condenatória, excluindoa da meramente declaratória e da constitutiva. Negando a relação necessária entre condenação e execução, Comoglio-Ferri-Taruffo, Lezioni..., cap. XXI, n. 9.1, p. 629.

${ }^{393}$ Cf. Couture, Fundamentos..., n. 284, p. 358.

${ }^{394}$ Cf. Dinamarco, Execução civil, n. 62, p. 114.
} 
execução indireta. Por fim, pode-se falar em execução como sinônimo de atividades de cumprimento do comando emergente de decisões declaratórias ou constitutivas, meramente documentadoras, como o registro da sentença translativa da propriedade. É o que se chama de execução imprópria. ${ }^{395}$ Contudo, no rigor da técnica processual, apenas a execução forçada é execução. ${ }^{396}$

De acordo com esse entendimento, seria execução forçada apenas a prática de atos de invasão patrimonial. Assim, a execução indireta não seria, propriamente, execução. Contudo, a técnica e os conceitos evoluíram; e hoje se entende que também a execução indireta se insere no conceito de execução forçada. Esta, assim, compreende tanto os atos de invasão patrimonial como os de coerção psicológica. ${ }^{397}$

\subsection{Tutela cautelar}

Chega a ser um truísmo afirmar a impossibilidade de o processo ofertar tutela jurisdicional tempestivamente. A atividade jurisdicional demanda tempo, que muitas vezes não pode ser suportado pela parte, sob pena de perecimento do direito. ${ }^{398}$ É justamente procurando evitar que isso ocorra que atua a tutela cautelar, que, ao conservar o estado de

\footnotetext{
395 Cf. Dinamarco, Execução civil, n. 54, pp. 100/102. Sobre os diferentes significados de execução, v., também, Liebman, Processo de execução, n. 3, pp. 5/6; e Flávio Yarshell, Tutela jurisdicional específica..., n. 2.3 , p. 28.

${ }^{396}$ Cf. Dinamarco, Execução civil, n. 54, p. 103.

${ }^{397}$ Recorre-se novamente a Dinamarco, que explica essa evolução conceitual em obra mais recente do que a mencionada nas notas anteriores: "As técnicas e conceitos evoluídos ao longo dos tempos em matéria de execução civil concentram-se naquela que se faz em um processo autônomo e basicamente mediante a imposição de medidas de sub-rogação (execução tradicional); reservava-se a ela com exclusividade o nome de execução forçada, em oposição à execução indireta que se faz mediante os atos de pressão psicológica. Mas, a partir de quando ambas as formas passaram a conviver paritariamente no mesmo nível, sem que uma seja ordinária e outra excepcional, tanto a execução tradicional como a que se faz mediante a indução a cumprir são modalidades de execução forçada; ambas são feitas mediante o exercício imperativo da jurisdição e, por um modo ou por outro, o Estado-juiz força (impõe) a satisfação do direito à custa de algum sacrifício da esfera jurídica do obrigado. A execução é forçada quando o Estado-juiz atua sobre os bens, mas também forçada quando ele atua sobre o espírito do obrigado, ou seja, sobre sua vontade - e tal é a execução caracterizada no direito brasileiro como cumprimento de sentença (CPC, art. 475-I c/c arts. 461 e 461-A)" (cf. Instituições..., v. IV, n. 1.327, p. 35). Também incluindo os atos de pressão psicológica no conceito de execução, Leonardo Greco, O processo de execução, v. 1, n. 3.1, p. 163..

${ }^{398}$ Botelho de Mesquita bem captou esse espírito, ao afirmar que no processo o tempo é o grande inimigo de quem tem razão e um ótimo aliado de quem não a detém, e que a ação cautelar nasce da constatação de que a efetiva tutela de direitos pressupõe a rápida atuação estatal (Cf. Da ação civil, p. 116). De forma análoga, Calamandrei disse que a atividade cautelar tem por fim dar tempo à Justiça para cumprir eficazmente a sua obra (Cf. Instituciones..., v. I, n, 18-c, p. 158). Carnelutti também apontou a relação entre processo e tempo, e a necessidade da tutela cautelar (cf. Sistema..., v. I, p. 205). No mesmo sentido, v. Andrea Lugo, Manuale..., p. 410 .
} 
coisas, tem por finalidade afastar o dano marginal do processo, isto é, um dano qualificado, decorrente da demora na outorga da tutela definitiva. ${ }^{399}$

Embora os efeitos do provimento cautelar sejam os mesmos dos provimentos cognitivo e executivo, bem como a atividade desempenhada pelo juiz na emissão daquele seja idêntica às atividades desempenhadas nestes, diz a doutrina que a tutela cautelar é um terceiro gênero em razão de sua finalidade de prevenção. ${ }^{400}$ Mas só a prevenção não basta para qualificar a tutela cautelar, mormente porque ela é qualidade também da chamada tutela preventiva, espécie de tutela de conhecimento.

Além da prevenção, a tutela cautelar é marcada pelas características de instrumentalidade, provisoriedade, urgência e sumariedade.

Instrumentalidade porque, embora toda tutela jurisdicional seja um instrumento posto a serviço da efetivação do direito substancial, em relação a este a tutela cautelar possui finalidade mediata: não visa diretamente a atuá-lo e a fazer justiça, mas sim a garantir a eficácia prática do provimento final. Daí se falar em instrumentalidade qualificada, instrumentalidade elevada ao quadrado e instrumento do instrumento. Existe, pois, relação de dependência entre a tutela cautelar e a definitiva, cuja eficácia aquela procura assegurar preventivamente. ${ }^{401}$

Relacionada a isso está a característica de provisoriedade da tutela cautelar. As tutelas cognitiva e executiva visam a reintegrar em termos definitivos a ordem jurídica lesada. Por isso são tutelas jurisdicionais satisfativas. A ambas se contrapõe a tutela cautelar, que apenas assegura, provisoriamente, a eficácia prática de providências cognitivas e executivas (função assecurativa). Ela sempre será dependente de confirmação da tutela definitiva.

\footnotetext{
${ }^{399}$ Cf. Calamandrei, Introducción..., n. 8-c, p. 42. Essa finalidade, na realidade, é comum a todas as tutelas sumárias, seja ela cautelar ou não cautelar (cf. José Roberto dos Santos Bedaque, Tutela cautelar..., pp. 250/251).

${ }^{400}$ Cf. Cintra-Grinover-Dinamarco, Teoria geral..., n. 203, p. 327.

${ }^{401}$ Ao se conceder tutela cognitiva ou executiva, está sendo conferida tutela satisfativa, que terá por fim alterar a ordem jurídica de modo definitivo. A tutela cautelar, por sua vez, não satisfaz definitivamente o direito subjetivo perseguido, mas apenas assegura que a tutela principal perseguida (de conhecimento ou execução) possa ser fruída quando de sua prestação. Para Calamandrei, aliás, a instrumentalidade é a nota verdadeiramente típica da tutela cautelar (cf. Introducción..., n. 9, pp. 44/45).
} 
Quanto à urgência, não se trata de uma urgência qualquer. É uma urgência qualificada, decorrente do risco do dano marginal do processo, que, por sua vez, advém da impossibilidade de se aguardar a tutela ordinária definitiva sob pena de se produzir ou agravar o dano pela espera. É nisso que consiste o periculum in mora: uma urgência qualificada pela impossibilidade de se aguardar o tempo que os trâmites processuais ordinários levam, sob pena de se tornar ineficaz a tutela definitiva. A mora da providência definitiva é a própria causa do dano que se quer evitar com o provimento cautelar. ${ }^{402}$

A tutela cautelar, ainda, é marcada pela sumariedade de cognição. Como decorrência do caráter urgente dessa modalidade de tutela, o julgador não dispõe do tempo necessário para conhecer a controvérsia em sua integralidade e, assim, confere o provimento cautelar em favor da parte que parece estar amparada pelo direito material. Se ao cabo do iter procedimental ordinário o juiz adotará entendimento diverso é outra questão; naquele momento, premido pela urgência, ele confere a proteção a quem aparenta estar com a razão à luz do direito substancial. Daí se falar em fumus boni iuris (fumaça do bom direito).

A doutrina que prevalece no Brasil entende que tutela de urgência é gênero do qual as tutelas cautelar e antecipada são espécies. A cautelar ampararia o próprio processo, apenas assegurando a eficácia do provimento final; e a antecipada anteciparia os efeitos práticos do provimento final perseguido no processo de cognição ou execução, amparando as pessoas imediatamente. O próprio Projeto de Novo Código de Processo Civil (PL 8.046, de relatoria do Senador Valter Pereira) adotou esse entendimento, ao dispor em seu art. 269 que "a tutela de urgência e a tutela da evidência podem ser requeridas antes ou no curso do processo, sejam essas medidas de natureza cautelar ou satisfativa". 403

\footnotetext{
402 Calamandrei bem sintetizou isso ao fazer menção à "mora indispensable para el cumplimiento del ordinario iter procesal" (cf. Introducción..., n. 8-c, p. 43).

${ }^{403}$ No Projeto não há mais livro específico dedicado ao processo cautelar. Os provimentos cautelares passam a ser disciplinados no Título IX do Livro I (Parte Geral), sob a nomenclatura de "Tutela de urgência e tutela da evidência". Extingue-se a chamada "ação" cautelar, de modo que a tutela cautelar passa a ser concedida no bojo do próprio processo principal, ainda que, no caso de medida antecedente, preveja-se um procedimento - e não processo - anterior à dedução do pedido principal. O Anteprojeto, além disso, exclui os chamados procedimentos cautelares típicos, estabelecendo, apenas, uma espécie de poder geral de cautela tanto para as medidas cautelares conservativas como para as antecipatórias.
} 
Aqui, contudo, adota-se a noção de que tutela cautelar é gênero do qual cautelar conservativa e cautelar antecipatória (respectivamente, cautelar e tutela antecipada para a doutrina brasileira dominante) são espécies. Quando se empregar a locução tutela cautelar neste trabalho, portanto, se estará fazendo menção ao que no Brasil se convencionou chamar de tutela antecipada e de tutela cautelar. ${ }^{404}$

\section{Momento de eficácia. Relevância da tutela cautelar nos provimentos constitutivos e declaratórios}

Questão relevante para os fins desta investigação é a que diz com o momento de eficácia dos provimentos. Quando se alude a momento de eficácia não se está mencionando quais as situações jurídicas que, cronologicamente, são abarcadas pelas decisões. Sob esse último aspecto, chamado por alguns de retroatividade da sentença, ${ }^{405}$ parte da doutrina defende que, como a tutela constitutiva promove uma modificação de situações jurídicas, atuando como título da alteração, os seus efeitos operam-se ex nunc, ao passo que, como o provimento declaratório apenas poria fim a um estado de incerteza, reconhecendo a ausência ou inexistência de algo que lhe precede, este teria efeitos $e x$ tunc. ${ }^{406}$ Essa questão, contudo, guarda relação com os limites objetivos do provimento e da coisa julgada - que são equivocadamente nomeados de limites temporais da coisa

\footnotetext{
${ }^{404}$ Em sentido semelhante, Dinamarco acertadamente defendeu deverem ser reduzidas as preocupações com a necessidade de identificar e separar as duas espécies de tutela cautelar, as quais são "dois irmãos quase gêmeos", e não dois estranhos, como se costuma pensar (cf. A reforma da reforma, p. 90). Por essa razão, em outro estudo ele preconizou a "recondução das medidas antecipatórias e cautelares a um gênero só, que as engloba, ou a uma categoria próxima, que é a das medidas de aceleração da tutela jurisdicional" (cf. "O regime jurídico das medidas urgentes", in Nova era do processo civil, p. 67).

${ }^{405}$ Cf.Tomás Pará Filho, Estudo sobre..., p. 137.

${ }^{406}$ Cf. Satta, Direito processual..., v. 1, n. 147, p. 276; Luigi Montesano, La tutela giurisdizionale dei diritti, n. 95, p. 257; Liebman, Manual..., v. 1, n. 86, p. 246; Cintra-Grinover-Dinamarco, Teoria geral.., n. 197, p. 314; Flávio Yarshell, "Tutela jurisdicional meramente declaratória", p. 46; e Francesco Terrusi, L'invalidità..., n. 5.3, p. 228. Sobre essa distinção e a doutrina que a preconiza, v. a análise e a crítica feitas por Corrado Ferri, para quem a retroatividade da sentença depende da fattispecie que, no caso concreto, o ato viciado possui, e não de uma pretensa regra geral aplicável a todas as hipóteses de cada modalidade de provimento. Assim, para Ferri, a sentença constitutiva produziria efeitos ex nunc não por conta de uma característica intrínseca dela, mas sim porque o art. 324 do CPC italiano assim determina (cf. Profili.., pp. 171/174, 191/194 e 198). Acolhendo a crítica de Ferri, v. Andrea Proto Pisani, "Appunti sulla tutela di mero accertamento", p. 669. Isso já fora apontado por Goldschmidt, que negou haver relação necessária entre sentença constitutiva e eficácia ex nunc: "El acto del juez puede tener efectos 'ex nunc' (por ejemplo, divorcio) o 'ex tunc' (por ej., nulidad del matrimonio). Por esto no existe razón alguna para que se reconozan como verdaderas sentencias constitutivas solamente las que producen efecto 'ex nunc" (cf. Derecho procesal civil, § 15, p. 112).
} 
julgada $^{407}$-, não com o momento de eficácia da tutela jurisdicional, ${ }^{408}$ e será abordada no item 16 abaixo. Quando empregarmos a expressão momento de eficácia, estaremos designando o momento a partir do qual a tutela jurisdicional pode ser "executada" ou mais propriamente nas hipóteses de provimentos declaratório e constitutivo - efetivada.

De modo geral, entende-se que os provimentos constitutivos e declaratórios só se tornam eficazes após a incidência da coisa julgada material, rejeitando-se a possibilidade de uma constituição ou declaração provisórias. ${ }^{409}$ A tutela condenatória, por outro lado, seria passível de execução provisória. Mas qual a razão desse entendimento?

Com relação a todo e qualquer sentença, a regra é que o julgado só se torne eficaz com o trânsito em julgado. ${ }^{410}$ Embora eficácia do provimento e autoridade da coisa julgada sejam coisas diversas, o ato estatal sentença só se torna imperativo antes da passagem em julgado quando há autorização expressa do ordenamento nesse sentido. ${ }^{411}$

${ }^{407}$ Cf. Eduardo Talamini, Coisa julgada..., n. 2.4, p. 87. O mesmo alerta é feito por Remo Caponi, ao aludir aos dois significados de eficácia da sentença no tempo: "il primo porta a individuare il momento del tempo nel quale la sentenza comincia a produrre i suoi effetti e la loro stabilità. Il secondo concerne l'incidenza dell'efficacia della sentenza passata in giudicato nel tempo delle situazioni sostanziali oggeto del giudizio" (cf. L'efficacia del giudicato civile nel tempo, cap. I, n. 1, p. 3).

408 Embora não faça essa mesma distinção entre momento de eficácia e limites objetivos do provimento, Barbosa Moreira, tratando do momento em que a sentença é eficaz, isto é, daquele a partir do qual pode ser efetivada, diz que "outra questão, contudo, é a referente a eventuais efeitos retroativos do pronunciamento judicial (...)" (cf. "Eficácia da sentença de interdição por alienação mental”, in Temas de direito processual, $4^{\mathrm{a}}$ série, n. 1, p. 185). De modo semelhante, distinguindo a questão que diz respeito às situações que são atingidas pelo provimento e o momento a partir do qual é possível impor os efeitos do provimento, v. Dinamarco, "Momento de eficácia...”, n. 530, p. 949.

${ }^{409}$ Cf. Jauernig, Direito processual..., n. 53, p. 342; e Luigi Montesano, La tutela..., n. 87, p. 241. De forma análoga, Paulo Lucon afirma que, em regra, a eficácia de sentenças meramente declaratória ou constitutiva "só se produz quando houver o esgotamento de todos os recursos cabíveis" (cf. Eficácia das decisões..., p. 150). Francesco Terrusi aponta que esse entendimento vem sendo aos poucos mitigado pela doutrina e jurisprudência italianas (cf. L'invalidità delle delibere..., n. 6.1., pp. 280/281).

${ }^{410}$ Cf. Barbosa Moreira, "Coisa julgada e declaração", in Temas de direito processual, $1^{\text {a }}$ Série, p. 88; e Liebman, "Eficácia e autoridade...", nn. 8 e 9, pp. 38/40. Explicando essa última passagem, Dinamarco afirma que "o que acaba de ser dito não se choca com a prestigiosa distinção, proposta por Liebman e aceita pelos doutrinadores em geral (máxime brasileiros), entre a eficácia da sentença e a auctoritas rei judicatae. (...) Dizendo que aquela pode anteceder a esta, jamais disse Liebman que essa procedência seja uma constante ou regra geral. (...). O que quis e logrou Liebman foi demonstrar, com tais argumentos, que o direito positivo pode outorgar eficácia à sentença sem aguardar o trânsito em julgado" (cf. "Momento de eficácia...”, n. 534, pp. 962/963). V., ainda, Luigi Montesano, La tutela..., n. 87, pp. 239/240.

${ }^{411}$ Quer se trate de condenação, quer se trate de constituição, a "regra é a espera pelo julgamento final e trânsito em julgado" (cf. Dinamarco, "Momento de eficácia...", n. 536, p. 968). De forma similar, v. Elio Fazzalari, Istituzioni..., cap. IX, n. 3, p. 423. 
Exemplo disso é o regime da execução da sentença condenatória impugnada por recurso sem efeito suspensivo. A regra é que a satisfação da obrigação contida no título executivo - com a prática de atos de execução direta ou indireta, se necessários - ocorra apenas a partir da incidência da coisa julgada, quando se dirá com certeza - ainda que essa não corresponda à verdade, já que a verdade é inatingível ${ }^{412}$ - que dada pessoa deve pagar tal quantia a tal pessoa. Mas o direito posto autoriza a execução provisória da sentença condenatória $^{413}$ e, portanto, ela é cabível (CPC, art. 475-O).

Essa regra geral aplica-se às tutelas meramente declaratória e constitutiva. Em se tratando dessas modalidades de provimento, seria impróprio falar-se em execução provisória, uma vez que, não sendo título executivo, as sentenças meramente declaratória ou constitutiva jamais poderiam dar ensejo a uma execução. ${ }^{414}$ Como os efeitos a que se destinam decorrem plenamente do provimento, elas são auto-satisfativas e, portanto, não demandam atos materiais para que se efetivem.

De qualquer modo, ainda que não seja correto falar em execução das decisões constitutivas e declaratórias - ao menos não no sentido clássico de execução forçada -, é de se indagar se essas decisões são aptas a, excepcionalmente, produzir efeitos antes do trânsito em julgado ou se devem seguir, em qualquer hipótese, a regra geral enunciada acima. A pergunta que deve ser feita é se a falta de atribuição de efeito suspensivo ao recurso interposto contra as sentenças constitutiva ou declaratória autoriza que o resultado contido nessas sentenças seja imposto desde logo ao vencido, sem se aguardar o trânsito em julgado. ${ }^{415}$

\footnotetext{
${ }^{412}$ Cf. Piero Calamandrei, "Verità e verosimiglianza nel processo civile", in Studi sul processo civile, v. 6, pp. 111/112; Santiago Sentís Melendo, La prueba - los grandes temas del derecho probatorio, p. 44; Luiz Guilherme Marinoni e Sérgio Cruz Arenhart, Comentários ao Código de Processo Civil, v. 5, t. I, p. 43; Humberto Theodoro Jr., "Prova - princípio da verdade real - poderes do juiz - ônus da prova e sua eventual inversão - provas ilícitas - prova e coisa julgada nas ações relativas à paternidade (DNA)", Revista de direito privado, n. 17, p. 12; e Guilherme Setoguti J. Pereira, "Verdade e finalidade da prova", RePro, n. 213, pp. 161 e seguintes.

${ }^{413} \mathrm{O}$ que, de acordo com Ferri-Comoglio-Taruffo, seria sintomático da valorização do procedimento de primeiro grau de jurisdição (cf. Lezioni sul processo civile, v. 1, p. 537).

${ }^{414}$ Ainda que o inciso I do art. 475-N do CPC impropriamente estabeleça ser título executivo judicial "a sentença proferida no processo civil que reconheça a existência de obrigação de fazer, não fazer, entregar coisa ou pagar quantia".

415 A indagação é de Dinamarco. E embora englobe apenas a tutela constitutiva, aplica-se também à meramente declaratória (cf. "Momento de eficácia...”, n. 535, p. 964).
} 
Não há disposição legal específica autorizando regime de constituição provisória ou declaração provisória, ao contrário do que ocorre com as decisões condenatórias. Em princípio, portanto, a resposta à indagação acima deveria ser negativa: se a regra geral é o condicionamento da eficácia da sentença ao trânsito em julgado e não há nenhuma regra específica que excepciona a regra geral, a resposta já estaria dada.

Como reforço desse entendimento, a doutrina valeu-se da analogia e, invocando as regras do regime de execução provisória da sentença condenatória, aplicou-as no âmbito das decisões constitutivas. Com efeito, o provimento constitutivo é reputado o mais eficaz dentre todas as modalidades de decisões, pois é autosuficiente, já que não exige ato posterior para que produza os efeitos a que se destina. O resultado almejado pelo demandante é obtido por meio do próprio provimento, que promove todas as alterações jurídicas perseguidas, diversamente da sentença condenatória, que depende do cumprimento espontâneo por parte do devedor ou de atos de execução forçada, caso aquele não haja.

Por conta desse caráter "executivo" e da falta de disposição legal tratando da efetivação provisória da sentença constitutiva, quando em vigor a redação original do Código de Processo Civil de 1973 a doutrina buscava nesse regime, especialmente no revogado art. 588, regras para serem aplicadas analogamente à “execução" provisória da sentença constitutiva. Assim, se em relação à sentença condenatória (i) o sistema vedava a prática de atos irreversíveis ou de difícil reversão, condicionando alguns deles à prestação de caução (art. 588, II); (ii) estabelecia a resolubilidade da execução provisória em caso de reforma da sentença (art. 588, I); e (iii) firmava a responsabilidade do exequente por danos causados ao executado (art. 588, III), a fortiori deveriam ser rechaçadas as modificações jurídicas causadas pela sentença constitutiva antes do trânsito em julgado, pois aí os efeitos do provimento são produzidos automática e imediatamente, dificultando-se o retorno ao status quo ante. ${ }^{416}$

\footnotetext{
${ }^{416}$ Cf. Dinamarco, “Momento de eficácia...”, n. 535, pp. 964/965. Nesse sentido, Flávio Yarshell apontou que "Partindo desse paralelismo, já se sustentou, com autoridade, que a sentença constitutiva - salvo expressa disposição legal em sentido diverso - não pode ser imperativa antes de seu trânsito em julgado. É que entendimento diverso afrontaria a regra que proíbe a execução definitiva de provimentos sobre os quais ainda paira a incerteza decorrente da pendência de recurso com efeito meramente devolutivo" (cf. "Antecipação de tutela...", n. 4, p. 176).
} 
A analogia com a execução provisória da sentença condenatória restou um pouco enfraquecida após as alterações empreendidas pela Lei 10.444/02, que fez parte da onda de alterações legislativas havida entre os anos de 2001 e 2002. ${ }^{417}$ A Lei 10.444/02 alterou a redação do art. 588 para o fim de permitir transferências de domínio na execução provisória, desde que prestada caução (art. 588, II), e até mesmo dispensando-a em algumas hipóteses $\left(\operatorname{art} .588, \S 2^{\circ}\right.$ ). Embora esse dispositivo tenha sido revogado pela Lei 11.232/05, de modo geral a disciplina nele contida perdura até hoje (CPC, arts. 475-O, 685-A, 685-C e 686).

Foram, portanto, aproximados os regimes de execução provisória e definitiva, o que acabou por enfraquecer o argumento analógico antes invocado para negar a possibilidade de uma constituição provisória. Mas ainda hoje há motivos que justificam a adoção da posição de que os efeitos constitutivos produzem-se apenas após o trânsito em julgado.

Um deles é que no binômio condenação-execução os atos de sub-rogação incidem sobre bens materiais, ao passo que o provimento constitutivo incide sobre relações jurídicas, imediatamente afetando direitos, obrigações ou situações jurídicas. ${ }^{418}$ Por esse motivo, a sentença constitutiva é de mais difícil reversão, o que justifica maiores cuidados na liberação provisória de seus efeitos.

Essa distinção guarda relação com os diferentes graus de reversibilidade dos efeitos da tutela jurisdicional. No caso da condenatória, a reversibilidade é, em regra, maior, pois, incidindo os resultados da tutela sobre bens materiais, no mais das vezes será possível que aqueles retornem ao patrimônio do devedor. Não o sendo, este será compensado pelo valor equivalente. Quando se está diante de modificações jurídicas, a reversibilidade é menor ou até mesmo impossível de ser obtida. E ainda que seja possível a reversão ao status quo ante, ela pode causar graves transtornos às partes e, o que é pior, a terceiros que nesse ínterim tenham estabelecido relações jurídicas com as partes. ${ }^{419}$ Ou

\footnotetext{
${ }^{417}$ E que abalizada doutrina houve por bem nomear de reforma da reforma, diferenciando-a da precedente onda ocorrida entre 1994 e 1995.

${ }^{418}$ Cf. Dinamarco, "Momento de eficácia...", n. 535, p. 966.

${ }^{419}$ Cf. Dinamarco, "Momento de eficácia...", n. 536, p 967.
} 
seja, a resolubilidade - principal atributo da execução provisória - sofre grandes ressalvas no âmbito da tutela constitutiva.

A sentença constitutiva, por esses motivos, só é eficaz a partir do trânsito em julgado, ${ }^{420}$ a menos que a lei disponha de modo diverso. ${ }^{421}$

Tais considerações, embora feitas no âmbito da tutela constitutiva, aplicam-se também à meramente declaratória. Primeiro porque, assim como aquela, esta não possui regra específica autorizando a sua efetivação provisória. Portanto, também para ela vigora a regra geral enunciada por Liebman. Segundo porque à base de todo o raciocínio desenvolvido acima está o "caráter executivo" da decisão constitutiva, na medida em que, sendo provimento com elevado grau de eficácia, é como se conjugasse atos de cognição e execução, satisfazendo, automática e imediatamente, o direito nele contido. Acontece que esse entendimento aplica-se também ao provimento declaratório, que, como visto, é igualmente auto-satisfativo, já que o bem perseguido em uma demanda declaratória é a certeza jurídica e esta se produz única e diretamente por meio do pronunciamento jurisdicional. $^{422}$

Se o autor de demanda declaratória pretende, além da declaração, a satisfação do direito que o provimento tornou certo, ele terá que se valer da tutela condenatória,

${ }^{420}$ Cf. Tomás Pará Filho, Estudo sobre..., pp. 71 e 146.

${ }^{421}$ Cf. Corrado Ferri, Profili..., p. 191: "La sentenza costitutiva, allo stesso modo della sentenza meramente dichiarativa, produze effetti dal momento del suo passaggio in giudicato, salvo che la legge ne stabilisca espressamente la retroatività".

422 Sobre o caráter auto-satisfativo da tutela declaratória, v. Chiovenda, Instituições..., v. I, n. 59, p. 210; Tomás Pará Filho, Estudo sobre..., p. 68; e Cintra-Grinover-Dinamarco, Teoria geral..., n. 194, p. 312. A respeito da equiparação entre as tutelas meramente declaratória e constitutiva sob esse aspecto, Flávio Yarshell corretamente afirmou que "guardadas as notórias diferenças de essência já indicadas, a sentença meramente declaratória também pode ser, e muitas vezes o é, instrumento apto a proporcionar uma eficaz realização do direito, em casos em que nenhuma atividade material ('alteração do mundo sensível') é necessária para proporcionar ao vencedor o pleno gozo da utilidade prática devida, consumando-se em si mesma, excetuando-se eventual 'execução imprópria”" (cf. Tutela jurisdicional específica..., n. 2.3., p. 29). Como bem apontou Barbosa Moreira, "o que existe de comum a ambas as classes é a circunstância de que não lhes sobrevive qualquer necessidade de determinado comportamento, por parte do vencido, para a satisfação do vencedor" (cf. "Tendências na execução...”, p. 217). Analogamente, v. Flávio Yarshell, "Tutela jurisdicional meramente declaratória”, n. 4, p. 51. Esclarecendo melhor o pensamento deste autor, veja-se a diferença por ele construída entre declaração positiva e declaração negativa: "quando se presta simplesmente a estabelecer certeza sobre a existência de uma relação jurídica de que resulte uma prestação (fazer, não-fazer ou dar) - tutela positiva -, de fato, a tutela meramente declaratória distancia-se daquela aludida 'autosuficiência' da tutela constitutiva e o respectivo grau de efetividade reduz-se substancialmente. Mas, quando dita tutela estabelece certeza sobre a inexistência de uma relação jurídica - tutela negativa -, o grau de efetividade atingido aumenta substancialmente, de sorte a dispensar nova atuação jurisdicional" (cf. "Tutela jurisdicional meramente declaratória”, n. 4, p. 52). 
propondo nova demanda. Mas essa é outra questão. Na premissa de que o objeto da demanda meramente declaratória é apenas a obtenção da certeza jurídica - como reconhecido pela doutrina clássica ${ }^{423}$-, isto é, que o autor quer apenas a certeza, inegável é que esse bem jurídico é fornecido única e tão-somente pelo provimento.

Por isso, todas as considerações feitas acima no tocante às decisões constitutivas aplicam-se também às declaratórias. ${ }^{424}$ A tutela declaratória, é dizer, só se reputa eficaz após a passagem em julgado do provimento de mérito. ${ }^{425}$

Daí, portanto, a importância da tutela de urgência nos provimentos constitutivo e declaratório. Se os efeitos decorrentes desses provimentos produzem-se apenas após o exaurimento dos recursos eventualmente interpostos - o que na realidade brasileira pode levar décadas -, é evidente que em muitos dos casos, quando a tutela for prestada, já terá perecido o direito. Não sendo possível a efetivação provisória dessas sentenças - ao contrário do que se dá com as condenatórias -, de grande importância se mostra a tutela de urgência, com o intuito de afastar o tempo como fator de corrosão de direitos. ${ }^{426}$

\subsection{Crítica da distinção entre efeitos principais e efeitos práticos. Defesa da constituição e declaração provisórias}

Como visto, embora já tenha havido resistência da doutrina em se admitir a antecipação de provimentos declaratórios e constitutivos, hoje está razoavelmente pacificada a posição contrária. O que se costuma defender é que não se antecipa a própria tutela jurisdicional pleiteada (isto é, os efeitos declaratório e constitutivo pleiteados de forma definitiva), mas apenas efeitos práticos decorrentes dessas modalidades de tutela. ${ }^{427}$

Nesse sentido, para Humberto Theodoro Jr. é intuitivo que a declaração de certeza sobre uma relação jurídica ou a constituição de nova situação jurídica não possam

\footnotetext{
${ }^{423}$ Cf. Celso Agrícola Barbi, Comentários..., v. 1, t. 1, p. 68; e João Batista Lopes, Ação declaratória, n. 3.8, p. 93, embora pensemos haver fortes razões para se questionar isso.

${ }^{424}$ Apesar de Montesano ter dito que há uma radical diferença entre as tutelas declaratória e constitutiva (cf. La tutela..., n. 87, p. 242), cremos que, para os fins acima expostos, podem ser elas equiparadas.

${ }^{425}$ Nesse sentido, v. João Batista Lopes, “Tutela antecipada nas ações declaratórias”, RT, v. 806, n. 3.3, p. 30.

${ }^{426}$ A expressão é de Dinamarco, "O regime jurídico...”, n. 29, p. 64.

${ }^{427}$ Cf. Fredie Didier Jr., Paula Sarno Braga e Rafael Oliveira, Curso de direito processual civil, v. II, p. 481.
} 
ser obtidas provisoriamente. Daí por que não seria possível antecipar, puramente, o efeito declaratório ou constitutivo. Haver-se-ia que diferenciar os efeitos declaratórios e constitutivos dos efeitos práticos que decorrem da declaração e da constituição. ${ }^{428}$ Dinamarco também parece aderir a esta corrente, ao dizer que nem sempre se poderá antecipar a própria tutela, mas, em alguns casos, apenas os efeitos dela decorrentes. ${ }^{429} \mathrm{De}$ modo aparentemente convergente, Flávio Yarshell escreveu que nada impede sejam antecipados efeitos da sentença constitutiva, distinguindo tutela jurisdicional de efeitos da tutela jurisdicional. ${ }^{430}$ Para Luiz Guilherme Marinoni, quem percebe que o que na realidade busca o autor de demanda constitutiva está no plano dos efeitos conclui que é viável a antecipação dos efeitos concretos da sentença constitutiva. ${ }^{431}$ João Batista Lopes, por sua vez, também advoga a tese de que a proibição de adiantamento da tutela declaratória não se estende aos efeitos práticos dela decorrentes, ${ }^{432}$ ao que se alinhou José Roberto dos Santos Bedaque ao asseverar que uma das distinções entre tutela antecipada e julgamento antecipado é que este é técnica destinada a antecipar o provimento final, ao passo em que aquela permite a fruição antecipada de apenas efeitos do provimento. ${ }^{433}$

Em resumo, valendo-se da distinção entre tutela jurisdicional (ou efeitos principais) e efeitos práticos/fáticos/concretos da tutela jurisdicional, a doutrina em geral defende que no âmbito dos provimentos declaratórios e constitutivos é cabível a antecipação de tutela, mas que esta está restrita aos tais efeitos práticos, de modo que não é

\footnotetext{
${ }^{428}$ Cf. “Antecipação de tutela em ações declaratórias e constitutivas”, RT, v. 763, p. 15.

429 "Nem sempre a tutela jurisdicional postulada na inicial comporta antecipação integral e nem sempre se admite antecipar a própria tutela, senão apenas os seus efeitos, ou alguns deles. Se o pedido principal é de anulação de uma assembléia societária na qual fora deliberada a alienação de um bem integrante do patrimônio social, o juiz antecipa somente a proibição de alienar, mas não pode anular provisoriamente a própria assembléia, o que também seria um absurdo" (cf. "Momento de eficácia...”, n. 536, p. 968). Contudo, Dinamarco já afirmou que o que se antecipa provisoriamente é "o exercício do próprio direito afirmado pelo autor" e que "a lei fala em 'antecipar... os efeitos da tutela pretendida no pedido inicial', no pressuposto conceitual de que a tutela seja o próprio provimento a ser emitido pelo juiz. Antecipar os efeitos da tutela seria antecipar os efeitos do provimento, ou da sentença que no futuro se espera. Na realidade, tutela jurisdicional é a proteção em si mesma e consiste nos resultados que o processo projeta para fora de si e sobre a vida dos sujeitos que litigam. Ela coincide com os efeitos dos provimentos emitidos pelo juiz. Beneficiar-se de efeitos antecipados, como está na letra do art. 273, é precisamente beneficiar-se da tutela antecipada" (cf. A reforma..., pp. 141 e 142).

${ }^{430}$ Embora no mesmo parágrafo o autor afirme que " "provisoriamente' é possível antecipar tutela constitutiva como provisoriamente é possível antecipar atos de execução" (cf. Antecipação de tutela..., n.3, p. 177).

${ }^{431}$ Cf. "A tutela antecipatória...”, p. 83.

${ }^{432}$ Cf. “Tutela antecipada nas ações declaratórias”, $R T$, v. 806, p. 31.

${ }^{433}$ Cf. Código de Processo Civil Interpretado (coord. Antonio Carlos Marcato), p. 803. Melhor explicando, Bedaque entende que "o pedido de antecipação não se refere à própria tutela declaratória, condenatória ou constitutiva, mas aos efeitos que qualquer delas tende a produzir no plano material e que não possam aguarda o momento oportuno para que tal ocorra, sob de não mais terem utilidade para o titular do direito" (p. 801).
} 
possível antecipar a própria tutela final pleiteada (declaração ou constituição). Ou seja, a tutela antecipada permitiria a fruição não da tutela final, mas apenas dos efeitos (práticos) dela decorrentes. E, na verdade, isso já é o que ocorreria com a antecipação de todas as formas de tutela, inclusive a condenatória. ${ }^{434}$

Mas, afinal, o que são tais efeitos principais e qual a diferença entre eles e os efeitos práticos?

De acordo com os partidários da distinção exposta, os provimentos de mérito produzem efeitos no plano jurídico (declaração, constituição e condenação), que só podem ser obtidos pela tutela definitiva. Ao lado desses efeitos existiriam também os práticos - ou efeitos sociais, na terminologia de Teori Zavascki -, que se pronunciariam sobre a realidade ${ }^{435}$ e operacionalizariam aqueles efeitos jurídicos no plano fático. Efeitos práticos, portanto, seriam aqueles que o provimento opera sobre o mundo fenomênico e que decorrem logicamente dos efeitos principais. Estes, por sua vez, seriam os efeitos jurídicos perseguidos pelo autor da demanda (declaração, constituição ou condenação).

O que se anteciparia, assim, não seria a certificação do direito, a constituição da situação jurídica ou a condenação, mas sim os tais efeitos práticos daquelas decorrentes. ${ }^{436}$ A tutela definitiva atuaria no plano jurídico, definindo a regra de direito material que regerá a situação concreta, e, por isso, teria efeito normativo. Já a tutela antecipada trabalharia no plano dos fatos, antecipando os efeitos práticos que decorrem daquela definição. Permitir-se-ia apenas que o demandante usufruísse antecipada e provisoriamente de situações jurídicas reflexas que decorreriam naturalmente do provimento final. ${ }^{437}$

\footnotetext{
${ }^{434}$ Cf. Fredie Didier Jr., Paula Sarno Braga e Rafael Oliveira, Curso..., v. II, p. 480.

${ }^{435}$ Cf. Teoria Zavascki, Antecipação da tutela, pp. 48/49.

${ }^{436}$ Confira-se a seguinte passagem de Teori Zavascki: "Antecipar significa satisfazer, total ou parcialmente, o direito afirmado pelo autor e, sendo assim, não se pode confundir medida antecipatória com antecipação $d a$ sentença. $\mathrm{O}$ que se antecipa não é propriamente a certificação do direito, nem a constituição e tampouco a condenação porventura pretendidas como tutela definitiva. Antecipam-se, isto sim, os efeitos executivos daquela tutela. Em outras palavras: não se antecipa a eficácia jurídico-formal (ou seja, a eficácia declaratória, constitutiva e condenatória) da sentença; antecipa-se a eficácia que a futura sentença pode produzir no campo da realidade dos fatos" (cf. Antecipação da tutela, p. 48). No mesmo sentido, Bedaque: "O pedido de antecipação não se refere à própria tutela declaratória, condenatória ou constitutiva, mas aos efeitos que qualquer delas tende a produzir no plano material e que não possam aguardar o momento oportuno para que tal ocorra, sob pena de não mais terem utilidade para o titular do direito" (cf. Tutela cautelar..., p. 388).

${ }^{437}$ Cf. José Roberto dos Santos Bedaque, Tutela cautelar..., p. 321, nota 55 e pp. 392 e 393. Bedaque afirma que "não se antecipa a declaração, a condenação, nem a constituição. Antecipam-se efeitos, não o conteúdo jurídico da sentença, ou seja, seu efeito normativo. (...) Na antecipação dos efeitos existe um juízo
} 
Em que pese essa construção, parece-nos que a tutela definitiva produz não só efeitos jurídicos mas também práticos, na medida em que estes são decorrência lógica daqueles. A consequência do pensamento da doutrina exposto acima é que, por exemplo, não poderia ser desconstituído provisoriamente um negócio jurídico ou provisoriamente reconhecida a inexistência de um casamento. Mas poderiam ser antecipados os efeitos que decorreriam da desconstituição. Poderia, por exemplo, ser decretada provisoriamente a separação de corpos ou determinado ao demandado que se abstenha de levar a protesto título cuja desconstituição é pleiteada em tutela final, ou que entregue a posse de móvel transladado em decorrência de contrato de compra e venda que se quer ver declarado nulo.

A definição do que serão os efeitos práticos depende da situação de direito material envolvida no processo. Como os efeitos práticos são decorrência lógica dos efeitos principais, isto é, da tutela jurisdicional pleiteada, e esta, por sua vez, define-se pela crise jurídica submetida a julgamento, ${ }^{438}$ é lícito concluir que os efeitos práticos dependerão, também, da situação de direito material controvertida. Mas, na maior parte das vezes - senão em todas elas -, tais efeitos fáticos serão ordens dirigidas às partes. ${ }^{439}$ Serão comandos impondo às partes obrigações de fazer ou não fazer, com o fim de que não se frustre o resultado final almejado. ${ }^{440}$ Os provimentos antecipados, portanto, via de regra terão conteúdo condenatório ou mandamental, para os que admitem essa última forma.

Firmada a premissa que seriam antecipáveis apenas os efeitos práticos, e não propriamente a tutela final - premissa essa que será questionada à frente -, surge a dúvida: há necessidade de se cumular pedido cominatório (condenatório ou mandamental) final para que possam ser antecipados tais efeitos práticos? Ou seja, nas hipóteses em que o demandante não pleiteie a imposição de condenação ou ordem ao demandado, mas apenas a constituição ou declaração de situação jurídica, é possível que, em sede de antecipação de tutela, sejam impostos os "efeitos práticos" consistentes na imposição de um mandamento ou obrigação de fazer ou não fazer?

declaratório, mas limitado ao reconhecimento dos requisitos necessários à antecipação, fundado em cognição sumária" (cf. Tutela cautelar..., p. 393).

${ }^{438}$ Cf. Tomás Pará Filho, Estudo sobre..., p. 28.

${ }^{439}$ Cf. José Roberto dos Santos Bedaque, Tutela cautelar..., pp. 390; e Humberto Theodoro Jr., “Antecipação de tutela...", n. 4, p. 16.

${ }^{440}$ Vide exemplos dados por Ferruccio Tommaseo, I provveddimenti..., p. 256. 
Em princípio, a resposta é negativa, uma vez que, se a antecipação de tutela presta-se a antecipar efeitos do provimento final e os efeitos pedidos estão fora do objeto do processo, decisão que as concedesse seria extra ou ultra petita (CPC, art. 460). ${ }^{441}$ Por essa razão, há quem tenha defendido não ser possível antecipar efeitos de demandas declaratórias ou constitutivas desacompanhadas de demandas cumuladas portadoras de eficácia condenatória/mandamental e que, caso não tenha havido o cúmulo de pedido mandamental, deve o julgador determinar ao autor que emende a inicial, para que faça constar do pedido o que pretende ver antecipado. ${ }^{442}$

Com base nisso, Teori Zavascki entende que uma das distinções entre tutela cautelar e tutela antecipada é que enquanto esta deve guardar relação de pertinência com a tutela definitiva, aquela ostenta conteúdo próprio, diferente da tutela definitiva. Por isso, diz, terá natureza cautelar a providência que não coincidir com as decorrentes do direito que se quer ver consolidado. ${ }^{443}$ Essas considerações dão a entender que, não tendo sido o efeito prático pleiteado expressamente como tutela definitiva, não poderia ser antecipado. Seria como se, em demanda de desconstituição de deliberação tomada por sócios de empresa autorizando a venda de imóvel da sociedade, não tendo o autor pleiteado a restituição do bem a título de tutela final, não pudesse também pleitear fosse determinada provisoriamente a retomada da posse do imóvel.

Essa, porém, não parece ser a melhor solução. O efeito prático - que, repita-se, no mais das vezes terá por conteúdo impor obrigação de fazer ou não fazer - é aquele que decorre logicamente do provimento final. No caso das sentenças constitutivas e declaratórias, o efeito inibitório é o que decorre, lógica e naturalmente, da declaração e da constituição contidas no pedido mediato.

\footnotetext{
${ }^{441}$ Cf. Teori Zavascki, Antecipação da tutela, p. 50: "se a medida antecipatória é a que adianta efeitos da tutela definitiva, os efeitos antecipáveis são os mesmos que o demandante quer ver consolidados definitivamente, isto é, por tempo maior que o da duração do processo".

${ }^{442}$ Cf. Luiz Fernando Pereira, "Tutela antecipada...", pp. 66 e 80.

${ }^{443}$ Cf. Antecipação da tutela, p. 51. No mesmo sentido, Luiz Fernando Pereira é categórico: "Em síntese, mesmo que invocado o $\S 7^{\circ}$ do artigo da antecipação, não será possível antecipar decisão satisfativa inviável de ser confirmada ao final. Para que possa ser concedida uma decisão cautelar (isto no processo ordinário, com a inovação, ou mesmo no processo cautelar clássico), a ausência de satisfatividade é condição. Já para a antecipação satisfativa, a condição está na possibilidade de, ao final, se confirmar o liminarmente deferido" (cf. "Tutela antecipada...", p. 61).
} 
Nesse sentido, Humberto Theodoro Jr. defende que todas as sentenças, mesmo as meramente declaratórias e as constitutivas, contêm um preceito básico dirigido à parte perdedora e que consiste em não realizar ato colidente com o direito reconhecido ou constituído em favor do vencedor. ${ }^{444}$ Os provimentos declaratório ou constitutivo consistem em um comando jurídico, isto é, uma norma jurídica que regerá a situação submetida a julgamento. Esse comando, por sua vez, possui duas eficácias: uma positiva, que consiste em uma declaração ou constituição; e uma negativa, que traz um dever de que o réu se abstenha de contrariar o direito certificado. ${ }^{445}$ É natural que da própria tutela declaratória e constitutiva decorram essas imposições de conduta. Portanto, tanto melhor que o demandante, ao formular o pedido definitivo, faça-o de modo a contemplar expressamente os efeitos práticos que decorreriam daquele efeito definitivo. Isso afasta eventuais dúvidas quanto ao cabimento da tutela antecipada e possibilita ao demandado que exerça o contraditório de forma mais efetiva. Mas, a rigor, não é necessária a formulação desse pleito específico: desde que o efeito prático decorra da constituição ou declaração pleiteadas, ele poderá ser concedido em sede de antecipação de tutela e, com ainda maior razão, incluso estará na tutela definitiva.

Como visto, a doutrina de modo geral parte da distinção entre efeitos principais e práticos para defender o cabimento da antecipação de tutela no âmbito dos provimentos declaratório e constitutivo - embora poucos atentem que essa dicotomia aplica-se também à tutela condenatória. Essa distinção, porém, é correta? Parece-nos que não.

É um jogo de palavras afirmar que nos provimentos antecipatórios o autor não obtém a tutela final pleiteada, mas sim o efeito prático decorrente do julgamento do mérito da demanda declaratória ou constitutiva. ${ }^{446}$ Dizer que o que é passível de ser antecipado são os efeitos decorrentes da tutela, e não a própria tutela, não responde à indagação e parece-nos uma resposta equivocada.

Tutela jurisdicional é a proteção conferida pelo órgão jurisdicional ao sujeito que está amparado pelo direito material. É o resultado jurisdicional concedido ao titular do

\footnotetext{
${ }^{444}$ Cf. "Antecipação de tutela...”, n. 4, p. 16. Aparentemente de acordo, Paulo Lucon, Eficácia das decisões..., pp. 285/286.

${ }^{445}$ Cf. Fredie Didier Jr., Paula Sarno Braga e Rafael Oliveira, Curso..., v. 2, p. 482.

${ }^{446}$ As palavras são de João Batista Lopes, "Tutela antecipada...”, p. 31.
} 
direito material. Acontece que esse resultado consiste nos efeitos jurídicos e fáticos que decorrem do provimento, de modo que tutela jurisdicional são os efeitos que amparam a parte que tem razão à luz do direito material. Não é possível distinguir tutela de efeitos da tutela porque são a mesma coisa. Não há sentido em diferenciar tutela jurisdicional (ou efeitos principais) de efeitos práticos, sociais ou fáticos. Todos esses efeitos compõem a tutela jurisdicional e, portanto, a tutela é ela própria efeitos.

E mais. Afora a existência de disposições legais específicas, não há razão para distinguir as tutelas declaratória e constitutiva da condenatória. Também no caso da execução provisória da sentença condenatória não se pode dizer que o direito instrumentalizado no título é definitivo, pois ele também está sujeito a eventual modificação quando do julgamento do recurso. A principal característica da execução provisória da sentença condenatória é a resolubilidade, e não se vê por que as objeções levantadas acima por parte da doutrina não se aplicariam também nesse âmbito, rechaçando-se também a condenação provisória.

Todas as modalidades de tutela cognitiva possuem um elemento declaratório, consistente no reconhecimento de que o direito alegado pelo demandante está presente no caso concreto. Por isso, na decisão condenatória, que, como visto, é reconhecida e amplamente passível de antecipação, também há referido elemento, que atua como pressuposto lógico da aplicação da sanção, e, portanto, nela também há uma declaração provisória. Ou seja, a rigor, os que admitem a condenação provisória - e não parece haver quem a negue ${ }^{447}$ - não se dão conta de que, ao assumirem essa posição, estão defendendo, também, a declaração provisória, ainda que apenas do elemento declaratório que está contido em todo e qualquer provimento.

O mesmo se dá com a tutela constitutiva. Há casos em que inegavelmente existe verdadeira constituição provisória. Um exemplo é o aluguel provisório fixado enquanto pendente a ação revisional de aluguel, previsto pelo art. 68, II da Lei 8.245/91. Irrefutável que, ao invés de simplesmente estar sendo antecipado o efeito prático condenatório da

\footnotetext{
${ }^{447}$ E mais. A tutela condenatória é o âmbito "di più sicura applicazione del procedimento d'urgenza", como apontou Ferruccio Tommaseo, I provvedimenti..., p. 254.
} 
tutela principal, está havendo verdadeira constituição provisória. A relação obrigacional é alterada, ainda que provisoriamente. ${ }^{448}$

Não é só. É difícil aceitar a ideia de que seja concedido apenas o consequente (efeitos) e não o antecedente (declaração ou constituição), na medida em que, por sua própria definição, o antecedente atua como causa (jurídica) do consequente. Melhor explicando, temos certa dificuldade em compreender como se podem antecipar efeitos sem que se antecipe o título jurídico desses efeitos, que é a declaração ou a constituição.

A rigor, a ideia que se está combatendo agora é a negação do maior legado de Liebman: a distinção entre efeitos do provimento e autoridade da coisa julgada material. Não é porque ainda pende discussão judicial que os efeitos do provimento - ainda que resultantes de cognição sumária - não possam se produzir. Os efeitos podem se produzir a qualquer momento, bastando haver decisão judicial que lhes atue como causa. $\mathrm{O}$ grande problema é o custo jurídico da liberação prematura da eficácia das decisões judiciais.

Portanto, deixando de lado o fato de que existem disposições legais expressamente autorizando a execução provisória da sentença condenatória, não se entende a razão pela qual se admite a antecipação dessa modalidade de tutela, e não das tutelas declaratória e constitutiva. Em nosso entender, é cabível a antecipação dessas duas espécies de provimento; e ela não está limitada aos efeitos práticos. É sim possível, portanto, a declaração e a constituição provisórias.

É verdade que não há disposição legal específica autorizando a efetivação provisória das tutelas meramente declaratória e constitutiva. Portanto, como visto acima, vigora para essas modalidades de provimento a regra geral enunciada por Liebman, de que a liberação de efeitos anteriormente ao trânsito em julgado depende de permissão do direito posto. Contudo, também como visto, a tutela cautelar tem sede constitucional e parece que a melhor interpretação é a de que a própria Constituição, ao estatuir que "a lei não excluirá da apreciação do Poder Judiciário lesão ou ameaça a direito" (art. 5º XXXV), está permitindo a antecipação de qualquer forma de tutela, desde que necessária para afastar lesão ou ameaça de lesão a direito.

${ }^{448}$ Aparentemente de acordo, Luiz Guilherme Marinoni, "A tutela antecipatória...”, p. 83. 
Embora, realmente, a liberação de efeitos das tutelas declaratória e constitutiva dependa do trânsito em julgado do provimento de mérito que as concede, isso não significa que não é possível a antecipação de tais efeitos provimentos declaratórios e constitutivos. Esta é cabível e permite a fruição de efeitos fáticos e jurídicos que decorreriam da tutela jurisdicional final, que, enquanto tal, é ela própria constituída de efeitos. É necessário maior rigor para a antecipação dessas espécies de tutelas, pois, em regra, têm um grau de irreversibilidade maior do que as condenatórias. Mas a questão toda se resolve unicamente na avaliação dos graus de reversibilidade da medida, e não no conteúdo das modalidades de tutelas jurisdicionais.

Uma coisa é afirmar que as tutelas meramente declaratórias e constitutivas só se tornam eficazes com o trânsito em julgado. Isso é correto e, a rigor, o que ocorre também com a condenatória. Mas não se pode concordar com as posições de que não seria cabível a antecipação daquelas modalidades de provimento ou que, sendo cabível, estaria restrita ao que se convencionou chamar de efeitos práticos. Pelo contrário, na antecipação dessas modalidades de tutelas jurisdicionais, há verdadeira declaração e constituição provisórias. A pedra de toque para a possibilidade de imposição de efeitos de uma sentença não definitiva é o seu grau de reversibilidade. Quer se trate de condenação, de constituição ou de declaração, a regra é a espera pelo julgamento definitivo. Mas, havendo necessidade e estando atendidos os requisitos legais, poderá haver liberação antecipada de efeitos.

Por isso é que, para além da distinção entre as modalidades de tutelas jurisdicionais, parece-nos que o correto é colocá-las juntas e ter-se a percepção de que tudo se resolve na reversibilidade ou não da medida. Pouco importa de qual tutela se esteja tratando. O que importa é a relação custo/benefício que a medida representará, levando-se em consideração a perspectiva da reversibilidade.

Caberá aos sujeitos processuais utilizarem as ferramentas jurídicas disponibilizadas pelo sistema para minorar o risco jurídico inerente à efetivação provisória dessas modalidades de tutelas (caução, responsabilização objetiva da parte beneficiada pela medida etc). Mas esta é outra questão, que não cabe ser abordada aqui. O importante é assentar que a declaração e a constituição provisórias são sim possíveis. E essa 
consideração é importante porque, embora não seja esse exatamente o objeto deste trabalho, aqui se procura estudar a maneira pela qual atua a jurisdição na desconstituição de deliberações assembleares, à qual não raro estão atreladas as chamadas demandas de suspensão de deliberações sociais.

\section{Vícios de deliberações assembleares e conteúdo do provimento}

O provimento que julga improcedente pedido de desconstituição de deliberação assemblear possui conteúdo declaratório negativo, pois apenas atesta a inexistência do direito que fundamenta a pretensão deduzida na demanda. Quer se trate de anulabilidade, quer de nulidade, a sentença que julgar improcedente qualquer pedido - e não só o de desconstituição de atos jurídicos - será sempre meramente declaratória. ${ }^{449}$ Questão diversa - e mais complexa - é a que diz respeito ao conteúdo da sentença de procedência.

Diante dos conceitos expostos anteriormente, logo se vê que a desconstituição de deliberações assembleares não é exercida por meio das tutelas executiva ou cautelar. Quando se pleiteia a desconstituição de atos jurídicos não se está pedindo a atuação prática de uma norma jurídica concreta condenatória, tampouco a concessão de providência que minimize os efeitos deletérios do decurso do tempo. Não se pede decisão com o fito de invadir patrimônio do devedor ou de coagi-lo psicologicamente a adimpliar a sua prestação (tutela executiva), nem de prevenir o dano marginal do processo (tutela cautelar). Referida desconstituição é exercida por meio da tutela cognitiva. Resta saber por meio de qual de suas subclasses.

\footnotetext{
${ }^{449}$ Cf. Edoardo Ricci, "Sugli effetti del rigetto dell'impugnazione di delibera assembleare di S.P.A.”, Rivista di diritto processuale, v. 50, n. 1, p. 59; Jauernig, Direito processual..., n. 59, p. 308; Chiovenda, "Azioni e sentenze di mero accertamento" e "Azione di mero accertamento", pp. 19 e 51; Andrea Proto Pisani, “Appunti sul giudicato civile e suoi limiti oggettivi”, Rivista di diritto processuale, v. 45, n. 2, p. 405 e “Appunti sulla tutela di mero accertamento", p. 622; Arruda Alvim, Manual..., n. 299, p. 1.086; e Heitor Sica, $O$ direito de defesa no processo civil brasileiro, n. 10.2, p. 211. De acordo com Botelho de Mesquita, contudo, a sentença de improcedência possui apenas elemento declaratório, e não efeito declaratório, na medida em que, para ele, apenas as sentenças de procedência são aptas a emanar efeitos, isto é, alterar o mundo jurídico (cf. "Sentença e coisa julgada", in Teses, estudos e pareceres de direito processual civil, v. 2, p. 159). Com efeito, na sua peculiar teoria, a sentença de improcedência não produz efeitos, isto é, não gera nenhuma alteração no mundo jurídico. Com o trânsito em julgado a conclusão da sentença de improcedência torna-se imutável entre as partes. Mas isso não é um efeito da sentença, e sim do trânsito em julgado, que está limitado às partes. A sentença de procedência, portanto, produz efeitos subjetivamente irrestritos; a de improcedência limita-se às partes (cf. "A coisa julgada no Código do Consumidor”, in José Rogério Cruz e Tucci (coord.), Processo civil: evolução, 20 anos de vigência, pp. 143/144).
} 
Afastada a tutela executiva, desde logo deve ser afastada também a tutela condenatória, por haver relação de complementaridade entre elas: só se fala em execução quando há condenação e, não havendo condenação sem execução (a menos que haja cumprimento espontâneo), as duas formas de tutela são indissociáveis. Ademais, esta última é adequada para a superação de crises de adimplemento, e não há crise desse tipo na invalidade de deliberação. O que se quer com a impugnação de uma deliberação é extirpar do mundo jurídico o ato que se supõe inválido - ou, quando menos, excluir seus efeitos. Restam, assim, as tutelas meramente declaratória e constitutiva, que, de fato, são as usualmente atreladas à impugnação de atos jurídicos.

Costuma-se, com efeito, associar-se a impugnação do ato jurídico nulo e do inexistente ao provimento meramente declaratório e a impugnação do ato anulável ao provimento constitutivo negativo. À base desse raciocínio está a ideia de que a nulidade priva integralmente o ato jurídico de efeitos jurídicos, o qual, em razão disso, desde a sua gênese ( $a$ b ovo) sequer produziria efeito jurídico a ser desconstituído. Quod nullum est, nullum producit effectum: o ato nulo é ineficaz ipso iure e, portanto, não produz efeitos, de modo que diante dele não existe crise de situação jurídica, mas apenas de certeza. ${ }^{450}$ Assim, apenas declarar-se-ia a nulidade do ato, sem necessidade de serem desconstituídos seus efeitos. O próprio vício seria a causa da ineficácia. ${ }^{451}$ Já os atos anuláveis, por serem eficazes - ainda que apenas precariamente -, deveriam ser objeto da tutela constitutiva, para que seus efeitos sejam eliminados. O provimento que se pronuncia pela anulabilidade, pois, ostentaria natureza constitutiva, pois é ele que atuará como causa da modificação jurídica pretendida. $\mathrm{O}$ ato anulável produziria efeitos precários e a supressão desses efeitos operar-se-ia por força da decisão judicial, que funcionaria, portanto, como causa ou título da mutação. ${ }^{452}$ A nulidade, logo, deveria ser atacada por provimento declaratório, e a anulabilidade, por provimento constitutivo.

\footnotetext{
450 Cf. Andrea Pisani Massarmormile, "Invalidità delle delibere...", n. 2, p. 57; e Antigono Donati, L'invalidità..., n. 15, p. 58. Nesse sentido, Carnelutti afirma que "en el proceso de nulidad de un contrato, la declaración de certeza es mera, porque la validez o la nulidad del contrato existe exactamente igual antes o después del juicio" (cf. Instituciones..., v. 1, n. 34, p. 71).

${ }^{451}$ Cf. Chiara Besso, La sentenza civile inesistente, cap. I, n. 2, p. 22. Essa posição, como apontou Andrea Proto Pisani, "si tratta di affermazioni comuni a tutta la manualistica di diritto privato" ("Appunti sulla tutela di mero accertamento", p. 665, nota 87).

452 Cf. Fazzalari, Istituzioni..., cap. IX, n. 3, p. 417; Hörster, A Parte Geral..., n. 348, p. 213; e Stefano Villata, Impugnazioni..., cap. II, n. 14, p. 243. A seguinte passagem de Liebman sintetiza esse pensamento: "Toda diferença entre nulidade e anulabilidade está precisamente nisso: a primeira é consequiência de um defeito tão radical que o contrato nunca veio a ter existência jurídica, enquanto as causas de anulabilidade
} 
Esse entendimento, colhido no âmbito da teoria geral dos atos jurídicos, é, como apontou Carnelutti ao comentar o art. 163 do antigo Código Comercial italiano, de modo geral adotado pelos comercialistas ${ }^{453}$ e transposto também para o terreno da invalidade das deliberações assembleares.

No direito italiano, com efeito, Stefano Villata registrou ser tradicional e dominante a afirmação de que a demanda de anulação de deliberação é tipicamente constitutiva, e que a que versa sobre uma causa de nulidade é declaratória. ${ }^{454} \mathrm{E}$, de fato, já na doutrina peninsular da primeira metade do século passado podem ser apontados os seguintes defensores da ideia: Mario Vaselli, ${ }^{455}$ Aurelio Candian, ${ }^{456}$ Pietro Trimarchi, ${ }^{457}$ Romano-Pavoni ${ }^{458}$ e Antigono Donati. ${ }^{459}$ Também Ascarelli, fazendo considerações ao art. 156 do revogado DL 2.627/40 brasileiro, expressamente afirmou ser declaratória a sentença que se pronuncia sobre a ineficácia, a nulidade ou a inexistência, e constitutiva a

permitem a existência do contrato, ainda que viciado, e apenas a sentença do juiz produzirá sua anulação" (cf. Manual..., v. 1, n. 86, p. 244). Flávio Yarshell também afirma que "sentenças de conteúdo meramente declaratório" aplicam-se aos casos de nulidade, ao passo em que sentenças constitutivas aplicam-se aos casos de anulabilidade (cf. "Tutela jurisdicional meramente declaratória", p. 49). Barbosa Moreira igualmente diz que "a sentença que pronuncie a nulidade será meramente declaratória, e a que anule o contrato será constitutiva" ("Reflexões críticas...", pp. 75/76). Invoque-se ainda Arruda Alvim, que, tratando de nulidade de contrato, preconiza que, em se tratando de nulidade absoluta, o remédio adequado é a demanda declaratória, ao passo que, em se tratando de anulabilidade ou nulidade relativa, a parte deve valer-se de demanda constitutiva negativa (cf. "Ação declaratória de nulidade de cláusula contratual”, RePro, n. 47, p. 126). E mais: esse autor rechaça expressamente a ação desconstitutiva para impugnar o vício de nulidade: "A circunstância de uma cláusula contratual não poder prevalecer, porque contrária à lei, torna-a nula. E se esta nulidade não pudesse (como, de fato, pode) ser declarada por meio de ação declaratória, cabe indagar-se, por que meio o seria? Se não se admite a ação declaratória para se declarar nulo um contrato, qual seria o instrumento idôneo para obter essa declaração de nulidade do Poder Judiciário? Certamente, não a ação desconstitutiva, pois nada haveria a desconstituir-se!” (p. 127). Indo na mesma direção, Tomás Pará Filho asseverou que, em se tratando de ato nulo, a sentença será declaratória, e em se tratando de ato anulável, constitutiva (cf. Estudo sobre..., p. 31). Para Cintra-Grinover-Dinamarco, também a decisão que se pronuncia sobre a nulidade de ato jurídico é meramente declaratória e que a que o anula é constitutiva (cf. Teoria geral, nn. 194 e 196, pp. 311 e 313). No mesmo sentido, Orlando Gomes, Introdução..., n. 279, p. 474; Serpa Lopes, Curso..., v. 1, n. 357, p. 506; e Álvaro Villaça Azevedo, Código..., p. 337. Na doutrina portuguesa, Paulo Olavo Cunha ensina que "um acto nulo é um acto que não produz quaisquer efeitos, podendo a ordem declará-lo nesses termos sem dependência de prazo" e que "enquanto os actos nulos não produzem efeitos, os que são meramente anuláveis produzem efeitos até que serem invalidados" (cf. Direito das sociedades..., n. 30.4.2, p. 696). V., ainda, Corrado Ferri, que bem aponta que a natureza declaratória ou constitutiva da sentença depende da natureza (material) do vício cujo acertamento tem por objeto (cf. Profili..., p. 197).

${ }^{453}$ Cf. "Eccesso di potere...", p. 176.

${ }^{454}$ Cf. Impugnazioni..., cap. II, n. 13, p. 230.

${ }^{455}$ Cf. Mario Vaselli, Deliberazioni..., parte II, cap. II, n. 5, pp. 72/73.

${ }^{456}$ Cf. Nullità e annulabilità di delibere di assemblea delle società per azioni, n. 71, p. 139.

${ }^{457}$ Cf. Invalidità..., cap. XIII e XIV, pp. 207/209.

${ }^{458}$ Cf. Le deliberazioni..., n. 35, p. 131.

${ }^{459}$ Cf. L'invalidità..., nn. 73 e 78, pp. 224/225 e 241. 
que diz respeito à anulabilidade, ${ }^{460}$ enquanto Chiovenda vinculou o direito de impugnar deliberações à tutela constitutiva, incluindo tal direito na categoria dos potestativos. ${ }^{461}$ Mais recentemente, Francesco Terrusi e Giorgio Meo aderiram às dicotomias nulidadetutela meramente declaratória e anulabilidade-tutela constitutiva, ${ }^{462}$ ao passo em que Gianluca Guerrieri aponta ser essa a posição da doutrina predominante. ${ }^{463}$

No direito português, o art. 59 do Código das Sociedades Comerciais refere-se à "acção de anulação" de deliberações dos sócios, ao passo em que o art. 60 menciona a "acção de declaração" de nulidade. ${ }^{464}$ Sobre essa distinção, Pinto Furtado afirma que a demanda que tem por objeto impugnar deliberação inexistente é meramente declaratória,

${ }^{460}$ Cf. "Vícios das deliberações...", pp. 386 e 414. Tratando do art. 163 do antigo Codice Commerciale italiano, Ascarelli fez as mesmas considerações (cf. Appunti di diritto commerciale - società e associazioni commerciali, pp. 281 e 284/285). Embora com considerações singulares, que se distanciam do esquema tradicional, Corrado Ferri também alude à dicotomia demanda declaratória/demanda anulatória (cf. "Le impugnazioni...", n. 1, p. 52). V., ainda, Stefania Pacchi Pesucci, "Impugnazione di delibere...”, pp. 45/46.

${ }^{461}$ Cf. "L'azione...”, p. 21. Da mesma forma Corrado Ferri, que diz ser potestativo o direito à anulação da deliberação inválida (cf. "Le impugnazioni...”, n. 3, p. 58).

${ }^{462}$ Cf. L'invalidità..., n. 5.3, 5.4 e 6.1., pp. 228, 229 e 279; e Gli effetti..., cap. V, n. 1, pp. 273/274.

${ }^{463}$ Cf. La nullità..., cap. V, n, 14, p. 350.

${ }^{464}$ Artigo $59^{\circ}$ (Acção de anulação)

1. A anulabilidade pode ser arguida pelo órgão de fiscalização ou por qualquer sócio que não tenha votado no sentido que fez vencimento nem posteriormente tenha aprovado a deliberação, expressa ou tacitamente.

2. O prazo para a proposição da acção de anulação é de 30 dias contados a partir:

a) Da data em que foi encerrada a assembleia geral;

b) Do 3. ${ }^{\circ}$ dia subsequente à data do envio da acta da deliberação por voto escrito;

c) Da data em que o sócio teve conhecimento da deliberação, se esta incidir sobre o assunto que não constava da convocatória.

3. Sendo uma assembleia geral interrompida por mais de quinze dias, a acção de anulação de deliberação anterior à interrupção pode ser proposta nos 30 dias seguintes àquele em que a deliberação foi tomada.

4. A proposição da acção de anulação não depende de apresentação da respectiva acta, mas se o sócio invocar impossibilidade de a obter, o juiz mandará notificar as pessoas que, nos termos desta lei, devem assinar a acta, para a apresentarem no tribunal, no prazo que fixar, até 60 dias, suspendendo a instância até essa apresentação.

5. Embora a lei exija a assinatura da acta por todos os sócios, bastará para o efeito do número anterior, que ela seja assinada por todos os sócios votantes no sentido que fez vencimento.

6. Tendo o voto sido secreto, considera-se que não votaram no sentido que fez vencimento apenas aqueles sócios que, na própria assembleia ou perante notário, nos cinco dias seguintes à assembleia tenham feito consignar que votaram contra a deliberação tomada.

Artigo $60^{\circ}$ (Disposições comuns às acções de nulidade e de anulação)

1. Tanto a acção de declaração de nulidade como a de anulação são propostas contra a sociedade.

2. Havendo várias acções de invalidade da mesma deliberação, devem elas ser apensadas, observando-se a regra do n. 2 do artigo $275 .^{\circ}$ do Código de Processo Civil.

3. A sociedade suportará todos os encargos das acções propostas pelo órgão de físcalização ou, na sua falta, por qualquer gerente, ainda que sejam julgadas improcedentes. 
que, se acolhida, não promoverá qualquer alteração na ordem jurídica, já que, por definição, estar-se-á na presença de algo que não tem existência jurídica. A demanda que pretende o reconhecimento da ineficácia da deliberação também é declaratória - de simples apreciação, diz o autor. ${ }^{465}$ Já a demanda anulatória prevista pelo art. 59 do Código das Sociedades Comerciais, ainda de acordo com esse autor, possuiria natureza constitutiva, na medida em que não culmina na mera certificação do direito, mas sim em sentença que anula a deliberação. ${ }^{466}$ A demanda declaratória de nulidade, prevista pelo art. 60 do Código das Sociedades Comerciais, por sua vez, seria de mero acertamento ou, para utilizar a terminologia do direito português, ação de simples apreciação. ${ }^{467}$

Ainda no direito lusitano, Vasco da Gama Lobo Xavier reporta-se à ação de simples apreciação ao tratar da nulidade da deliberação, invalidade essa que operaria desde o início e de pleno direito. ${ }^{468}$ Também L. P. Moitinho de Almeida, ${ }^{469}$ Carneiro da Frada, ${ }^{470}$ Paulo Olavo Cunha ${ }^{471}$ e Menezes Cordeiro ${ }^{472}$ acolhem essa relação.

A AktG alemã prevê para a anulabilidade das deliberações uma demanda de anulação (§ 246) e para a nulidade uma demanda de declaração de nulidade (§ 249). ${ }^{473}$ Já a Lei de Sociedades Anônimas espanhola, de 1989, alterou a lei anterior, de 1951, que distinguia uma acción de impugnación, para as deliberações anuláveis, e uma acción de nulidad, para os vícios de nulidade (arts. 69 e 70). A atual lei espanhola contempla apenas uma acción de impugnación, tanto para os acuerdos nulos como para os acuerdos

\footnotetext{
${ }^{465}$ Cf. Deliberações de sociedades..., nn. 97 e 110; pp. 714 e 751. Diz o citado autor: "Acção de declaração de nulidade é a oposto a deliberação eivada de nulidade. Utiliza-se a expressão declaração de nulidade para salientar o efeito meramente declarativo da sentença - efeito que ocorrerá também nas acções que se dirijam a uma deliberação ineficaz stricto sensu ou ferida de inexistência jurídica" (cf. Curso..., n. 85, p. 470).

${ }^{466}$ Cf. Deliberações de sociedades..., p. 726.

${ }^{467}$ Cf. Curso..., n. 82, p. 450; e Deliberações de sociedades..., p. 751.

${ }^{468}$ Para o negócio jurídico em geral, "a nulidade opera desde logo, ipso jure ou ipsa vi legis, sem necessidade de declaração judicial”, o que se aplicaria também às deliberações. Indica farta doutrina italiana, alemã e espanhola nesse sentido (cf. Anulação..., n. 4, p. 70, inclusive nota 5).

${ }^{469}$ Cf. Anulação e suspensão..., p. 52.

${ }^{470}$ Cf. Renovação de deliberações sociais, n. 1, p. 3.

${ }^{471}$ Cf. Direito..., n. 30.4.2, p. 696.

472 Cf. Direito..., v. I, n. 294, p. 809.

${ }^{473}$ Cf. Von Gierke, Derecho comercial y de la navegación, v. I, pp. 468/472; Kubler, Derecho de sociedades, p. 342/345; e Würdinger, German company law, p. 59: "Under German law a distinction is made between void and voidable resolutions. Void resolutions are invalid from their inception; judicial annulment can be applied for by any person, and is merely declaratory. Voidable resolutions, on the other hand, are effective, but may be invalidated by the court on the ground of a material or procedural defect. The resolution becomes void only when the court so rules in an acion".
} 
anulables (art. 116), embora estabeleça distinções, quanto aos dois tipos de vícios, no que diz respeito ao prazo para o exercício do direito de ação e à legitimidade processual. ${ }^{474}$ Apesar disso, Jose Vicente Soria Ferrando faz menção às demandas de anulidade e de nulidade ao tratar da impugnação de acuerdos de la junta general de la sociedad anónima. $^{475}$

Essas conclusões fazem eco na doutrina brasileira. Erasmo Valladão França expressamente atrelou a pretensão meramente declaratória às deliberações nulas e ineficazes, e a pretensão constitutiva às deliberações anuláveis, ${ }^{476}$ embora tenha afirmado, em obra recente, ter revisto essa posição. ${ }^{477}$ Priscila Corrêa da Fonseca menciona demandas de nulidade e anulação, ligando aquela à tutela meramente declaratória, e esta, à constitutiva. ${ }^{478}$ De acordo com Luiz Fernando C. Pereira, após ajuizar a demanda de suspensão de deliberação, a parte deve ajuizar demanda desconstitutiva ou declaratória negativa: aquela, caso queira anular a deliberação; esta, caso queira declarar a nulidade ou inexistência da deliberação. ${ }^{479}$ Eduardo Talamini anota que a demanda será de anulação ou declaração de nulidade de deliberações da assembleia geral de sociedade anônima, a depender da natureza do vício (nulidade ou anulabilidade). ${ }^{480}$ Também Dinamarco, ${ }^{481}$ Barbosa Moreira $^{482}$, Egas Moniz de Aragão ${ }^{483}$, José Rogério Cruz e Tucci ${ }^{484}$, Heitor Sica e Marcelo Bonício ${ }^{485}$ e Paulo Cézar Aragão ${ }^{486}$ aludem às ações de anulação e de declaração de nulidade de deliberação de assembleia.

\footnotetext{
${ }^{474}$ Cf. Jorge Henrique da Cruz Pinto Furtado, Deliberações de sociedades..., p. 751.

${ }^{475} \mathrm{Cf}$. La legitimación activa para la impugnación de acuerdos de la junta general de la sociedad anónima, cap. I, n. 3, p. 24.

${ }^{476}$ Cf. Invalidade..., nn. 20.1.1, 20.1.3 e 21, pp. 119, 121 e 126/127, especialmente notas 132 e 140.

${ }^{477}$ Cf. Erasmo Valladão França e Marcelo Adamek “Algumas notas...”, p. 157, nota 1.

${ }^{478}$ Cf. Suspensão..., cap. IX, p. 152.

${ }^{479}$ Cf. Luiz Fernando C. Pereira, Medidas urgentes..., p. 159.

${ }^{480}$ Cf. Coisa julgada..., p. 99, embora em trabalho mais recente tenha escrito que "fica afastada, aliás, a ideia - incorreta, de resto, também em outros campos - de que a impugnação por nulidade envolveria mera providência declaratória. Mesmo o ato nulo há de ser desconstituído, na medida em que precisa ser retirado da ordem jurídica" (cf. "Legitimidade, interesse...", p. 114, nota 27).

${ }^{481}$ Cf. Litisconsórcio, n. 93, p. 228.

${ }^{482}$ Cf. Litisconsórcio unitário, nn. 7, 11, 48, pp. 21, 26, 74 nota 50, 81 e 130.

${ }^{483}$ Cf. Sentença e coisa julgada, n. 208, p. 302.

${ }^{484}$ Cf. "Impugnação judicial...", p. 464.

${ }^{485}$ Cf. "Litisconsórcio unitário: aspectos materiais e processuais" (inédito), p. 10.

${ }^{486}$ Cf. "Aspectos processuais da legislação societária”, $R T$, v. 641, p. 64.
} 
Conquanto amplamente difundida, essa distinção é correta? A deliberação nula realmente deve ser impugnada por demanda meramente declaratória e a anulável por demanda constitutiva?

A tutela meramente declaratória, como visto, exaure-se em um enunciado que procura conferir certeza a uma situação jurídica. ${ }^{487}$ Visa, apenas, a debelar uma crise de certeza. No caso da declaração de nulidade de deliberação social, pode-se dizer que há apenas uma crise de certeza? Parece-nos que não.

Ainda que se afirme, em peso, que o ato nulo não produz efeito algum, ele é, ainda que minimamente, eficaz (v. item 12). Por isso, é necessário um provimento judicial para que os seus efeitos sejam banidos do mundo jurídico. A despeito do brocardo quod nullum est, nullum producit effectum, a assertiva de que o ato nulo é absolutamente ineficaz deve ser vista com ressalva. ${ }^{488}$ Daí já se ter dito inexistir incompatibilidade ontológica entre nulidade e eficácia. ${ }^{489}$

Negar que o ato nulo produza efeitos e defender que o pronunciamento judicial vem apenas a reconhecer tal ineficácia é uma ficção que nega a natureza das coisas. Em defesa disso, veja-se que parte da doutrina, ao tratar dos atos nulos, fala em desaparecimento dos efeitos produzidos. Nesse sentido, de acordo com Silvio Venosa, a regra enunciada no brocardo há pouco referido deve ser vista com temperamentos, em decorrência dos chamados efeitos materiais que podem decorrer do ato nulo. Referido autor cita como exemplo o negócio jurídico celebrado por alienado mental com contratante de boa-fé: o ato é nulo, mas o sistema lhe reconhece certos efeitos. ${ }^{490}$

Outro exemplo é o casamento putativo, isto é, celebrado quando pelo menos um dos contraentes ignora algum impedimento. Ele é nulo, mas, premiando a boa-fé, o Código Civil lhe atribui efeitos: “Art. 1.561. Embora anulável ou mesmo nulo, se contraído de boafé por ambos os cônjuges, o casamento, em relação a estes como aos filhos, produz todos

\footnotetext{
487 "Nas sentenças declaratórias, a atestação autoritativa de uma vontade concreta da lei esgota o escopo do provimento" (cf. Tomás Pará Filho, Estudo sobre..., p. 28).

${ }^{488}$ Cf. Francesco Terrusi, L'invalidità..., n. 5.2, p. 225.

${ }^{489}$ Cf. Gianluca Guerrieri, La nullità..., cap. V, n. 14, p. 333.

${ }^{490}$ Cf. Direito Civil, v. I, pp. 592/593.
} 
os efeitos até o dia da sentença anuatória". Ainda, o $§ 1^{\circ}$ desse artigo dispõe que "se um dos cônjuges estava de boa-fé ao celebrar o casamento, os seus efeitos civis só a ele e aos filhos aproveitarão", ao passo em que o $§ 2^{\circ}$ determina que "se ambos os cônjuges estavam de má-fé ao celebrar o casamento, os seus efeitos civis só aos filhos aproveitarão". A eficácia do casamento em relação aos filhos, ainda que aquele seja nulo, é incondicional. ${ }^{491}$

Em outras hipóteses há efeitos indiretos, ${ }^{492}$ como é o caso do negócio jurídico translativo de domínio, que anulado não serve à transmissão da propriedade, mas vale como causa justificativa da posse. Outros exemplos são o da nulidade do instrumento hipótese em que ocorre o aproveitamento do ato como prova da obrigação ${ }^{493}$, o cumprimento de relação de trabalho com base em contrato nulo e a nulidade de atos de registro de imóveis, que produzem efeitos a favor de terceiros de boa-fé. ${ }^{494}$ Antonio Junqueira de Azevedo dá como exemplos de atos nulos eficazes o do casamento putativo, o da caducidade do legado e o do contrato de trabalho. ${ }^{495}$

Ainda que se trate de efeitos menores e diversos dos efeitos do ato válido, é inegável que eles são produzidos pelo ato nulo e que a sua existência só pode ser

${ }^{491}$ Cf. Marcos Bernardes de Mello, Teoria do fato jurídico - plano da validade, p. 40.

${ }^{492}$ Zeno Veloso aponta que "como regra geral, o negócio nulo não produz quaisquer efeitos jurídicos. (...) Excepcionalmente, porém, o nulo produz algum efeito, efeito indireto, efeito reflexo. Isso ocorre muito raramente, poucos são os casos, apontando-se na doutrina: a) casamento putativo (art. 1.561); b) citação, mesmo nula por incompetência do juiz, interrompe a prescrição e constitui o devedor em mora (CPC, art. 219); c) a declaração feita em instrumento nulo serve como começo de prova; d) o negócio translativo de propriedade nulo funciona, não obstante, como causa justificativa da posse" (cf. Invalidade..., n. 25, p. 146).

${ }^{493}$ Cf. Caio Mário da Silva Pereira, Instituições..., v. I, p. 550. O autor citado confere ainda exemplo do direito processual, como é o caso da citação nula por incompetência do juízo, que interrompe a prescrição e constitui o devedor em mora (CPC, art. 219). Quanto a isso, cabe observar que o regime de nulidades no direito processual é radicalmente diverso do no direito civil, e que o ato processual, enquanto ato estatal imperativo, sempre deve ser desconstituído, não se podendo falar em nulidade processual de pleno direito. A respeito da relação entre os dois sistemas, v. Heitor Sica, “Contribuição ao estudo...”. Por outro lado, há quem diga que o ato nulo deve ser necessariamente desconstituído em duas hipóteses: quando há dúvida acerca da nulidade e registro público do ato nulo, como é o caso do casamento e do acordo de transmissão do bem imóvel (cf. Marcos Bernardes de Mello, Teoria do fato jurídico - plano da validade, p. 41). Com relação à primeira hipótese, não se trata de efeitos que devem ser desconstituídos: o que existe é dúvida, que deve ser debelada pelo provimento. Portanto, havendo apenas dúvida sobre a nulidade a tutela adequada é a meramente declaratória, e não a constitutiva. Mesmo Bernardes de Mello parece reconhecer isso ao afirmar que "caso seja evidente, indiscutível a nulidade e não haja registro público do ato jurídico, é despicienda sua desconstituição judicial, uma vez que esta se refere, apenas, ao ato em si, para expulsá-lo do mundo jurídico, pois não há efeitos a desfazer" (p. 41). Na segunda hipótese, não existem efeitos a serem desconstituídos, pois tais efeitos já foram desconstituídos, sendo necessária apenas a prática de uma formalidade (execução imprópria).

${ }^{494}$ Cf. Ilaria Pagni, Le azioni..., cap. VI, n. 5, p. 590.

${ }^{495}$ De acordo com o eminente civilista, essas são hipóteses excepcionais, nas quais nem sempre os efeitos produzidos são os próprios ou típicos dos atos (cf. Negócio jurídico..., cap. 2, n. 4, pp. 49/52). 
contrabalanceada por uma decisão judicial. Daí porque mesmo a sentença que se pronuncia sobre uma causa de nulidade deve ser considerada constitutiva. ${ }^{496}$ Parte da doutrina processual contemporânea, a propósito, põe em dúvida a teoria clássica de que, por serem os atos nulos desprovidos de efeito, a tutela meramente declaratória seria a adequada para esses tipos de vícios. Isso porque certos atos nulos produzem efeitos alguns efeitos secundários que, ainda que minoritários, estão sempre presentes. Por isso, a demanda de nulidade não deve ser qualificada como meramente declaratória, mas sim como constitutiva. ${ }^{497}$

Também negando ser l'azione di nullità meramente declaratória, Andrea Proto Pisani defende que, embora o ato nulo não produza os mesmos efeitos que o válido, também é verdade que gera certa quantidade de efeitos que não podem ser simplesmente desconsiderados. São efeitos quantitativamente menores e diversos daqueles produzidos pelo ato válido, mas que mesmo assim devem ser levados em conta. Por isso, para que o ato nulo seja privado desses efeitos - que, nas palavras do professor de Firenze, são limitados mas sempre existentes -, é necessário provimento que os remova, provimento esse que, portanto, é mais corretamente enquadrado como constitutivo. ${ }^{498}$

Pontes de Miranda igualmente advogou a tese de que as demandas de nulidades e anulação são constitutivas. E estava com razão quando afirmou que a demanda que pede a "declaração" de nulidade de certa relação jurídica é uma constitutiva negativa disfarçada. A relação jurídica se constituiu e dela emanaram efeitos, com base nos quais muito provavelmente constituíram-se novas relações jurídicas. Não se pode, tempos depois, simplesmente negar que aquela relação jurídica primitiva nunca existiu. Daí porque para o polêmico jurista alagoano tanto as demandas de nulidade quanto as de anulação são constitutivas negativas. ${ }^{499}$ A distinção entre elas estaria em que a decretação da nulidade

\footnotetext{
${ }^{496}$ Cf. Andrea Proto Pisani, “Appunti sulla tutela di mero accertamento”, p. 666.

${ }^{497}$ Cf. Stefano Villata, Impugnazioni..., p. 244.

${ }^{498}$ Cf. Andrea Proto Pisani, "Appunti sulla tutela di mero accertamento”, p. 666.

499 Cf. Tratado das ações, t. I, p. 120. Nesse sentido: “A ação declaratória em que se pede a 'declaração' da nulidade de uma relação jurídica, em vez da declaração da sua inexistência, é ação constitutiva negativa disfarçante; ou ocorre a troca de um dos sentidos de 'declarar' por outro. 'Declara-se' a nulidade do casamento, ou do contrato; mas êsse 'declara' está aí no sentido de direito material, que é o de dizer que já se constituíra, antes, alguma relação jurídica, em oposição a só se constituir, agora. 'Declarar', no sentido do direito processual, é menos e mais do que isso: é não-condenar, não-constituir, não-executar, não-mandar, mas, apenas, enunciar, autoritaritativamente, que existe, ou que não existe" (pp. 203/204). Melhor explicando, de acordo com a peculiar construção pontiana, toda sentença possui, em graus diferentes e
} 
desconstitui o ato nulo (que, embora existente, é ineficaz), ao passo que a decretação da anulabilidade desconstitui o ato jurídico anulável e a sua eficácia, já que este, contrariamente ao nulo, é existente e eficaz. ${ }^{500}$ Seguindo essa lição, Carlos Alberto Alvaro de Oliveira defendeu que a decisão meramente declaratória pressupõe existência ou inexistência, e não pode subir ao plano da validade, que é próprio da nulidade e da anulabilidade. $^{501}$ Também Agnelo Amorim Filho sustentou que as demandas que pretendem a nulidade de um ato jurídico são decididamente constitutivas, pois o ato ingressou no mundo jurídico (existe) e, logo, exige ser removido. ${ }^{502}$

Imbuído desse mesmo espírito, Adolfo di Majo asseverou que as dicotomias nulidade-tutela meramente declaratória e anulabilidade-tutela constitutiva são fruto de uma tradição doutrinária secular, mas que, em que pese a sua predominância, possui consistência científica escarsa e é fruto de uma conceituação excessiva. Para ele, mesmo o negócio jurídico nulo produz certos efeitos, quando menos no confronto com terceiros. Diferentemente do negócio inexistente, o nulo existe no mundo jurídico, de onde, da mesma forma que o anulável, deverá ser extirpado. Em ambas as hipóteses o ato produz

variáveis, cinco cargas de eficácia, quais sejam, declaratória, constitutiva, condenatória, mandamental e executivo: "não há qualquer sentença em que não haja elementos declarativo, constitutivo, condenatório, mandamental e executivo: tôda sentença favorável declara, pelo menos, que podia ser exercida a pretensão à tutela jurídica, ou o interesse do autor; tôda sentença favorável constitui, pelo menos, a si mesma, isto é, não havia, antes, sentença, e passa a haver; tôda sentença favorável condena o réu, pelo menos, a sofrer a fôrça e a eficácia da sentença e as consequências processuais; tôdas as sentenças têm elemento mandamental, que se exprime na observância de registro, certidões e outros atos; tôda sentença favorável, ainda se não retira bem da vida de um para outro patrimônio, pôe na esfera jurídica do autor o julgado, que é plus em relação à situação da esfera jurídica do réu, em que êsse se pôs em atitude, ou foi pôsto em atitude, que justificou o minus expresso na decisão" (p. 128). Com base nisso, Pontes de Miranda sustentou que quando se "declara" a nulidade de uma relação jurídídica, está-se diante, na realidade, de sentença predominantemente constitutiva negativa: "Todas as ações de decretação de nulidade são ações constitutivas negativas: declaratividade, 3 ; constitutividade, 5; condenatoriedade, 1; mandamentalidade, 2; executividade, 4. Também são constitutivas negativas as ações de anulação, de resolução e de rescisão" (p. 128.). E mais: "Não é ação declarativa aquela em que se pede a 'declaração' de nulidade, ainda que ex tunc, de qualquer ato; porque aí relação existe, embora nula" (p. 205). No mesmo sentido, "ambas as sentenças que decretam a nulidade e a anulabilidade são constitutivas negativas" (cf. Tratado..., t. IV, n, 363, p. 33) Ainda de acordo com Pontes de Miranda, a deliberação nula existiria, o que não existiria seriam seus efeitos (cf. Tratado de direito privado, t. 50, n. 5.323, p. 294), no que é seguido por Marcos Bernardes de Melo, Teoria do fato jurídico - plano de validade, n. 74, p. 287. Também com fundamento em Pontes de Miranda, Comparato afirmou que, quando se pleiteia a desconstituição de norma estatutária inválida, a tutela pedida ostenta conteúdo declaratório, pois o objeto da sentença "é a norma em si mesma, cuja invalidade deve ser proclamada". Diversa, contudo, é a arguição da invalidade de relações jurídicas determinadas (como, por exemplo, uma deliberação assemblear), na medida em que nesse caso "o efeito da sentença objetivada com a ação é de natureza constitutiva, pois consiste no desfazimento da eficácia do ato ou de relação" (cf. "Da imprescritibilidade...", p. 223).

${ }^{500}$ Cf. Tratado..., t. IV, n. 364, p. 33/34.

${ }^{501}$ Cf. Alienação da coisa litigiosa, n. 31, p. 264.

502 Amorim Filho empregou a locução ações aparentemente declaratórias para designar as demandas de nulidade (cf. “Critério científico...", pp. 742/743). 
efeitos precários e o juiz deve proceder de modo a tolher qualquer força jurídica do ato viciado. $^{503}$

Ainda de acordo com Di Majo, se existe uma disciplina que não reproduz a distinção clássica entre nulidade e anulabilidade é a da invalidade matrimonial, na medida em que, uma vez celebrado entre pessoas de sexos diversos, o casamento é existente e, portanto, qualquer demanda de impugnação só poderá apenas requerer a eliminação de tal existência. A razão para essa peculiaridade consiste em que, diferentemente de outros contratos, o casamento envolve interesses de vários gêneros, que extravasam a órbita dos contratantes: interesses dos filhos, interesse público de tutelar a monogamia etc. Por isso, a demanda que procura ver reconhecida a invalidade de um matrimônio visa a eliminar o estado de cônjuge e todos os efeitos daí decorrentes, que só são reputados extirpados do ordenamento após o pronunciamento judicial. E, mesmo com a desconstituição do vínculo matrimonial, o ordenamento resguarda alguns efeitos. Um exemplo é a condição de filho: o filho nascido na constância do matrimônio nulo é considerado fillho legítimo. ${ }^{504}$

As hipóteses expostas evidenciam que, quando menos, a posição de que o ato nulo não produz efeito algum e, portanto, a tutela adequada para o reconhecimento do vício seria a meramente declaratória, deve ser vista com ressalvas. Se essas hipóteses não comprovam, por si só, o acerto da tese aqui defendida - pois de fato são excepcionais ${ }^{505}$-, ao menos sinalizam nesse sentido.

\footnotetext{
${ }^{503}$ Cf. La tutela civile..., v. 3, cap. IV, n. 2.1, pp. 349/352.

${ }^{504}$ Cf. La tutela civile..., v. 3, cap. IV, n. 2.2., pp. 353/354.

505 Por isso é que Stefano Villata, analisando a ideia de Andrea Proto Pisani citada em uma das notas precedentes, diz que apenas a existência de tais efeitos secundários não é suficiente para demonstrar a constitutividade da demanda de nulidade (cf. Impugnazioni..., cap. II, n. 15, p. 244). Também Antonio Junqueira de Azevedo admite que os negócios nulos eventualmente produzem efeitos. Mas, para o ilustre civilista, "é inegável que os casos de efeitos do nulo são exceções no sistema de nulidades e como tais devem ser tratadas. Os efeitos do nulo não são, em sua maior parte, também como havíamos salientado, os efeitos próprios do ato (isto é, os efeitos manifestados como queridos), e, portanto, nesses casos, não se pode dizer que o negócio tenha passado para o plano da eficácia; todavia, ainda quando se trate de eficácia própria, tal e qual ocorre no casamento putativo e em algumas outras poucas hipóteses, tem-se, se pudermos expressarmonos assim, um 'furo' na técnica de eliminação com que os negócios são tratados; é a exceção que confirma a regra, tanto mais que, depois de o negócio haver entrado no plano seguinte, o sistema jurídico corrige a falha, impedindo que o negócio continue a produzir efeitos (a entrada dos negócios nulos no plano da eficácia, pois, não, é definitiva)" (cf. Negócio jurídico..., cap. 2, n. 5, p. 64). A explicação, contudo, não convence e não consegue afastar o "furo" que o próprio Junqueira de Azevedo reconhece na doutrina tradicional. As deliberações inválidas são justamente uma das "outras poucas hipóteses" que o ilustre civilista aponta junto ao casamento putativo.
} 
Para refutar a tese ora defendida, poder-se-ia argumentar: esses são apenas alguns efeitos menores, reflexos, de modo que para eles seria cabível a tutela constitutiva, ao passo que, para os efeitos principais potenciais do ato (não produzidos em razão da nulidade), seria adequada a tutela meramente declaratória. Nesse sentido, José de Oliveira Ascensão reconhece que o ato nulo produz efeitos, mas nunca os efeitos negociais a que se destinou: apenas efeitos secundários ou indiretos, resultantes de comportamentos fáticos, e não do próprio ato. ${ }^{506}$ Já Hörster alude a efeitos jurídicos laterais, estabelecidos na lei. ${ }^{507}$ Então, talvez fosse útil a ideia de Pontes de Miranda de cargas de eficácia, a indicar que uma decisão é sempre composta por todas as eficácias, variando apenas o peso delas. ${ }^{508}$

Contudo, quando afirmamos que mesmo os atos nulos estabelecem relações jurídicas e produzem efeitos, não estamos aludindo apenas a efeitos secundários, mas sim aos efeitos principais, isto é, aqueles projetados pelo ato. ${ }^{509}$ Ainda que possa parecer um absurdo falar-se em anular o nulo, é justamente o que nos parece ocorrer.

E mais. As considerações feitas pelos estudiosos do direito constitucional no sentido de que, apesar do nome, a declaração de inconstitucionalidade de um ato normativo é, na verdade, constituição negativa, corroboram a tese ora defendida. ${ }^{510}$

Ir a fundo nesse tema, contudo, extrapolaria os limites deste trabalho. Dentro das margens desta dissertação - demarcadas pelo tema da invalidade das deliberações assembleares -, o motivo definitivo para que se defenda essa tese consiste nas

\footnotetext{
${ }^{506}$ Cf. Direito civil..., n. 208, p. 320.

${ }^{507}$ Cf. A Parte Geral..., n. 347, p. 212.
}

${ }^{508}$ Ao que tudo indica, essa seria a posição de Kazuo Watanabe, que, conforme exposto por Flávio Yarshell, teria defendido que o ato nulo não é necessariamente desprovido de efeitos e, portanto, o provimento que pronuncia a sua nulidade ostentaria certa carga de constitutividade (cf. Tutela jurisdicional específica..., $\mathrm{n}$. 2.3 , p. 30, nota 52).

${ }^{509}$ Essa ideia é defendida também por Hamid Charaf Badine Jr., Efeitos do negócio jurídico nulo, cap. 12, pp. 162 e seguintes. Betti, por sua vez, afirma que o negócio jurídico nulo pode produzir alguns de seus efeitos correspondentes ou mesmo outros distintos (cf. Teoría general..., n. 58, p. 353). Por outro lado, parece ser equivocado o pensamento de Zeno Veloso de que o ato nulo não produz os efeitos próprios, isto é, os jurídicos típicos, mas apenas os efeitos fáticos ou secundários (cf. Invalidade..., n. 25, p. 149).

${ }^{510}$ Cf. Regina Maria Macedo Nery Ferrari, Efeitos da declaração de inconstitucionalidade, pp. 173/175; Thomas da Rosa de Bustamante, "A Lei 9.868/99 e a Possibilidade de Restrição dos Efeitos da Declaração de Inconstitucionalidade. Inaplicabilidade na Fiscalização de Normas de Direito Tributário”, Revista Dialética de Direito Tributário, n. 59, 2000, p. 113; e Caio Augusto Silva dos Santos, "Os efeitos das decisões no controle concentrado de constitucionalidade", $R T$, n. 831, p. 95. 
peculiaridades do regime de nulidades do direito societário. ${ }^{511}$ Se o atrelamento entre aquelas duas tutelas aos vícios de nulidade e anulabilidade deve ser repensado já em sede de teoria geral dos atos jurídicos, a fortiori o devem no direito societário. ${ }^{512}$ Todas as considerações feitas podem ser aplicadas às deliberações assembleares: exigências vindas do direito material impõem que, todo e qualquer remoção de efeitos seja produzida por via judicial, mediante um provimento de conteúdo constitutivo negativo.

A existência de efeitos que decorrem da deliberação nula ${ }^{513}$ e que devem ser preservados mesmo após o acolhimento do pedido desconstitutivo impõe reconhecer que a tutela jurisdicional que tem por objeto vício dessa espécie é constitutiva negativa. Se já no direito privado comum a assertiva de que os atos nulos não produzem efeito algum sofre sérias ressalvas, pelos motivos vistos acima, com maior razão isso ocorre com as deliberações societárias, cujas invalidades respeitam regime peculiar, no qual se deve preservar a estabilidade e as situações jurídicas que decorrem mesmo da deliberação viciada (v. item 7).

A nulidade das deliberações assembleares possui mais elementos diversos do que comuns com a nulidade do direito civil comum. Nada mais natural, portanto, que o processo também siga tal peculiaridade. As singularidades do direito material contaminam

\footnotetext{
${ }^{511}$ Nesse sentido, afirma-se que no direito societário tanto a eficácia dos atos como a eliminação deles são construídas de modo a se assegurar o desenvolvimento da atividade social (cf. Ilaria Pagni, Le impugnazioni..., cap. VI, n. 5, p. 592). Ou seja, confirmando o que aqui se defende, a especificidade do direito societário (material) acarreta peculiaridades na aplicação do direito material via processo.

${ }^{512}$ Evitando-se, como disse Edoardo Ricci, uma aplicação mecânica e rígida dos cânones daquela teoria geral (cf. "Gli effetti...", pp. 23/24).

${ }^{513}$ Um exemplo é a seguinte passagem de Erasmo Valladão França, que, ao procurar demonstrar a existência da categoria das deliberações nulas, afirma que "se o regime de anulabilidades, adotado originariamente no Decreto-lei n. 2.672/40, e repetido na Lei n. 6.404/76, fosse aplicável a todo e qualquer vício de deliberações assembleares, aos acionistas seria permitida a produção dos efeitos jurídicos que bem entendessem, caso nenhum deles viesse a impugnar o ato no prazo legalmente previsto" (cf. Invalidade..., n. 16, p. 73). Ou seja, Valladão invoca o seguinte argumento - de demonstração pelo absurdo, como ele próprio classifica: tanto existe a categoria da nulidade de deliberações (que devem ser objeto de demanda meramente declaratória, não sujeita a prescrição ou a decadência) que, caso contrário, os acionistas poderiam imutabilizar os efeitos jurídicos decorrentes de deliberações aberrantemente ilegais. Disso decorre, portanto, que as deliberações nulas produzem efeitos. Ainda no direito brasileiro, Priscila Corrêa da Fonseca defendeu o cabimento da demanda de suspensão dos efeitos da deliberação nula pois, "malgrado o ato nulo, em tese, não produza efeitos, na prática estes podem ocorrer, de modo a ensejar, até mesmo, prejuízos de vulto" (cf. Deliberações..., p. 154). Ilaria Pagni também afirma que o direito societário é um dos campos em que o direito positivo reconhece a idoneidade do ato de produzir "una certa quantità di effetti a casi di atto invalido anche in modo radicale" (cf. Le azioni..., cap. VI, n. 5, p. 589), ao passo em que Francesco Terrusi aponta que a deliberação nula produz efeitos, mesmo "contra jus" (cf. L'invalidità..., n. 5.2, p. 224).
} 
o direito processual, que tem de reagir diferentemente, buscando dar efetividade àquele; que é o que acontece com as invalidades do casamento, tanbém como exposto.

E mais. A principal razão na distinção entre atos nulos e inexistentes reside em que estes não produzem sequer os poucos efeitos que em algumas hipóteses se atribui àqueles. Ora, se os atos nulos produzem alguns poucos efeitos é porque tais efeitos devem ser desconstituídos. Nesse sentido é que Wilson de Souza Campos Batalha defendeu que mesmo no caso de nulidade é necessário o provimento judicial e, portanto, o provimento que se pronuncia sobre a nulidade de deliberação é constitutivo e não meramente declaratório. ${ }^{514}$ Declaratórias seriam apenas as decisões que reconhecem a inexistência do ato. $^{515}$

Sintomática da peculiaridade que o regime das deliberações assembleares inválidas ostenta é a posição de Edoardo Ricci. Para ele, ao lado das demandas de nulidade e anulatória existe a "azione impugnativa caducante", instrumento típico do direito societário italiano e que teria por finalidade desconstituir determinados efeitos da deliberação nula, não extirpados do mundo jurídico por meio do provimento meramente declaratório. Ou seja, mesmo nas hipóteses de vícios de nulidade (art. 2.379 do CC italiano) o provimento seria constitutivo, e não declaratório. ${ }^{516}$ Isso se deve, ainda de acordo com o ilustre professor italiano, ao princípio de que no direito societário existe uma regra vital de que a deliberação nula é sempre idônea a valer como ato de funcionamento da sociedade. Por isso que a exigência de se preconizar, ao lado da tutela declaratória em geral, "un mezzo caducante", é própria da matéria, que particularmente atribui efeitos aos atos nulos. ${ }^{517}$ Defendeu Ricci, portanto, que o provimento meramente declaratório não

\footnotetext{
${ }^{514}$ Cf. Sociedades anônimas e mercado de capitais, v. II, p. 796: "Não obstante, não vemos motivos para a distinção, posto que, mesmo na hipótese de nulidade, é indispensável o seu reconhecimento por via judicial e, embora a desconstituição se opere ex tunc, a ação continua sendo do tipo constitutivo e não meramente declaratória".

${ }^{515}$ Cf. Sociedades anônimas..., v. II, p. 804.

${ }^{516}$ Cf. "Gli effetti...”, p. 27. Daí ter Stefano Villata dito que, a partir dessa ótica, pode-se concordar com Ricci, pois o provimento meramente declaratório, longe de apenas declarar a existência ou inexistência de uma relação jurídica, elimina os efeitos do ato, de modo que, sob o ponto de vista funcional, esse provimento é desconstitutivo (cf. Impugnazioni..., cap. II, n. 15, p. 251).

${ }^{517}$ Cf. "Gli effetti...", pp. 24 e 26.
} 
elimina os efeitos que a deliberação nula produz e, portanto, a fim de que tais efeitos sejam extirpados do mundo jurídico, é necessário um provimento constitutivo. ${ }^{518-519}$

A mitigação ao princípio da retroatividade dos efeitos da decisão que se pronuncia sobre nulidade - defendida pela doutrina especializada quando o assunto é deliberação inválida, como visto anteriormente - é mais um sinal de que o ato nulo produz efeitos que devem ser desconstituídos, e não simplesmente declarados ineficazes. ${ }^{520}$

Quando se fala em demanda declaratória de nulidade e anulatória, o que se pretende em ambas é o mesmo resultado prático: a remoção da deliberação impugnada - e de seus efeitos - do mundo jurídico. O vício que está à base do pedido de tutela formulado ao julgador pode até variar, mas atividade judicante será sempre a mesma e redundará sempre em um provimento constitutivo. Sob uma perspectiva funcional, as demandas são análogas, pois são o único meio de eliminar a deliberação. As duas possuem idêntica função cassatória ou demolitória ${ }^{521-522}$ e em ambas o objeto litigioso do processo é rigorosamente o mesmo: a eliminação dos efeitos do ato impugnado. ${ }^{523}$

${ }^{518}$ Cf. "Gli effetti...", p. 16. Por isso que Ricci afirma que "la domanda mirante alla caducazione degli effetti, che la deliberazione nulla è in grado di pruodurre, costituisce l'unico strumento pensabile, affinché quegli effetti siano eliminati” (p. 26). Bruno Cavallone critica a construção de Ricci de defender a existência de uma impugnativa caducante como tertium genus de demanda, ao lado da anulatória (art. 2.377 do CC italiano) e da declaratória de nulidade (art. 2.379 do CC italiano). Em primeiro lugar porque não vê por que razão um provimento declaratório de nulidade seria inidôneo a alcançar também os efeitos que decorrem da deliberação nula. Pelo contrário, como opera ex tunc, alcançaria todos esses efeitos e os atos subsequentes. Em segundo lugar, o terceiro gênero proposto por Ricci coincidiria quase perfeitamente com a ação anulatória prevista pelo citado art. 2.377; uma dessas semelhanças é a natureza constitutiva. As únicas diferenças entre elas seria que a impugnativa caducante poderia ser exercida até mesmo pelos sócios presentes à assembleia e não dissidentes, e a não sujeição da impugnativa caducante à decadência (cf. Bruno Cavallone, "Interventi", in Processo civile e società commerciali, pp. 194/195). Enfim, Cavallone nega a existência desse terceiro genêro e, consequentemente, a construção de Ricci.

519 Tratando da invalidade das deliberações de assembléias de condomínios - raciocínio que se aplica às deliberações de qualquer ente coletivo, inclusive das sociedades por ações -, João Batista Lopes afirma que em se tratando de invalidade (nulidade e anulabilidade), a demanda objetivando a reconhecê-la será constitutiva negativa, e não declaratória, pois a sentença não se limita a reconhecer a existência ou inexistência de relação jurídica, mas sim desconstitui o ato, alterando o mundo jurídico (cf. Condomínio, p. 109).

${ }^{520}$ Nesse sentido é que Wilson Souza de Campos Batalha disse que quer se tratando de nulidade, quer de anulabilidade, o provimento terá efeitos ex tunc, não afetando apenas a esfera de terceiros de boa-fé (cf. Sociedades anônimas..., v. II, p. 806).

${ }^{521}$ Confira-se: "l'azione di nullità appare analoga a quella di annullamento: essa rappresenta l'unico mezzo che consente di eliminare quello che si è chiamato il valor organizzativo della deliberazione con efficacia erga omne sócios. L'identica finalità cassatoria appare in tutta la sua evidenza (...). Nella'ottica della tecnica di tutela e dell'atore che di essa si serve si tratta infatti, in entrambi di casi, di una tipica forma di impugnazione con finalità demolitorie" (cf. Stefano Villata, Impugnazioni..., cap. II, n. 16, p. 263; v., ainda, cap. II, n. 15, p. 253). Em outra passagem, Villata refuta a ideia de Ilaria Pagni e afirma haver indícios seguros que demonstram ser a sentença, e somente ela, apta a extirpar os efeitos da deliberação viciada, não 
A demanda que impugna deliberação nula e a que impugna deliberação anulável dão origem a um processo que possui o mesmo objeto. Se acolhidas, desembocarão em um provimento com o mesmo conteúdo e o mesmo efeito (constitutivo). ${ }^{524}$ A estrutura processual (conteúdo) do provimento que se pronuncia sobre uma deliberação inválida, reconhecendo o vício e aplicando as consequências previstas pelo ordenamento, é idêntica e consiste na declaração do direito afirmado pelo autor da demanda mais a desconstituição dos efeitos. Existem menos diferenças entre nulidade e anulabilidade do que se pensa, e as que existem tratam-se mais de diferenças quantitativas do que qualitativas. ${ }^{525}$ Disso decorre a equivalência dos provimentos que se pronunciam sobre tais vícios.

sendo suficiente para tanto o exercício de um pretenso direito substancial (p. 235). Tanto é isso verdade que, para paralisar interinamente os efeitos de uma deliberação reputada inválida, o acionista (ou qualquer outro sujeito legitimado) deve recorrer a um procedimento judicial específico (art. 2.378, IV do CC italiano), que suspenderá os efeitos da deliberação e que, assim, "produce effetti innovativi". Não pode o acionista, portanto, liberar o efeito substancial que teria o condão de sustar os efeitos do ato, mas deve pedir a um juiz que "con un provvedimento giudiziale paralizzi gli effetti costitutivi della deliberazione invalida" (pp. 235/236). Também Chiovenda anotou que a sentença que anula uma deliberação inválida é constitutiva, pois "toglie di mezzo talle rapporto" (cf. "Sul litisconzorcio necessario", in Saggi di diritto processuale, v. 2, n. 6, p. 451).

${ }^{522}$ Sob outro enfoque, Fábio Comparato sustenta que a demanda será meramente declaratória quando pretender o reconhecimento da nulidade da norma estatutária inválida, e constitutiva quando pretender desconstituir relação ou ato jurídico constituídos com base na mesma norma estatutária. A distinção entre as modalidades de provimento, de acordo com o ilustre jurista, dá-se não em decorrência do interesse tutelado pela norma desrespeitada - entendimento que, como visto, prevalece em doutrina -, mas sim pelo objeto do provimento. Se se trata de uma norma (estatutária) abstrata, "o interesse de agir não está ligado a um interesse material próprio, mas unicamente ao interesse geral da comunidade para a qual a norma foi editada", de modo que tal interesse "consiste na defesa do princípio da hierarquia normativa". Diferente é o caso em que se pleiteia a desconstituição de um ato praticado com fundamento nessa norma nula, hipótese em que o ato ostenta características subjetivas e, portanto, o direito à sua anulação é um direito pessoal. Daí por que, para Comparato, a primeira demanda não se submete a prazos prescricionais (embora pensemos que o mais correto fosse falar em decadência), diversamente da segunda (cf. "Da imprescritibilidade...", pp. 223/225). Embora Comparato não tenha feito esta afirmação, parece-nos que para ele uma deliberação inválida deverá ser sempre desconstituída, pois, ao contrário de quando se pede o reconhecimento da invalidade de uma norma geral e abstrata (norma estatutária), o reconhecimento da invalidade de um ato jurídico inválido (deliberação, por exemplo) deverá ocorrer sempre por provimento constitutivo, pouco importa a natureza do vício.

${ }^{523}$ Cf. Stefato Villata, Impugnazioni..., pp. 262/263. De acordo com Villata, a distinção entre nulidade e anulabilidade é mais uma distinção de direito material do que de direito processual, não havendo razão para distinguir o objeto litigioso do processo em relação às duas espécies de ações. Nesse sentido, observa Ilaria Pagni que "ha comportato l'unitilità di distinguere sul piano dogmativo tra la nullità e l'annullamento. Sotto questo profilo, si è potuto constatare che le ragioni che portano all'intervento del giudice prescindono completamente dal tipo d'invalidità (nullità o annullabilità) che si faccia valere di volta in volta nel processo" (cf. Ilaria Pagni, Le azioni..., cap. VII, n. 5, p. 673). Embora discordemos da conclusão a que essa autora chega, essa observação é correta e se alinha com o que aqui se defende: a natureza do vício da deliberação é, para fins de definição do conteúdo da tutela jurisdicional, absolutamente irrelevante.

${ }^{524}$ Daí ter dito Stefano Villata que as únicas diferenças entre as duas demandas dizem respeito à legitimidade ad causam e aos prazos decadenciais (cf. Impugnazioni..., cap. II, n . 15, pp. 258/259).

${ }^{525}$ Cf. Gianluca Guerrieri, La nullità..., cap. VI, n. 14, p. 355. 
Advogando tese oposta, Ilaria Pagni afirma que, embora somente o provimento judicial possa contrabalançar, no plano formal, a existência de uma deliberação inválida, isso não significa que tal provimento seja constitutivo e modifique uma situação jurídica substancial. O provimento assumiria apenas uma função formal para evitar a consolidação de uma situação que, aos olhos de sócios e terceiros, ostenta aparência de validade. ${ }^{526}$ Não importaria, assim, se o provimento se pronunciaria sobre uma causa de anulabilidade ou de nulidade; ele conterá apenas um juízo sobre a presença, ou não, dos requisitos substanciais do ato. Quem pede a desconstituição de uma deliberação pediria apenas o acertamento negativo da existência dos fatos constitutivos do ato (ou o acertamento positivo de fatos impeditivos). A decisão que se pronuncia sobre a invalidade de uma deliberação, portanto, seria sempre meramente declaratória. A necessidade de recorrer ao juiz decorreria não da presença de um direito potestativo cujo exercício exige o recurso ao Estado-juiz, mas sim de uma formalidade de, assim como quando emitida a deliberação, realizar-se um novo procedimento, desta feita para que seja reconhecida invalidade daquela. ${ }^{527}$

A necessidade de uma formalidade para que se reconheça a invalidade da deliberação constituiria um reflexo da especialidade da matéria de fundo, como ocorre no direito societário e no direito de família (desconstituição de casamento). Nesses ramos do direito, continua Pagni, o sistema de invalidade é estruturado observando exigências de certeza e publicidade nas relações sociais. A decisão judicial seria necessária apenas para eliminar o valor que a deliberação representou para a sociedade, e assim ostentaria a qualidade de uma espécie de título documental. ${ }^{528}$ Em sentido análogo, Federico Carpi aludiu à presunção de legitimidade de que goza a deliberação, em analogia com o ato administrativo. $^{529}$

\footnotetext{
${ }^{526}$ Cf. Le azioni..., cap. VI, n. 6, pp. 593/595.

${ }^{527}$ Cf. Le azioni..., cap. VI, n. 6, p. 600. Em sentido semelhante, Francesco Terrusi afirma que a particularidade das deliberações societárias nulas diz respeito à necessidade de serem ressalvados os direitos de terceiros de boa-fé, o que, contudo, não é suficiente para que se negue o caráter meramente declaratório da decisão se pronuncia sobre uma deliberação nula (cf. L'invalidità..., n. 5.3., p. 229). Contudo, diferentemente de Pagni, esse autor reconhece o conteúdo constitutivo da sentença que se pronuncia sobre uma deliberação anulável. Apreciando a teoria de Pagni, v. Stefano Villata, Impugnazioni..., cap. II, n. 14, pp. 233/235, inclusive nota 302. De acordo com Villata, Ilaria Pagni defende que o vício que inquina o ato jurídico caracteriza-se como uma controfattispecie que impede a produção de efeitos do ato, efeitos esses que são liberados por meio de um exercício de poder substancial, cujo exercício não depende de atividade jurisdicional. Assim, o juiz se limitaria a acertar a existência ou a inexistência do vício. Por isso, a sentença não produziria efeitos constitutivos, mas estes derivariam exclusivamente do ato substancial por meio do qual se liberam os efeitos impeditivos dos fatos invalidantes.

${ }^{528}$ Cf. Le azioni..., cap. VI, n. 6, pp. 602 e cap. VI, n. 4, p. 657.

${ }^{529}$ Cf. L'efficacia..., n. 36, p. 155.
} 
À base desse raciocínio está o entendimento de que, na desconstituição de qualquer ato jurídico, esta decorre não do provimento judicial, mas sim de elementos de fato exteriores ao processo. As condições necessárias para a produção da transformação jurídica (desconstituição) estariam contidas em uma fatispécie que se contrapõe à fatispécie de produção normal dos efeitos do ato. A cessação dos efeitos do ato adviria de um fato impeditivo ou extintivo que elimina o efeito daquele. O provimento, portanto, apenas conferiria certeza sobre a presença ou ausência do fato impeditivo ou modificativo. ${ }^{530}$

De acordo com essa autora, em alguns setores do direito (direito de família e direito societário, por exemplo) as peculiaridades do direito substancial exigem maior formalidade na desconstituição de atos jurídicos. A tutela prestada continua a ser meramente declaratória, mas é necessária a sentença como uma espécie de titolo documentale. $^{531}$ Tanto é isso verdade, aponta Pagni, que nesses setores deve haver pronúncia judicial mesmo em caso de nulidades radicais. Ora, parece-nos que esse raciocínio comprova justamente o equívoco da posição por ela assumida: se as especificidades do direito material ditam a necessidade de um pronunciamento para que se promova a desconstituição, não há razão para dizer que essa é uma mera formalidade. A segurança e a certeza que o sistema de invalidade de deliberações societárias exige impõem reconhecer justamente o inverso do que defende Ilaria Pagni, isto é, reconhecer que as peculiaridades do direito material demandam a tutela constitutiva, independentemente da natureza do vício. ${ }^{532}$ Contrapor ao poder substancial um análogo poder substancial paralisante dos efeitos daquele primeiro poder traz o risco de criar um círculo vicioso de poder e contrapoder, ${ }^{533}$ com o qual não se pode contar.

E mais. Embora não haja relação intrínseca entre provimento constitutivo e necessariedade - tanto é que existem as demandas constitutivas não necessárias -, a

\footnotetext{
${ }^{530}$ Cf. Le azioni..., cap. VII, n. 1, pp. 621/622. Contrariamente à teoria de Pagni, v. Stefano Villata, Impugnazioni..., cap. II, n. 13, pp. 235/241.

${ }^{531}$ Cf. Le azioni..., cap. VII, n. 1, p. 624.

${ }^{532}$ Essa é também a conclusão de Villata, Impugnazioni..., cap. II, n. 13, p. 241.

${ }^{533}$ A observação é, novamente, de Villata, Impugnazioni..., cap. II, n. 13, p. 242.
} 
imprescindibilidade da intervenção estatal para que se repute ineficaz uma deliberação inválida propende para o caráter constitutivo dessa decisão. ${ }^{534}$

Talvez pudéssemos falar que apenas as deliberações inexistentes têm relação com a tutela declaratória, pois apenas o ato inexistente é que não produz efeito algum. Contra essa afirmação, porém, pode-se objetar que não existem deliberações inexistentes, como afirma a maior parte da doutrina comercialista, que iguala inexistência com nulidade (v. item 7.2). Poder-se-ia dizer, ainda, que mesmo as deliberações inexistentes produzem efeitos - ainda que reflexos, mas não só eles - e que a partir delas surgem situações jurídicas, de modo que também elas podem ser eficazes.

Não é possível moldarmos os institutos processuais para que atendam ao direito material. Não se pode defender que o provimento ostenta conteúdo declaratório apenas para que a pretensão não seja fulminada pela decadência e o vício convalide - sobretudo porque, como visto, não há relação necessária entre decadência e provimento constitutivo. É preciso, em realidade, tratar os institutos como eles de fato são, extraindo daí as consequências corretas. O que distingue as classes de tutelas cognitivas são as suas estruturas processuais (v. item 10.1.3). Haverá tutela meramente declaratória unicamente quando o provimento consistir em um enunciado de certeza, e nada mais. E se esse seguramente não é o caso da invalidação de atos jurídicos, menos ainda é o da impugnação de deliberações assembleares.

${ }^{534}$ Cf. Villata, Impugnazioni..., cap. III, n. 15, p. 261. 


\section{CAPÍTUlo IV - LIMITES OBJETIVOS DO PROVIMENTO E DA COISA JULGADA}

\section{O eixo lógico entre objeto litigioso do processo, objeto do provimento e limites objetivos da coisa julgada}

Em nosso direito processual civil vigoram as regras de que o que é pedido deve ser julgado - pela parte dispositiva da sentença - e de que o que é julgado imutabiliza-se pela coisa julgada material (CPC, art. 469). Ou seja, os limites objetivos da coisa julgada são delimitados pela amplitude objetiva do provimento de mérito (ditada pelo dispositivo sentencial), circunscrita pelo objeto do processo, que, por sua vez, coincide com a pretensão do demandante. Existe, pois, um eixo lógico que liga objeto do processo, objeto do provimento e limites objetivos da coisa julgada. ${ }^{535} \mathrm{Em}$ função da regra da demanda (CPC, art. 262), o processo civil começa por iniciativa da parte e, embora haja fenômenos restritivos e ampliativos, é a demanda apresentada - ou, mais precisamente, a pretensão processual nela contida - que delimita o objeto do processo, ou, como preferimos, o objeto litigioso do processo. ${ }^{536}$ É sobre a demanda e o objeto litigioso do processo, por sua vez,

${ }^{535}$ Cf. Ernesto Heinitz, I limiti oggettivi della cosa giudicata, n 13, pp. 143/146; Sergio Menchini, I limiti oggettivi del giudicato civile, pp. 9/11 e Il giudicato civile, pp. 44/45; Schwab, El objeto litigioso en el processo civil (trad. de Tomas A. Banzhaf), n. 12, pp. 187/189; Chiovenda, Instituições..., v. 1, n.129, p. 410; Rosenberg, Tratado de derecho procesal civil (trad. de Angela Romera Vera), pp. 42/44; Jauernig, Direito procesual..., n. 63, p. 328; Barbosa Moreira, "Os limites objetivos da coisa julgada no sistema do novo Código de Processo Civil”, in Temas de direito processual civil, $1^{\mathrm{a}}$ série, p. 91; e Ada Pellegrini Grinover, "Considerações sobre os limites objetivos e a eficácia preclusiva da coisa julgada", Revista do advogado, n. 65, p. 73.

${ }^{536}$ Objeto do processo é diferente de objeto litigioso do processo: aquele é mais amplo e compreende o mérito e as questões preliminares e prejudiciais, ao passo que o objeto litigioso é composto apenas pelo mérito (cf. Arruda Alvim, Manual..., n. 135, p. 441). Além do mérito ou fundo do litígio (objeto litigioso do processo), existem também as questões preliminares e as prejudiciais, que, em conjunto com a lide, compõem o objeto do processo. O objeto litigioso é colhido apenas na petição inicial e, pois, é o autor que o fixa, salvo hipóteses em que ao réu é dado ampliar referido objeto, como é o caso de reconvenção, ação declaratória incidental, denunciação da lide etc. Por isso é que, de acordo com Arruda Alvim, o réu "fixa o pontos controvertidos de fato e de direito, mas não aumenta o objeto litigioso, salvo se se servir da declaratória incidental ou de reconvenção. (...) O juiz, ao julgar, aprecia e decide todas as questões que se encontram no processo, mas só sobre o objeto litigioso (lide) é que pesará a autoridade da coisa julgada" (cf. Manual..., n. 135, p. 441). Rogério Lauria Tucci prefere distinguir em objeto material e objeto formal do processo: aquele é o mérito, este as questões preliminares ao julgamento do mérito (cf. Do julgamento conforme o estado do processo, nn. 1/2 e 37, pp. 3/5 e 87/88). Na mesma linha são os ensinamentos de José Rogério Cruz e Tucci, para quem, apesar do uso indiscriminado das duas expressões, objeto do processo indica toda a matéria submetida à cognição judicial, ao passo que objeto litigioso do processo indica a pretensão processual. Aquele, portanto, é gênero; e este é espécie. Por isso é que Cruz e Tucci também utiliza a expressão objeto material para designar a pretensão processual e a expressão objeto formal para indicar os pressupostos processuais e as condições da ação (cf. A causa petendi..., n. 3.7.1., pp. 95/96, nota 47). Também Ricardo de Barros Leonel emprega a expressão objeto litigioso e afirma que este está contido no objeto do processo. Este, por sua vez, refere-se a todo o material submetido à cognição judicial, incluindo-se fatos, fundamentos jurídicos, questões, pedidos, pressupostos processuais ou condições da ação que surjam 
que o juiz deverá se debruçar para resolver a crise de direito material, em princípio não lhe sendo permitido ficar aquém, ir além ou decidir fora desses limites (CPC, arts. 128 e 460). O objeto litigioso do processo, portanto, define o objeto do provimento. É, por fim, com base no comando que emerge da sentença que são estabelecidos os limites objetivos da coisa julgada, cristalizando-se a solução dada à causa. ${ }^{537}$ Questões para as quais o demandante não pediu decisão principaliter - e, portanto, não estiveram contidas no pedido - não constam do dispositivo e não podem se tornar definitivas, ainda que tenham sido resolvidas incidentalmente.

Analisar o conteúdo do ato que dá início à relação processual - demanda - é, portanto, o primeiro passo para delimitar o conteúdo e os limites da tutela jurisdicional que deve ser prestada pelo julgador. Essa a razão de ser da afirmativa corrente em doutrina de que a demanda é o projeto de provimento pleiteado. $\mathrm{O}$ estudo da amplitude objetiva da sentença e dos limites objetivos da coisa julgada na impugnação de deliberações assembleares deve começar, pois, pelo estudo do objeto litigioso do processo nas tantas vezes referidas demandas declaratória de nulidade e anulatória de deliberações assembleares.

\section{Objeto litigioso do processo}

Existiu e, de certa forma, ainda existe grande incerteza doutrinária a respeito do conceito de objeto litigioso do processo. Tanto é isso verdade que, em 1954, no prefácio do que até hoje é uma das maiores referências sobre o tema, Schwab anotou que, após mais de

no curso do processo. Ou seja, tudo que é objeto de cognição do julgador (cf. "Objeto litigioso e o princípio do duplo grau de jurisdição", in José Roberto dos Santos Bedaque e José Rogério Cruz e Tucci (coord.), Causa de pedir e pedido no processo civil (questões polêmicas), p. 351. Dinamarco critica o emprego de objeto do processo para designar as questões, mas ressalva que se trata de divergência meramente terminológica (cf. "O conceito de mérito...”, n. 165, p. 337).

${ }^{537}$ De acordo com Schwab, essa relação é um dos pilares básicos da doutrina da coisa julgada material (cf. El objeto litigioso..., n. 13, p. 188). De forma deveras didática, Bruno Vasconcelos Carrilho Lopes explica ser "corrente na doutrina a afirmação de um estreito encadeamento lógico entre objeto do processo, objeto da sentença e limites objetivos da coisa julgada. O objeto do processo é definido pela demanda do autor, podendo ser ampliado por demanda do réu (reconvenção, denunciação da lide...) ou de terceiro que apresente intervenção (oposição, intervenção litisconsorcial voluntária...). Ao traçar o objeto do processo, a demanda apresenta ao juiz a crise de direito material que deverá ser solucionada no julgamento da causa e, em conseqüência, determina o objeto da sentença. O encadeamento lógico é concluído com referência à função da coisa julgada de impedir o novo julgamento de uma causa já decidida, que circunscreve os limites objetivos da coisa julgada ao objeto da sentença” (cf. Limites objetivos e eficácia preclusiva da coisa julgada, p. 4). Em sentido similar, v. Flávio Yarshell, Ação rescisória, p. 127. 
setenta anos da entrada em vigor da ZPO, ainda não havia na doutrina alemã um conceito uniforme para o instituto. ${ }^{538}$

Etimologicamente, objeto nasce da junção entre a preposição latina $o b$ com o verbo jactio, gerando o verbo composto objicio. Aquela preposição significa defronte, enquanto jacio quer dizer arremessar, lançar, atirar. Dessa conjugação nasce o significado de objicio, que é propor (pro + por), pôr diante de. Objeto - forma vernacular do substantitivo latino criado a partir desse verbo (objectus) -, portanto, designa algo que se põe diante de alguém. ${ }^{539}$ Daí porque objeto do processo é o que se põe defronte ao julgador, à espera do pronunciamento judicial. Isto é, o mérito. Mas, novamente, o que é o mérito?

Uma teoria define mérito como a lide ${ }^{540}$ Essa ideia foi transposta para o Código de Processo Civil de 1973, como aponta a Exposição de Motivos ao afirmar que a lide é o objeto principal do processo (item 8 da Exposição). Exemplo disso é o art. 128, pelo qual

${ }^{538}$ Cf. El objeto litigioso..., p. 1. Na mesma obra, Schwab apontou que "pese a los esfuerzos de largas décadas, a los muchos estudios que con sagaz inteligencia dedicaron a este problema precisamente los mejores mestres del derecho procesal, la meta no se ha alcanzado aún. No se ha hallado un concepto unitario, válido para todas las especies de procedimientos civiles, que cuente con aceptación general" (n. 1, p. 3). Embora já conte com mais de meio século, essa obra monumental continua atual e apresenta uma excelente resenha das correntes doutrinárias alemãs sobre o tema, que, grosso modo, ainda habitam a nossa realidade. A importância da obra torna-se ainda mais evidente pela constatação de que os processualistas alemães preocuparam-se sobremaneira com a investigação do que é o objeto litigioso do processo, elevado por eles a verdadeiro polo metodológico de investigação, ao contrário dos processualistas italianos, que centraram seus esforços no estudo da ação. Corroborando a inicial afirmação de Schwab, escreveu Rogério Lauria Tucci que definir o que é mérito é "uma das mais árduas tarefas dos estudiosos do Direito Processual" (cf. Do julgamento..., n. 39, p. 100).

${ }^{539}$ Cf. Andrés De La Oliva Santos, Objeto del processo y cosa juzgada en el processo civil, p. 24; e Dinamarco, “O conceito de mérito...”, n. 152, p. 305.

${ }^{540}$ Cf. Buzaid, Do agravo de petição..., nn. 36, 46 e 47, pp. 82, 101 e 102, que diferenciou o processo (iudicium), concebido como o continente, do seu objeto, concebendo-o como o mérito da causa (res in judicium deducta). O processo seria a relação jurídica de direito público constituída entre as partes e o juiz, ao passo que o objeto do processo pertenceria ao direito privado e seria composto pelo conflito de pretensões a respeito da res. Para Buzaid, o objeto do processo ou mérito é a realidade social que o autor da demanda submete ao julgamento do Estado. Indo além, Buzaid - notório seguidor de Carnelutti - conceituou essa realidade social como a lide. Esta, entendida como um conflito intersubjetivo de interesses qualificado por uma pretensão resistida (cf. Carnelutti, Instituciones..., v. 1, n. 5, p. 28), portanto, é que seria o objeto do processo na concepção buzaidiana, De acordo com Buzaid, o conflito de interesses seria o elemento material da lide, ao passo em que a pretensão e a resistência os seus elementos formais (embora, como bem apontado por Dinamarco, Carnelutti nunca tenha sido tão radical e expresso em afirmar que ao mérito é a lide; cf. "O conceito de mérito...", n. 158, p. 320). Em outra obra, igualmente obrigatória para o estudioso do direito processual civil, Buzaid explicita sua posição: "o objeto de um processo é a lide" (cf. Ação declaratória..., n. 246, p. 387). Aderiu a essa posição também Rogério Lauria Tucci: "Daí não termos dúvida em adotar a conceituação de mérito consubstanciada na própria lide, submetida à apreciação de órgão jurisdicional com os limites determinados pelo autor, ao deduzir sua pretensão em juízo por meio de uma petição inicial" (cf. Do julgamento..., n. 39, p. 102). Aparentemente, essa é também a posição de Ada Pellegrini Grinover (cf. Ação declaratória incidental, n, 26, p. 45). 
"o juiz decidirá a lide nos limites em que foi proposta". ${ }^{541}$ Essa ideia, contudo, não parece ser correta. Primeiro porque há processos sem conflito, como é o caso dos chamados processos de jurisdição voluntária. ${ }^{542}$ Casos como o da revelia, do reconhecimento do pedido, da demanda executiva e do momento anterior à apresentação da contestação (CPC, arts. 319 e 269, II), em que não há contraposição de pedidos, também não são explicados por essa teoria, cuja aceitação nos faria defender que nesses casos o processo não possuiria objeto. ${ }^{543}$ E mais: o processo e a pretensão nele deduzida pressupõem o conflito, mas com ele não se confundem. O conflito é apenas o pano de fundo: o que se coloca diante do julgador é a pretensão processual.

Uma segunda corrente enxerga no mérito o complexo formado pelas questões de mérito, ${ }^{544}$ isto é, o conjunto de questões cuja resolução pode influenciar a procedência ou improcedência da demanda. Essa teoria também não é de se aceitar, pois mérito não se confunde com questões de mérito: estas são resolvidas pelo juiz na motivação da sentença, como caminho lógico rumo ao mérito, e apenas após resolvê-las é que, no dispositivo, o julgador conclui a respeito da pretensão do autor, julgando-o (CPC, art. 458). ${ }^{545}$ A solução

\footnotetext{
${ }^{541}$ Contudo, o Código acaba por utilizar o termo lide também com outros significados (por exemplo, art. 70, que, ao aludir à "denunciação da lide", está se referindo ao processo), bem como a empregar mérito como sinônimo de lide (por exemplo, arts. 267 e 269, que, após a alteração promovida pela Lei 11.232/05, aludem a "resolução do mérito"). Também Arruda Alvim identificou na lide o objeto litigioso do processo. Como já visto, o eminente jurista distingue objeto do processo de objeto litigioso do processo: aquele compreenderia a lide e as questões preliminares e prejudiciais, ao passo que o objeto litigioso seria composto apenas pela lide. Para Arruda Alvim, portanto, o objeto litigioso do processo é sinônimo de lide, mérito ou fundo de litígio (cf. Manual..., n. 138, p. 441).

${ }^{542} \mathrm{O}$ "processo voluntário", afirmava Carnelutti, tinha por fim a prevenção da lide, em posição ao "processo contencioso", cujo fim era a justa composição da lide (cf. Instituciones..., v. 1, nn. 17 e 18, pp. 43/44). Também Luiz Guilherme Marinoni afirma que a jurisdição voluntária não se destina a solucionar conflitos de interesses, mas sim a "zelar por algumas situações de direito material que, diante de sua relevância social e ao ver do legislador, não podem ficar entregues apenas aos particulares envolvidos" (cf. Teoria geral do processo, n. 8.1., pp. 145 e 147). Dinamarco, porém, entende que a ideia de conflito não é estranha à jurisdição voluntária, na qual "existe sempre alguma situação conflituosa e um estado de insatisfação que afligem pessoas e necessitam solução" (cf. Instituições..., v. I, n. 123, p. 326).

${ }^{543}$ As judiciosas observações são de Dinamarco (cf. "O conceito de mérito...”, n. 158, pp. 321/322).

${ }^{544}$ Exemplo disso é Liebman, para quem mérito seria o conjunto de questões cuja resolução pode influir no acolhimento ou na rejeição do pedido (cf. Manual..., n. 80, pp. 222/223). Embora, verdade seja feita, em outro trabalho Lieman tenha dado destaque ao pedido e afirmado que a lide, entendida como "o conflito efetivo ou virtual de pedidos contraditórios, sobre o qual o juiz é convidado a decidir", é que seria o objeto do processo (cf. "O despacho saneador e o julgamento do mérito", in Estudos sobre o processo civil brasileiro, n. 8, p. 89). V., também, Carnelutti, Instituciones..., v. I, n. 13, p. 37.

${ }^{545}$ Cf. Barbosa Moreira, "Os limites objetivos...", p. 93. Para chegar ao mérito, o julgador resolve questões preliminares e questões de mérito. Estas últimas têm pertinência à relação material in judicium deducta, o que não significa que o componham. Existe uma escalada lógica representada pela própria estrutura da sentença: as questões de mérito são resolvidas na motivação, e somente após terem sido resolvidas todas elas é que se passa ao julgamento do mérito, no dispositivo. As questões já foram solucionadas e o juiz realiza sua conclusão, respondendo ao pedido formulado. Quando faz isso, o juiz não está julgando questões, mas sim a
} 
das questões integra o iter processual, que redundará no julgamento da pretensão processual, isto é, do mérito; mas com este não se confundem tais questões.

Uma terceira corrente identifica o mérito com a vontade concreta da lei cuja atuação é pedida na demanda. Nesse sentido Chiovenda, que, fiel à sua concepção concretista do direito de ação, afirmou que o objeto do processo é a vontade concreta da lei. ${ }^{546}$ Essa concepção também não é a melhor, pois a vontade concreta da lei, entendida como a norma individualizada, será um efeito, e não um objeto do processo. Além disso, a ação (ou, mais propriamente, a demanda) é um ato formal e apenas o veículo de uma pretensão, esta sim o que se coloca à frente do julgador. Portanto, a demanda ou o pedido é apenas o continente; o conteúdo é a pretensão, este sim o verdadeiro mérito. ${ }^{547}$

Uma quarta corrente enxerga o objeto litigioso do processo como a alegação de descumprimento do direito ou, como disse Fazzalari, a situação substancial. ${ }^{548} \mathrm{O}$ objeto litigioso do processo, pois, seria a (mera) alegação de violação ao direito material deduzida na petição inicial. A essa posição adere Sergio Menchini, ao fazer alusão à

pretensão própria, ou, como diria Carnelutti, compondo a lide. Daí por que, para Dinamarco, “decididamente, resolver o mérito não é o mesmo que resolver as questões de mérito". O mérito, assim, não são as questões de fundo, mas sim o próprio fundo. É equivocada, portanto, a redação do art. 458, III do CPC, ao dizer que na parte dispositiva "o juiz resolverá as questões, que as partes lhe submeteram" (cf. "O conceito de mérito...", n. 155 , pp. 309/310).

546 "De quanto se assentou, resulta que objeto do processo é a vontade concreta de lei, cuja afirmação e atuação se reclamam, assim como o próprio poder de reclamar-lhe a atuação, isto é, a ação" (cf. Instituições..., v. 1, n. 15, p. 50). Como é notório, Chiovenda possuía uma concepção concretista do direito de ação. Tanto é que identificou as condições da ação como "condições necessárias a que o juiz declare existente e atue a vontade concreta da lei invocada pelo autor, vale dizer, as condições necessárias para obter um pronunciamento favorável" (cf. Instituições..., v. 1, n. 19, p. 66).

${ }^{547}$ Cf. Dinamarco, “O conceito de mérito...", n. 156, p. 315.

${ }^{548}$ Embora alerte que não se pode falar propriamente em objeto de processo, na medida em que este é composto por vários atos processuais, cada qual possuindo conteúdo e objetos próprios e específicos, Fazzalari afirma que no processo de cognição a res in iudicium deducta é a "realtà sostanziale" (cf. Istituzioni..., p. 336). A situação substancial, para Fazzalari, é composta por um dever e por seu inadimplemento, isto é, por um ilícito (cf. Istituzioni..., p. 255). José Rogério Cruz e Tucci, por outro lado, entende que a demarcação do objeto litigioso do processo exige a consideração da relação existente entre o direito material e o ato processual, o que é promovido justamente pela causa de pedir. Valendo-se da construção fazzalariana de situação substancial (entendida como o desrespeito a um direito subjetivo, isto é, a lesão ao direito), Cruz e Tucci afirma textualmente que objeto litigioso do processso é a circunstância jurídica concreta deduzida em juízo in statu assertionis, a qual seria individualizada pela situação fática contrária ao direito material (cf. "A denominada situação substancial como objeto do processo na obra de Fazzalari”, in Scritti in onore di Elio Fazzalari, v. 2, n. 7, p. 45). Sobre o conceito de situação substancial, afirma Cruz e Tucci que "deve, pois, a situação substancial ser articulada: $a$ ) num dever e na respectiva transgressão. A existência de um dever implica a violação de uma norma material qualificadora de uma especificada conduta. A desobediência consiste numa conduta desconforme ao modelo normativo; e, $b$ ) no direito subjetivo correspondente ao dever, bem como na lesão do direito correlata à inobservância do dever". Também Remo Caponi equivale situação substancial com o objeto litigioso do processo (cf. L'efficacia..., p. XIV). 
situação subjetiva afirmada, a respeito da qual o julgador é chamado a se pronunciar. ${ }^{549} \mathrm{~A}$ violação a um direito subjetivo, contudo, parece-nos ser mais uma questão do que o próprio objeto do processo. O juiz deve analisar fatos e direito e ver se realmente aqueles se passaram da maneira afirmada e se isso configura violação à ordem jurídica. Mas o faz apenas com o intuito de julgar a pretensão.

Autores há, ainda, que identificam o objeto litigioso do processo com o direito que se quer valer por meio da demanda: o mérito não seria composto por fatos ou atos, mas sim por direitos. 550

Há muitas outras teorias sobre o assunto, em especial entre os alemães, cujos estudos têm o objeto litigioso do processo como verdadeiro polo metodológico diversamente dos italianos, durante muito tempo focados no estudo da ação. ${ }^{551}$

Em que pese todas essas divergências, há hoje razoável entendimento - ao menos na doutrina brasileira - de que o objeto litigioso do processo é sinônimo de mérito ${ }^{552}$ e que

\footnotetext{
${ }^{549}$ Cf. I limiti..., p. 45.

${ }^{550}$ Cf. Andre Proto Pisani, “Appunti sul giudicato civile e sui limiti oggettivi”, Rivista di diritto processuale, v. 45, n. 2, p. 387. Ou seja, o objeto do processo seria o accertamento acerca da existência ou inexistência do direito que se pretende ver protegido (cf. Comoglio-Ferri-Taruffo, Lezioni..., cap. XXI, n. 7, p. 625).

${ }^{551}$ Para um aprofundamento da matéria, remete-se às obras de Schwab (El objeto...), Buzaid (cf. Do agravo de petição..., nn. 34/44, pp. 81/99), Dinamarco (cf. "O conceito de mérito...”, nn. 154/158 e 165/167, pp. 306/322 e 334/341), Kazuo Watanabe (cf. Da cognição..., n. 18, pp. 71/82); José Rogério Cruz e Tucci (cf. A causa petendi..., n. 3.7, pp. 95/109); Ricardo de Barros Leonel, Causa de pedir e pedido: o direito superveniente, nn. 2 e seguintes, pp. 31 e seguintes; Gustavo Badaró, Correlação entre..., n. 3.2, pp. 44 e seguintes; e Fábio Peixinho Gomes Corrêa, $O$ objeto litigioso no processo civil, n. 1, pp. 26 e seguintes.

552 De acordo com Dinamarco, o termo mérito provém do verbo mereo, merere, que, dentre outros significados, tem o de pedir, pôr preço. Possui a mesma raiz de meretriz, vocábulo em que também há a noção de pôr preço. Por isso é que mérito é aquilo que alguém vem a juízo pedir, postular, requerer (cf. Vocabulário..., n. 9, pp. 186/187). Também Heitor Sica identifica mérito com pretensão, ao afirmar que defesa de mérito ocorre quando o réu apresenta resposta que, de algum modo, interfira no conteúdo da decisão sobre o fundo da pretensão do autor (cf. $O$ direito de defesa no processo civil brasileiro, n. 6.1, p. 81). Ainda conforme Dinamarco, é um "preconceito irracional" entender que o mérito existe apenas no processo de conhecimento, e não no de execução. Esse preconceito "tem origem na inadmissibilidade do julgamento da pretensão executiva no próprio procedimento executivo", na medida em que apenas nos embargos à execução (CPC, art. 745) ou na impugnação ao cumprimento de sentença (CPC, art. 475-L) é que o juiz se pronuncia sobre a existência ou inexistência do direito alegado pelo exequente. Isso não quer dizer que não existe mérito na execução, mas apenas que o mérito não é apreciado no processo executivo. Na execução o mérito consiste na pretensão executiva deduzida na petição inicial da execução por título extrajudicial ou no pedido de prosseguimento do processo em caso de título judicial (cf. "O conceito de mérito...,", n. 163, pp. 329/331).
} 
equivale à pretensão processual, ${ }^{553}$ que, por sua vez, é a exigência de satisfação de um interesse mediante subordinação de um interesse alheio.

Por meio da demanda, a parte coloca diante do julgador a sua pretensão (processual), consistente em uma exigência de emissão de provimento jurisdicional que solucione a crise jurídica que lhe afeta. Em um primeiro momento lógico, a pretensão refere-se ao provimento postulado; no momento seguinte, ao bem da vida pleiteado. No primeiro caso, fala-se em objeto imediato do pedido; no segundo, em objeto mediato. ${ }^{554}$ Mérito, pretensão processual e objeto litigioso do processo são, portanto, sinônimos que

${ }^{553}$ Na definição de Carnelutti, pretensão processual é "exigencia de subordinación de un interés ajeno ao interés propio" (cf. Instituciones..., v. 1, n. 5, p. 28). Fala-se em pretensão processual para indicar o que se pede no processo e diferenciá-la da pretensão material. Esta é a posição subjetiva de poder exigir de outrem o cumprimento de uma obrigação. Situa-se, pois, no âmbito do direito material. Um exemplo: a partir do momento em que se torna exigível uma obrigação de pagar quantia firmada em contrato, o credor, que até então era apenas titular de um direito subjetivo, passa a poder exercer sua pretensão, isto é, a exigir o cumprimento do dever. Essa pretensão pode ser manifestada de diversas formas (uma conversa, um telefonema, um telegrama, um e-mail etc.) e dependerá da vontade do devedor para que seja satisfeita (cf. Fábio Luiz Gomes, Teoria geral..., p 118). Não o sendo, restará ao credor apenas valer-se do Judiciário, exercendo seu direito de ação. Ainda sobre a pretensão, vale ressaltar que se trata de um ato, não um poder. Por isso, a pretensão é algo que alguém exerce, não que alguém possui, e que não supõe o direito subjetivo, pois é possível que alguém exerça pretensão (infundada) sem ser o titular do direito. Nesse caso, diz-se que há pretensão sem razão. E, assim como há pretensão sem direito, há também direito sem pretensão, nomeado por Carnelutti de direito inerte (cf. Instituciones..., v. 1, nn. 8 e 10, pp. 31 e 32). Invocando a lição de De Stefano, José Rogério Cruz e Tucci aponta que a concepção processual de pretensão tem início a partir do momento em que se passa a falar de pretensão pura e simples, diversa da concepção de Windscheid. O termo Streitgegenstand passou a ser empregado na Alemanha "para indicar algo meramente afirmado, um simples conteúdo hipotético, cuja única utilidade consiste em definir o objeto da discussão e da decisão, sem qualquer alusão direta à situação de direito substancial" (cf. A causa petendi..., n. 3.7.1, p. 97). Novamente, Schwab: "La pretensión procesal es el objeto litigioso. Trátase de conceptos sinónimos, que pueden sustituirse el uno por el outro o intercambiarse sin dificultad, aun cuando desde el punto de vista idiomático, y probablemente también por su contenido, su significado sea distinto. 'Pretensión procesal' expresa el anhelo, la petición del actor. 'Objeto litigioso', en cambio, es un concepto neutral, objetivado, que requiere ser llenado y plantea la cuestión de su contenido. Es, de cierto modo, el molde que la pretensión procesal viene a llenar. Pero ambos conceptos guardan entre si una conexión sumamente estrecha" (cf. El objeto litigioso..., n. 1, pp. 5/6).

${ }^{554}$ Por isso que Dinamarco afirma que "conceitualmente, toda pretensão deduzida em juízo apresenta duas faces distintas, sendo portanto invariavelmente bifronte: ela é em um primeiro plano pretensão a dado provimento jurisdicional, de determinada natureza e conteúdo, mas, em última análise, pretensão também a um certo bem da vida" (cf. "O conceito de mérito....", n. 152, pp. 303/304). Com esse espírito é que Schwab disse ter sido fundamental à ciência processual civil tomar consciência de que o objeto litigioso do processo é um fenômeno de natureza processual, que não se identifica com a pretensão de direito material (cf. El objeto litigioso..., n. 1, p. 3). Na doutrina portuguesa, Lebre de Freitas faz alusão a uma determinação material (pedido mediato) e processual (pedido imediato) da pretensão (cf. Introdução..., cap. I, n. 4.6, p. 56). Questão complexa é saber se o objeto do processo é alterado pela mudança do pedido imediato ou apenas pela mudança do pedido mediato. A respeito disso, Arruda Alvim escreveu que "o tipo de tutela jurídica integra o objeto litigioso" e que, portanto, as duas feições do pedido integram o objeto do processo; logo, a mudança de um deles configuraria outra demanda e, assim, outro objeto do processo. Por isso é que para ele uma demanda declaratória negativa proposta pelo devedor em face do credor não impede o ajuizamento de demanda condenatória por este último: as duas possuem objetos diversos e, pois, não há litispendência. Haveria litispendência, contudo, caso tivesse sido ajuizada primeiramente a condenatória, pois esta é mais ampla do que a meramente declaratória, já que contém pedido de declaração e de imposição da sanção (cf. Manual..., n. 138, pp. 443/445). 
designam a exigência que uma pessoa, mediante a demanda, apresenta ao julgador. ${ }^{555}$ É o $^{\circ}$ que se almeja alcançar com a demanda. Mas ainda assim persiste uma dúvida: a pretensão processual é composta apenas pelo pedido ou também pela causa de pedir?

Embora identifiquem o objeto litigioso do processo com o pedido, alguns autores ressalvam que este é delineado pela causa de pedir. Assim Heinitz ${ }^{556}$ e Rogério Lauria Tucci, segundo o qual o objeto litigioso é formado pela afirmação do direito (objeto da pretensão) e pelo fato da vida (fundamento da pretensão). ${ }^{557}$ Aparentemente no mesmo sentido vai Eduardo Talamini, ao afirmar que o objeto do processo resulta da conjugação entre, de um lado, o mecanismo processual de tutela pretendida, e, de outro, a situação substancial carente de tutela, e que é a causa de pedir que estabelece tal ligação. ${ }^{558}$

Já Dinamarco diz que, após amadurecer seu pensamento, chegou à conclusão de que o objeto do processo é o pedido, e somente ele. Os fundamentos da demanda (causa de pedir) e da defesa ligam-se à fundamentação da sentença, onde são solucionadas as questões. Existe um segundo eixo sistemático, ligando o pedido e o dispositivo sentencial, onde se dirá sim ou não à pretensão do autor. Assim como o núcleo da sentença reside no dispositivo, o da demanda estaria no pedido. Os fundamentos do pedido seriam mero apoio lógico deste. E, pois, a causa de pedir, diz o mestre, decididamente não integra o objeto litigioso do processo. ${ }^{559}$ Sustentando posição intermediária, Ricardo de Barros Leonel diz que a causa de pedir não integra a pretensão processual, mas que esta não pode ser

\footnotetext{
${ }^{555}$ Cf. Dinamarco, "O conceito de mérito...", n. 159, p. 322. Cintra-Grinover-Dinamarco também entendem que o objeto do processo é a pretensão processual, isto é, a exigência trazida a juízo de que haja a subordinação de um interesse alheio a um próprio (cf. Teoria geral..., n. 180, p. 296). No mesmo sentido, Rogério Lauria Tucci, Do julgamento..., n. 1, p. 3.

${ }^{556}$ Cf. I limiti oggetivi..., n. 12, p. 135: "Ci pare quindi preferibile attenerci all'insegnamento, secundo cui l'oggeto del processo, la pretesa processuale, si identifica mediante petitum e causa petendi".

${ }^{557}$ Cf. Do julgamento..., n. 1, p. 3.

${ }^{558}$ Cf. Coisa julgada..., n. 2.3.1, pp. 79/81.

${ }^{559}$ Cf. Dinamarco, "O conceito de mérito...”, n. 170, pp. 346/348. Também Galeno Lacerda relacionou o mérito com o pedido. Mais precisamente, o processualista gaúcho definiu mérito como "a propriedade de o pedido do autor conformar-se ou não com o direito e, em consequência, ser acolhido ou rejeitado". Dessa forma, "todo juízo de valor sôbre o pedido será sentença de mérito" (cf. Despacho saneador, cap. IV, n. 7, p. 83). Na doutrina portuguesa, Lebre de Freitas também identifica julgamento de mérito como a resposta ao pedido do autor e o objeto do processo com o pedido, pois é ele que determina o conteúdo da decisão de mérito (cf. Introdução..., cap. I, n. 3.5, pp. 40 e 48). Dessa afirmação não se deve extrair que a demanda seja o mérito da causa. Nesse sentido, mais uma vez invocando-se a lição precisa de Dinamarco, a demanda não é "o mérito da causa", mas "apenas o veículo de algo externo ao processo e anterior a ele". Em razão disso, diz Dinamarco, "não terá saído da superfície aquele que identificar o meritum causae com a demanda, que é mera via de acesso dos sujeitos ao processo" (cf. "O conceito...", n. 156, p. 315).
} 
corretamente entendida sem que se visualize os fundamentos do pedido, pois são esses fundamentos que delimitam o objeto litigioso do processo. ${ }^{560}$

Essa discussão vai longe e extrapola os limites deste trabalho. Ressalvada reflexão mais amadurecida, nossa posição é de que o objeto litigioso do processo é composto pelo pedido e pela causa pedir. Para que se diga qual a pretensão deduzida em juízo, não basta analisar o que, mas também por qual fundamento se pede. De toda forma, a análise do objeto litigioso do processo neste trabalho serve apenas para firmar premissas e, após, passarmos ao estudo da amplitude objetiva da sentença e dos limites objetivos da coisa julgada na impugnação de deliberações assembleares. Por isso, apesar de haver várias teorias que procuram conceituar objeto litigioso do processo, de modo geral os processualistas concordam que, adotando-se a teoria dos tres eadem, a identificação do conteúdo da sentença e dos limites objetivos da coisa julgada é feita com base no pedido e na causa de pedir. Por isso, não sendo intuito desta dissertação chegar a uma posição definitiva quanto ao conceito de mérito/objeto litigioso do processo, basta aqui ressaltar que, para fins de definição da amplitude objetiva do provimento, isto é, dos limites objetivos da sentença, é relevante a consideração não só do pedido mas também da causa de pedir (teoria dos tres eadem). É o que basta.

\subsection{Demanda declaratória de nulidade e demanda anulatória: distinção quanto ao objeto litigioso do processo?}

Qual o objeto litigioso do processo na impugnação de deliberações assembleares? Ele é diverso nas chamadas demandas declaratória de nulidade e anulatória?

Adotando-se a ideia de objeto litigioso do processo como pretensão processual sem que sequer seja necessário tomar partido quanto à tormentosa discussão sobre se a pretensão é composta só pelo pedido ou também pela causa de pedir -, essas duas demandas contariam com pretensões diversas: se na demanda anulatória a pretensão é a desconstituição e na declaratória é a mera declaração da nulidade do ato impugnado, só por

\footnotetext{
${ }^{560}$ Cf. Causa de pedir..., n. 2.1.11, p. 104. Aparentemente em sentido contrário, o seguinte trabalho do mesmo autor: "Objeto litigioso...", n. 10.2, p. 366.
} 
isso o provimento jurisdicional pleiteado seria diverso e, portanto, igualmente diversos seriam os objetos litigiosos do processo. Essa, porém, não parece ser a resposta correta.

Isso porque, conforme concluímos (v. item 12), não importa o vício que inquina a deliberação, a tutela adequada para resolver a crise de direito material será sempre constitutiva. Não há, pois, diversidade quanto ao pedido mediato (conteúdo da tutela jurisdicional). E o mesmo se dá com relação ao pedido imediato (bem da vida): em ambas as demandas o que se pretende é o mesmo resultado prático: a remoção da deliberação impugnada e de seus efeitos do mundo jurídico. $\mathrm{O}$ vício que está à base do pedido de tutela formulado ao julgador pode até variar, mas atividade judicante será sempre a mesma. Sob uma perspectiva funcional, as demandas são idênticas: são o único meio de eliminar a deliberação. Ambas possuem idêntica finalidade cassatória ou demolitória. A estrutura processual do provimento - isto é, seu conteúdo - será sempre igual: verificar (acertar) se a deliberação está viciada pela enfermidade alegada e, no momento lógico seguinte, promover a alteração jurídica decorrente da certificação do direito. Nessas duas demandas, a pretensão e, portanto, o objeto litigioso do processo são os mesmos. ${ }^{561} \mathrm{O}$ que se quer e o que se pede é sempre o reconhecimento da ilicitude e a remoção (desconstituição) do ato e de seus efeitos da ordem jurídica. Pouco importa se a causa invalidante é de nulidade ou anulabilidade, o objeto litigioso será o mesmo.

\footnotetext{
${ }^{561}$ Cf. Stefano Villata, Impugnazioni..., cap. II, n. 16, p. 262/263. De acordo com esse autor, a distinção entre nulidade e anulabilidade é mais uma distinção de direito material do que de direito processual, não havendo razão para distinguir o objeto do processo em relação às duas demandas: "In realtà, lo si è già osservato nel paragrafo precedente, la scelta di distinguere tra due forme di invalidità è una scelta di diritto sostanziale più che di diritto processuale (...). In una prospettiva funzionale, che trascuri per un istante i concreti efffeti della tutela esperita, l'azione di nullità appare analoga a quella di annullamento: essa rapresenta l'unnico mezzo che consente di eliminare quello che si è chimaato il valore organizzativo della deliberazione con efficacia erga omnes socios (...). Nella'otica della tecnica di tutela e dell'atore che di essa si serve si trata infatti, in entrambi i casi, di una tipica forma di impugnazione con finalità demolitorie". De maneira similar, Montesano afirma que os limites objetivos do provimento são determinados de maneira idêntica nas demandas declaratória de nulidade e anulatóra de negócios jurídicos (cf. "Limiti oggettivi di giudicati su negozi invalidi”, Rivista di diritto processuale, v. 46, p. 44). E embora Ilaria Pagni adote posição contrária à aqui defendida, no sentido de que a tutela prestada na invalidação de deliberações assembleares será sempre declaratória, ela afirma que entre as demandas movidas com base nos arts. 2.377 e 2.379 do Código Civil Italiano (que disciplinam, respectivamente, as demandas de anulação e de nulidade) não há diferença substancial quanto à causa invalidante, nem quanto à disciplina do processo (cf. Le azioni..., n.. 618). Em sentido contrário, Pinto Furtado afirma que "em termos de pedido, supomos, por conseguinte, dever concluirse com segurança não haver identidade entre o pedido de declaração de nulidade e o pedido de anulação, entre o pedido de declaração de inexistência e o pedido de ineficácia em sentido restrito" (cf. Deliberações..., n. 120, p. 820).
} 


\section{Correlação entre demanda e provimento}

Se ao juiz fosse permitido desconsiderar o que foi pleiteado pelas partes e julgar livremente, a pretensão processual seria irrelevante para o alcance da sentença. $O$ eixo lógico entre objeto litigioso do processo e amplitude objetiva do provimento de mérito, por isso, só assume relevância em decorrência da regra de congruência ou de correlação entre demanda e provimento. ${ }^{562}$

Por tal regra, a decisão de mérito deve guardar nexo de referência com a demanda, de modo que julgue tudo e somente o que constar dessa: a decisão não pode ir além ou fora, tampouco ficar aquém da demanda. ${ }^{563}$ A regra impõe o dever de o julgador ir até aos limites da demanda e a proibição de ultrapassar os landmarks por ela

\footnotetext{
${ }^{562}$ Regra da correlação e regra da congruência serão aqui utilizadas como sinônimos. Embora se use em doutrina também o termo regra da adstrição, essa expressão parece designar mais corretamente a regra pela qual o pedido deve ser interpretado de maneira estrita, estabelecida no art. 293 do CPC: "Os pedidos são interpretados restritivamente, compreendendo-se, entretanto, no principal os juros legais".

${ }^{563}$ Cf. Giovanni Verdi, Profili del processo civile, v. 1, cap. 4, n. 1, pp. 113 e seguintes; e Dinamarco, Instituições..., v. III, p. 272. O primeiro fundamento que se costuma invocar para a regra da correlação é o princípio dispositivo - ou, na linguagem de Cintra-Grinover-Dinamarco, princípio da disponibilidade processual (cf. Teoria geral..., p. 62). Com efeito, invocando o princípio dispositivo como fundamento da regra de correlação: Milton Paulo de Carvalho, Do pedido no processo civil, p. 164; e Teresa Arruda Alvim Wambier, Nulidades do processo e da sentença, p. 298. Na doutrina italiana, Comoglio-Ferri-Taruffo afirmam que a determinação de correspondenza tral il chiesto e il pronunciato desdobra-se em duas perspectivas: a da parte, que age em juízo pleiteando tutela jurisdicional, e a do juiz, que tem de outorgar a tutela requerida, pronunciando-se sobre a tutela requerida. Sob a primeira ótica, a regra de correlação guarda relação com os princípios dispositivo e da demanda (cf. Lezioni..., p. 299). A razão disso é que se costuma confundir princípio dispositivo com princípio da demanda - também chamado de princípio da ação ou da inércia da jurisdição. Costuma-se dizer que o princípio dispositivo estabelece o poder das partes apresentarem ou não a sua pretensão em juízo, bem como de apresentá-la da forma que melhor lhes aprouver, e, ainda, a iniciativa das partes em relação aos fatos e às provas. Com razão, Barbosa Moreira critica o atrelamento do princípio dispositivo à regra em análise sob o fundamento de que aquele é termo equívoco, que designa coisas diversas, como (i) iniciativa de instauração do processo e de delimitação do objeto do processo, ou seja, a ideia de que cabe à parte decidir se vai haver processo e sobre o quê o processo vai versar; (ii) iniciativa na produção de provas; e (iii) atos de disposição do direito litigioso, como renúncia, transação, reconhecimento do pedido etc. De acordo com o processualista carioca, não é possível vincular essa última noção às demais; e, por isso, não se pode utilizar o termo princípio dispositivo de forma unívoca e, portanto, também não se pode afirmar haver relação entre princípio dispositivo e regra da correlação (cf. "Correlação entre o pedido e a sentença", RePro n. 83, pp. 208/209; "Reformas processuais e poderes do juiz", in Temas de direito processual, $8^{\text {a }}$ Série, p. 43; e "O problema da 'divisão do trabalho' entre juiz e partes: aspectos terminológicos”, in Temas de direito processual, $4^{\mathrm{a}}$ Série, p. 38.). Portanto, quando se diz que há vinculação entre regra da correlação e princípio dispositivo, na verdade se está dizendo que essa vinculação é com o princípio da demanda. Por princípio dispositivo deve-se entender apenas a imposição de iniciativa das partes em relação aos fatos e às provas. Por outro lado, deve ser reservada ao princípio da demanda a ideia de que o juiz é inerte para apreciar o direito material, inércia que deve ser rompida apenas se e na forma em que o demandante exercitar o poder de ação (cf. Leonardo Greco, Instituições de direito processual civil, v. 1, p. 546; e Ovídio Batista da Silva, Teoria geral..., p. 43). A respeito da regra de correlação, v., por todos, Gustavo Badaró, Correlação entre acusação e sentença.
} 
estabelecidos, ${ }^{564}$ de modo que julgue tudo, mas somente o que se contém nela. ${ }^{565}$ Estatuem-se limites positivo e negativo ao juiz, quais sejam, o de pronunciar-se sobre toda, e não outra, demanda. ${ }^{566}$ Embora em decorrência da dicção dos artigos 128 e, em especial, 460 do CPC $^{567}$ seja comum tratar a regra da correlação apenas sob o ângulo do pedido, entendendo-se que haveria necessidade de vinculação somente entre a sentença e o pedido $^{568}$ - do que são sintomáticas as expressões citra, ultra e extra petita, por se referirem ao petitum -, a correlação abrange todos os elementos da demanda: pedido, causa de pedir e partes. ${ }^{569}$

Com relação ao pedido, apesar de o art. 293 do CPC preceituar que "os pedidos são interpretados restritivamente", o correto é que a interpretação deve ser estrita. Se for restritiva, a decisão será viciada, pois estará sendo apreciado menos do que o proposto pelo autor. A decisão será, como se verá a seguir, citra ou infra petita. ${ }^{570}$

\footnotetext{
${ }^{564}$ A expressão é de Dinamarco (cf. Instituições..., v. III, p. 274).

565 De acordo com Milton Paulo de Carvalho, a regra da correlação impõe a exata correspondência entre a pretensão processual formulada pelo autor e o pronunciamento de mérito, de maneira que este abranja tudo e só o que se contém na pretensão (cf. Do pedido..., pp. 162/163).

${ }^{566}$ Cf. Andrea Proto Pisani, Lezioni..., p. 221.

567 “Art. 128. O juiz decidirá a lide nos limites em que foi proposta, sendo-lhe defeso conhecer de questões, não suscitadas, a cujo respeito a lei exige a iniciativa da parte."

"Art. 460. É defeso ao juiz proferir sentença, a favor do autor, de natureza diversa da pedida, bem como condenar o réu em quantidade superior ou em objeto diverso do que lhe foi demandado"

${ }^{568}$ Cf. Moacyr Amaral Santos, Comentários..., v. IV, p. 441. Embora não afirme expressamente, Antonio Carlos de Araujo Cintra entende que a regra de correlação diz respeito apenas ao pedido, chegando até mesmo a, comentando o art. 460 do CPC, falar em "princípio da correlação entre pedido e sentença" (cf. Comentários ao Código de Processo Civil, v. IV, p. 286). Posteriormente, fala em "princípio da correlação entre a ação e a sentença", mas continua a examinar a regra apenas sob a ótica do pedido (p. 290). Cássio Scarpinella Bueno destaca que o art. 460 do CPC engloba também a causa de pedir e os fundamentos de defesa (Cf. Curso..., v. 2, t. I, p. 359).

${ }^{569} \mathrm{O}$ art. 128 do CPC deve ser interpretado de maneira a se compreender que o juiz está vinculado aos limites objetivos (pedido e causa de pedir) e subjetivos (partes) da demanda. A tutela jurisdicional deve guardar relação de correspondência com todos os três elementos da demanda. Da mesma forma, embora o artigo 460 do CPC refira-se ao pedido, deve ser lido sistematicamente de modo a obter-se esse mesmo entendimento. A regra de correlação abrange todos os elementos da demanda (partes, pedido e causa de pedir) - embora Pontes de Miranda afirme que as expressões dizem respeito apenas a infidelidades relativas ao pedido, e não aos fundamentos do pedido (cf. Comentários ao Código de Processo Civil, t. II, p. 358) -, são consagradas na doutrina as expressões citra, extra ou ultra petita para designar as decisões que ficam aquém, vão fora ou além de tais elementos. Ainda que linguisticamente incorretas tais expressões, pois dizem respeito apenas ao pedido (petitum), por serem largamente utilizadas, serão aqui adotadas, com a ressalva de que designam decisões portadoras de vícios relativos a todos os elementos da demanda, e não só ao pedido.

570 É comum, contudo, falar-se em interpretação restritiva, como faz Milton Paulo de Carvalho (cf. Do pedido..., p. 112).
} 
No que diz respeito às causas de pedir e de defesa, a regra de correlação incide apenas sobre os fatos, e não sobre os fundamentos jurídicos da demanda. ${ }^{571}$ Não obstante a causa de pedir seja composta por fundamentos de fato e de direito, apenas aqueles - e ainda assim apenas os fundamentos relativos a fatos essenciais, isto é, os que constituem a causa de pedir - é que vinculam o julgador. Os fundamentos jurídicos da pretensão devem ser enunciados na petição inicial (CPC, art. 282, III), mas não vinculam o julgador e podem ser por ele alterados. Isso porque da chamada presunção de conhecimento da lei (LICC, art. $3^{\circ}$ ) decorrem duas regras, expressas nos brocardos jura novit curia (o juiz conhece o direito) e narra mi factum dabo tibi jus (narra-me o fato e dar-te-ei o direito). As partes agem em juízo de acordo com os fatos, não com a sua qualificação jurídica. ${ }^{572} \mathrm{~A}$ respeito da causa petendi e à causa excipiendi, portanto, o julgador está adstrito somente aos fatos essenciais, e não aos fundamentos jurídicos: está limitado àqueles e não pode considerar elementos a ele estranhos, tampouco omitir-se quanto a algum deles. Tais são os fatos constitutivos, isto é, que compõem a causa de pedir (CPC, art. 128, primeira parte). Fatos circunstanciais (fatos simples) podem ser levados em conta sem que se cogite de alteração da causa de pedir.

A segunda parte do art. 128 do CPC veda ao julgador conhecer também de questões que não foram suscitadas e a cujo respeito a lei exige a iniciativa da parte. Ao julgador é defeso conhecer as chamadas exceções em sentido estrito, ${ }^{573}$ isto é, defesas do réu para as quais a lei confere à sua alegação a condição de ônus absoluto. Ou seja, fatos impeditivos, modificativos ou extintivos do direito do autor e que só podem ser considerados se suscitados pelo réu.

Firmadas as premissas de que é na pretensão processual que se deve buscar o objeto litigioso do processo e de que este é que define o alcance objetivo da sentença de mérito, é de se concluir que, em princípio, a análise do pedido e da causa de pedir é

\footnotetext{
${ }^{571}$ Como aponta Milton Paulo de Carvalho, "não haverá alteração da causa de pedir se o autor der ao fato por ele descrito uma qualificação jurídica, e o juiz acolher o pedido por qualificação diferente do mesmo fato (...). Aqui também vale o adágio da mihi factum, dabo tibi ius" (cf. Do pedido..., p. 174). No mesmo sentido, José Roberto dos Santos Bedaque, "Os elementos objetivos da demanda examinados à luz do contraditório", in José Roberto dos Santos Bedaque e José Rogério Cruz e Tucci (coord.), Causa de pedir e pedido no processo civil, p. 32.

572 Defendendo posição contrária à aqui preconizada, Humberto Theodoro Jr. afirma que há julgamento fora do pedido quando o juiz "defere a prestação pedida mas com base em fundamento jurídico não invocado como causa do pedido na propositura da ação" (cf. Curso..., v. 1, p. 577).

${ }^{573}$ Sobre o assunto, v. Heitor Sica, $O$ direito de defesa..., nn. 7.1 e seguintes, pp. 94 e seguintes.
} 
suficiente para aquilatar qual o conteúdo e quais os limites que a sentença deverá ter. Há, porém, exceções a essa regra. É o caso dos chamados pedidos implícitos, que, ainda que não formulados, podem - ou melhor, devem - ser apreciados pelo órgão julgador. Matérias que devem ser conhecidas de ofício também excepcionam a regra. Outro exemplo é o caso das chamadas decisões ultra e extra petita, nas quais ocorre um indevido transbordamento dos limites da demanda, que, conquanto ilícitas, se não impugnadas, convalidam por conta da eficácia sanatória da coisa julgada.

\section{1. Infidelidades objetivas}

A decisão omissa em relação a algum dos três elementos da demanda é citra ou infra petita. ${ }^{574}$ Receberá essa denominação, por exemplo, a sentença que deixar de se manifestar sobre um dos fatos essenciais debatidos no processo (causa de pedir), não considerar um pedido deduzido (pedido) ou deixar de apreciar a pretensão em relação a um dos sujeitos indicados na inicial (partes). Já a decisão que decide fora dos limites da demanda, isto é, para outras pessoas, por outros fundamentos ou com relação a outro objeto ao invés dos indicados na demanda, é nomeada extra petita. Aqui o julgador inventa, extravasando dos limites objetivos e subjetivos traçados pelas partes. Por fim, a decisão que suplanta os lindes postos pelo demandante, qualitativa ou quantitativamente, é ultra petita. ${ }^{575}$

\footnotetext{
${ }^{574}$ Há quem sustente que as expressões infra petita e citra petita não designariam o mesmo fenômeno. Para esses autores, citra petita seria a decisão que fica aquém do pedido, isto é, não aprecia todo ele, ao passo que infra petita seria a decisão que, embora analise todo o pedido, acolhe-o apenas parcialmente. Nessa classificação, em suma, citra petita é a decisão portadora de violação restritiva à regra de correlação e infra petita a decisão de procedência parcial. Conquanto tal diferenciação seja feita por doutrina de peso (cf. Dinamarco, Instituições..., v. II, p. 140, nota 24), aqui as expressões são tomadas como sinônimas.

${ }^{575}$ A distinção entre decisão extra e a ultra petita é tênue. Alguns autores entendem que só há decisão extra petita quando não é apreciado qualquer dos elementos da demanda, isto é, quando a decisão não guarda, em absoluto, nenhuma relação com a demanda. Apenas nessas hipóteses é que haveria decisão fora da demanda. Nesse sentido, v. Fredie Didier Jr., Paula Sarno Braga e Rafael Oliveira, Curso..., v. 2, p. 312. Esses mesmos autores, contudo, ainda que não de modo expresso, admitem que a decisão extra petita nem sempre será aquela que não guarda absolutamente qualquer relação com a demanda, ao afirmarem que "se a decisão contém vários capítulos e apenas quanto a um deles se mostra extra petita, bastará que se anule o capítulo viciado" (p. 316). Na decisão ultra petita, por sua vez, o magistrado apreciaria todos os elementos da demanda e iria além deles, quantitativa ou qualitativamente, apreciando provimento além do pleiteado, analisando outros fatos essenciais além dos suscitados ou decidindo para outros sujeitos constantes da relação processual, além destes. Outros autores sustentam que na decisão extra petita não é que o julgador simplesmente deixa de apreciar a demanda, concedendo provimento absolutamente desconectado daquela. Embora seja perfeitamente possível essa hipótese, o que ocorre na prática, em regra, é que o órgão judicial aprecia o pedido e, indo além, também determina providência diversa (cf. Flávio Yarshell, Ação rescisória..., pp. 91/92). Parece-nos que a primeira posição é a correta. Embora quem defenda a segunda posição faça questão de afirmar que a decisão ultra petita é aquela que vai além dos elementos da demanda, quantitativa e
} 
A decisão que viola a regra de correlação e importa nos vícios listados anteriormente é, em princípio, nula. ${ }^{576}$ Mas essa afirmação deve ser vista com ressalvas, pois são tantas as variáveis envolvidas que é imprescindível o estudo de cada uma das hipóteses de vícios. A análise das consequências de tais vícios deve partir de duas considerações: (i) o fundamento da regra de correlação e (ii) a distinção entre transgressões restritivas e ampliativas.

É essencial entender que as transgressões ampliativas violam a garantia do contraditório e surpreendem os sujeitos do processo, pois trazem decisões a quem não é parte, resultados diversos dos pleiteados ou fundamentos de fatos não alegados e discutidos regularmente. ${ }^{577}$ Já as transgressões restritivas afetam, fundamentalmente, a garantia de acesso à justiça, na medida em que, ao deixar de manifestar-se sobre um pedido formulado, um fato debatido ou sobre os efeitos que a decisão deverá projetar sobre certo sujeito, o órgão julgador estará incidindo em verdadeira desconsideração do direito de ação. $^{578}$

qualitativamente, não explica como a decisão seria ultra petita qualitativamente. Adotando-se essa segunda posição, haveria uma zona cinzenta entre a decisão extra petita e a ultra petita, de modo que a decisão ultra petita limitar-se-ia a ampliações quantitativas (por exemplo, diante de pedido de condenação ao pagamento de 100, a sentença confere 150). A afirmação de Teresa Arruda Alvim Wambier de que será ultra petita a sentença que conceder quantidade ou quantia maior do que a pleiteada pela parte (cf. Nulidades do processo..., p. 305) bem demonstra que, adotando-se a posição aqui combatida, a sentença ultra petita fica reduzida a questões quantitativas, o que não parece ser correto. Posteriormente, a autora afirma que "em certos casos, pode-se, quando materialmente possível, reduzir a sentença aos limites correspondentes ao pedido, ainda quando se trate de sentença extra petita, desde que, além da decisão que desborda os limites do pedido, tenha o juiz decidido, também, o pedido, propriamente dito, sendo a sentença, na verdade, ultra e extra petita" (p. 307). Não parece ser possível, porém, que a sentença possua os dois vícios. No caso, a decisão é, apenas ultra petita e, realmente, é cabível a sua redução, não sendo necessária a anulação. Por isso, sempre que a sentença guardar nexo de referibilidade com parte da demanda, mas, mesmo assim e além disso, fundar-se em fatos não debatidos, conferir providência diversa ou para sujeitos estranhos ao processo, será ultra petita. Apenas se a decisão inovar por completo é que será extra petita. Outro aspecto interessante de observar e pouco notado é que, via de regra, a decisão extra petita será, sob certo aspecto, também infra petita, na medida em que, ao conceder providência diversa da pleiteada, deixa de se manifestar sobre um pedido formulado, uma questão levantada ou uma parte da relação jurídica processual (cf.. Flávio Yarshell, Ação rescisória..., p. 91; e Fredie Didier Jr., Paula Sarno Braga e Rafael Oliveira, Curso..., v. 2, p. 312). As decisões extra petita, portanto, ao mesmo tempo em que ampliativas, são também restritivas.

${ }^{576}$ Nesse sentido, Cássio Scarpinella Bueno, Curso..., v. 2, t. I, p. 360; Vicente Greco Filho, Direito processual civil brasileiro, v. 2, p. 258; Humberto Theodoro Jr., Curso..., v. 1, p. 577; e Moacyr Amaral Comentários..., v. IV, pp. 438 e 442.

${ }^{577}$ Cf. Dinamarco, Instituições..., v. III, p. 290.

${ }^{578}$ Andrea Proto Pisani diferencia a omissão total e a parcial. Aquela é o extremo da denegação de justiça, ao passo que esta representa vício de atividade (cf. Lezioni..., p. 222). Vicente Greco Filho fala em violação ao princípio da indeclinabilidade da jurisdição (cf. Direito processual..., v. 2, p. 258.). 
A decisão ultra petita apresenta vício de procedimento (error in procedendo) e, por isso, é nula. ${ }^{579}$ Contudo, não deve ser anulada quando possa ser reduzida na instância superior, isto é, quando o excesso puder ser cortado pelo tribunal. ${ }^{580}$ A invalidação deve se limitar ao excesso, ou seja, ao capítulo decisório que transborda da demanda - embora parte da doutrina e da jurisprudência ainda relute em admitir a anulação parcial da sentença, desconhecendo a teoria dos capítulos de sentença. No que diz respeito à decisão que concede mais do que o pedido, ela pode ser cindida em pelo menos dois capítulos: um que aprecia a demanda, outro que supera os limites por ela traçados e, assim, caracteriza um plus. O primeiro deve ser mantido; o segundo, anulado, desde que não haja relação de derivação entre eles. ${ }^{581}$ A correção da sentença portadora desse vício, portanto, deve se limitar a reduzir o excesso, preservando-se os demais capítulos. O norte é sempre o confinamento das nulidades (CPC, art. 248, parte final).

Diante da decisão que vai além dos fundamentos de fato postos em juízo, abremse duas hipóteses. Se não houve prejuízo, não deve ser anulada a decisão. É o que ocorre, por exemplo, quando o fundamento de fato invocado pelo autor é considerado na motivação da decisão e suficiente para que se alcance a conclusão contida no dispositivo. Ainda que tenha sido levado em conta outro fato essencial para que se chegasse à conclusão sentencial, a consideração não acarretou prejuízo e a decisão, portanto, não deve ser anulada. Por outro lado, se a tomada de fatos essenciais diversos dos postos na demanda causar prejuízo a alguma das partes, a anulação se impõe. Se, por exemplo, para rejeitar o pedido o julgador vale-se de fato essencial não suscitado pelas partes e tampouco cognoscível de ofício, a decisão deverá ser anulada, pois da violação resultou efetivo prejuízo ao demandante. ${ }^{582}$

Sob o aspecto dos elementos objetivos da demanda, há dois tipos de decisão citra petita: (i) a que não apreciou um pedido e (ii) a que não apreciou uma questão de fato, isto é, ponto controvertido que tem o condão de influenciar o julgamento do mérito. ${ }^{583}$ Nos dois

\footnotetext{
${ }^{579}$ Cf. Andrea Proto Pisani, Lezioni..., p. 222.

${ }^{580}$ Cf. Wellington Moreira Pimentel, Comentários ao Código de Processo Civil, v. III, p. 530; Moacyr Amaral Santos, Comentários..., v. IV, p. 438; e Humberto Theodoro Jr., Curso..., v. 1, p. 577.

${ }^{581}$ Cf. Dinamarco, Capítulos..., pp. 84/85.

${ }^{582}$ Cf. Didier-Braga-Oliveira, Curso..., v. 2, p. 314.

${ }^{583}$ Flávio Yarshell discorda dessa posição, afirmando que citra petita é a sentença que deixa de apreciar todo o pedido e que a omissão quanto a uma questão é ausência de adequada fundamentação, o que não geraria as
} 
casos, a decisão é, antes de tudo, omissa, e, dessa forma, impugnável via embargos de declaração (CPC, art. 585, II). Porém, não sanada a omissão e interposto recurso de apelação, qual postura deve adotar o tribunal? A posição clássica é de que, a fim de não permtir a chamada supressão de instância e consequente violação ao duplo grau de jurisdição, deve ser anulada a sentença e remetidos os autos para o juízo inferior, para que este aprecie o pedido ou questão negligenciados. Essa, porém, não é a melhor, nem a única, alternativa que se abre ao tribunal, a depender das circunstâncias do caso concreto e, principalmente, de que se o que foi omitido foi um pedido ou uma questão.

Com relação ao pedido não examinado, simplesmente não há provimento judicial. ${ }^{584}$ No tocante a esse pedido decisão não existe e não há que se falar em nulidade. Não se pode invalidar algo que inexiste. Da mesma forma, não há coisa julgada quanto a esse pedido omitido, e não se pode impedir o autor de repropor demanda com esse intuito. ${ }^{585}$ Como é possível a propositura de nova demanda tendo por objeto a pretensão que foi negligenciada, uma das alternativas à anulação da sentença é julgar o recurso, dentro dos limites estabelecidos pela decisão, e remeter a parte à propositura de nova demanda. Tanto a remessa para nova demanda ou a anulação da sentença têm, contudo, o inconveniente de postergar a outorga da tutela jurisdicional, em violação, para dizer pouco, à garantia da duração razoável do processo. Surge, então, uma alternativa interessante: constatando-se a omissão quanto a um pedido, anula-se parcialmente a sentença e devolvese para novo julgamento o que não foi apreciado no grau inferior, prosseguindo a marcha processual com relação aos demais pedidos. ${ }^{586}$ Operacionalmente, deve ser extraída carta de sentença, a fim de que não haja prejuízo ao andamento do processo. ${ }^{587}$

consequências normalmente extraídas para a sentença que deixa de julgar um pedido (cf. Ação rescisória..., p. 86, nota 41). Realmente, as consequências são diversas para as duas situações. Mas isso não significa que a ausência de apreciação de uma questão não importe em violação ao princípio da correlação. Com a ressalva já feita de que é terminologicamente inapropriado nomear infra petita a decisão que desrespeite os demais elementos da demanda que não o pedido, discorda-se dessa posição, inclusive para que haja coerência com a posição aqui defendida de que a regra de correlação aborda todos os elementos da demanda, e não só o pedido.

${ }^{584}$ Milton Paulo de Carvalho expressamente afirma que nesse caso não há sentença, mas sim denegação de justiça (cf. Do pedido..., p. 171).

${ }^{585}$ Cf. Flávio Yarshell, Ação rescisória..., p. 86; e Fredie Didier Jr., Paula Sarno Braga e Rafael Oliveira, Curso..., v. 2, p. 319.

${ }^{586}$ Cf. Flávio Yarshell, Ação rescisória..., p. 89.

${ }^{587}$ Cf. Didier-Braga-Oliveira, Curso..., v. 2, p. 320. 
Ainda tratando da decisão citra petita quanto ao pedido, isto é, omissa em relação a um pedido ou parte dele, as consequências do vício dependem do objeto da omissão. Em se tratando de pedidos autônomos, que gerem capítulos de sentença igualmente autônomos, a não apreciação de um daqueles não impede a remessa para nova demanda ou a anulação parcial. Tratando-se de omissão quanto a pedido que é antecedente lógico de pedido cumulado em ordem sucessiva, a única alternativa será a anulação integral da decisão. ${ }^{588}$

Situação diversa ocorre quando a decisão é omissa quanto a uma questão de fato cuja solução poderia alterar o resultado do julgamento. Quando a decisão deixa de apreciar uma questão indispensável para a solução do pedido, a decisão é inválida, por violação à exigência constitucional de motivação (CF, art. 93, IX). Contudo, devido ao efeito devolutivo amplo da apelação, que submete ao tribunal todas as questões suscitadas e discutidas no processo, ainda que não apreciadas na sentença (CPC, art. $515 \S \S 1^{\circ}$ e $2^{\circ}$ ), pode o tribunal conhecer dessas questões independente de pedido da parte prejudicada. Mesmo que o exame da questão omissa dependa de prova não realizada em primeiro grau, a sentença não deverá ser anulada, para que prossiga a instrução perante o juízo inferior: ${ }^{589}$ o tribunal deverá converter o julgamento em diligência e determinar a realização da prova omitida (CPC, art. 515, $\left.\S 4^{\circ}\right)$.

Por fim, a decisão extra petita é aquela que, como visto, decide fora dos limites traçados pela demanda e, como tal, implica error in procedendo, de modo que, em uma primeira análise, deve ser anulada. Foi igualmente visto que essa decisão é, sob certo ângulo, citra petita, na medida em que, ao decidir fora dos elementos da demanda, omitese em relação a estes.

À base da consideração de que a sentença deve ser anulada para que o juízo inferior promova novo julgamento está, assim como nos casos de decisão citra petita, a impossibilidade de haver supressão de um grau de jurisdição. Também aqui a análise das situações concretas que podem surgir é essencial para que se chegue à solução mais adequada.

\footnotetext{
${ }^{588}$ Essas são ponderações de Flávio Yarshell, com as quais concordamos (cf. Ação rescisória..., p. 90). ${ }^{589}$ Nesse sentido, Dinamarco, Instituições..., v. III, p. 292.
} 
Primeiro de tudo, é necessário definir o que se entende por decisão extra petita, sobretudo no cotejo com a decisão ultra petita, conforme diferenciação feita acima. Se entendermos que é aquela que decide integralmente fora dos limites da demanda, ou, para utilizar o léxico comum, a que erra o alvo completamente - posição aqui adotada -, os efeitos dos vícios e a maneira de saná-los serão uns. Se, por outro lado, entendermos que é a decisão em que a demanda ou parte dela é julgada mas, mais do que isso, o julgamento vai além, serão outros os efeitos e os remédios para a correção do vício. Em ambas as hipóteses a decisão será citra petita, excetuada a em que toda a demanda é apreciada e, indo além, confere-se provimento diverso (isso, repita-se, para quem adota o conceito de decisão extra petita aqui combatido).

Na hipótese em que não há nenhuma relação entre a demanda e a decisão, a única solução cabível é a anulação da sentença, por error in procedendo ${ }^{590}$ Não cabem aqui as alternativas de anulação parcial - pois não há capítulo de sentença a ser aproveitado - e de remessa para outra demanda. Adotando-se o segundo conceito de sentença extra petita (de decisão que decide parte da ou toda a demanda, mas também vai fora desses limites), muda-se de figura. Agora, há capítulos de sentença, que devem ser aproveitados, e capítulos inválidos, de modo que a invalidação de toda a sentença é medida a ser tomada apenas quando não for possível o aproveitamento de atos.

Se os pedidos contidos na demanda - e eventualmente deduzidos pelo réu - foram todos apreciados e resolvidas todas as questões de fato contidas no processo, a solução a ser adotada é simples, a mesma da decisão ultra petita: cabe ao tribunal reduzir o excesso. Situação diferente é a da decisão em que (i) parte da demanda é apreciada, (ii) outra parte não o é e, além disso, (ii) é julgado pedido não deduzido ou considerados fundamentos de fato não discutidos no processo. ${ }^{591}$ A solução é um amálgama das alternativas possíveis para as decisões ultra e citra petita. Firmada a premissa de que a anulação integral da sentença deve ser promovida apenas em último caso, o capítulo excedente deve ser extirpado pelo órgão recursal. No que diz respeito ao pedido ou a questões omitidas, o tribunal pode remeter a parte prejudicada para outra demanda ou anular parcialmente a sentença, determinando que o juízo a quo promova novo julgamento apenas do pedido ou

\footnotetext{
${ }^{590}$ Cf. José Roberto dos Santos Bedaque, Código de Processo..., p. 355.

${ }^{591}$ Embora analisando a questão apenas sob a ótica do pedido, e não das questões de fato, Flávio Yarshell diz que essa seria a hipótese mais comum de sentença extra petita (cf. Ação rescisória..., p. 91).
} 
da questão omitidos (e, se a questão puder alterar o resultado do julgamento de um dos pedidos já julgados, também deve ser anulado este). A anulação integral da sentença e a remessa para outra demanda possuem os inconvenientes já tratados acima, sendo preferível, portanto, a anulação parcial, também pelos motivos já expostos alhures. Tudo isso, ressalva-se novamente, na premissa de que o segundo conceito de decisão extra petita exposto seja o correto. Reputando-se extra petita a decisão em que o julgador inventa por completo, isto é, não aprecia nenhum dos pedidos e decide por fato essencial não deduzido, a única solução é a anulação integral da sentença, pois não há o que ser aproveitado. ${ }^{592}$

Como visto anteriormente, em regra, para os casos de decisões citra petita e extra petita preconiza-se a anulação da decisão para que o juízo inferior profira nova sentença, a remessa da parte para outra demanda ou a anulação parcial e remessa dos autos para que o juízo inferior aprecie o que foi omitido, prosseguindo o processo com relação ao que fora validamente decidido. Todas essas alternativas partem, basicamente, da mesma premissa: a impossibilidade de supressão de um grau de jurisdição e de afronta ao duplo grau de jurisdição ou até mesmo à garantia do juiz natural, uma vez que a competência dos tribunais é, em regra, a de rever decisões, sendo poucas as hipóteses de competência originária dos tribunais estabelecidas na Constituição da República. Há, contudo, uma quarta alternativa que, se cabível nos casos concretos, deve ser aplicada com preferência sobre as demais.

Apesar de o art. 515, $\S 3^{\circ}$ do CPC disciplinar o caso de apelação interposta contra sentença terminativa, deve ser aplicado aos casos de sentenças que padecem de vícios de infidelidade à regra de correlação, notadamente vícios restritivos. O dispositivo estabelece que "nos casos de extinção do processo sem julgamento do mérito (art. 267), o tribunal pode julgar desde logo a lide, se a causa versar questão exclusivamente de direito e estiver em condições de imediato julgamento". Pela literalidade da lei, portanto, diante de apelação interposta contra sentença terminativa e desde que atendidos os requisitos de (i) a controvérsia ser exclusivamente de direito e (ii) estar a causa em condições de imediato

\footnotetext{
${ }^{592}$ Nesse sentido, Teresa Arruda Alvim Wambier afirma que a sentença extra petita é inaproveitável e deve o juízo a quo proferir outra em seu lugar (cf. Nulidades do processo..., p. 305).
} 
julgamento, o tribunal pode passar desde logo à apreciação do mérito, ao invés de anular a sentença e determinar que o juízo a quo promova novo julgamento. ${ }^{593}$

Todavia, embora a redação do parágrafo exija a presença dos dois requisitos expostos anteriormente, o critério de a causa versar questão exclusivamente de direito não é exato. Mesmo que o processo envolva questões de fato, pode ser aplicado o art. $515, \S 3^{\circ}$ do CPC, bastando que os pontos de fato tenham sido debatidos, tenha havido produção probatória suficiente e não haja questões pendentes de prova. O único requisito legítimo para a aplicação do dispositivo é que a causa esteja madura, devendo se entender por isso o processo no qual houve efetivo exercício do contraditório, resolução de todos os pontos de fato e, portanto, não pende de prova qualquer questão de fato relevante para o deslinde da controvérsia. E mais: toda vez que forem desnecessárias outras provas além das já produzidas, estaremos diante de hipótese em que há questão exclusivamente de direito, pois apenas por exceção é necessária prova para resolver questão de direito (CPC, art. 337). Por isso, teria sido melhor ter sido adotada, com as devidas adaptações, a redação do art. 330, I do CPC: "quando a questão suscitada no recurso for unicamente de direito ou, sendo de direito e de fato, não houver necessidade de outras provas". ${ }^{594-595}$

\footnotetext{
${ }^{593}$ Trata-se de clara técnica de aceleração do processo, pela qual se mitiga a garantia do duplo grau de jurisdição e se premiam os princípios da duração razoável do processo e da economia processual, permitindose ao tribunal que julgue determinada matéria que, embora "pronta" para julgamento, não foi apreciada pelo juízo hierarquicamente inferior. Para os que questionam a aplicação do dispositivo em comento sob o argumento de que afrontaria o duplo grau de jurisdição, Barbosa Moreira responde que o princípio do duplo grau de jurisdição "não está definido em texto algum, nem tem significação universal fixada a priori: seu alcance será aquele que resulta do exame do ius positum, e portanto discutir se o infringe ou não disposição legal como a que ora se comenta é inverter os termos da questão" (cf. Comentários ao Código de Processo Civil, v. V, p. 431).

${ }^{594}$ A observação e a sugestão de lege ferenda são de Barbosa Moreira (cf. Comentários..., p. 432). Também entendendo que para a aplicação do dispositivo em comento a causa deva versar questão exclusivamente de direito ou, versando questões de fato e de direito, esteja madura para julgamento, isto é, não demande mais provas, estão Fredie Didier Jr. e Leonardo José Carneiro da Cunha (cf. Curso de direito processual civil, v. 3, p. 111). Gilson Delgado Miranda e Patrícia Miranda Pizzol, também partidários dessa posição, preconizam interpretação do dispositivo em consonância com o art. 330 do CPC, especialmente o seu inciso I (cf. Recursos no processo civil, p. 59).

595 Outra controvérsia que existe diz respeito à necessidade de haver pedido da parte interessada para que o tribunal possa aplicar o dispositivo em tela. Embora a sua redação estabeleça que "o tribunal pode julgar desde logo a lide", o que, quando menos, indicaria que se trata de faculdade do julgador, a doutrina diverge. Flávio Cheim Jorge defende que o art. 515, $\S 3^{\circ}$ seja aplicado apenas quando houver pedido do recorrente, por força do princípio dispositivo e da disciplina do efeito devolutivo da apelação, pelo qual apenas a matéria impugnada deve ser apreciada. Julgamento do mérito do recurso manejado contra sentença terminativa, portanto, apenas se houve pedido expresso nesse sentido (cf. Teoria geral dos recursos cíveis, pp. 289/291). Assim também Fredie Didier Jr. e Leonardo José Carneiro da Cunha (cf. Curso..., v. 3, p. 110). Adotando outra posição, Flávio Yarshell advoga a tese de que a aplicação desse dispositivo independe de pedido da parte interessada, argumentando que, se o órgão de primeiro grau pode julgar a lide antecipadamente ainda que as partes tenham especificado provas, também nesse caso pode o tribunal passar ao julgamento direto do mérito, se entender que não pendem de solução questões de fato. Havendo julgamento desfavorável ao
} 
Estabelecidas essas premissas, é cabível a aplicação do art. 515, § $3^{\circ}$ do CPC para a correção dos vícios restritivos que violem a regra de congruência, porque nessas hipóteses, assim como nas sentenças terminativas, há a apreciação pelo tribunal de matérias que não foram apreciadas pelo juízo inferior. A razão que inspirou a edição daquele dispositivo é a mesma que está por trás do raciocínio ora defendido, de tal sorte que é perfeitamente possível a sua aplicação nas decisões citra petita e extra petita. ${ }^{596}$ Tendo havido efetivo contraditório entre as partes quanto ao pedido ou à questão omitida pela sentença citra ou extra petita, e estando a causa em condições de imediato julgamento, isto é, não pendendo de solução questão de fato, deve ser aplicado o dispositivo, com primazia sobre todas as outras alternativas discutidas acima (anulação, remessa para nova demanda ou anulação parcial). Apenas se não cabível no caso concreto a solução do art. $515, \S 3^{\circ}$ é que se deve recorrer às demais vias.

A regra, enfim, é a de que a sentença adstrinja-se aos limites postos pelo autor e eventualmente alargados por demanda apresentada pelo réu. Violações à referida regra geram a nulidade da decisão ou de parte dela, na forma vista acima. Sentenças que, julgando demanda de impugnação de deliberação assemblear, não respeitem a regra de correlação, seguem o regime ordinário de violação a tal regra. Ou seja, são, como qualquer outra sentença infra, extra ou ultra petita: ocorre uma violação aos limites da demanda, que, embora indevida, pode vir a ser sanada pela coisa julgada material. Sob a perspectiva da regra de correlação entre demanda e provimento, a demanda que pretenda a invalidação de deliberação assemblear segue as regras ordinárias e recebe o mesmo tratamento de uma demanda ordinária.

apelante, não se estará diante de reformatio in pejus e o error in procedendo consistirá, eventualmente, no julgamento direto sem estarem presentes os requisitos legais para aplicação do dispositivo (cf. Ação rescisória..., p. 88). Também defendendo a aplicação do dispositivo de ofício, Gilson Delgado Miranda e Patrícia Miranda Pizzol, Recursos..., p. 61. Essa última posição é a mais acertada, quer pelos argumentos expostos, quer por dispor o dispositivo em tela que o tribunal pode desde logo julgar o mérito. Parece que, ao assim dispor, o Código está abrindo a possibilidade ao tribunal - ainda que se entenda tratar-se de um poderdever -, retirando a aplicação da norma do âmbito da iniciativa do recorrente.

596 Defendendo essa possibilidade, Flávio Luiz Yarshell, Ação rescisória..., p. 89. Como apontam Gilson Delgado Miranda e Patrícia Miranda Pizzol, se o tribunal "pode o mais" - analisar o mérito diante de sentença terminativa -, também "pode o menos" - ou seja, reformar a decisão por violação à regra de correlação (cf. Recursos..., p. 60). Aparentemente contrário à aplicação aqui preconizada, Flávio Cheim Jorge invoca o exemplo da sentença sem fundamentação, argumentando que, nesse caso, a Constituição Federal impõe a sua nulidade $(\mathrm{CF}$, art. 93, IX), de modo que o julgador não poderia relevar o vício e adentrar ao exame do mérito: "A sanção de nulidade imposta pela Constituição constitui-se em óbice à aplicação do $\S 3^{\circ}$ do art. 515, do CPC quando reconhecido o vício de falta de fundamentação" (cf. Teoria geral..., p. 291). 


\subsection{Nulidade relativa ou absoluta?}

Embora o assunto não seja pacífico na doutrina, a principal razão (e utilidade) da distinção entre nulidades processuais absolutas e relativas é a de que aquela pode ser conhecida de ofício e esta depende de alegação da parte interessada para que possa ser reconhecida. ${ }^{597}$ Os atos absolutamente nulos são os portadores de vícios que prejudicam a própria prestação jurisdicional e por isso afetam o interesse público da Justiça, ${ }^{598}$ razão pela qual devem ser controlados de ofício pelo juiz (CPC, art. 245, parágrafo). Já os atos relativamente nulos prejudicam os interesses das partes, dependendo de provocação da parte interessada no momento adequado para que sejam desconstituídos, sob pena de preclusão. $^{599}$

As infidelidades à regra de correlação são nulidades relativas e, por isso, dependem de provocação do interessado para que sejam sanadas. ${ }^{600}$ Se a decisão foi além do pedido ou considerou fundamentos de fato não discutidos no processo (ultra petita), somente a parte prejudicada possui interesse em requerer a invalidação, que, como visto

\footnotetext{
${ }^{597}$ Digna de nota é a doutrina de José Roberto dos Santos Bedaque: “O único efeito prático da distinção entre nulidade absoluta e relativa está na possibilidade, ou não, de o juiz, porque presumido o prejuízo, poder reconhecer de ofício a irregularidade e decretar a nulidade do ato" (cf. Efetividade..., p. 454). Em sentido semelhante, v. Dinamarco, Instituições..., v. II, p. 612.

${ }^{598}$ Cf. Dinamarco, Instituições..., v. II, p. 594; e Cintra-Grinover-Dinamarco, Teoria geral..., p. 353.

599 Roque Komatsu, adotando classificação diversa, divide os atos inválidos em três categorias: (i) absolutamente nulos, quando ocorre violação de norma cogente e que tutela interesse público; (ii) relativamente nulos, quando se dá violação de norma cogente e que tutela interesse privado; e (iii) anuláveis, quando se viola norma dispositiva e que tutela interesse privado (cf. Da invalidade no processo civil, p. 210). Por sua vez, Calmon de Passos rejeita a divisão das nulidades em absolutas e relativas com base no direito tutelado pela norma descumprida. Diz, em tom de certa ironia, que não há no processo civil normas que tutelem apenas direitos privados, haja vista os fins de justiça que a ordem processual possui, de maneira que "não há, pois, dessa perspectiva, como distinguir nulidades", ("Esboço de uma teoria das nulidades", RePro n. 56, p. 18). José Miguel Garcia Medina e Teresa Arruda Alvim Wambier dizem que "no que diz respeito à situação enquanto o processo estiver em curso, a distinção carece de importância, já que, como se verá, o regime jurídico da nulidade e da inexistência é o mesmo: ausência de preclusão, para o juiz e para as partes, e possibilidade de manifestação ex officio. Os regimes só passam a se diferenciar depois do fim do processo, e são, a nosso ver, diferentes as formas através das quais se podem impugnar as decisões proferidas em processos com estes vícios.” (cf. O dogma da coisa julgada, p. 31). José Roberto dos Santos Bedaque, por sua vez, tomando por base o princípio da instrumentalidade das formas (CPC 250), propõe o abandono dos conceitos de nulidade relativa e absoluta: se não houver prejuízo e se o escopo do ato for atingido, deve ser preservado o ato, mesmo que a nulidade seja considera absoluta e mesmo que haja cominação expressa. A única razão nessa distinção seria a de que pela nulidade absoluta presume-se o prejuízo e por isso o juiz pode reconhecê-la de ofício (cf. "Nulidades e apelação", in Meios de impugnação ao julgado civil: estudo em homenagem a José Carlos Barbosa Moreira, p. 409).

${ }^{600}$ Cf. Dinamarco, Instituições..., v. III, pp. 290/291. Teresa Arruda Alvim Wambier, por outro lado, entende serem nulidades absolutas (cf. Nulidades do processo..., p. 308).
} 
acima, deverá em regra se limitar ao capítulo excessivo. Se a decisão é extra petita, tanto o réu como o autor podem requerer a anulação, pois aquele pode ter sido surpreendido e a este pode não convir o provimento diferente. ${ }^{601}$ As mesmas considerações valem para as sentenças que não se atêm à causa de pedir, consideram fundamentos não trazidos pelo réu ou conhecem de matérias que a lei veda conhecer de ofício: o conhecimento do vício depende de alegação do sujeito prejudicado.

Por outro lado, como as infidelidades restritivas em regra prejudicam somente o autor, apenas ele possui interesse no pleito de anulação. A menos, é claro, que o que foi desconsiderado tenha sido algum fundamento de defesa levantado pelo réu ${ }^{602}$ ou a sentença tenha sido favorável ao réu.

Quando as infidelidades ampliativas forem relativas ao elemento subjetivo da demanda (partes), os vícios só comportarão alegação pelo terceiro atingido ou pelo autor. O interesse do terceiro decorre da surpresa de uma sentença imposta em processo do qual não participou, e o do autor decorre da denegação de tutela em relação ao sujeito indicado na demanda.

\section{Alcance temporal do provimento na desconstituição de deliberações assembleares:} ex nunc, ex tunc ou modulação de efeitos?

No item 11 tratamos do momento de eficácia do provimento, isto é, daquele a partir do qual a tutela jurisdicional pode ser "executada" ou - mais propriamente nas hipóteses de provimentos declaratório e constitutivo - efetivada. Igualmente relevante para os fins desta pesquisa é falarmos do alcance temporal do provimento, isto é, das situações jurídicas que, na linha do tempo, são abarcadas pela sentença desconstitutiva; o que nada mais é do que um aspecto dos limites objetivos da sentença.

\footnotetext{
${ }^{601}$ Cf. Dinamarco, Instituições..., v. III, p. 291. Adotando-se o conceito de decisão extra petita como aquela que aprecia parte do que foi pedido mas vai além, a anulação deve ser limitada ao capítulo excessivo a não ser que a decisão tenha sido integralmente extra petita, sem decidir nada do objeto da demanda, hipótese em que deve ser totalmente anulada.
}

${ }^{602}$ Cf. Dinamarco, Instituições..., v. III, p. 292. 
Sobre tal aspecto, chamado por alguns de retroatividade da sentença, ${ }^{603}$ é comum em doutrina a afirmação de que, como a decisão constitutiva atua como título/causa da alteração jurídica, os seus efeitos operam-se ex nunc, pois produziram-se até então e só serão removidos a partir de quando a sentença tornar-se eficaz, ao passo que, como o provimento declaratório apenas põe fim a um estado de incerteza, reconhecendo a ausência ou inexistência de algo que lhe precede, teria efeitos ex tunc. ${ }^{604}$ À base desse raciocínio está a ideia de que a nulidade priva integralmente o ato jurídico de efeitos jurídicos e assim, desde a sua gênese ( $a b$ ovo) este não produz efeito jurídico algum que necessite ser desconstituído, diversamente do que ocorreria com o ato anulável, que produz efeitos precários.

De fato, colhe-se em Chiovenda que a sentença constitutiva normalmente age $e x$ nunc, pois produz um estado jurídico que não existia anteriormente a ela. Contudo, em casos especiais, por expressa disposição de lei, essa espécie de provimento atuaria ex tunc, é dizer, com eficácia desde a prolação da sentença provisória, desde a propositura da demanda ou desde o nascimento do estado jurídico que é alterado. Embora seja comum à sentença constitutiva, o efeito ex nunc não é da sua essência. ${ }^{605}$ A retroatividade da sentença depende da fattispecie que no caso concreto o ato viciado possui, e não de uma pretensa regra geral aplicável a todas as hipóteses de cada tipo de provimento. ${ }^{606}$ Essa

${ }^{603}$ Cf. Tomás Pará Filho, Estudo sobre..., p. 137.

${ }^{604}$ Cf. Satta, Direito processual..., v. 1, n. 147, p. 276; Luigi Montesano, La tutela..., n. 95, p. 257; Liebman, Manual..., v. 1, n. 86, p. 246; Cintra-Grinover-Dinamarco, Teoria geral..., n. 197, p. 314; Flávio Yarshell, "Tutela jurisdicional meramente declaratória", p. 46; Francesco Terrusi, L’invalidità..., n. 5.3, p. 228; Gianpaolo Impagnatiello, "La provvisoria esecutorietà delle sentenze costitutive", Rivista trimestrale di diritto e procedura civile, v. 46. n. 1, p. 51; Nelson Eizirik, A Lei das S/A..., v. III, p. 579; e Heitor Sica, "Contribuição ao estudo...", p. 186. No mesmo sentido, Caio Mário da Silva Pereira ("a anulabilidade, por ser de interesse privado, não pode ser pronunciada senão a pedido da pessoa atingida, e a sentença produz efeitos ex nunc, respeitando as consequências geradas anteriormente"; cf. Instituições..., v. 1, n. 111, p. 551) e Serpa Lopes: "enquanto o ato nulo surge como se nunca houvera existido (non valet) sendo retroativos os efeitos da sentença que o decretar, operando ex tunc, o ato anulável, enquanto não decretada a anulabilidade por sentença (...) continua portador de todos os efeitos como se válido fosse, e os do reconhecimento dessa ineficácia só começam a partir do trânsito em julgado da sentença (ex nunc)"; cf. Curso..., v. 1, n. 357, p. 506).

${ }^{605}$ Cf. Principii..., pp. 185/186, lição integralmente acolhida por Moacyr Amaral Santos, o que demonstra a sua aplicabilidade também ao direito brasileiro (cf. Comentários..., v. IV, n. 321, p. 432).

${ }^{606}$ Cf. Corrado Ferri, Profili..., pp. 171/174, 191/194 e 198, segundo quem a sentença constitutiva produz efeitos ex nunc no direito italiano não por conta de uma característica intrínseca, mas porque o art. 324 do Código de Processo Civil italiano assim determina. Acolhendo a crítica de Ferri, Andrea Proto Pisani, "Appunti sulla tutela di mero accertamento", p. 669. No mesmo sentido, Arruda Alvim: "Nas sentenças constitutivas, normalmente, os efeitos produzidos o são a partir da própria sentença (ex nunc), e, por exceção, são ex tunc. Este aspecto depende, basicamente, do Direito material, e há de ser equacionado em função da proteção que o Direito material deve realizar e para isto reclama o instrumental do Direito processual" (cf. Manual de direito processual civil, v. 2, p. 639); Humberto Theodoro: "Já o efeito das sentenças constitutivas 
mesma ausência de relação necessária entre sentença constitutiva e eficácia ex nunc já fora apontada também por Goldschmidt. ${ }^{607}$

Tanto não existe desvinculação necessária entre eficácia retroativa e tutela constitutiva negativa que, ao contrário do que sustenta a corrente doutrinária referida anteriormente, quer no caso de nulidade, quer no de anulabilidade deve ser restituído o estado anterior ao ato invalidado, fulminando-se este e seus efeitos desde quando ingressaram no mundo jurídico. Não importa o tipo da invalidade, a decisão que a reconhece e sanciona atua retroativamente. Daí porque, de acordo com Zeno Veloso, embora faça menção apenas à anulação, o art. 182 do CC ("anulado o negócio jurídico, restituir-se-ão as partes ao estado em que antes dele se achavam, e, não sendo possível restituí-las, serão indenizadas com o equivalente") aplica-se também aos casos de nulidade. ${ }^{608}$ Vincular a anulabilidade ao efeito ex nunc é equivocado e decorre de uma leitura distorcida do art. 177 do Código Civil, que preceitua que "a anulabilidade não tem efeito antes de julgada por sentença, nem se pronuncia de ofício". O que na realidade esse artigo dispõe é que o negócio jurídico anulável produz efeitos e que é necessária decisão judicial que os remova. Ou seja, que tais efeitos são precários, mas, advindo sentença anulatória, devem ser desconstituídos ab initio. $\mathrm{O}$ artigo nada diz sobre o alcance temporal da decisão. Quer em caso de nulidade, quer de anulabilidade, a sentença tem eficácia retroativa e, se não for possível a restituição ao estado anterior, a invalidade resolve-se em perdas e danos (CC, art. 182). ${ }^{609}$

é normalmente ex nunc. Produz-se para o futuro, a partir do trânsito em julgado" (cf. Curso de direito processual civil, v. 1, p. 471); e Frederico Marques: "As sentenças declaratórias e as condenatórias produzem efeitos ex tunc: as constitutivas, de regra, efeitos ex nunc, e, excepcionalmente, o efeito ex tunc" (cf. Manual..., v. 1, p. 51). Ainda, v. Moacyr Amaral Santos, Primeiras linhas..., v. 3, p. 34 e Cássio Scarpinella Bueno, Curso..., v. 1, p. 296.

${ }^{607}$ Cf. Derecho procesal civil, § 15, p. 112: "El acto del juez puede tener efectos 'ex nunc' (por ejemplo, divorcio) o 'ex tunc' (por ej., nulidad del matrimonio). Por esto no existe razón alguna para que se reconozan como verdaderas sentencias constitutivas solamente las que producen efecto 'ex nunc".

${ }^{608}$ Cf. Invalidade..., n. 25, pp. 150. Entendimento que, na égide do CC/16, era colhido na obra de Bevilaqua, em decorrência da dicção do art. 158 daquele diploma (cf. Theoria geral..., n. 67, p. 340).

${ }^{609}$ Cf. Zeno Veloso, Invalidade..., nn. 67 e 68, pp. 332 e 334. E é peremptório: "Temos de repudiar, portanto, e com toda a energia, a falsa afirmação de que a sentença de nulidade opera retroativamente e a sentença de anulação ex tunc, prospectivamente. Ambas têm eficácia ex tunc" (n. 68, p. 338). Ainda de acordo com Veloso, seria absurdo o atrelamento da nulidade à eficácia ex tunc da sentença e o da anulabilidade à eficácia ex nunc, "absurdo que cresce de tamanho quando se sabe que as causas que determinam a anulação são contemporâneas à formação, ao nascimento do negócio" (cf. Invalidade..., n. 71, p. 357). Também Betti afirmou que tanto o negócio jurídico nulo como o anulável devem ser removidos com "fuerza retroactiva", ressalvados apenas alguns efeitos em relação a pessoas determinadas (cf. Teoría general..., n. 58, p. 353 e 360). No mesmo sentido, Álvaro Villaça Azevedo: "Seja caso de anulabilidade ou de nulidade, a anulação ou o decreto de nulidade do negócio opera sua completa invalidade, como se o negócio jamais tivesse existido" 
Sob esse aspecto, é irrelevante a natureza do vício - o que reforça a ideia aqui defendida de que existem menos diferenças entre nulidade e anulabilidade do que se costuma dizer: o ato inválido e seus efeitos devem ser sempre desconstituídos retroativamente, pois o vício é contemporâneo ao nascimento do ato. ${ }^{610}$ A decisão certifica que o ato já nasceu com um defeito congênito e, no momento lógico subsequente, cassa o ato e seus efeitos, restaurando a ordem normativa. É isso, aliás, o que, com apoio no art. $289^{\circ}$ do seu Código Civil ("tanto a declaração de nulidade como a anulação do negócio têm efeito retroactivo, devendo ser restituído tudo o que tiver sido prestado...”), defende a doutrina portuguesa ao aludir a deficiências genéticas. ${ }^{611}$

Também no âmbito do direito societário prevalece a ideia de que a sentença que invalida uma deliberação, seja ela nula ou anulável, tem efeitos ex tunc. ${ }^{612}$. Todavia, é

(cf. Código Civil Comentado, v. II, p. 337). Essa posição é colhida também em Pontes de Miranda, com a peculiaridade de que para ele, embora a eficácia ex tunc seja comum aos dois tipos de vícios, no caso do nulo a eficácia desconstitui apenas o ato, e não seus efeitos, já que estes não se produzem; enquanto que no caso do anulável a eficácia desconstitui o ato e seus efeitos (cf. Tratado..., t. IV, nn. 364/365, pp. 34 e 38). Liebman também afirmou que "a declaração de nulidade ou a anulação do ato jurídico agem retroativamente" (cf. "Eficácia e autoridade...", n. 44, p. 154). Na mesma linha Carlos Alberto Alvaro de Oliveira: "desconstituído o ato, nulo ou anulável, a eficácia da sentença é ex tunc" (cf. Alienação..., n. 31, p. 263). Transpondo essas considerações para o âmbito da anulação do ato administrativo, Maria Sylvia Zanella di Pietro, "os princípios da proteção à confiança, da segurança jurídica e da boa-fé na anulação do ato administrativo", Fórum administrativo, n. 100, p. 163. No direito português, José de Oliveira Ascensão diz que "a nulidade é automática; a anulação do negócio retroage à data deste. Ambas são retroativas, no dizer do art. 289. Portanto, tudo o que se passou ficará destruído". Para Ascensão, portanto, a eficácia retroativa existe tanto nos atos nulos como nos anuláveis, mas por diferentes razões e modos: o ato nulo não produz efeitos negociais, ao passo em que o anulável os produz mas estes devem ser retroativamente destruídos (cf. Direito civil..., nn. 204/212, pp. 314 e 327).

${ }^{610}$ Toda invalidade é originária, isto é, surge no momento da concretização do ato jurídico. Causas de invalidade posteriores não invalidam o ato jurídico (por exemplo, compra e venda realizada por pessoa que, posteriormente à celebração do negócio, tornou-se incapaz), embora possam, em alguns casos, justificar a sua resolução (por exemplo, compra e venda de produto cuja comercialização posteriormente tornou-se ilícita; não há invalidade: se o contrato já foi cumprido, a inovação normativa é ineficaz; se está sendo cumprido, resolve-se) (cf. Marcos Bernardes de Mello, Teoria do fato jurídico - plano da validade, n. 23, p. 110). No mesmo sentido o civilista português José de Oliveira Ascensão: "Só há invalidades originárias" (cf. Direito civil: teoria geral, v. II, n. 204, p. 314).

${ }^{611}$ Cf. Hörster, A Parte Geral..., nn. 346, 349 e 857, pp. 211/213 e 515.

${ }^{612}$ Mario Vaselli escreveu que a deliberação anulável possui eficácia ex tunc, ressalvados os direitos de terceiros de boa-fé. Havendo nulidade não existiria tal ressalva (cf. Deliberazioni nulle..., pp. 107 e 111). Também Aurelio Candian defendeu a eficácia ex tunc da desconstituição do ato anulado e de todos aqueles que dele forem derivados (cf. Delibere..., n. 86, p. 162). Já Antigono Donati entendia que também a sentença de anulação de deliberação anulável possui eficácia ex tunc, "al momento del sorgere della deliberazione che essa annulla" e que não há dúvida de que "la deliberazione nulla o annullata non può più produrre gli effetti ai quali mirava" (cf. L'invalidità..., nn. 73 e 88, pp. 225 e 272). Essa foi também a conclusão de Ascarelli, ao defender que em relação a terceiros a nulidade ou a anulação de uma deliberação não tem eficácia retroativa, mas o tem em relação aos acionistas: "no que respeita às modificações estatutárias, o que importa, é a exclusão da eficácia retroativa quanto aos terceiros, não sendo, ao contrário, oportuno excluí-la também quanto aos acionistas" (cf. "Vícios...”, n. 5, p. 389, inclusive nota 66). Em outro texto, Ascarelli afirma 
exato afirmar que ao ser desconstituída uma deliberação deve ser sempre e necessariamente reputada ineficaz $a b$ ovo?

A resposta parece-nos negativa, pois, embora a regra geral seja mesmo a de que, como acontece com qualquer ato jurídico, a deliberação e seus efeitos devem ser desconstituídos desde o início, as peculiaridades do regime de invalidades no direito societário impõem que tal regra seja excepcionada, ao menos com maiores frequência e intensidade do que também é excepcionada para os atos jurídicos em geral. Naquele meio há uma superação da relação de necessariedade que existe entre invalidação e eficácia retroativa. Os atos societários não estão sujeitos ao regime comum de nulidades $^{613}$ e a mitigação à regra da retroatividade da sentença desconstitutiva é a mais contundente prova disso. Defender que as deliberações sejam invariavelmente desconstituídas ex tunc é negar a existência da especialidade desse regime, que, moldado pelos imperativos de certeza e segurança, tem na recusa à retroatividade pura e absoluta um de seus mais fortes pilares. ${ }^{614}$

Em defesa da mitigação da eficácia retroativa da sentença no âmbito do direito societário, some-se a circunstância de que a deliberação da sociedade por ações depende de registro e publicação, o que a submete a um controle duplo: (i) ampla publicidade perante interessados e terceiros e (ii) juízo de legalidade promovido pelo órgão de registro (ainda

expressamente que a anulação da deliberação possui eficácia retroativa (cf. "Appunti....", n. 11, p. 285). No mesmo sentido, embora não afirme expressamente, Erasmo Valladão França dá a entender que, quer em caso de nulidade, quer em caso de anulabilidade, a decisão terá eficácia retroativa, ressalvados direitos de terceiros (cf. Invalidade..., n. 22, pp. 131/133). Lobo Xavier também defende ser a regra o efeito retroativo da decisão que pronuncia a invalidade de uma deliberação. Tanto é que até em caso de anulação devem ser desde o início removidos os efeitos: "O que acontece é que, por força da sentença anulatória, à qual não compete uma eficácia meramente ex nunc, tais efeitos são eliminados retroactivamente. Assim a deliberação anulada deve considerar-se $a b$ initio desprovida de efeitos" (cf. Anulação..., n. 16, pp. 285 e 291). Francesco Terrusi igualmente defende a eficácia retroativa, ressalvados os direitos de terceiros de boa-fé, em razão do princípio da estabilidade dos atos societários (cf. L'invalidità..., nn. 5.3 e 6.7, pp. 229 e 298).

${ }^{613}$ Apesar de ter afirmado que as partes "devem ser repostas ao estado anterior ao ato, e somente quando isso é impossível é que prevalece o princípio da indenização", Trajano de Miranda Valverde também asseverou que, no direito societário, no que diz respeito à regra da restituição, "encontram-se na prática os mais sérios obstáculos à sua aplicação e não pode realmente ser aplicada, sem graves distúrbios na vida econômica, às sociedades comerciais, principalmente às sociedades por ações" (cf. Sociedades por ações, v. III, p. 97). Mais incisivo, Nelson Eizirik escreveu que, sobre as deliberações societárias, que "não há efeitos retroativos que decorram automaticamente de declaração de nulidade, cabendo ao julgador levar em conta os prejuízos que deles podem decorrer" (cf. A Lei das S/A..., v. III, p. 600).

614 Aliás, para aqueles que, diversamente de nós, adotam a ideia de que o ato anulável é sempre desconstituído ex nunc, o nosso direito positivo sinaliza justamente que a desconstituição das deliberações deve sempre ocorrer com essa eficácia, na medida em que os arts. 286 e 115, $\S 4^{\circ}$ da LSA aludem apenas a deliberações anuláveis. Por isso, a leitura que parece ser mais razoável para os partidários dessa corrente é a de que, como o legislador brasileiro não diferenciou deliberações nulas das anuláveis, para todas elas aplicarse-ia a regra geral de desconstituição ex nunc. 
que meramente formal). Tudo isso reforça a consolidação dos efeitos da deliberação no decorrer do tempo, ainda que ela seja inválida. Tanto é que, mesmo aqueles que defendem que nem sempre é necessário o pronunciamento judicial para a desconstituição do ato nulo (porque este supostamente seria ineficaz de pleno direito), pensam que essa regra não se aplica aos atos sujeitos a registro. ${ }^{615}$ Também os que defendem a eficácia retroativa da sentença entendem que em se tratando de deliberações sujeitas ao registro público os terceiros de boa-fé estão resguardados, ainda que se trate de nulidade. ${ }^{616} \mathrm{E}$ mais: autorizadas vozes entendem que os órgãos da administração têm o dever de recusar valor e eficácia a uma deliberação nula e, em alguns casos, anulável, ${ }^{617}$ de modo que a deliberação inválida estaria sujeita a mais esse controle. Todos esses aspectos, que funcionam como verdadeiras redes de proteção contra as deliberações inválidas, justificam que, por outro lado, os atos assembleares que, embora viciados, tenham passado incólumes por tais barreiras, tenham seus efeitos, ou pelo menos parte deles, preservados, contrariando a regra geral da desconstituição ex tunc.

Embora a nosso ver sem a devida fundamentação, Lobo Xavier afirma que as razões de certeza e segurança jurídica não são suficientes para afastar a eficácia retroativa da sentença anulatória. ${ }^{618}$ Contudo, além da suspensão dos efeitos da deliberação, existe a possibilidade de, fechada a via da tutela específica (desconstitutiva), tutela indenizatória. A indenização é uma alternativa a um dano que já se consolidou e a suspensão evita que os efeitos da deliberação anterior se prorroguem no tempo e, assim, novas situações jurídicas sejam constituídas. Quanto mais se prorroga no tempo a validade de um ato, maior deve ser a proteção de sua estabilidade.

As deliberações seguem a mesma regra dos demais atos jurídicos privados inválidos: o reconhecimento da invalidade e a consequente desconstituição de eventuais efeitos produzidos em princípio operam-se ex tunc, qualquer que seja a natureza do vício (nulidade ou anulabilidade), pois como o vício lhes é contemporâneo, a decisão reconhece

\footnotetext{
${ }^{615}$ Nesse sentido, Marcos Bernardes de Mello: "Há, porém, atos jurídicos cuja desconstituição é essencial, pela sua natureza. É o caso, por exemplo, dos atos jurídicos sujeitos a registro e registrados" (cf. Teoria do fato jurídico - plano da validade, n. 74, p. 290).

${ }^{616}$ Cf. Erasmo Valladão França, Invalidade..., n. 22, p. 135.

${ }^{617}$ Cf. Lobo Xavier, Anulação..., n. 20, pp. 347/352 e 365; e Erasmo Valladão França, Invalidade..., n. 15, p. 64, inclusive nota 107.

${ }^{618}$ Cf. Lobo Xavier, Anulação..., n. 31, pp. 430/431.
} 
a violação à ordem legal e cassa o ato e seus efeitos desde o nascimento. A única diferença é que nos atos assembleares com maior deve frequência haver um temperamento a essa regra. Por isso, parece-nos que a melhor alternativa é que o alcance temporal da sentença que desconstitui deliberação seja fixado pelo julgador, de acordo com (i) o pedido (em razão da regra de correlação entre demanda e provimento) e (ii) as circunstâncias do caso concreto. Embora em princípio sejamos contrários a soluções que remetam ao caso concreto, ${ }^{619}$ essa nos parece a melhor alternativa, pois qualquer solução apriorística não seria satisfatória. Daí a adequação da modulação dos efeitos da invalidação.

\subsection{Modulação de efeitos na invalidação: admissibilidade no direito brasileiro}

Entender que, diante de qualquer invalidade, a deliberação e seus efeitos devem ser desconstituídos ab ovo gera graves problemas no que diz respeito aos acionistas (que, sobretudo em grandes companhias de capital disperso, podem representar um número elevado de pessoas), aos agentes econômicos que contrataram com a sociedade e à própria companhia. O caminhar de um ente societário cria um emanharado de relações jurídicoeconômicas que não podem conviver com a instabilidade que um sistema de remoção retroativa dos efeitos de atos inválidos acarreta. É comum que se preconize ressalvar os direitos de terceiros de boa-fé. Mas pouco se diz sobre a boa fé dos agentes envolvidos na formação e sobretudo no cumprimento da deliberação, isto é, dos sócios e especialmente da própria companhia. Se não houve má-fé ou consciência da ilicitude da deliberação e a companhia portou-se como se válida e eficaz aquela fosse, trata-se de dado relevante que, apesar de não ser suficiente para o reconhecimento da validade e da eficácia do ato, deve ser levado em consideração em favor da manutenção dos efeitos deste, ainda que de apenas alguns deles.

Realmente, mesmo os autores que advogam a eficácia retroativa da invalidação de atos civis ressalvam que essa é uma regra que, como tal, possui exceções. ${ }^{620} \mathrm{E}$ as

\footnotetext{
${ }^{619}$ Não achamos que a saída seja invocar a ponderação de valores ou os "princípios" da razoabilidade e proporcionalidade, com faz Hamid Charaf Badine Jr. Esse autor, ainda, fundamenta a possibilidade de serem conferidos efeitos ao negócio nulo com base no art. 421 do Código Civil, que estabelece a função social do contrato (cf. Efeitos do negócio..., caps. 12 e 13, pp. 171 e 190). Não vemos, contudo, como fundamentar a modulação dos efeitos da nulidade nesse dispositivo legal.

${ }^{620}$ Cf. Zeno Veloso, Invalidade..., n. 68, p. 338. Embora também apresente ressalvas às diferenciações costumeiras entre nulidade e anulabilidade, Marcos Bernardes de Mello defende que a desconstituição do ato anulável também se opera ex tunc (cf. Teoria do fato jurídico - plano da validade, n. 68, pp. 269).
} 
características das invalidades no direito societário a fortiori justificam a ressalva. Em regra, as deliberações devem ser desconstituídas ex tunc, mas a sentença pode dispor de forma diversa, justificando a menor extensão da tutela. Por tais motivos, não há, sob o aspecto do alcance temporal do provimento, diferenciação a priori entre as deliberações assembleares nulas e anuláveis: não importa a natureza do vício, o ordinário é que os atos devem ser desconstituídos retroativamente. A espécie do vício torna-se relevante apenas na valoração a ser feita em eventual modulação, pois o ato nulo, em tese, exige maior rigor na desconstituição.

Poder-se-ia dizer que o ora defendido levaria a uma situação de insegurança jurídica e que as opções deveriam ser feitas de antemão pelo legislador, e não pelo julgador. A grande questão, contudo, é que no Brasil essa opção não foi feita em sede legislativa, uma vez que, diga-se novamente, a lei é omissa a respeito da disciplina das deliberações inválidas. Por conta dessa omissão, quase todos os entendimentos que existem em nosso sistema sobre a invalidade de deliberações carece de base legal expressa e são construídos ora com base em normas voltadas para situações similares, ora com base em construções doutrinárias e jurisprudenciais. Não só nos parece possível como recomendável que, em razão das peculiaridades de direito material que se procura demonstrar neste trabalho, as consequências das invalidades dos atos assembleares sejam moduladas conforme o pedido e as circunstâncias do caso concreto. ${ }^{621}$ E nem se diga que não haveria autorização legal para a modulação das nulidades de atos privados. $\mathrm{O}$ laconismo do direito brasileiro a respeito das deliberações inválidas faz com que esse regime deva ser construído pelos aplicadores do direito.

O chamado princípio da proteção da confiança também pode ser invocado como fundamento da modulação. Referido princípio consiste em uma ferramenta de defesa de interesses individuais em hipóteses em que o particular, não tendo a proteção do ato jurídico perfeito ou do direito adquirido, em qualquer seara - e não apenas no direito público -, exerce sua liberdade confiando na suposta validade de um ato normativo mas,

\footnotetext{
${ }^{621}$ Note-se que, ao se pronunciar sobre a lei do anonimato, nossa doutrina já defende juízos que remetem à circunstâncias do caso concreto. Exemplo disso é o entendimento de Carvalhosa de que a análise da conduta dos administradores para os fins da responsabilização prevista no art. 158 da legislação do anonimato deva levar em consideração (i) as diferenças de gestão das companhias fechadas e abertas; (ii) o ramo de atividade da sociedade; (iii) o tamanho desta e o seu grau de profissionalização; e (iv) os usos e costumes da atividade empresarial (cf. Comentários..., $3^{\circ}$ v., p. 438). A lei não estabelece esses parâmetros, mas eles, diz essa autorizada doutrina, devem ser considerados.
} 
posteriormente, tem essa confiança frustrada por ato posterior que afeta a validade daquele primeiro ato. Procura-se conferir estabilidade às relações jurídicas ${ }^{622}$ e às expectativas legítimas diante de uma mudança normativa abrupta por meio da proteção ao interesse do particular que, no passado, agiu juridicamente orientado. ${ }^{623}$ Tal princípio é operacionalizado de modo a, dentre outras medidas, manter determinados efeitos de atos que, embora ilícitos, ostentaram aparência de licitude e, assim, orientaram os sujeitos a se comportarem de uma determinada maneira que, posteriormente, veio a ser reconhecida ilegal.

Diversos autores, de fato, defendem a aplicação do princípio da proteção da confiança não só no direito público - onde foi cunhado -, mas também no privado. Exemplo disso é Judith Martins Costa, para quem referido princípio não só está na base de todas as relações jurídicas, de direito público e privado, como perpassa toda a teoria do negócio jurídico, ${ }^{624}$ e Celso Antonio Bandeira de Mello, que afirma que o princípio em

${ }^{622} \mathrm{E}$ apesar desse princípio não ser protegido por um dispositivo constitucional expresso, ele é protegido pelo art. $5^{\circ}, \S 2^{\circ}$ da $\mathrm{CF} / 88$, que estabelece que "os direitos e garantias expressos nesta Constituição não excluem outros decorrentes do regime e dos princípios por ela adotados". A proteção da confiança, assim, "é uma eficácia reflexa do princípio da segurança jurídica, em conjunto com os direitos fundamentais de liberdade e de propriedade. (...) A sua falta de previsão expressa possui apenas o efeito de a sua proteção depender de uma ponderação concreta com outros princípios eventualmente colidentes e da sua relação com os direitos fundamentais de liberdade, propriedade e igualdade; ao contrário do que ocorre com as regras que protegem o direito adquirido, o ato jurídico perfeito, a coisa julgada e o fato gerador ocorrido do ponto de vista legal". O princípio da proteção da confiança atua no plano microjurídico, protegendo o interesse de uma pessoa específica, ao contrário do princípio da segurança jurídica, que foca o âmbito macrojurídico e é uma norma objetiva, de aspecto mais geral e não necessariamente ligada a um sujeito específico. O princípio da proteção da confiança, portanto, representa um mecanismo de concretização da justiça individual, por meio da proteção de "uma confiança" em particular (cf. Humberto Ávila, Segurança jurídica, pp. 366/369). No mesmo sentido, Maria Sylvia Zanella di Pietro, para quem “o princípio da proteção à confiança leva em conta a boa-fé do cidadão, que acredita e espera que os atos praticados pelo poder público sejam lícitos e, nessa qualidade, serão mantidos e respeitados pela própria Administração e por terceiros". Ainda de acordo com di Pietro, referido princípio decorre implicitamente do ordenamento jurídico brasileiro (cf. "Os princípios da proteção à confiança...”, p. 158). Sobre esse princípio, v., ainda, Raphael Manhães Martins, que inclusive entende que se trata de princípio implícito do ordenamento brasileiro (cf. "O princípio da confiança legítima e o enunciado n. 362 da IV Jornada de Direito Civil", Revista CEJ, n. 40, pp. 12 e seguintes). Sobre a aplicação do princípio da proteção da confiança no direito português, v. José de Oliveira Ascensão, Direito civil..., n. 214, pp. 331/335). Ainda, v. as considerações de Flávio Yarshell sobre o princípio da confiança legítima no âmbito do direito processual civil (cf. Antecipação da prova sem o requisito da urgência e direito autônomo à prova, n. 16, p. 92).

${ }^{623}$ A função jurídica do princípio da proteção da confiança, para Valter Shuenquener, consiste em que "os cidadãos devem ter o direito a uma relativa continuidade das decisões estatais em que depositaram uma dose de confiança e devem poder confiar em que seus atos e planos empreendidos com base em comandos pretéritos do Poder Público serão plenamente reconhecidos e respeitados pelo ordenamento". E mais: "Expectativas de comportamento devem ser honradas" e o princípio da proteção da confiança "tem como propósitos específicos preservar a posição jurídica alcançada pelo particular e, ainda, assegurar uma continuidade das normas do ordenamento" (cf. O princípio da proteção da confiança, n. 1.4, pp. 58/60).

${ }^{624}$ Cf. "A proteção da legítima confiança nas relações obrigacionais entre a Administração e os particulares", Revista da Faculdade de Direito da Universidade Federal do Rio Grande do Sul, n. 22, p. 232. 
comento possui aplicação em todos os ramos do Direito. ${ }^{625}$ Tanto referida aplicação se dá fora das fronteiras do direito público que o Enunciado 362 da IV Jornada de Direito Civil diz que "a vedação ao comportamento contraditório (venire contra factum proprium) funda-se na proteção da confiança, tal como se extrai dos arts. 187 e 422 do Código Civill". ${ }^{626}$ E mesmo no âmbito das deliberações assembleares inválidas já Pietro Trimarchi sustentara que os direitos de terceiros de boa-fé devem ser ressalvados em caso de invalidação de deliberação, sempre que haja uma aparência idônea a criar confiança. ${ }^{627}$ Analogamente Aurelio Candian, que traçou um paralelo entre a produção de efeitos da deliberação nula e o princípio da presunção de legitimidade do ato administrativo. ${ }^{628} \mathrm{O}$ direito privado, portanto, e não só o direito público, protege a confiança legítima.

Para justificar a modulação pode ser invocada também a teoria do fato consumado. Defende a doutrina que, no direito administrativo, por conta do interesse público envolvido, as nulidades não apresentam as mesmas características daquelas do direito civil, especialmente no que diz respeito ao fato de que o ato nulo, no direito privado, é absolutamente nulo. Daí se defender que, em algumas hipóteses excepcionais, nas quais houve consolidação de uma situação de fato, mesmo o ato nulo convalide-se, como um reflexo do decurso do tempo como fator de segurança jurídica. ${ }^{629}$ A inércia da Administração em revogar e dos interessados em se insurgirem contra o ato inválido gera, excepcionalmente, a inalterabilidade da situação de fato decorrente do ato ilícito, ainda que esse padeça de uma invalidade grave. ${ }^{630}$ Esse entendimento, embora firmado no âmbito do direito administrativo, pode ser transposto também para o direito privado, mormente em casos em que a deliberação inválida atingiu uma vasta esfera de terceiros que, com base

\footnotetext{
${ }^{625}$ Cf. "Segurança jurídica, boa-fé e confiança legítima", Revista trimestral de direito público, n. 51/52, p. 8. ${ }^{626}$ Para uma análise desse enunciado e do seu fundamento, v. Raphael Manhães Martins, "O princípio da confiança...".

${ }^{627}$ Cf. Invalidità..., cap. XV, n. 1, p. 249.

${ }^{628}$ Cf. Nullità..., n. 113, p. 217. Um dos argumentos contrários à aplicação do princípio da proteção da confiança nos processos individuais, isto é, fora do âmbito dos atos administrativos, é o de que as decisões proferidas naqueles produzem efeitos relevantes apenas entre as partes (nesse sentido, Valter Shuenquener, $O$ princípio da proteção..., n. 6.2, p. 198). Contudo, na invalidação de deliberações assembleares o ato impugnado pode tocar a esfera jurídica de inúmeras pessoas, mormente quando se trata de companhia aberta.

${ }^{629}$ Cf. Mauro Roberto Gomes de Mattos, "Princípio do fato consumado no direito administrativo", Revista de Direito Administrativo, v. 220, pp. 196/197; e Luiz Carlos Figueira de Melo e Anderson Rosa Vaz, "Princípio da segurança jurídica e o fato consumado no direito administrativo", Revista do curso de direito da Universidade Federal de Uberlândia, v. 31, pp. 89/91.

${ }^{630}$ Cf. Marga Inge Barth Tessler, "O fato consumado e a demora na prestação jurisprudencial”, Revista CEJ, n. 27 , pp. $96 / 99$.
} 
nessa situação jurídica, contraíram direitos e obrigações cuja desconstituição gerará mais danos do que a manutenção da ilegalidade.

O sistema clássico de controle de constitucionalidade estadunidense é marcado pela noção de ineficácia absoluta e retroativa da lei inconstitucional, considerada null and void. Como consequência, o julgador declara a nulidade da norma e, com isso, são reputados igualmente ineficazes desde o início todos os atos praticados com base nessa lei. ${ }^{631}$ Contudo, mesmo naquele país, defende-se, como aponta Mauro Cappelletti, o respeito a efeitos consolidados produzidos por atos fundados em leis posteriormente reputadas violadoras da Constituição. O fundamento dessa teoria é justamente o de que levar às últimas consequências a noção de ineficácia retroativa do ato inconstitucional em certos casos pode trazer graves repercussões sobre a certeza e a estabilidade das relações jurídicas. ${ }^{632}$

No direito brasileiro podem ser invocadas, quando menos por analogia, as regras que permitem a modulação de efeitos na Lei 9.868/99 (que trata do controle concentrado de constitucionalidade), ${ }^{633}$ na Lei 9.882/99 (que regula a arguição de descumprimento de preceito fundamental) ${ }^{634}$ e na Lei $11.417 / 06$ (que disciplina a súmula vinculante). ${ }^{635}$ As

\footnotetext{
${ }^{631}$ Em oposição ao sistema clássico austríaco, em que, "ao contrário, a Corte Constitucional não declara uma nulidade, mas anula, cassa ('aufhebt') uma lei que, até o momento em que o pronunciamento da Corte não seja publicado, é válida e eficaz, posto que inconstitucional" (cf. Mauro Cappelletti, O controle judicial de constitucionalidade das leis no direito comparado (trad. Aroldo Plínio Gonçalves), cap. V, n. 1, pp. 115/117). No modelo austríaco, portanto, a decisão ostenta caráter constitutivo e possui eficácia ex nunc ou pro futuro. A dicotomia é bem sintetizada na seguinte passagem de Cappelletti: "Resumindo, então: enquanto o sistema norte-americano de controle judicial de legitimidade constitucional das leis tem - pelo menos segundo a concepção tradicional que, no entanto, nos últimos decênios, sofreu notáveis oscilações e atenuações (...) - o caráter de um controle meramente declarativo, o sistema austríaco assume, ao invés, o caráter de um controle constitutivo da invalidade e da conseqüente ineficácia das leis que contrastam com a Constituição; e disto, com total coerência, deriva, ainda, que, no primeiro sistema, a eficácia (meramente declarativa) opera, em princípio, ex tunc, retroativamente (...) no sistema austríaco, ao contrário, a eficácia (constitutiva, ou seja, de anulação) do pronunciamento de inconstitucionalidade opera ex nunc ou, com toda certeza, pro futuro, não se admitindo qualquer retroatividade da eficácia da anulação".

${ }^{632}$ Cf. $O$ controle judicial..., cap. V, n. 4, p. 124.

${ }^{633}$ Art. 27. Ao declarar a inconstitucionalidade de lei ou ato normativo, e tendo em vista razões de segurança jurídica ou de excepcional interesse social, poderá o Supremo Tribunal Federal, por maioria de dois terços de seus membros, restringir os efeitos daquela declaração ou decidir que ela só tenha eficácia a partir de seu trânsito em julgado ou de outro momento que venha a ser fixado.

${ }^{634}$ Art. 11. Ao declarar a inconstitucionalidade de lei ou ato normativo, no processo de argüição de descumprimento de preceito fundamental, e tendo em vista razões de segurança jurídica ou de excepcional interesse social, poderá o Supremo Tribunal Federal, por maioria de dois terços de seus membros, restringir os efeitos daquela declaração ou decidir que ela só tenha eficácia a partir de seu trânsito em julgado ou de outro momento que venha a ser fixado.
} 
considerações feitas para o controle de constitucionalidade das leis podem e devem ser aproveitadas para a invalidação de atos privados e, especialmente, de deliberações societárias. ${ }^{636}$ Como ensinado por Celso Ribeiro Bastos e Ives Gandra da Silva Martins, no âmbito da inconstitucionalidade de atos normativos não é aplicável a teoria de nulidades do direito civil, no qual, em regra, os atos jurídicos, em decorrência de seu caráter privado, possuem pouca abrangência subjetiva. As leis provocam reações de grande volume e relevância, de modo que há razões jurídicas e fáticas que impedem sejam desconsiderados em absoluto os efeitos criados pela norma que posteriormente veio a ser reputada inválida. ${ }^{637} \mathrm{O}$ mesmo raciocínio aplica-se às deliberações assembleares, especialmente de grandes companhias de capital aberto. Daí a razão para que sejam modulados os efeitos da invalidação, levando-se em consideração as circunstâncias do caso concreto, dentre as quais está justamente o espectro de esferas jurídicas atingidas. Quanto maiores forem a relevância e a amplitude subjetiva da deliberação, maior deverá ser a preocupação do julgador com a retroação dos efeitos de sua decisão.

Ainda que não houvesse essa legislação seria cabível a modulação aqui preconizada. Já antes da Lei $9.868 / 99$ a doutrina ${ }^{638}$ e a jurisprudência ${ }^{639}$ defendiam a

${ }^{635}$ Art. $4^{\text {o }}$ A súmula com efeito vinculante tem eficácia imediata, mas o Supremo Tribunal Federal, por decisão de $2 / 3$ (dois terços) dos seus membros, poderá restringir os efeitos vinculantes ou decidir que só tenha eficácia a partir de outro momento, tendo em vista razões de segurança jurídica ou de excepcional interesse público.

${ }^{636}$ Com efeito, Regina Maria Macedo Nery Ferrari escreveu que "a lei inconstitucional existiu, validamente, até o momento do pronunciamento da decisão que assim a considera. Dizer que a mesma é simplesmente nula, já que inválida desde o início, como se não tivesse existido, e que tal característica foi apenas constatada através de uma sentença declaratória, é esquecer que toda lei nasce com a presunção de validade do mundo jurídico, gera direitos, deveres e efeitos no plano do ser físico, e neste não há ato humano nulo ou anulável, visto que, uma vez praticado, jamais deixará de ter sido, 'pois fora do mundo jurídico não há reversibilidade do tempo" Daí porque, ainda de acordo com Ferrari, "cheios de razão estão os juristas aqui citados, quando reconhecem que a lei inconstitucional cria, durante sua vigência, efeitos que não podem nem devem ser ignorados. Desde sempre foi essa a nossa opinião" (cf. Efeitos da declaração de inconstitucionalidade, pp. 283 e 289).



${ }^{638}$ Com efeito, já em 1948, em obra clássica do nosso direito, Lúcio Bittencourt ressalvou que "é manifesto, porém, que essa doutrina da ineficácia $a b$ initio da lei inconstitucional não pode ser entendida em termos absolutos, pois que os efeitos de fato que a norma produziu não podem ser suprimidos, sumariamente, por simples obra de um decreto judiciário" (cf. O controle jurisdicional da constitucionalidade das leis, p. 147). Em obra igualmente clássica, datada de 1966, Themistocles Brandão Cavalcanti escreveu que "em primeiro lugar e tecnicamente, as coisas não se passam pela forma apresentada, isto é, a declaração de inconstitucionalidade, em nenhum momento, tem efeitos tão radicais. Nem os funcionários nomeados com aplicação de leis inconstitucionais, nem as consequiências sobre os contratos já concluídos, principalmente os de natureza patrimonial, partem do pressuposto da inexistência da lei. (...) A jurisprudência no Brasil, como no estrangeiro, não tem aplicado a doutrina da nulidade $a b$ initio da lei inconstitucional. Ela não exprime a realidade e a sua aplicação seria extremamente injusta, porque a lei continua a ser aplicada a numerosos casos, como já o fora anteriormente à declaração de inconstitucionalidade" (cf. Do controle da 
modulação de efeitos na declaração de inconstitucionalidade. Isso se deve ao fato de que, nas palavras de Eduardo Talamini, a modulação de efeitos no controle de constitucionalidade possui suporte direto em princípios constitucionais (segurança jurídica, boa-fé etc.), de modo que tal base principiológica autorizaria a modulação mesmo antes da Lei 9.868/99. ${ }^{640}$ Da mesma forma Luís Roberto Barroso, para quem a modulação temporal já era admitida antes da referida lei com base na segurança jurídica, na justiça e em outros valores constitucionais. ${ }^{641}$

E mesmo no controle de constitucionalidade concreto e incidental - de atribuição de todos os órgãos judiciais, e não apenas do STF -, que também não conta com previsão legal para a modulação, defende-se a preservação dos efeitos da lei inválida, mediante um juízo concreto. ${ }^{642}$ Assim também a jurisprudência, que admite a modulação dos efeitos da declaração de inconstitucionalidade por tribunais estaduais, apesar de a Lei 9.868/99 conferir tal prerrogativa apenas ao STF. ${ }^{643}$ Há quem defenda, ainda, a modulação em caso

constitucionalidade, pp. 169 e 175). Também Celso Ribeiro Bastos e Ives Gandra da Silva Martins, antes da promulgação da lei 9.868/99, alertaram que, "ao ser posta em vigor, uma lei passa a gerar efeitos desde logo e muitas vezes isso perdura por longos anos, até que sobrevenha a declaração de inconstitucionalidade. Em situações como essa, há que se ponderar se a retroação não acarretará um mal maior do que o bem que se quer atingir. Em outras palavras, essa retroação pode provocar verdadeira calamidade jurídica atingindo um sem-número de situações já consolidadas sob a vigência da lei agora tida por inconstitucional. A Constituição italiana para obviar esses inconvenientes transformou em regra a declaração com efeitos meramente ex nunc" (cf. Comentários à Constituição do Brasil, $4^{\circ}$ v., t. III, 1997, p. 85). No mesmo sentido foi Clèmerson Merlin Clève, em trabalho de 1997: "É preciso, então, nesse ponto, deixar absolutamente transparente que a declaração de inconstitucionalidade não afeta todos os atos singulares praticados com fundamento na lei inconstitucional, destruindo-os desde logo. (...). A doutrina e o Judiciário brasileiro, mesmo o STF em determinadas hipóteses, admite, no juízo concreto, homenageando as situações consolidadas pelo tempo, a boa-fé, a aparência de legitimidade do ato impugnado e a ocorrência de injustiça ainda maior com a fulminação do ato singular ou concreto praticado em decorrência da norma inconstitucional, a possibilidade de restrição de alguns efeitos produzidos pela declaração de inconstitucionalidade" (cf. "Declaração de inconstitucionalidade de dispositivo normativo em sede de juízo abstrato e efeitos sobre os atos singulares praticados sob a sua égide", Cadernos de direito constitucional e ciência política, n. 19, pp. 307 e 302). V., ainda, Carlos Roberto Siqueira Castro, "Da declaração de inconstitucionalidade e seus efeitos", Revista da Procuradoria-Geral da República, n. 8, p. 20.

${ }^{639}$ Com ampla referência, v. Eduardo Talamini, Novos aspectos da jurisdição..., n. 4.4, p. 197.

${ }^{640} \mathrm{Cf}$. Novos aspectos da jurisdição..., n. 3.17.2.1, p. 162.

${ }^{641} \mathrm{Cf}$. O controle de constitucionalidade no direito brasileiro, p. 92.

${ }^{642}$ Cf. Eduardo Talamini, Novos aspectos da jurisdição..., nn. 4.6 e 4.6.3, pp. 209 e 211; e Valter Shuenquener, $O$ princípio da proteção..., n. 6.3, p. 188. Entendimento que é seguido pela jurisprudência: STF, Pleno, RE 273844/SP, Rel. Maurício Corrêa, DJ 21.5.04; e STF, Pleno, ADIn 2.240/BA, Rel. Eros Grau, DJ 3.8.07. Isso foi percebido também por Celso Antonio Bandeira de Mello: "o STF adotou o mesmo procedimento contemplado nos referidos preceptivos fora da hipótese de controle concentrado, isto é, em alguns casos, embora raros, de declarações de inconstitucionalidade no exercício do controle difuso" (cf. "Segurança jurídica...", p. 11).

${ }^{643}$ Nesse sentido já decidiu o STJ: "Possibilidade de Tribunal de Justiça, no exercício de controle concentrado, aplicar o disposto no art. 27 da Lei n. 9.868/99 e, levando em consideração razões de segurança jurídica ou excepcional interesse social, restringir os efeitos do reconhecimento da inconstitucionalidade e 
de mudança de interpretação constitucional, de modo que se preservem os efeitos constituídos sob a égide da anterior interpretação, ${ }^{644}$ e a extensão ao STJ da possibilidade de modulação, não mediante analogia, mas sim por $a b d u c ̧ a \tilde{o} .{ }^{645}$

De fato, com base no art. 27 da Lei 9.868/99, Dinamarco diz ser ilegítimo impor surpresa a empresas que se portaram e realizaram seu planejamento econômico de acordo com uma interpretação constitucional que, embora pacífica, veio a ser objeto de grave mudança. ${ }^{646}$ Note-se que o ilustre processualista não trata da declaração de inconstitucionalidade, mas de mera mudança de entendimento jurisprudencial - o que se justifica cada vez mais no cenário de valorização dos precedentes em que vivemos. Não há autorização legal para a modulação dos efeitos da declaração inconstitucionalidade no controle difuso, menos ainda no controle de legalidade, reconhece Dinamarco. Mas razões de ordem sistemática impõem que sejam modulados os efeitos, ainda que a despeito de não existir autorização legal para tanto. Embora em contexto diverso, aquele processualista defendeu também que, ao haver mudança jurisprudencial acerca de um determinado tema tributário, não haja radical negação de aplicação da interpretação que grassava até então. Apesar do ulterior reconhecimento da cessação de vigência das normas, elas devem ser aplicadas a situações já consumadas anteriormente à referida mudança jurisprudencial, diz o mestre. ${ }^{647}$ Em sentido semelhante, Roque Antonio Carrazza e Nelson Nery Jr., ao

fixar momento diverso que o da sua promulgação. Precedente do Supremo Tribunal Federal" (STJ, $5^{\text {a Turma, }}$ RMS 19951/RJ, Rel. Jorge Mussi, DJe 04.10.2010). No mesmo sentido: STJ, $1^{\text {a }}$ Turma, AgRg no REsp 1140158/RJ, Rel. Benedito Gonçalves, DJe 25.11.2010; e TJRS, Pleno, EDcl 70043623784, Rel. Genaro José Baroni Borges, DJ 06.09.2011. Embora não tenha determinado a modulação, julgado do Órgão Especial do TJSP ressalvou: "devendo, porém, ser observado que, embora a declaração de inconstitucionalidade de uma lei a nulifique e de tal nulidade em regra direito não nasça, tornam-se imunes àquela as situações jurídicas formalmente constituídas com base em ato praticado de boa-fé sob norma que só posteriormente se declarou inconstitucional" (TJSP, Órgão especial, Ação Direta de Inconstitucionalidade 0221010-10.2009.8.26.0000, Rel. Palma Bisson, j. 26.05.2010).

${ }^{644}$ Cf. Eduardo Talamini, Novos aspectos da jurisdição..., nn. 4.6 e 4.6.7, p. 214. V., ainda, doutrina citada por Bruno Vasconcelos Carrilho Lopes que advoga a ideia de que a alteração de entendimento jurisprudencial consolidado deve ter eficácia ex nunc, de modo que o novo entendimento seja aplicado apenas aos fatos ocorridos após a mudança de orientação (cf. Limites objetivos..., n. 12.1, p. 73).

${ }^{645}$ Cf. Tércio Sampaio Ferraz Jr., "Irretroatividade e jurisprudência judicial", in Efeito ex nunc e as decisões do STJ, pp. 23/26.

${ }^{646}$ Cf. "Modulação dos efeitos da declaração de inconstitucionalidade", in Processo civil empresarial", n. 14, pp. 69/70. E, de fato, diz Valter Shuenquener que embora o princípio da proteção da confiança tenha ocorrido primeiramente em relação aos atos do Executivo e do Legislativo, espraiou-se para o controle de atos jurisdicionais, especialmente em razão de mudanças bruscas de entendimentos jurisprudenciais consolidados" (cf. O princípio da proteção..., n. 6.3., p. 173).

${ }^{647}$ Cf. "Modulação dos efeitos...", n. 14, p. 68. Em outro parecer, publicado na mesma obra, esse autor é claro: "No parecer aqui reproduzido alvitrei também a modulação dos efeitos de eventual decisão do Col. Supremo Tribunal Federal pela constitucionalidade dos atos infraconstitucionais que a consulente impugna, embora consciente de que somente com relação ao controle concentrado de constitucionalidade existe 
defenderem a irretroatividade da mudança de entendimento jurisprudencial há longo tempo assentado e a possibilidade de que os Tribunais Superiores modulem os efeitos de tal mudança. $^{648}$

A modulação é admitida pela doutrina também no caso da invalidação de atos administrativos. ${ }^{649}$ Na jurisprudência, cita-se julgado do Tribunal de Justiça de São Paulo que em ação civil pública movida pelo Ministério Público com o objetivo de invalidar contrato administrativo modulou os efeitos da declaração de nulidade (ex nunc). ${ }^{650} \mathrm{Em}$ sentido análogo, outro julgado do TJSP fixou que, embora tenha sido reconhecida a inconstitucionalidade da lei que criou determinado cargo em comissão, os efeitos remuneratórios do servidor deveriam ser salvaguardados. ${ }^{651}$

Zeno Veloso, por sua vez, advoga a modulação dos efeitos da invalidação de negócios jurídicos privados, de modo que seja revisto e relativizado o dogma da retroação da invalidação. A falta de autorização legal expressa não seria, de acordo com o civilista, um argumento insuperável ou obstáculo intransponível. ${ }^{652} \mathrm{E}$ mais: ao se defender que,

autorização legal para tanto (lei n. 9.868, de 10.11.99, art. 27). A sustentação feita assenta em fundamentos a meu ver dotados de muita consistência e apoiados na garantia constitucional do due process of law" (cf. "Controle difuso de constitucionalidade: eficácia da decisão, in Processo civil empresarial, n. 33, p. 93).

${ }^{648} \mathrm{Cf}$, respectivamente, "Segurança jurídica e eficácia temporal das alterações jurisprudenciais", in Efeito ex nunc e as decisões do STJ, pp. 66/70; e "Boa-fé objetiva e segurança jurídica", in Efeito ex nunc e as decisões do STJ, pp. 98 e 102/103.

${ }^{649}$ Cf. Celso Antonio Bandeira de Mello, "Segurança jurídica...", p. 10; Maria Sylvia Zanella di Pietro, "Os princípios da proteção à confiança...”, p. 164; e Valter Shuenquener, O princípio da proteção..., n. 4.2., p. 141.

650 “Sem lesão ao erário e sem caracterização de dolo ou má-fé da empresa contratada, que, por vários anos, prestou serviços de remoção e estadia de veículos apreendidos, sob permissão da Administração Pública, é admissível a excepcional modulação dos efeitos da nulidade, declarada com eficácia ex nunc" (TJSP, $1^{\text {a }}$ Câmara de Direito Público, Ap. 0304824-17.2009.8.26.0000, Rel. Vicente de Abreu Amadei, j. 14.02.2012). Em sentido contrário, inadmitindo a modulação fora das expressas hipóteses legais, v. STJ, $1^{a}$ Seção, EDcl no REsp 541239/DF, Rel. Luiz Fux, DJe 31.03.2008; e STJ, 2ª Turma, AgRg nos EDcl no Ag 983549/DF, Rel. Mauro Campbell Marques, DJe 13.05.2009.

651 TJSP, 13 ${ }^{\mathrm{a}}$ Câmara de Direito Público, Ap. 0019888-66.2009.8.26.0348, Rel. Borelli Thomaz, j. 04.05.2011. No mesmo sentido, TJSP 7 ${ }^{\mathrm{a}}$ Câmara de Direito Público, Ap. 9141556-66.2002.8.26.0000, Rel. Nogueira Diefenthaler, j. 16.03.2007.

${ }^{652}$ Cf. Invalidade..., n. 71, pp. 362/366. Confira-se: "Em nossa legislação, não há um dispositivo expresso, determinando a relativização do comando, para atender casos que merecem consideração e amparo, como existe na lei italiana, na portuguesa e na argentina. (...) Mas este não é um argumento insuperável, nem um obstáculo intransponível. Na falta de modernização, de atualização dos textos legais, pode e deve o juiz interpretá-los progressivamente, aplicá-los construtivamente (...). Diante do conflito entre princípios - de um lado, o que ordena a desconstituição ex tunc e erga omnes do negócio invalidado; de outro, o que manda que se proteja o terceiro de boa-fé, o que acreditou e confiou numa situação que tinha toda a aparência de legítima -, o juiz deve eliminar a contradição que se manifesta, analisando cuidadosamente as circunstâncias do caso concreto, dando a solução mais equitativa e razoável (...).” (n. 71, p. 364). 
apesar da ausência de disposição legal nesse sentido, os direitos de terceiros de boa-fé devem ser ressalvados na invalidação de atos jurídicos privados, ${ }^{653}$ se está, na verdade, defendendo uma espécie de modulação. Com efeito, as únicas disposições que versam sobre o assunto no Código Civil são o $\S 2^{\circ}$ do art. 167, que dispõe que "ressalvam-se os direitos de terceiros de boa-fé em face dos contraentes do negócio jurídico simulado", e o art. 1.563, que preceitua que "a sentença que decretar a nulidade do casamento retroagirá à data da sua celebração, sem prejudicar a aquisição de direitos, a título oneroso, por terceiros de boa-fé, nem a resultante de sentença transitada em julgado". As hipóteses previstas por esses artigos são, unicamente, a da simulação e a do casamento nulo, mas a doutrina e a jurisprudência estendem a ressalva, ainda que em caráter excepcional, aos direitos de terceiros de boa-fé a outros casos de invalidação. ${ }^{654}$ Se já existe essa possibilidade de verdadeira modulação (modulação subjetiva), por que não poderia haver outras diante de atos assembleares inválidos, que, em decorrência dos imperativos de segurança e estabilidade, apresentam peculiaridades no plano do direito material e do direito processual?

Também o Projeto de Lei 1.572/11, que procura instituir novo Código Comercial, estabelece expressamente a possibilidade de que, na invalidação de contratos empresariais, sejam modulados os efeitos da decisão judicial: “O juiz decidirá se o contrato empresarial invalidado produzirá efeitos, definindo-os" (art. 324, parágrafo).

A jurisprudência e a boa doutrina, nos mais variados ramos do direito, enfim, já defendem a modulação dos efeitos da invalidação fora das hipóteses para as quais existe expressa autorização legal. Não vemos razão para não adotarmos a mesma possibilidade diante de deliberações assembleares inválidas, terreno no qual, além de tudo o que já se disse anteriormente, imposições vindas do direito material justificam a medida. Isso confere inclusive maior efetividade à tutela jurisdicional prestada em favor de quem vem a juízo pedir a invalidação, pois evita situações em que, na prática, fazendo um juízo de ponderação de valores, o julgador entenda por julgar improcedente a demanda por reputar

\footnotetext{
${ }^{653}$ Assim fazendo, o seguinte julgado: "Tratando a demanda de nulidade de testamento e de cessão de direitos hereditários, na qual inconteste a boa-fé dos atuais terceiros que são os proprietários dos bens, mostra-se desnecessária a inclusão deles no pólo passivo. Caso em que, pela boa-fé dos atuais proprietários, eventual procedência total dos pedidos iniciais não se resolveria pela desconstituição de todos os negócios jurídicos subseqüentes, mas sim em perdas e danos" (TJRS, Apelação 70046884185, Rel. Rui Portanova, $8^{\text {a }}$ Câmara Cível, j. 29.03.2012).

${ }^{654}$ Cf. Zeno Veloso, Invalidade..., nn. 68/69, pp. 338/ 350; e Serpa Lopes, Curso..., n. 362, p. 510.
} 
que a desconstituição do ato levaria a situações de tamanha perplexidade e injustiça que o melhor é não promovê-la. Permitindo-se que o julgador delimite o quê deve ser desconstituído e o quê não deve, evitam-se decisões baseadas no "ou tudo ou nada”. ${ }^{655}$

Não se desconhece que a modulação de invalidades envolve a manutenção de efeitos contrários ao Direito e, portanto, traz consigo o que se pode chamar de "contraordem" ou "contracomando": se o Direito estabelece um dever mas permite que os efeitos de atos contrários a esse dever sejam mantidos, está, de certa forma, por vias reflexas, incentivando a conduta antijurídica. Ou seja, estabelece-se uma espécie de duplo comando, internamente contraditório, que pode prejudicar a cognoscibilidade, a confiabilidade e a calculabilidade do Direito. ${ }^{656} \mathrm{O}$ risco de que condutas antijurídicas sejam, no fim das contas, toleradas de fato existe e não é aqui ignorado. A modulação, porém, é ela própria um meio de efetivação da segurança jurídica e essa constatação por si só já bastaria para justificar a assunção do risco. Ademais, ainda que sejam preservados efeitos do ato inválido, sempre restará a tutela indenizatória e, consequentemente, essa “contraordem" é de certa forma minimizada, pois a modulação não significa que não se

\footnotetext{
${ }^{655}$ Nesse sentido é a observação de Eduardo Talamini a respeito do controle direto de constitucionalidade: “a possibilidade de excepcionalmente restringir os efeitos retroativos ou mesmo atribuir apenas efeitos prospectivos à declaração de inconstitucionalidade - ao contrário do que possa parecer - confere maior operacionalidade ao sistema de controle abstrato. A regra de retroatividade absoluta e sem exceções acaba fazendo com que o tribunal constitucional, naquelas situações de conflito entre os valores acima mencionados, acabe muitas vezes simplesmente deixando de declarar a inconstitucionalidade da norma, para assim evitar gravíssimas conseqüências que adviriam da eficácia ex tunc dessa declaração. O poder de modulação dos efeitos (...) afasta as soluções à base do 'ou tudo ou nada"”. Como exemplo disso, Talamini cita ações diretas movidas contra a Lei de criação dos municípios: nos primeiros julgamentos, embora vislumbrasse inconstitucionalidade, o então Ministro Eros Grau cogitou de improcedência considerando os graves prejuízos à segurança jurídica e ao interesse público que decorreriam da inconstitucionalidade ex tunc. A saída encontrada foi a modulação, sugerida pelo Ministro Gilmar Mendes, conferindo-se ao Estadomembro a possibilidade de sanar o vício (STF, ADI 2.240, Pleno, v.u., Rel. Eros Grau, DJE 3.8.07) (cf. Novos aspectos da jurisdição..., n. 4.5.1.2, p. 200). E é possível deixar de reconhecer a inconstitucionalidade de determinado ato por já estar consolidado, ainda que tenha sido praticado com base em lei declarada inconstitucional. Trata-se de casos em que "o próprio conteúdo da decisão é que foi alterado em razão do entendimento de que os atos praticados não mais poderiam ser revistos nem desfeitos", em oposição a casos em que há graduação dos efeitos da decisão (cf. Humberto Ávila, Segurança jurídica, pp. 526/527). No mesmo sentido, Maria Sylvia Zanella di Pietro afirma que excepcionalmente a anulação de um ato administrativo - atividade vinculada - pode deixar de ser feita, em atenção ao interesse público, na hipótese em que o prejuízo decorrente da invalidação for maior do que a manutenção do ato ilegal (cf. "Os princípios da proteção à confiança...”, p. 158).

${ }^{656}$ Cf. Humberto Ávila, Segurança jurídica, p. 507. Daí por que, para Ávila, "a modulação de efeitos é técnica decisória cuja compatibilidade com os princípios do Estado de Direito e da segurança jurídica é muito, muito, mas muito restrita. Toda modulação de efeitos temporais da declaração de inconstitucionalidade envolve uma contradição do Direito consigo mesmo: ao manter o que lhe é contrário, o Direito como que devora a si próprio, tal como uma cobra que engole sua própria cauda" (cf. Segurança jurídica, pp. 569/570). Também Maria Sylvia Zanella di Pietro apontou a necessidade de haver cautela na manutenção de atos ilegais (como uma decorrência do princípio da proteção à confiança), pois isso pode “tornar-se um incentivo à prática de atos ilegais" (cf. "Os princípios da proteção à confiança...”, p. 160).
} 
reconhece o caráter antijurídico do ato ilícito, mas sim que a sua desconstituição não é a forma adequada de tutela, e sim a indenização (ainda que, por outro lado, não se desconheçam os aspectos negativos da tutela indenizatória, como, por exemplo, a dificuldade com a prova do dano). E mais: a própria existência de mecanismos como a decadência - que, no caso das deliberações assembleares, deveria ocorrer em menor tempo do que os dois anos do art. 286 da LSA - já representa esse risco da "contraordem", pois permite que efeitos derivados de ato viciado convalidem-se diante da inércia dos interessados.

Em resumo: também no direito societário a regra é a de que o ato deve ser desconstituído retroativamente, seja em caso de nulidade, seja de anulabilidade. As diferenças são que aqui (i) o nulo, em regra, produz efeitos - daí a adequação da tutela constitutiva - e que (ii) deve existir maior permissividade para a relativização daquela regra (modulação). Cabe ao juiz, de acordo com o pedido e as circunstâncias do caso concreto, definir o alcance do julgado, definindo quais situações jurídicas devem ser afetadas (desconstituídas) pela decisão. Em princípio, no plano abstrato, assim como no controle abstrato de constitucionalidade, a regra é que a desconstituição deve ser feita com eficácia retroativa (ex tunc). Na prática, porém, o magistrado está autorizado a adequar a tutela jurisdicional ao caso concreto. O que se prega aqui, enfim, é um modelo de retroatividade atenuada ${ }^{657}$ e a aplicação do princípio da segurança jurídica em seu sentido objetivo como meio de proteção da confiança. ${ }^{658}$

É importante destacar que quando se fala em modulação dos efeitos não se está referindo apenas ao controle do alcance temporal da decisão. É possível, também, serem modulados outros aspectos eficaciais, como o espacial, o objetivo e o subjetivo: podem ser excluídas do âmbito de incidência da norma as situações jurídicas relativas a determinadas pessoas, a certo lugar ou mesmo a determinadas matérias. ${ }^{659}$ Mesmo sob o aspecto

${ }^{657}$ A expressão é colhida, mais uma vez, em Eduardo Talamini, Novos aspectos da jurisdição..., n. 4.3, p. 194.

${ }^{658}$ Sob pena de criar-se instabilidade institucional. Sobre o assunto, Humberto Ávila dá notícia de decisões do STF em que, "no entendimento do Tribunal - e empregando outras palavras -, a eficácia declaratória da decisão afetaria a própria credibilidade institucional do Direito como pressuposto do exercício potencial do conjunto de liberdades, especialmente pela quantidade de atos praticados sob o amparado da legislação anterior" (cf. Segurança jurídica, p. 545). Trata-se de decisões e considerações feitas na seara do controle direto de constitucionalidade, mas com fundamentos que podem e devem ser aproveitados para a tese que aqui se defende.

${ }^{659}$ Cf. Eduardo Talamini, Novos aspectos da jurisdição..., n. 3.17.2.2, p. 162. 
temporal existem inúmeras possibilidades: ser estabelecido um marco temporal (i) anterior à decisão, mas posterior ao nascimento do vício; (ii) contemporâneo ao trânsito em julgado; ou (iii) posterior ao trânsito. ${ }^{660}$ Todas essas possibilidades devem ser consideradas pelo julgador.

Resta a dúvida de qual a eficácia cronológica da decisão que desconstitui deliberação mas silencia sobre o seu alcance temporal. Doutrina de peso, aqui tantas vezes referida, entende que, no controle concentrado de constitucionalidade, o silêncio não basta para que se conclua pela eficácia retroativa, pois é possível que, em processo judicial ao examinar-se um dado caso concreto, entenda-se pela preservação dos efeitos de certos atos praticados com fundamento no dispositivo normativo inconstitucional. ${ }^{661}$ Entendemos, contudo, que, não sendo possível extrair da motivação e de outras balizas interpretativas ${ }^{662}$ que a decisão determinou a modulação, ela terá eficácia ex tunc, ressalvados, contudo, os direitos de terceiros de boa-fé. ${ }^{663}$ Essa é a regra.

${ }^{660}$ Cf. Eduardo Talamini, Novos aspectos da jurisdição..., n. 4.5.4, p. 200. Sobre o assunto, v., ainda, Humberto Ávila, Segurança jurídica..., pp. 509 e ss.

${ }^{661}$ Cf. Eduardo Talamini, Novos aspectos da jurisdição..., n. 4.5.4, p. 205.

${ }^{662}$ Em uma concepção clássica, a norma jurídica existe latente no ordenamento jurídico e, diante de um litígio específico, o juiz deve apenas concretizá-la. O julgador, assim, limitar-se-ia a declarar as normas, que já existiriam desde o momento em que o legislador criou a lei. Daí a célebre frase atribuída a Montesquieu de que o juiz é a boca da lei: ao Poder Legislativo caberia elaborar as leis, ao Poder Judiciário apenas segui-las. Embora correta sob alguns aspectos, essa visão é criticável sob outros. Hoje se sabe que, por mais claro que seja o texto legal, o ato de aplicação da lei exige, antes de tudo, interpretação, que, por sua vez, não é uma relação matemática. Pelo contrário, exige-se do intérprete, sempre, um esforço do intérprete, ainda que mínimo. E ao interpretarem, por mais objetivos e racionais que procurem ser, o juiz e os cidadãos são movidos por impressões, valores e perspectivas pessoais. Enquanto enunciado normativo, a sentença deve, sempre, ser objeto de interpretação. E nesse mister, não sendo o dispositivo claro o suficiente para que de sua leitura surja a norma concreta, o intérprete deve se valer de referências como (i) a motivação da sentença, (ii) o pedido e a causa de pedir e (iii) as disposições legais (cf. Betti, Interpretación de la ley y de los actos jurídicos, pp. 326/331; Alfredo Rocco, La sentencia..., p. 63; Satta, Direito processual..., v. 1, p. 249; Chiovenda, Instituições..., v. I, pp. 375/376; Couture, Fundamentos..., pp. 428/429; Celso Neves, Coisa julgada civil, p. 493; Moacyr Amaral Santos, Primeiras linhas..., v. 3, p. 21; Egas Moniz de Aragão, Sentença e coisa julgada, n. 179, p. 251; Dinamarco, Instituições..., v. III, pp. 677/682; Ada Pellegrini Grinover, Direito processual civil, pp. 91/92 e "Considerações sobre...”, p. 75; Humberto Theodoro Júnior, "Execução de Sentença - Iniciativa do Devedor - Interpretação de Sentença”, Revista Jurídica, n. 299, pp. 7/10; José Rogério Cruz e Tucci, A motivação da sentença no processo civil, p. 22; Carlos Alberto Alvaro de Oliveira, "Coisa julgada. Respeito que merece. Interpretação da sentença. Princípios pertinentes", Revista Forense, n. 383, pp. 253/255; Estêvão Mallet, "Breves notas sobre a interpretação das decisões judiciais", Revista do Tribunal Regional do Trabalho - $9^{a}$ Região, n. 60, pp. 271 e seguintes; e Marcelo José Magalhães Bonício, Capítulos de sentença e efeitos dos recursos, pp. 20/21).

${ }^{663}$ Cf. Erasmo Valladão França, Invalidade..., n. 22, p. 135; Pietro Trimarchi, Invalidità..., cap. XV, n. 1, p. 249; e Romano-Pavoni, Le deliberazioni..., n. 105, pp. 393 e seguintes. De acordo com Ascarelli, ainda que o provimento tenha eficácia retroativa, não deve afetar os terceiros de boa-fé, na medida em que a deliberação devidamente arquivada e publicada já teve a sua legalidade verificada pelo órgão registrário e, portanto, o terceiro possuía uma justa expectativa de que a deliberação era válida (cf. "Vícios das deliberações assembleares...”, p. 388). Em sentido contrário, v. Antigono Donati, L’invalidità..., n. 94, p. 284. No direito italiano, o art. 2.377 do Código Civil dispõe que, embora a anulação da deliberação vincule todos os sócios, 


\subsection{Critérios decisionais}

Não há, como visto, disposição legal expressa para a modulação dos efeitos da desconstituição de deliberações inválidas. Portanto, também não há critérios legais para essa modulação. Mesmo as Leis 9.868/99, 9.882/99 e 11.417/06, que poderiam servir de analogia, não trazem tais critérios e, pois, transferem ao julgador a incumbência de, no caso concreto, estabelecê-los.

Assim como os conceitos jurídicos indeterminados, ${ }^{664}$ soluções que remetem a um juízo do caso concreto possuem como vantagem a adaptabilidade às peculiaridades da situação levada a julgamento e a possibilidade de evolução da norma de acordo com os valores da sociedade no momento histórico em que ela é aplicada. Permitem que o julgador balanceie a sua aplicação a essas peculiaridades, prestando tutela jurisdicional que, em tese, é mais adequada que a outorgada com fundamento em critérios legais rígidos. Por outro lado, tais soluções são marcadas por algum grau de discricionariedade ${ }^{665}$ e têm na falta de critérios pré-estabelecidos - e na insegurança e imprevisibilidade dela decorrentes - o seu ponto fraco. ${ }^{666}$

Diante disso, como e quais balizas estabelecer para que a modulação dos efeitos da invalidação das deliberações não seja um tiro pela culatra, isto é, uma solução que, embora procure prestigiar as especificidades do regime de invalidades especial do direito

\footnotetext{
"In ogni caso sono salvi i diritti acquistati in buona fede dai terzi in base ad atti compiuti in esecuzione della deliberazione". Da mesma forma o art. 61 do Código das Sociedades Comerciais, de Portugal, que apesar de determinar que a coisa julgada vincula a todos os sócios e órgãos sociais, ainda que estranhos ao processo, ressalva que "A declaração de nulidade ou a anulação não prejudica os direitos adquiridos de boa-fé por terceiros, com fundamento em atos praticados em execução da deliberação; o conhecimento da nulidade ou da anulabilidade exclui a boa-fé".

${ }^{664}$ Sobre esses, v. Barbosa Moreira, "Regras de experiência e conceitos juridicamente indeterminados", in Temas de direito processual, $2^{\mathrm{a}}$ série, pp. 63 e seguintes.

${ }^{665}$ Ao contrário do que muitos sustentam, existe sim discricionariedade na aplicação da norma: “Às vezes a lei atribui a quem tenha de aplicá-la o poder de, em face de determinada situação, atuar ou abster-se, ou ainda, no primeiro caso, o poder de escolher, dentro de certos limites, a providência que adotará, tudo mediante a consideração da oportunidade e da conveniência. É o que se denomina poder discricionário. Costuma-se apontar a atividade administrativa como o campo de eleição de tal poder; mas a verdade é que também o juiz não raro se vê autorizado pelo ordenamento a opções discricionárias" (cf. Barbosa Moreira, "Regras de experiência...", p. 65).

${ }^{666}$ Em palestra proferida em 17.9.12 na Faculdade de Direito da USP, Juan Montero Aroca manifestou a opinião de que o emprego de conceitos jurídicos indeterminados pela lei é um claro indício de fraqueza do legislador.
} 
societário, marcado por imperativos de segurança, certeza e estabilidade, torne a oferta de tutela jurisdicional incerta, imprevisível e arbitrária?

Em atenção à regra de correlação entre demanda e provimento (v. item 15), a primeira baliza do julgador deve ser o pedido deduzido pelo autor. Aquele está vinculado ao pedido deduzido pelo demandante (CPC, arts. 128, 263 e 460) e lhe é defeso desconsiderar os lindes que este traçou. Quem vai a juízo pleitear a desconstituição de deliberação tem o ônus, portanto, de delimitar precisamente qual o alcance temporal que espera do provimento judicial, valendo-se, inclusive, da regra de eventualidade ao formular o pedido (CPC, art. 289). A vinculação da modulação ao pedido, mais ainda, prestigia e efetiva o contraditório ( $\mathrm{CF}$, art. $\left.5^{\circ}, \mathrm{LV}\right)$ : sabendo a extensão do pedido, a companhia poderá apresentar defesa profícua.

Por isso, embora não determinante, o pedido é relevante para que haja a modulação. Caso ele não estabeleça o alcance temporal que pretende, presume-se que se pretendeu a desconstituição $a b$ initio. Nesse caso, ainda que não tenha sido pedida a modulação, o julgador poderá promovê-la, pois isso equivalerá a uma procedência parcial. Caso na demanda seja expressamente pedida a modulação (o autor pede, por exemplo, que os efeitos da deliberação sejam desconstituídos desde o trânsito em julgado), o julgador não poderá ir além e estabelecer uma eficácia retroativa mais extensa do que a pleiteada. A decisão que extrapolar este limite será ultra petita e, assim, comportará anulação.

Mas levar em conta apenas o pedido não basta. Ao aqui defendermos a análise das circunstâncias do caso concreto, estamos preconizando que o julgador considere (i) a natureza e a expressão econômica dos interesses envolvidos; (ii) a modalidade do vício (a nulidade impõe maior rigor); (iii) os direitos dos terceiros envolvidos; (iv) o tipo de sociedade (se de capital aberto ou fechado); ${ }^{667}$ (v) a boa ou má-fé dos agentes envolvidos; (vi) as relações jurídicas que se formaram a partir do ato inválido; e (vi) o grau de confiabilidade que decorreu do ato inválido.

${ }^{667}$ Aqui vale lembrar a distinção de natureza feita por Comparato entre as companhias abertas e fechadas, a justificar a superação de uma regulação uniforme para os dois tipos de sociedades (cf. "A natureza da sociedade anônima...", pp. 116 e seguintes). No mesmo sentido, v. Erasmo Valladão França, Conflito de interesses..., cap. II, n. 4, p. 48. 
Sobre o último aspecto apontado (proteção da confiança), Humberto Ávila defende que, no terreno do controle de constitucionalidade, quanto maiores forem os graus de vinculação, de aparência de legitimidade, de permanência/definitividade e de eficácia no tempo do ato inválido, dentre outros critérios, tanto maior deverá ser a proteção dos seus efeitos, como um desdobramento da proteção da confiança nele depositada. ${ }^{668}$

Assim, empregando-se o primeiro daqueles critérios enunciados por Ávila, quanto mais forte for o grau de vinculação do ato tido por inválido, maior deverá ser a proteção conferida a quem seguiu essa orientação. Quanto maior for a vinculação do ato, maior é a expectativa que o cidadão deve ter com relação ao seu cumprimento e, logo, menor é o âmbito de liberdade de escolha deste, ${ }^{669}$ de modo que o mesmo Direito que lhe direcionou ao cumprimento deve resguardar a esfera jurídica desse cidadão que agiu conforme tal expectativa. De forma análoga, Valter Shuenquener diz que, para que se possa aplicar o princípio da proteção da confiança, é necessário que exista a confiança no plano subjetivo, isto é, indícios de que o sujeito depositou confiança no ato estatal. ${ }^{670}$

Partindo-se para o segundo critério, maior deve ser a proteção aos efeitos do ato inválido quando maior for o seu grau de aparência de legitimidade. O princípio da legalidade só funciona corretamente, e o Direito só é eficaz, se lhe for atribuída presunção de validade. O preço de tal presunção é justamente não permitir que o cidadão, que confiou nela e a seguiu, seja posteriormente prejudicado. Daí porque os atos portadores de irregularidade grosseira em princípio não são merecedores de confiança (ao menos por este critério) e porque o conhecimento do vício pelo sujeito, assim como a sua participação na produção do vício, militam contrariamente à proteção da confiança. ${ }^{671}$

${ }^{668}$ Cf. Segurança jurídica, pp. 380/399.

669 "O princípio da segurança jurídica, no aspecto aqui examinado, é instrumento de respeitabilidade da liberdade exercida no passado sob a orientação do próprio Direito. Sendo assim, ele deve proteger tanto mais o cidadão quanto mais ele tiver seguido a orientação fornecida pelo Direito. E isso ocorre quanto maior for a força vinculativa do ato gerador da confiança, visto que, quanto maior ela for, maior será a influência do Direito no exercício da liberdade" (cf. Segurança jurídica, p. 381). De maneira similar, ao tratar da aplicação do princípio da proteção da confiança diante de mudanças jurisprudenciais, Valter Shuenquener diz que, quanto maior for a posição hierárquica do órgão jurisdicional emissor do provimento em que se depositou confiança, maior deve ser a proteção dispensada ao particular, pois, naturalmente, mais consistente será a confiança depositada (cf. O princípio da proteção..., n. 6.3, p. 179).

${ }^{670}$ Cf. O princípio da proteção..., n. 1.6.2, p. 89.

671 "Para que o Direito possa servir de orientação para o cidadão, ela precisa poder ser conhecido e executável; para que ele seja cognoscível e minimamente eficaz, porém, é necessário que o cidadão confie na validade dos atos normativos (...). Sem nenhuma obediência não há como existir um mínimo de efetividade. O preço da efetividade é, portanto, a proteção daqueles que, confiando na validade dos atos estatais, seguiram 
Pelo terceiro critério, quanto maior for o grau de permanência do ato, maior deve ser o grau de proteção da confiança nele depositado. O grau de confiança que o sujeito deposita em um ato de duração efêmera e transitória não é o mesmo do que deposita em um ato com maior pretensão de definitividade. E essa expectativa também deve ser levada em consideração e tutelada pelo ordenamento. ${ }^{672}$

Já o quarto critério impõe que quanto mais duradoura no tempo for a eficácia temporal do ato maior deve ser a proteção da confiança nele depositada, pois o passar do tempo consolida e reforça a sua aparência de legitimidade. O tempo funciona, portanto, como fator gerador de confiança, embora também possa atuar como fator de irreversibilidade fática ou jurídica. Embora se tratem de hipóteses conceitualmente diversas, em ambas o decurso do tempo milita em favor da manutenção do ato tido por inválido, tutelando a estabilidade das relações jurídicas. ${ }^{673}$

Todos esses elementos devem ser analisados conjuntamente, de modo que a baixa intensidade de um deles seja compensada pela maior presença dos demais, em favor de uma base confiável de confiança, como em um autêntico sistema de vasos comunicantes. ${ }^{674}$ A proteção da confiança decorre da articulação dentre esses critérios.

a sua orientação, ainda que esses atos, mais tarde, sejam declarados ilícitos” (cf. Segurança jurídica, pp. 381/382). Em sentido semelhante Maria Sylvia Zanella di Pietro, para quem, se o administrado agiu de máfé, sabendo da ilicitude do ato administrativo que o beneficiou, não pode ser beneficiado com a manutenção do ato (cf. "Os princípios da proteção à confiança...”, p. 160).

${ }^{672}$ Cf. Humberto Ávila, Segurança jurídica, p. 387.

673 “O tempo, aqui, 'cria' ou 'reforça' a confiança do particular na base normativa. (...) O essencial é que a prática continuada seja capaz de gerar no cidadão impressão de validade do ato, de tal modo que a descontinuidade futura da produção dos efeitos possa ser vista como ato de deslealdade" (cf. Humberto Ávila, Segurança jurídica, pp. 389/390). V., também, Maria Sylvia Zanella di Pietro, "Os princípios da proteção à confiança...", pp. 160 e 165.

${ }^{674}$ Cf. Humberto Ávila, Segurança jurídica, pp. 400, 409 e 415. O citado autor chega a elaborar algumas regras, que, por sua pertinência, são aqui transcritas:

“1 ${ }^{a}$ regra - O grau de proteção da confiança será tanto maior quanto maior for o grau da presença dos elementos normativos, pertinentes à situação de fato, abaixo indicados:

- vinculatividade - quanto maior for o grau de vinculação normativa do ato, maior deve ser a proteção da confiança nele depositada;

- aparência de legitimidade do ato - quanto maior for o grau de aparência de legitimidade do ato, maior deve ser a proteção da confiança nele posta;

- modificabilidade - quanto maior for o grau de permanência do ato, maior deve ser a proteção da confiança a ele atribuída; 
Ávila fornece, ainda, outros critérios, que não cabem ser analisados aqui. A sua tese é, como de costume, profunda, cheia de meandros e com vasto suporte bibliográfico. Por isso remete-se à obra do professor gaúcho, sem que confessadamente ela seja por nós analisada com o detalhamento que merece. E embora as suas considerações tenham sido feitas no âmbito do direito tributário, onde há uma oposição entre o poder do Estado e a esfera de liberdade do cidadão, elas podem e devem ser aqui aproveitadas. Embora no âmbito do direito societário o particular não sofra ingerência em sua esfera de liberdade por conta da deliberação da mesma maneira que o cidadão defronte ao Estado, ele também possui uma expectativa de validade em relação às deliberações. Assim como no direito tributário o particular que age com base na validade da norma estatal e na credibilidade da atuação estatal, aquele (seja ele acionista, terceiro ou mesmo a própria sociedade) que formula sua conduta confiando na validade (ou aparência de validade) de uma deliberação societária, deve ser protegido, pois, repita-se, direcionou a sua liberdade de acordo com essa expectativa. Ademais, na medida em que a invalidação de uma deliberação ocorre por meio de ato jurisdicional estatal - ou arbitral -, é possível dizer que um dos requisitos que

- efetividade - quanto maior for o grau de realização da finalidade subjacente à regra supostamente violada, tanto maior deve ser a proteção dos efeitos do ato inquinado de ilegal;

- indução - quanto maior for o grau de indução decorrente do ato, maior deve ser a proteção merecida pela confiança com base nele exercida;

- individualidade - quanto maior for o grau de proximidade do ato, maior deve ser a proteção da confiança nele depositada;

- onerosidade - quanto maior for o grau de onerosidade do ato, maior deve ser a proteção da confiança nele recaída;

- durabilidade - quanto mais duradoura no tempo for a eficácia temporal do ato, maior proteção merece a confiança nele depositada.

$2^{\mathbf{a}}$ regra - Quanto maior for a presença do elemento durabilidade, isto é, quanto maior o tempo transcorrido entre a prática do ato e a decisão a respeito da sua anulação ou da sua revogação, tanto menor poderá ser a presença dos outros elementos.

$3^{\text {a }}$ regra - O baixo grau da presença de um elemento deve ser compensado pelo alto grau da presença dos outros.

$4^{\text {a }}$ regra - No caso da norma tributária com finalidade extrafiscal, deve-se afastar o efeito retrospectivo sempre que o objetivo puder ser atingido deixando os referidos atos passados de fora do âmbito normativo da nova lei e o efeito comportamental da mudança não atingir o comportamento dos contribuintes relativamente aos atos já praticados.

$5^{\mathbf{a}}$ regra - Se o objeto só poder ser atingido com a eficácia retrospectiva da nova lei, ele deverá ser tanto mais importante quanto mais intensamente forem restringidos os direitos de liberdade e de propriedade do cidadão.

$\mathbf{6}^{\mathbf{a}}$ regra - Os direitos de liberdade e de propriedade do cidadão são tanto mais restringidos quanto mais brusca e drástica for a modificação normativa, mais difícil a reversão das disposições, maior a dependência do ato e mais extensos os prejuízos causados.

$7^{\mathbf{a}}$ regra - Ainda que o efeito retrospectivo seja necessário e a sua importância justifique a restrição da dimensão passada do princípio da segurança jurídica, ele deve ser afastado se a restrição da dimensão futura desse princípio for ainda mais restringida” (cf. Segurança jurídica, pp. 414/415). 
preconiza parte da doutrina para a aplicação do princípio em análise - de que haja um comportamento estatal que fruste a confiança ${ }^{675}$ - está, de certa forma, atendido.

Tais critérios são aplicáveis neste âmbito e oferecem outros critérios que afastam a incerteza e a insegurança que andam juntas com remissões ao caso concreto. Os critérios para a proteção da confiança, brevemente tratados anteriormente, conferem maior segurança e previsibilidade na modulação, de modo que, de um lado, as pessoas possam orientar suas condutas e, de outro, os julgadores tenham standards decisionais. Apesar do subjetivismo na aplicação da proteção da confiança e dos enunciados normativos similares, já antes expostos, é necessário procurarmos objetivar tal aplicação, de modo a afastar ao máximo a zona de subjetivismo. E os critérios de Humberto Ávila e Valter Shuenquener atingem esse escopo.

Em suma, ao modular os efeitos da invalidação de uma deliberação assemblear o julgador deverá partir do pedido formulado na demanda e das circunstâncias do caso concreto, como: (i) a natureza e a expressão econômica dos interesses envolvidos; (ii) a modalidade do vício (a nulidade impõe maior rigor); (iii) os direitos dos terceiros envolvidos; (iv) o tipo sociedade (se de capital aberto ou fechado); (v) a boa ou a má-fé dos agentes envolvidos; (vi) as relações jurídicas que se formaram a partir do ato inválido; e (vi) o grau de confiabilidade que decorreu do ato inválido. Ao analisar esse último aspecto, o julgador deverá empregar os critérios propostos por Ávila. Cremos que a conjugação de todos esses elementos, aliada ao dever constitucional de motivação das decisões (CF, art. 93, IX e CPC, art. 131), permita que a modulação dos efeitos da invalidação de deliberações inválidas ocorra de modo, se não absolutamente satisfatório, pelo menos mais seguro, previsível e controlável do que se simplesmente relegada aos critérios particulares de cada julgador.

\section{Impugnação de deliberações e atos conexos}

Também a temática do objeto litigioso do processo e do alcance objetivo da sentença na invalidação de deliberações é marcada por peculiaridades advindas do direito ${ }^{675}$ Cf. Valter Shuenquener, O princípio da proteção..., n. 1.6.4, pp. 103 e seguintes. Para uma análise mais
detida sobre os requisitos de aplicação da norma, v. n. 1.6, pp. 82 e seguintes. 
material. Uma dessas singularidades decorre da relação de dependência que pode eventualmente haver entre a deliberação impugnada e outros atos - inclusive, mas não só, deliberações - que não estiveram expressamente incluídos no objeto litigioso do processo. $^{676}$

Dentre outras indagações que podem ser levantadas, questiona-se se a sentença que anula a deliberação (i) pode estabelecer expressamente a desconstituição de atos jurídicos que não foi pedida, sem que seja taxada de nula (extra ou ultra petita), e se, (ii) não fazendo qualquer menção a tais atos, mesmo assim sobre eles projeta efeitos cassatórios. Essa última dúvida diz com a possibilidade de que a sentença conte com um efeito expansivo que afete outro ato jurídico que guarda relação com o ato assemblear. ${ }^{677}$ Duas perguntas, assim, motivam esta fase do trabalho: a sentença pode invalidar um ato cuja anulação não constou do pedido?; e a invalidação derivada ocorre pela simples anulação da deliberação pressuposta ou exige a remoção dos efeitos em via constitutiva? ${ }^{678}$ É do que se passa a tratar.

\subsection{A sentença pode determinar a desconstituição de ato cuja invalidação não foi pedida?}

A sentença que extrapola o pedido e concede tutela jurisdicional diversa ou além da que foi pedida é nula (ultra ou extra petita) e, assim, atacável via recurso de apelação. Se provocado (pois se trata de nulidade relativa, conforme item 15.2), o tribunal deverá reduzir o excesso e manter os demais capítulos do decisório. Se a sentença não foi impugnada ou se, por qualquer outra razão, for mantido o capítulo excedente, a coisa julgada material sanará a invalidade; e, assim, o capítulo deve ser considerado válido e eficaz (v. item 15.1). A sentença não pode determinar a desconstituição que não foi

\footnotetext{
${ }^{676}$ Para Stefano Villata, esta situação e a de deliberações que reiteram o mesmo conteúdo de uma deliberação já desconstituída são questões que raramente surgem em "nei normali processi aventi ad oggeto questioni di diritto soggetivo o di rapporti fondati sull'autonomia privata", o que justifica a tentativa de elaborar uma construção que se destaque "dalle comuni teorizzazioni sull'oggeto del giudicato costitutivo" (cf. Impugnazioni..., cap. III, n. 1, p. 266).

${ }^{677}$ A esse respeito, Stefano Villata dá notícia de decisão de tribunal italiano que reputou carecedor de ação, por falta de interesse processual, autor de demanda anulatória contra deliberação derivada de deliberação já desconstituída, por entender que esta já imporia aos administradores o dever de modificar também as deliberações subsequentes à declarada inválida (cf. Impugnazioni..., p. 268).

${ }^{678}$ Cf. Stefato Villata, Impugnazioni..., p. 456.
} 
pedida. ${ }^{679}$ Se em nenhum momento do processo houve o pleito de invalidação de um dado ato, o julgador não poderá invalidá-lo.

Questão diversa é a que trata da sentença que concede tutela jurisdicional pleiteada fora do momento processual próprio, que, para o autor, é a propositura da demanda ou até os momentos em que lhe é permitido alterar a demanda (CPC, arts. 294 e 264); e, para o réu, quando deve apresentar sua pretensão, nas hipóteses em que lhe é dado demandar. Em princípio, essa sentença também será ultra ou extra petita e, portanto, nula, e caberá ao tribunal reduzir o excesso ao apreciar eventual recurso interposto contra a decisão.

Em situações-limite, todavia, onde houve efetivo contraditório entre as partes a respeito da questão objeto do capítulo excedente, pode ser admitida a validade da parte do decisório que apreciou e acolheu pedido formulado após o momento de estabilização do objeto litigioso do processo. Se a sentença apreciar tal pedido - que embora não formulado no momento adequado foi objeto de debate entre as partes (contraditório) -, o capítulo não será nulo. Havendo respeito ao contraditório, a violação à regra de correlação torna-se irrelevante e, pois, não se trata de sentença ultra petita. ${ }^{680}$

\footnotetext{
${ }^{679}$ Nem mesmo se tratar-se de um ato inquinado de nulidade ou inexistência. O que o julgador pode, de ofício, considerar é uma alegação não feita pela parte ou uma questão pelas partes não suscitada. Mas não pode de ofício invalidar um ato contra o qual nenhuma das partes dirigiu sua pretensão.

${ }^{680}$ Cf. José Roberto dos Santos Bedaque, "Os elementos objetivos...”, n. 1.5, p. 35: "pode ocorrer que, embora indevidamente, com violação às regras técnicas sobre preclusão e estabilização da demanda, elemento objetivo seja introduzido no processo após o momento próprio. Se atentarmos para a razão maior da vedação, lícito será afirmar que, se a matéria foi submetida ao contraditório e à ampla defesa, concedendo-se às partes todas as oportunidades para produzir prova a respeito, o vício concernente à técnica processual não constitui óbice à participação. Assegurou-se a efetivação do contraditório e da ampla defesa. (...) A exposição minuciosa dos fatos e a formulação precisa da pretensão permitem ao réu saber exatamente o que deve apresentar como matéria de defesa. O que mais importa, pois, é que o pedido e a causa de pedir sejam submetidos ao devido processo legal, ainda que sua introdução não tenha observado as exigências legais"; e Efetividade do processo..., cap. III, n. 12, p. 222: "a violação à regra de correlação torna-se irrelevante se observado o contraditório em relação ao excesso. Nem nulidade há, pois, ao contrário do que se sustenta, a necessária adstrição da sentença aos elementos objetivos da demanda não decorre do denominado 'princípio dispositivo', nem da inércia da jurisdição, mas da impossibilidade de o julgamento abordar aspectos do litígio não submetidos ao contraditório". A mesma posição tem Ricardo de Barros Leonel: "se determinado fundamento da demanda ou da defesa, ou determinada pretensão, que não foram afirmados expressamente em conformidade com as regras técnicas do processo (na inicial ou na contestação) decorreram amplamente dos debates, com largo contraditório e aceitação pelas partes, pode ocorrer sua admissão, até mesmo de ofício pelo juiz, e frise-se: sem que isso represente obrigatoriamente motivo de nulidade da decisão por violação aos princípios da inércia, da demanda e da congruência” (cf. Causa de pedir..., n. 5.1.4, p. 240). V., ainda, Bruno Vasconcelos Carrilho Lopes, Limites objetivos..., n. 11, p. 59.
} 
É possível, pois, em situações extremas e desde que atendidos os requisitos acima enunciados, que a sentença licitamente determine a desconstituição de um ato cuja invalidação não foi pedida no momento adequado. Para tanto, é necessário que a invalidade do ato que dependa da deliberação tenha (i) se tornado controvertida e (ii) sido discutida (isto é, tenha se tornado uma questão), com ampla discussão das causas invalidantes. Se houver cognição exauriente e contraditório suficiente a respeito da causa invalidante desse segundo ato, de modo que a dúvida referente à sua validade tenha, de fato, tornado-se uma questão e sobre ela tenha havido debate claro e suficiente, bem como se as partes tiverem consciência de que a validade do ato foi incluída no objeto litigioso do processo, a questão poderá excepcionalmente ser admita na amplitude objetiva da sentença.

Essa possibilidade - que, repita-se, deve ser excepcional - encontra fundamento no princípio da economia processual, que determina o máximo aproveitamento do processo. Atribui-se, assim, eficácia de coisa julgada a todas as decisões que possuem os requisitos constitucionais para um julgamento definitivo: cognição prévia e exauriente e atendimento ao contraditório. ${ }^{681}$

Evidente que o julgamento desse pedido não formulado no momento oportuno só pode ocorrer em relação a atos praticados por quem já é parte no processo - problema que não se coloca quando o ato subsequente é uma deliberação da própria sociedade, pois esta, sendo a parte legítima passiva ad causam, necessariamente participará do processo. Se um dos emissores do ato não integrar a relação processual, não é possível aplicar a exceção, não só porque não podem ser impostos tais efeitos substanciais a quem não faz parte do processo, mas também porque é logicamente impossível ter havido debate/contraditório com esse sujeito. E ainda que se entenda pela validade do capítulo decisório, a coisa julgada que sobre ele recair não poderá ser oposta ao terceiro.

Em suma: a sentença não pode invalidar um ato contra o qual as partes não dirigiram pretensão desconstitutiva. O que ela pode é, em hipóteses excepcionais, atendidos os requisitos enunciados acima (viabilização do contraditório e da ampla defesa),

${ }^{681}$ Cf. Bruno Vasconcelos Carrilho Lopes, Limites objetivos..., n. 12.1, p. 64; José Roberto dos Santos Bedaque, Efetividade do processo..., cap. II, n. 5, p. 81; e Ricardo de Barros Leonel, Causa de pedir..., n. 5.1 .4 , p. 241. 
determinar a desconstituição de ato que foi pleiteada intempestivamente e que guarde relação de dependência com a deliberação cuja validade já era objeto de discussão judicial.

\subsection{A sentença desconstitui ato cuja invalidação não foi expressamente} determinada, mas que guarda relação de dependência com a deliberação anulada (efeito expansivo)?

Resta enfrentar a segunda indagação enunciada, mais complexa do que a primeira: é possível cogitar um efeito expansivo da sentença, de modo que, ainda que não tenha sido objeto da decisão, um ato seja desconstituído, apenas por ser juridicamente dependente do ato invalidado?

Como fruto da opção política ${ }^{682}$ do legislador, nosso direito processual civil dita que apenas o preceito concreto contido no dispositivo sentencial é que projeta efeitos substanciais exteriores ao processo e que somente ele fica protegido pela coisa julgada material. Assim, rejeitando a posição dos que, capitaneados por Savigny, defendiam que os motivos fundamentais da sentença tornar-se-iam imutáveis, o Código vigente afasta qualquer possibilidade desse entendimento ser adotado, ao dispor que "não fazem coisa julgada: I - os motivos, ainda que importantes para determinar o alcance da parte dispositiva da sentença" (CPC, art. 469, caput e inc. I). Isso significa que nem mesmo as questões de mérito, isto é, pontos controvertidos de fato e direito de cuja resolução depende logicamente o julgamento do mérito e que são resolvidos incidentalmente na motivação (incidenter tantum) - autênticas questões prejudiciais-, ${ }^{683}$ integram o dispositivo sentencial. Não podem, pois, serem acobertadas pela coisa julgada material (CPC, art. 469, III), a menos que tenha sido formulado pedido de declaração incidental (CPC, arts. $5^{\circ}, 325$ e 470). Apenas o que estiver contido no dispositivo é objeto de decisão e, logo, apto a se imutabilizar.

\footnotetext{
${ }^{682}$ Cf. Egas Moniz de Aragão, Sentença e coisa julgada, n. 138, p. 189. Os limites objetivos da coisa julgada podem ser mais amplos do que o objeto da sentença e restringir a coisa julgada ao dispositivo sentencial é opção de política legislativa (cf. Bruno Vasconcelos Carrilho Lopes, Limites objetivos..., nn. 4 e 5, pp. 17 e 23).

${ }^{683}$ Essa relação existente entre as questões resolvidas na motivação e o comando proferido no dispositivo trata de verdadeira manifestação da prejudicialidade, embora, como tal, costume passar despercebida, como adverte Clarisse Leite, segundo quem, "a bem da precisão conceitual é preciso entender que essa é, sim, uma relação de prejudicialidade" (cf. Prejudicialidade no processo civil, n. 22, p. 127). Sobre o assunto, v., ainda, Barbosa Moreira, "Os limites objetivos...", p. 93. A respeito do conceito de prejudicialidade, v., por todos, Antonio Scarance Fernandes, Prejudicialidade, nn. 8/18, pp. 30/53.
} 
O sistema exclui as questões prejudiciais do objeto litigioso do processo e, ao fazer isso, veda o julgamento de mérito sobre elas. Elas são objeto de cognitio, mas não de decisão. ${ }^{684}$ Por outro lado, contudo, o mesmo sistema municia as partes de ferramentas para que tais questões sejam decididas principaliter (ação declaratória incidental), de sorte que também a solução a tais questões seja objeto do preceito imperativo e concreto ditado pelo julgador como resposta à pretensão da parte (dispositivo sentencial). O que dizer, contudo, a respeito das questões e relações prejudicadas, isto é, daquelas afetadas por decisão de mérito já tomada em um processo? Qual o tratamento que lhes dispensa o nosso direito processual civil?

Em decorrência da chamada função positiva da coisa julgada material, o que foi objeto de decisão em processo anterior não pode voltar a ser discutido em processo posteriormente desenvolvido entre as mesmas partes. Ou seja, em processo superveniente, o julgador deve tomar o resultado do julgamento anterior como uma premissa inquestionável. ${ }^{685}$ Esse aspecto da coisa julgada impede que se questione o resultado a que se chegou anteriormente, isto é, a vontade imperativa reconhecida no dispositivo da sentença já proferida. Ou, em nosso caso que se volte a discutir se a deliberação que foi desconstituída é válida ou não. ${ }^{686} \mathrm{O}$ teor de uma decisão transitada em julgado a respeito da invalidade de uma deliberação vincula processos posteriores entre as mesmas partes, atuando como verdadeira causa prejudicial ou preliminar. ${ }^{687}$ A decisão imperativa sobre

${ }^{684}$ Cf. Barbosa Moreira, "Os limites objetivos...”, p. 93.

${ }^{685}$ Cf. Ugo Rocco, L'autorità della cosa giudicata e suoi limiti soggettivi, n. 128, p. 405; Pugliese, Giudicato civile, n. 27, p. 872; Andrés de la Oliva Santos, Objeto del processo..., p.109; e Eduardo Talamini, Coisa julgada..., n. 2.6, p. 130: "há a função (ou aspecto, ou eficácia) 'positiva' da coisa julgada. O decisum (resultado) sobre o qual recai a coisa julgada terá de ser obrigatoriamente seguido por qualquer juiz, ao julgar outro processo, entre as partes, cujo resultado dependa logicamente da solução a que se chegou no processo em que já houve a coisa julgada material". Sobre o assunto, v., também, Celso Neves, Coisa julgada civil, p. 489, e Liebman, que entende que a chamada função positiva da coisa julgada é simplesmente a eficácia natural da sentença (cf. "Eficácia e autoridade...", n. 18, pp. 54/55).

${ }^{686}$ É o que Sergio Menchini chama de relação de prejudicialidade-dependência: "l'oggetto della decisione integra un elemento della fattispecie del diritto fatto valere nel sucessivo giudizio, si che, per accertare il modo di essere del secondo, è indispensabile verificare quello del primo" (cf. I limiti..., Introdução, p. 3).

${ }^{687}$ Relação prejudicial e relação preliminar são espécies de relações de antecedência lógica pelas quais a decisão sobre uma relação projeta efeitos sobre a decisão de outra delas. Se há relação de prejudicialidade entre duas demandas, o resultado da prejudicial poderá afetar o resultado da prejudicada (por exemplo, sentença que anula parcialmente contrato de mútuo cujo crédito é pedido em ação de cobrança); se há relação preliminar, o resultado daquela afetará a própria admissibilidade desta, gerando, neste caso, via de regra a carência de ação superveniente (exemplo, sentença que nega a naturalização de estrangeiro que atua como autor de ação popular). Prejudicialidade ocorre quando a solução de uma questão pode influir no teor substancial do julgamento de outra. Barbosa Moreira assim define questões prejudiciais: "as concernentes a 
aquela controvérsia não poderá mais ser questionada pelas mesmas partes, de modo que essa antes questão prejudicial torne-se apenas um ponto prejudicial, inserido na cadeia de raciocínio do julgador como uma premissa assentada, e não como objeto de incerteza e discussão. ${ }^{688}$

Trata-se, como dito, da função positiva da coisa julgada. De como ela se opera não há dúvida. Mas não é do que se quer tratar aqui. O que queremos saber é se a sentença constitutiva negativa conta com um plus, de modo que também um ato dependente da deliberação invalidada seja considerado incluído no objeto do provimento e, assim, também ele seja objeto de desconstituição (efeito expansivo). É do que se passa a tratar.

\subsubsection{Título desconstitutivo e decisões implícitas}

O sistema processual civil brasileiro não permite decisões implícitas e, pois, o que não foi decidido não produz efeitos substanciais. À primeira vista, por esse motivo, a dúvida que se procura solucionar neste momento deveria ser de plano respondida pela negativa: firmada a premissa de que é necessário um pronunciamento judicial constitutivo negativo para que a deliberação seja extirpada do mundo jurídico, e, afastada a possibilidade de decisões implícitas, igualmente afastada estaria a possibilidade de tal efeito expansivo, pois as situações jurídicas alheias à decisão (ou, mais precisamente, ao dispositivo sentencial), ainda que dependentes do ato desconstituído por ela, não poderiam desaparecer do mundo jurídico por mera relação de causa e efeito.

Em princípio, portanto, admitir um efeito como esse seria impensável. Abordar a questão - e trancar a discussão - por esse ângulo, porém, é equivocado, porque o título desconstitutivo (sentença) existe e, logo, não pode ser negado o efeito expansivo pelo

relações jurídicas distintas da deduzida em juízo pelo autor, mas de cuja existência ou inexistência dependa logicamente o teor do pronunciamento sobre o pedido" (cf. "Os limites objetivos..." p. 90). Ocorre sempre que uma das demandas (prejudicial) versa sobre a existência, inexistência ou modo de ser de uma dada relação jurídica fundamental, de que dependa a relação jurídica controvertida na outra demanda (prejudicada). O exemplo clássico é da ação de investigação de paternidade, prejudicial à de alimentos, pois só tem direito aos alimentos quem for parente. O principal efeito da prejudicialidade é impedir a reapreciação da relação jurídica fundamental apreciada na demanda prejudicial julgada por sentença transitada em julgado: "A coisa julgada que se forma sobre a decisão da causa prejudicial obriga o juiz da causa a tomar como premissa necessária e indiscutível o que a propósito daquela houver sido declarado (CPC, art. 470)" (cf. Dinamarco, Instituições..., v. II, n. 466, p. 161). Sobre a distinção entre prejudicial e preliminar, v., ainda, Antonio Scarance Fernandes, Prejudicialidade, n. 17, pp. 47/52.

${ }^{688}$ Cf. Allorio, La cosa..., n. 33, p. 71, inclusive nota 10; e Clarisse Leite, Prejudicialidade..., n. 53, p. 294. 
argumento de que não houve causa para a invalidação. Há um título desconstitutivo (sentença) e a verdadeira dúvida diz com a sua amplitude. A questão diz respeito, portanto, ao alcance do provimento, isto é, até onde a sentença estende a sua influência jurídica. ${ }^{68}$

\subsubsection{Efeitos secundários?}

Poder-se-ia dizer que a desconstituição dos atos dependentes da deliberação invalidada decorreria por conta de efeitos secundários da sentença. É o que sustenta Zeno Veloso, ao defender que a sentença que invalida ato jurídico possui o efeito referido, que gera a nulidade dos atos baseados no ato invalidado, em verdadeiro efeito "cascata" ou “dominó" (retroeficácia). Anulado o ato, anular-se-iam também os que dele seriam dependentes, como consequência da reposição das coisas ao estado anterior. ${ }^{690}$

O efeito secundário da sentença é aquele, que, automaticamente por força de lei, sem que seja pedido, produz-se reflexa, acessória e consequencialmente aos efeitos principais do decisório. Em decorrência da falta de autonomia e da relação de acessoriedade com os efeitos principais, todavia, os secundários não podem ser produzidos separadamente destes. ${ }^{691}$ Por isso, logo se descarta a acomodação de eventual efeito expansivo da sentença nessa categoria, na medida em que a desconstituição dos atos dependentes da deliberação pode, obviamente, ser objeto de um juízo impugnatório

\footnotetext{
${ }^{689}$ Já existem hipóteses em que se ampliam os limites objetivos da sentença e da coisa julgada. Por exemplo, parte da doutrina interpreta o art. 474 do CPC - que estabelece a chamada eficácia preclusiva da coisa julgada - de forma ampla, entendendo que não seria possível a propositura de demanda veiculando o mesmo pedido de demanda já rejeitada, ainda que com causa de pedir diversa. Isso é apontado por Bruno Vasconcelos Carrilho Lopes, que cita Araken de Assis e Gustavo Garcia como partidários dessa corrente ampliativa (cf. Limites objetivos..., n. 1, p. 6).

${ }^{690}$ Cf. Invalidade..., n. 69, p. 341 e seguintes: "há um grave efeito secundário da sentença, que é, como diz Federico de Castro y Bravo, uma reação em cadeia que se produz, ao estender-se a condição de nulo a todos os direitos e títulos baseados no negócio cuja nulidade foi declarada - titulus invalidus non potest aliquem effectum validum operari. Pode-se falar, então, em nulidades 'consequenciais' ou 'por arrastamento' (...). A retroeficácia da sentença que declara a nulidade, ou da que decreta a anulação do negócio, vai atingir todos os outros atos ou negócios que foram realizados e que se apoiavam no que foi desconstituído".

${ }^{691}$ Nesse sentido, Liebman: "são simplesmente acessórios e consequentes aos efeitos principais e ocorrem automaticamente por força de lei, quando se produzem os principais. Não têm por isso os efeitos secundários condições próprias de admissibilidade, que o juiz deva reconhecer e declarar existentes (...). E assim como não poderiam ser produzidos separadamente dos principais, não podem, tampouco, ser denegados quando se pronunciam aqueles" (cf. "Eficácia e autoridade...", n. 23, p. 75). Na mesma linha Moacyr Amaral Santos Comentários..., v. IV, n. 338, pp. 453/455; Dinamarco, Instituições..., v. III, n. 897, pp. 206/208; Heinitz, I limiti oggettivi..., n. 9, pp. 107 e seguintes; e Cássio Scarpinella Bueno, Curso sistematizado..., v. 2, t. I, p. 378. Ovídio Baptista da Silva critica a nomenclatura efeitos secundários, preferindo efeitos anexos (cf. "Eficácias da sentença e coisa julgada", in Sentença e coisa julgada, n. 7, pp. 112/114).
} 
autônomo. Além disso, o efeito secundário depende de expressa disposição de lei ${ }^{692}$ (caso da hipoteca judiciária; art. 466), ${ }^{693}$ o que não existe no caso.

\subsubsection{A posição da doutrina acerca das deliberações conexas}

Invocando-se novamente a experiência italiana, há notícia de decisão do Consiglio di Stato que, tratando da hipótese em que o ato impugnado constitui o único pressuposto do ato consequencial (e que não foi objeto de invalidação no processo anterior), assentou que a invalidação do ato posterior não acarreta uma simples invalidade derivada, mas sim a própria impossibilidade de que o ato consequencial produza qualquer efeito em razão de ter sido privado de seu objeto. ${ }^{694}$ De modo similar, já se disse que a eliminação do ato anterior não causa exatamente a eliminação do posterior, mas sim a remoção da disciplina jurídica em que este se assentava e, por via de consequência, a cassação dele. A invalidação do ato anterior refletir-se-ia, portanto, na relação jurídica que existe entre um ato e outro. ${ }^{695}$ Falou-se também de efeito pressuposto, que, se retroativamente eliminado, eliminaria $a b$ origine o ato sucessivo, por relação de causalidade. Não se trataria de invalidação derivada, mas de inidoneidade do segundo ato a produzir efeitos. ${ }^{696}$

Ainda que com diferenças, todas essas ideias são variações de uma mesma matriz, qual seja, a de que existe tal relação de dependência entre os atos que a desconstituição de um gera efeitos automáticos sobre a validade ou a eficácia do outro. Como o direito brasileiro resolve a questão?

Nossos direito processual civil e direito processual do trabalho preveem expressamente a regra de contaminação das nulidades, pela qual o efeito invalidante

\footnotetext{
${ }^{692}$ Paulo Lucon propõe um redimensionamento do conceito de efeitos secundários da sentença, para que ele não fique restrito apenas às hipóteses expressamente previstas em lei. $\mathrm{O}$ núcleo central do instituto, para Lucon, é que os efeitos sejam produzidos acessória e consequencialmente aos efeitos principais da sentença. Mas, de qualquer maneira, ressalva que são marcados por "absoluta falta de autonomia" (cf. Eficácia das decisões..., n. 103, p. 377).

${ }^{693}$ A respeito da hipoteca judiciária, v. Egas Moniz de Aragão, Sentença e coisa julgada..., nn. 124/137, pp. $170 / 188$.

${ }^{694}$ Cf. Stefano Villata, Impugnazioni..., cap. III, n. 9, p. 358 e 361.

${ }^{695}$ Cf. Impugnazioni..., cap. III, n. 9, p. 364. Observa Villata, contudo, que todas essas teses são casuísticas, senão arbitrárias (p. 366).

${ }^{696}$ Cf. Impugnazioni..., cap. III, n. 9, p. 367 e 370.
} 
propaga-se a atos que, embora sadios, possuem relação de dependência com o ato anulado. É o que se chama de efeito expansivo (Dinamarco), ${ }^{697}$ princípio da causalidade (Antonio do Passo Cabral) ${ }^{698}$ ou invalidade derivada (Antonio Dall' Agnol). ${ }^{699}$ Nessa direção vão o art. 248 do CPC, que dispõe que "anulado o ato, reputam-se de nenhum efeito todos os subsequientes, que dele dependam; todavia, a nulidade de uma parte do ato não prejudicará as outras, que dela sejam independentes", e o art. 798 da Consolidação das Leis Trabalhistas (CLT), segundo o qual "a nulidade do ato não prejudicará senão os posteriores que dele dependam ou sejam conseqüência”. Por esses dispositivos, portanto, uma vez desconstituído um ato processual, todos os demais que dele dependem devem ser reputados sem efeito. ${ }^{700}$

Nosso direito civil, porém, não conta com regra expressa determinando o que deve ocorrer com a invalidade de atos jurídicos que guardem entre si relação de dependência. A disposição que mais proximamente disciplina o assunto é a segunda parte do art. 184 do CC, que, repetindo o contido no art. 153 do revogado CC/16, determina que "a invalidade da obrigação principal implica a das obrigações acessórias, mas a destas não induz a da obrigação principal". Uma leitura apressada desse dispositivo poderia dar a entender que, invalidado um ato jurídico, todos os que dele decorrem devem ser também invalidados. Mas o que na verdade esse artigo determina é que isso ocorre apenas quando há uma relação de acessoriedade, representada pelo adágio acessorium sequitur principale. É o caso, por exemplo, da invalidação do contrato de compra e venda e da consequente invalidação da hipoteca que o garante. A relação de principal e acessório é diversa da relação que existe entre, por exemplo, a deliberação que aprova o aumento de capital por subscrição de novas ações (LSA, art. 170) e a que, com os votos dos acionistas que

\footnotetext{
${ }^{697}$ Cf. Dinamarco, Instituições..., v. II, n. 715, p. 615.

${ }^{698}$ Cf. Nulidades no processo moderno, n. 1.3.5.5, p. 54. Sobre o assunto, v., ainda, Egas Moniz de Aragão, Comentários..., v. II, n. 370, p. 288.

${ }^{699}$ Cf. Antonio Dall'Agnol, Comentários..., v. III, n. 94.1, p. 466.

${ }^{700}$ Embora, é verdade, tanto o CPC como a CLT determinem que, ao pronunciar a nulidade, o julgador delimite quais são os atos atingidos pela invalidação (CPC, art. 249 e CLT, art. 797). Ou seja, embora haja disposições expressas acolhendo o efeito expansivo das nulidades ou o princípio da causalidade tanto no CPC como na CLT, esses mesmos diplomas determinam que a propagação do efeito cassatório deva ser enunciada pelo julgador, em uma autêntica mostra de sopesamento feito pelo legislador entre os princípios da causalidade e da instrumentalidade das formas. Sobre a relação entre os dois princípios, v. Antonio do Passo Cabral, Nulidades..., n. 1.3.5.5, p. 55. Ainda que se possa extrair uma relação de dependência entre ato e outro, portanto, cabe ao juiz delimitar até onde a invalidade estenderá suas mãos; o que, na verdade, é um reflexo de que não existem atos nulos, mas apenas anuláveis, pois os atos processuais são eficazes até que sejam desconstituídos por decisão.
} 
subscreveram o aumento, aprovou a reforma do estatuto (LSA, art. 135). Neste exemplo, pode haver conexão ou dependência, mas, no rigor, não há acessoriedade.

Não existe em nosso direito civil, salvo melhor juízo, regra expressa determinando que a invalidação de um ato gere a automática invalidação do ato que dele decorre. ${ }^{701}$ Ressalvada reflexão mais amadurecida, tal entendimento carece de base legal e deriva de uma regra implícita e inerente ao sistema das nulidades, que estabeleceria uma relação de dependência lógica entre ato e outro. Mas aqui vale a advertência de Lobo Xavier, que, embora feita em outro contexto, pode ser aproveitada ao ressalvar que o que precisamos não é de um critério lógico, mas sim jurídico. Por isso, descarta-se uma posição que se funda na natureza das coisas ou em uma lógica subjacente ao direito positivo. ${ }^{702-703}$

Ainda no direito civil, discussão análoga existe a respeito dos contratos coligados, que, na definição de Francisco Marino, são aqueles que, em razão de lei, da natureza acessória de um deles ou do seu conteúdo, estão em relação de dependência unilateral ou recíproca. Nesse âmbito, costuma-se invocar o brocardo simul stabunt, simul cadent (“juntos permanecerão, juntos cairão") para transmitir a noção de que a invalidade ou ineficácia de um dos contratos deve refletir a correspondente invalidade no contrato coligado. ${ }^{704}$ Mas mesmo nesse âmbito defende-se que a contaminação da invalidade não é

\footnotetext{
${ }^{701}$ São análogas as considerações de Nelson Eizirik a respeito de nosso direito civil, de acordo com quem "a invalidade do contrato principal contaminará o acessório; contudo, inexistindo dependência entre os 2 (dois) contratos, não há regra geral sobre como a invalidade de 1 (um) influenciará os demais negócios jurídicos conexos, tratando-se de questão valorativa, em que devem ser pesadas as circunstâncias do caso concreto" (cf. A Lei das S/A..., v. III, p. 601).

${ }^{702}$ Cf. Anulação..., nn. 24 e 29, pp. 394 e 416.

703 Digna de nota é a corrente jurisprudencial que entende que se, ao impugnar edital de concorrência pública, o demandante não formular pedido de anulação do futuro contrato administrativo que pode vir a ser celebrado como decorrência do certame, uma vez celebrado este há falta de interesse processual superveniente, em decorrência da perda de objeto da demanda (STJ, RO 14.938-PR, Rel. Luiz Fux, 1 $^{\text {a }}$ Turma, DJU de 30/6/03: "Impetrado Mandado de Segurança visando a impugnar ato no curso de procedimento licitatório, a superveniência de conclusão do respectivo certame, por não lograr êxito a tentativa do recorrente de paralisá-lo via deferimento do pleito liminar, leva à extinção do writ por falta de interesse processual superveniente". No mesmo sentido, TRF-5, Ap. 91668/RN, Rel. Francisco Barros Dias, j. 7/7/09. No STJ, contudo, a questão parece estar pacificada em sentido contrário, conforme o seguinte julgado da Corte Especial: "a superveniente adjudicação não importa na perda de objeto do mandado de segurança, pois se o certame está eivado de nulidades, estas também contaminam a adjudicação e posterior celebração do contrato" (AgRg na SS 2.370/PE, Rel. Ari Pargendler, Corte Especial, DJe 23.9.11). No mesmo sentido: REsp 1.128.271/AM, Rel. Castro Meira, Segunda Turma, DJe 25.11.09; e REsp 1.059.501/MG, Rel. Mauro Campbell Marques, Segunda Turma, DJe 10.9.09.
}

704 Diz Marino, contudo, que essa fórmula geral apresenta pouca ou nenhuma utilidade, pois além de excessivamente genérica e destituída de fundamentação dogmática, apresenta uma solução equivocada (cf. Contratos coligados no direito brasileiro, nn. 12 e 23.1, pp. 99 e 189/190). Essa fórmula é incorreta, 
um efeito automático, pois deve ser examinado o prejuízo que tal invalidade acarreta à função comum representada pelo grupo de negócios. Havendo disposições aproveitáveis, vigora o princípio da conservação. ${ }^{705}$

No âmbito das deliberações societárias, a discussão sobre eventual contaminação das invalidades gira em torno das chamadas deliberações conexas, entendidas como as que possuem tal vínculo entre si que a posterior extrai da outra o seu fundamento de validade. $^{706}$

De acordo com uma classificação doutrinária, há duas espécies de invalidades, sob a perspectiva do nexo da conexão existente entre um ato e outro: a caducante e a invalidante. A primeira ocorre quando o ato cronologicamente anterior representa o pressuposto único do ato subsequente, de modo que a anulação do primeiro gera a automática invalidação do segundo. A segunda ocorre quando não existe tal nexo e é necessário valer-se de um juízo de impugnação autônomo. ${ }^{707} \mathrm{O}$ ato pressuposto é aquele que incide indiretamente sobre a produção de efeitos do ato posterior e que, embora não constitua parte integrante ou constitutiva da fatispécie ou do procedimento que culminou neste, é elemento necessário para a produção de efeitos do posterior. ${ }^{708}$ Ainda de acordo com tal proposta doutrinária, haverá invalidação do ato posterior (pressuponente) apenas e se o ato anterior (pressuposto) assumir a qualificação de pressuposto único e inderrogável.

principalmente, porque, em regra, a invalidade de um contrato gerará a ineficácia do contrato a ele coligado (ineficácia superveniente), e não a sua invalidade, embora haja casos em que a relação de dependência entre um e outro acarreta a nulidade ou anulabilidade (cf. n. 23.1, p. 197). Sobre o aforismo latino, v. Carlos Nelson Konder, Contratos conexos, p. 222.

705 Cf. Carlos Nelson Konder, Contratos conexos, p. 222. A respeito da aplicação desse princípio às deliberações assembleares, v. Gianluca Guerrieri, La nullità..., cap. III, n. 8, p. 194.

${ }^{706} \mathrm{O}$ fenômeno é magistralmente explicado por Vasco da Gama Lobo Xavier, autor de obra obrigatória a respeito do tema, tantas vezes já citada aqui: "Sucede muitas vezes que as deliberações de assembleia geral de sociedades anônimas ou das sociedades por quotas (...) são susceptíveis de afectar deliberações subsequentes, interferindo por vários modos no processo formativo ou no próprio conteúdo destas últimas. (...) Pois bem. O problema que, a título principal, vamos discutir neste trabalho é o de saber qual, em casos destes, a influência da sentença que anula a deliberação primeiramente aprovada sobre o destino daquela outra que entretanto teve lugar. Determinará esta sentença a invalidade também da última deliberação?" (cf. Anulação..., n. 1, pp. 33/41).

${ }^{707}$ Cf. Stefano Villata, Impugnazioni..., cap. III, n. 9, p. 359.

${ }^{708} \mathrm{O}$ ato pressuposto não integra o iter procedimental do ato sucessivo. Ele concorre e é essencial para a formação do ato subsequente, mas não é ele próprio um elemento integrante deste. Há entre eles autonomia funcional: o ato pressuposto é geralmente um ato final de um procedimento, pronto e acabado, cuja ulterior produção de efeitos sobre o ato sucessivo é meramente acidental. Ou seja, a sua qualificação como pressuposto é algo que surge em um segundo momento, dada a sua idoneidade de produzir também efeitos diretos sobre o ato que emanará de um novo e autônomo procedimento (cf. Stefano Villata, Impugnazioni..., cap. III, n. 9, p. 372/273). 
Então não será necessário impugnar o ato precedente, pois esse será privado de seu objeto ou pressuposto único. Em todas as demais hipóteses, quando a relação de dependência é mais débil e existe mais de um ato pressuposto, é necessário impugnar autônoma ou cumulativamente o ato sucessivo. No primeiro caso, a invalidade será caducante; no segundo, viciante. ${ }^{709}$

O problema mais grave, alerta Stefano Villata, é coordenar essa construção com a regra de correlação entre demanda e provimento. Se a insurgência se dá contra o ato consequencial, embora não formalmente, existe uma situação. Diversa é a situação em que é censurado apenas o ato pressuposto. Nesta última hipótese, não poderá o juiz anular o ato consequencial, embora tal caducação possa ser reconduzida ao plano do direito material. ${ }^{710}$

Parte da doutrina, ainda, diz que o problema da invalidade derivada não se coloca diante das deliberações conexas nulas, já que, como estas seriam absolutamente ineficazes, eventuais atos que nelas se fundamentem caem por terra assim que "declarada" a nulidade do ato assemblear. $\mathrm{O}$ mesmo ocorreria com as deliberações ineficazes. ${ }^{711}$ Por isso, ainda que a primeira deliberação só venha a ter a sua nulidade ou ineficácia reconhecida após ter sido regularmente tomada a segunda, esta deveria ser desconstituída por mera relação de causa e efeito assim que invalidada a primeira, independente de ter sido incluída no objeto litigioso do processo. Em se tratando de deliberações nulas e ineficazes, a única pergunta a ser respondida seria, portanto, se há dependência entre as deliberações. ${ }^{712}$ Sendo positiva a resposta, a seguinte deveria ser automaticamente desconstituída. ${ }^{713}$ A esse propósito, Antigono Donati defendeu a existência de um princípio pelo qual, nulo ou anulado um negócio jurídico, caem por terra também os negócios que daquele descendem diretamente. E como parte da premissa de que esse princípio realmente existe, o problema para ele é o

\footnotetext{
${ }^{709}$ Cf. Stefano Villata, Impugnazioni..., cap. III, n. 9, p. 376.

${ }^{710}$ Cf. Stefano Villata, Impugnazioni..., cap. III, n. 9, p. 380.

711 Cf. Lobo Xavier, Anulação..., n. 4, pp. 68/71; e Erasmo Valladão França, "Invalidade de deliberações conexas da companhia", in Temas de direito societário, falimentar e teoria da empresa, n. 7, p. 414.

${ }^{712}$ Francisco Marino diz que a relação de dependência que há entre os contratos coligados está à base da teoria que sustenta a propagação da invalidade entre eles (cf. Contratos coligados..., n. 23.1, p. 190). Da mesma forma, Carlos Nelson Konder diz que não basta haver conexão entre contratos para que a invalidade de um produza efeitos sobre o outro; é necessário examinar a natureza da vinculação entre eles (cf. Contratos conexos, p. 233).

713 Evidentemente, o problema não se coloca na eventualidade de a deliberação posterior invocar como fundamento de validade uma deliberação que já foi desconstituída. Nesta hipótese, não há dúvida de que aquela também é inválida e, portanto, sujeita à impugnação.
} 
de delimitar quando haverá tal relação de dependência. ${ }^{714} \mathrm{Na}$ mesma linha foi Mario Vaselli, para quem a desconstituição de uma deliberação implica a invalidação das deliberações sucessivas que com aquela tenham relação de conexão causal necessária. ${ }^{715}$

A questão que restaria ser enfrentada, ainda conforme a doutrina ora analisada, surgiria na hipótese em que a deliberação posterior fosse tomada com base em deliberação cuja validade, à época, era incerta ou sujeita à impugnação. Ou seja, quando a primeira deliberação é anulável, já que esta produziria todos os efeitos a que se destina até que eventualmente anulada (CC, art. 176). ${ }^{716}$ Nessa circunstância, diz Lobo Xavier, deve ser feita a seguinte pergunta: o que sucederia com a deliberação posterior caso, no momento em que ela tivesse adentrado o mundo jurídico, já tivesse sido proferida decisão definitiva desconstituindo a primeira?

A razão de ser dessa indagação é que não é qualquer conexão que justifica a desconstituição da deliberação posterior. Não basta nem mesmo que haja apenas influência de uma na outra; deve haver dependência. ${ }^{717}$ Se a influência é irrelevante, os efeitos da invalidação não se alastram. E, portanto, não existe conexão.

Distingue-se, além disso, em conexão necessária ou objetiva e conexão voluntária. Aquela é um vínculo que decorre do próprio modo de ser dos atos em causa, independente da vontade de se estabelecer tal ligação, ao passo que a segunda advém da vontade dos sócios de que, por alguma razão, a eficácia de certa deliberação dependa das peculiaridades de uma deliberação anterior. ${ }^{718}$ Assim, quando houver conexão necessária, existe dependência entre ato e outro; e, portanto, os efeitos invalidantes alastram-se. Se a

\footnotetext{
${ }^{714}$ Cf. L'invalidità..., n. 90-b, p. 274. Para os critérios estabelecidos por Donati na verificação de quando há dependência, v. n. 94, pp. 284/285.

${ }^{715}$ Cf. Deliberazioni nulle..., p. 114.

${ }^{716}$ Cf. Erasmo Valladão França, "Invalidade de deliberações conexas da companhia", n. 8, p. 415.

${ }^{717}$ No terreno do direito processual civil, considerações análogas foram feitas por Antonio Dall'Agnol, ao afirmar que " desse modo, a nulidade (lato sensu) de um ato anterior só contagiará o posterior (ou posteriores), se esse não for independente; ou, talvez melhor, se não for o ato sucessivo dependente do anterior inválido. A dependência é um liame que liga o ato sucessivo ao antecedente, não apenas em razão da cronologia, mas, fundamentalmente, porque esse (o antecedente) evidencia-se como indispensável para a realização daquele (o sucessivo). (...) Inexistindo laço de dependência, o ato sucessivo não será contagiado (se alguma nulidade existir, é ela originária e não derivada)" (cf. Comentários ao Código de Processo Civil, v. III, n. 94.3, p. 468).

${ }^{718}$ Embora em regra as situações de dependência surjam apenas diante das conexões necessárias, podem aparecer também nas conexões voluntárias (cf. Lobo Xavier, Anulação..., n. 5, pp. 74/86, inclusive nota 44, e pp. 81 e 85).
} 
conexão é voluntária, só assume relevância jurídica caso a vontade dos sócios tenha sido condicionar um ato a outro, de modo que o seguinte extraia do outro o seu fundamento de validade.

Como a decisão que anula uma deliberação possui eficácia retroativa, explica a doutrina ora analisada, eventuais deliberações dependentes da anulada serão também anuláveis. E não importa se a deliberação anterior foi tomada anterior ou posteriormente à decisão que anulou a primeira. Em qualquer dos casos, o tratamento será o mesmo: desconstituição da segunda. ${ }^{719}$ Em se tratando de conexão voluntária, a anulação da primeira deliberação acarretaria a automática ineficácia da segunda deliberação; não por conta de uma invalidade derivada, mas sim porque os acionistas que aprovaram a segunda deliberação assim quiseram. ${ }^{720}$

\subsubsection{Deliberação que afeta o processo formativo da deliberação posterior}

Essa mesma doutrina distingue entre deliberação que afeta o processo formativo e aquela que influencia o conteúdo da outra.

Na primeira hipótese, a deliberação anterior, que vem a ser anulada (Deliberação A), afeta de forma relevante o iter formativo da deliberação posterior (Deliberação B). É o caso em que a Deliberação A altera disposições estatutárias referentes ao modo de convocação ou instalação da assembleia, quórum para votação ou representação dos acionistas; e a Deliberação B vem a ser tomada com base nessas novas regras. Mais concretamente, são as hipóteses em que, por exemplo, a Deliberação A reduz o quórum qualificado exigido pelo estatuto para votação de determinada matéria, delibera o aumento de capital e este é subscrito por pessoa que até então não era acionista ou delibera o resgate de ações e, assim, o acionista que era titular das ações fica impedido de ingressar no conclave posterior. ${ }^{721}$ Por uma razão irrelevante - mas que acarreta a sua anulabilidade, e não a nulidade -, a Deliberação A é invalidada e, assim, a Deliberação B, que havia sido

\footnotetext{
${ }^{719}$ Cf. Lobo Xavier, Anulação..., n. 41, p. 521.

${ }^{720}$ Cf. Lobo Xavier, Anulação..., n. 47, p. 575; e Erasmo Valladão França, “Apontamentos sobre...”, p. 97.

${ }^{721}$ Todos exemplos de Erasmo Valladão França (cf. “Apontamentos...”, p. 93).
} 
tomada com base naquelas regras procedimentais instituídas pela Deliberação A, passa a padecer de uma "invalidade superveniente". ${ }^{722}$

Como a violação a normas procedimentais gera a anulabilidade do ato societário (v. item 7.2), a Deliberação B passa a padecer de um vício de anulabilidade. Contudo, como a Deliberação A também era meramente anulável, não há invalidação em cascata (contaminação de nulidades de pleno direito); o que surge é apenas a possibilidade de que também a Deliberação B seja impugnada judicialmente. Contudo, dizem Erasmo Valladão França e Lobo Xavier, para que a Deliberação B seja impugnada deve ser observado o prazo decadencial fixado em lei para a impugnação do segundo ato (no caso do Brasil, os dois anos do art. 286 da LSA), sob pena de convalidação do vício que a contamina. ${ }^{723-724}$ Havendo duas demandas diversas - uma pleiteando a anulação da Deliberação A, outra da Deliberação B -, esta última deverá permanecer suspensa, por prejudicialidade, como manda o art. 265, IV, "a" do CPC. ${ }^{725}$

A primeira crítica a ser dirigida a essa posição é que, embora o prazo bienal do art. 286 seja até longo para o direito societário - e, por isso, com razão defenda-se de lege ferenda a sua redução -, na verdade ele é curto para a hipótese de invalidade superveniente, pois na realidade judicial brasileira é improvável que a sentença desconstitutiva da Deliberação A seja proferida e transite em julgado dentro de dois anos da publicação da Deliberação B. Por isso, dificilmente a "invalidade superveniente" surgirá antes de esgotado referido prazo decadencial.

\footnotetext{
${ }^{722}$ Coloca-se entre aspas a expressão porque, como já visto, não existem invalidades supervenientes, já que toda invalidade é necessariamente contemporânea ao nascimento do ato. No caso, em razão da retroeficácia da desconstituição da Deliberação A, é como se a invalidade desta também retroagisse ao momento do nascimento da Deliberação B. Contudo, a expressão "invalidade superveniente" é útil para que se visualize de qual invalidade se está falando.

${ }^{723}$ Erasmo Valladão França confere dois exemplos. O primeiro trata de aumento de capital subscrito por não acionista e de deliberação sucessiva, em que o novo acionista vota de forma determinante para a formação da maioria. O segundo exemplo trata da alteração do estatuto da empresa, para estabelecer que certa matéria pode ser aprovada por maioria simples, e não mais por maioria qualificada. Nos dois exemplos, caso sejam anuladas as primeiras deliberações, qual a sorte das segundas? Serão anuláveis, pois a anulação das primeiras fez surgir um vício no procedimento das segundas: no primeiro, foi permitido o voto de pessoa que não era acionista; e, no segundo caso, violou-se o quórum de deliberação previsto no estatuto (cf. "Invalidade de deliberações conexas...", p. 416).

${ }^{724}$ Cf. Lobo Xavier, Anulação..., n. 23, pp. 380/382. E confirmando que o prazo para impugnação da segunda deliberação conta-se ordinariamente, isto é, sem ser afetado pela anulação da segunda, veja-se a seguinte passagem do jurista português: "A circunstância de esta sobrevir ao dito acto, em lugar de o anteceder, nem sequer afecta a contagem do prazo dentro do qual pode proceder-se à impugnação daquele, se for o caso dela" (cf. Anulação..., n. 41, p. 521).

${ }^{725}$ Cf. “Apontamentos sobre...”, p. 95.
} 
Restariam apenas duas hipóteses em que, na prática, seria possível obter a invalidação da Deliberação B antes da decadência: (i) o próprio autor da demanda impugnatória da Deliberação A ajuíza uma segunda impugnatória, dirigida à Deliberação B (dentro do prazo decadencial para impugnação desta, é claro); ou (ii) o autor da demanda impugnatória da Deliberação A formula, em cúmulo sucessivo, na mesma demanda dirigida contra a Deliberação A, pedido de invalidação também da Deliberação B.

Adotadas as premissas da teoria que ora se analisa, estas duas últimas alternativas seriam as únicas possibilidades de, levando-se em conta a ordinariedade de nossa realidade judicial, ser invalidada a Deliberação B, pois dificilmente outro sujeito legitimado a impugná-la teria conhecimento da propositura da primeira demanda impugnatória - pois, ao contrário do direito alemão, que determina à companhia que informe todos os acionistas de que há em curso uma demanda judicial movida contra uma deliberação da sociedade, ${ }^{726}$ no Brasil não há nenhuma regra nesse sentido e, na maior parte dos casos, apenas a administração e eventualmente o acionista controlador é que toma conhecimento de tais demandas - e, assim, poderia exercer seu direito de ação de forma tempestiva, antes que se esvaísse o prazo do art. $286 .{ }^{727}$ Caso fosse proposta essa segunda demanda impugnatória, quer pelo autor da primeira, quer por terceiro, ela também deveria permanecer suspensa em razão da prejudicialidade, na forma do art. 265, IV, “a” do CPC.

A solução preconizada por Lobo Xavier e Erasmo Valladão França, por isso, é insatisfatória sob o ponto de vista da oferta de tutela jurisdicional efetiva a quem não é o autor da primeira demanda: o autor tem consciência do vício da Deliberação A e do reflexo que a invalidação desta pode ter na validade da Deliberação B, e possui, portanto, o ônus de ajuizar a segunda demanda impugnatória ou de cumular pedido impugnatório na primeira demanda. Mas e os terceiros, como poderão saber em tempo hábil que a Deliberação B também pode vir a se tornar (supervenientemente) inválida?

\footnotetext{
${ }^{726}$ Cf. Marcelo von Adamek, “Acertamento...”, n. 35.3.5, p. 522, nota 24.

${ }^{727}$ Nesse sentido, embora se possa contra-argumentar que cabe ao terceiro fazer um juízo sobre a invalidade também da primeira deliberação, já que este vício importará no vício da segunda, é válida a observação de Lobo Xavier de que, ao menos nas hipóteses de nulidade, "não pode fazer-se um juízo seguro sobre a eficácia do acto senão após a decisão do processo em que se impugnou a deliberação antecedente: o vício não se manifesta plenamente no momento da aprovação da deliberação sobre que incide - mas num momento porventura muito posterior, visto que é possível que decorra ainda um longo período até que seja pronunciada referida decisão" (cf. Anulação..., n. 31, p. 429).
} 
Para contornar essa incongruência, a solução que se poderia cogitar é defender prazos decadenciais com termos iniciais distintos para o autor da demanda e os demais interessados na invalidação da Deliberação B. Para aquele, o termo a quo do lapso decadencial para impugnar a Deliberação B seria a data da publicação desta, como para qualquer outra deliberação. Para terceiros, o que ocorresse primeiro: o trânsito em julgado da sentença que desconstitui a Deliberação A ou o conhecimento inequívoco a respeito da demanda já proposta contra a Deliberação A, momento em que surgiria a sua pretensão à invalidação da Deliberação B. Obviamente que este entendimento só vigoraria para a hipótese de que a causa de pedir da demanda do terceiro se fundasse unicamente no vício superveniente da Deliberação B, que surgiria com a invalidação da Deliberação A. Para deduzir qualquer outra pretensão contra a Deliberação B, o terceiro estaria sujeito ao mesmo termo a quo do prazo decadencial que o autor da primeira demanda, isto é, publicação da Deliberação B.

Essa possibilidade de haver múltiplos prazos decadenciais (pois de regra existirão inúmeros terceiros e cada um pode tomar conhecimento da primeira demanda movida em momentos diversos) deve ser descartada, contudo, porque, conforme a clássica e acertada lição de Câmara Leal, a decadência corre contra todos, sendo irrelevantes as situações pessoais de cada um. ${ }^{728}$ Portanto, adotada a teoria que ora se analisa, o prazo para impugnação da Deliberação B seria mesmo de dois anos contados da publicação desta, ainda que diante de vício "superveniente" originado na invalidação da Deliberação A. E, de fato, entendimento contrário ao aqui preconizado poderia gerar demandas ad infinitum, em verdadeiro efeito cascata. Ao menos na realidade judicial brasileira, portanto, a teoria aqui analisada é, salvo melhor juízo, insuficiente. Resta saber se há uma solução melhor.

\footnotetext{
${ }^{728}$ Cf. Da prescrição..., n. 82, p. 113: “A decadência, sendo um fenômeno objetivo, em que o elemento subjetivo não tem qualquer influência, porque não é estabelecido em atenção às pessoas, mas exclusivamente em virtude da inércia e do tempo, sem que se indague os motivos determinantes dessa inércia, o seu prazo corre contra todos e se completa, fatalmente, no momento de sua expiração. Isto posto, as pessoas contra as quais não corre a prescrição não ficam, igualmente, isentas dos efeitos da decadência”. E confere vários exemplos em que não se cogita de prazos decadenciais diversos, como o dos que se acham em guerra.
} 


\subsubsection{Deliberação que afeta o conteúdo da deliberação posterior}

Sempre que a deliberação anterior influenciar o procedimento formativo da deliberação posterior, sendo aquela anulada esta última será apenas anulável, já que vícios relativos ao iter assemblear geram a anualabilidade. Diversa é a hipótese em que a anulação da primeira deliberação (Deliberação 1) influi no conteúdo da segunda (Deliberação 2), de modo tal que, se à época em que tomada a posterior já tivesse sido invalidada a anterior, aquela devesse ser considerada inválida, à luz das regras jurídicas aplicáveis até então.

Na hipótese em que a deliberação afeta o conteúdo da posterior, nem sempre a Deliberação 2 será meramente anulável. Pelo contrário, é necessário perquirir qual o vício que a inquina, considerando a invalidação da Deliberação 1 e a natureza do vício que surgiu em decorrência dela, de acordo com os critérios firmados no item 7.2.

Erasmo Valladão França confere três exemplos. No primeiro, a Deliberação 1 autoriza o aumento de capital pela subscrição de novas ações e a Deliberação 2 confere certo privilégio às ações emitidas. No segundo, a Deliberação 1 autoriza aumento de capital; com isso determinado sujeito passa a ser acionista da companhia e é eleito, pela Deliberação 2, para o conselho de administração. No terceiro exemplo, a Deliberação 1 modifica o estatuto social para excluir cláusula que determina a destinação de parte dos resultados para um fundo de reserva e a Deliberação 2 determina a distribuição de lucros sem a observância da restrição que antes existia. ${ }^{729}$ Pois bem. Anulada a Deliberação 1, qual o destino da Deliberação 2, em cada um desses exemplos?

No primeiro deles, a Deliberação 2 seria nula em decorrência da impossibilidade de objeto (CC, art. 145, II), já que não se poderia conceder privilégios a ações que não mais existissem, em razão da anulação do aumento de capital. No segundo exemplo, disse Valladão França, também seria caso de nulidade, porque a Deliberação 2 teria eleito para o conselho de administração pessoa não acionista, violando lei imperativa (LSA, art. 146). Aqui cabe apenas uma observação: o artigo do ilustre comercialista foi escrito antes da edição da Lei 12.431/11, que alterou o art. 146 da LSA e passou a permitir que, assim

${ }^{729}$ Cf. “Apontamentos...”, pp. 95/96. 
como a diretoria, o conselho de administração possa ser composto por não acionistas. O exemplo não é mais válido, mas continua claro e didático: se, por força da desconstituição da Deliberação 1, a Deliberação 2 passar a violar norma imperativa de forma duradoura, esta será nula. Nesses dois casos, como a Deliberação 2 padeceria de nulidade, ela cairia automaticamente com a decretação da invalidade da Deliberação $1,{ }^{730}$ também com força retroativa, pois o fundamento jurídico em que se apoiara deixou de existir com eficácia retroativa. $^{731}$

Já no terceiro exemplo, o vício da Deliberação 2 seria o de anulabilidade, pois, se à época em que tivesse sido tomada já tivesse sido invalidada a Deliberação 1, aquele teria violado o estatuto social, vício que gera a anulabilidade, ${ }^{732}$ conforme item 7.2.

\subsubsection{Nossa posição sobre o chamado efeito expansivo: admissão de ineficácia derivada e negação de desconstituição como efeito direto do provimento}

A posição da doutrina ora analisada, como já visto, é a de que, em qualquer hipótese, a eficácia retroativa que tem a invalidação da deliberação anterior gera efeitos também retroativos sobre o ato posterior, levando à sua nulidade ou anulabilidade. Pouco importa, assim, que a primeira deliberação seja invalidada posteriormente à tomada da segunda. Por conta da retroação de efeitos, reputa-se que a segunda é inválida porque, no momento em que ela é adotada, já não podia ter sido. ${ }^{733} \mathrm{E}$ para que se determine qual vício inquina a deliberação posterior, é necessário perquirir qual seria esse vício se, no momento

\footnotetext{
${ }^{730}$ Nesse sentido, invoca-se novamente a lição de Erasmo Valladão França: "tratando-se de nulidade verdadeira e própria, não será necessário que o interessado impugne a segunda deliberação, a qual não produzirá quaisquer efeitos, caindo automaticamente, por força da decretação da invalidade da primeira" (cf. “Apontamentos...", p. 95). No mesmo sentido, "Invalidade de deliberações...", n. 10, p. 418, desse mesmo autor.

${ }^{731}$ Cf. Lobo Xavier, Anulação..., n. 28, pp. 407/411 e n. 30, p. 423.

732 Cf. Erasmo Valladão França, “Apontamentos...”, p. 96.

${ }^{733}$ Cf. Lobo Xavier, Anulação..., n. 41, p. 521: “Quando agora consideramos em conjunto os resultados assim obtidos, a reflexão que logo nos ocorre é a de que as soluções acolhidas para todas as modalidades de conexão das deliberações sociais que se encararam vêm a ser pura e simplesmente aquelas mesmas que já derivariam da estrita aplicação às hipóteses analisadas do princípio da eficácia retroactiva da sentença anulatória em causa. De acordo com tal princípio, na verdade, a deliberação anulada deve julgar-se $a b$ origine desprovida de efeitos - e assim mesmo, portanto, no momento em que foi aprovado o ato subsequente. Ora, o que as nossas soluções justamente significam é que o facto de a anulação da primeira deliberação só vir a ser decretada posteriormente à data da segunda não assume, ao fim e ao cabo, qualquer relevância. Pois este último acto - aquele sobre cuja sorte nos interrogamos - receberá exactamente o mesmo tratamento que lhe caberia, se ao tempo em que teve lugar já houvesse ocorrido a referida anulação".
} 
em que assumiu constituída, já tivesse sido invalidada a deliberação da qual extraiu seu fundamento de validade.

A primeira crítica a ser feita a esse entendimento é que, como se procura sustentar neste trabalho, em caso de nulidade ou de anulabilidade os efeitos do ato assemblear produzem-se, em princípio, regularmente, de sorte que não é exata a noção de uma ineficácia retroativa de pleno direito das deliberações nulas. Não é correta, pois, uma das premissas em que se assenta aquele raciocínio doutrinário, qual seja, a de que diante das deliberações nulas o problema das deliberações conexas já estaria resolvido em decorrência da absoluta ineficácia da deliberação anterior. Não é de se aceitar que, por ser nula a deliberação originária, o ato que dela depende também seja automaticamente e de pleno direito nulo. Também na hipótese de deliberação nula, portanto, para que se possa cogitar de um efeito expansivo ou de uma invalidade derivada é necessário, antes de tudo, que a primeira deliberação - que representa o suporte jurídico dos atos subsequentes - seja objeto de desconstituição judicial. Apenas nessa hipótese é que se poderá cogitar de alguma espécie de efeito dominó (e ainda com certas ressalvas, como será visto).

A segunda crítica é que, via de regra, a dependência entre a deliberação e um ato jurídico gera, em caso de invalidade da primeira, a ineficácia do ato, e não a sua invalidade. $\mathrm{O}$ que existe, em regra, é a perda de um fator de eficácia. ${ }^{734}$ Daí por que Francisco Marino diz que no direito brasileiro a solução mais adequada é entender que a invalidade de um contrato leva, normalmente, à ineficácia superveniente do contrato que lhe é coligado. A validade do contrato atua como condição de permanência da eficácia do contrato que dele depende, de modo que a sua invalidade funciona como condição resolutiva da eficácia do outro contrato. ${ }^{735}$

\footnotetext{
${ }^{734}$ Exatamente nesse sentido é a doutrina de Francisco Marino: "Ora, a invalidade de um contrato não acarreta a invalidade do contrato a ele coligado. Este não possui um vício simultâneo à formação, que dê causa à sanção de invalidade. O que há é perda de um fator de eficácia. A autonomia estrutural entre os contratos impõe seja vista a invalidade de um deles como circunstância extrínseca ao outro" (cf. Contratos coligados..., n. 23.1, p. 194), embora o próprio Marino reconheça que, em alguns casos, a questão possa resolver-se pela invalidade do contrato coligado (n. 23.1, p. 197).

${ }^{735}$ Referida ineficácia superveniente atua por meio da impossibilidade superveniente do objeto do contrato ou perda da sua função social, conforme o art. 421 do CC (cf. Contratos coligados..., nn. 23.1 e 24.3, pp. 195, 197 e 204). Abordar o problema sob a ótica da ineficácia, aliás, facilita conciliar a teoria da invalidade de atos dependentes e a ideia de que o ato societário possui um valor organizacional que exige expressa desconstituição para que seja reputado desprovido de efeitos.
} 
A tomada de posição acerca da invalidação derivada de uma deliberação ou ato jurídico em decorrência da invalidação de uma deliberação da qual depende diz respeito ao direito material e, portanto, tratando-se de um estudo de direito processual civil - ainda que com tema interdisciplinar -, não nos cabe dizer em quais hipóteses deve ou não haver tal invalidação derivada. Essa dependência jurídica é uma relação de direito material; e são os estudiosos do direito civil e do direito comercial que devem designar quais atos perdem o seu suporte jurídico como decorrência da anulação da deliberação e de quais modos deve ocorrer essa relação de causa e efeito. De fato, há hipóteses, analisadas anteriormente, em que a relação entre ato e outro é de dependência tal que a anulação do anterior faz com que o seguinte perca objeto ou passe a padecer de um vício superveniente. Por isso, embora tenhamos procurado fazer considerações críticas sobre as relações que possa haver entre uma deliberação anulada e outros atos jurídicos, bem como analisar e sistematizar a produção doutrinária sobre o assunto, cabe, em última análise, aos estudiosos do direito material fixar em quais situações a anulação da deliberação influenciará a eficácia ou a validade de um ato posterior e, principalmente, de que forma ocorrerá essa influência.

A posição que predomina, como visto, corporificada nas excelentes obras de Lobo Xavier e Erasmo Valladão França, é a de que, havendo determinados tipos de conexões, a invalidação de uma deliberação torna a dependente viciada, muitas vezes de modo automático e imediato. ${ }^{736}$ Contudo, mesmo dentre os estudiosos do direito societário há aqueles que, como Nelson Eizirik, defendem que a mera existência de conexão/dependência entre duas deliberações não significa que a invalidação da primeira deve ocorrer automaticamente, e que eventual contaminação da nulidade deve ser objeto

\footnotetext{
${ }^{736} \mathrm{Na}$ jurisprudência, colhem-se exemplos que ratificam essa posição: "Decretada a nulidade, pelo Poder Judiciário, da Portaria de Remoção da servidora, por ausência de motivação, todos os atos administrativos subseqüentes, inclusive o Processo Administrativo, são nulos e, em consequiência, inexistentes, porquanto eivados de vícios de nulidade desde o nascedouro, não podendo a autoridade reclamada falar em abandono de cargo, devido à ausência do 'animus abandonandi' e já que estamos diante de uma invalidação judicial do ato, por vício insanável. Registro que a questão estava sub judice, não sendo permitido à autoridade administrativa discutir a possibilidade de executoriedade ou não do julgado proferido por este Colegiado Superior de Justiça (...)" (STJ, Rcl 1.351/DF, Rel. Jorge Scartezzini, 3ª Seção, j. 28/5/03, DJ 23/06/2003, p. 234). Na mesma linha: "Ante a anulação, pelo Poder Judiciário, do edital do concurso que prestou o impetrante, os atos subsequentes, tais como os de nomeação e posse, são inválidos, porquanto eivados de vícios de nulidade desde o nascedouro, não acarretando qualquer direito a seus beneficiários (cf. RMS ${ }^{\circ}$ 10.405/SC)" (STJ, RMS 14.220/TO, Rel. Jorge Scartezzini, 5a Turma, j. 4/2/03, DJ 10/03/2003, p. 252). E mais: "Mandado de Segurança - Administrativo - Licitação - Anulação do Ato Impugnado e dos Atos Subsequentes - Artigos 128 e 460, CPC. (...) é certo que, anulado um ato, fatalmente cessam os efeitos dos posteriores. Não houve, assim, julgamento diverso do pretendido.” (STJ, REsp 39.630/SP, Rel. Milton Luiz Pereira, $1^{\text {a }}$ Turma, j. 19.4.95). V., ainda: TJSP, Apelação 0046650-48.1999.8.26.0000, Rel. Rodrigues de Carvalho, $5^{\mathrm{a}}$ Câmara de Direito Privado, j. 17.05.2001.
} 
de valoração pelo julgador. ${ }^{737}$ De forma similar Moitinho de Almeida, para quem uma das características especiais do regime de invalidades do direito societário é justamente a relativização à regra de contaminação das nulidades. Ou seja, anulada uma deliberação não necessariamente devem ser reputados inválidos as deliberações e os atos que bom base nela foram praticados. ${ }^{738}$

No plano do direito material, soa mais adequada e coerente essa última posição. Parece que, diante (i) da inexistência de regra legal que imponha a invalidação automática derivada (v. item 17.2) e (ii) das peculiaridades do regime de nulidades do direito societário cabe ao autor da demanda pedir e ao julgador dispor quais os atos devem ser afetados pela invalidação. Ressalvada a hipótese em que há perda de objeto - porque, aqui, realmente o ato subsequente não pode subsistir, embora o possam os efeitos já produzidos -, não havendo pedido e decisão nesse sentido os atos subsequentes deveriam ser reputados hígidos, assim como os efeitos que deles emanaram. Não é possível extrair um efeito expansivo de uma decisão implícita. Em decorrência das já tantas vezes referidas peculiaridades do regime de invalidades dos atos societários, marcado pelos imperativos de segurança e certeza, portanto, os atos dependentes de uma deliberação inválida deveriam ser objeto de impugnação autônoma. Ainda que o ato posterior tivesse como único fundamento jurídico a deliberação impugnada, e esta viesse a ser invalidada com eficácia ex tunc, parece-nos que a melhor ideia é aquela segundo a qual o que importa é que, no momento em que assumiu existência jurídica, aquele ato o fez de forma válida, respeitadas as condições então vigentes. ${ }^{739}$ Por isso, apenas no caso do ato em específico e da sua causa invalidante serem objeto de apreciação e acertamento judicial é que se poderia falar em desconstituição. Quando muito se poderia falar, em determinados casos, em

\footnotetext{
${ }^{737}$ Cf. A Lei das S/A..., v. III, p. 601: "o reconhecimento da conexão entre deliberações assembleares não significa que a anulação de uma implique automaticamente a invalidade da outra; a natureza da vinculação entre elas e os prejuízos decorrentes da extensão dos efeitos do vício existente na deliberação anulada, entre outros fatores, devem ser analisados caso a caso pelo julgador". Adotando posição semelhante, o STJ já decidiu que "é importante consignar que na ação anulatória ajuizada por Mosaic e Outra não há pretensão dirigida contra a reorganização societária, objeto de outra Assembléia Ordinária, ocorrida em 28.4.2006, por ser ela mera conseqüência à escolha do novo Conselho de Administração da Fértifos, motivo pelo qual o objeto da controvérsia aqui analisada cinge-se à validade ou não da Assembléia Geral Ordinária da empresa Fértifos, realizada em 27.4.2006, por meio da qual a Bunge, na condição de acionista controladora da Fértifos, promoveu a substituição dos 3 (três) conselheiros indicados pelas recorridas Mosaic e Outra" (STJ, REsp 1102424/SP, Rel. Massami Uyeda, $3^{\text {a }}$ Turma, j. 18/8/09, DJe 08/10/2009).

${ }^{738}$ Cf. Anulação e suspensão..., p. 15.

${ }^{739}$ Em sentido contrário, Lobo Xavier, Anulação..., n. 41, p. 521.
} 
desconstituição derivada, mas ressalvados os efeitos já produzidos sob a ordem jurídica anterior.

Existe uma tendência moderna de, tanto quanto possível, evitar a pronúncia da invalidade. ${ }^{740}$ Isso é muito claro no direito processual civil, onde vigoram com firmeza as ideias de instrumentalidade das formas ${ }^{741}$ e de aproveitamento dos efeitos do ato ${ }^{742}$ no direito constitucional, onde existe a ideia de modulação das nulidades; ${ }^{743}$ no direito administrativo, no qual se preconiza a relativização da eficácia retroativa na invalidação de atos da Administração ${ }^{744}$ e no qual há expressa disposição legal vedando a retroação de nova interpretação a respeito de norma administrativa; ${ }^{745}$ e no direito civil, em que também existem ideias de aproveitamento ou conservação dos efeitos do ato. ${ }^{746}$ Ressalvadas as

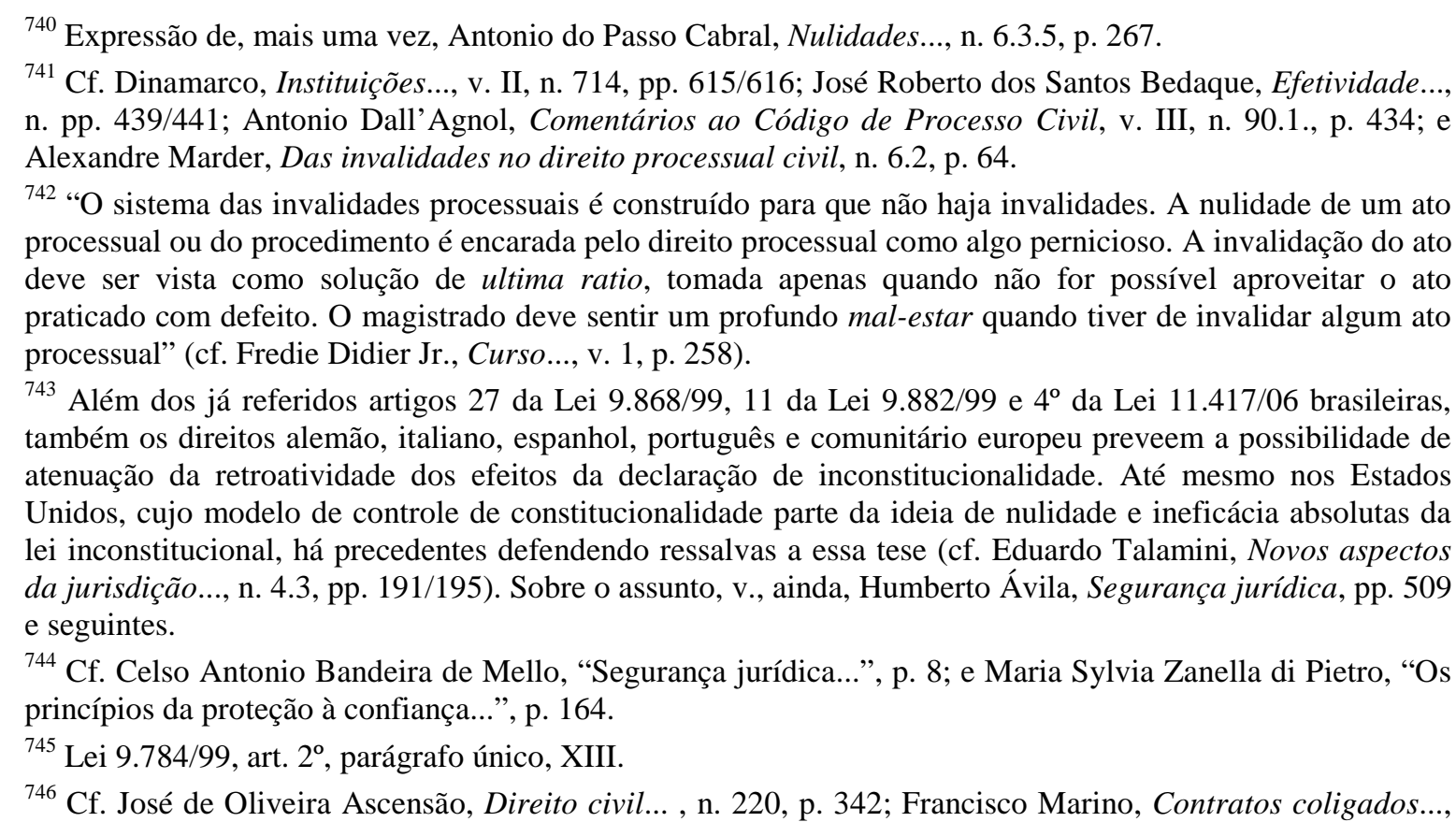
23.1, p. 190; e Carlos Nelson Konder, Contratos coligados, p. 219. Exemplos claros disso são os artigos 167 do CC, caput e $\S 2^{\circ}$ ("É nulo o negócio jurídico simulado, mas subsistirá o que se dissimulou, se válido for na substância e na forma" e "Ressalvam-se os direitos de terceiros de boa-fé em face dos contraentes do negócio jurídico simulado"); 170 do CC ("Se, porém, o negócio jurídico nulo contiver os requisitos de outro, subsistirá este quando o fim a que visavam as partes permitir supor que o teriam querido, se houvessem previsto a nulidade"); 176 do CC ("Quando a anulabilidade do ato resultar da falta de autorização de terceiro, será validado se este a der posteriormente"); 183 do CC ("A invalidade do instrumento não induz a do negócio jurídico sempre que este puder provar-se por outro meio"; e 184 do CC ("Respeitada a intenção das partes, a invalidade parcial de um negócio jurídico não o prejudicará na parte válida, se esta for separável; a invalidade da obrigação principal implica a das obrigações acessórias, mas a destas não induz a da obrigação principal"). No direito do trabalho e no processo civil, podem ser citados exemplos semelhantes: artigos 708 da CLT ("É nulo o negócio jurídico simulado, mas subsistirá o que se dissimulou, se válido for na substância e na forma"); 154 do CPC ("Os atos e termos processuais não dependem de forma determinada senão quando a lei expressamente a exigir, reputando-se válidos os que, realizados de outro modo, lhe preencham a finalidade essencial”); 244 do CPC ("Quando a lei prescrever determinada forma, sem cominação de nulidade, o juiz considerará válido o ato se, realizado de outro modo, lhe alcançar a finalidade”); e 248 do 
peculiaridades de cada um desses microssistemas - como, por exemplo, o fato de que a maioria dos atos processuais são atos jurídicos em sentido estrito, cujas consequências são impostas pelo ordenamento independentemente do objetivo perseguido pelo agente, de modo que, ainda que desrespeitada a forma legal, o ato é válido se atingiu a sua finalidade $^{747}$-, é inegável que existe uma tendência ao abrandamento dos rigores da invalidação. Também no direito societário existe a preocupação com a preservação dos negócios e com a estabilidade das relações jurídicas, ${ }^{748}$ como visto no item 7 . De fato, não há razão para o direito societário ficar infenso a essa tendência, se justamente nesse âmbito, com maior razão ainda, deve haver uma preocupação com a preservação dos atos jurídicos.

A invalidação de um ato só deveria gerar relevância sobre o subsequente se houvesse discussão sobre a validade deste. Se o ato posterior não tiver sido incluído no objeto do processo, só poderia ser invalidado se sua causa invalidante fosse, ainda que indevidamente, discutida no curso do processo - ou seja, se tivesse sido resolvida essa questão - e a sentença dispusesse expressamente sobre ele. Caso contrário, não se poderia admitir a sua invalidação. A dependência entre a deliberação e um ato poderia surgir apenas como um dos pressupostos para que se pudesse falar em um efeito expansivo. Os outros dois pressupostos seriam (i) efetivo debate judicial e (ii) expressa determinação no dispositivo sentencial.

Todavia, todas essas considerações que fazemos, tornamos a dizer, indicam apenas uma predileção nossa, já que cabe aos civilistas e comercialistas delimitar de qual maneira a invalidação de um ato impacta outro que deste seja dependente. O fato é que os comercialistas, diga-se mais uma vez, representados pelas obras de Lobo Xavier e Erasmo Valladão França, admitem a invalidade derivada - que, em nossa opinião, deveria ser mais propriamente vista como uma ineficácia derivada.

O que nos cabe firmar é que, sob a perspectiva processual - limite a que nos circunscrevemos -, nosso direito não permite que anulação que não tenha sido determinada

CPC ("Anulado o ato, reputam-se de nenhum efeito todos os subseqüentes, que dele dependam; todavia, a nulidade de uma parte do ato não prejudicará as outras, que dela sejam independentes").

${ }^{747}$ Cf. Calmon de Passos, Esboço..., nn. 18/22, pp. 28/33; e José Roberto dos Santos Bedaque, Efetividade..., pp. 419 e 440.

${ }^{748}$ Cf. Nelson Eizirik, A Lei das S/A..., v. III, p. 592. 
pelo dispositivo sentencial esteja contida nos limites objetivos do provimento ${ }^{749}$ e, com maior razão ainda, que se torne imutável. Ainda que se admita a possibilidade de uma invalidação derivada e automática, não se pode defender que a desconstituição desse ato subsequente esteja contida no dispositivo sentencial e, portanto, no comando judicial que emerge da sentença.

A desconstituição (ou ineficácia) do ato subsequente pode ocorrer por uma relação de causa e efeito que se dá unicamente por um mecanismo situado no plano do direito material. Pode ser, por exemplo, que o ato subsequente perca razão de ser ou tornese ilícito em decorrência da invalidação da deliberação em que se assentou. Mas isso ocorre no plano do direito material, como decorrência, parece-nos, de uma ineficácia derivada. Sempre que o ato subsequente tiver como pressuposto único a deliberação invalidada, ele poderá se tornar ineficaz.

O que não nos parece possível defender, dentro das conformações de nosso processo civil, é que a invalidação em cascata seja um efeito da decisão judicial. Quando muito, é um efeito refratário, atribuível não à sentença, mas à supressão, no plano do direito material, do suporte jurídico do ato subsequente. Em outro contexto, é o que parece ter sido afirmado por Antigono Donati, para quem a sentença tem eficácia direta sobre o ato deduzido em juízo, e eficácia reflexa sobre as relações jurídica que dele dependem. ${ }^{750}$ Eventual efeito expansivo, portanto, ocorre no plano do direito material.

Firmada essa premissa, conclui-se que a invalidação ou a ineficácia de ato dependente como decorrência de tal efeito expansivo poderá ser objeto de discussão judicial em novo processo, sem que se possa invocar a objeção de coisa julgada (CPC, art. 267, V). O beneficiário do ato subsequente, que se reputou desconstituído, poderá, por exemplo, ajuizar demanda declaratória de validade de tal ato. E o demandado não poderá invocar a coisa julgada para trancar o processo (função negativa da coisa julgada). Poderá unicamente invocar a função positiva da coisa julgada, ou seja, alegar que a invalidação da primeira deliberação é uma premissa assentada e fora de discussão. Mas não poderá

\footnotetext{
${ }^{749}$ Apesar de feita em outro contexto, a seguinte afirmação de Dinamarco vem a calhar: "Por mais amplo que possa ser o objeto do conhecimento do juiz, por mais que ele haja de formar convicção sobre a situação global representada pela realidade fática estampada na relação complexa, a decisão da causa incidirá exclusivamente sobre o que tiver sido objeto da demanda" (cf. Litisconsórcio, n. 13, p. 51).

${ }^{750}$ Cf. L'invalidità..., n. 91-a, p. 276.
} 
impedir o debate a respeito da validade do segundo ato, discussão essa que versará sobre a existência ou não de dependência entre o ato e a deliberação já desconstituída. E, realmente, se não houve acertamento judicial no processo anterior sobre a invalidação do ato subsequente, não é possível sustentar que foi reconhecida a dependência e que está fora de dúvida que houve a propagação da invalidade. A discussão partirá da premissa de que a deliberação foi anulada, mas, repita-se, deverá ser objeto de apreciação judicial a eventual relação de dependência entre o ato e aquela.

Torna-se a dizer que até se pode defender que, pelos desígnios do direito material, o segundo ato perdeu sua eficácia ou, mais ainda, foi desconstituído. O que não é possível dizer é que, pelas regras de nosso direito processual civil, essa segunda (implícita) desconstituição foi determinada pela sentença e acobertada pela coisa julgada. E, por isso, a questão a respeito da invalidade do ato dependente poderá e deverá ser objeto de discussão e posterior debate judicial, sem que se possa invocar a exceptio rei judicatae $\left(\mathrm{CPC}\right.$, art. 267, V). ${ }^{751}$

Embora em outro contexto, ao tratar dos limites subjetivos da sentença e da coisa julgada, Liebman fez considerações que devem ser aqui aproveitadas. De acordo com o processualista peninsular, a desconstituição de um ato jurídico age retroativamente e, por isso, pode ser oposta até mesmo a terceiros que tenham auferido direitos a partir desse ato jurídico, ainda que tal aquisição tenha se dado anteriormente à prolação da sentença. Mas os terceiros podem opor-se à coisa julgada, contestando a decisão. A sentença produz efeitos em relação aos terceiros, mas estes podem contestá-la. A questão, como Liebman destacou, desdobra-se em duas análises. A primeira, de direito substancial, consiste em saber se a invalidação da Alienação 1 acarretará também a invalidação da Alienação 2. Se a resposta for afirmativa, surge a segunda questão, de direito processual, que é a de saber como a sentença de invalidação do Ato 1, proferida em processo movido entre o Sujeito A e o Sujeito B, irá se imutabilizar em relação ao Sujeito C. $^{752}$

\footnotetext{
751 "A exceção de coisa julgada é fato impeditivo da constituição válida da relação jurídica processual” (cf. Celso Neves, Coisa julgada civil, p. 492). Sobre a exceção de coisa julgada, v. Pietro Cogliolo, Trattato teorico e pratico della eccezione di cosa giudicata, v. I, especialmente pp. 93 e ss.

${ }^{752}$ Cf. "Eficácia e autoridade...”, n. 44, pp. 154/155 e 158.
} 
O trabalho de Liebman trata dos limites subjetivos da sentença e da coisa julgada, mas pode ser invocado para tratarmos dos limites objetivos: caso se entenda que, pelo direito material, um ato foi desconstituído ou tornado ineficaz por mera relação de causa e efeito, não se poderá negar que qualquer interessado na manutenção desse ato ajuíze demanda declaratória de validade, mesmo que ele tenha sido parte no processo anterior (a companhia, por exemplo); se não tiver sido parte, com maior razão ainda.

Apenas uma disposição legal específica, que excepcione a regra geral de que somente o que está contido no dispositivo da sentença de mérito é apto a produzir efeitos substanciais, é que poderá considerar que algo que não foi determinado expressamente pela sentença esteve incluído em sua amplitude objetiva. Nosso direito prevê pedidos implícitos, mas não decisões implícitas. ${ }^{753}$ Tanto é isso verdade que, ainda que um pedido implícito não tenha sido objeto de decisão - e a parte interessada não tenha interposto embargos de declaração -, não se poderá dizer que há um capítulo do decisório que apreciou esse pedido. É o caso da condenação ao pagamento de honorários advocatícios: dúvida não há de que ela independe de pedido da parte. Contudo, se uma sentença sobre eles não dispuser, o título executivo não conterá a condenação e, assim, os honorários não poderão ser executados.

Em desabono da tese ora defendida poder-se-ia invocar casos em que o sistema convive com uma espécie de invalidade/ineficácia derivada, ainda que não expressamente determinada pela decisão judicial. É a hipótese, poder-se-ia dizer, da fraude de execução, em que todos os posteriores atos de alienação são automaticamente considerados ineficazes, ${ }^{754}$ em uma autêntica reação em cadeia. Assim, talvez se pudesse transplantar esse entendimento para o tema desta dissertação: se o sistema já convive com essa possibilidade na fraude de execução, também deveria conviver com o mesmo na invalidação de deliberações.

\footnotetext{
${ }^{753}$ Sobre o giudicato implicito, v. Pugliese, Giudicato civile..., n. 24, pp. 865/866.

${ }^{754}$ A sanção atribuída pela lei é de ineficácia, e não invalidade. A fraude não é um defeito intrínseco do ato, que prejudica algum de seus requisitos e, assim, causa a sua invalidade. Trata-se de vício extrínseco, que impõe resistência à produção dos efeitos do ato (cf. Dinamarco, Execução civil, n. 159, p. 256).
} 
Contudo, embora já se tenha entendido que o reconhecimento da fraude de execução acarreta a ineficácia de todos os atos de alienação sucessiva, ${ }^{755}$ prevalece hoje o entendimento - cristalizado na Súmula 375 do STJ - de que não só o primeiro adquirente pode ilidir a presunção de má-fé, como, com mais razão, podem fazê-lo os adquirentes sucessivos. ${ }^{756}$ Ou seja, predomina a visão de que não há mera relação de causa e efeito na fraude de execução. Não basta ser decretada a ineficácia do primeiro ato da cadeia de alienação; o ânimo subjetivo de todos os adquirentes é relevante e deve ser objeto de apreciação judicial, sob pena de ser interrompida a referida corrente. A menos que haja transcrição da penhora no registro de imóveis - do que decorre uma presunção de conhecimento geral do gravame -, cabe ao credor demonstrar que cada um dos atos foi praticado em fraude de execução. Essa posição leva a crer que mesmo no âmbito da fraude de execução, portanto, não há uma extensão dos limites objetivos da decisão; é preciso haver apreciação judicial para que haja ineficácia. E ainda que se admitisse um efeito expansivo absoluto na fraude de execução, ele decorreria não de uma regra geral, que pudesse ser transposta para as deliberações inválidas, mas sim de uma expressa exceção legal (CPC, art. 592): a extensão do alcance do decisório para fora dos limites do processo decorre de expressa disposição de lei. ${ }^{757}$ Ou seja, há nesse âmbito, por vontade do legislador, uma ressalva à regra geral de limitação do alcance objetivo ao dispositivo ${ }^{758}$, e

755 "Sentença mantida por esta Corte, no sentido de que houve fraude à execução na alienação do imóvel em questão, contamina as posteriores alienações" (STJ, REsp 217.824/SP, Rel. Antônio de Pádua Ribeiro, $3^{\mathrm{a}}$ Turma, DJ 17/5/04).

756 "Em qualquer caso, impõe-se resguardar a situação do adquirente de boa-fé. Para tanto, é importante considerar que a penhora, o seqüestro e o arresto são medidas que importam, em regra, a retirada do bem da posse de seu proprietário. Assim, é lícito que se presuma, em se tratando de bem móvel, a boa-fé do terceiro que o adquire de quem detenha a posse, sinal evidente da ausência de constrição judicial. A mesma presunção milita em favor de quem adquire bem imóvel, de proprietário solvente, se nenhum ônus ou constrição judicial estiver anotado no registro imobiliário, presunção que, com maior razão, se estende aos posteriores adquirentes, se houver alienações sucessivas" (STJ, REsp 494.545/RS, Rel. Teori Albino Zavascki, $1^{\text {a }}$ Turma, DJ 27/9/04).

${ }^{757}$ CPC, art. 592, caput, I e V: "Ficam sujeitos à execução os bens: I - do sucessor a título singular, tratandose de execução de sentença proferida em ação fundada em direito real; e (....) V - alienados ou gravados com ônus real em fraude de execução".

758 E, de fato, conforme ensinou Alcides Mendonça Lima, o art. 592 excepciona a regra geral de responsabilidade limitada ao próprio patrimônio, enunciada no art. 591 do CPC: "esta regra geral, consubstanciada no art. 591, comporta exceções, largamente formuladas desde priscas eras. Sempre se levaram em conta situações que a prática e a experiência vão criando, na gama infindável da vida social. Assim sendo, há bens que estão fora do patrimônio do 'devedor' e, mesmo assim, são suscetíveis de execução contra ele movida, seja qual for o título que serviu de fundamento. Isso ocorre ou porque os bens ainda são, juridicamente, do devedor, e, apenas, na aparência de terceiro (incisos I, III e V); ou são de terceiro, mas que, por circunstância especial, respondem, mesmo assim, por obrigação do devedor (incisos II e IV)" (cf. Comentários ao Código de Processo Civil, v. VI, t. II, n. 1.044, p. 533). Também Dinamarco atribui essa excepcionalidade à vontade do legislador: "Seja ao sancionar a fraude contra credores, seja a de execução, quis o legislador combater atos com que o devedor intente desfalcar o seu patrimônio e, com isso, a garantia dos seus credores" (cf. Execução civil, n. 158, p. 255). 
se estabelece um efeito expansivo - ou, nos dizeres de Liebman, uma responsabilidade executória secundária ${ }^{759}$-, de modo que se considere ineficaz o ato de alienação e, assim, o bem alienado responda pelo débito do proprietário originário. Quis o legislador que uma circunstância externa ao ato de alienação -identificada com o interesse do terceiro lesado pela alienação -, impedisse a produção dos efeitos do ato, gerando a sua ineficácia. ${ }^{760}$

A própria eficácia preclusiva da coisa julgada, que determina que a decisão proferida fique imune a posteriores impugnações, ainda que fundamentada em questões que não foram apreciadas no processo anterior (CPC, art. 474), está limitada pelo objeto do julgamento (amplitude objetiva da sentença). A coisa julgada cobre o deduzido e o dedutível, mas dentro dos limites do objeto do que foi efetivamente julgado. ${ }^{761}$ Ou seja, só pode ser acobertado pela coisa julgada o que constituiu objeto de apreciação. E, da mesma forma que em nosso sistema vigente não é sustentável a extensão da coisa julgada aos fundamentos da decisão, ${ }^{762}$ não é possível dizer, de lege lata, que ato que não foi objeto do dispositivo também foi desconstituído.

Mesmo a tese de Allorio de eficácia reflexa da coisa julgada, por conta de nexo de subordinação entre uma relação jurídica decidida (prejudicial) e outra exterior (prejudicada) significa apenas que se torna preclusa a discussão a respeito do elemento constitutivo da relação prejudicada. ${ }^{763} \mathrm{Ou}$ seja, transpondo-se esse raciocínio para as deliberações conexas, é como se referida eficácia impedisse apenas a discussão sobre ser

\footnotetext{
${ }^{759}$ Cf. Liebman, Processo de execução, n. 39, p. 95.

${ }^{760} \mathrm{Cf}$. Dinamarco, Execução civil, n. 159, p. 256. E mais. Ainda que se admitisse essa eficácia expansiva sem a comprovação (ou presunção) da má-fé de todos os posteriores adquirentes, não se poderia impedir que o terceiro afetado pelo decreto da fraude se insurgisse contra este e procurasse rediscutir o preenchimento dos requisitos legais para o decreto da fraude. É o que ocorre nos embargos de terceiro: decretada a ineficácia de uma alienação por suposta fraude de execução, são cabíveis embargos de terceiro (cf. José Eli Salamacha, "Fraude à execução - proteção do credor e do adquirente de boa-fé", in Execução civil - estudos em homenagem ao Professor Humberto Theodoro Jr., pp. 38/39; e Dinamarco, Execução civil, n. 177, p. 288), pelos quais o terceiro prejudicado procurará (re)discutir a questão e desconstituir a decisão. Se nos embargos de terceiro admite-se que o terceiro rediscuta a própria causa da ineficácia, é porque, ainda que se cogite tal eficácia expansiva, ela ocorre apenas no plano do direito material. E o direito processual não impede a discussão pelo terceiro. Não há algo sequer semelhante com a eficácia negativa da coisa julgada, que obste o prosseguimento dos embargos de terceiro ao fundamento de que a questão já foi decidida. Verdade que essa questão é de limites subjetivos. Mas pode ser também de limites objetivos, pois o que importa é a imutabilidade dos limites objetivos da decisão.

${ }^{761}$ Cf. Barbosa Moreira, "Os limites objetivos...", pp. 90 e 96; e "A eficácia preclusiva...", p. 99.

${ }^{762}$ Mesmo que defenda essa extensão e entenda que ela seria salutar para o nosso direito, Bruno Vasconcelos Carrilho Lopes reconhece que essa sugestão é feita apenas no plano legislativo, pois esbarra no direito vigente (cf. Limites objetivos..., n. 12.1, p. 77).

${ }^{763}$ É o que afirma Monteleone (cf. I limiti..., n. 3, p. 29).
} 
válida ou não a primeira deliberação; o que não significa que há o reconhecimento, isto é, o acertamento, do nexo de prejudicialidade. A menos que o julgado prejudicialcondicionante faça referência explícita e clara também à relação jurídica prejudicadacondicionada, não se pode, nem lógica e nem juridicamente, extrair daquele primeiro julgado uma eficácia reflexa sobre a segunda relação. Entre a mera existência de um nexo de prejudicialidade e o seu refletir sobre a relação condicionada existe um salto lógico $e$ um abismo jurídico. ${ }^{764}$ Esse é o grande obstáculo que opomos ao efeito expansivo da forma como construído pela doutrina que tratou das deliberações conexas.

Se não houve acertamento a respeito da invalidade dos atos posteriores, não se pode dizer que eles foram desconstituídos por relação de causa e efeito. O provimento constitutivo atua mediante o acertamento e, no momento seguinte, alteração da ordem jurídica (v. item 10.2.2). Se não há acertamento não há desconstituição. ${ }^{765}$ É o reconhecimento de que o ato está em desacordo com a ordem jurídica (acertamento) que libera a eficácia desconstitutiva da decisão.

Em conclusão, pode ser admitido que, na dinâmica das relações de direito material, a desconstituição de uma deliberação acarreta a invalidade (ou, como pensamos, a ineficácia) do ato dependente. Levantamos inúmeras ressalvas a esse entendimento, mas ele é, em certas hipóteses, acertado, e cabe aos estudiosos do direito civil e comercial estabelecer quando ocorre. Mas não é possível sustentar que nos limites objetivos da sentença esteja contida também a desconstituição ou o tornar ineficaz outros atos que dela

\footnotetext{
${ }^{764}$ A expressão é de Monteleone e foi utilizada em contexto diverso mas que ora pode ser aproveitado : "Ma è altrettanto vero, certo e ed indubitabile che quelle medesime norme sostanziali, dalle quali si ricava l'esistenza del nesso di pregiudizialità-dipendenza fra i rapporti, non dispongono affatto che l'accertamento contenuto nella sentenza passata in giudicato intorno al rapporto giuridico condizionante sai opponibile, immutabile ed incontrovertibile rispetto al terzo, titolare del rapporto condizionato. Fin quando le norme sostanziali, che regolano determinati rapporti giuridici formatosi intorno a quello pregiudiziale o condizionante, estendedone la efficacia a quello pregiudicato o condizionato, non si può ricavara né logicamente né giuridicamente dal semplice nesso di pregiudizialità la cosidetta efficacia riflessa del giudicato" (cf. I limiti..., n. 3, pp. 30/31). Além disso, interpretando a obra de Allorio, Monteleone diz que a eficácia reflexa da coisa julgada só ocorre quando normas específicas de direito material impõem o nexo de prejudicialidade-dependência. È irrelevante que a fattispecie da relação condicionada seja constituída pela relação condicionante. Isso não influi sequer minimamente no objeto do acertamento judicial, que é constituído unicamente da relação condicionante, não tratando, ao menos não em via principal, da relação condicionada (cf. Monteleone, I limiti..., n. 3, pp. 28/30 e 35/36).

${ }^{765}$ Cai como luva a seguinte passagem de Liebman: "O pronunciamento declarativo e o consequente pronunciamento constitutivo de uma sentença estão estritamente ligados entre si, porque o primeiro justifica o segundo e este não pode subsistir sem o apoio daquele" (cf. "A coisa julgada nas questões de estado", in Eficácia e autoridade da sentença e outros escritos sobre a coisa julgada, p. 190).
} 
dependam. E muito menos que o reconhecimento dessa eventual invalidade ou ineficácia expansiva estará acobertada pela coisa julgada.

Por fim, cumpre dizer que nos casos em que se admite referida ineficácia superveniente, ela ocorre ex nunc, pois a invalidação da deliberação atua como causa resolutiva da eficácia do ato que dela depende (ineficácia superveniente). ${ }^{766}$ Até se pode reputar automaticamente desconstituído ou ineficaz o ato subsequente, mas não com eficácia retroativa. Para que o ato subsequente seja desconstituído ex tunc é necessária decisão com essa determinação. Se não há decisão determinando quais atos dependentes devem ser desconstituídos, mas essa desconstituição ou ineficácia tem como causa o suposto efeito expansivo, a decisão, nesse particular, tem eficácia ex nunc. É ônus do autor, portanto, impugnar todos os atos que pretende ver desconstituídos com eficácia ex tunc.

\subsubsection{Alternativas para que os atos subsequentes sejam desconstituídos pela eficácia direta do provimento (não apenas reputados ineficazes por eficácia reflexa)}

A posição há pouco defendida não é formalista ou legalista. E, salvo reflexão mais amadurecida, é a única possível de ser seguida em nosso sistema processual. Há, contudo, alternativas para que os atos subsequentes e dependentes da deliberação impugnada sejam, eles também, incluídos no objeto do processo e, assim, expressamente desconstituídos pela sentença.

Com relação aos atos já praticados antes da propositura da demanda, a questão resolve-se pelo ônus de impugnar: se o demandante não dirigiu sua pretensão contra um dado ato, é porque não quis desconstituí-lo e ao julgador é defeso fazê-lo. Se o fizer, a sentença será extra ou ultra petita e, portanto, nula. Se o ato subsequente já existia no momento da propositura da demanda não há porque o pedido de sua desconstituição não ser formulado. O pedido de desconstituição é um ônus do autor da demanda, que, como tal, é um imperativo em seu próprio interesse.

A verdadeira questão reside nos atos praticados durante o curso da demanda.

\footnotetext{
766 Nesse sentido, Francisco Marino entende que a invalidade de um contrato acarreta a ineficácia superveniente do contrato coligado e que "esta ineficácia superveniente operará, normal mas não necessariamente, ex nunc" (cf. Contratos coligados..., n. 23.1, p. 195).
} 
A respeito desses, existem duas possibilidades iniciais, que podem afastar o problema no caso concreto. A primeira é a de que, ao ter ciência da demanda, a companhia faça um juízo de probabilidade a respeito do êxito da pretensão anulatória e deixe de praticar um ato que extraia seu único fundamento de validade da deliberação sub judice. A segunda possibilidade é o demandante formular pedido de antecipação de tutela para sustar os efeitos da deliberação impugnada, que, se deferido, impedirá que a companhia pratique novos atos com base na deliberação. Nessas duas hipóteses sequer se coloca o problema da prática de atos dependentes durante o curso do processo.

É possível, contudo, que não ocorra nenhuma dessas alternativas e seja praticado um ato ou tomada uma deliberação que extraiam fundamento de validade daquela primeira que já se encontra sub judice. Quais alternativas nosso direito oferece para que, em situações como essa, o autor da demanda anulatória fique resguardado e não se veja obrigado a propor tantas demandas quantos forem os novos atos?

A primeira e melhor possibilidade é que o autor, ao ajuizar a demanda impugnatória, formule, em cúmulo sucessivo, ${ }^{767}$ pedido genérico de invalidação de todos os atos subsequentes que da deliberação sejam dependentes.

A doutrina identifica o pedido genérico (CPC, art. 286) com o pedido ilíquido, isto é, indefinido apenas quanto aos seus aspectos quantitativos, ${ }^{768}$ posição que parece se dever principalmente à circunstância de que usualmente associa-se o pedido genérico à tutela condenatória e, mais precisamente, indenizatória. Sintomático disso é o clássico e recorrente exemplo da demanda indenizatória proposta em momento em que ainda não era possível calcular todos os prejuízos decorrentes de um acidente de trânsito. No âmbito da

\footnotetext{
${ }^{767}$ Sobre o cúmulo sucessivo, v. Dinamarco, Instituições..., v. II, n. 473, p. 172.

768 “A lei tolera, entretanto, o pedido relativamente indeterminado, que o Código chama de genérico. Essa relativa indeterminação é restrita ao aspecto quantitativo do pedido (quantum debeatur), inaceitável qualquer indeterminação no tocante ao ser do pedido (an debeatur)" (cf. Calmon de Passos, Comentários ao Código de Processo Civil, v. III, n. 95, p. 157). Na mesma linha foi Frederico Marques ("Pedido genérico é o que se opõe a pedido líquido e especial. Indeterminado quantitativamente, o pedido deve ser completado por ulterior liquidação"; cf. Manual..., v. II, n. 358, p. 77) e Fredie Didier Jr. (“A indeterminação ficará restrita à quantidade ou à qualidade das coisas ou importâncias pleiteadas"; cf. Curso..., v. 1, n. 5.7.2., p. 439). Também Dinamarco, Sérgio Sahione Fadel, Wellington Moreira Pimental e Fábio Luiz Gomes identificam a generalidade com a iliquidez (cf., respectivamente, Instituições..., v. II, n. 444, p. 124; Código de Processo Civil Comentado, v. I, p. 487; Comentários..., v. III, p. 175; e Teoria geral..., p. 222).
} 
tutela indenizatória talvez seja justificável que a questão seja vista apenas sob a ótica da quantificação, mas a redação da lei não permite que se exclua a aplicação do inciso II no âmbito das tutelas declaratória e constitutiva. E nestas o pedido genérico não deve ser visto apenas sob o aspecto quantitativo.

Acreditamos que o inciso II do art. 286 do CPC, ao enunciar que uma hipótese de pedido genérico é a de "quando não for possível determinar, de modo definitivo, as consequências do ato ou fato ilícito", abarca aquela em que se pede a desconstituição de atos sucessivos com fundamento em uma invalidade ou ineficácia derivada. Não se trata de mera questão de quantificação. O pedido deve ser certo e determinado quanto à providência jurisdicional desejada. ${ }^{769} \mathrm{O}$ pedido não pode ser dúbio ou incerto, ${ }^{770}$ mas, desde que seja formulado expressa e claramente, individualizando-se a tutela pretendida, deve ser admitido o genérico. ${ }^{771}$

O próprio exemplo do acidente de trânsito comprova o que se defende aqui. Quando se ajuíza demanda pleiteando o pagamento de gastos que serão incorridos no curso do processo, não se trata de mera quantificação, pois o julgador terá que fazer, também, um juízo qualificativo, para que conclua se dada despesa teve ou não nexo com o acidente. O pedido genérico, portanto, não é apenas aquele que é incompleto sob a perspectiva da quantificação. Por essa razão é que, de forma muito feliz, Heitor Sica diz que pedido ilíquido não é sinônimo de pedido de genérico, e defende que o pedido genérico pode recair sobre uma probabilidade de dano, hipótese em que se baseará em fatos que ainda não ocorreram no momento da propositura da demanda. $\mathrm{O}$ pedido formulado com amparo no art. 286, II do CPC pode vir a ser mais do que meramente ilíquido, pois pode basear-se em uma mera probabilidade de que virão outras consequências do ato contrárias à ordem normativa. Daí ser chamado de genérico. ${ }^{772} \mathrm{Na}$ escala de indeterminação, portanto, o

\footnotetext{
${ }^{769}$ Mas a lei admite a indeterminação quanto ao pedido imediato (e apenas em relação a este, adverte Barbosa Moreira) (cf. O novo processo..., p. 13). Assim também Fábio Luiz Gomes, Teoria geral..., p. 222.

${ }^{770} \mathrm{O}$ pedido certo é o que foi manifestamente deduzido, pois apenas excepcionalmente e nas hipóteses previstas em lei admite-se o chamado pedido implícito. Pedido certo, portanto, é o oposto de pedido tácito.

771 “A certeza supõe estar fora de dúvida o que se pede, no tocante à qualidade, quer no tocante à quantidade ou extensão" (cf. Pontes de Miranda, Comentários..., t. IV, p. 47)

${ }^{772}$ Cf. "A nova liquidação de sentença e suas velhas questões", in Cassio Scarpinella Bueno e Teresa Arruda Alvim Wambier (coords.), Aspectos polêmicos da nova execução, pp. 215/216. Para melhor entendimento do pensamento de Sica, confira-se a seguinte passagem: "Fiquemos, por enquanto, com a idéia de que o pedido que se enquadre no artigo 286, II, do CPC pode ser mais do que simplesmente ilíquido. À falta de uma designação melhor, podemos chamar o pedido que se encaixa no inciso II desse dispositivo de pedido
} 
pedido genérico está um grau acima do pedido ilíquido, porque este é indeterminado apenas quanto ao aspecto quantitativo, enquanto que aquele é indeterminado enquanto à própria ocorrência do fato gerador que o fundamenta. E mais. Embora predomine a ideia de que o rol do art. 286 do CPC é taxativo, ${ }^{773}$ há hipóteses outras em que se admite o pedido genérico ou ilíquido, como, por exemplo, o caso do pedido ilíquido de condenação ao pagamento de indenização por danos morais, ${ }^{774}$ que, embora não se enquadre em nenhum dos incisos do art. 286, é hoje admitido quase que unanimemente pela jurisprudência. ${ }^{775}$ Desde que o autor formule o pedido de forma expressa e delimite qual a tutela jurisdicional que pretende, deve ser admitido o pedido genérico.

O ideal, portanto, é que o autor da demanda anulatória de deliberação peça, já na petição inicial, a desconstituição também de todos os atos que dependam da deliberação impugnada, de modo que, sendo estes praticados anteriormente à prolação da sentença, sejam noticiados no processo e objeto de debate entre as partes e produção de prova. ${ }^{776}$

Pode ocorrer, todavia, que o autor não formule o pedido genérico na forma exposta. É possível que se aproveite o processo já instaurado e se inclua no objeto litigioso do processo a pretensão à invalidação dos atos dependentes? Parece-nos que sim.

Não há dúvida de que os atos sucessivos podem ser objeto de juízo impugnatório autônomo, isto é, de novas demandas anulatórias. Caso isso ocorra, as demandas devem ser reputadas conexas e tramitar conjuntamente (CPC, arts. 103/105 e 301, VII, $\S 4^{\circ}$ ). Se por essa via é admitido que se alcance o resultado almejado (desconstituição do ato superveniente), não há por que não se admitir que o mesmo resultado seja atingido pela via

genérico, pois recai sobre mera probabilidade de dano. O pedido, assim formulado, tem marcante característica 'generalizante', como fica claro nos dois exemplos acima enunciados ('eventuais tratamentos médicos futuros, até fim da convalescença' e 'eventuais danos sofridos no imóvel, a serem constatados depois de reintegrado o autor na sua posse')".

${ }^{773}$ Cf. Wellington Moreira Pimentel, Comentários..., p. 176; e Pontes de Miranda, Comentários..., t. IV, p. 53.

${ }^{774}$ Cf. Heitor Sica, “A nova liquidação...”, p. 216.

${ }^{775}$ Nesse sentido, v. STJ, REsp 401.704/PR, Rel. Honildo Amaral de Mello Castro, 4ª Turma, DJe 2/9/09; e REsp 486.022/SC, Rel. Castro Filho, $3^{\mathrm{a}}$ Turma, DJ 13/2/06.

776 Comentando o art. 286, II do CPC, Pontes de Miranda disse: "Tanto o autor como o réu, na fase probatória, é de esperar-se que faça a prova” (cf. Comentários..., t. IV, p. 49). 
transversa, isto é, pela posterior ampliação do objeto litigioso do processo. ${ }^{777}$ É possível, melhor explicando, que, flexibilizada a regra de estabilização da demanda, seja incluída no processo já em curso a pretensão à desconstituição desses atos, desde que disso não resulte prejuízo à marcha processual ou, pelo menos, um prejuízo que, globalmente analisado, seja maior do que remeter as partes para uma nova contenda judicial. Deve ser efetivado o contraditório e possibilitado à companhia que apresente manifestação em defesa do ato, bem como assegurada às partes a produção de prova.

Negar a possibilidade de inclusão do direito superveniente ${ }^{778}$ no objeto litigioso do processo, nas palavras de Ricardo de Barros Leonel, significa obrigar as partes a submeterem-se a um novo processo, com todas as consequências daí decorrentes, como incerteza, demora, custos etc. ${ }^{779}$ Permitir que elas resolvam, de uma vez por todas, toda a extensão da controvérsia decorrente daquele primeiro ato ilícito, que serviu de supedâneo jurídico para os demais atos, prestigia inclusive um dos escopos sociais do processo, qual seja, o de pacificação com justiça. Encerra-se a discussão em sua integralidade (o Estado não busca consenso a respeito de suas decisões, mas sim imunizá-las contra o ataque dos contrariados) e põe-se fim ao estado psicológico de incerteza e angústia. ${ }^{780}$

A posição ora defendida encontra amparo nos arts. 303, 462 e 517 do CPC, ${ }^{781}$ que, embora não permitam seja incluído pedido novo após o momento próprio, indicam

\footnotetext{
${ }^{777}$ Cf. Cássio Scarpinella Bueno, Curso..., v. 2, t. I, n. 7.8.2, pp. 133/134; e Ricardo de Barros Leonel, Causa de pedir..., n. 5.1.6, p. 246.

${ }^{778} \mathrm{O}$ conceito de direito superveniente adotado por Leonel não é apenas o do art. 303, I do CPC, pois conjuga fato e direito, ou, mais precisamente, "a sucessão temporal de efeitos jurídicos ocorridos no plano do direito substancial". Daí a ideia de eficácia jurídica, no sentido de que o fato e o direito só assumem relevância se conjugados (n. 2.2.3, pp. 116/117). Direito superveniente, contudo, é qualquer evento juridicamente qualificado que possa alterar a pretensão deduzida em juízo ou justificar uma nova pretensão, mas que guarde relação com a já proposta.

${ }^{779}$ Cf. Causa de pedir..., nn. 5.1.4 e 5.1.6, pp. 241 e 244.

${ }^{780}$ Sobre os escopos sociais, v. Dinamarco, A instrumentalidade..., n. 21, pp. 188/191.

781 Art. 303. Depois da contestação, só é lícito deduzir novas alegações quando:

I - relativas a direito superveniente;

II - competir ao juiz conhecer delas de ofício;

III - por expressa autorização legal, puderem ser formuladas em qualquer tempo e juízo.
}

Art. 462 Se, depois da propositura da ação, algum fato constitutivo, modificativo ou extintivo do direito influir no julgamento da lide, caberá ao juiz tomá-lo em consideração, de ofício ou a requerimento da parte, no momento de proferir a sentença. 
que o nosso direito processual civil quer que a sentença reflita, o máximo possível, a situação de fato vigente no momento em que prolatada. ${ }^{782}$ Outros exemplos disso são as disposições relativas às obrigações alimentares $(C C$, art. 1.699) e às prestações periódicas (CPC, art. 290).

Embora razões mais do que legítimas justifiquem as regras de correlação entre demanda e provimento, inércia da jurisdição e estabilização do objeto litigioso do processo, é igualmente legítimo que, respeitados os critérios acima destacados, sejam essas regras excepcionalmente mitigadas para que, assim, seja ofertada tutela jurisdicional mais adequada possível. E um dos predicados da adequação é o de que ela esteja atualizada de acordo com os desdobramentos do ato e solucione toda a crise jurídica dele decorrente.

Ao admitir a pretensão superveniente, o julgador deve alertar expressamente os demais sujeitos processuais, para que não haja dúvida e eles possam se manifestar e produzir prova. O respeito ao contraditório e a plenitude de informações são essenciais para que se cogite a hipótese ora defendida. Por outro lado, ela deve ser rejeitada quando resultar de má-fé da parte, que, portanto, deve justificar o pedido de introdução da pretensão superveniente. Deduzido esse pedido, o julgador deve fazer um juízo a respeito do proveito da sua admissão. Se da inovação advier tumulto processual ou necessidade de ampla e complexa instrução probatória, o demandante dever ser remetido para demanda ulterior, ${ }^{783}$ pois os prejuízos serão superiores aos benefícios. A exceção, por isso, não se justifica.

A via ora defendida só será possível se a pretensão de desconstituição do ato subsequente tiver como um de seus fundamentos a relação de dependência com a deliberação sub judice. Se o acionista quer impugnar o ato subsequente unicamente por outro vício, isto é, por outra causa de pedir, não é caso de aproveitamento do processo em curso. Portanto, àquele acionista resta unicamente valer-se de um juízo impugnatório

Art. 517. As questões de fato, não propostas no juízo inferior, poderão ser suscitadas na apelação, se a parte provar que deixou de fazê-lo por motivo de força maior.

${ }^{782}$ E, de fato, como aponta Heitor Sica, "apesar de alguma controvérsia, pode-se dizer que o artigo 462 do CPC dá margem à alteração das causae petendi e excipiendi, pois obriga o juiz, de ofício ou a requerimento, considerar fatos constitutivos, extintivos, modificativos ou impeditivos do direito do autor supervenientes aos momentos em que deveriam ter sido alegados (petição inicial e contestação, conforme artigos 282 e 300 , CPC, respectivamente)" (cf. “A nova liquidação...”, p. 215).

${ }^{783}$ Cf. Ricardo de Barros Leonel, Causa de pedir..., n. 5.1.6, p. 249. 
autônomo. Também não pode ser admitido que, tendo sido a demanda inicial ajuizada pelo Acionista A, seja incluída no processo a pretensão desconstitutiva sobre o ato subsequente formulado pelo Acionista B. Nessa hipótese, também, só resta a recondução do Acionista B a um juízo impugnatório autônomo.

\section{Efeito inibitório?}

O julgado que tem como objeto a desconstituição de uma deliberação é peculiar porque, estruturalmente, distancia-se do esquema de invalidação de um ato jurídico “ordinário". Lá, no centro do processo anulatório, ao invés de uma relação jurídica bilateral para cuja formação é necessária a convergência de vontades de todos os que ficarão obrigados, há um ato de exercício de poder, pelo qual um sujeito - a sociedade, por meio da maioria - tem o poder de influenciar unilateralmente a esfera jurídica dos seus acionistas, inclusive ausentes ou dissidentes. ${ }^{784}$ Desconstituída a relação negocial, o seu conteúdo não poderá ser repetido, a menos que todos os sujeitos envolvidos assim desejem. Com a deliberação, passa-se de forma diversa: desconstituída, ela pode ser renovada unilateralmente, uma vez que se trata de ato colegial regido pelo princípio majoritário. A assembleia geral, assim, detém o poder de intervir na esfera do acionista, mesmo contrariamente à sua vontade.

É correto, contudo, que sob a perspectiva da tutela do direito do acionista vitorioso em demanda impugnatória precedente ele fique desprotegido da emissão de atos de conteúdo idêntico, à mercê da vontade do colégio de sócios? Será ele obrigado a propor tantas demandas quantas forem necessárias, à medida que forem sendo renovadas deliberações de mesmo conteúdo? Surge, nesse contexto, a questão de se é legítimo e, mais ainda, possível que se extraia da sentença que desconstitui a deliberação uma eficácia inibitória de emissão de deliberação futura com conteúdo idêntico, de modo que se evite o que, em feliz conceituação - embora dada em outro contexto -, Marcelo von Adamek disse ser uma vitória de Pirro. ${ }^{785}$

\footnotetext{
${ }^{784}$ Cf. Stefano Villata, Impugnazioni..., p. 267.

${ }^{785}$ Cf. “Ação de acertamento...”, n. 35.3, p. 519.
} 
É verdade que o acionista pode ser amparado pela tutela inibitória. Se ao pedido desconstitutivo for cumulado pedido inibitório - de natureza condenatória -, nem surge o problema levantado. A questão proposta, contudo, é outra: caso o autor da demanda não formule pleito dessa natureza e o provimento nada disponha nesse sentido - pois aí o problema seria de violação à regra de correlação -, é possível extrair da sentença tal eficácia proibitiva? ${ }^{786}$

Conforme Stefano Villata, quando desconstitui uma deliberação viciada, o julgador declara a sua ilegitimidade e, no momento seguinte, pronuncia a sua desconstituição e também a dos seus efeitos, atividade que seria o acertamento de uma situação objetiva, não subjetiva. O processo de anulação de uma deliberação, continua o autor, gira em torno da questão objetiva da legitimidade da deliberação - isto é, seria uma qualificação normativa do ato, e, como decorrência disso, adviria uma ulterior função do provimento: prevenir futuras violações à regra jurídica declarada no processo. O julgado fixaria a regra jurídica reguladora daquela situação e projetaria a eficácia do acertamento para condutas futuras. O objeto litigioso do processo, assim, não se limitaria à eliminação da deliberação impugnada, mas diria respeito também à declaração da regra jurídica que emerge do provimento. ${ }^{787}$ É como se a desconstituição fosse apenas um reflexo indireto da sentença, cujo objeto principal seria a declaração da norma concreta, que, por sua vez, vincularia as partes pro futuro.

A sentença, nessa medida, não se limitaria a caducar o ato jurídico impugnado, mas conteria uma certificação in futuro, que deveria servir de guia para a organização societária nas atividades sucessivas. Trata-se de certificação limitada, dada a esfera de liberdade de empresa que o julgador não deve invadir. Este não pode interferir na decisão societária e delimitar como a sociedade deverá se comportar após aquele momento, mas poderá restringir a sua liberdade de atuação, qualificando determinados comportamentos como ilegítimos, ${ }^{788}$ isto é, proibindo certas condutas já objeto de sanção.

\footnotetext{
786 Luigi Montesano defende análoga extensão dos limites objetivos da coisa julgada. Admite ele certa operatividade da sentença para o futuro, de modo que a sentença abarque também comportamentos que, idênticos ao já julgado, se reproduzam no decorrer da mesma relação jurídica (cf. Montesano, "Limiti oggetivi di giudicati su negozi”, Rivista di diritto processuale, v. 46, n. 1, p. 25).

${ }^{787}$ Cf. Stefano Villata, Impugnazioni..., cap. III, n. 12 e 15, pp. 418, 420 e 436.

${ }^{788}$ Cf. Stefano Villata, Impugnazioni..., cap. III, n. 15, pp. 442/443.
} 
Parte da doutrina italiana, com efeito, alude a uma eficácia ultraconstitutiva da sentença que se pronuncia sobre um ato administrativo ou uma deliberação inválida, sustentando que o centro do processo de impugnação não é o ato em particular, ou seus efeitos, mas sim a relação jurídica controversa. Como nesses setores o ato é o reflexo de um poder que depois do processo pode ser exercitado novamente, também o processo deve seguir esse fluxo e, assim, colocar-se como um momento intermediário entre o exercício passado do poder (do qual resultou o ato inválido) e o exercício futuro. Por isso, continua essa doutrina, não deve ser reconhecido à sentença apenas o efeito de remover o ato e seus efeitos, mas também eficácia que impeça a emissão de ato de idêntico conteúdo. ${ }^{789}$

Por essa razão é que no direito administrativo - e, por analogia, no âmbito das deliberações inválidas - essa mesma doutrina defende que a sentença não se limita a eliminar o ato, mas fixa também a maneira correta de exercício do poder. Procura-se, assim, assegurar a estabilidade do provimento por meio do alargamento do objeto litigioso do processo a matérias transcendentes ao ato impugnado, estendendo-o ao próprio modo de exercício do poder que gerou o ato inválido. A decisão deixa de ser episódica para assumir um caráter geral, de conformação da maneira pela qual deve ser exercitado o poder. Sempre que houver exercício de poder, ainda que privado, deve, de acordo com essa tese, ser reconhecida à sentença de mérito a idoneidade de impor às partes uma norma que regule a relação entre elas. A tutela jurisdicional prestada na anulação de um ato de poder, assim, assumiria não apenas função cassatória, mas também certificadora do modo de exercício do poder. $^{790}$

Stefano Villata diz que, deixando de lado a discussão sobre o objeto litigioso do processo, existe certa unanimidade em atribuir-se ao julgado administrativo uma eficácia conformativa sobre os sucessivos provimentos administrativos. O juiz não se limitaria a eliminar o ato impugnado, mas, ao declarar o conteúdo pelo qual o ato deve ser legitimamente exercido, acaba por determinar a correta modalidade de expressão da vontade estatal. O processo administrativo, portanto, possuiria a função normativa de estabelecer uma regra de comportamento para a Administração. ${ }^{791}$ Por isso, o objeto do processo administrativo seria a questão de legitimidade/ilegitimidade do ato

\footnotetext{
${ }^{789}$ Sobre isso, v. Ilaria Pagni, Le azioni..., pp. 606/611.

${ }^{790}$ Cf. Bruno Sassani, Impugnativa ..., cap. IV, n. 1, pp. 151/152; e Ilaria Pagni, Le azioni..., p. 616.

${ }^{791}$ Cf. Impugnazioni di delibere..., cap. III, n. 10, pp. 350/351
} 
administrativo, ou seja, a qualificação normativa de um comportamento. De tal maneira que, em caso de reiteração do ato com o mesmo conteúdo e o mesmo vício, a autoridade judiciária, atendendo aos reclamos de nova demanda instaurada, deverá confrontar o ato com a regola iuris individuada na sentença precedente. ${ }^{792}$

Disso decorreria um verdadeiro efeito inibitório/normativo. Como ocorre no processo administrativo, a sentença que desconstitui uma deliberação assemblear constitui um momento intermediário entre dois atos de exercício de um mesmo poder. Após a extinção de situação jurídica promovida pela sentença, a sociedade deverá, por um lado, adequar-se à nova situação constituída pela sentença e, por outro, manter-se fiel ao quanto estatuído na sentença, caso vá realizar nova manifestação de vontade sobre o assunto. ${ }^{793} \mathrm{E}$, de fato, também Giorgio Meo afirmou que a sentença que desconstitui uma deliberação constitui um vínculo para que a organização societária aja conforme ao julgado, de modo que não se quede inerte ou perpetue a ilegitimidade, neutralizando, dessa forma, o que foi disposto na decisão. ${ }^{794}$

Por essa razão é que, quando for desconstituída uma deliberação "necessária", como a de nomeação de administradores ou aprovação das demonstrações financeiras, surgiria o dever da sociedade - advindo das regras do direito material - de realizar uma nova manifestação que supra a lacuna criada pela decisão. Mas ao preencher essa lacuna a sociedade deverá, diz Giorgio Meo, comportar-se de acordo com a regra jurídica emanada da decisão. ${ }^{795}$ Villata vai ainda além: para ele, se houver a reiteração de deliberação com conteúdo idêntico, essa será inválida, porque contrastante com a regra jurídica reconhecida pela sentença. Apenas um fato superveniente ao julgado poderá superar essa relação de prejuízo. $^{796} \mathrm{O}$ provimento de desconstituição de deliberação possuiria, assim, um

\footnotetext{
${ }^{792}$ Cf. Impugnazioni di delibere..., cap. III, n. 8, pp. 353/355.

793 "In questa riedizione del potere assembleare la società non si troverà libera, come invece si trovava nel momento dell'emanazione della prima deliberazione, ma dovrà attenersi al capo di accertamento contenuto nelle sentenze di invalidazione" (cf. Stefano Villata, Impugnazioni..., cap. III, n. 15, p. 441).

${ }^{794}$ Cf. Invalidità ..., cap, IV, n. 5, pp. 244/246. Referido efeito é assim explicado pelo autor: "Il problema degli effetti dell'invalidità della delibera accertata con sentenza definitiva, pertanto, consiste nell'individuazione dell'incidenza esercitata dal giudicato sulla conduzione dei processi deliberativi ed attuativi degli organi competenti. Esso è in altri termini - com'è stato felicimente intuito - problema dei vincoli che in forza della sentença si rifflettono sulla sfera di liberta dell'ordinamento particolare a schegliere il contenuto dei propi atti".

${ }^{795}$ Cf. Giorgio Meo, Invalidità..., cap. IV, n. 6, p. 254. V., também, Stefano Villata, Impugnazioni..., cap. III, n. 15 , p. 444.

${ }^{796}$ Cf. Stefano Villata, Impugnazioni..., cap. III, n. 15, pp. 444/445.
} 
verdadeiro acertamento de uma situação jurídica que se projetaria não só sobre a atividade sucessiva da sociedade, mas também sobre eventual processo a respeito de tal atividade. ${ }^{797}$

Embora sem fazer associação com a doutrina ora analisada, Eduardo Talamini alude, no âmbito do controle concentrado de constitucionalidade, a uma eficácia anexa da decisão, que imporia a órgãos estatais o dever de cumprir o comando declaratório nela contido, no qual se pode antever até mesmo certo grau de força mandamental, no sentido que, se o comando não for observado, haverá desrespeito à autoridade do órgão jurisdicional. A qualificação anexa derivaria do fato de que não é preciso a decisão expressamente afirmar a sua força vinculante para que deva ser observada; a própria norma legal é que atribuiria tal eficácia à decisão (sentença como fato jurídico). ${ }^{798}$

Assim exposta a doutrina que tratou do tema, cabe-nos tecer nossas observações. De fato, a extensão dos limites objetivos do julgado a futuras e eventuais deliberações de conteúdo idêntico ao da já desconstituída poderia trazer bons frutos práticos, especialmente sob o ângulo da efetividade da tutela prestada a quem pediu e foi atendido com a anulação pregressa. ${ }^{799}$ Mas, por outro lado, é difícil de ser aceita em nosso ordenamento, regido não só pela regra de correlação entre demanda e provimento, como também pela limitação da coisa julgada ao que foi expressamente estabelecido no dispositivo sentencial, como visto anteriormente.

Cremos, por isso, que o direito brasileiro não admite citada eficácia inibitória. Quando se pleiteia e é concedida a desconstituição de uma deliberação, o provimento terá apenas o efeito de invalidar a deliberação e seus efeitos. Não é possível sustentar, portanto, que o julgado oriente a conduta da sociedade em momentos posteriores ou mesmo fulmine deliberações que conflitem com a regra concreta anteriormente emanada, como faz parte da doutrina analisada.

Poder-se-ia objetar que a construção doutrinária acima exposta, e que ora combatemos, deveria ser admitida, sob o argumento de que, se a tutela constitutiva envolve a declaração da regra jurídica concreta, o objeto de um processo constitutivo já conteria a

\footnotetext{
${ }^{797}$ Cf. Stefano Villata, Impugnazioni..., cap. III, n. 15, p. 445.

${ }^{798}$ Cf. Novos aspectos da jurisdição..., n. 3.1.4, pp. 88/89.

${ }^{799}$ Cf. Stefano Villata, Impugnazioni..., p. 4.
} 
declaração dessa regra concreta. Todavia, para que haja referida eficácia inibitória não basta declaração; exige-se, na verdade, a imposição de uma ordem. É necessária decisão condenatória, ou, para os que a admitem, mandamental. Pelo menos no direito brasileiro, parece-nos que somente assim se poderá cogitar de referido efeito inibitório.

$\mathrm{E}$, de forma análoga ao que fizemos no item 17.2.3.4, quando negamos que nos limites objetivos da sentença haja um efeito expansivo que desconstitua atos conexos, também aqui é necessário, para que não se cogite de que nossa posição é deveras restritiva, indicar alternativas que o sistema propõe a quem quer ser protegido de futuras e idênticas violações cometidas pela sociedade. $\mathrm{E}$, aqui, a resposta é similar à que demos naquele terreno: basta que o autor formule pedido nesse sentido. Desde que este seja fundamentado e não viole a liberdade de iniciativa da sociedade, ele poderá ser acolhido, impedindo-se, assim, que a sociedade volte a violentar a esfera jurídica de quem já teve reconhecida a seu favor a ilicitude de tal conduta.

\section{Fato superveniente: confirmação, renovação e revogação da deliberação}

De acordo com o art. 462 do CPC, "se, depois da propositura da ação, algum fato constitutivo, modificativo ou extintivo do direito influir no julgamento da lide, caberá ao juiz tomá-lo em consideração, de ofício ou a requerimento da parte, no momento de proferir a sentença". É dever do juiz, portanto, a qualquer momento do processo levar em consideração o fato superveniente que possa influir no julgamento da controvérsia. Cabe estabelecer, assim, quais consequências a revogação, a confirmação e a renovação da deliberação geram no processo já em curso.

A revogação é ato praticado pela própria companhia e importa na extinção do ato e dos seus efeitos, com eficácia retroativa. Por consequência, não haverá mais interesse na desconstituição do ato e, se ao pedido anulatório não foi cumulado nenhum outro pleito, o processo deve ser extinto por perda superveniente do interesse processual (CPC, art. 267, IV).

Já a confirmação (também chamada de ratificação) é ato praticado pelos titulares do direito de impugnação e equivale à renúncia a tal direito. Ela importa na convalidação 
retroativa do ato anterior, que passa a existir sem o vício que o inquinava. A fonte de efeitos jurídicos é, portanto, o ato confirmado. ${ }^{800}$

No direito civil, vigora a regra de que apenas o ato anulável é sanável. Esse pode ser confirmado, não o nulo. Nesse sentido é que o art. 148 do CC/16 dispunha que "o ato anulável pode ser ratificado pelas partes, salvo direito de terceiro", e que os arts. 169 e 172 do CC/02 determinam, respectivamente, que "o negócio jurídico nulo não é suscetível de confirmação, nem convalesce pelo decurso do tempo" e "o negócio anulável pode ser confirmado pelas partes, salvo direito de terceiro". E, continua a lei, "a confirmação expressa, ou a execução voluntária de negócio anulável, nos termos dos arts. 172 a 174, importa a extinção de todas as ações, ou exceções, de que contra ele dispusesse o devedor" (CC, art. 175). No direito civil, portanto, apenas os atos anuláveis podem ser sanados por confirmação.

No direito societário, a doutrina concorda que a confirmação da deliberação anulável é possível e que esta retroage à data em que foi tomada a deliberação. Assim, caso haja confirmação por todos os legitimados, ou pelo menos pelo autor da demanda, o processo também deverá ser extinto por perda superveniente do interesse processual (CPC, art. 267, IV). A confirmação terá efeitos ex tunc, mormente porque, como visto, os atos anuláveis produzem efeitos (precários) até que haja proclamação judicial. ${ }^{801}$

Há, contudo, divergência a respeito da possibilidade de ser ratificada a deliberação nula. Parte da doutrina entende que não é possível a retificação ou confirmação da deliberação nula, ${ }^{802}$ mas apenas a renovação. ${ }^{803}$ Outros sustentam a ampla possibilidade de confirmação, sob o fundamento de que um dos aspectos onde o regime de invalidades do direito societário distancia-se do regime do direito civil é justamente a possibilidade de

${ }^{800}$ Cf. Carneiro da Frada, Renovação de deliberações..., nn. 2.1/2.3, pp. 8/14; Orlando Gomes, Introdução..., n. 283, p. 479; e Álvaro Villaça Azevedo, Código Civil..., pp. 312/313.

${ }^{801}$ Cf. Ricardo Tepedino, Direito das companhias, v. I, n. 261, p. 988. E, conforme ensina Carneiro da Frada, também no direito português a renovação e confirmação do ato impugnado geram a perda superveniente do direito do autor, de acordo com o art. $663 .^{\circ}$ do Código de Processo Civil daquele país (cf. Renovação de deliberações..., n. 2.3, p. 12).

${ }^{802}$ Embora a confusa redação não permita concluir com segurança, essa parece ser a posição de Pontes de Miranda, Tratado de direito privado, t. LI, n. 5.359, pp. 106/107. No mesmo sentido Ricardo Tepedino, que diz haver apenas uma exceção: no caso de assembleia não convocada, se posterior conclave regularmente realizado renovar a deliberação, esta terá efeito ex nunc, mas poderá ter efeito ex tunc se houver aprovação unânime (cf. Direito das companhias, v. I, n. 261, p. 988).

${ }^{803}$ Cf. Carneiro da Frada, Renovação de deliberações..., n. 2.3, p. 11. 
naquele serem sanados os vícios do ato (princípio da convalidação). Em reforço, essa mesma doutrina invoca a aplicação do parágrafo do art. 285 da LSA a todas as assembleias da companhia, e não só as de constituição. Referido artigo estabelece que, em caso de vício de constituição da companhia, "ainda depois de proposta a ação, é lícito à companhia, por deliberação da assembléia-geral, providenciar para que seja sanado o vício ou defeito". A companhia poderia, portanto, a qualquer momento até o trânsito em julgado, retificar, ratificar (confirmar) ou revogar a deliberação, com eficácia retroativa à data da deliberação. ${ }^{804}$

E, de fato, parece-nos que não há empecilho para que as deliberações nulas sejam confirmadas. O óbice, porém, decorre de outro aspecto: ela exige a concordância de todos os legitimados à invalidação do ato e, em se tratando de nulidade, isso será, no mais das vezes, muito difícil de ser obtido, para não dizer impossível. Por isso, para além dessa discussão sobre poder ou não ser confirmada a deliberação nula, trata-se de instituto de pouca utilidade prática no âmbito das deliberações, uma vez que exige a concordância de todos os titulares do direito à impugnação. ${ }^{805}$

Por fim, a renovação consiste em tomar uma nova deliberação, de conteúdo idêntico ao da anterior, mas suprida a irregularidade. O ato é constituído ex novo, como se não tivesse existido o anterior, e os efeitos são imputados ao ato renovatório. A mesma discussão existe aqui a respeito da possibilidade de ser renovada deliberação nula. Mas, também aqui, um olhar mais atento demonstra que essa discussão possui valor prático menor do que se pensa.

A renovação só será efetiva se a nova deliberação não estiver inquinada pelo mesmo vício da deliberação renovada. Diante disso, fica logo descartada a renovação de deliberações que apresentem vícios de conteúdo, pois se a segunda não contiver o mesmo conteúdo da primeira, não será caso de renovação, mas sim de emissão de ato distinto. ${ }^{806} \mathrm{~A}$

\footnotetext{
${ }^{804}$ Cf. Trajano de Miranda Valverde, Sociedades por ações, v. III, n. 832, pp. 115/116; Lamy Filho, "Mudança do objeto...", pp. 545/546; e Nelson Eizirik, A Lei das S/A..., v. II, pp. 582 e 591/593.

${ }^{805}$ Cf. Carneiro da Frada, Renovação de deliberações..., n. 2.3, p. 13.

${ }^{806}$ Cf. Menezes Cordeiro, Direito das sociedades, v. I, n. 297, p. 813: "há uma lógica subjacente irrecusável: uma verdadeira 'renovação', postula que a segunda deliberação tenha um conteúdo idêntico ao da primeira, sob pena de lidarmos com algo de distinto, que se suceda no tempo. Ora, um conteúdo idêntico e sem vícios só será compaginável com problemas de ordem formal".
} 
renovação, assim, fica limitada aos vícios no procedimento assemblear (inclusive atinentes a quórum de votação), que, como visto, geram a anulabilidade (v. item 7.2). Portanto, a única hipótese em que cabe a renovação é, salvo reflexão mais amadurecida, a de vício no procedimento assemblear, que gera a anulabilidade, sendo irrelevante a discussão sobre a possibilidade de renovação de deliberação nula.

A renovação, além disso, importa na criação de uma nova deliberação, que é a fonte emanadora de efeitos. Ela não sana, a rigor, a deliberação anterior. Ela possui eficácia pro futuro $^{807} \mathrm{e}$, por isso, não acarreta a perda de interesse processual superveniente.

Em todos os casos em que houver extinção do processo por perda do interesse processual em razão de fato superveniente, o ônus de arcar com as despesas processuais e os honorários advocatícios é, pela regra de causalidade, de quem deu causa ao ajuizamento da demanda. Referido ônus, portanto, devem ser firmados com abstração do fato superveniente. $^{808}$

\section{Causa de pedir nas demandas declaratórias positivas, negativas e desconstitutivas}

Um último assunto que deve ser analisado neste capítulo diz com as diferentes funções que a causa de pedir desempenha nas demandas "positivas" (meramente declaratória ou condenatória) e nas ações "negativas" (desconstitutivas e declaratórias negativas).

Quando se pleiteia a declaração de existência de um direito, no fundamento do pedido estão incluídos todos os fatos que possam levar à inexistência, extinção, modificação ou impedimento de referido direito. A causa de pedir é abrangente na medida em que o julgamento de procedência pressupõe que não há qualquer motivo que obste a plena eficácia jurídica do ato.

\footnotetext{
${ }^{807}$ De acordo com Carneiro da Frada, essa é a regra geral, embora ele reconheça que, por expressa disposição da lei portuguesa (Código das Sociedades Comerciais, art. $62 .^{\circ}, \mathrm{n}^{\circ} 1^{\circ}$ ), existe a possibilidade de atribuição de eficácia retroativa à renovação, dentro de certos limites (cf. Renovação de deliberações..., n. 6.4, p. 28).

${ }^{808}$ Cf. Cássio Scarpinella Bueno, Curso sistematizado..., v. 2, t. I, p. 367.
} 
Nas demandas "negativas", por outro lado, a causa de pedir está adstrita ao fato invocado como fundamento da pretensão de ver reconhecida a inexistência, invalidade ou ineficácia da situação jurídica impugnada. ${ }^{809}$ Se rejeitada a pretensão, nada impede que o mesmo autor ajuíze nova demanda, fundamentada em vício distinto. Por essa razão, aliás, Montesano diz que na anulação de negócio jurídico os limite objetivos da sentença e da coisa julgada são restritos à causa de nulidade alegada. ${ }^{810}$

Nessa medida, sendo ajuizada demanda declaratória de validade de uma deliberação, a causa de pedir abrange todos os fundamentos fático-jurídicos que conduzem à validade do ato e, por isso, é ônus da ré deduzir todas as defesas cabíveis, sob pena de não poder fazê-lo posteriormente (CPC, arts. 300, 303 e 474). Já na demanda de impugnação, cada fundamento constitui uma causa de pedir autônoma e, assim, não tendo sido invocado determinado vício em uma dada demanda, ele poderá justificar uma segunda, sem que se cogite de litispendência ou coisa julgada. ${ }^{811}$

\footnotetext{
${ }^{809}$ Tudo o que acaba de ser dito foi colhido na obra de Eduardo Talamini (cf. "Legitimidade, interesse...", p. 151; e Coisa julgada..., n. 2.3.1, pp. 75/76).

${ }^{810}$ Cf. "Limiti oggettivi di giudicati su negozi invalidi", Rivista di diritto processuale, v. 46, n. 1, p. 44.

${ }^{811}$ Novamente, cf. Eduardo Talamini, "Legitimidade e interesse...", p. 151; e Coisa julgada..., n. 2.3.1, pp. 75/76. V., ainda, Chiovenda, Instituições..., v. 1, n. 111, pp. 362/364.
} 


\section{CAPÍtulo V - Limites SUbJETIVOS DO PROVIMENTO E DA COISA JULGADA}

\section{Correlação entre demanda e provimento e eficácia natural do provimento: efeitos diretos e efeitos reflexos}

O julgador está adstrito não só aos elementos objetivos da demanda (pedido e causa de pedir), mas também ao seu elemento subjetivo (partes): ele deve proferir a sentença unicamente em relação às pessoas delimitadas na petição inicial, sob pena de a sentença ser ultra ou extra petita. Assim como o alcance objetivo do provimento de mérito, também o subjetivo obedece à regra de correlação entre demanda e provimento. ${ }^{812}$ Caso seja proferida sentença em face de sujeitos que não são partes, terá sido exercida jurisdição de ofício, com violação aos arts. 128 e 460 do CPC, que positivam a máxima ne eat judex ultra vel extra petita partium (não vá o juiz além ou fora dos pedidos das partes ${ }^{813}$ ). Haverá igualmente violação da regra da demanda ou da inércia da jurisdição, positivada nos arts. $2^{\circ}$ e 262 do CPC, que representam a máxima do nemo judex sine actore (ninguém é juiz sem um autor).

Também em relação à amplitude subjetiva da sentença, portanto, o eixo lógico existente entre provimento e sentença só assume relevância por conta da regra de correlação. Se ao juiz fosse dado proferir sentença desconsiderando os lindes subjetivos colocados pelas partes, não haveria tal relação lógica.

Ao dispor que "a sentença faz coisa julgada às partes entre às quais é dada, não beneficiando, nem prejudicando terceiros", o art. 472 do CPC positiva a chamada regra da relatividade da coisa julgada ${ }^{814} \mathrm{e}$, assim, determina que o comando que emerge da sentença imutabilize-se apenas entre as partes que integraram a relação jurídico-processual. A regra é um desdobramento das garantias constitucionais do devido processo legal, da

\footnotetext{
${ }^{812}$ Ainda que também neste terreno existam fenômenos ampliativos (p. ex.: reconvenção, denunciação da lide, oposição, intervenção litisconsorcial voluntária, chamamento ao processo etc.) e restritivos (p. ex.: dissolução parcial do litisconsórcio) que acabam por temperar essa regra.

${ }^{813}$ Cf. Dinamarco, Vocabulário..., p. 370.

${ }^{814}$ Que nada tem a ver com a chamada relativização da coisa julgada.
} 
ampla defesa e, sobretudo, do contraditório, pois, se somente os sujeitos processuais é que cooperaram no procedimento - e, logo, apenas eles puderam influir na formação da decisão que dali emergiu, exercendo os poderes, faculdades, ônus, deveres e sujeições próprios das partes -, também somente a eles é que pode ser imposta decisão com contornos de definitividade. ${ }^{815}$ Em razão dessa conformação sócio-política do instituto, aliás, é que Carpi escreveu que a limitação subjetiva da coisa julgada varia de acordo com as características do sistema constitucional de cada país. ${ }^{816}$

Mas essa regra possui um segundo fundamento: os próprios efeitos da sentença produzem-se em princípio apenas entre as partes do processo, na medida em que, no mais das vezes, todos os interessados diretos no litígio integram o processo: em regra, a sentença será juridicamente irrelevante para terceiros. ${ }^{817}$ Por isso, na premissa de que todos os que possuem interesse imediato no litígio demandaram ou foram demandados, ${ }^{818}$ a sentença produzirá efeitos apenas entre eles. O confinamento dos efeitos do provimento às partes do processo ocorre, logo, não só por conta das limitações constitucionais expostas de início,

\footnotetext{
${ }^{815}$ Cf. Ada Pellegrini Grinover, $O$ processo em sua unidade, v. II, pp. 60/61 e "Coisa julgada erga omnes, secundum eventum litis e secundum eventum probationem", RePro, n. 126, p. 17; Liebman, "A autoridade da coisa julgada...”, n. 25, p. 80; Rogério Lauria Tucci e José Rogério Cruz e Tucci, Constituição de 1988 e processo, p. 60; José Rogério Cruz e Tucci, Limites subjetivos..., n.4, p. 39; Dinamarco, Instituições..., v. III, n. 963, p. 315 e Litisconsórcio, n. 14, p. 53; Eduardo Talamini, Coisa julgada..., n. 2.5, p. 96; Monteleone, I limiti..., nn. 13/14, pp. 146/163; Comoglio-Ferri-Taruffo, Lezioni..., cap. 26, n. 6, p. 765; Shönke, Derecho procesal..., n. 77, p. 277; Andrés de la Oliva Santos, Objeto del processo..., p. 183; e Giovanni Verdi, Profili del processo civile, v. 2, cap. 9, n. 6, p. 340.

${ }^{816}$ Cf. L' efficacia..., n. 1, p. 6, nota 8.

${ }^{817}$ Cf. Dinamarco, Instituições..., v. III, n. 963, pp. 315/316: "Como a sentença e seus efeitos têm sempre referência a determinado bem da vida, ordinariamente a decisão só atinge os titulares de direitos, obrigações ou mesmo meras pretensões que incidam sobre esse bem. Se sou condenado a entregar determinado bem a determinada pessoa, meu vizinho não está vinculado pela autoridade da coisa julgada, que incidir sobre essa sentença, não somente porque a lei diz que não, mas antes disso porque a decisão não lhe diz respeito e portanto lhe é juridicamente indiferente. Os terceiros absolutamente indiferentes, que compõem um número infinito de pessoas, praticamente toda a população do globo terrestre, não são autorizados a repor em discussão os efeitos da sentença proferida inter alios, não porque a coisa julgada os atinja, mas porque sua vida não fica afetada por eles; e, consequentemente, no plano do direito matéria falta-lhes legitimidade $a d$ causam. Antes de ser vedada por motivos político-constitucionais, portanto, a eficácia erga omnes da coisa julgada material é excluída pelo próprio objeto da sentença de mérito e pelas regras relativas à titularidade do direito material".

${ }^{818}$ A legitimação para agir corresponde à pertinência subjetiva da ação, ou seja, identidade entre quem propôs a demanda e quem detém, no plano do direito material, o direito que afirma ter sido lesado. Nesse sentido, Egas Moniz de Aragão conceitua que, "em regra geral, portanto, 'parte' no processo é precisamente quem já o era na relação material ou situação litigiosa, que através do processo será submetida ao julgamento do magistrado" (cf. Sentença e coisa julgada ..., n. 207, p. 291).
} 
mas também como decorrência da irrelevância que a decisão ostenta para os terceiros. Isto é, em razão do próprio objeto litigioso do processo. ${ }^{819}$

Mas, novamente, as coisas não são tão simples assim. Como qualquer fato jurídico, a sentença ingressa no mundo do direito e produz seus efeitos indistintamente. Enquanto ato estatal imperativo que é, ela é dotada do que Liebman chamou de eficácia natural e, assim, pode atingir a esfera jurídica de quem não foi parte no processo em que proferida. ${ }^{820}$ Daí falar a doutrina em efeitos reflexos ou indiretos da sentença, ${ }^{821} \mathrm{em}$ oposição aos efeitos diretos: estes são sofridos apenas pelas partes, aqueles afetam também quem não ostentou tal condição. É por isso, aliás, que Allorio, ao defender a célebre posição de que os limites subjetivos da coisa julgada nada mais são do que os seus limites objetivos, disse que a sentença regula diretamente apenas a relação jurídica mantida entre as partes. Perante essas, no mais das vezes ela possui uma eficácia direta (efeitos precípuos da sentença); perante terceiros, uma eficácia reflexa (efeitos não precípuos). ${ }^{822}$

Essa é, de certa forma e guardadas as devidas proporções, a mesma discussão que entre os civilistas se colhe a respeito da chamada regra de relatividade dos contratos. Por ela, o contrato faz lei entre as partes contratuais e, assim, seus efeitos produzem-se apenas entre estas, isto é, não beneficiam nem prejudicam terceiros, pois não podem ser impostos efeitos obrigacionais aos que não participaram da criação do vínculo obrigacional. ${ }^{823} \mathrm{~A}$ própria doutrina, contudo, ressalva que, enquanto fato social que são, os contratos acabam

\footnotetext{
${ }^{819}$ Por esse motivo é que Betti afirmou que a secular regra de relatividade da coisa julgada significa que a sentença é juridicamente irrelevante para terceiros, pois embora em seu confronto produzam-se certos efeitos jurídicos que lhe são próprios, não se produzem outros efeitos produzidos para as partes (cf. Trattato..., cap. I, n. 2, pp. 8/9).

${ }^{820}$ Cf. Liebman, "Eficácia e autoridade...", n. 34, pp. 123/125; e Ovídio Baptista da Silva, "Eficácias da sentença...", nn. 6 e 8, pp. 104/108 e 114.

${ }^{821}$ Que, conforme Dinamarco, surgem "como consequência natural da vida em sociedade e dos intrincados modos com o as pessoas e as próprias relações jurídicas interagem e reciprocamente interferem uma nas outras" (cf. Intervenção de terceiros, n. 2, p. 15; v., ainda, Instituições... n. 963, p. 316). Sobre o assunto, v. Mandrioli, Diritto processuale..., v. II, n. 85, p. 573; Moacyr Amaral Santos, Comentários..., v. IV, n. 368, pp. 488/489; e as críticas de Liebman, "Eficácia e autoridade...", n. 27, pp. 84/86. Para Ovídio Baptista da Silva, o efeito reflexo da sentença "só ocorre nos casos de colidência entre relações jurídicas conexas" (cf. "Eficácias da sentença...", n. 7, p. 112).

${ }^{822}$ Cf. La cosa.., nn. 29 e 66, pp. 64/65 e 114; Comoglio-Ferri-Taruffo, Lezioni..., cap. 26, n. 6, p. 764; e Carpi, L'efficacia..., n. 56, p. 262.

${ }^{823}$ Cf. Orlando Gomes, Contratos, p. 43. Sobre o paralelo existente entre a regra de relatividade dos contratos e a de relatividade da coisa julgada, v. José Rogério Cruz e Tucci, Limites subjetivos..., n. 4, p. 40, especialmente nota 29.
} 
por produzir efeitos perante terceiros, ${ }^{824}$ que não podem ignorar a sua existência e comportarem-se alheios a eles. ${ }^{825}$

A sentença, portanto, possui eficácia subjetivamente irrestrita, o que equivale a dizer que pode produzir efeitos na esfera jurídica de todos os sujeitos da ordem jurídica, inclusive terceiros. ${ }^{826-827}$ Tais efeitos, porém, só serão relevantes para o terceiro caso este relacione-se com o litígio, isto é, desde que haja algum ponto de intersecção entre a sua esfera e a situação jurídica objeto de julgamento. ${ }^{828} \mathrm{O}$ que acontece é que, no mais das vezes, perante os terceiros o julgado irá produzir apenas efeitos indiretos, reflexos, juridicamente irrelevantes. Em regra, pois, o terceiro não só não é vinculado pela definitividade representada pela coisa julgada como nem faria sentido que fosse, pois a sentença lhe é estranha.

Talhada na perspectiva de litígios individuais entre João e Maria, essa regra geral apresenta exceções. E uma delas ocorre justamente com a impugnação de deliberações assembleares.

\footnotetext{
${ }^{824}$ Cf. Serpa Lopes, Curso de direito civil, v. III, pp. 108/109.

825 Cf. Antonio Junqueira de Azevedo, "Princípios do Novo Direito Contratual e Desregulamentação do Mercado - Direito de exclusividade nas relações contratuais de fornecimento - Função Social do contrato e responsabilidade aquiliana do terceiro que contribui para inadimplemento contratual”, $R T, \mathrm{n}$. 750, p. 116. A doutrina, assim, divide os efeitos dos contratos em internos e externos. Os primeiros são direitos e obrigações que emergem do próprio contrato, e não alcançam terceiros, ao passo que os segundos decorrem da existência do contrato como fato social e exigem dos terceiros um dever de abstenção e respeito (cf. Patrícia Cardoso, "Oponibilidade dos efeitos dos contratos: determinante da responsabilidade civil do terceiro que coopera com o devedor na violação do pacto contratual", Revista trimestral de direito civil, v. 20, pp. 130/131). A respeito da eficácia dos contratos perante terceiros, v., por todos, Luciano de Camargo Penteado, Efeitos contratuais perante terceiros.

${ }^{826}$ Cf. Chiovenda, Instituições..., v. I, nn. 133/134, pp. 414/415; Pontes de Miranda, Comentários..., t. II, p. 8; José Ignacio Botelho de Mesquita, "A coisa julgada no Código do Consumidor", p. 143; José Rogério Cruz e Tucci, Limites subjetivos..., p. 78; e Eduardo Talamini, Novos aspectos da jurisdição..., n. 3.1.2, p. 86.

${ }^{827}$ Por esse motivo que, para Stefano Villata, estendem-se a todos os envolvidos no ato anulado não só o efeito desconstitutivo, mas também o efeito declarativo, que reconhece e declara a ilicitude do ato. E esse accertamento dell'illegitimità do ato administrativo ou da deliberação impugnados é, ainda de acordo com Villata, fundamental para que a doutrina alemã sustente que a parte vitoriosa está protegida da reiteração de um ato com conteúdo idêntico (cf. Impugnazioni..., cap. III, n. 7, p. 347).

${ }^{828}$ Cf. Moacyr Amaral Santos, Comentários..., v. IV, n. 367, pp. 487/488; José Rogério Cruz e Tucci, Limites subjetivos..., n. 4, p. 40; e Allorio, La cosa..., n. 30, p. 67. A coisa julgada não pode ser imposta ao terceiro, mas o julgado, em si, é eficaz perante todas as pessoas, tenham elas sido partes processuais ou não. Equivocada, por isso, a afirmação de Erasmo Valladão França de que o julgado só será eficaz para as partes e não para terceiros: "Evidentemente, a eficácia do julgado perante terceiros somente poderá ocorrer se os mesmos forem partes na demanda (art. 472 do CPC)" (cf. Invalidade, n. 22, p. 131, nota 185).
} 


\section{Incindibilidade da deliberação assemblear e eficácia constitutiva erga omnes}

É natural que, como visto, sendo a sentença um ato destinado a pôr fim a um dado conflito, os seus efeitos imponham-se apenas entre os sujeitos envolvidos com o próprio conflito. Uma sentença desconstituindo o contrato celebrado entre Pedro e Gabriel não produzirá efeitos na esfera jurídica de João, a menos que haja alguma comunhão de interesses que gere conexão entre a esfera de João e o litígio submetido a julgamento. Mas nada impede que o contrário ocorra. Existem situações-limite em que essa regra é relativizada e nas quais a sentença projeta efeitos diretos - e não apenas reflexos - na esfera de terceiros. Dentre as inúmeras hipóteses em que isso ocorre está aquela na qual o direito objeto de controvérsia diz respeito a pessoas ligadas por uma mesma relação jurídica base. ${ }^{829-830}$ É o que ocorre, por exemplo, nas hipóteses em que: (i) tanto o cônjuge como os descendentes pleiteiam, individualmente, a invalidação da venda de ascendente e a descendente (CC, art. 496); (ii) um cidadão pede a invalidação de um ato administrativo; ou (iii) um dos litisconsortes unitários propõe ação rescisória. ${ }^{831}$ Outro exemplo clássico é o da invalidação de deliberações assembleares.

Devido à natureza incindível que a deliberação ostenta, a sentença que a desconstitui transborda dos lindes subjetivos do processo e projeta efeitos na esfera de muitas outras pessoas que não integram o processo (acionistas que não demandaram a companhia, por exemplo). A deliberação é um ato jurídico e, como tal, não é possível que seja anulada ou reputada válida para uns e não para outros. ${ }^{832}$ Qualquer decisão que se

${ }^{829}$ Cf. Redenti, Il giudizio..., cap. I, pp. 1/47; e Carpi, L’efficacia..., n. 55, p. 251. Sobre o assunto, José Rogério Cruz e Tucci afirma que "ocorre que a interdependência das relações negociais e a complexidade do comércio jurídico acabam rompendo as fronteiras do denominado princípio da relatividade da coisa julgada e, com isso, torna-se inexorável a projeção, ainda que por via indireta ou reflexa, dos efeitos da decisão e, às vezes, em caráter excepcional, da própria expansão da autoridade da coisa julgada a terceiros" (cf. Limites subjetivos..., n.4, pp. 40/41). Ainda conforme tal autor, esse fenômeno, apesar de raro, não é inusitado, sobretudo porque o Código prevê inúmeras hipóteses em cuja base está a extensão ultra partes dos efeitos da sentença e da coisa julgada: intervenção de terceiros (arts. 56 a 80); legitimidade do terceiro interessado para ajuizar ação rescisória (art. 487, II); e legitimidade do terceiro para opor embargos de terceiro (art. 1.046) (cf. Limites subjetivos..., n. 4, p. 41).

${ }^{830}$ A projeção de efeitos ultra partes na anulação de atos incindíveis não é exclusiva das deliberações. Tanto é isso verdade que, como aponta Alessandro Lolli, a doutrina italiana no passado já considerou que o julgado administrativo opera-se apenas entre as partes processuais, exceção feita à decisão de anulação de ato incindível (cf. I limiti soggettivi..., cap. I, n. 1, pp. 1, 2 e 10).

${ }^{831}$ Os exemplos são de Eduardo Talamini (cf. Coisa julgada..., n. 2.5.2, p. 98).

832 Cf. Vivante, Trattato..., n. 527, p. 260; Víctor Fairen Guillén, El processo en la Ley de Sociedades Anónimas, cap. IV, n. 2, pp. 69 e 71; Allorio, La cosa..., n. 159, p. 273, Carpi, L'efficacia..., n. 35, p. 155; Chiovenda , "Sul litisconsorzio...", pp. 444 e 449/451 e Instituições..., v. I nn. 109 e 135, pp. 356 e 419; Egas 
pronuncie sobre a validade de uma deliberação - inclusive a que rejeita a demanda ${ }^{833}$ produzirá rigorosamente os mesmos efeitos na esfera de todos os acionistas, tenham ou não constituído o processo.

É por esse motivo, aliás, que a decisão que decreta a fraude contra credores, apesar da criticável redação dos arts. 158/165 do CC, gera ineficácia da alienação fraudulenta, e não a sua invalidade. Não há anulação do negócio jurídico e cancelamento do registro imobiliário. Ambos subsistem como se válidos fossem. O adquirente torna-se o

Moniz de Aragão, Sentença e coisa julgada..., n. 208, III, pp. 302/303; Ada Pellegrini Grinover, "Coisa julgada erga omnes...”, p. 10; José Rogério Cruz e Tucci, Limites subjetivos..., n. 6.6., p. 81; e "Impugnação judicial...", n. 2, p. 465; Athos Gusmão Carneiro, Intervenção de terceiros, n. 2.5, p. 12; Willis Santiago Guerra Filho, "Efficacia ultra partes...”, p. 191; Ilaria Pagni, Le azioni..., pp. 596 e 598; e Paulo Roberto de Oliveira Lima, Contribuição à teoria da coisa julgada, n. 4.3, p. 43. As mesmas considerações foram feitas por Liebman, em diversos trabalhos de sua obra: "Um ato que se afirma ilegítimo é, com efeito, um só e não pode subsistir ou decair na sua totalidade; cada um dos interessados não veria satisfeito o seu direito de outro modo que com a sua destruição; esta é a finalidade comum a todos, o resultado único que, embora obtido pela ação de um único, satisfaz ao mesmo o interesse de todos" (cf. "Pluralidade de legitimados...", n. 2. pp. 223/224); "A ação pertence a cada sócio individualmente, mas, dada a necessidade de que a deliberação subsista ou fique sem efeitos para todos, a demanda de cada um tende à anulação total do ato e, portanto, as ações dos vários sócios se encontram em relação de concurso: acolhida a demanda de um deles, o resultado se estende para todos, e as ações dos outros são absorvidas e extintas justamente porque concorrentes" (cf. “Ações concorrentes", n. 6, p. 218); e "Tais deliberações não podem conservar ou perder o vigor senão perante todos os sócios, de sorte que, em caso de acolhimento da impugnação de um deles, se anula a deliberação para todos, ao passo que, em caso de rejeição, ficaria preclusa a impugnação de todos os outros sócios" (cf. "Eficácia e autoridade...", n. 30, p. 96). Também Barbosa Moreira tratou do assunto: "A nota comum a todos êsses processos consiste em que o respectivo resultado é impensável como referido apenas a uma das pessoas habilitadas a instaurá-los, pois define uma situação jurídica que, tal qual afirmada ou negada pela sentença, não pode ser senão verdadeira para tôdas ou falsa para tôdas" (cf. "Coisa julgada: extensão subjetiva...”, p. 275). Fazendo considerações a respeito de demanda ajuizada por um dos consumidores em que este pede a invalidação de um contrato, Heitor Sica e Marcelo Bonicio dizem que "o juiz não poderá dizer que o contrato é válido para alguns dos contratantes e inválido para outros, por razões puramente lógicas" (cf. "Litisconsórcio unitário...", p. 2). De acordo com Cássio Scarpinella Bueno, "as decisões da assembléia são válidas ou não são. Não existe uma terceira opção do ponto de vista material" (cf. Partes $e$ terceiros..., cap. III, v. 4.3, p. 101). A esse fenômeno Ovídio Baptista da Silva e Celso Neves dão o nome de eficácia constitutiva erga omnes da sentença (cf., respectivamente, "Eficácias da sentença...", n. 8, pp. 117/118 e Coisa julgada civil, p. 495). É o que consta, ainda, de artigo de Paulo Cézar Aragão, embora com o equívoco de confundir eficácia da sentença com eficácia da coisa julgada: "quando a decisão judicial transitada em julgado considera inválida a deliberação, não pode existir grande dúvida acerca do fato de que a invalidade atinge todos os interessados na deliberação anulada ou declarada nula, quer tenham participado ou não no processo judicial (...). Não se poderia, evidentemente, admitir a possibilidade de que a deliberação fosse válida para alguns acionistas e inválida para os demais" (cf. "Aspectos processuais....”, p. 64). Attardi vai além, ao sustentar que toda decisão constitutiva pode manifestar-se erga omnes (cf. Diritto processuale..., v. 1, p. 496). Embora reconheça o fenômeno, Redenti entende que a anulação da deliberação projeta efeitos reflexos (ou de fato) na esfera dos acionistas, uma vez que a deliberação é ato da sociedade e somente ela é que sofre os efeitos diretos do provimento. Esse posicionamento decorre dos entendimentos de que os sócios possuem um interesse de fato ao bom andamento do ente e de que a deliberação não cria direitos e deveres para os sócios (cf. Il giudizio..., cap. II, nn. 42 e 50, pp. 55/57 e 67/69, inclusive notas 45 e 62).

${ }^{833}$ Há quem entenda que apenas a sentença que julga procedente a demanda anulatória é que projeta efeitos na esfera dos demais interessados. Esse é, aliás, um dos fundamentos para que se defenda a coisa julgada secundum eventum litis em caso de concurso subjetivo de ações. Mas a lição não é de ser seguida. Também a decisão que rejeita a demanda é unitária e, assim, afeta a esfera dos demais interessados, como bem ensinado por Redenti (cf. Il giudizio..., cap. I, n. 43, p. 57). 
efetivo dono da coisa, mas não pode opor ao credor essa condição, de forma a excluir a responsabilidade que incide sobre o bem. Tudo se dá no plano da eficácia, ${ }^{834}$ pois não é possível anular o ato para uns e não para outros.

\subsection{Direito potestativo concorrente: irrelevância do pólo ativo}

A natureza incindível da deliberação assemblear, por um lado, e sua influência direta na esfera jurídica de inúmeros sujeitos, por outro, gera, assim como ocorre com outros atos jurídicos - atos da Administração Pública, por exemplo -, o fenômeno da concorrência de direitos à sua anulação. ${ }^{835}$ Nessa hipótese, entre o direito da parte e o direito do terceiro existe um nexo de concorrência tal que a satisfação do direito daquele implica imediata satisfação (ou violação) do direito deste. O que define o direito concorrente, assim, é que a sua satisfação produz uma mutação jurídica que exorbita da esfera jurídica do titular a quem foi outorgada tutela jurisdicional. Tudo isso não permite concluir que o cotitular age como órgão no interesse na massa dos demais cotitulares: ele age em seu próprio interesse, mas a estrutura peculiar do direito impõe que o resultado da sua iniciativa reverbere também na esfera dos demais ${ }^{836}$ (v. item 9). Como decorrência de tal nexo, existe uma pluralidade de legitimados à impugnação do ato (concurso de ações), não como decorrência de uma criação contratual, mas sim da lei, da própria conformação do ato e de seu possível alcance lesivo a numerosos sujeitos. ${ }^{837}$

Em razão da natureza incindível da deliberação assemblear e da concorrência de direitos à sua anulação, para fins de delimitação da amplitude subjetiva da sentença é irrelevante quem compõe o polo ativo da demanda, pois, quer quando o demandante é acionista minoritário, quer nos casos em que é o Ministério Público ou todos os acionistas em litisconsórcio, a eficácia da sentença será a mesma: desconstituição ou manutenção do

\footnotetext{
${ }^{834}$ Cf. Liebman, Processo de execução..., n. 44, pp. 105/106; e Dinamarco, "100 anos de Liebman”, in Fundamentos..., t. I, n. 11, p. 53.

${ }^{835}$ Nesse sentido, Chiovenda: “Tutti i soci hanno diritto d'impugnare la deliberazione dell'assemblea. Questo diritto ha causa dai vizi della deliberazione. Come la deliberazione è atto unico rispetto a tutti i soci, che tutti vi sono soggetti, il diritto d'impugnarla spetta a un socio in quanto esse spessa a tutti gli altri soci. Ogni socio si trova necessariamente in un unico rapporto colla società rispetto alla deliberazione; e l'anullamento della deliberazione, come atto costitutivo che toglie di mezzo quello rapporto, non può concerdersi ad un socio dal giudice se non in quanto se sarebbe potuto concedere ad ogni altro socio istante" (cf. Chiovenda, "Sul litisconsorzio...”, n. 6, p. 451).

${ }^{836}$ Cf. Allorio, La cosa .., nn. 154 e 159, pp. 262 e 272/273.

${ }^{837}$ Cf. Liebman, "Pluralidade de legitimados...", pp. 221/229, “Eficácia e autoridade...”, n. 30, pp. 96/98 e “Ações concorrentes”, n. 6, p. 218; e Ovídio Baptista da Silva, “Eficácias da sentença...”, n. 8, p. 117.
} 
ato impugnado. O polo ativo da demanda, portanto, é irrelevante para a fixação dos limites subjetivos da sentença.

\subsection{Legitimação passiva: a importância do conceito de "ato colegial"}

A deliberação assemblear é um negócio jurídico unilateral colegial, fruto da convergência de vontades dos sócios, que, por meio de um procedimento, participam da realização de um ato final regido pelo princípio majoritário e representante da vontade coletiva. Vários sujeitos exercem seus poderes e, mediante um procedimento deliberativo, participam da feitura de um ato final que, pelas regras da maioria (princípio majoritário), representará a coletividade. As vontades (votos) unem-se e formam um todo unitário. Assim, apesar de fruto da intervenção conjunta de uma pluralidade de sujeitos, cada qual produzindo atos individuais, a deliberação é um ato unitário, da sociedade (v. item 4).

E sendo ato da sociedade, é a esta imputável, ${ }^{838}$ razão pela qual o legitimado passivo para a demanda de impugnação de uma deliberação assemblear é sempre a sociedade. Com base nisso, a doutrina é unânime em defender que no polo passivo de demanda de impugnação de deliberação deve figurar a sociedade. ${ }^{839}$ Daí a importância do conceito de ato colegial para a fixação da legitimação passiva para a demanda em apreço.

\section{Partes e terceiros: a condição de parte como critério geral para a fixação dos limites subjetivos da coisa julgada}

Ao dispor que "a sentença faz coisa julgada às partes entre a quais é dada, não beneficiando nem prejudicando terceiros", o art. 472 do CPC circunscreve a coisa julgada apenas a quem foi parte no processo e, ao assim fazer, enuncia uma regra milenar, ${ }^{840}$

\footnotetext{
${ }^{838}$ Cf. Víctor Fairen Guillén, El processo..., cap. III, n. 7, p. 60; Kübler, Derecho de sociedades, p. 345; e Bulhões Pedreira, "Deliberação de sócios...”, p. 656: "O que fundamenta a imputação da deliberação coletiva a todo o grupo é a natureza unitária do ato coletivo criado pelo procedimento de deliberação, que transforma a multiplicidade de atos de vontade individuais em um único ato coletivo, que é ato do grupo".

${ }^{839}$ Cf. Erasmo Valladão França, "Ilegitimidade de parte...”, pp. 381/382; Pontes de Miranda, Tratado de direito privado, t. 51, p. 118; Priscila Corrêa da Fonseca, Suspensão..., p. 105; Luiz Fernando C. Pereira, Medidas urgentes..., p. 146; e Fábio Ulhoa Coelho, Curso de direito comercial, v. 2, p. 200.

${ }^{840}$ Cum res inter alios iudicata nullum aliis praeiudicium facient (a coisa julgada não causa nenhum prejuízo a terceiros; Ulpiano D. 44.2.1); res inter alios iudicata aliis non paeiudicare (a coisa julgada não prejudica terceiros; Mader D. 44.1.63); e no oportet ex sententia sive iusta sive iniusta, pro alio habita alium pregravari (a sentença produzida entre as partes, seja justa ou injusta, não deve atingir terceiros; Paulo D.
} 
encartada já nas fontes romanas. ${ }^{841}$ A sentença, enquanto fato jurídico e ato estatal imperativo que é, pode produzir efeitos subjetivamente ilimitados, mas imutabiliza-se apenas entre aqueles que integraram o processo - em especial quando é para prejudicá$\operatorname{los}^{842}-\mathrm{e}$, assim, puderam influir no resultado a que nele se chegou. Em regra, portanto, o provimento de mérito não se solidifica para terceiros, que, sofrendo prejuízo jurídico, poderão impugná-lo. É fundamental, diante disso, definir o que se entende por parte e por terceiro.

O juiz e as partes são os sujeitos principais do processo. ${ }^{843} \mathrm{Em}$ um conceito processual (formal ou puro), partes são os sujeitos interessados - em contraposição ao juiz, sujeito desinteressado -, isto é, que levam a controvérsia a julgamento. São os personagens do contraditório instaurado perante o julgador, isto é, os sujeitos contrapostos na dialética do processo. ${ }^{844-845}$ Em sentido substancial, são os titulares dos direitos e das obrigações

3.2.21). As Ordenações, por sua vez, seguiram a tradição e mantiveram a regra: "a sentença não aproveita nem empece mais que às pessoas entre que é dada” (Livro 3. ${ }^{\circ}$, Título 81, pr.) (cf. Moacyr Amaral Santos, Comentários..., v. IV, p. 486).

${ }^{841}$ Cf. Pugliese, Giudicato civile..., n. 28, p. 874; Betti, Trattato..., cap. I, n. 2, p. 8; Monteleone, I limiti soggettivi..., n. 1, p. 10; Manoel Aureliano de Gusmão, Coisa julgada no cível, no crime e no direito internacional, pp. 9 e 59/61; e Alessandro Lolli, I limiti soggettivi..., cap. III, n. 1, pp. 90 e seguintes. De acordo com José Rogério Cruz e Tucci, "provém das fontes romano-canônicas o princípio de que a extensão da coisa julgada limita-se às partes do processo, não podendo beneficiar nem prejudicar terceiros" (cf. Limites subjetivos..., n. 39, p. 345), enquanto que para Ada Pellegrini Grinover a regra vem do direito comum (cf. "Coisa julgada erga omnes...", p. 9; e "Coisa julgada e terceiros", Revista Magister de Direito Civil e Processual Civil, n. 12, p. 5). Sobre a evolução dessa regra ao longo do direito romano, canônico, comum e contemporâneo, v. Allorio, La cosa..., n. 16, pp. 43/46. Chiovenda, contudo, dirigiu crítica à ideia de que a coisa julgada seja "comune a tutti i popoli", ao fundamento de que estudos históricos demonstram que alguns sistemas jurídicos antigos ignoraram completamente o instituto da coisa julgada e que só posteriormente, com o desenvolvimento do comércio e a consequente multiplicação das relações jurídicas, é que se passou a estabelecer a imutabilidade da sentença em termos peremptórios (cf. "Sulla cosa giudicata", in Saggi di diritto processuale civile, v. II, p. 400). Também Alessandro Lolli disse que, apesar da regra geral de que res inter alios iudicatas aliis non praeiudicat, havia no direito romano diversas hipóteses de extensão da coisa julgada ultra partes e, em particular, erga omnes (cf. I limit soggettivi..., cap. III, n. 3, pp. 90/91).

842 Cf. Chiovenda, Instituições..., v. 1, n. 144, p. 414; Satta, Direito processual..., v. 1, n. 117, p. 243; e Humberto Theodoro Jr., Curso de direito processual civil, v. 1, p. 546.

${ }^{843} \mathrm{O}$ juiz, o autor e o réu são os principais protagonistas da relação processual, ao encarnarem a jurisdição, a ação e a defesa (cf. José Rogério Cruz e Tucci, Limites subjetivos..., n. 3, p. 30). Os auxiliares da Justiça são sujeitos secundários do processo, pois desenvolvem atividades complementares à do juiz (cf. Dinamarco, Instituições..., v. II, n. 514, p. 247).

${ }^{844}$ Cf. Zanzucchi, Diritto processuale..., pp. 321/322; Wach, Manual de derecho procesal civil, v. II (trad. de Tomás Banzhaf), n. 46, pp. 281/283; Liebman, Manual..., v. 1, n. 41, pp. 123/124; e Dinamarco, Instituições..., v. II, n. 520, p. 252. Satta alude aos sujeitos privados do processo (cf. Direito processual..., v. 1, n. 49, p. 129), enquanto que Comoglio-Ferri-Taruffo definem partes como os sujeitos diversos do juiz e de seus auxiliares que integram o processo e destinatários dos efeitos dos provimentos do juiz, ressalvando, contudo, que se trata de noção equívoca, uma vez que a própria lei italiana utiliza a palavra "parte" com diferentes significados (cf. Lezioni..., cap. 12, n. 1, pp. 323/325).

${ }^{845}$ Adquire-se a posição de parte por três modos: propositura de demanda, citação e intervenção (voluntária ou coata). E, conforme a lição de Dinamarco, "ainda quando a integração do sujeito à relação processual se 
discutidos no processo ou, no léxico carneluttiano, sujeitos da lide ou do negócio jurídico discutido em juízo. ${ }^{846}$

Embora via de regra os titulares da relação jurídica (partes materiais) debatida sejam as partes legítimas para o processo e, por isso, acabem por integrá-lo (partes processuais), ${ }^{847}$ o conceito substancial de parte é irrelevante para a fixação dos limites subjetivos da coisa julgada, já que o art. 472 do CPC a estende apenas a quem foi parte no processo. A coisa julgada é, salvo exceções - como, por exemplo, na substituição processual, onde, embora o substituído seja terceiro, e não parte processual, é atingido pela coisa julgada $^{848}-$, oposta apenas às partes processuais.

Ao conceito de terceiros chega-se por um critério de exclusão: são todos os que não são partes, de modo que mesmo quando a parte substancial não integra a relação processual deve ser considerada terceiro. ${ }^{849} \mathrm{E}$ apesar de Allorio ter dito ser arbitrário diferenciar terceiros, ${ }^{850}$ é inegável que existem diferentes classes de terceiros.

Há, por um lado, os terceiros juridicamente indiferentes, estranhos à relação jurídica decidida pela sentença, mas titulares de direito com ela compatível (sujeição imprópria à coisa julgada). Embora para eles a decisão possa eventualmente causar algum

dá por ordem do juiz (litisconsórcio necessário; art. 47, par.), ele só se torna parte quando citado" (cf. Instituições..., v. II, n. 533, p. 286; e Intervenção..., n. 3, p. 17). Não apenas quem propôs e em face de quem foi proposta a demanda são partes, mas todos os que, por algum motivo, integraram o processo nessa condição, como o que substituiu a parte originária (sucessor) ou o que interveio em defesa de direito próprio (opoente), em auxílio da parte (interveniente litisconsorcial ou mesmo por provocação de uma das partes originárias (denunciado, chamado ou nomeado) (cf. José Rogério Cruz e Tucci, Limites subjetivos..., n. 3, pp. 33/34).

${ }^{846}$ Cf. Carnelutti, Instituciones..., v. I, n. 101, p. 174. Com base nessa distinção, Romano-Pavoni diz que, ajuizada uma demanda anulatória por um acionista, os demais acionistas são terceiros em sentido material, mas não formal, pois embora participem da relação controvertida, não integram o processo (cf. Le deliberazioni..., n. 102, p. 384).

${ }^{847}$ Regra geral que, como natural, apresenta exceções (cf. Redenti, Il giudizio..., prefácio, n. III, p. XIII).

${ }^{848}$ Cf. Antonio Carlos de Araújo Cintra, "Estudo sobre a substituição processual no direito brasileiro", $R T$, v. 809, pp. 748/749 e 754/755. A razão de ser dessa exceção à regra de relatividade da coisa julgada é que "toda a atividade jurisdicional desenvolvida é voltada para a satisfação do interesse de um terceiro, e não da parte" (cf. Camilo Zufelato, Coisa julgada..., n. 3.7.1, p. 154). Outro exemplo é o do sucessor da parte que não adentra o processo: mesmo sendo terceiro, está sujeito à coisa julgada $\left(\mathrm{CPC}\right.$, art. $\left.42, \S 3^{\circ}\right)$.

849 Novamente, v. Liebman, Manual..., v. 1, n. 41, p. 124; Dinamarco, Litisconsórcio, n. 5, p. 30; e Instituições..., v. II, n. 587, p. 380; e José Rogério Cruz e Tucci, “Impugnação judicial...”, n. 1, p. 462.

${ }^{850}$ Cf. La cosa..., n. 66, p. 114. Para Vicente Greco Filho, “terceiro é o legitimado para intervir que ingressa em processo pendente entre outras partes, sem exercitar direito de ação próprio ou de outrem" (cf. Intervenção de terceiros, n. 17, p. 35). Trata-se, evidentemente, de conceito de terceiro no contexto das modalidades de intervenção, isto é, de terceiro interveniente. 
prejuízo de fato, ela é juridicamente irrelevante. Sob o aspecto jurídico, portanto, esses terceiros encontram-se na posição de não serem prejudicados e nem beneficiados. ${ }^{851}$ Por outro lado, há os terceiros juridicamente interessados, não sujeitos à coisa julgada: aqueles que, embora titulares de uma situação jurídica incompatível com a decisão, não se submetem à coisa julgada. A sentença é juridicamente irrelevante até mesmo como coisa julgada entre as partes. Há, por fim, aqueles que são juridicamente interessados e sujeitos à coisa julgada, isto é, que se encontram subordinados à coisa julgada e possuem um interesse jurídico na sentença. ${ }^{852}$

Os acionistas que não integraram o processo em que se pediu a desconstituição de uma determinada deliberação são terceiros. Apesar de a sentença projetar efeitos nas esferas jurídicas da companhia e de todos os seus acionistas, aquela em princípio não vincula ninguém além das partes. Tais acionistas, porém, são terceiros juridicamente interessados, na medida em que estão juridicamente ligados à situação acertada pela sentença.

\section{Pluralidade de legitimados para impugnação de ato incindível: a insuficiência do art. 472 do CPC}

A regra geral, portanto, é a de que a coisa julgada é oponível apenas a quem foi parte no processo em que foi editado o provimento. Um dos fundamentos do preceito é que, embora enquanto fato jurídico a sentença ostente eficácia subjetivamente irrestrita, é natural que no mais das vezes ela projete efeitos diretos apenas entre as partes, pois, na premissa de que todos os envolvidos no litígio integram o processo, a decisão que resolve esse litígio só será mesmo relevante para elas. Contudo, além de situações em que em decorrência da interdependência de relações jurídicas pode-se cogitar de uma eficácia reflexa ou indireta da sentença, existe a peculiar hipótese na qual, em razão da natureza de um determinado ato jurídico, o provimento que se pronuncia sobre pretensão de desconstituição desse ato ostenta eficácia direta para todos os sujeitos de alguma forma

\footnotetext{
${ }^{851}$ A respeito de prejuízo de fato e de direito, v. Chiovenda, Instituições..., v. I, n. 134, pp. 419/420.

${ }^{852}$ Cf. Betti, Trattato..., cap. II, n. 1, pp. 147 e seguintes; e Chiovenda, Instituições..., v. I, n. 136, p. 421. Daí ter Betti dito, sobre essa última categoria, que "in quanto la sua efficacia vincolante si comunica loro (= estensione vera e propria della cosa giudicata per efficacia direta o riflessa)" (cap. II, n. 2, p. 175). Essa classificação, aliás, reflete a afirmativa de Allorio de que em se tratando da relação entre coisa julgada e terceiros, importa apenas nexo de direito, não o de fato (cf. La cosa ..., n. 30, p. 68).
} 
envolvidos com o ato. Esses sujeitos, assim, podem sofrer da decisão uma influência não só reflexa e fática como também direta e jurídica.

É o que ocorre quando há unitariedade no plano do direito material, ou seja, quando o caráter incindível da relação faz com que determinadas decisões a seu respeito produzam o mesmo efeito na esfera de todos os que a compõem ou, de forma intensa, com ela se relacionam. As características da situação material impõem que todos os envolvidos recebam tratamento homogêneo, de modo que a decisão seja uniforme para todos eles: ou se rejeita ou se acolhe o pedido, em bloco. ${ }^{853}$ Nesses casos, há mais de um sujeito legitimado ordinário para impugnar o mesmo ato e, portanto, a alteração do estado jurídico do ato repercutirá igualmente na esfera de todos esses sujeitos. É o que ocorre nas chamadas ações subjetivamente concorrentes, ${ }^{854}$ do que até hoje exemplo recorrente em livros e salas de aula é a demanda de impugnação de deliberação assemblear. ${ }^{855}$

Esse fenômeno gera perplexidade, pois como os acionistas que não participaram do processo são considerados terceiros juridicamente interessados, segundo o art. 472 do CPC podem instaurar a mesma controvérsia e reiniciar discussão já travada entre a companhia e o outro acionista. Diante disso, parte da doutrina brasileira conclui que,

${ }^{853}$ Cf. Araújo Cintra, Do litisconsórcio, cap. IV, n. 3, p. 46. Exemplo interessante foi dado por Barbosa Moreira - para quem unitariedade é a inevitabilidade de decisão uniforme - ao aludir à demanda de nulidade de patente: como ela tem por objeto uma situação jurídica que diz respeito direta e homogeneamente a uma pluralidade de pessoas, o resultado por ela alcançado deverá se impor, com igual eficácia, a todos esses sujeitos (cf. "Coisa julgada: extensão subjetiva...”, pp. 274/275 e 288). O mestre ainda ilustra com outros exemplos: ação pauliana, ajuizável por qualquer dos credores lesados; ação de nulidade de casamento; ação de dissolução de sociedade; ação de anulação de deliberação assemblear, dentre outras: todos exemplos de demandas constitutivas. Outro bom exemplo é dado por Flávio Yarshell, qual seja, demanda movida em face de agência reguladora e que pretende, de alguma forma, alterar a sua atividade regulatória: há unitariedade porque todos os agentes econômicos são igualmente afetados por qualquer alteração na relação jurídica incindível em que estão envolvidos, isto é, na regulação" (cf. "Brevíssimas reflexões a propósito da legitimidade passiva nas ações civis públicas envolvendo atividades sujeitos à regulação", in Paulo Lucon (coord.), Tutela coletiva, p. 112).

${ }^{854}$ Por ações concorrentes entendem-se demandas que possuem o mesmo escopo e proporcionam "ao sujeito diferentes vias para a busca de realização do direito material ameaçado ou violado”. Ou seja, caracterizam a "possibilidade de utilização de mais de uma ação para a satisfação do mesmo interesse garantido no plano material" (cf. Luiz Eduardo Boaventura Pacífico, Ações concorrentes, n. 1, pp. 12/13). Há três espécies de ações concorrentes: por (i) concurso objetivo (partes e objeto idênticos, causa de pedir diversa); (ii) concurso impróprio (partes e causa de pedir idênticas, pedido diverso); e (iii) concurso subjetivo (pedido e causa de pedir idênticos, partes diversas).

${ }^{855}$ Cf. Botelho de Mesquita, “A coisa julgada no Código do Consumidor”, p. 144; Allorio, La cosa..., n. 68, p. 118; e Chiovenda, Instituições..., v. I, n. 135, p. 419, os dois últimos exemplificando com o art. 163 do antigo Codice di Commercio italiano, de 1882, posteriormente substituído pelo art. 2.377 do atual Codice Civile daquele país. Liebman, por sua vez, alude à "conexão incindível entre a relação jurídica do terceiro e a relação atingida pela coisa julgada" (cf. "Eficácia e autoridade...”, n. 30, p. 96) e ilustra com a impugnação de deliberação assemblear. 
embora de lege ferenda o ideal fosse haver algum mecanismo que cientificasse os interessados para que, querendo, eles interviessem no processo e, assim, submetessem-se à coisa julgada - sugestão feita já pela doutrina clássica, como Vivante ${ }^{856}$-, pelas regras vigentes o único entendimento possível seria que a coisa julgada vale apenas entre as partes. ${ }^{857}$ Apesar da indivisibilidade da situação de direito material, o legislador, assim, já teria feito a opção de facilitar o acesso à justiça e, assim, não qualificar esse litisconsórcio como necessário. Ao fazer essa opção e rechaçar a imposição da coisa julgada a terceiros, continua essa doutrina, o legislador teria assumido o risco de haver decisões conflitantes para um indivisível e único ato. ${ }^{858}$

Embora essa seja a resposta dada pelo art. 472 do CPC, ela é claramente insuficiente, pois permitir que a controvérsia seja infinitamente rediscutida pode gerar, além de um conflito prático e jurídico entre julgados, grave insegurança jurídica. ${ }^{859} \mathrm{~A}$ alternativa é ainda antieconômica, pois abre espaço para que a companhia tenha que se defender e o Judiciário julgar um sem-número de demandas que deduzam a mesma pretensão, escorada nos mesmos fundamentos.

De lege ferenda, nas hipóteses em que o litígio envolver certo número de esferas jurídicas, em posição semelhante ou idêntica, abrem-se duas vias para o legislador contornar o problema: ou se inclui o caso dentre as hipóteses de litisconsórcio necessário, chamando-se todos os interessados para integrarem o processo, ou ampliam-se os limites subjetivos da coisa julgada, vinculando-se todos à decisão proferida no processo individual. Mas são perspectivas que em princípio são cabíveis apenas se houver alteração legislativa que derrogue parcialmente o art. 472. Nesse sentido, embora reconheça que a extensão da coisa julgada a terceiros seja técnica bastante utilizada em outros países,

\footnotetext{
${ }^{856}$ Cf. Trattato..., v. II, n. 528, p. 261.

${ }^{857}$ Cf. José Rogério Cruz e Tucci, "Impugnação judicial...”, n. 4, p. 472.

${ }^{858}$ Cf. Eduardo Talamini, "Coisa julgada...", n. 2.5.2, p. 103; e "Legitimidade, interesse, possibilidade jurídica e coisa julgada nas ações de impugnação de deliberações societárias”, in Flávio Yarshell e Guilherme Setoguti (coords.), Processo societário, p. 148.

${ }^{859}$ Cf. Heitor Sica e Marcelo Bonício, "Litisconsórcio unitário...”, p. 5: "Essa fórmula, no entanto, parece insuficiente, ou inexata, quando há necessidade de solução uniforme do litígio, porque a alteração promovida pela decisão judicial atingirá intensamente inclusive aqueles que não estão no processo, conforme já foi demonstrado no presente estudo, de maneira que, ao menos em princípio, permitir que essas pessoas possam rediscutir aquilo que já foi decidido parece algo que pode provocar, para além do conflito prático e lógico das decisões, grave insegurança jurídica”.
} 
Dinamarco observa que no Brasil ela é de rara aplicação e limitada aos casos expressos em lei. $^{860}$

Verdade que na realidade judiciária brasileira a situação relatada pode vir a ser apenas um falso problema, ou que na prática apresente importância menor do que costumamos pensar. ${ }^{861} \mathrm{O}$ prazo decadencial para impugnação da deliberação inválida é de 2 anos - prazo esse que, de acordo com nosso entendimento, aplica-se não só às deliberações anuláveis mas também às nulas (v. item 7.1). Por isso, é provável que, se o acionista esperar o resultado do processo já instaurado para só então aforar a sua própria demanda, é provável que, na realidade judiciária brasileira, isso só ocorra após o fim do prazo decadencial de 2 anos. Se isso ocorrer, o segundo processo deverá ser extinto por decadência (CPC, art. 269, IV) e, portanto, nem prosseguirá, afastando-se o risco de decisões contraditórias. Restaria apenas a hipótese em que a segunda demanda é proposta dentro dos 2 anos e enquanto ainda tramita o primeiro processo. Nesses casos, contudo, as demandas devem ser reunidas para julgamento conjunto, de modo que as pretensões de ambas - ou das demais, caso haja várias - sejam apreciadas pelo mesmo julgador, ${ }^{862}$ o que em princípio afasta o conflito prático de julgados. O art. 100, IV, “a” do CPC, ademais, diz ser competente o foro da sede da pessoa jurídica para julgar demandas em que esta for ré e, assim, as demandas deverão ser propostas no mesmo foro. E ainda que sejam propostas em foros diversos, nada impede a reunião.

De fato, a reunião de processos procura conferir racionalidade, economia, uniformidade e coerência na prestação de tutela jurisdicional. Interessa ao Estado e a todos a formação de uma convicção única a respeito de uma mesma controvérsia, ainda que refletida em mais de uma demanda. As disposições que permitem a prorrogação da competência e a reunião de processos por conexidade premia não só a harmonia de julgados, mas também a economia do processo (remuneração de servidores, manutenção da estrutura do Judiciário, papel deslocamento de partes, instrução probatória etc.). Em razão desse interesse público subjacente à reunião de causas conexas, esta independe de

\footnotetext{
${ }^{860}$ Cf. Instituições..., v. III, n. 965, p. 321.

${ }^{861}$ Tanto é que, fazendo referência à invalidação de deliberação, Eduardo Talamini afirmou que "o risco de haver sucessivas ações em sentidos opostos, ajuizadas por diferentes legitimados, é muito mais teórico do que concreto" (cf. "Legitimidade, interesse...", p. 149).

862 Já em 1898 Alfredo Rocco aludiu à necessidade de reunião de causas (cf. Le società..., n. 177, pp. 251 e 252). Também assim, Carpi L'efficacia..., n. 36, p. 156.
} 
vontade das partes e deve ser promovida de ofício (CPC, art. 102), ${ }^{863}$ que, aliás, é o que dispõe a legislação espanhola: "Cuando la demanda tenga por objeto la impugnación de acuerdos sociales se acumularán de oficio todas las que pretendan la declaración de nulidade o de anulabilidad de los acuerdos adoptados en una misma Junta o Asamblea o en una misma sesión de órgano colegiado de administración y que se presenten dentro de los cuarenta días siguientes a aquel em que se hubiera presenta la primera". ${ }^{864}$

Por esses motivos, parece-nos que na realidade brasileira o problema pode ser muito menos relevante do que se costuma pensar.

Essa observações, contudo, não justificam o abandono do tema. Ainda que se confirme a premissa de que se trata de questão de pouca relevância prática - o que, reconhecemos, é questionável, não só porque pode haver julgamento célere ou não haver reunião, mas também por conta do entendimento, do qual discordamos, de que as deliberações nulas não estão sujeitas ao prazo decadencial de 2 anos ou estão ao prazo ordinário de 10 anos -, ainda assim valeria debruçarmo-nos sobre ele, pois se trata de verdadeiro hard case, cuja solução pode, quando menos, contribuir para a solução de outras questões que deverão ser resolvidas no desenrolar do raciocínio.

Nesta última etapa da dissertação, assim, pretende-se verificar quais os limites subjetivos da sentença e da coisa julgada nas demandas de impugnação de deliberações assembleares e, especialmente, se no ordenamento vigente é possível que tais demandas recebam um tratamento quanto aos limites subjetivos da coisa julgada que fuja da regra ordinária do art. 472 do CPC.

\subsection{Ações subjetivamente concorrentes e a teoria de Liebman}

O fenômeno das ações subjetivamente concorrentes, como já adiantado, está presente quando uma demanda, apesar de poder ser proposta por vários sujeitos

\footnotetext{
${ }^{863}$ Cf. Dinamarco, Instituições..., v. I, n. 303, pp. 595/596; Moacyr Amaral Santos, Primeiras linhas de direito processual civil, v. I, pp. 263/264; José Roberto dos Santos Bedaque, "Prorrogação legal da competência: aspectos teóricos e práticos", Revista do Advogado, n. 88, pp. 136/137; Cássio Scarpinella Bueno, Curso sistematizado..., v. II, t. I, pp. 45/46; e Marcelo Abelha Rodrigues, Elementos de direito processual civil, v. I, p. 160.

${ }^{864}$ Cf. Andrés de la Oliva Santos, Objeto del processo..., p 191.
} 
individualmente, leva a um resultado que afeta igualmente todos os demais colegitimados. ${ }^{865}$ É o que ocorre com os chamados direitos potestativos concorrentes, que, devido ao fato de que sua satisfação exorbita a esfera jurídica de seu titular, foram taxados por Allorio de direitos fungíveis. ${ }^{866}$ Os exemplos recorrentes na doutrina são o das obrigações solidárias e o da demanda de anulação de deliberação de assembleia, em que embora o direito à anulação pertença a todos os sócios e outros legitimados, o resultado obtido em demanda movida por apenas um deles projeta efeitos aos demais.

Em conhecido ensaio, Liebman tratou do tema, afirmando que, de acordo com a solução do direito Justinianeu clássico, o exercício da ação por um dos colegitimados extinguiria as demais ações concorrentes. ${ }^{867}$ No período romano clássico (pré-Justinianeu), explicou, vigorou o princípio enunciado no brocardo "quoties concurrant plures actiones eiusdem rei nomine, una quis experiri debet" (ULP, 43, § $1^{\circ}$, D., 50, 17), segundo o qual o mero exercício de uma ação extinguiria as demais que lhe são concorrentes. No Direito Justinianeu o princípio teria sido alterado, fixando-se que apenas a satisfação da ação - e não mais o seu mero exercício - operaria referido efeito extintivo. ${ }^{868}$ No direito moderno, outra solução impor-se-ia.

Com efeito, partindo da distinção entre eficácia da sentença e autoridade da coisa julgada material, Liebman defendeu que, sendo desconstituída a deliberação, esta é anulada para todos os sócios, ${ }^{869}$ pois não é possível que o ato seja anulado para uns e não para

\footnotetext{
${ }^{865}$ Fenômeno diverso é o de cumulação de ações, que ocorre quando, em um mesmo processo, reúnem-se mais de uma demanda, que devem ser instruídas e decididas simultaneamente (cf. Leonardo Greco, Instituições de direito processual civil, v. 1, p. 213).

${ }^{866}$ Cf. La cosa..., n. 159, pp. 272/273. À base desse fenômeno estão, de acordo com Carpi, situações jurídicas plurissubjetivas (cf. L'efficacia..., nn. 17 e 36, pp. 65 e 155).

${ }^{867}$ Cf. "Ações concorrentes", p. 218.

868 Cf. "Ações concorrentes”, pp. 209/210: "Portanto, pelo direito clássico, quer entre duas pessoas concorressem duas ou mais ações, quer estas concorressem entre mais pessoas, ativa ou passivamente, o simples exercício de uma dessas ações extinguia também todas as ações concorrentes. A opinião geralmente acolhida explica esse resultado como conseqüência da eficácia consumptiva da litis contestatio, que se produzia ipso iure, ou por força da exceptio rei iudicatae vel in iudicium deductae, segundo a qualidade da ação proposta. Essa eficácia consumptiva se manifestava bem além dos limites da ação individual exercida, porque obedecia ao princípio bis eadem re ne sit actio, e para ter a eadem res não se precisavam nem eadem actio nem eadem, personae: ULP., 5, D., 44, 2. De eagem re agere videtur et qui non eadem actione agat, qua ab initio agebat, sed eatíam si alia experiatur, de eadem tamen re. Assim, a pura e simples contestação da lide, intervinda na ação, exinguia contemporaneamente ipso iure ou ope exceptionis todas as ações concorrentes, isto é, todas as que se referiam à eadem res, quer entre as mesmas pessoas, quer entre pessoas diversas, e independentemente do êxito do julgamento e da satisfação efetiva".

${ }^{869}$ Cf. "Eficácia e autoridade...", n. 30, p. 98: "não porque se tenha uma extensão da coisa julgada além dos seus limites subjetivos, mas tão-só porque o efeito extintivo da sentença não pode ser parcial, por causa da
} 
outros. Se outro legitimado propuser nova demanda com a mesma pretensão, o processo deverá ser extinto por falta de interesse processual (CPC, art. 267, IV), pois a tutela jurisdicional perseguida já fora atingida. Nos dois casos a coisa julgada restringe-se às partes do processo. Da mesma forma, se a demanda proposta pelo primeiro sócio for julgada improcedente, a decisão projetará efeitos nas esferas dos demais acionistas. Ou seja, a todos será oponível a declaração de que é incabível a anulação da deliberação. Mas a coisa julgada também se limitará às partes, de tal sorte que outro acionista poderá propor nova demanda, ainda que fundada na mesma causa de pedir, veiculando a pretensão dantes rejeitada. E não lhe poderá ser objetada a coisa julgada. ${ }^{870}$

Em resumo, Liebman procurou resolver a questão sustentando que o efeito da sentença produz-se para todos, pois não é possível anular o ato para uns e não para outros. Da mesma forma, rejeitada a pretensão o ato continuaria válido para todos. Nesta última hipótese, como a coisa julgada não se coloca entre terceiros, a via impugnatória continuaria aberta para os demais legitimados, ao passo que a procedência extinguiria o interesse processual destes, já que o escopo comum por todos perseguido já teria sido atingido.

A grande crítica que, com acerto, Barbosa Moreira e, seguindo este, a doutrina brasileira em peso dirigem à Liebman é que este desconsiderou a situação em que os demais acionistas querem a manutenção da deliberação. ${ }^{871}$ A solução sob a ótica do interesse processual, portanto, é claramente insatisfatória. Não fosse assim, seria uma excelente saída - genial e ao mesmo tempo simples - para conciliar o art. 472 do CPC com a situação acima relatada.

natureza e estrutura incindível do ato impugnado, que só pode permanecer ou cair por completo". A essa lição aparentemente aderiu Lopes da Costa (cf. Manual elementar..., p. 111).

${ }^{870}$ Cf. "Eficácia e autoridade...", n. 30, p. 98: "O exercício vitorioso de uma delas atinge o escopo comum a todas as outras e, por isso, as absorve e consome; ao revés, a rejeição de uma não prejudica as outras, que são todas entre si independentes e devem poder todas tentar a sua sorte". V., ainda, Ada Pellegrini Grinover, nota a Liebman, "Eficácia e autoridade...", p. 113. Vale notar que de acordo com Botelho de Mesquita a sentença de improcedência não produz efeitos, nem mesmo declaratórios. Apenas o trânsito em julgado da sentença de improcedência é que os produziria, ainda assim restritos às partes. Aparentemente, Botelho de Mesquita acolhe a lição de Liebman, ao afirmar que "tendo todas essas ações o mesmo objeto, a hipótese é de concorrência de ações. A improcedência de uma não prejudicaria as demais e a procedência de qualquer delas a todos os credores aproveitaria" (cf. "A coisa julgada no Código do Consumidor", pp. 143/144 e 147).

${ }^{871}$ Cf. Barbosa Moreira, "Coisa julgada: extensão subjetiva...", p. 282; Ada Pellegrini Grinover, Nota a Liebman, "Ações concorrentes", pp. 229/230; e Eduardo Talamini, Coisa julgada..., n. 2.5.1, p. 101. Essa crítica, contudo, não sensibilizou Dinamarco, que segue seu mestre (cf. Litisconsórcio, n. 92, pp. 224/225). 


\subsection{Litisconsórcio unitário: necessário ou facultativo?}

Uma segunda possibilidade de conciliação do art. 472 do CPC com a situação ora examinada seria entender que ela configura litisconsórcio necessário. Assim sendo, todos os interessados deveriam ser citados, para que, querendo, interviessem no processo e, assim, lhes fosse oponível a coisa julgada (CPC, art. 47).

Ocorre litisconsórcio quando duas ou mais pessoas unem-se como autores ou réus, voluntariamente ou por determinação legal, para juntas litigarem no mesmo polo da relação jurídica processual. Trata-se da situação que há entre duas ou mais pessoas ao serem réus ou autores no mesmo processo, em razão de comunidade de direito ou de obrigações, conexão de causas ou afinidade de questões, ${ }^{872}$ feição que, aliás, demonstra que, apesar de tipicamente processual, é instituto moldado pelo direito material. ${ }^{873}$

Uma das classificações dos tipos de litisconsórcio parte do regime de tratamento dos litisconsortes. Há, assim, duas categorias: o litisconsórcio comum (ou simples) e o unitário. O comum é pautado pela independência entre os colitigantes e consequente possibilidade de que o processo lhes ofereça diferentes resultados. Trata-se do regime ordinário (daí a nomenclatura comum), ${ }^{874}$ ao ponto de o art. 48 do CPC dispor que "salvo disposição em contrário, os litisconsortes serão considerados, em suas relações com a parte adversa, como litigantes distintos; os atos e as omissões de um não prejudicarão nem beneficiarão os outros"; repetindo o que, com redação ligeiramente diversa, estabelecia o art. 89 do CPC/39. ${ }^{875}$ É por esse motivo, aliás, que Redenti criticou o vocábulo "litisconsórcio", pois dá a entender que há um consórcio, isto é, uma comunhão de

${ }^{872}$ Cf. Guilherme Estellita, Do litisconsórcio no direito brasileiro, p. 18; Hélio Tornaghi, Comentários ao Código de Processo Civil, v. I, p. 215; Sérgio Ferraz, Assistência litisconsorcial no direito brasileiro, nn. 1 e 3, pp. 1 e 15; Dinamarco, Litisconsórcio..., n. 8, p. 36; Pontes de Miranda, Comentários..., t. II, p. 3; e Goldschmidt, Derecho procesal..., n. 69, p 437.

${ }^{873}$ Cf. Araújo Cintra, Do litisconsórcio, cap. I, n. 2, pp. 2/4. Sobre a relação entre litisconsórcio e direito material, v. Maria Encarnación D’Avila Millan, Litisconsorcio necessario - concepto y tratamento procesal, p. 47; e Jorge Americano, Comentários ao Código de Processo Civil do Brasil, v. I, p. 128. Guilherme Estellita, contudo, ressalvou que não apenas na natureza da relação jurídica se justifica o litisconsórcio. Há outras razões para o instituto, como a economia processual e a tentativa de impedir decisões discordantes (cf. Do litisconsórcio..., pp. 18/19).

${ }^{874}$ Cf. Dinamarco, Litisconsórcio, n. 25, p. 78; e Sérgio Ferraz, Assistência litisconsorcial..., n. 4, p. 22.

${ }^{875}$ A doutrina, àquela época, também reconhecia o princípio da autonomia dos litisconsortes (cf. Araújo Cintra, Do litisconsórcio, cap. IV, n. 5, pp. 37/38, e cap. V, n. 1, p. 40). 
interesses, atos e sorte entre os colitigantes, o que nem sempre acontece. ${ }^{876} \mathrm{O}$ litisconsórcio unitário, por sua vez, está presente quando o litígio só pode ser decidido de modo uniforme para os litisconsortes. Diversamente do que acontece com o comum, nele os atos de um colitigante impactam da mesma forma as esferas jurídicas de todos os consortes.

Uma segunda distinção entre os tipos de litisconsórcio é a que parte do poder de aglutinação que conduz à sua formação. ${ }^{877}$ Neste caso, a divisão se dá entre litisconsórcio necessário e facultativo. Como é intuitivo, o necessário é, na singela porém eficiente definição de Celso Agrícola Barbi, aquele cuja formação não pode ser dispensada pelas partes. ${ }^{878}$ A lei impõe a reunião de sujeitos e, assim, a questão resolve-se em termos de legitimação ad causam: se foi imposto que todos os titulares de uma dada relação material devem necessariamente litigar em conjunto, um desses titulares não poderá demandar ou ser demandado individualmente, sob pena de ser reputado carecedor de ação (CPC, art. 47, parágrafo único). No litisconsórcio facultativo, por outro lado, a reunião depende do desejo dos envolvidos. ${ }^{879}$

Embora a confusa e criticável redação do art. 47 e respectivo parágrafo dê a entender que o litisconsórcio unitário e o necessário sejam o mesmo fenômeno ou diversos mas indissociáveis - e, de fato, a doutrina clássica assim enxergava ${ }^{880}$-, são coisas distintas e que podem andar separadas: via de regra o litisconsórcio unitário será necessário, mas há casos de litisconsórcio unitário facultativo e de litisconsórcio necessário não unitário.

Nosso ordenamento, com efeito, admite o litisconsórcio unitário facultativo, situação em que, apesar de o mérito só poder ser resolvido uniformemente para todos os cotitulares do direito envolvido, dispensa-se a reunião de todos eles no processo. ${ }^{881}$

\footnotetext{
${ }^{876}$ Cf. Il giudizio..., prefácio, n. IV, p. XIV. O mesmo foi apontado por Guilherme Estellita, que, contudo, contornou a crítica ao afirmar que apenas "em regra" os consortes terão a mesma sorte (cf. Do litisconsórcio..., p. 18).

${ }^{877}$ Cf. Litisconsórcio, n. 24, p. 76.

${ }^{878}$ Cf. Comentários..., v. I, t. I, n. 297, p. 274.

${ }^{879}$ Cf. Dinamarco, Litisconsórcio, n. 24, p. 76.

${ }^{880}$ Cf. Zanzucchi, Diritto processuale..., p. 326; e Goldschmidt, Derecho procesal..., n. 69, p. 439.

${ }^{881}$ Cf. Sérgio Ferraz, Assistência litisconsorcial..., n. 4, p. 24; Pontes de Miranda, Comentários..., t. II, pp. 16, 20/21 e 33/34; Araújo Cintra, Do litisconsórcio, cap. V, n. 2, p. 49, e cap. VII, p. 53; José Roberto dos Santos Bedaque, Direito e processo, n. 26.1, p. 119; e Dinamarco, "Cumulação de pedidos em matéria tributária, litisconsórcio necessário e concurso eletivo de foros", in Processo civil empresarial, n. 315, p.
} 
Existem relações de direito material que dizem respeito a uma pluralidade de pessoas, das quais, como decorrência disso, resulta a legitimidade de mais de um desses sujeitos para defender os direitos próprios e, em certos casos, alheios. Em hipóteses excepcionais, por razões de conveniência ${ }^{882}$ permite-se que, mesmo diante de relações jurídicas incindíveis, cada um dos interessados seja individualmente legitimado para deduzir sua pretensão em juízo. Os cotitulares dispõem de uma legitimação concorrente, e não conjunta, não havendo, pois, vedação para que ajam individualmente. O contraditório estará tão regularmente instalado com a presença de um como da totalidade dos indivíduos, e eventual litisconsórcio entre eles será facultativo. ${ }^{883}$ Exemplos disso são legitimidade de: (i) qualquer credor para exigir integralmente a dívida indivisível (CC, art. 260); (ii) cada um dos credores solidários para demandar o cumprimento da obrigação integral (CC, art. 267); (iii) condômino para reivindicar a coisa comum e agir em defesa da sua posse (CC, art. 1.314); (iv) herdeiro para defender, até a partilha, a herança (CC, art. 1.791, parágrafo); e (v) qualquer dos titulares do direito ameaçado para ajuizar mandado de segurança (Lei $12.016 / 09$, art. $\left.1^{\mathrm{o}}, \S 3^{\mathrm{o}}\right){ }^{884}$

E, mais uma vez, figura assiduamente invocada pela doutrina para exemplificar a teoria é a demanda de anulação de deliberação societária: Chiovenda, ${ }^{885}$ Víctor Fairen Guillén, ${ }^{886}$ Dinamarco, ${ }^{887}$ Arruda Alvim, ${ }^{888}$ Celso Agrícola Barbi, ${ }^{889}$ Ada Pellegrini Grinover, ${ }^{890}$ Sérgio Sahione Fadel, ${ }^{891}$ Hélio Tornaghi, ${ }^{892}$ Pontes de Miranda, ${ }^{893}$ Andrea

498: "Já vão longe os toscos tempos em que se acreditava que o litisconsórcio unitário fosse uma subespécie do necessário".

${ }^{882}$ Como reflexo da necessidade de democratizar do exercício do direito de ação, a facultatividade é a regra geral (cf. Dinamarco, Litisconsórcio, n. 92, pp. 223/225).

${ }^{883}$ Cf. Barbosa Moreira, “Coisa julgada: extensão subjetiva...”, p. 275. Em razão disso, Redenti diz que seria ilógico e contraditório exigir que um sujeito, que age em defesa de um direito próprio, associasse-se a outros para que pudesse pleitear tutela em seu favor (cf. Il giudizio..., cap. I, n. 44, p. 61).

${ }^{884}$ Todos exemplos de Eduardo Talamini (cf. "Legitimidade, interesse...”, p. 105).

${ }^{885}$ Que diz que embora não seja necessário que todos os acionistas sejam chamados ao processo, o julgamento é necessariamente único, mesmo para os que não participaram da relação processual, "come se tutti fossero in causa" (cf. "Sul litisconsorzio...", p. 449).

${ }^{886}$ Cf. El processo..., cap. IV, n. 2, p. 70.

${ }^{887}$ Cf. Litisconsórcio, nn. 90/93, pp. 220, 222, 223 e 228.

${ }^{888}$ Cf. Código..., v. II, pp. 390/391; e Manual..., n. 41-A, pp. 612/613.

${ }^{889}$ Cf. Comentários..., v. I, t. I, nn. 301 e 307, pp. 276 e 283.

${ }^{890}$ Cf. "Coisa julgada erga omnes...”, p. 11; e Nota a Liebman, “Ações concorrentes”, p. 230.

${ }^{891}$ Cf. Código..., v. 1, p. 136.

${ }^{892}$ De acordo com Tornaghi, litisconsórcio unitário e necessário são coisas diversas: aquele impõe que a controvérsia seja decidida de modo uniforme para todos, ao passo em que este determina "a necessidade de figurarem no processo todos os que em conjunto e incindivelmente são titulares perante o Direito material de 
Proto Pisani, ${ }^{894}$ Romano-Pavoni, ${ }^{895}$ Carpi, ${ }^{896}$ Willis Santiago Guerra Filho, ${ }^{897}$ Athos Gusmão Carneiro ${ }^{898}$ e Eduardo Talamini, ${ }^{899}$ para citar alguns autores. ${ }^{900} \mathrm{E}$, de fato, a despeito da unitariedade da relação jurídica, exigir de um dos legitimados que obtenha a adesão de todos os demais (que podem pode ser centenas ou mesmo milhares de pessoas) equivaleria a, em termos práticos, impedir o exercício do direito de ação. ${ }^{901}$

A impugnação de deliberação assemblear gera inegavelmente litisconsórcio unitário facultativo e, portanto, a ela não se aplica o parágrafo do art. 47 do CPC, que dispõe que "o juiz ordenará ao autor que promova a citação de todos os litisconsortes necessários, dentro do prazo que assinar, sob pena de declarar extinto o processo". Equivoca-se Egas Moniz de Aragão ao sustentar a aplicação do parágrafo do art. 47 e a

um mesmo direito subjetivo ou de uma só obrigação". E mais: "O litisconsórcio pode ser unitário sem ser necessário, isto é: vão a juízo como litisconsortes os que quiserem, mas a sentença será igual para todos, os que ali forem. Na obrigação solidária a sentença é uniforme em relação a todos os que vão a juízo. Mas não se exige que estejam todos presentes" (cf. Comentários..., v. I, p. 215).

${ }^{893}$ Cf. Comentários..., t. II, pp. 20/21.

${ }^{894}$ Referido autor alude às hipóteses em que é deduzida em juízo uma relação plurissubjetiva mas que não gera "fenomini di litisconsorzio necessario", por ele qualificadas de "litisconsorzio unitario o quasi necessario". Dentre os exemplos dados estão a demanda reivindicatória ajuizada por um coproprietário, a condenatória ajuizada por um credor solidário e a de impugnação de deliberação assemblear. Nesses casos, quando há intervenção de um dos litisconsortes no processo já em curso, ocorre conexão de demandas por identidade do direito (causa de pedir) (cf. "Appunti sul litisconsorzio necessario e sugli interventi”, in Rivista de diritto processuale, v. 49, n. 2, abr./jun. 1994, p. 364).

${ }^{895}$ Referido autor, com efeito, nega ser caso de litisconsórcio necessário e diz que o interessado pode intervir voluntariamente no processo em curso (cf. Le deliberazioni..., n. 102, p. 383).

${ }^{896}$ Cf. L'efficacia..., n. 55 , p. 258.

${ }^{897}$ Cf. "Efficacia ultra partes...", pp. 191/192.

${ }^{898} \mathrm{Cf}$. Intervenção de terceiros, n. 2.5, p. 12.

${ }^{899}$ Cf. "Legitimidade, interesse...", pp. 104/105. Embora não o afirme expressamente, essa também parece ser a posição de Paulo Roberto de Oliveira Lima (cf. Contribuição à teoria..., n. 4.3, p. 44).

${ }^{900}$ Posição interessante assume Arruda Alvim, para quem nas demandas movidas em face de sociedade ou associação não existe litisconsórcio necessário e nem unitário entre aquelas e seus sócios ou associados, uma vez que (i) a situação da pessoa jurídica é inconfundível com a de seus integrantes e (ii) o provimento não afeta a esfera desta da mesma forma que as daqueles. Os sócios não sofrem efeitos diretos da sentença e, portanto, não se trata de lide unitária, a caracterizar o litisconsórcio unitário. Da mesma forma, como a lei não exige pluralidade de sujeitos no polo passivo, não se trataria de litisconsórcio necessário: "Não há como se aceitar a afirmação de que a esfera jurídica destes últimos seria atingida da mesma forma que a da pessoa jurídica, pois não existe essa identidade de situações, até porque só existe litisconsórcio necessário e unitário quando há lei que o estabeleça, o que não acontece na proposição em estudo" (cf. "A posição dos sócios e associados em relação a ações movidas contra as sociedades e associações de que façam parte", in Flávio Yarshell e Guilherme Setoguti J. Pereira (coords.), Processo societário, pp. 60 e 63). E, de fato, a ideia é correta. Que não se trata de litisconsórcio necessário não há dúvida. Com relação à unitariedade, de fato, ela não existe entre a sociedade e os sócios, mas sim entre estes. Por isso, em caso de demanda anulatória de deliberação proposta em face da sociedade, será caso de litisconsórcio ativo unitário - entre os sócios -, mas não de unitário passivo - entre a sociedade e os seus sócios. Caso o sócio queira litisconsorciar-se à sociedade, poderá fazê-lo, mas esse litisconsórcio não será unitário.

${ }^{901}$ Cf. Eduardo Talamini, "Legitimidade, interesse...”, p. 106. 
consequente citação de todos os acionistas como uma maneira de superar os problemas decorrentes da não oposição da coisa julgada aos acionistas que não participaram do processo em que foi editada a sentença, indicando a citação por edital como uma alternativa para os casos em que há um quadro acionário muito amplo. ${ }^{902}$ Também assim Cássio Scarpinella Bueno, que não obstante dê como exemplo de litisconsórcio unitário facultativo a impugnação de deliberação societária, ${ }^{903} \mathrm{em}$ outra passagem da mesma obra afirma expressamente que essa hipótese é de litisconsórcio necessário, razão pela qual deve haver citação de todos os sócios, para que, se quiserem, intervenham no processo, no polo em que bem entenderem. As dificuldades para citação, diz o autor, devem ser superadas caso a caso. ${ }^{904}$

Conquanto, de fato, a citação por edital de todos os interessados seja uma saída simples e eficiente de conciliar a situação analisada com a regra do art. 472 do CPC, a posição é de ser afastada, porque não se trata de litisconsórcio necessário, única hipótese a que se dirige o comando do parágrafo do art. 47. Não sendo caso de cientificação de todos os acionistas - providência que bem poderia surgir de lege ferenda, ${ }^{905}$ preferencialmente

${ }^{902}$ E vai além: diz que, se não citados todos os sócios, o provimento de mérito "poderá ser vão ('por causa da natureza e estrutura incindível do ato impugnado, que só pode permanecer ou cair por completo') pois terá sido infringida a regra do art. 47 e a sentença (por isso inutiliter data) para ninguém valerá" (cf. Sentença.., n. 208, pp. 303/304). Chiovenda entendia ser caso de litisconsórcio facultativo unitário, mas também aludiu à citação editalícia, sem a acolher (cf. "Sul litisconsorzio...", p. 449, nota 1). Defendendo a citação de todos os interessados, Redenti disse que a sentença que não cumpra essa determinação é nula (cf. Il giudizio..., cap. III, nn. 182 e 189, pp. 260 e 267).

903 Cf. Partes e terceiros..., cap. III, n. 4, p. 95: "Inversamente, há casos em que há mera permissibilidade do litígio conjunto (litisconsórcio facultativo) e, não obstante, a solução será uniforme para todos aqueles que estão em juízo (litisconsórcio unitário). Assim, nos casos em que há pluralidade de sujeitos para impugnação de um mesmo ato (acionistas que pretendem declarar a nulidade de assembléia)".

904 Cf. Partes e terceiros..., cap. III, n. 4 e 4.3, pp. 95 e 102/103: "Nesta situação, justamente pela ausência de regra que autorize a legitimação extraordinária, não há outra opção senão a de determinar a citação dos demais sócios para que, querendo, intervenham como partes na demanda já proposta, escolhendo, de acordo com suas convicções pessoais, qual o pólo da relação processual que pretendem ocupar". E, peremptoriamente, afirma: "Quando inexiste autorização para a legitimação extraordinária - anulação de assembléia por sócio, por exemplo -, o caso não pode ser tratado como de 'intervenção litisconsorcial'. O caso é de litisconsórcio necessário, e a dificuldade na sua realização prática (citação de todos os interessados) é a questão a ser superada consoantes das circunstâncias e as características de cada caso concreto" (cap. III, n. 6, p. 121). Nas edições mais recentes de seu Curso, contudo, o ilustre professor posicionou-se no sentido de que a hipótese é mesmo de litisconsórcio facultativo unitário (cf. Curso..., v. 2, t. I, Parte VIII, Cap. 2, n. $3)$.

905 Nesse sentido, José Rogério Cruz e Tucci ("O ideal seria, a exemplo do que se verifica no procedimento norte-americano das class actions e no art. 94 do Código de Defesa do Consumidor, a instituição de um mecanismo processual, rápido, eficiente e não dispendioso, que se prestasse a dar ciência da ação a todos os co-legitimados, para que pudessem assumir, caso desejassem, a posição processual que melhor lhes conviesse"; cf. "Impugnação judicial...", n. 4, p. 471); e Eduardo Talamini ("De lege ferenda, parece adequado estabelecer norma expressa determinando a citação de todos os co-legitimados para que, querendo, optem por ingressar em um dos pólos da ação, e para que fiquem, de todo modo, submetidos à coisa julgada 
mediante ato mais simples e informal do que a citação -, continua sem solução o problema de como vincular os demais acionistas à sentença que dali aflorará.

\subsection{Substituição processual}

A legitimidade ativa para o ajuizamento de demanda é ordinariamente atribuída ao titular da pretensão deduzida, isto é, ao titular do direito material que a fundamenta (legitimidade ordinária; $\mathrm{CPC}$, art. $6^{\circ}$ ). Mas a lei prevê, em situações excepcionais, que pessoa dissociada da relação litigiosa defenda-a em juízo, atuando em nome próprio mas em defesa de direito alheio (legitimidade extraordinária). Trata-se do fenômeno da substituição processual.

Apesar de similares, representação e substituição processual são figuras diversas. Em ambas existe dissociação entre o direito material alegado e o que se pretende defender em juízo; daí a aludida similaridade. Mas enquanto naquela o substituto defende direito alheio em nome próprio, nesta o representante defende direito alheio em nome alheio. ${ }^{906} \mathrm{O}$ substituto é parte no processo, o representante não.

Exemplos clássicos de substituição processual são os da defesa de interesses supraindividuais pelo Ministério Público, do autor popular e do terceiro interessado na extinção da obrigação, que, em razão de mora do credor, promove ação de consignação em pagamento (CPC, art. 890 c/c CC, arts. 304 e 334). Outro exemplo, colhido na LSA, é o da demanda subsidiária do acionista para responsabilização de administrador (LSA, art. 159, $\S \S 3^{\circ}$ e $4^{\circ}$ ): o $\S 3^{\circ}$ traz hipótese de substituição processual derivada ou demanda social substitutiva, enquanto o $\S 4^{\circ}$, de substituição processual originária ou demanda social derivada. $^{907}$

gerada nesse processo em que foram citados. (...) Havendo regra expressa nesses termos, aqueles colegitimados que tiverem sido citados e optarem por não participar efetivamente do processo ficarão atingidos pela coisa julgada (mas repise-se: isso dependeria de regra expressa, e a coisa julgada estaria atingindo esses co-legitimados precisamente porque se lhes teria dado ciência do processo e oportunidade de dele participar"; cf. Coisa julgada..., n. 2.5.2, pp. 103/104; e "Legitimidade, interesse...”, p. 149).

${ }^{906}$ Cf. Zanzucchi, Diritto processuale..., p. 343/345; Antonio Carlos de Araújo Cintra, "Estudo sobre...”, pp. 744/745; Dinamarco, Instituições..., v. II, nn. 439/440 e 548, pp. 119/120 e 317/318; Athos Gusmão Carneiro, Intervenção de terceiros, n. 18, p. 53; e Cássio Scarpinella Bueno, Partes e terceiros..., cap. II, n. 6, p. 42.

${ }^{907}$ Cf. Araújo Cintra, “Atuação por via processual...”, p. 75; Marcelo Von Adamek, Responsabilidade civil..., nn. 7.3.3.2.1, pp. 370 e seguintes; e Tiago Asfor Rocha Lima, “A legitimidade ativa e passiva nas ações de 
Há quem defenda que, independente da procedência ou improcedência da demanda, a coisa julgada estende-se aos demais sócios ao fundamento de que o acionista é substituto processual dos demais interessados na invalidação e que a sociedade é a substituta dos interessados na manutenção. ${ }^{908}$ Como visto no item 9, todavia, o acionista que requer anulação de uma deliberação defende uma posição jurídica individual, ${ }^{909}$ ainda que com reflexos coletivos, isto é, que acarrete também a realização dos direitos de terceiros. Não é caso de substituição, mas de legitimação concorrente e ordinária.

Além disso, ao menos no sistema brasileiro, legitimação extraordinária só existe por expressa disposição de lei, uma vez que o art. $6^{\circ}$ do CPC determina que "ninguém poderá pleitear, em nome próprio, direito alheio, salvo quando autorizado por lei”. E como não há autorização legal para que o acionista vá a juízo em nome de outro acionista, ${ }^{910}$ não se pode impor a este a coisa julgada, ao menos não por este fundamento.

responsabilidade civil contra o administrador e o controlador na Lei das S/A", in Flávio Luiz Yarshell e Guilherme Setoguti J. Pereira (coords.), Processo societário, pp. 714 e seguintes.

${ }^{908}$ Cf. Ada Pellegrini Grinover, Notas a Liebman, “Ações concorrentes”, pp. 234/235: “Adotando-se a tese de que o autor, co-legitimado à ação, seria substituto processual dos demais sócios, que se encontram na mesma situação jurídica, o problema ficaria resolvido, uma vez que, na substituição processual, a coisa julgada abrange o substituto e os substituídos. Poder-se-ia argumentar que, nesse caso, não haveria comunhão de interesses entre todos os sócios, pois alguns poderiam ter interesse na anulação, e outros na validade da assembléia. Contudo, haverá sempre interesses contrapostos no processo e comunhão de interesses de cada grupo de sócios com uma das partes. É certo inexistir, no ordenamento brasileiro, lei que autorize o sócio a pleitear, em nome próprio, direito alheio. No entanto, a escolha do art. $6^{\circ}$ do CPC já foi superada pela doutrina que, antes da entrada em vigor da Lei da Ação Civil Pública, entendeu que, nas obrigações indivisíveis, haveria de se dar uma interpretação mais elástica ao dispositivo, para vislumbrar a legitimação à ação coletiva do membro do grupo, em razão de ser o interesse, ao mesmo tempo, próprio e alheio: ninguém duvida, foi acrescentado, da legitimidade de qualquer credor para, sozinho, reclamar em juízo a prestação. Com maior razão, portanto, uma operação de simples hermenêutica seria suficiente para entender ser o sócio que pretende a anulação da assembléia substituto processual dos demais, que se encontram na mesma situação jurídica. Na mesma causa, os sócios interessados na validade da assembléia são substituídos pela parte contrária. Trata-se simplesmente de observar a natureza das coisas e é exatamente à natureza das coisas que devem se adaptar os princípios e até mesmo as garantias constitucionais" (v., ainda, "Coisa julga e terceiros", p. 11). Também Paulo Cézar Aragão alude à substituição, aparentemente acolhendo a tese (cf. "Aspectos processuais...", p. 64), o que foi negado por Liebman (cf. "Eficácia e autoridade...", n. 30, p. 97). Embora não seja claro, Willis Santiago Guerra Filho aparentemente entende que, em casos de litisconsórcio facultativo unitário há representação (cf. "Fenomenologia em direito processual: apontamentos para um estudo sobre a relativização dos limites subjetivos da coisa julgada em conexão com o litisconsórcio necessário de uma perspectiva filosófica fenomenológica", Revista autônoma de processo, n. 4, p. 79).

${ }^{909}$ Cf. Carpi, L'efficacia..., n. 36, p. 155; e Allorio, La cosa ..., n. 160, pp. 273/275.

${ }^{910}$ Cf. Cássio Scarpinella Bueno, Partes e terceiros..., cap. III, n. 4.3, p. 103; e Eduardo Talamini, Coisa julgada..., n. 2.5.1, p. 99. 


\subsection{Coisa julgada secundum eventum litis}

Outra leitura feita por alguns é entender que a coisa julgada é secundum eventum litis: estender-se-ia aos demais acionistas em caso de procedência e limitar-se-ia ao autor da demanda no de improcedência. Referida leitura parte da ideia de que, por ser constitutiva, a sentença de procedência apresenta eficácia erga omnes, diversamente da de improcedência, que se limitaria a acertar a inexistência do direito do autor. Nesse último caso, o juiz apenas declararia a inexistência do direito potestativo do sócio à desconstituição, sem fazer qualquer juízo sobre o direito dos demais sócios, que continuariam a poder ir a juízo e invocar tutela. ${ }^{911}$

Reflexo desse entendimento, o art. 2.377 do Código Civil italiano dispõe que a anulação da deliberação societária produz efeitos em relação a todos os sócios ("L'anullamento della deliberazione ha effetto rispetto a tutti i soci"). Mesmo reconhecendo a falta de clareza do texto legal, ${ }^{912}$ a doutrina peninsular predominante interpreta esse dispositivo no sentido de que, como a lei silenciou a respeito da rejeição da impugnação, a coisa julgada erga omnes produz-se apenas em caso de procedência, e não de improcedência, ${ }^{913}$ embora haja autores que, como Attardi, defendam não haver razão para essa diferença ao sustentarem que, com base em interpretação extensiva, a coisa julgada seja ultra partes nas duas situações. ${ }^{914}$

No direito brasileiro, contudo, essa posição não prospera. Primeiro porque, de um lado, não há dispositivo de lei que determine a coisa julgada secundum eventum litis no

\footnotetext{
${ }^{911}$ Como já visto anteriormente, na peculiar teoria de Botelho de Mesquita a sentença de improcedência não produz efeitos, isto é, não gera nenhuma alteração no mundo jurídico. Com o trânsito em julgado a conclusão da sentença de improcedência tornar-se-ia imutável entre as partes, o que, contudo, não seria um efeito da sentença, mas sim do trânsito em julgado. Daí por que a imutabilidade decorrente da improcedência de uma ação concorrente só se tornaria imutável e indiscutível entre as partes. A sentença de improcedência não produziria nenhum efeito, nem declaratório; ela possuiria apenas elemento declaratório. Assim, continua Botelho de Mesquita, não existe coisa julgada secundum eventum litis, pois a imutabilidade e a indiscutibilidade do julgado operam-se toda vez que uma sentença transita em julgado. O que é secundum eventum litis é a eficácia da sentença, pois depende do conteúdo da decisão (cf. "A coisa julgada no Código do Consumidor", pp. 143/144).

${ }^{912}$ Cf. Carpi, L'efficacia..., n. 33, p. 144.

913 Cf. Monteleone, I limiti..., n. 12, p. 141; Ada Pellegrini Grinover, Notas a Liebman, "Ações concorrentes", pp. 231/232; e Edoardo Ricci, "Sugli effetti...”, pp. 49 e seguintes.

914 Cf. Diritto processuale..., v. 1, p. 494. A questão, de fato, não é pacífica, e já autores clássicos negaram referida teoria, como era o caso de Alfredo Rocco (cf. Le società..., nn. 174 e 177, pp. 246 e 251).
} 
caso em exame, ${ }^{915} \mathrm{e}$, de outro, existe um postulado geral que determina que a coisa julgada independe do conteúdo da decisão. ${ }^{916}$ Segundo porque, havendo identidade de causa de pedir, os direitos de todos os legitimados são idênticos ou, na expressão de Allorio, fungíveis. Logo, se um deles é rechaçado, a rejeição é também dos demais. ${ }^{917} \mathrm{O}$ entendimento, ainda, é inadequado para o caso de algum sócio pretender a validade da deliberação. ${ }^{918}$ Trata-se, pois, de um equívoco transparente, como pontuou Ovídio Baptista da Silva. $^{919}$

Não convence, ademais, o argumento de que a sentença de improcedência não vincula os terceiros porque se quer evitar que eventual conluio entre as partes tranque a via impugnatória. ${ }^{920}$ Além de o conluio ser a patologia e não podermos traçar a regra geral de

915 E, conforme Allorio, a coisa julgada que varia de acordo com o resultado da sentença deve ser explicitamente consagrada na lei (cf. La cosa..., n. 158, p. 272). No mesmo sentido Carpi, para quem "l'eficcacia secundum eventum è ammissibilie soltanto in caso di espressa provisione legislativa, come ad esempio proprio nell'art. 2.377, comma $3^{\circ}$, c.c." (cf. L'efficacia..., n. 36, p. 156).

${ }^{916}$ Cf. Barbosa Moreira, "Coisa julgada: extensão subjetiva...", p. 283. Igualmente, Carpi diz que a ideia de que a coisa julgada se põe para todas as partes da mesma maneira se trata de um "principio da lungo tempo" (cf. L'efficacia..., n. 67, p. 347); o que, é evidente, não significa que a regra não possa apresentar exceções.

917 Cf. Vícto Fairen Guillén, El processo..., cap. IV, n. 3, p. 73; Ada Pellegrini Grinover, Notas a Liebman, “Ações concorrentes", p. 232; e Barbosa Moreira, Litisconsórcio unitário, n. 86, p. 148.

${ }^{918}$ Cf. Eduardo Talamini, Coisa julgada..., n. 2.5.2, pp. 99/100.

${ }^{919}$ Cf. "Eficácias da sentença...", n. 8, pp. 117/118. Daí por que, para o ilustre professor gaúcho, mesmo a sentença que anule a deliberação "não impedirá que outro sócio, ou até mesmo, um terceiro, estranho à sociedade, se legitime para impugnar a sentença anulatória, visando a restaurar o ato anulado", no que foi seguido por José Rogério Cruz e Tucci (cf. "Impugnação judicial...”, n. 2, p. 467). Também Chiovenda rejeitou a coisa julgada secundum eventum litis: "Rejeite-se a opinião eclética; pois, com vemos acima, a coisa julgada tem efeito, não secundum eventum litis, mas para ambas as partes. Uma vez, portanto, que o próprio vencido pode opor a coisa julgada a todos quantos lhe estão sujeitos, não pode depender da vontade de um interessado, sequer estranho à lide, fazer valer ou não a coisa julgada, conforme lhe convenha; e, logo, a coisa julgada deve ou obrigar ou não obrigar os cointeressados não partícipes, qualquer que seja o evento da lide" (cf. Instituições..., v. I, n. 135, p. 417). Sobre o assunto, v., ainda, Willis Santiago Guerra Filho, "Efficacia ultra partes...", p. 192.

${ }^{920}$ Nesse sentido, conquanto não tenha expressamente adotado a ideia de que a coisa julgada erga omnes em ações concorrentes deve ser rejeitada por conta da possibilidade de fraude, ao fazer considerações sobre a ação popular e a impugnação de deliberação, Arruda Alvim afirmou que, em razão do risco de conluio, talvez fosse o caso de ser revista a extensão erga omnes da sentença na ação popular: "Qual, porém, o grande fundamento econômico ou moral, condicionador da solução indicada? Era o problema da moralidade das sociedades comerciais, no sentido de que, se houvesse realmente um negócio fraudulento, se se considerasse que teria havido coisa julgada, seria muito fácil um sócio mancomunado com a direção da sociedade anônima intentar um processo fraudulento e, obtida a coisa julgada com conteúdo não anulatório do negócio (isto é, a sentença improcedente), estaria tamponada a via judicial para qualquer outra ação. Ora, tais ponderações, se aplicáveis no campo do Direito Privado, talvez recomendassem uma revisão da coisa julgada na ação popular, no âmbito do Direito Público, nos termos em que foi feita. Vários autores são unânimes em considerar que a ação popular está preordenada a garantir a moralidade da Administração Pública, no sentido de dar aos cidadãos uma administração decente e moralizada, mercê de fiscalização jurisdicional. Conseqüentemente, talvez, fosse o caso de se rever a extensão erga omnes consagrada em lei" (cf. Código..., v. I, p. 445). Em outro volume de seu Código de Processo Civil Comentado, o ilustre professor da PUC/SP torna a falar em fraude no contexto da anulação de deliberação assemblear (v. II, p. 390). 
acordo com esta, ${ }^{921}$ o sistema conta com mecanismos de proteção à fraude e simulação, como será visto no item 26.1.3. No Brasil, enfim, nada há a autorizar a coisa julgada secundum eventum litis na impugnação de deliberações assembleares.

\subsection{Teorias que defendem a coisa julgada erga omnes em decorrência da natureza da relação jurídica material}

Existem outras inúmeras teorias que defendem a coisa julgada ultra partes e que, apesar de apresentarem muitas peculiaridades, ostentam um aspecto comum: invocam as características da relação de direito material para justificar referida extensão.

Já em 1898 Alfredo Rocco escreveu que, embora em decorrência do fato de que a sociedade constitui ente personalizado distinto de seus sócios, a sentença pronunciada contra aquela não pode vincular o sócio, essa regra não se aplica à sentença proferida em processo de anulação de deliberação assemblear. Neste caso, a sentença é eficaz perante todos os sócios, uma vez que os não dissidentes - isto é, aqueles que não impugnam a deliberação em juízo, pois de acordo com sua teoria para assumir a qualidade de dissidente não basta ter votado contra a deliberação em assembleia, é preciso impugná-la em juízo são representados pela sociedade. Caso contrário, se fosse dado aos sócios desconhecer o estado de direito que resultou da sentença, haveria a estranha situação em que deliberação seria válida para uns e não para outros. De acordo com Rocco, portanto, não há representação pelo sócio que vai a juízo, como defende a doutrina que advoga a tese da substituição processual, mas sim representação pela sociedade de todos os sócios que não vão a juízo. E o fundamento para tal representação, disse Rocco, é o contrato de sociedade, ${ }^{922}$ ou seja, a especial natureza da relação jurídica que une os sócios.

\footnotetext{
921 Nesse sentido vai Paulo Cézar Aragão, para quem a coisa julgada é erga omnes em decorrência de substituição processual: "Este argumento ad terrorem, no entanto, não pode ser aceito, pois, como se sabe, 'abusus non tollit usus"”. (cf. "Aspectos processuais...”, p. 64). Considerações análogas foram feitas por Marcelo Von Adamek a respeito da possibilidade de, na demanda de responsabilidade de administrador, haver conluio entre o substituto processual e o demandado, em prejuízo da companhia (cf. Responsabilidade civil..., n. 8.8.2, p. 491).

922 Cf. Le società commerciale in rapporto al giudizio civile, nn. 173-B/177, pp. 244, 244/245 e 251/252: "L'unico critério dunque da cui si possa partire per giungere a risultati apprezzablie è quello, già ripetuto, che fra i soci non essendovi personalità, i rappresentanti della società sono i rappresentanti della colletività dei soci, e quindi di tuttti i non dissidenti: e perciò di fronte a tutti deve dirsi che la sentenza pronunciata costituisce res iudicata, senza alcuna distinzione, od eccezione".
} 
Mesmo tendo defendido a regra geral de que os terceiros devem reconhecer a coisa julgada formada entre terceiros, exceto quando for para prejudicá-los, Chiovenda disse haver situações em que a relação que existe entre o Sujeito A e o B é tal que, à luz do direito material, referida relação não pode subsistir entre esses dois sem que exista também entre o Sujeito A e o C. Por isso, se houve o pronunciamento judicial a respeito da validade da relação entre aqueles dois primeiros, o provimento abarcará também o vínculo entre os Sujeitos A e C. Não por conta de uma extensão do julgado ou porque o Sujeito C esteve representado, mas em razão da natureza do direito. ${ }^{923}$

Um ato jurídico não pode existir para uns e não para outros. Em razão disso, nos casos em que há concorrência de direitos potestativos à anulação desse ato, a coisa julgada formada no processo, sustentou Chiovenda, exclui o direito de impugnar dos demais cotitulares, porque não é possível anular um ato para um acionista quando já fora reconhecida a sua validade perante outro deles. A especial natureza do direito debatido mitiga a regra geral de que a coisa julgada só se opera entre as partes. O enunciado de identidade subjetiva sofre, nesse âmbito, profunda alteração: o que está em jogo é o ato jurídico, e as pessoas passam em segundo plano. Os sócios, perante a sociedade - e também os administrados perante o Poder Público -, encontram-se em uma condição comum, e a natureza da relação que entre eles há, no confronto com o ato da autoridade, faz com que a coisa julgada seja imposta a todos. ${ }^{924}$

\footnotetext{
${ }^{923}$ Cf. Chiovenda, Instituições..., v. I, n. 135, p. 417.

${ }^{924}$ Cf. Chiovenda, Instituições..., v. I, nn. 109 e 135, pp. 356 e 419/420: "devendo necessariamente o ato impugnável subsistir ou não para todos quantos lhe estão sujeitos (por sua qualidade de sócios ou de administrados), sòmente pode haver uma decisão, embora as ações sejam subjetivamente diversas; a identidade da qualidade substitui, nesta hipótese, a identidade da pessoa; a coisa julgada, constituída com respeito a um, exclui a ação dos outros" e "a regra, portanto, de que uma sentença não pode ter importância relativamente às ações de terceiros, sofre alguma limitação, decorrente da natureza especial de alguns direitos. São êstes os correspondentes às relações em que diversos titulares de direito estão todos sujeitos ao ato que se vai mudar, e, por conseqüência, se acham ligados por essa qualidade comum entre eles, como sucede a todos os que estão sujeitos aos atos de uma mesma autoridade (Estado, Município, sociedade. (...) Sòmente podem manter-se ou anular-se tais atos com respeito a todos. O estarem diversas pessoas sujeitas ao mesmo ato coloca-se numa condição comum, que explica como são prejudicadas por uma sentença proferida em relação a qualquer entre os que se encontram naquela condição, se bem que sejam terceiros no tocante a essa sentença, e não representados no processo". No mesmo sentido, v., "Sul litisconsorzio...", pp. 449/451, inclusive nota 1 da página 449: "Qui torno a dire che la questione non deve porsi sulla influenza della cosa giudicata di fronte ai terzi, ma sulla esistenza di rapporti giuridici tali, secondo il diritto civile, che non possano esistere fra A e B senza insieme esistere necessariamente fra A e C" e "fra i soci corre un rapporto tale che il diritto d'impugnazione non può spettare ad uno se fu negato rispetto ad altri”.
} 
Acolhendo essa lição, Víctor Fairen Guillén defendeu que a coisa julgada obtida em demanda de impugnação de deliberação aplica-se a todos os sócios, não porque o autor da demanda representou os demais, mas porque todos eles estão ligados à sociedade por uma única e mesma relação no que se refere à deliberação, de modo que o pronunciamento judicial sobre tal relação diz respeito a todos. A qualidade da relação jurídica, assim, substitui a identidade pessoal dos litigantes. ${ }^{925}$

Por sua vez, Betti afirmou que a coisa julgada produz-se em relação aos terceiros em situações em que a posição jurídica desses é subordinada à relação deduzida em juízo, de modo que é vedado ao terceiro desconhecer/desconsiderar o julgado. Esse nexo de subordinação pode ocorrer em quatro hipóteses: (i) sucessão, (ii) substituição processual, (iii) conexão incindível (concorrência alternativa) entre relações jurídicas e (iv) dependência necessária. ${ }^{926}$

Nos casos em que há concorrência alternativa entre a relação litigiosa e a relação jurídica mantida com o terceiro, existiria entre os sujeitos titulares das ações concorrentes uma relação de subordinação recíproca e eventual, resultante da interdependência que há entre eles. Após a litis contestatio - momento a partir do qual a resposta à demanda é apresentada e, assim, são conhecidos (e estabilizados) os limites da controvérsia ${ }^{927}$ - a subordinação, de eventual e recíproca, torna-se unilateral e efetiva. O ajuizamento da demanda cria a favor do cotitular uma prevenção para o exercício ativo da ação, ${ }^{928}$ prevenção que, prosseguiu Betti, consiste em que, tornando-se litigiosa a relação jurídica, as outras relações jurídicas com ela concorrentes não mais poderão tornar-se litigiosas com eficácia jurídica, nem no juízo pendente, nem em outro qualquer. Assim que uma ação concorrente é exercida, as ações dos demais cotitulares tornar-se-iam preclusas. ${ }^{929-930}$

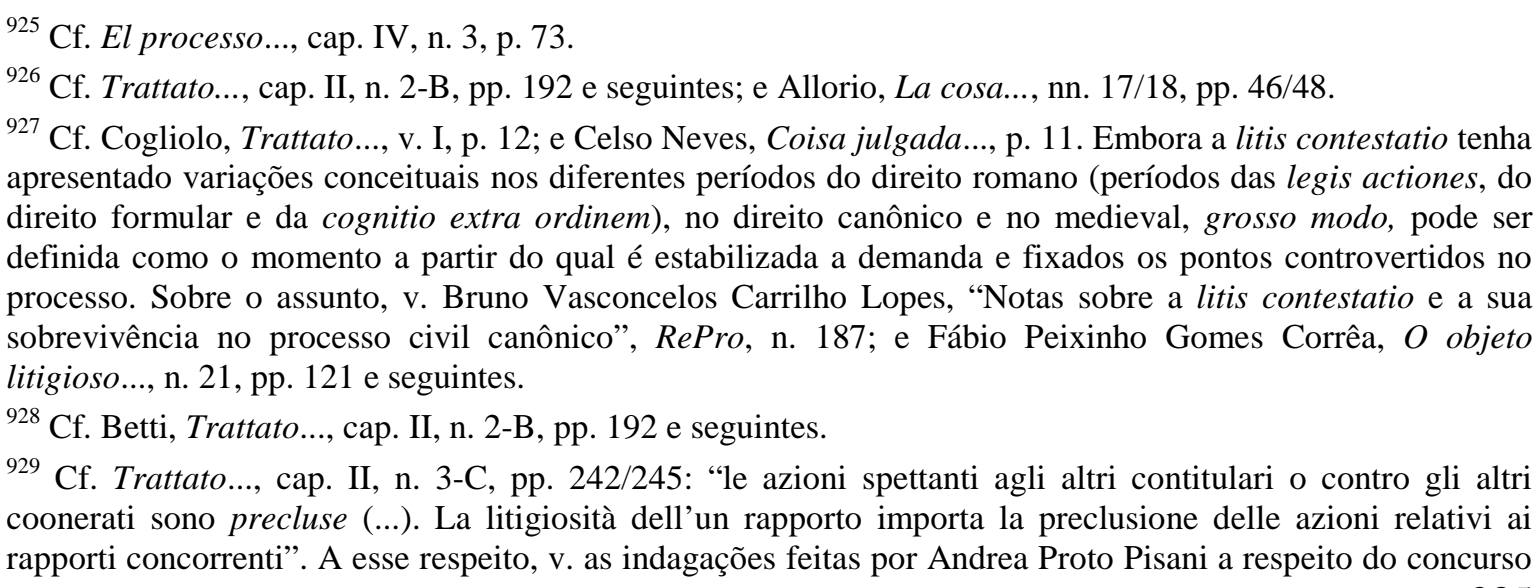


Por efeito de referida preclusão, poder-se-ia objetar a exceptio rei in iudicium deducta, enquanto o processo é pendente, ou a exceptio rei iudicatae, se já há coisa julgada. ${ }^{931} \mathrm{Com}$ algumas diferenças, mas em sentido análogo, sustentou Redenti que, ao contrário da opinião comum de que se forma coisa julgada para os terceiros no julgamento da impugnação de deliberação assemblear, não há coisa julgada, mas sim consumação da ação, pela preclusão da possibilidade de ser reproposta a mesma demanda. ${ }^{932}$

Ainda na doutrina italiana, Allorio distinguiu dois fenômenos em que a coisa julgada alcança terceiros: a reflexão e o alargamento (ou extensão).

O primeiro deles, regular e natural, ocorre quando entre a relação decidida e outra exterior existe nexo de prejudicialidade-dependência (subordinação) de modo que seja juridicamente relevante, para a segunda relação, a existência daquela primeira. É o que ocorre, por exemplo, nos casos de sucessão universal e particular e de garantia. Em um momento posterior, em que o julgador é chamado a decidir sobre essa segunda relação, deve ser considerada a primeira decisão como incontroversa e condicionante. ${ }^{933}$ Há, neste caso, eficácia reflexa da coisa julgada: a sentença transitada em julgado reflete-se sobre a relação dependente, ainda que esta envolva terceiros.

O segundo fenômeno, especial e excepcional, se dá quando, em decorrência de uma relação de coordenação necessária entre direitos concorrentes, o julgado atinge direta e imediatamente o terceiro, havendo, portanto, eficácia direta da coisa julgada. Aqui, a posição do terceiro em nada se diferencia da posição de parte, e a necessidade de que a sua situação receba a mesma regulação que a do outro sujeito deve-se a razões práticas, e não a uma relação de subordinação, como na outra hipótese: enquanto que a relação de

de direitos (ou de ações), no qual supostamente o exercício de um desses direitos extinguiria os demais (cf. “Appunti sul giudicato...", pp. 402/405).

930 A teoria desenvolvida por Betti é, de certa forma, uma variação do brocardo do período romano préJustinianeu "quoties concurrant plures actiones eiusdem rei nomine, una quis experiri debet" (ULP, 43, § $1^{\circ}$, D., 50, 17), que, de acordo com Liebman, enuncia genericamente que o exercício de uma ação apresenta eficácia extintiva sobre as demais que lhe são concorrentes (cf. “Ações concorrentes”, pp. 209/210).

${ }^{931}$ Cf. Betti, Trattato..., cap. II, n. 3-c, pp. 247/248.

932 Cf. Il giudizio..., cap. I, n. 43, pp. 57/60.

${ }^{933}$ Cf. Allorio, La cosa..., n. 33, p. 71: "L'accertamento del rapporto pregiudiziali influisce sul rapporto dipendente per questa via: che quella della fattispecie del rapporto dipendene, che è costituita dal rapporto pregiudiziale, resta fissata secondo le linee tracciate nella sentenza". V., ainda, Monteleone, I limiti..., n. 3, pp. $28 / 29$. 
prejudicialidade-dependência é uma decorrência natural da estrutura interna dos direitos, a de coordenação necessária impõe-se mais por razões práticas do que jurídicas. E o típico setor em que ocorre esse segundo fenômeno, de alargamento da coisa julgada, é o das relações jurídicas similares, dentre as quais se situam os direitos potestativos concorrentes. $^{934}$

Entre os direitos concorrentes, prossegue Allorio, não há relação de prejudicialidade-dependência, uma vez que um não está subordinado ao outro; o que existe é coordenação necessária. E o exemplo invocado é o da deliberação assemblear viciada: se o autor da demanda aceita o vício e, assim, desiste da demanda, esse ato não produzirá nenhum efeito sobre os direitos concorrentes dos demais sócios, pois entre eles não há subordinação ou prejudicialidade. ${ }^{935}$ A prejudicialidade-dependência gera a eficácia reflexa da coisa julgada, enquanto que a coordenação necessária leva ao alargamento da coisa julgada; aquela é o regime normal da eficácia da coisa julgada ao terceiro, este o excepcional.

Ainda conforme essa teoria, em caso de direitos concorrentes à anulação de um ato jurídico - e o típico seria o do art. 163 do revogado Código Comercial italiano -, o resultado vinculará os demais titulares desses direitos concorrentes à anulação, como decorrência do alargamento da coisa julgada. A sentença de improcedência extingue o direito dos demais sócios à anulação, pois tais direitos tornam-se incompatíveis com o novo regramento estabelecido pelo julgado. $O$ alargamento da coisa julgada e o litisconsórcio necessário atendem à mesma exigência prática de impor coordenação e uniformidade entre decisões que regulam mais de uma relação jurídica. ${ }^{936}$ Allorio, assim, negou a ideia bettiana de que o julgamento de uma ação leva à preclusão das demais ações que lhe são concorrentes. Nesse caso, há verdadeiro alargamento da coisa julgada, de modo que esta abarque também a relação de terceiros titulares de direitos potestativos

\footnotetext{
${ }^{934}$ Cf. Allorio, La cosa..., nn. 29, pp. 64 e seguintes, e 69, pp. 120 e seguintes; e Monteleone, I limiti..., nn. 2 e 10, pp. 18/24 e 115 e seguintes, que, contudo, dirige duras críticas ao conceito de eficácia reflexa da coisa julgada, negando-a (n. 9, pp. 105/114).

${ }^{935}$ Cf. Allorio, La cosa..., nn. 68/69, pp. 119/121.

${ }^{936}$ Cf. $L a$ cosa..., nn. 74 e 161, pp. 31 e 275: "Dopo la pronuncia di rigetto, non la azione è preclusa, ma il diritto d'impugnativa d'ogni terzo non esiste più, è estinto, perchè è incompatibile col nuovo regolamento che, dal giudicato, tutta la complessa situazione ha ricevuto. Il fenomeno che ci sta di fronte è, perciò, nient'altro che allargamento della cosa giudicata".
} 
concorrentes. ${ }^{937}$ Em suma, enquanto a eficácia reflexa da coisa julgada decorreria de um nexo de prejudicialidade-dependência entre duas relações, o alargamento da coisa julgada implica a existência de uma única e idêntica relação jurídica; ou de relações jurídicas paralelas mas estreitamente coligadas. É isso que justifica, para Allorio, a extensão da coisa julgada aos cotitulares da relação jurídica deduzida em juízo ou aos titulares de relações jurídicas coordenadas e conexas. ${ }^{938}$

Após realizar profunda resenha doutrinária e afirmar que em determinadas situações a coisa julgada estende-se aos terceiros, Pugliese distinguiu duas hipóteses. Na primeira, a situação jurídica objeto da sentença transitada em julgado é prejudicial à situação jurídica do terceiro, enquanto que na segunda é a mesma situação do terceiro, uma vez que, embora a parte do processo a quo não fosse o representante deste, estava autorizada a deduzir a situação jurídica relativa a este. É o caso, por exemplo, do colegitimado ao exercício de uma mesma demanda. Na segunda hipótese, o terceiro é cotitular da situação jurídica decidida ou titular de situação análoga. ${ }^{939}$ O terceiro da primeira hipótese é atingido pela eficácia reflexa, ao passo que o terceiro da segunda hipótese é atingido pela eficácia direta da coisa julgada. Em ambos os casos, contudo, são afetados pela imutabilidade resultante da coisa julgada. ${ }^{940}$

Prosseguindo com seu raciocínio, Pugliese diz que essa é uma teoria cabível de lege lata no direito italiano, na medida em que seria possível interpretar o art. 2.909 do Código Civil daquele país de modo que por "parti” se entenda não só as partes processuais, mas também as materiais, isto é, os titulares de situações idênticas ou análogas à já decidida. Defendeu também que, mediante interpretação extensiva da expressão "aventi causa", a coisa julgada se projeta para os terceiros que se encontram na primeira situação relatada, isto é, que sejam titulares de situação jurídica strettamente dipendente da situação objeto do julgado. E para que ocorra referida expansão da coisa julgada, diz, é necessário que (i) seja reconhecida a legitimidade das partes do processo a quo a deduzir, individual e integralmente, a situação jurídica que fundamenta a sua pretensão; ou seja, que tais sujeitos

\footnotetext{
${ }^{937}$ Cf. La cosa..., n. 161, p. 275. Dentre outras razões, Allorio diz não ser exatamente certo que o fenômeno da preclusão de direitos empregado na teoria bettiana exista no direito moderno, como existia no direito romano.

${ }^{938}$ Cf. Monteleone, I limiti..., n. 10, p. 116.

${ }^{939}$ Cf. Giudicato civile..., n. 30, p. 883.

${ }^{940}$ Cf. José Rogério Cruz e Tucci, Limites subjetivos..., n. 6.8, p. 93.
} 
sejam os legítimos contraditores. O segundo requisito é que (ii) o terceiro não se afirme o titular ou cotitular autônomo da situação jurídica já decidida ou de uma situação com essa incompatível, de maneira tal que lhe seja permitido deduzi-las em juízo. O último requisito é que (iii) não haja dolo ou colusão entre as partes do processo originário, cabendo, nesse último caso, ao terceiro oferecer opposizione di terzo revocatoria. ${ }^{941}$

Em suma, Pugliese extraiu da cotitularidade ou da relação de dependência entre terceiros e o julgado o fundamento para o entendimento de que tais terceiros são partes substanciais e, portanto, sujeitos à coisa julgada, sem que, para isso, seja necessário alterar a regra geral contida no art. 2.909 do CC italiano.

Também Carpi, em última análise, extraiu do caráter unitário do ato e da concorrência de direitos os fundamentos para a coisa julgada ultra partes na anulação de deliberações societárias e em todas as outras hipóteses em que se pede a invalidação de ato único que diz respeito a uma comunidade/organização. Embora trate apenas da anulação de deliberação, o art. 2.377 do Código Civil italiano assume, de acordo com esse autor, um significado paradigmático para todas aquelas outras hipóteses análogas: uma vez exercitada a pretensão impugnatória por algum dos interessados, a legitimidade à impugnação dos demais interessados converter-se-ia em legitimação à intervenção. ${ }^{942}$

Na doutrina alemã, Rosenberg defendeu que, embora em princípio a coisa julgada surta efeitos apenas entre as partes, há situações em que se aconselha e se justifica a sua extensão a terceiros, seja para beneficiá-los, prejudicá-los ou ambas as coisas. Dentre os casos em que a coisa julgada produz efeitos para e contra todos, arrolou as sentenças sobre invalidade de matrimônio, vínculo de paternidade e invalidade de deliberações societárias. Neste último caso, a ampliação subjetiva justificar-se-ia pela particularidade do objeto

${ }^{941}$ Cf. Giudicato civile..., n. 30, pp. 884/885. Tratando especificamente da hipótese em que há cotitularidade, pela qual cada um dos cotitulares possui um direito próprio para, individualmente e de forma autônoma, deduzi-lo em juízo, Pugliese afirma que o direito moderno responde a ela de duas formas opostas: ou ampliase a conexão entre esses direitos, de modo que se considere esse feixe de situações jurídicas um só complexo (processo de entificação), que, dotado ou não de personalidade jurídica, seja capaz de fazer valer esses direitos por meio de um órgão comum; ou amplia-se a autonomia do direito, restringindo-se, em contrapartida, a eficácia do ato individual ao sujeito a que deu causa ou à sua quota-parte no todo. Essa última tendência é o que ocorreria com as obrigações solidárias e as indivisíveis (pp. 886/887). E, de fato, como escreveu Attardi, existe na doutrina italiana uma orientação que defende que o art. 2.909 do Código Civil daquele país teria acolhido um conceito composto, que compreenderia também uma noção substantiva de parte; com o que não concorda Attardi (cf. Diritto processuale..., v. 1, p. 483).

${ }^{942}$ Cf. L'efficacia..., n. 36 , pp. 155/156. 
litigioso e pelo fato de que, por motivos de conveniência, quer-se evitar a confusão produzida por decisões contraditórias. Assim, a coisa julgada produz-se para e contra todos os materialmente interessados na relação controvertida. ${ }^{943}$ No mesmo sentido, também afirmando haver exceções à regra de limitação subjetiva da coisa julgada, Goldschmidt, ${ }^{944}$ Jauernig $^{945}$ e Shönke. ${ }^{946}$

Na Espanha, Andrés de la Oliva Santos escreveu que, em razão da especial natureza do direito objeto da sentença e da interdependência de relações jurídicas, há situações em que se ampliam os limites subjetivos da coisa julgada. E, de fato, especificamente no caso da impugnação de acuerdos societarios, o legislador espanhol teria optado por atender a uma necessidade de que a decisão valha para todos os sócios, reputando que os instrumentos de intervenção processual, de acumulação de causas conexas e os mecanismos de informação sobre o funcionamento dos órgãos sociais sejam suficientes para que se afaste o risco de prejuízo ao direito dos terceiros ("Las sentencias que se dicten sobre impugnación de acuerdos societarios afectarán a todos los socios, aunque no hubieren litigado"; Ley de Enjuiciamento Civil, art. 222.3, par. $\left.3^{\circ}\right) .{ }^{947}$ Ainda dentre os espanhóis, Sonia Calaza López admite a excepcionalização da regra de relatividade da coisa julgada em hipóteses em que haja conexão ou interdependência entre relações jurídicas, como, por exemplo, nas questões de estado e na impugnação de deliberações societárias. Especificamente neste último caso, diz, a extensão de efeitos justifica-se não apenas na celeridade do tráfego societário e na possibilidade de uma multiplicação massiva de processos, mas, fundamentalmente, na necessidade de segurança jurídica, que nesse âmbito é mais vulnerável do que de costume. ${ }^{948}$

Entre nós, quem primeiro acolheu, de maneira fundamentada, a coisa julgada ultra partes na hipótese aqui analisada foi Barbosa Moreira, que, também reconhecendo a influência do direito material na conformação da coisa julgada, escreveu que a cabal

\footnotetext{
${ }^{943}$ Cf. Tratado..., t. II, n. 151, pp. 501/504.

${ }^{944}$ Cf. Derecho procesal..., n. 63, pp. 393/395.

${ }^{945}$ Cf. Direito processual..., n. 63, pp. 328/330.

${ }^{946}$ Cf. Derecho procesal..., n. 77, pp. 277/280.

${ }^{947}$ Cf. Objeto del processo..., pp. 184 e 189/191.

${ }^{948}$ Cf. La cosa juzgada, cap. IV, nn. 7.1 e 7.1.3, pp. 160 e 174/175.
} 
explicação da unitariedade do litisconsórcio ${ }^{949}$ e da extensibilidade da coisa julgada está em uma peculiar característica da situação jurídica substancial. Nesse sentido, defendeu que certas situações plurissubjetivas apresentam vinculação tão íntima e uniforme que qualquer regra jurídica concreta que altere essa situação substancial deve ser uniforme para todos os nela envolvidos. ${ }^{950}$ Assim, ao analisar a hipótese dos colegitimados para impugnação de um mesmo ato incindível, Barbosa Moreira disse que a norma jurídica concreta imposta no processo deve valer para todos, pois o ato não pode subsistir para uns e não para outros. Admitir o contrário geraria um conflito entre julgados não apenas lógico, mas prático. ${ }^{951}$

Firmada essa premissa, o jurista carioca concluiu que, em situações unitárias plurissubjetivas, não só é caso de litisconsórcio unitário - isto é, devem todos os litigantes ocupantes do mesmo polo processual receber idêntico tratamento - como também a coisa julgada deve alcançar os que permaneceram estranhos ao processo, quer na procedência, quer na improcedência. Isso seria um mal menor do que permitir o conflito de julgados. ${ }^{952}$ E ainda que não haja regra expressa acolhendo essa posição no direito brasileiro, ela é de ser admitida entre nós, disse Barbosa Moreira. ${ }^{953}$ No fim das contas, portanto, o ilustre

${ }^{949}$ O critério para identificar a unietariedade é o seguinte: "Daí se pode tirar o critério utilizável para reconhecer-se, processualmente, a ocorrência da unitariedade. O eixo e referência é sempre o resultado prático a que tende o processo, à vista do pedido e da causa petendi. Se esse resultado for tal que haja de incidir sobre ponto de inserção homogênea dos vários co-autores ou co-réus na situação jurídica substancial, o litisconsórcio será ativa ou passivamente unitário" (cf. Barbosa Moreira, Litisconsórcio unitário, n. 85, p. 146).

${ }^{950}$ Cf. Litisconsórcio unitário, n. 83, pp. 142/143.

${ }^{951}$ Cf. "Coisa julgada: extensão subjetiva...", p. 275. Lembram-se as palavras de Liebman de que "o simples conflito teórico de julgados não pode obstar à rigorosa aplicação dos princípios da coisa julgada e de seus limites subjetivos" (cf. "Ações concorrentes", aditamento "f", p. 220). No caso, contudo, o conflito não é meramente teórico. De acordo com Araújo Cintra, há dois tipos de conflitos entre decisões. O primeiro é o abstrato, que diz respeito meramente à divergência no direito em tese, isto é, nas teses jurídicas adotadas pelos julgados contraditórios. O segundo é o conflito concreto, que se dá quando se resolve diferentemente "quanto às mesmas pessoas ou aos mesmos bens, as questões suscitadas em juízo". Essa segunda espécie de divergência é resolvida mediante os institutos da litispendência e da coisa julgada. Embora o direito conviva com o conflito abstrato, ele é pernicioso ao sistema, diz Araújo Cintra, segundo o qual "o mais adequado instrumento processual utilizado para se evitar a contradição parcial de julgados é o litisconsórcio que congregue em juízo o maior número de pessoas interessadas nos bens jurídicos controvertidos" (cf. Do litisconsórcio, cap. I, n. 4, pp. 15/18).

${ }^{952}$ Cf. Litisconsórcio unitário, nn. 83, pp. 144/145.

${ }^{953} \mathrm{E}$ como óbice aos que poderiam dizer que esse entendimento só poderia ser esposado diante de norma que excepcionasse a regra geral, argumenta com a doutrina italiana, que, antes do art. 2.377 do Código Civil daquele país, já defendia a mitigação à regra de relatividade de coisa julgada na impugnação de deliberação assemblear. Ou seja, mesmo diante da regra geral limitadora da autoridade da coisa julgada já se defendia naquele país a imposição da coisa julgada aos demais acionistas: "mesmo em um sistema jurídico dotado de norma expressa limitadora, no plano subjetivo, do âmbito de atuação da auctoritas rei iudicatae, não trepidam os especialistas em saltar por sôbre a letra da lei para admitir, em casos como o de que trata a 
jurista deduz da unitariedade do ato jurídico a extensão da coisa julgada a todos os litisconsortes potenciais. ${ }^{954-955}$

A coisa julgada obtida em demanda anulatória de deliberação, assim, vincularia todos os interessados, independentemente do resultado do processo. A explicação para a extensão da coisa julgada para os litisconsortes potenciais, portanto, está em plano puramente processual e consistiria na impossibilidade de haver coisas julgadas contraditórias. $^{956}$

Também Moacyr Lobo da Costa afirmou que, quando há pluralidade de legitimados para o ajuizamento de demanda constitutiva, não só a sentença que acolhe ou rejeita a pretensão de um deles, mas também a coisa julgada é eficaz no confronto de todos, pois exclui a ação dos demais. Isso ocorreria com a ação popular, as demandas de anulação de casamento, invalidação de deliberação de sociedade anônima e, de modo geral, com todas as demandas de nulidade de ato jurídico. ${ }^{957}$ Por sua vez, Sérgio Ferraz sustentou que os litisconsortes facultativos unitários que poderiam ter participado do processo, mas não o fizeram (quer porque não quiseram intervir, quer porque não foram cientificados), serão atingidos pela coisa julgada, uma vez que a sentença relativa a uma relação jurídica unitária é prejudicial ao julgamento de qualquer outra demanda que possa

consulta, a extensão do vínculo aos terceiros co-legitimados" (cf. "Coisa julgada: extensão subjetiva...”, pp. 285/286).

${ }^{954}$ Cf. “Coisa julgada: extensão subjetiva...”, p. 289; e Litisconsórcio unitário, n. 80, p. 139. Embora adotem a tese restritiva dos limites subjetivos da coisa julgada, que, com base no mandamento constitucional que protege o contraditório, restringe a coisa julgada às partes do processo, Comoglio-Ferri-Taruffo aparentemente também entendem pela extensão da coisa julgada em casos específicos de cotitularidade da situação substancial plurissubjetiva deduzida em juízo (cf. Lezioni..., cap. 26, n. 6, p. 766). Voltando ao Brasil, Paulo Cézar Aragão é outro autor que defende a coisa julgada erga omnes, mesmo à míngua de disposição legal autorizadora expressa (cf. "Aspectos processuais...", p. 64). Sobre unitariedade do direito material e a sua consequência no processo, v. Gabriel de Rezende Filho, Curso de direito processual civil, v. I, p. 258.

955 Barbosa Moreira, ademais, invocou o fato de que, à época em que escrito o ensaio ora analisado - 1969, antes do CPC de 1973, portanto - não havia norma de caráter geral que limitasse às partes processuais o vínculo da coisa julgada. (cf. "Coisa julgada: extensão subjetiva...”, p. 287). E, de fato, o CPC de 1939 não trazia nenhuma regra semelhante ao art. 472 do CPC de 1973. Tanto é que, nos comentários ao art. 472 do CPC/73, Moacyr Amaral Santos anota: "DIREITO ANTERIOR - Omisso o Código de Processo Civil de 1939" (cf. Comentários..., v. IV, n. 366, p. 485). De toda forma, afirmou Barbosa Moreira, mesmo a doutrina que reconhece a validade da regra geral não lhe confere validade absoluta, conferindo-lhe temperamentos (cf. "Solidariedade ativa: efeitos da sentença e coisa julgada na ação de cobrança proposta por um único credor", in Revista do Advogado, n. 84, dez/05, p. 71). No mesmo sentido Jorge Salomão, ao afirmar que "no Brasil, já o frisamos, o ordenamento vigente não indica, de modo explícito, quais sejam os limites subjetivos da coisa julgada" (cf. Da coisa julgada nas ações de estado, n. 90, p. 116).

${ }^{956}$ Cf. Barbosa Moreira, Litisconsórcio unitário, nn. 79/80, pp. 138 e 140.

${ }^{957}$ Cf. Assistência, n. 9, p. 123. 
contrariar referida sentença. Tal entendimento, diz o autor, não colide com o art. 472 do CPC, uma vez que a pessoa que não ingressou no processo, mas está sujeita à unitariedade no plano material, não é considerada terceiro, já que terceiro é aquele totalmente estranho à lide. ${ }^{958}$

Em artigo publicado em agosto de 2005 e, posteriormente, na quarta edição da tradução do livro de Liebman Eficácia e autoridade da sentença e outros escritos sobre a coisa julgada, de 2006, Ada Pellegrini Grinover afirma ter revisto, em suas próprias palavras, sua posição "intransigente" de total indiferença da coisa julgada por todo e qualquer terceiro e passado a seguir a ideia de que a coisa julgada é erga omnes em decorrência da indivisibilidade do objeto da demanda e da identidade de situações jurídicas. ${ }^{959} \mathrm{~A}$ ilustre professora afastou a crítica de que essa posição violaria as garantias do devido processo legal e do contraditório mediante a adoção da ideia de que o autor da demanda seria substituto processual dos demais colegitimados. Embora não haja disposição legal que autorize o sócio a pleitear em nome próprio direito alheio, diz Grinover que basta uma operação de simples hermenêutica para se entender que o sócio é substituto dos demais sócios, uma vez que já mesmo antes da Lei de Ação Civil Pública a doutrina interpretava elasticamente o art. $6^{\circ}$ do CPC para, nas obrigações indivisíveis, conferir legitimidade para a ação coletiva ao membro do grupo, sob o fundamento de que defenderia interesse que é, ao mesmo tempo, próprio e alheio. ${ }^{960}$ Barbosa Moreira disse que quando se trata de direitos indivisíveis há razões não só lógicas mas práticas que exigem uniformidade de decisões para todos os virtuais litisconsortes unitários. Seria,

\footnotetext{
${ }^{958}$ Cf. Assistência litisconsorcial..., n. 5, pp. 39/41. Embora sem fazer referência, Sérgio Ferraz valeu-se do entendimento de Pugliese exposto anteriormente.

${ }^{959}$ Cf. "Coisa julgada erga omnes...", p. 13; e Notas a Liebman, "Eficácia e autoridade...", p. 114: "Hoje, revendo minha posição anterior, manifestada na $3^{\text {a }}$ edição desta obra, entendo que mesmo a rejeição do pedido de anulação da assembleia faz coisa julgada erga omnes, dada a indivisibilidade do objeto da demanda e o litisconsórcio facultativo necessário que se estabelece entre os sócios". Cremos que há erro material quando a autora alude ao "litisconsórcio facultativo necessário", pois essa é uma contradição em termos. Acreditamos que o que ela quis dizer é "litisconsórcio facultativo unitário", que é o que fora afirmado na p. 9 do mesmo artigo. No mesmo sentido: "Revendo minha posição anterior, radicada em uma postura intransigente de total indiferença à coisa julgada por todo e qualquer terceiro, acompanho hoje a posição sempre lúcida de BARBOSA MOREIRA, que demonstra que a extensão a terceiros, virtuais litisconcortes unitários, da coisa julgada que verse sobre bem de natureza indivisível torna impossível a formulação de regras jurídicas concretas em relação àqueles que, se participassem do juízo, obteriam sentenças uniformes" (cf. notas a Liebman, "Ações concorrentes", p. 233).

${ }^{960}$ Cf. notas a Liebman, “Ações concorrentes”, p. 234.
} 
assim, a natureza das coisas quem obriga a coisa julgada erga omnes, em detrimento das garantias constitucionais do contraditório e da ampla defesa. ${ }^{961}$

Também mais recentemente, em excelente obra sobre o tema da coisa julgada coletiva, Camilo Zufelato aludiu ao absolutismo do art. 472 do CPC, que, embora tenha positivado a limitação inter partes da coisa julgada de forma absoluta, filiando-se a um obsoleto modelo individualista de limites subjetivos da coisa julgada, inapto a dar resposta a uma realidade de interdependência de relações jurídicas, ${ }^{962}$ não impediu que a doutrina apontasse a insuficiência desse regramento. ${ }^{963}$ Assim, haveria no direito pátrio e alienígena uma evidente transformação pela qual vem passando o princípio de restrição da coisa julgada às partes. Apesar de a teorização dos processos coletivos ser recente - nos sistemas de civil law iniciada apenas nos anos de 1960 -, busca suas origens em hipóteses já antigas de expansão da coisa julgada para terceiros. Trata-se, assim, do instrumento adotado para tutelar adequadamente situações materiais que não são estritamente individuais. Em certas situações, em que o objeto do processo não está adstrito às partes do processo, a coisa julgada atingirá terceiros que estejam vinculados à relação jurídica apreciada. ${ }^{964}$

Ocorre, assim, o que Zufelato chama de coletivização da coisa julgada, justificada pela característica não exclusivamente individual do direito material objeto da controvérsia, ou seja, pela indivisibilidade do objeto do processo e identidade de situações jurídicas. ${ }^{965}$ A coletivização da coisa julgada seria algo presente já desde a concepção do instituto, que foi desvirtuada pelas primeiras codificações civis modernas. Adotar a regra de relatividade da coisa julgada de modo absoluto é negar não só a natureza das coisas mas as próprias raízes históricas do instituto. Em certas situações, portanto, a coisa julgada

\footnotetext{
961 Cf. "Coisa julgada erga omnes...", p. 17.

962 Cf. Coisa julgada..., n. 3.5, p. 125.

963 Cf. Coisa julgada..., n. 3.5, p. 125. Veja-se, por exemplo, a afirmação de Dinamarco de que "da regra romanística de limitação da coisa julgada às partes (...) poderia emanar a impressão de que jamais alguém, sem ter sido parte no processo, viesse de algum modo a suportar qualquer vínculo inerente à auctoritas rei judicatae. Mas a realidade mostra que as coisas não se passam precisamente assim e que o próprio art. 472 oferece uma primeira abertura para a mitigação da aparente rigidez" (cf. Instituições...v. III, n. 963, p. 316). Também Couture apontou que a regra de relatividade da coisa julgada é apenas um enunciado de princípio: "por principio, la cosa juzgada alcanza tan solo los que han litigado" (cf. Fundamentos..., n. 275, p. 344).

${ }^{964}$ Cf. Coisa julgada..., n. 3.8.2, pp. 161/162: “A relevância da extensão subjetiva da coisa julgada se projeta exatamente no momento em que no âmbito do direito privado existem situações que não se enquadram de modo exclusivo no arquétipo puro de direito subjetivo, mudança esta que impõe a necessidade de modificações na estrutura do direito processual, tais como a legitimação para agir a eficácia do julgado".

${ }^{965}$ Cf. Coisa julgada..., n. 3.8.2, pp. 163 e 171.
} 
apresenta força expansiva, ultrapassando as partes entre as quais foi dada a sentença. E, novamente, um desses casos seria o da impugnação de deliberação assemblear. ${ }^{966}$

\subsection{Direito comparado: tendência ao alargamento da coisa julgada}

Como já visto pela análise da doutrina feita no item precedente, existe uma tendência dos países da Europa continental em expandir ultra partes a coisa julgada na impugnação de deliberações assembleares.

Na Itália, como exposto em diversas passagens deste trabalho, o art. 2.377 do Código Civil impõe a coisa julgada ultra partes na impugnação de deliberação assemblear, que, de acordo com a doutrina dominante, aplicar-se-ia apenas aos casos de procedência, ${ }^{967}$ conquanto, também como já exposto, haja doutrina minoritária que sustente a expansão subjetiva também na improcedência. ${ }^{968}$

Em Portugal, o art. 61 do Código das Sociedades Comerciais determina que "a sentença que declarar nula ou anular uma deliberação é eficaz contra e a favor de todos os sócios e órgãos da sociedade, mesmo que não tenham sido partes ou não tenham intervindo na ação", ressalvando que "a declaração de nulidade ou a anulação não prejudica os direitos adquiridos de boa-fé por terceiros, com fundamento em atos praticados em execução da deliberação; o conhecimento da nulidade ou da anulabilidade exclui a boa-fé". Tal dispositivo, de nítida inspiração alemã, diz Pinto Furtado, vincula os acionistas à coisa julgada quer na hipótese de procedência quer na de improcedência da demanda ("é eficaz contra e a favor"). Trata-se, é dizer, de uma eficácia geral ou erga omnes socios organaque societaris, ${ }^{969}$ que põe a salvo apenas os direitos de terceiros de boa-fé adquiridos com base no cumprimento do ato.

\footnotetext{
${ }^{966}$ Cf. Coisa julgada..., n. 3.8.2, pp. 164 e 171/172.

${ }^{967}$ Cf. Carpi, L'efficacia..., n. 36, p. 156; Monteleone, I limiti..., n. 12, p. 141; Ada Pellegrini Grinover, Notas a Liebman, “Ações concorrentes”, pp. 231/232; e Edoardo Ricci, "Sugli effetti...”, pp. 49 e seguintes.

968 Cf. Attardi, Diritto processuale..., v. 1, p. 494; e Alfredo Rocco, Le società..., nn. 174 e 177, pp. 246 e 251.

${ }^{969}$ Cf. Pinto Furtado, Deliberações..., n. 118, pp. 803/806.
} 
A legislação alemã, por sua vez, dispõe que a decisão proferida em demanda de impugnação de deliberação societária é oponível a todos os sócios, ${ }^{970}$ desde que eles tenham sido notificados pela companhia a respeito do ajuizamento da demanda. Prevê, ainda, a possibilidade de que o acionista intervenha no processo, dentro de até um mês da notificação (AktG, $\S \S 246, \mathrm{IV}, 248$ e 252). ${ }^{971} \mathrm{O} \S 248$ da AktG estabelece que "(1) sempre que através de uma decisão seja declarada, com trânsito em julgado, a nulidade da deliberação, a decisão será eficaz a favor e contra todos os acionistas, membros do conselho de administração e do conselho fiscal, mesmo quando não tenham sido parte (...)", enquanto que o $§ 252$ estatui que "sem um acionista (...) suscitarem contra a sociedade uma ação de verificação de nulidade de eleição pela assembleia geral de um membro do conselho fiscal, uma decisão que apure a nulidade, com trânsito em julgado será eficaz a favor e contra todos os acionistas e todos os trabalhadores da sociedade (...)". ${ }^{972}$ Em suma, os efeitos da decisão que julga demanda de impugnação de deliberação assemblear estendem-se a todos os interessados, desde que a administração dê aos acionistas ciência da demanda. ${ }^{973}$

$\mathrm{O}$ art. 122 da Ley de sociedades anônimas espanhola dispõe, a respeito da impugnação dos acuerdos sociales ou societários, que "la sentencia que estime la acción de impugnación producirá efectos frente a todos los accionistas, pero no afectará a los derechos adquiridos por terceros de buena fe a consecuencia del acuerdo impugnado". Ainda naquele país, o também já referido art. 222.3, par. $3^{\circ}$ da Ley de Enjuiciamento Civil estabelece que "las sentencias que se dicten sobre impugnación de acuerdos sociales afectarán, en exclusiva, a todos los socios, y ello aunque no hubieren litigado".974

Em nosso país, porém, não só o legislador não seguiu a tendência de alargamento da coisa julgada como, pior, negligenciou o assunto, não positivando nenhuma norma a esse respeito.

\footnotetext{
${ }^{970}$ Cf. Kübler, Derecho de sociedades, p. 345.

${ }^{971}$ Cf. Marcelo Von Adamek, "Ação de acertamento...”, p. 522, notas 22 e 24.

972 Tradução encontrada em Pinto Furtado, Deliberações..., n. 118, p. 804.

${ }^{973}$ AktG, §§ 246, VI, 248 e 249 (cf. Marcelo Von Adamek, "Ação de acertamento...”, p. 522, notas 21 e 24).

${ }^{974}$ Cf. Andrés de la Oliva Santos, Objeto del processo..., p. 189; e Sonia Calaza López, La cosa juzgada, cap. IV n. 7.1.3, p. 174.
} 


\section{Direito e processo: a influência do direito material nos limites subjetivos da coisa julgada}

Variam as razões e os caminhos percorridos, mas a maior parte da doutrina analisada que conclui pelo alargamento da coisa julgada na hipótese ora analisada o faz com fundamento no fato de que tais sentenças dizem respeito a uma relação jurídica em torno da qual gravitam outras relações jurídicas que com aquela guardam alguma relação de dependência. E, de fato, o germe do alargamento da coisa julgada é expressão de uma esigenza speciale da matéria objeto do julgado ou, mais especificamente no caso da impugnação de deliberações assembleares (e em situações similares), é uma resposta à estrutura do direito potestativo concorrente que fundamenta a pretensão anulatória ${ }^{975}$ (v. item 9). Da mesma forma que, como apontam Remo Caponi e Ada Pellegrini Grinover, as especiais características do direito societário exigem um processo mais célere e sumarizado, ${ }^{976}$ são as características do direito material que, em situações excepcionais, justificam a extensão da coisa julgada a sujeitos estranhos ao processo.

Com amparo nisso é que Guilherme Estellita escreveu que, embora os problemas relativos aos limites subjetivos da coisa julgada ainda devessem ser resolvidos pela doutrina, qualquer análise do tema deve considerar sempre dois elementos: a natureza da relação jurídica objeto da sentença e o interesse do terceiro por esta afetado. ${ }^{977}$ Reconhecendo o mesmo, José Roberto dos Santos Bedaque afirma que os limites objetivos e subjetivos da coisa julgada são profundamente influenciados pela relação de direito material, sendo esta a razão pela qual existem sentenças que se dizem não sujeitas ao trânsito (condenatória de alimentos, por exemplo) e outras que se tornam imutáveis em relação a terceiros, como nas ações de estado e nas coletivas. ${ }^{978}$ A noção de que as

${ }^{975}$ Cf. Allorio, La cosa..., nn. 69 e 159, pp. 121 e 272. Attardi, por sua vez, diz que as hipóteses de extensão subjetiva da coisa julgada atendem a exigências particulares das situações de direito material (cf. Diritto processuale..., v. 1, p. 484).

${ }^{976}$ Cf. Remo Caponi, "La tutela sommaria...”, pp. 1.376/1.377; e Ada Pellegrini Grinover, "Realização de assembléia...", p. 393. Em sentido similar a afirmação de Calmon de Passos de que as nulidades no processo penal "sofrem acentuada influência do princípio da tipicidade do direito penal material e do entendimento do valor liberdade como sendo indisponível" (cf. "Esboço de uma teoria das nulidades", RePro, n. 56, p. 12).

${ }^{977}$ Cf. Da cousa julgada - fundamento jurídico e extensão aos terceiros, parte II, cap. VII, p. 229.

${ }^{978}$ Cf. Direito e processo, n. 28, pp. 124/125: "Outro instituto que releva o nexo intenso entre o processo e o direito material é, sem dúvida, a coisa julgada. Sua concepção e seus limites, objetivos e subjetivos, estão profundamente influenciados pela própria natureza do direito a que o provimento judicial diz respeito. Vale a pena, portanto, reexaminar este tema processual, principalmente à luz das modernas noções de interesses ou direitos difusos, coletivos e individuais homogêneos. (...) O regime dos limites da coisa julgada, sem dúvida, 
chamadas sentenças determinativas ou dispositivas transitam em julgado mas podem ser alteradas pela mudança das circunstâncias fáticas (CPC, art. 471, I e Lei 5.478/68, art. 15) em razão natureza mutável da relação jurídica material, ${ }^{979}$ aliás, é um indicativo disso.

Realmente, deve haver compatibilidade entre a natureza do direito objeto da controvérsia e os limites subjetivos da coisa julgada. Não de modo que haja um predomínio absoluto do direito material sobre o processo, mas sim uma relação de necessária coordenação. Com base nessa premissa é que Camilo Zufelato critica o descompasso entre direito material e processo e defende, com base no postulado de que o processo contemporâneo é marcado pela ideia de efetividade e máximo proveito ao jurisdicionado (processo civil de resultados), que o processo adapte-se às situações substanciais carentes de tutela. Deve haver, assim, um tratamento peculiar do processo a cada espécie de direito. ${ }^{980}$ Também Satta defendeu a variação da eficácia subjetiva do julgado de acordo com a matéria decidida pela sentença, ao propor diferentes regimes diante de questões absolutas e relativas a prestação. ${ }^{981}$ Corroborando essa lição, Carpi escreveu que o regramento dos limites subjetivos da coisa julgada deve ser interpretado elasticamente, para que não haja um contraste insanável entre o que o justifica e a situação de direito material, dando como exemplo o caso da deliberação de assembleia. Direito e

deve ser considerado em função de o direito referir-se a apenas uma pessoa, a várias determinadas, ou a titulares indeterminados. Isto é, também para a concepção desse instituto processual não se pode prescindir da situação da vida sobre que o provimento jurisdicional irá projetar seus efeitos". Também Sérgio Gilberto Porto alude à necessidade de adequar a coisa julgada à natureza do direito posto em causa (cf. Coisa julgada..., n. 4.4, p. 74). E é em razão dessa dialética de mútua-implicação entre direito material e processo que se torna evidente em algumas situações que Willis Santiago Guerra Filho, tratando do litisconsórcio necessário que decorre de uma peculiaridade do direito material, emprega a expressão double faceldupla face (cf. "Efficacia ultra partes...", p. 189; e "Fenomenologia em direito processual...", p. 69).

979 Cf. Liebman, "Eficácia e autoridade...", n. 5, p. 28: "O que há de diverso nestes casos não é a rigidez menor da coisa julgada, mas a natureza da relação jurídica, que continua a viver no tempo com conteúdo ou medida determinados por elementos essencialmente variáveis". Sobre as sentenças determinativas, v., ainda, Flávio Yarshell, Ação rescisória..., n. 55, pp. 173/174.

${ }^{980}$ Cf. Coisa julgada..., n. 3.8, pp. 157 e 161. E, de fato, como bem apontado por Willis Santiago Guerra Filho, casos como o dos limites subjetivos da coisa julgada apresentam dificuldades, dentre outros motivos, pela visão tradicional (liberal) de processo civil, que supostamente só pode versar sobre um litígio envolvendo duas pessoas (cf. "Efficacia ultra partes della sentença, litisconsorzio necessario e principio del contraditorio", in Processo civile e società commerciali, p. 186).

981 Cf. Direito processual..., v. 1, n. 117, pp. 243/244. No primeiro dos casos, dos quais são exemplos a propriedade de um determinado bem, a qualificação de herdeiros e a declaração de um status, disse Satta não haver exatamente amplitude subjetiva do julgado, mas apenas "o raciocínio comum de uma condição objetivamente acertada entre as partes legítimas". Sobre o pensamento desse autor, v. Monteleone, I limiti..., n. 15 , p. 166. 
processo, assim, atuam como vasos comunicantes. ${ }^{982}$ Assim, prosseguiu, o enunciado de relatividade da coisa julgada, expresso no art. 2.909 do Código Civil italiano, continua válido como regra geral, e o que justifica o alargamento da coisa julgada são especiais características da situação material e do interesse controvertido. ${ }^{983} \mathrm{Na}$ mesma linha, Francesco Terrusi escreveu que o que está à base do dispositivo legal italiano que impõe a eficácia ultra partes da coisa julgada no caso em análise é a peculiaridade do fenômeno deliberativo: a deliberação é um fenômeno organizativo e, portanto, o ato do juiz sobre ela deve produzir efeitos perante todos os sujeitos que com ela se relacionem. ${ }^{984}$

As teorias analisadas que defendem a coisa julgada ultra partes em situações de ações subjetivamente concorrentes apresentam especificidades, mas têm em comum a circunstância de que se fundam na especial natureza da relação de direito material controvertida no processo. Contudo, é preciso mais do que dizer que o direito controvertido apresenta natureza especial; é preciso definir no que consiste essa especialidade.

\subsection{Unitariedade da relação jurídica: demandas "individuais de alcance coletivo" e demandas "pseudoindividuais"}

Quando uma decisão proferida em processo individual produz efeitos intensos na esfera jurídica de terceiros, estamos diante do que, na feliz definição de Kazuo Watanabe, podem ser chamadas de demandas individuais com alcance coletivo. ${ }^{985}$ Trata-se de pretensões que, conquanto possam ser deduzidas individualmente, a natureza incindível da relação jurídica de direito material a que dizem respeito impede sejam classificadas como verdadeiramente individuais. Mais uma vez, a teoria é ilustrada com a invalidação de deliberação assemblear que versa sobre matéria que diz respeito ao colégio de acionistas.

\footnotetext{
982 Para uma breve exposição sobre a teoria dos vasos comunicantes, v. Flávio Luiz Yarshell e Guilherme Setoguti J. Pereira, "Antecipação de tutela nos contratos de seguro-saúde”, in Luiz Augusto Ferreira Carneiro (org.), Planos de saúde: aspectos jurídicos e econômicos, pp. 171/193.

${ }^{983}$ Cf. Carpi, L'efficacia..., nn. 21 e 62, pp. 80, 82 e 307 e seguintes, o que foi negado por Monteleone (cf. I limiti..., n. 14, pp. 161/163).

${ }^{984}$ Cf. L'invalidità..., n. 6.7, p. 301.

985 Cf. "Relação entre demanda coletiva e demandas individuais", in Ada Pellegrini Grinover, Kazuo Watanabe e Aluisio Gonçalves de Castro Mendes (orgs.), Direito processual coletivo e o anteprojeto de Código Brasileiro de Processos Coletivos, p. 156. De acordo com Heitor Sica e Marcelo Bonício, tais demandas são assim chamadas "porque os efeitos de suas decisões atingem intensamente a esfera jurídica de pessoas que não estão no processo em virtude da unitariedade" (cf. "Litisconsórcio unitário...", n. 1, p. 7).
} 
Apesar de sua feição individual, a pretensão anulatória não é fragmentável e, assim, ostenta alcance coletivo: satisfeita a pretensão nela veiculada serão tutelados também os direitos dos demais acionistas. ${ }^{986}$

O ilustre professor dá ainda outro exemplo. Imagine-se uma demanda ajuizada por cidadão que pleiteie a cessação da poluição emitida por uma fábrica. Ela é individual apenas no sentido de que proposta por uma única pessoa, pois sua pretensão é de alcance coletivo, já que o seu acolhimento beneficia uma coletividade que está na mesma situação do autor. Mais um exemplo: as demandas relativas ao não pagamento da assinatura telefônica.

Dito isso, conclui Watanabe que a solução mais adequada seria proibir demandas individuais que veiculem a mesma pretensão de uma demanda coletiva ou outras demandas individuais com o mesmo escopo, pois importam em bis in idem. De lege ferenda, assim, o recomendável seria proibir tais demandas, embora, de lege lata, a suspensão dos processos possa, na prática, produzir efeitos próximos ao da proibição. ${ }^{987}$

Como diz o referido jurista, o Anteprojeto de Código Brasileiro de Processos Coletivo traz disposições que procuram solucionar esse problema. Trata-se, com efeito, do art. $6^{\circ}$ do referido Código projetado, que versa sobre a relação entre demandas coletivas e individuais. ${ }^{988} \mathrm{O}$ mesmo ocorre com o Projeto de Lei 8.046/10, que procura instituir novo

\footnotetext{
${ }^{986}$ Cf. "Relação entre demanda...”, p. 156.

987 Cf. "Relação entre demanda...”, pp. 157/160. Isto, na premissa, é claro, de que os juízos em que suspensos os processos sigam a solução dada à primeira demanda e, assim, evite-se conflito de julgados.

${ }^{988}$ Art. $6^{\circ}$ Relação entre demanda coletiva e ações individuais - A demanda coletiva não induz litispendência para as ações individuais em que sejam postulados direitos ou interesses próprios e específicos de seus autores, mas os efeitos da coisa julgada coletiva (art. 12 deste Código) não beneficiarão os autores das ações individuais, se não for requerida sua suspensão no prazo de 30 (trinta) dias, a contar da ciência efetiva da demanda coletiva nos autos da ação individual.

$\S 1^{\circ}$ Cabe ao demandado informar o juízo da ação individual sobre a existência de demanda coletiva que verse sobre idêntico bem jurídico, sob pena de, não o fazendo, o autor individual beneficiar-se da coisa julgada coletiva mesmo no caso de a ação individual ser rejeitada.

$\S 2^{\circ}$ A suspensão do processo individual perdurará até o trânsito em julgado da sentença coletiva, facultado ao autor requerer a retomada do curso do processo individual, a qualquer tempo, independentemente da anuência do réu, hipótese em que não poderá mais beneficiar-se da sentença coletiva.

$\S 3^{\circ} \mathrm{O}$ Tribunal, de ofício, por iniciativa do juiz competente ou a requerimento da parte, após instaurar, em qualquer hipótese, o contraditório, poderá determinar a suspensão de processos individuais em que se postule a tutela de interesses ou direitos referidos a relação jurídica substancial de caráter incindível, pela sua própria natureza ou por força de lei, a cujo respeito as questões devam ser decididas de modo uniforme e globalmente, quando houver sido ajuizada demanda coletiva versando sobre o mesmo bem jurídico.
} 
Código de Processo Civil, uma vez que a Comissão Especial destinada a proferir parecer ao referido projeto sugeriu dispositivo contendo a possibilidade de conversão de ação individual em coletiva, o que resultou no art. 334 daquele Código. ${ }^{989}$ Referido artigo conta com duas hipóteses de conversão. Em umas delas, prevista no inciso II, encaixa-se a invalidação de deliberação: trata-se de demanda individual que veicula pedido que "tenha por objetivo a solução de conflito de interesse relativo a uma mesma relação jurídica plurilateral, cuja solução, pela sua natureza ou por disposição de lei, deva ser necessariamente uniforme, assegurando-se tratamento isonômico para todos os membros do grupo".

Heitor Sica e Marcelo Bonício dão outros exemplos de demandas por eles chamadas de "pseudoindividuais": (i) pedido, em processo individual, para que o Poder Público inclua dado remédio na lista do Sistema Único de Saúde; e (ii) impugnação de disposição de edital de licitação, realizada por apenas um dos interessados antes da realização do certame. $\mathrm{O}$ acolhimento dessas pretensões individuais repercute em inúmeras pessoas não apenas faticamente (como é o caso, para citar outro exemplo desses autores, da demanda movida por vizinho de terreno onde se erigirá um empreendimento que, além de prejudicar os direitos de referido vizinho, trará prejuízo também aos demais que vivem no entorno e à ordem urbanística), mas juridicamente. E a pergunta a ser feita é: tais processos

$\S 4^{\circ} \mathrm{Na}$ hipótese do parágrafo anterior, a suspensão do processo perdurará até o trânsito em julgado da sentença coletiva, vedada ao autor a retomada do curso do processo individual antes desse momento.

${ }^{989}$ Capítulo IV - Da conversão da ação individual em ação coletiva.

Art. 334. Atendidos os pressupostos da relevância social e da dificuldade de formação do litisconsórcio, o juiz, ouvido o Ministério Público, poderá converter em coletiva a ação individual que veicule pedido que:

I - tenha alcance coletivo, em razão da tutela de bem jurídico coletivo e indivisível, cuja ofensa afete, a um só tempo, as esferas jurídicas do indivíduo e da coletividade;

II - tenha por objetivo a solução de conflito de interesse relativo a uma mesma relação jurídica plurilateral, cuja solução, pela sua natureza ou por disposição de lei, deva ser necessariamente uniforme, assegurando-se tratamento isonômico para todos os membros do grupo.

$\S 1^{\circ}$ Determinada a conversão, o juiz intimará o Ministério Público, a Defensoria Pública ou outros legitimados para a condução de um processo coletivo, que, no prazo fixado, poderão aditar ou emendar a petição inicial, para adequá-la à tutela coletiva.

$\S 2^{\circ} \mathrm{O}$ autor originário da ação individual atuará na condição de litisconsorte do legitimado para a condução do processo coletivo.

$\S 3^{\circ}$ Após a conversão, observar-se-ão as regras do processo coletivo.

$\S 4^{\circ}$ A conversão poderá ocorrer mesmo que autor tenha cumulado pedido de natureza estritamente individual, mas o seu processamento dar-se-á em autos apartados e ficará sobrestado até o julgamento da ação coletiva, ressalvada a possibilidade de concessão de tutela de urgência. 
são individuais, coletivos ou pertencem a um tertium genus (uma categoria híbrida), a dos processos "pseudoindividuais"? 990

Prosseguindo com sua análise, Sica-Bonício dizem que situações nas quais há uma pluralidade de pessoas legitimadas para impugnar o mesmo ato incindível, a gerar litisconsórcio unitário, dividem-se em dois grupos.

No primeiro, os colegitimados são identificáveis e existe uma probabilidade razoável de que tenham conhecimento da demanda e possam intervir no processo na condição de litisconsortes ulteriores. Para ele, no qual se inclui a impugnação de deliberação assemblear, Sica-Bonício defendem a aplicação da coisa julgada erga omnes, independente do resultado do processo. Parece aceitável, dizem, que a coisa julgada possa atingir todos os sócios de uma companhia, até mesmo para prejudicá-los, pois, ao terem ingressado nos quadros de uma sociedade, tiveram a consciência de que poderiam ser atingidos pelos efeitos de uma decisão - e da sua anulação - tomada em assembleia. ${ }^{991}$

No segundo grupo, existe dispersão "quase que aleatória" dos colegitimados, de maneira a ser pouco provável que tenham ciência do ajuizamento da demanda. O exemplo dado é o da demanda individual que pede a disponibilização de um medicamento pelo Estado. Neste caso, a coisa julgada é secundum eventum litis, ${ }^{992}$ nos moldes do art. 103, III do CDC, pois, continuam esses autores, a situação assemelha-se muito mais à dos direitos individuais homogêneos, para os quais a coisa julgada coletiva pode beneficiar, mas nunca prejudicar, os direitos individuais. ${ }^{993} \mathrm{E}$ concluem: se essas demandas são individuais apenas no nome, é uma consequência natural serem analisadas à luz do microssistema de processos coletivos. ${ }^{994}$

\footnotetext{
990 Cf. "Litisconsórcio unitário...", pp. 18/20.

991 Cf. "Litisconsórcio unitário...”, pp. 25/26.

992 “Cf. Litisconsórcio unitário...”, pp. 21 e 24/27. A respeito da impugnação de deliberação societária, consignam: "Daí por que parece aceitável que as restrições da coisa julgada possam atingi-los, inclusive quando a decisão não os beneficiar, posto que, ao assumirem a condição de sócios de uma determinada empresa, já sabiam que poderiam ser atingidos pelos efeitos de uma decisão tomada em assembleia" (pp. 25/26).

993 Cf. "Litisconsórcio unitário...", pp. 26/27.

${ }^{994}$ Cf. "Litisconsórcio unitário...”, pp. 27/31.
} 


\section{Coisa julgada erga omnes: admissibilidade no direito brasileiro (unitariedade de relações jurídicas plurissubjetivas e impossibilidade de conflitos de julgados)}

A doutrina é unânime em reconhecer a insuficiência do art. 472 do CPC para reger situações nas quais, embora existam inúmeros legitimados para impugnar um mesmo ato, a lei não estabelece forma de cientificá-los do processo e vinculá-los ao resultado que dali emergirá. Prova disso é que muitos dos que negam o alargamento da coisa julgada recomendam no plano legislativo a criação de algum mecanismo que dê ciência aos interessados sobre o processo e, assim, seja-lhes oposta a res iudicata. A divergência que existe na doutrina diz respeito apenas ao seguinte: enquanto alguns entendem que de lege lata não é possível fugir do regramento geral do art. 472, outros defendem, pelos mais variados motivos, a ampliação dos limites subjetivos da coisa julgada. Quer nos parecer, porém, que os últimos é que estão corretos. Ou seja, parece-nos que a coisa julgada na impugnação de deliberações assembleares, independente do resultado, é erga omnes.

Historicamente, a regra de relatividade da coisa julgada não é, nem nunca foi, absoluta. Mesmo o direito romano, no qual vigorou o postulado geral de que a coisa julgada não pode prejudicar terceiros, contava com diversas hipóteses de extensão subjetiva daquela, via de regra em casos em que havia nexo de dependência entre a situação decidida e a do terceiro. ${ }^{995}$ Também nossa legislação vigente prevê situações expressas de ampliação dos limites subjetivos da coisa julgada, como o que ocorre com a ação popular e os processos coletivos. Outra dessas hipóteses é a contida no art. 274 do Código Civil, que dispõe que “o julgamento contrário a um dos credores solidários não atinge os demais; o julgamento favorável aproveita-lhes, a menos que se funde em exceção pessoal ao credor que o obteve".

Inclusive críticos ferrenhos da extensão da coisa julgada a terceiros, ademais, ressalvaram que a regra geral de que a coisa julgada vale apenas entre as partes apresenta exceções, pois há situações em que a sua aplicação irrestrita leva a resultados inaceitáveis, quer por conta da natureza da relação de direito material, quer em razão da conexão entre

${ }^{995}$ Cf. Alessandro Lolli, I limiti soggettivi..., cap. III, n. 1, pp. 90/91; e Guilherme Estellita, Da cousa julgada..., parte, I, cap. I, p. 154. 
essa relação e as esferas de terceiros. ${ }^{996}$ E, de fato, como bem exposto por Edoardo Ricci, quando se trata da disciplina de grupos organizados e, especialmente, de iniciativas judiciais individuais contra atos do grupo, é inevitável que haja algum sacrificio del contraddittorio. Por isso é que, para esse autor, a disposição do direito italiano de que a anulação da deliberação produz efeitos contra todos os acionistas sem que todos esses tenham que ser chamados ao processo nada tem de escandalosa e decorre, na verdade, da necessidade de não obstaculizar o exercício do direito à impugnação. ${ }^{997}$

Entre nós, o que justifica a coisa julgada ultra partes nos processos coletivos são as disposições legais nesse sentido, contidas no Código de Defesa do Consumidor, na Lei de Ação Popular e na Lei da Ação Civil Pública. Mas, antes de tudo, esses dispositivos encontram sua razão de ser e legitimam-se na indivisibilidade do objeto da demanda. ${ }^{998} \mathrm{Ou}$ seja, essas disposições de lei reconhecem uma especial qualidade do direito discutido e, com base nisso, estabelecem um regime específico de limites subjetivos da coisa julgada.

\footnotetext{
996 Sobre os casos em que, excepcionalmente, devido à interpendência das relações negociais e à complexidade do comércio jurídico, mitiga-se a regra de relatividade da coisa julgada e projetam-se seus efeitos a terceiros, v. José Rogério Cruz e Tucci, Limites subjetivos..., n. 4, pp. 40/41. Uma dessas situações é a da sentença em controvérsias de estado, para a qual Liebman concordou com a doutrina majoritária no sentido de que a coisa julgada é erga omnes, embora por fundamentos diversos (cf. "A coisa julgada nas questões de estado", in Eficácia e autoridade..., nn. 1 e 5, pp. 188 e 196). A razão de ser dessa exceção, de acordo o referido autor, reside "na necessidade de que certas situações fundamentais das pessoas, importantes para uma série indefinida de relações jurídicas, apareçam de modo fixo e uniforme para todos". V., ainda, Liebman, "Limites à coisa julgada nas questões de estado", in Eficácia e autoridade..., p. 197. Liebman reconheceu que nas questões de estado, em decorrência de sua incindibilidade e de exercerem influência sobre várias relações jurídicas dependentes e número indeterminado de pessoas, a coisa julgada é erga omnes (cf. "Limites à coisa julgada...”, p. 201). No mesmo sentido Jorge Salomão, segundo quem se atribui eficácia erga omnes às sentenças de estado "em razão da natureza singular do conceito de status e do relevantíssimo papel que se lhe reserva na disciplina das relações familiares, sôbre as quais assenta, por sua vez, a própria organização da Sociedade e do Estado" (cf. Da coisa julgada..., p. 133). De acordo com Betti, porém, a sentença em questão de estado não representa, como equivocadamente já se entendeu, uma derrogação das regras que firmam os limites subjetivos da coisa julgada. Trata-se, na verdade, de um efeito reflexo da relação entre o ato e os terceiros direta ou indiretamente participantes da relação decidida. Como a decisão abarca não uma única relação jurídica, mas um status que acolhe a inteira personalidade de um homem como centro de relações jurídicas, é natural que o julgado vincule um número maior de pessoas (cf. Trattato..., cap. II, n. 3-d, pp. 286/287). A respeito dos juízos sobre questões de estado, v. Redenti, Il giudizio..., cap. III, nn. 59, pp. 77 e seguintes; Allorio, La cosa..., cap. X, pp. 295 e seguintes; e Monteleone, I limiti..., n. 11, pp. $124 / 140$.

${ }^{997}$ Cf. "Sugli effetti...”, pp. 66/67.

${ }^{998}$ Cf. Bedaque, Direito e processo, n. 28.1, p. 127: “verifica-se a profunda alteração nos limites subjetivos da coisa julgada em demandas versando interesses indivisíveis, que acabam alcançando pessoas que não participaram do contraditório instaurado perante o juiz. Tal ocorre pelo simples fato de haver o direito material instituído essa categoria de direitos, denominados difusos e coletivos. A indivisibilidade do bem implica tratamento uniforme, o que afasta a possibilidade de decisões diferentes. Daí a necessidade de o disposto na sentença tornar-se imutável para todos. É, pois, a indivisibilidade do objeto da demanda que determina a extensão dos limites subjetivos da coisa julgada erga omnes ou ultra partes. A coisa julgada erga omnes, portanto, nos processos cujo objeto seja um interesse difuso ou coletivo, decorre de circunstância inerente à própria natureza do direito, isto é, sua indivisibilidade".
} 
Se isso é verdade, a indivisibilidade do direito que fundamenta a pretensão de anulação de deliberação assemblear também deveria justificar a coisa julgada erga omnes, pois à base de todos esses interesses está o mesmo fenômeno: uma relação jurídica que, por ser incindível, deve ser julgada uniformemente para todos.

O que justifica o regime especial de limites subjetivos da coisa julgada na invalidação de deliberações assembleares são as características do direito que fundamenta a pretensão anulatória (v. item 9). Referidas características, por sua vez, desdobram-se em dois aspectos: de um lado, a indivisibilidade do ato jurídico (unitariedade), ${ }^{999} \mathrm{e}$, de outro, a identidade de situações jurídicas (cotitularidade do direito potestativo à anulação). Com base nesses dois aspectos de um mesmo fenômeno entendemos que a coisa julgada na impugnação de deliberações assembleares vincula a todos.

Ao entendimento ora defendido poder-se-ia objetar que não há, no direito positivo brasileiro, nenhuma regra que derrogue parcialmente o art. 472 do CPC e, portanto, este é que deveria reger todas as situações ordinárias. Mas também esse argumento é criticável. Não basta dizer que a questão já teria sido resolvida pelo legislador porque, no caso das deliberações inválidas, não foi. Considerando a especial natureza da relação jurídica e a necessidade de que esta tivesse sido objeto de disciplina legal específica, que fugisse da regra ordinária, talvez se possa dizer que há verdadeira lacuna normativa no caso. Diante disso, é legítima uma solução hermenêutica. Em determinados casos em que não encontramos a resposta exata na lei, devemos valer-nos de interpretatio

\footnotetext{
${ }^{999}$ Embora a unitariedade do direito talvez não seja suficiente para, por si só, justificar a coisa julgada erga omnes, note-se que ela, quando menos, sinaliza nesse sentido, com o principal intuito de evitar conflitos de julgados. Tanto é isso verdade que, no regime brasileiro de processos coletivos, a coisa julgada diante de direitos coletivos ou difusos (indivisíveis) é ultra partes, salvo se houver improcedência por falta de provas. No direito norte-americano, a Federal Rule 23, de 1966, nas mandatory class actions (empregadas, grosso modo, em defesa de direitos difusos e coletivos) alcança terceiros para beneficiá-los e prejudicá-los, enquanto que as not mandatory class actions (empregadas, grosso modo, em defesa de direitos individuais homogêneos), a coisa julgada também vincula terceiros, a menos que estes tenham exercido seu direito de autoexclusão dos efeitos da decisão (cf. Zufelato, Coisa julgada..., n. 4.3.1, pp. 192/193). Existe, aliás, uma tendência de suprimir o direito de ação individual no que diz respeito às obrigações indivisíveis. Fazendo considerações sobre tais obrigações, Botelho de Mesquita disse que, antes do Código de Defesa do Consumidor, haveria tantas ações quantos fossem os direitos e tantos direitos quanto fossem os credores, em caso de direitos coletivos ou difusos. Em decorrência da indivisibilidade da obrigação, cada credor agiria em nome próprio e por direito próprio (ações concorrentes), mas a procedência de qualquer uma dessas ações beneficiaria os demais credores. A partir do CDC, nenhum credor mais pode fazer valer os direitos coletivos ou difusos, uma vez que a ação pertence às entidades listadas no art. 82 daquele Diploma (cf. "A coisa julgada no Código do Consumidor”, p. 147).
} 
iuris, com auxílio de critérios gerais. A lei, assim, deve ser dotada de certo grau de ductibilidade, ${ }^{1000}$ de modo que se adapte à situação de direito material carente de tutela.

Com efeito, a frase "a sentença faz coisa julgada às partes entre as quais é dada" contida no art. 472 do CPC pode ser interpretada de forma que, em decorrência das características do contrato de sociedade, que une sócios e sociedade, a sentença proferida em demanda movida entre qualquer um deles vincula os demais. A sentença é proferida apenas entre quem integra o processo, mas o vínculo jurídico existente entre a sociedade, o autor da demanda e os demais sócios faz com que essa eficácia e a respectiva coisa julgada sejam transpostas/transplantadas para todo o colégio de sócios. Pouco importa a natureza jurídica do contrato de sociedade: contrato plurilateral, contrato associativo ou qualquer outra categoria. O importante é a existência de um vínculo jurídico que una sócios e sociedade de tal forma que a modificação de questões relativas a essa comunidade deve ser aplicável a todos os seus membros indistintamente. É como se, ao adentrar uma sociedade, o sujeito concorde em, para matérias que dizem respeito a todos, abrir mão de sua individualidade para que, inserido no contexto do grupo, aceite se submeter a um regramento uniforme, regra sem a qual seria posta em xeque a própria existência do grupo. Não há nenhuma disposição de lei que firme esse entendimento, mas cremos que ele pode ser extraído das peculiaridades do contrato de sociedade e da deliberação assemblear.

Grande crítico da extensão da coisa julgada a terceiros, em especial da teoria alloriana, Monteleone defendeu posições radicalmente diversas da que ora assumimos. Contudo, ainda que com conclusão diversa, o seu raciocínio é, quando menos, similar ao nosso em um aspecto, e pode ser invocado para ilustrar o que ora se defende. Com efeito, referido autor analisou o caso das deliberações assembleares e aduziu que, apesar de a lei italiana estatuir que a sentença de anulação vincula todos os sócios, entender que aqui haja coisa julgada ultra partes é fruto de uma illusione ottica, pelo seguinte motivo: a sociedade possui personalidade jurídica, e é em face dela que deve ser proposta a demanda anulatória, de maneira que o contraditório esteja regularmente instaurado se apenas ela for parte. Fruto de um fenômeno institucional e organizativo, a sociedade é um sujeito de direito que não se distingue dos órgãos que a compõem, antes se identifica perfeitamente com eles, como é o caso da assembleia e, em última análise, dos sócios que a compõem. Esses órgãos estão

${ }^{1000}$ É o que afirmou Redenti (cf. Il giudizio..., prefácio, n. II, p. XII). 
vinculados às decisões que vinculam a sociedade e, assim, o art. 2.377 do Código Civil italiano, longe de ser uma derrogação da regra dos limites subjetivos da coisa julgada, é uma manifestação explícita de um princípio inerente à organização e ao funcionamento do ente societário. O que há, portanto, é uma normal vinculação da sociedade à sentença. ${ }^{1001}$

Trata-se, como visto, de posição que colide com a que aqui defendemos. Contudo, os dois pensamentos apresentam um aspecto comum: ambos defendem que a ampliação da coisa julgada (embora Monteleone não enxergue o fenômeno dessa forma) decorre de um postulado inerente à organização e ao funcionamento do ente societário, qual seja, o postulado de que a decisão a respeito de questões estenda-se à sociedade e a todos os que a integram. É isso o que queremos dizer quando sustentamos que o art. 472 do CPC pode ser interpretado conforme o contrato de sociedade.

Mas, além de jurídica, a defesa da coisa julgada erga omnes na hipótese das deliberações de assembleia decorre também de razões pragmáticas, ${ }^{1002}$ quais sejam, impossibilidade de haver conflitos jurídicos e de se submeter a companhia e o Judiciário a infindáveis e idênticas discussões sobre uma mesma controvérsia. Para que não haja a emissão de regras jurídicas concretas contraditórias, a coisa julgada deve abranger todos aqueles que estejam inseridos em uma mesma relação jurídica, de modo que esta seja decidida uma única vez. Deve haver, assim, coordenação necessária entre as demandas concorrentes (v. item 24.5).

O fundamento jurídico-político da limitação subjetiva da coisa julgada a quem integrou o processo são as garantias do contraditório, do devido processo legal e da ampla defesa. Mas outro fundamento da coisa julgada é a pacificação dos litígios e, consequentemente, o rechaço à eternização das discussões e ao conflito de julgados. Subjaz à coisa julgada não só a limitação vinda do contraditório, da ampla defesa e do devido processo legal, mas também o valor constitucional da segurança jurídica. A coisa julgada, sob esse último aspecto, presta-se a imunizar decisões. Jurisdição é poder, e a imunização das decisões é essencial à mecânica do poder. Sem que haja imunização, o poder se

${ }^{1001}$ Cf. I limiti..., n. 12, pp. 141/143). Para esse autor, também a suposta eficácia ultra partes nas class actions é uma ilusão de ótica (n. 16, p. 178).

1002 Allorio invoca exigências práticas como fundamento para o alargamento da coisa julgada (cf. La cosa..., n. 69 , p. 120). 
esvazia. $^{1003}$ Não é possível dizer que uma decisão está imunizada se ela puder ser constantemente revista. Sustentar que uma mesma deliberação possa ser objeto de mais de uma sentença, as quais atribuam à controvérsia disciplinas contraditórias, é esvaziar os escopos sociais da jurisdição. E é com base neste fundamento que cremos que a coisa julgada vincula não só os sócios, mas também terceiros.

Em suma, parece ser possível defender que no direito brasileiro a coisa julgada na impugnação de deliberações assembleares é erga omnes. A explicação material para essa extensão são as especiais naturezas do contrato de sociedade e do direito que fundamenta a anulação, desdobrando-se esse último aspecto em dois subaspectos: unitariedade do ato jurídico e a identidade de situações jurídicas titularizadas pelos acionistas. A explicação processual, por sua vez, é a impossibilidade de tratamento diferenciado de uma mesma relação jurídica e a impossibilidade de conflitos de julgados. É isso que nos leva a sustentar que, mesmo que não haja regra que derrogue o art. 472 do $\mathrm{CPC}$, o direito brasileiro prevê, nessa hipótese, a ampliação subjetiva da coisa julgada.

Digna de nota é a posição de Barbosa Moreira, que invoca o art. 18 da Lei da Ação Popular (Lei 4.717/65) ${ }^{1004}$ por analogia para afirmar que a coisa julgada na impugnação de deliberações é erga omnes, exceto na improcedência por falta de provas. De fato, se a demanda de impugnação de deliberações é individual apenas no nome, e a decisão vai afetar um número indeterminado de pessoas, a análise dos resultados dessa demanda "pseudoindividual" talvez só possa ser feita sob a perspectiva do sistema das ações coletivas. ${ }^{1005}$

Para Barbosa Moreira, a Lei 4.717/65 deve, de lege ferenda, ser ampliada a outras situações do mesmo gênero, não impedindo, contudo, que, de lege lata, ela seja aplicada por analogia fora do terreno da ação popular. A solução, portanto, é que, em situações

\footnotetext{
${ }^{1003}$ Cf. Dinamarco, A instrumentalidade..., n. 12, pp. 107/112: “a imunização das decisões fundadas no poder constitui enérgica afirmação do poder mesmo, o qual sem isso ficaria sujeito a tantas impugnações que afinal terminaria por não prevalecer sobre as pessoas (então, supostamente) sujeitas a ele". Em sentido análogo, diz Monteleone que a essência da coisa julgada reside na incontrovertibilidade e imodificabilidade da sentença, sem as quais a coisa julgada deixa de existir enquanto tal (cf. I limiti..., n. 2, p. 22).

${ }^{1004}$ Art. 18. A sentença terá eficácia de coisa julgada oponível "erga omnes", exceto no caso de haver sido a ação julgada improcedente por deficiência de prova; neste caso, qualquer cidadão poderá intentar outra ação com idêntico fundamento, valendo-se de nova prova.

${ }^{1005}$ Como afirmaram Heitor Sica e Marcelo Bonício (cf. "Litisconsórcio unitário...”, pp. 27/31).
} 
como a de nulidade de patente ou deliberação assemblear, a decisão, por analogia ao art. 18 da Lei $4.717 / 65$, vincule todos os colegitimados à impugnação, exceto no caso de improcedência por falta de provas. ${ }^{1006}$ Trata-se de posição intermediária, que vincula terceiros apenas quando há certeza do julgador. E, devido ao caráter constitutivo negativo da ação popular e à circunstância de que também se trata de ação concorrente, a impugnação de deliberação, de fato, apresenta grandes semelhanças com a primeira. ${ }^{1007}$

Porém, apesar dessa ser uma posição digna de respeito, não só pela autoridade de quem a defende mas também porque, realmente, talvez fosse mais fácil defender a extensão da coisa julgada com base em uma regra positiva já existente, cremos que os reais fundamentos da coisa julgada erga omnes na impugnação de deliberações são aqueles que apontamos: as peculiaridades do direito material (unitariedade do ato jurídico, identidade de situações jurídicas e o vínculo que une sócios e sociedade) e o rechaço do sistema à eternização de conflitos e à contradição entre julgados. São estes elementos que, acreditamos, permitem interpretar o art. 472 do CPC de forma que a coisa julgada, nesta hipótese, seja erga omnes.

\subsection{A proteção aos terceiros: (i) mecanismos de reação, (ii) informação efetiva e (iii) conluio e atos de disposição do processo e do direito material}

A limitação da coisa julgada às partes resulta, fundamentalmente, da não participação dos terceiros e, assim, de não lhes ter sido possibilitado contribuir para a formação da decisão. Se lhes são ofertadas ferramentas para que (i) tenham ciência da existência de processo em que se discute relação jurídica que lhes diz respeito e (ii) intervenham nesse processo, a regra de relatividade da coisa julgada resta legitimamente

\footnotetext{
1006 Cf. "Coisa julgada: extensão subjetiva...", pp. 292/293. Também Paulo Cézar Aragão defende a coisa julgada erga omnes e invoca, por analogia, a Lei da Ação Popular (cf. “Aspectos processuais...”, p. 65).

${ }^{1007}$ Embora se possa dizer que isso não é bem verdade, uma vez que, fazendo-se uma analogia, é como se os interesses em jogo em uma demanda anulatória de deliberação assemblear aproximassem-se dos interesses coletivos stricto sensu, pois os acionistas são unidos por uma mesma relação jurídica-base (CDC, art. 81, II), ao passo que os interesses envolvidos em uma ação popular, uma anulatória de patentes e ação de estado seriam difusos, pois existe um grande número de interessados unidos apenas por circunstâncias de fato (CDC, art. 81, I). Nesse sentido, v. Camilo Zufelato, Coisa julgada..., n. 3.8.2, p. 170.
} 
enfraquecida. ${ }^{1008} \mathrm{O}$ contraditório, ainda que potencial, possibilita que a coisa julgada se opere perante sujeitos estranhos ao processo, como bem disse Alessandro Lolli. ${ }^{1009}$

A expansão da eficácia da decisão e da coisa julgada aos demais envolvidos com a deliberação impugnada é uma inegável realidade, com a qual devemos trabalhar. Em contrapartida, devem ser disponibilizados instrumentos de tutela aos terceiros. ${ }^{1010}$

\subsubsection{Mecanismos de reação}

Tanto vigora entre nós a projeção de efeitos da sentença a terceiros que nosso sistema processual já conta com expedientes que servem justamente para afastar referida eficácia, antes e depois da emissão da decisão - e até mesmo depois do trânsito em julgado. São os casos, por exemplo, de legitimação do terceiro para ajuizar ação rescisória (art. 487, II), ${ }^{1011}$ interpor recurso (art. 499), ajuizar embargos de terceiro (art. 1.046), intervir como assistente ${ }^{1012}$ ou até mesmo impetrar mandado de segurança. ${ }^{1013}$

${ }^{1008}$ Cf. Carpi, L'efficacia..., n. 65, pp. 334; Allorio, La cosa..., n. 39, pp. 80/81; e, de certa forma, Monteleone, I limiti..., n. 15, p. 168.

${ }^{1009}$ Cf. I limit soggettivi..., cap. III, n. 1, p. 91.

${ }^{1010}$ Por isso é que, aludindo à "tutela de terceiros como ponto de equilíbrio da extensão subjetiva dos efeitos do julgado", a doutrina apontou que "a configuração de qualquer modelo de coisa julgada coletiva deve passar necessariamente pela ponderação entre a necessidade ínsita de expansão do comando judicial e o respeito ao princípio do contraditório". E disse mais: "é preciso dotar o sistema processual de mecanismos que impeçam que o terceiro seja submetido de modo imutável ao comando judicial que causa prejuízo em sua esfera jurídica. Nesse sentido, a solução há de ser a harmônica coordenação entre técnicas de tutela substancial e garantias de defesa processual" (cf. Camilo Zufelato, Coisa julgada..., n. 4.2, pp. 174/175). Sobre o assunto, v. Willis Santiago Guerra Filho, "Efficacia ultra partes...", pp. 187/188, que alude à necessidade de tutelar o terceiro que teve violado o seu direito de ser ouvido.

${ }^{1011}$ Há respeitabilíssima doutrina que entende que, apesar da dicção do art. 487, II do CPC, somente ostenta legitimidade para a rescisória o terceiro que interveio em algum momento do processo originário. Isso porque, diante do que dispõe o art. 472 do CPC, não haveria "como sustentar a formação da coisa julgada em relação a quem não figurou como parte no processo", de modo que "não há interesse e não há legitimidade desse terceiro para propor a ação rescisória, na medida em que por outras vias adequadas poderá se opor ao comando que resultou do processo que não integrou" (cf. Flávio Yarshell, Ação rescisória..., n. 47, p. 144). No mesmo sentido, Luís Eulálio Bueno Vidigal: "pode propor ação rescisória sòmente quem foi parte no processo em que foi proferida a sentença rescindenda" (cf. Da ação rescisória..., n. 58, p. 53). Em sentido contrário, Pontes de Miranda, Comentários..., t. VI, p. 384. A primeira posição, contudo, não nos parece correta, porque, se realmente apenas quem participou do processo pudesse ajuizar rescisória não haveria sentido em dizer que o "terceiro" tem legitimidade para a rescisória, porque quem participou do processo assume a condição de sujeito processual e deixa de ser terceiro. Além disso, apesar de que, realmente, no mais das vezes o terceiro não está vinculado à coisa julgada, o que, de fato, pode lhe retirar o interesse e a legitimidade para a ação rescisória, há casos em que ele é afetado pela coisa julgada, como se quer demonstrar neste trabalho. Para essas hipóteses, apenas a ação rescisória servirá. Justamente nessa linha vai Barbosa Moreira: "o artigo 487, $\mathrm{n}^{\circ}$ II, em termos inequívocos, legitima o 'terceiro interessado' à propositura de ação rescisória - o que necessariamente pressupõe a admissão de hipóteses em que se estende a terceiros a auctoritas rei iudicatae, pois de outro modo não se explicaria a possibilidade, que se lhes abre, de intentar ação primacialmente ordenada ao afastamento da coisa julgada: se nenhum terceiro ficasse jamais sujeito a 
No caso da impugnação de deliberações assembleares, fora de dúvida o cabimento de recurso de terceiro prejudicado e de ação rescisória contra a sentença que tenha causado prejuízo jurídico ao sujeito estranho ao processo. O meio mais amplo e eficaz de defesa do terceiro, contudo, é intervir no processo, ${ }^{1014}$ pois assim ele pode não só expor suas razões desde o início da marcha processual como também formular verdadeira, própria e individual pretensão. A que título, porém, deve se dar tal intervenção?

\subsubsection{Assistência litisconsorcial ou intervenção litisconsorcial voluntária?}

Assistência é modalidade de intervenção de terceiros pela qual o assistente ingressa em processo alheio com o intuito de colaborar com alguma das partes e, assim, melhorar o resultado do processo, no qual possui interesse jurídico, ainda que reflexo.

Há dois tipos de assistência: simples (CPC, art. 50) e litisconsorcial (CPC, art. 54). A simples ocorre quando o assistente intervém no processo em auxílio de uma das partes porque os efeitos de decisão desfavorável à parte assistida afetam diretamente a relação jurídica que existe entre assistente e assistido (exemplos clássicos: sublocatário em ação de despejo movida contra o sublocador ou tabelião em demanda de falsidade de escritura, se da anulação possa ter que vir a indenizar a parte lesada). Já a assistência litisconsorcial se dá quando o assistente integra a mesma relação jurídica controvertida no

\footnotetext{
esta, nenhum teria interesse em utilizar o remédio" (cf. "Solidariedade ativa...", p. 71). No mesmo sentido, v. Eduardo Talamini, Coisa julgada..., n. 2.5.11, pp. 121/122 e, no direito italiano, Allorio, que invocou meios de defesa do terceiro, como intervento adesivo e opposizione di terzo, como forma de comprovar a tese de que a coisa julgada produz-se perante terceiros (cf. La cosa..., n. 39, pp. 80/81). Chama-se atenção, ainda, para as considerações de lege ferenda feitas por José Rogério Cruz e Tucci: "delineia-se de todo recomendável a introdução, em nosso direito positivo, de instituto análogo à opposizione del terzo ordinaria, com a finalidade de complementar o quadro dos meios de defesa daquele que não participou do processo, mas sofreu prejuízo, e, com isso, pôr termo à notória divergência de entendimento quanto à efetiva tutela do direito do terceiro atingido pela eficácia da sentença" (cf. Limites subjetivos..., n. 40, p. 350).

${ }^{1012}$ Cf. Camilo Zufelato, Coisa julgada..., n. 4.2, p. 179.

1013 Sobre todas essas figuras, v. José Rogério Cruz e Tucci, Limites subjetivos..., nn. 4 e 19.5, pp. 40/41 e 178/186; e "Impugnação judicial...”, n. 1, p. 463.

${ }^{1014}$ Colhe-se o mesmo entendimento em Chiovenda, para quem uma das classes de terceiro é o daqueles que têm de reconhecer a coisa julgada, porque são titulares do mesmo direito que já foi decidido anteriormente. Esses terceiros não podem simplesmente furtar-se ao resultado do processo, razão pela qual a lei lhes possibilita alguns instrumentos para se defender, como, por exemplo, intervir no processo e contribuir para o resultado que pretende (cf. Instituições..., v. I, n. 136, pp. 421/422).
} 
processo; aqui, o assistente poderia ter sido parte. ${ }^{1015} \mathrm{Em}$ ambos os casos é necessário ter interesse jurídico para intervir. ${ }^{1016}$ Porém, na primeira hipótese, o resultado do processo poderá ser reflexamente desfavorável ao terceiro; na segunda, a relação jurídica deduzida também lhe é pertinente. Com base nisso, parcela da doutrina sustenta que ao ingressar no processo em que se pediu a anulação de deliberação, o terceiro o faz na condição de assistente litisconsorcial. ${ }^{1017}$

Outra modalidade de intervenção de terceiros - muito próxima da que acaba de ser analisada - é a intervenção litisconsorcial voluntária, que não possui previsão no CPC. Embora haja quem negue a sua existência no direito brasileiro, ${ }^{1018}$ ela convive entre nós. Trata-se do ingresso em processo de cognição em curso, por meio de uma demanda conexa à do autor original, com pedido de tutela jurisdicional da mesma natureza da por este pleiteada e em face do mesmo réu. ${ }^{1019}$ Dela se origina litisconsórcio ativo, facultativo, ulterior e simples, ${ }^{1020}$ em que o terceiro intervém no processo e formula, em seu próprio nome, pretensão que, se acolhida, irá lhe conferir vantagem análoga à perseguida pelo autor original. Diferentemente da assistência, em que a intervenção é ad coadjuvandum, na figura ora analisada o terceiro ingressa no processo perseguindo tutela para si próprio e, assim, assume a condição de parte principal, diferentemente do assistente, que é parte auxiliar. ${ }^{1021} \mathrm{O}$ exemplo clássico é o dos servidores públicos que aderem a uma demanda que já se desenrola, movida por outro servidor com o intuito de obter determinado benefício da Administração.

1015 Cf. Vicente Greco Filho, Da intervenção..., cap. III, n. 2, 74; e Cássio Scarpinella Bueno, Partes e terceiros..., cap. IV, n. 1, pp. 135/136.

${ }^{1016}$ Cf. Moacyr Lobo da Costa, Assistência, pp. 159/161; e José Raimundo Gomes da Cruz, Pluralidade de partes e intervenção de terceiros, n. 4.2.3, p. 167.

1017 Nesse sentido, Eduardo Talamini, "Legitimidade, interesse...", p. 104; e Carlos Alberto Carmona, Arbitragem e processso: um comentário à Lei 9.307/96, p. 309.

${ }^{1018}$ Por exemplo, Vicente Greco Filho, Da intervenção..., cap. III, n. 2, p. 75. Ainda na égide do CPC de 1939, Barbosa Moreira escreveu que, à luz do texto legal, não era muito claro se o sistema contaria com a figura, mas que a maioria da doutrina inclinar-se-ia pela negativa; concluiu, porém, que o ordenamento contaria com a figura, exceção feita ao processo de execução (cf. "Intervenção litisconsorcial voluntária", in Direito processual civil, pp. 22/23 e 31/32).

${ }^{1019}$ Cf. José Raimundo Gomes da Cruz, Pluralidade de partes..., n. 4.2.8, p. 185; e Dinamarco, Instituições..., v. II, n. 594, p. 387. A respeito de figura similar no direito alemão, v. Wach, Manual..., v. II, n. 58, pp. 452 e seguintes.

${ }^{1020}$ Cf. Cássio Scarpinella Bueno, Partes e terceiros..., cap. III, n. 6, p. 118.

${ }^{1021}$ Parte auxiliar porque, apesar de ser parte, isto é, de possuir faculdades, ônus, poderes e deveres relativos à relação processual, o assistente possui algumas restrições, como decorrência do fato de que o direito controvertido não é seu: ele não pode dispor sobre o processo ou sobre a relação controvertida, e tampouco está autorizado a contrariar as decisões do assistido (cf. Dinamarco, Instituições..., v. II, n. 597, p. 396). 
A diferença básica entre a assistência e o litisconsórcio é que o litisconsorte participa do processo na defesa direta de um direito próprio, enquanto que o assistente defende de modo direto um direito alheio e apenas reflexamente um direito seu. $\mathrm{O}$ litisconsorte, é dizer, deduz relação jurídica da qual é titular, o que não ocorre com o assistente. $\mathrm{O}$ litisconsorte pede para si, o assistente para o assistido. ${ }^{1022}$

A intervenção litisconsorcial também pode ser de duas espécies. A primeira é a promovida pelo colegitimado: este adentra processo já em curso, aderindo à pretensão deduzida. A sua situação legitimante conduz à mesma coisa litigiosa e não há ampliação do objeto litigioso do processo. A segunda espécie é a exercitada por sujeitos legitimados a demandas conexas à já proposta ou a ela ligada por algum ponto comum de direito ou de fato (CPC, art. 46, II-III e IV: litisconsórcio por conexidade e litisconsórcio impróprio). Aqui, há ampliação do objeto litigioso do processo, pois são formulados novos pedidos, o que inclusive altera a estrutura subjetiva do processo e gera a necessidade de que, ainda que não formalmente estruturada dessa forma, a sentença contenha capítulos autônomos, cada qual respondendo à pretensão de cada litisconsorte. ${ }^{1023}$

Existe uma escalada de intensidade quanto à situação legitimante do terceiro. Da ligação mais tênue para a mais intensa, há: (i) assistência simples (terceiro intervém sem alterar objeto do processo e sem poderes para contrariar a vontade do assistido); (ii) assistência litisconsorcial (terceiro intervém sem alterar objeto do processo, mas com poderes para contrariar a vontade do assistido); (iii) intervenção litisconsorcial do colegitimado (terceiro que poderia ser parte desde o início intervém com os mesmos poderes da parte originária, mas sem alterar o objeto do processo); e (iv) intervenção litisconsorcial do titular de relação jurídica conexa ou afim à relação litigiosa (terceiro que poderia ser parte desde o início intervém com os mesmos poderes da parte a cujo lado se coloca, alterando o objeto do processo). Nos dois últimos casos, o terceiro assume a condição de parte (litisconsorte). ${ }^{1024}$

\footnotetext{
${ }^{1022}$ Cf. Barbosa Moreira, "Intervenção litisconsorcial...", p. 25.

${ }^{1023}$ Cf. Dinamarco, Intervenção de terceiros, n. 10, pp. 33/34; e Litisconsórcio, n. 18, pp. 64/65.

${ }^{1024}$ Cf. Dinamarco, Litisconsórcio, n. 19, pp. 65/66.
} 
Volvendo à impugnação de deliberação assemblear, como se trata de colegitimados à impugnação de um mesmo ato, caso um deles venha a ingressar em processo já instaurado o fará na condição de litisconsorte, e não na de assistente litisconsorcial. ${ }^{1025} \mathrm{O}$ assistente não é parte porque não pede ou porque em face dele nada é pedido. E é por isso que no caso em análise não se trata de assistência. Poder-se-ia dizer que o acionista-terceiro pode optar por intervir como terceiro, simplesmente auxiliando o seu sócio. Contudo, em decorrência da unitariedade da relação jurídica deduzida, ao ingressar em juízo e reforçar a pretensão anulatória, ele estará defendendo direito próprio $^{1026}$ (v. item 9) e, assim, agindo como litisconsorte. É caso, portanto, de intervenção litisconsorcial voluntária, não de assistência litisconsorcial. Se ingressar, porém, em defesa da deliberação, será assistente simples da companhia. ${ }^{1027}$

Ao conceituar o litisconsórcio de colegitimados, Dinamarco dá o exemplo da intervenção de uma associação em ação civil pública ajuizada por outra associação e a do sócio que adentra o processo instaurado por outro sócio, para anulação de deliberação societária. Em ambos os casos, diz, a intervenção não altera o objeto do processo, porque os litisconsortes são substitutos processuais de um só substituído e a demanda que vêm a sustentar é a mesma desde a propositura da inicial. ${ }^{1028}$ Essa observação, todavia, apresenta alguns equívocos.

O primeiro é entender que o acionista que demanda a anulação de deliberação age como substituto, pois, como procuramos demonstrar, ele atua em defesa de direito próprio

${ }^{1025}$ Cf. Dinamarco, Litisconsórcio, n. 17, p. 63: "É que todos esses autores (originários ou ulteriores) ocupam a mesmíssima posição jurídica perante o objeto do processo". Também Barbosa Moreira expressamente afirmou tratar-se de caso de intervenção litisconsorcial (cf. "Intervenção litisconsorcial...", n. 25, nota 6), enquanto que Arruda Alvim e Sica-Bonício limitaram-se a escrever que o sócio ingressa na condição de litisconsorte ulterior (cf., respectivamente, Manual..., n. 41-A, p. 613 e "Litisconsórcio unitário...", p. 25). Embora Lopes da Costa tenha utilizado a expressão intervenção litisconsorcial, dando como exemplo a demanda em tela, cremos que estava se referindo à assistência qualificada (litisconsorcial) (cf. Manual elementar..., pp. 111/112).

${ }^{1026}$ Ao que acaba de ser dito são plenamente aplicáveis as palavras de Barbosa Moreira: "Por mais que do litisconsórcio se aproxime a assistência qualificada, vê-se, assim, que entre ambos resta sempre uma distância apreciável. Se a posição jurídica de uma pessoa é tal que lhe permita pedir de outrem algo para si, ou que permita a outrem pedir algo dela - em suma: se a sua posição é tal que se haja de deduzir em juízo relação jurídica de que ela mesma seja titular -, não tem sentido apontar-lhe, para o ingresso na causa, a porta da assistência. A única porta adequada - se alguma existe - é a da intervenção litisconsorcial" e "seria um contra-senso reduzir, do ponto de vista processual, à posição de assistente o terceiro que tem direito próprio a defender" (cf. "Intervenção litisconsorcial...", pp. 26 e 29).

${ }^{1027}$ Cf. Carlos Alberto Carmona, Arbitragem e processo..., p. 309, que, contudo, entende que no caso em que o acionista combate a deliberação ele age como assistente.

${ }^{1028}$ Cf. Instituições..., v. II, n. 595, p. 389. 
(v. item 9). Não há substituição. Além disso, embora Dinamarco afirme que o ingressante adere à pretensão já formulada e, portanto, não acresce nada ao objeto litigioso do processo, ${ }^{1029}$ este é ampliado na medida em que é formulada demanda conexa à inicial.

Por fim, diz a doutrina que a intervenção litisconsorcial voluntária só deve ser admitida até a fase postulatória do processo, pois, após o saneamento, com definição de seu objeto e da prova a ser produzida, a intervenção é inadmissível mesmo que o réu assim consinta, pois representaria um retrocesso à marcha processual incompatível com o sistema brasileiro de procedimento rígido. Uma segunda limitação é que, embora no caso de litisconsórcio entre colegitimados deva haver maior liberalidade em sua admissão, quando a intervenção ampliar demasiadamente o polo ativo do processo, instituindo litisconsórcio multitudinário - formado um número insuportavelmente grande de colitigantes prejudicial ao andamento do processo (CPC, art. 46, par.), o litisconsórcio deve ser dissolvido, mediante desmembramento e formação de grupos menores. ${ }^{1030}$ Apesar daquela primeira limitação, contudo, deve ser admitida a intervenção na forma da assistência, caso já se tenha ultrapassado a fase postulatória.

\subsubsection{Informação}

Ferramentas para que terceiros defendam seus interesses já existem em nosso sistema e são mais do que suficientes para que se diga que aqueles estão suficientemente amparados sob essa ótica. A dúvida que existe diz respeito ao modo pelo qual esse terceiro pode tomar conhecimento do processo e, assim, lançar mão de tais ferramentas. ${ }^{1031} \mathrm{O}$ ponto sensível, portanto, diz não com a reação, mas com a informação.

O processo é, em regra, de acesso público e, portanto, considerando que a demanda de anulação de deliberação deve ser ajuizada no foro da sede da companhia (CPC, art. 100, IV, "a"), os acionistas têm condição de monitorar a propositura de demandas em face da sociedade. A possibilidade de monitoramento existe, embora,

${ }^{1029}$ Cf. Dinamarco, Intervenção de terceiros, n. 10, p. 34.

${ }^{1030}$ Cf. Dinamarco, Instituições..., v. II, nn. 594/595 e 567, pp. 387/389 e 348. Diversamente, a assistência é admitida em qualquer momento do processo (n. 586, p. 380).

1031 Preocupação similar foi manifestada por Nicolò Trocker, que aludiu à necessidade de instrumentos adequados de comunicação que deem aos terceiros uma oportunidade efetiva de se inserirem tempestivamente na relação processual (cf. Processo civile e Costituzione, pp. 433 e 465 e seguintes). 
reconheça-se, não seja razoável impor ao acionista o ônus de realizar tal pesquisa periodicamente. Isso não basta, portanto, para que se repute que ele está adequadamente informado.

É útil traçar um paralelo entre o regime de publicidade da convocação para assembleia - onde poderá ser constituída a deliberação - e o de processo de invalidação onde poderá ser desconstituída a deliberação.

A convocação do acionista para assembleias - fundamental ao exercício dos seus direitos de participação e fiscalização - está sujeita a um regime de publicidade que também não cientifica pessoalmente os acionistas da realização do conclave, muito semelhante à citação ficta. Os arts. 124 e 289 da LSA, com efeito, exigem que o edital de convocação seja publicado no mínimo três vezes, em órgão oficial da União ou do Estado e em jornal de grande circulação da sede da companhia. Para as companhias abertas, a CVM ainda poderá determinar que as publicações sejam feitas também em jornal de grande circulação nos locais em que as ações da companhia sejam negociadas em bolsa de valores ou mercado de balcão (LSA, art. 289, $\S 1^{\circ}$ ).

A lei, portanto, não estabelece nenhuma forma de cientificação pessoal. Se os acionistas estão sujeitos a esse regime de publicidade para a criação da deliberação - que, pelo princípio majoritário, vinculará inclusive ausentes -, não parece desarrazoado que estejam sujeitos a um regime de publicidade similar para o caso de anulação da deliberação.

E mais. É também possível que os acionistas exijam que a companhia os informe da propositura de demanda anulatória de deliberação, inclusive, se for o caso, mediante inserção de norma nesse sentido no estatuto social. Aqui vem sendo dito que em decorrência do seu caráter instrumental o processo deve, em certa medida, refletir as particularidades do direito material, moldando-se às situações carentes de tutela. Embora costumemos ver a relação de instrumentalidade apenas sob tal ótica, não se trata de via de mão única: o próprio direito material pode e deve, em certas condições, responder e suprir eventuais pontos sensíveis do processo. Os acionistas, assim, podem exigir a instituição de regras de governança que obriguem a administração a informá-los do ajuizamento de 
demanda que apresente pretensão a respeito da coletividade. Cabe aos acionistas constituírem grupos de pressão para que seja introduzida no estatuto social disposição impondo esse dever à sociedade. Apesar de não ser uma resposta exatamente processual, ela não pode ser descartada.

Nas companhias abertas, há, ainda, a possibilidade de que, a depender da envergadura da demanda, esta seja considerada fato relevante - cuja divulgação é disciplinada pela Instrução CVM 358 - e, assim, deva ser noticiada ao mercado. O art. $2^{\circ}$ dessa Instrução, com efeito, conceitua fato relevante como "qualquer decisão de acionista controlador, deliberação da assembléia geral ou dos órgãos de administração da companhia aberta, ou qualquer outro ato ou fato de caráter político-administrativo, técnico, negocial ou econômico-financeiro ocorrido ou relacionado aos seus negócios que possa influir de modo ponderável: I. na cotação dos valores mobiliários de emissão da companhia aberta ou a eles referenciados; II. na decisão dos investidores de comprar, vender ou manter aqueles valores mobiliários; III. na decisão dos investidores de exercer quaisquer direitos inerentes à condição de titular de valores mobiliários emitidos pela companhia ou a eles referenciados". Prosseguindo, o parágrafo do art. $2^{\circ}$ elenca, em rol exemplificativo, hipóteses que podem ser qualificadas como fato relevante. Nenhuma dessas hipóteses trata concretamente de impugnação de deliberação assemblear, mas essa claramente pode vir a se enquadrar em algum dos incisos do caput do art. $2^{\circ}$. Caso isso ocorra, a administração deverá noticiá-la aos acionistas e ao mercado, observadas as ressalvas dos arts. $6^{\circ} / 8^{\circ}$.

Sem dúvida, boa parte do que aqui acaba de ser dito resta prejudicado em se tratando de litígios submetidos à arbitragem, em razão do sigilo natural à maior parte dos processos arbitrais. Tanto é que já se apontou haver certa incompatibilidade entre o sigilo que caracteriza a arbitragem e o regime de full disclosure a que estão submetidas as companhias abertas. ${ }^{1032} \mathrm{~A}$ intervenção de terceiros na arbitragem gera questões complexas, multifacetadas e que ainda não foram devidamente resolvidas pela doutrina. A maior parte dos regulamentos dos órgãos arbitrais ainda não está preparada para resolver as dúvidas decorrentes da intervenção de terceiros no processo arbitral, ${ }^{1033}$ complexo e multifacetado,

${ }^{1032}$ Cf. Fernando Antonio Maia da Cunha e Walfrido Jorge Warde Júnior, “A arbitragem e os limites...”, p. 756.

${ }^{1033}$ Prova disso é a afirmação de Carlos Alberto Carmona de que "os problemas decorrentes da intervenção de terceiros na arbitragem farão correr rios de tinta antes de serem convenientemente sistematizados. Devem 
que apresenta, ainda, muitas outras questões (como, por exemplo, aquelas relativas à nomeação dos árbitros, eficácia da convenção arbitral diante do terceiro), que não cabem ser aqui analisadas. ${ }^{1034}$

Contudo, se o estatuto social da companhia estipular o dever de serem cientificados os acionistas, não há dúvida de que ele se impõe sobre qualquer sigilo estipulado na arbitragem. Da mesma forma com o fato relevante: se a demanda formulada em processo arbitral caracterizar fato relevante, a companhia tem o dever de comunicá-lo ao mercado, ainda que a arbitragem seja sigilosa. Prevalecem, em qualquer caso, as disposições estatutárias e a regulação da CVM.

De toda forma, a informação não é um requisito para a extensão da coisa julgada, de modo que a ausência daquela não deve servir para afastarmos a coisa julgada erga omnes. A eficácia subjetivamente irrestrita da coisa julgada deriva da especialidade do direito, independentemente da informação. O que se procurou aqui é apenas cogitar de ferramentas para que haja efetiva informação.

\subsubsection{Conluio e atos de disposição}

Uma terceira ordem de preocupação da doutrina com a coisa julgada erga omnes - e fundamento para a sua rejeição - diz com atos de conluio e de disposição do processo e do direito material, isto é, com a possibilidade de que, mancomunados, a companhia e algum interessado simulem o processo, ou o autor pratique atos de disposição do processo ou do direito material, tudo levando ao trancamento da via impugnatória. $\mathrm{O}$ ato fraudulento pode resultar, inclusive, de eventual influência que o acionista controlador possa ter na conduta da companhia em defender-se de demanda anulatória ajuizada pelo próprio

os operadores, de qualquer modo, atentar para o fato de que a maior parte dos regulamentos dos órgãos arbitrais não está aparelhada para resolver os impasses provocados pela necessidade ou conveniência de terceiros participarem de arbitragens já iniciadas" (cf. Arbitragem e processo..., p. 310).

${ }^{1034}$ Sobre intervenção de terceiros na arbitragem, v. Paula Costa e Silva e Marco Gradi, "A intervenção de terceiros no procedimento arbitral no direito português e no direito italiano", Revista brasileira de arbitragem, n. 28, jul/out 2003, pp. 41/92, com ampla indicação de doutrina estrangeira sobre o tema; Humberto Theodoro Júnior, "Arbitragem e terceiros - litisconsórcio fora do pacto arbitral - outras intervenções de terceiros", Revista de direito bancário, v. 14, pp. 375 e seguintes; J. E. Carreira Alvim, "Intervenção de terceiros na arbitragem", in Pedro A. Batista Martins e José Maria Rossani Garcez (coords.), Reflexões sobre arbitragem, pp. 264 e seguintes, e Tratado geral da arbitragem, pp. 463/466; e Marcelo Dias Gonçalves Vilela, Arbitragem no direito societário, pp. 225/228. 
controlador, o que pode ocorrer, por exemplo, em deliberação para a qual o controlador seja impedido de votar (LSA, art. 115, § $1^{\circ}$ ) e, assim, pleiteie a sua desconstituição. Embora esses temores possam ser qualificados como exagerados, ${ }^{1035}$ é possível que se concretizem na prática.

Dentre os atos de disposição está a desistência do processo, ${ }^{1036}$ que, prevista no art. 267, VIII do CPC, deve contar com anuência da companhia e ser reconhecida por sentença meramente homologatória (CPC, arts. 267, § $4^{\circ} \mathrm{c} / \mathrm{c} 158$, par.). ${ }^{1037}$ Não há, aqui, grandes problemas, uma vez que ela não leva à emissão de decisão de mérito e, portanto, tampouco à formação de coisa julgada material. Não há, portanto, impedimento de repropositura da demanda (CPC, art. 268), o que levou Sampaio de Lacerda a afirmar que na demanda de responsabilidade de administrador a desistência manifestada pelo substituto processual não repercute sobre a existência do direito litigioso. ${ }^{1038}$

Maior receio traz a renúncia ao direito em que se funda a demanda, pois, neste caso, embora não haja propriamente apreciação da pretensão - o que levou a doutrina a tachar a sentença homologatória de falsa sentença de mérito ${ }^{1039}$-, o Código impõe a extinção do processo com julgamento do mérito e, consequentemente, a formação de coisa julgada material. De lege ferenda, deveria haver regra que, a teor do que dispõe o art. 9 da Lei de Ação Popular, exigisse a cientificação dos demais interessados para que assumissem o polo ativo do processo. ${ }^{1040}$ Mas tal disposição não há e, portanto, a renúncia é ato

\footnotetext{
1035 Como fez Alfredo Rocco (cf. Le società..., n. 176, p. 250).

1036 Prefere-se a expressão desistência do processo à expressão consagrada na lei (desistência da ação) porque, como apontado por Egas Monis de Aragão, não se desiste da ação, mas sim do processo (cf. Comentários..., n. 531, p. 409). Também Dinamarco apontou que a desistência não atinge o direito de ação (cf. Vocabulário..., n. 58, p. 123). Barbosa Moreira, por sua vez, preferiu a expressão desistência do pedido ou da pretensão (cf. Litisconsórcio unitário, n. 126, p. 203).

${ }^{1037}$ Que, conforme Dinamarco, é sentença delibatória (cf. Instituições..., v. III, nn. 835 e 884, pp. 131/132 e 189/190).

${ }^{1038}$ Cf. Comentários..., v. III, p. 212.

1039 Cf. Dinamarco, Instituições..., v. III, nn. 887 e 928, pp. 193/194 e 256/257. Ainda de acordo com o mestre, "a renúncia ao direito é o ato unilateral com que o autor dispõe do direito subjetivo que vinha afirmando ter e que, se realmente, tivesse, por essa razão deixará de ter" (n. 933, p. 263).

${ }^{1040}$ Cf. Paulo Cézar Aragão, “Aspectos processuais...”, p. 70: “Andou mal, também, a lei brasileira ao não seguir a regra norte-americana, já constante, por sinal, do art. $9^{\circ}$ da nossa Lei da Ação Popular, acima lembrada, segundo a qual a desistência da ação (ou, mais tecnicamente, a renúncia ao direito sobre o qual se funda a ação de impugnação ou a ação de responsabilidade) pressupõe a adequada notícia a todos os demais interessados, para que, querendo, possam prosseguir com a demanda, afastando-se, assim, a possibilidade de acordos escusos". No mesmo sentido, Marcelo Von Adamek, Responsabilidade civil..., n. 8.9, p. 493.
} 
potestativo do demandante, que conduz ao julgamento de mérito. $\mathrm{O}$ ato, contudo, não afeta o direito dos demais acionistas.

Primeiro porque o primeiro pressuposto para a renúncia é que o direito seja disponível. E na premissa de que quem impugna deliberação age em defesa de direito próprio, conclui-se que ele só pode dispor de seu direito, não do de outrem. As posições jurídicas dos demais interessados ficam resguardadas, portanto. Em segundo lugar, aplicase o art. 48 do CPC, que determina que "salvo disposição em contrário, os litisconsortes serão considerados, em suas relações com a parte adversa, como litigantes distintos; os atos e as omissões de um não prejudicarão nem beneficiarão os outros". ${ }^{1041}$

Verdade que a doutrina entende que o art. 48 não se aplica aos casos de litisconsórcio unitário, na medida em que nele, em decorrência da incindibilidade da relação material, todos os litisconsortes devem receber o mesmo tratamento. Mas essa mesma doutrina reconhece que o ato de um litisconsorte unitário não pode prejudicar os demais consortes. Os atos de disposição, como confissão ou reconhecimento jurídico do pedido, conquanto válidos se praticados por apenas um dos consortes, são ineficazes perante os demais. ${ }^{1042}$ No litisconsórcio unitário os comportamentos determinantes só geram seus efeitos típicos quando manifestados pela totalidade dos consortes, razão pela qual uma das exceções à regra geral de extensão subjetiva da eficácia dos atos praticados pelo litisconsorte unitário é justamente a do reconhecimento do pedido e da renúncia. A menos que haja concordância de todos os litisconsortes, tais atos são ineficazes. ${ }^{1043}$ Entender o contrário equivaleria a conferir ao litisconsorte o poder de fazer perecer o direito dos demais. ${ }^{1044}$ A renúncia não afeta o direito dos demais acionistas, que continuam a titularizar o direito de impugnar o ato societário.

\footnotetext{
${ }^{1041}$ Por isso que Egas Moniz de Aragão diz que "em havendo litisconsórcio, seja qual for, a renúncia, na medida em que cabível, haverá apenas o direito do renunciante, não atingindo, de modo algum, o dos colitigantes (art. 48)" (cf. Comentários..., n. 560, p. 429).

${ }^{1042}$ Cf. Arruda Alvim, Código..., v. II, p. 416.

${ }^{1043}$ Cf. Barbosa Moreira, Litisconsórcio unitário..., nn. 19, 36, 65/66, 104 e 126, pp. 19, 37/38, 58, 112/115, 174 e 204; e "Reconhecimento do pedido", in Direito processual civil, p. 108. A essa lição adere Cássio Scarpinella Bueno, Partes e terceiros..., cap. III, n. 7.1, p. 126. A mesma posição é defendida por Clito Fornaciari Júnior para o reconhecimento do pedido no litisconsórcio unitário (cf. Reconhecimento jurídico do pedido, n. 11, pp. 26/27). Tratando da aceitação da deliberação viciada, também Allorio entende que ela não produz efeitos perante os demais acionistas (cf. La cosa..., n. 68, pp. 119/120).

${ }^{1044}$ Cf. Celso Agrícola Barbi, Comentários..., v. I, n. 312, p. 287.
} 
Bem analisadas, a desistência do processo e a renúncia ao direito em que se funda a demanda, portanto, não causam preocupação. A grande questão reside no processo simulado, isto é, que, apesar de aparentemente lícito, resulta de vontades veladas de fraudar a lei e/ou lesar terceiros, aos quais cabe tomar alguma medida contra a decisão. No direito italiano recorre-se, dentre outras ferramentas, às opposizioni di terzo ordinaria e revocatoria, ${ }^{1045}$ meios de impugnação extraordinários que podem ser utilizadas pelo terceiro prejudicado pela sentença, inclusive transitada em julgado. ${ }^{1046}$

No direito brasileiro, uma primeira defesa é o art. 129 do CPC, que dispõe que “convencendo-se, pelas circunstâncias da causa, de que autor e réu se serviram do processo para praticar ato simulado ou conseguir fim proibido por lei, o juiz proferirá sentença que obste aos objetivos das partes". O julgador, assim, pode extinguir o processo sem julgamento do mérito, ${ }^{1047}$ evitando a formação de coisa julgada material. ${ }^{1048}$ Pode, ainda, impor sanções por litigância de má-fé. ${ }^{1049}$

Não sendo o processo extinto por força do art. 129 do CPC, será sempre cabível recurso de terceiro prejudicado (CPC, art. 499), caso o processo ainda esteja em curso. Se o conluio for descoberto posteriormente à formação de coisa julgada, há a possibilidade de ação rescisória, com base no art. 485, III do CPC, ${ }^{1050}$ embora reconheçamos a dificuldade da prova da fraude ou simulação. ${ }^{1051}$

${ }^{1045}$ Cf. Romano-Pavoni, Le deliberazioni..., n. 102, p. 383; e Allorio, La cosa..., nn. 162/163 e 185/191, pp. 276, 278 e $307 / 316$.

${ }^{1046}$ Cf. Mandrioli, Diritto processuale..., v. II, nn. 71-c e 85, pp. 408 e 571; e Comoglio-Ferri-Taruffo, Lezioni..., cap. 25, nn. 6/8, pp. 744/750.

${ }^{1047}$ Embora haja dissenso na doutrina sobre se a sentença proferida com base no art. 129 seria de mérito ou terminativa, como apontado por Helena Abdo (cf. $O$ abuso do processo, n. 34.3, p. 239), cremos que se trata de sentença terminativa, que anula o processo (cf. Hélio Tornaghi, Comentários..., v. I, p. 401; e Arruda Alvim, Código..., v. V, pp. 192/193). Também Flávio Yarshell aponta que a doutrina não é unânime a esse respeito, embora diga que no processo de execução a extinção deve ocorrer sem julgamento do mérito (cf. "Simulação e processo de execução", in Teresa Arruda Alvim Wambier (coord.), Processo de execução e assuntos afins, p. 242). De todo modo, independente da posição que se adote, o fato é que o Código impõe ao juiz o poder-dever de extinguir o processo e, assim, obstar que as partes atinjam resultado ilícito.

${ }^{1048}$ Solução alvitrada por Paulo Cézar Aragão (cf. "Aspectos processuais...”, p. 64) e por Marcelo Von Adamek, este último ao tratar da simulação na demanda de responsabilidade de administrador (cf. Responsabilidade civil..., n. 8.8.2, p. 492).

1049 Cf. Flávio Yarshell, "Simulação e processo...", p. 233; e Helena Abdo, O abuso do processo, n. 25.3, p. 160. Sobre a simulação no processo civil português, v. Lebre de Freitas, Introdução..., cap. I, n. 3.6, pp. $42 / 45$.

${ }^{1050}$ Cf. Paulo Cézar Aragão, "Aspectos processuais...", p. 64. E, novamente fazendo considerações sobre a demanda de responsabilidade de administrador, plenamente aplicáveis à demanda de invalidação de deliberação, Araújo Cintra, “Atuação por via processual...”, p. 76; e Marcelo Von Adamek, Responsabilidade 
A doutrina italiana invoca, ainda, com base no art. 70 de seu Código de Processo Civil, dentre o rol de instrumentos de proteção do terceiro ao alargamento da coisa julgada, a intervenção do Ministério Público em processos que envolvem "interesse público", inclusive como meio de prevenir a fraude e a negligência. ${ }^{1052}$ No Brasil, contudo, não há base legal para entendimento similar, que deve ser rechaçado, exceto em casos em que o processo envolve interesse transindividual - como na hipótese da Lei 6.385/76, que dispõe sobre a ação civil pública de responsabilidade por danos causados aos investidores no mercado de valores mobiliários ${ }^{1053}$-, que devem realmente ser excepcionais.

\subsubsection{Controle de ingresso em juízo (representatividade adequada)?}

De acordo com doutrina de peso, ainda que não conte com previsão expressa, o microssistema brasileiro de processo coletivo admite o controle de representatividade adequada. ${ }^{1054}$ Diante disso, indaga-se: é possível que o juiz controle a representatividade de quem impugna deliberação assemblear, ao fundamento de que, como o resultado do processo irá se impor perante terceiros, é necessário verificar se o demandante tem condições de atuar como representante do colégio de interessados?

Uma das alternativas para a mitigação do contraditório que a coisa julgada erga omnes representa, de fato, é o controle de representatividade adequada, na linha do que prevê o art. $2^{\circ}$, I e $\S 2^{\circ}$ do Código Modelo de Processos Coletivos para Ibero-América. Tanto é isso verdade que já se afirmou que referido controle é a chave para a

civil..., n. 8.8.2, p. 492. A doutrina, contudo, distingue fraude de simulação, afirmando que apenas para a primeira é cabível a rescisória (cf. Flávio Yarshell, Ação rescisória..., n. 106, p. 317).

${ }^{1051}$ O que, aliás, levou a doutrina a sustentar que na simulação basta a prova indiciária (cf. Flávio Yarshell, "Simulação e processo...", p. 236).

${ }^{1052}$ Cf. Federico Carpi, L'efficacia..., n. 65, pp. 343/345.

1053 Sobre o assunto, v. Lionel Zaclis, Proteção coletiva dos investidores no mercado de capitais; Ada Pellegrini Grinover, "A tutela coletiva dos investidores no mercado de valores mobiliários: questões processuais", in Flávio Yarshell e Guilherme Setoguti J. Pereira (coords.), Processo societário, pp. 27 e seguintes; Rodolfo de Camargo Mancuso, "Ação civil pública para tutela dos interesses dos titulares de valores mobiliários", $R T$, v. 650; Paulo Fernando Campos Salles de Toledo, "A tutela jurisdicional do mercado de valores mobiliários", RT, v. 667; e Ricardo de Barros Leonel, Manual do processo coletivo, p. 117.

${ }^{1054}$ Cf. Ada Pellegrini Grinover, “Ações coletivas ibero-americanas: novas questões sobre a legitimação e a coisa julgada”, Revista Forense, n. 361, pp. 3 e seguintes. 
transmissibilidade da coisa julgada (binding effect) no direito norte-americano. ${ }^{1055}$ Realmente, se existe uma fiscalização sobre quem poderá defender um direito coletivo ou de reflexos coletivos, que exija desse sujeito preencher certos requisitos, fica mais fácil legitimar a extensão da coisa julgada a terceiros.

Porém, embora o direito que fundamenta a demanda anulatória de deliberação assemelhe-se ao coletivo em sentido estrito, não é cabível o controle da representatividade na impugnação de deliberações assembleares. Não só porque não há base legal para esse entendimento, mas principalmente porque quem vai a juízo deduzir essa pretensão não representa os demais, mas sim age em defesa de direito próprio. Não se pode exigir que ele "defenda adequadamente" a massa de acionistas simplesmente porque ele não os representa. Um controle de representatividade adequada, neste caso, violentaria a garantia constitucional da inafastabilidade do controle jurisdicional ( $\mathrm{CF}$, art. $\left.5^{\circ}, \mathrm{XXXV}\right)$, pois tolheria o interessado de defender um direito próprio, por mais que este possua reflexos coletivos. Não é possível, pois, de lege lata, barrar o acesso à via impugnatória ao fundamento de que o demandante não é o adequado representante do colégio de sócios. Mesmo que o acionista detenha parcela ínfima do capital social, ele está tão legitimado a pedir a invalidação de uma deliberação quanto o controlador ou um "minoritário qualificado".

\section{Sucessão, substituição e representação processuais}

Devem ser analisadas, por fim, algumas hipóteses em que determinados atos materiais repercutem, de alguma forma, na estrutura subjetiva da relação substancial deduzida em juízo e, em alguns casos, até mesmo na conformação do processo.

\footnotetext{
${ }^{1055}$ Cf. Camilo Zufelato, Coisa julgada..., n. 4.3.1, p. 195. No direito estadunidense, a coisa julgada vincula a todos quando se trata de direitos indivisíveis, mas, por outro lado, lá existe um rigoroso controle de representatividade. Em se tratando de direitos divisíveis, deve haver manifestação dos interessados a respeito de participarem do contraditório ou serem vinculados à decisão, mesmo sem terem participado do processo. No sistema brasileiro, em se tratando de direitos indivisíveis (difusos ou coletivos), a coisa julgada forma-se inter alios, salvo se houver improcedência por falta de provas. Aqui, adequada representação é verificada com critérios pouco rigorosos, mas, por outro lado, há participação obrigatória do Ministério Público nas demandas não propostas por ele e a possibilidade de rediscussão quando não há prova suficiente para a condenação. E, em caso de improcedência, continua aberta a via indenizatória pelos danos pessoais (cf. Camilo Zufelato, Coisa julgada..., n. 4.3.1, pp. 189/191).
} 


\subsection{Cessão de ações por ato inter vivos (alienação do direito litigioso)}

Se, uma vez ajuizada a demanda impugnatória, o acionista transfere todas as ações sociais que detém por ato inter vivos e retira-se da sociedade, trata-se de hipótese de alienação do direito litigioso ${ }^{1056} \mathrm{e}$, assim, aplica-se o disposto no art. 42 do CPC: em princípio não são alteradas as partes do processo e o adquirente poderá suceder - apesar da redação do $\S 1^{\circ}$ do art. 42, é caso de sucessão, não de substituição - o cedente, se consentir a parte contrária. Se não houver sucessão, o alienante prossegue no processo como autor da demanda, na condição de substituto processual do adquirente, a quem será facultado intervir como assistente. ${ }^{1057}$ Com a consumação da operação, o alienante deixa de ser legitimado ordinário e passa a ser legitimado extraordinário. ${ }^{1058}$

Questão diversa é a que diz respeito à legitimidade para impugnar a deliberação de quem não era acionista à época em que esta foi tomada, mas posteriormente adentrou o quadro societário. Neste caso, o adquirente é legitimado, como qualquer outro acionista, para pleitear a desconstituição da deliberação. Nesse sentido é que, embora de lege ferenda Erasmo Valladão França e Marcelo von Adamek recomendem a criação de dispositivo que exija a propriedade contemporânea como requisito de legitimidade ativa ad causam, reconhecem que pelo direito constituído não existe tal requisito e, portanto, não se pode negar legitimidade ao adquirente. ${ }^{1059}$

\footnotetext{
${ }^{1056}$ Sobre o conceito de coisa ou direito litigiosos, v. Carlos Alberto Alvaro de Oliveira, Alienação da coisa litigiosa; e José Maria Tesheiner, Coisa litigiosa!.

1057 Cf. Eduardo Talamini, "Legitimidade, interesse...", p. 117; e Carlos Alberto Alvaro de Oliveira, Alienação da coisa..., p. 113. A respeito da intervenção do adquirente do direito litigioso como assistente, $v$. Alexandre Freitas Câmara, "A admissão do assistente qualificado no processo civil - Algumas considerações sobre o adquirente de direito litigioso e sua intervenção", in Teresa Arruda Alvim Wambier e outros (coords.), O terceiro no processo civil brasileiro e assuntos correlatos - Estudos em homenagem ao Professor Athos Gusmão Carneiro, pp. 54/64.

${ }^{1058}$ Cf. Athos Gusmão Carneiro, Intervenção de terceiros, n. 21, p. 58.

${ }^{1059}$ Cf. "Algumas notas...", p. 173: "No direito pátrio, embora a exigência de propriedade contemporânea para o exercício de determinados direitos de sócio não seja desconhecida (em especial, para o exercício do direito de recesso), não existe para o manejo da ação anulatória e, portanto, à míngua de previsão legal, não pode ser exigida opes judicis nem pode ser criada pelo contrato social ou estatuto, que assim estaria impondo um requisito de condição da ação sem amparado na lei processual e em dissonância com o art. 109, $\S 2^{\circ}$, da Lei das S/A". Nesse sentido é que, fazendo considerações à luz do revogado Código Comercial italiano, Vivante escreveu que o direito de impugnar deliberações inválidas é titularizado a qualquer pessoa que seja sócia no momento em que exercitada a ação (cf. Trattato..., v. II, n. 521, ter, p. 256). A questão é analisada à luz do direito espanhol por Jose Vicente Soria Ferrando, La legitimación..., cap. II, n. 1.1, pp. 41 e seguintes.
} 


\subsection{Sucessão mortis causa}

Diversa é a situação em que a sucessão se dá mortis causa, isto é, se no curso do processo falece o autor e as ações societárias são transferidas aos herdeiros. Nesta situação, não se aplica o art. 267, IX do CPC (que impõe a extinção do processo sem julgamento do mérito em razão de falecimento do autor "quando a ação for considerada intransmissível por disposição legal"), mas o art. 43 do CPC, que permite a sucessão do falecido pelo espólio ou seus herdeiros ("Art. 43 Ocorrendo a morte de qualquer das partes, dar-se-á a substituição pelo seu espólio ou pelos seus sucessores, observado o disposto no art. 265”). A morte leva à suspensão do processo (CPC, art. 265, I) e, após, devem ser habilitados os herdeiros ou o espólio, sob pena de nulidade dos atos praticados em nome do falecido (CPC, arts. 43, 1.055, 1.060 e 1.062).

\subsection{Incorporação, fusão e cisão da sociedade (LSA, arts. 227/229)}

Fenômenos diversos ocorrem quando, em curso processo em que se pede a anulação de deliberação, a companhia passa por operações de fusão, incorporação e cisão. $^{1060}$

Pode ocorrer que o pleito anulatório "perca objeto" e, assim, não reste outra alternativa a não ser a extinção do processo por perda superveniente do interesse processual (CPC, art. 267, IV). Mas pode haver hipóteses em que, a despeito da operação, ainda remanesça interesse no processo e, portanto, este prossiga.

Tais fenômenos devem ser vistos, antes de tudo, à luz da teoria das invalidades das deliberações conexas, uma vez que é possível que, atendidos certos requisitos, a invalidação da deliberação prejudique e, consequentemente, invalide a própria operação. Imagine-se, por exemplo, o ajuizamento de demanda que impugne deliberação de aumento de capital e peça expressamente a anulação de todos os atos dela dependentes. Se

\footnotetext{
${ }^{1060}$ Simples alteração da denominação social ou mesmo transformação no curso do processo não geram alteração na estrutura subjetiva do processo, uma vez que tais hipóteses não compreendem extinção da pessoa jurídica nem transferência de direitos e deveres (cf. Carlos Alberto Alvaro de Oliveira, Alienação da coisa..., p. 110). Nesse sentido, afirma Bulgarelli que "a tendência moderna tem sido a de disciplinar a transformação, permanecendo a mesma pessoa jurídica sobre nova forma, sem que seja necessário dissolver a sociedade para constituir outra" (cf. Comentários ...., v. 4, p. 114).
} 
procedente essa pretensão, é possível que também seja, por exemplo, anulada incorporação ou fusão para cuja aprovação tenham sido determinantes os votos proferidos pelos titulares das ações emitidas em decorrência do referido aumento de capital (LSA, arts. 227, § $2^{\circ}$ e $\left.228, \S 1^{\circ}\right)$. Evidente que, em casos como esse, a sociedade incorporadora ou resultante da fusão têm interesse na improcedência da demanda e, portanto, no alcance desse resultado mediante prosseguimento do processo. Deve, então, ser esclarecido como essas operações impactam na conformação subjetiva do processo.

Em se tratando de fusão ou incorporação, os arts. 227 e 228 da LSA determinam a sucessão universal, ${ }^{1061}$ de modo que a sociedade resultante da operação suceda as incorporadas ou fusionadas em todos os seus direitos e obrigações. ${ }^{1062}$ A sociedade incorporadora ou resultante da fusão, portanto, deverá suceder a sociedade extinta no processo, na forma do art. 43 do CPC.

Embora Nelson Eizirik diga que a sucessão da incorporadora em processo em curso opera-se automaticamente, independente da concordância da parte contrária, essa afirmação é apenas em parte verdadeira. De fato, a sucessão independe da anuência da parte contrária, já que a situação é regrada pelo art. 43 do CPC, e não pelo art. 42. Mas, apesar da sucessão no plano do direito material, isto é, dos direitos e das obrigações, ocorrer de pleno direito assim que consumada a operação, a sucessão processual depende de notícia no processo e de decisão que a reconheça. Trata-se de mera formalidade, mas mera formalidade necessária. Cabe à incorporadora ou à sociedade nascida da fusão, assim, apresentar documentos que comprovem a operação e pedir a alteração do polo passivo do processo.

Disciplina diversa recebe a cisão. ${ }^{1063}$ Em caso de cisão total, em que desaparece a personalidade jurídica da parte original porque seu patrimônio foi todo destinado a uma ou mais sociedades, estas sucedem a cindida em todos os direitos e obrigações, inclusive nos

\footnotetext{
1061 Cf. Carvalhosa, Comentários..., v. 4, t. I, pp. 295/296 e 316.

1062 Cf. Paulo Cézar Aragão, “Aspectos processuais...", p. 69; e Nelson Eizirik, A Lei das S/A..., v. III, pp. 250 e 254.

${ }^{1063}$ Sobre o instituto, v., por todos, Mauro Brandão Lopes, A cisão no direito societário.
} 
não arrolados no protocolo de cisão (LSA, art. 233, caput). ${ }^{1064}$ Tais sociedades, assim, devem suceder a companhia extinta, ${ }^{1065}$ também na forma do art. 43 do CPC.

Já na cisão parcial, em que sobrevive a sociedade cindida, aquela que absorver parcela do seu patrimônio sucederá a cindida nos direitos e deveres relacionados no protocolo de cisão e responderá solidariamente com ela pelas obrigações anteriores à cisão (LSA, art. 233, caput). ${ }^{1066}$ Se entre o plexo de direitos e deveres transmitidos estiverem os relativos à demanda em curso, aplica-se o art. 42 do CPC (alienação do direito litigioso): se o autor da demanda não concordar com a sucessão da sociedade sucessora, permanecerá a parte original como sua substituta. A sociedade que absorveu o patrimônio poderá, contudo, intervir como assistente. A sentença, assim, afetará ambas as sociedades, a menos que se tenha excluído a solidariedade nos termos do art. 233 da LSA. ${ }^{1067}$

\subsection{Representação processual: a hipótese do art. 68 da LSA (agente fiduciário e comunhão de debenturistas)}

Resta analisar, por fim, o art. 68 da LSA, que trata da comunhão de debenturistas. O caput desse artigo dispõe que "o agente fiduciário ${ }^{1068}$ representa, nos termos desta Lei e da escritura de emissão, a comunhão dos debenturistas perante a companhia emissora", ao passo que o $\S 3^{\circ}$ estabelece que "o agente fiduciário pode usar de qualquer ação para proteger direitos ou defender interesses dos debenturistas, sendo-lhe especialmente facultado, no caso de inadimplemento da companhia".

O agente fiduciário, que deve atender aos requisitos do art. 66 da LSA e à regulamentação da Instrução CVM 28/83, é a pessoa que representa uma entidade despersonificada, a massa de debenturistas. ${ }^{1069}$ O agente pode tomar todas as medidas

\footnotetext{
${ }^{1064}$ Cf. Nelson Eizirik, A Lei das S/A..., v. III, p. 262.

1065 Paulo Cézar Aragão alude à "substituição processual”, como equivocadamente diz o art. 43 do CPC. Trata-se, contudo, de hipótese de sucessão processual.

1066 Cf. Nelson Eizirik, A Lei das S/A..., v. III, p. 262.

${ }^{1067}$ Cf. Paulo Cézar Aragão, “Aspectos processuais...”, p. 69.

1068 De acordo com a Exposição de Motivos da LSA, "para maior proteção dos investidores do mercado, o projeto prevê e regula a função do agente dos debenturistas, tomando por modelo o 'truste' do direito anglosaxão, e adaptando-o à nossa técnica jurídica".

1069 Cf. Lacerda Teixeira-Tavares Guerreiro, Das sociedades..., v. I, n. 126, p. 366; e Carvalhosa, Comentários..., v. 1, p. 898.
} 
necessárias à preservação do interesse dos representados, inclusive propor demandas em face da companhia emissora dos títulos de crédito. Não se descarta, portanto, que ajuíze demanda anulatória de deliberação assemblear que tenha prejudicado seus representados. E, fazendo-o, agirá não como substituto, mas sim como representante processual: agirá em nome e em defesa do interesse dos debenturistas, ${ }^{1070}$ que, como partes materiais e processuais que são, estarão vinculados às decisões proferidas no processo.

${ }^{1070}$ Cf. Luiz Gastão Paes de Barros Leães, Comentários..., v. II, n. 79, p. 81; Lacerda Teixeira-Tavares Guerreiro, Das sociedades..., v. I, n. 126, p. 373; Eduardo Talamini, Coisa julgada..., n. 2.5.7, p. 115, nota 162; e Fran Martins, Comentários..., v. I, n. 315, p. 432. De acordo com Carvalhosa, trata-se de representação orgânica, uma vez que o agente fiduciário é, assim como a assembleia de debenturistas, órgão da comunhão. Não há, portanto, representação por força de mandato, mas sim por conta de função organizacional (cf. Comentários..., v. 1, pp. 900, 909 e 912/913). Entendendo tratar-se de substituição processual, Nelson Eizirik afirma que o agente fiduciário é o próprio autor da demanda, invocando o Parecer PFE/CVM 005/2003 (cf. $A$ Lei das S/A..., v. 1, p. 424). O caput do art. 66 da LSA, porém, utiliza o verbo representar, deixando claro tratar-se de representação, e não de substituição. 


\section{CONCLUSÃo}

É corrente na literatura jurídica a afirmativa de que o processo civil deve moldarse às particularidades do direito material que atua; asserção que, ao cabo do trabalho, cremos ter demonstrado ser correta. Mas apenas dizer isso não bastava. Era preciso estabelecer no que consiste referida especificidade. Daí a escolha do tema desta dissertação, na qual se procurou examinar quais são o conteúdo e os limites objetivos e subjetivos do provimento e da coisa julgada na impugnação de deliberações de assembleias gerais das sociedades por ações.

O exame dos temas processuais objeto deste trabalho (modalidades de tutela jurisdicional e limites objetivos e subjetivos do provimento e da coisa julgada) promovido sob a ótica das deliberações assembleares inválidas revelou-se rico e frutífero, confirmando a assertiva de que a análise de questões processuais à luz de temas de direito material pode ser um excelente banco de prova para as posições assumidas pelo processualista.

Partindo da dicotomia nulidade/anulabilidade como polo metodológico em torno do qual gravitaram nossas reflexões, o primeiro capítulo destinou-se a estabelecer o regramento que o direito material dispensa à deliberação inválida. Qualificamos esta como negócio jurídico unilateral colegial, formada pelos votos manifestados em assembleia e que destes diferencia-se por conta do procedimento deliberativo, regido pelo princípio majoritário. Demonstramos a existência de um regime de invalidades próprio do direito societário, fundamentado, basicamente, pelos postulados de estabilidade e proteção da confiança e que importa em (i) maior tolerância às transgressões aos requisitos para a prática de atos, (ii) relativização à regra de contaminação das nulidades, (iii) prazos decadenciais mais curtos, (iv) limitação do rol de legitimados para demandas de impugnação e (v) preservação de efeitos. Concluímos, também, que, apesar de os arts. 115, $\S 4^{\circ}$ e 286 da LSA referirem-se apenas às deliberações anuláveis, o direito brasileiro conta com deliberações nulas, embora estas apresentem contorno diverso do que costuma afirmar a doutrina. Defendemos, com efeito, que as deliberações nulas e anuláveis possuem menos diferenças do que semelhanças, que também aquelas estão sujeitas ao prazo decadencial bienal do art. 286 da LSA - embora para algumas delas o termo inicial da decadência seja constantemente renovado - e que, sob o aspecto processual, a única razão da distinção 
entre as duas enfermidades é a fixação da legitimidade ativa para a demanda impugnatória. No que diz respeito ao conteúdo do provimento e aos limites objetivos e subjetivos do provimento e da coisa julgada não há rigorosamente nenhuma diferença entre deliberações nulas e anuláveis.

Ainda nesse capítulo, analisamos o interesse que fundamenta a pretensão do acionista que pede a invalidação de uma deliberação, concluindo que, embora se trate de um direito próprio, resultante da mera condição de sócio, a sua efetivação por meio do processo foge do esquema clássico de atuação de um direito individual. A estrutura concorrente desse interesse (direito potestativo concorrente) e a unitariedade da relação jurídica em que está inserido, melhor explicando, fazem com que a tutela jurisdicional prestada suplante a esfera individual de quem vai a juízo pedir a invalidação. Essa conclusão foi fundamental para as posições assumidas quanto aos limites subjetivos da coisa julgada.

No que diz respeito ao conteúdo do provimento, concluiu-se que, apesar da usual associação entre, por um lado, anulabilidade e tutela constitutiva negativa, e, por outro, nulidade e tutela meramente declaratória, a sentença que pronuncia os dois tipos de vícios é constitutiva negativa, uma vez que não só às anuláveis, mas também às nulas, o ordenamento reconhece efeitos precários que devem ser removidos em via constitutiva.

Prosseguindo com a investigação, procuramos demonstrar que existe um eixo lógico que liga objeto litigioso do processo, objeto do provimento e limites objetivos da coisa julgada, e que também com relação a esses aspectos não há diferença entre as demandas de nulidade e anulatória, uma vez que o que se pretende em ambas é o mesmo resultado prático: a remoção da deliberação impugnada e de seus efeitos do mundo jurídico. As duas demandas apresentam idêntica finalidade cassatória ou demolitória e o conteúdo do provimento será o mesmo: verificar se a deliberação está viciada pela enfermidade alegada e, no momento seguinte, promover a alteração jurídica decorrente da certificação do direito. O que se quer e o que se pede é sempre o reconhecimento da ilicitude e a remoção (desconstituição) do ato e de seus efeitos da ordem jurídica. As demandas, portanto, apresentam a mesma pretensão processual. 
A respeito do alcance temporal do provimento que desconstitui uma deliberação, afirmamos que, embora a regra geral seja mesmo a de que, como acontece com qualquer ato jurídico, a deliberação e seus efeitos devam ser desconstituídos com força retroativa (ex tunc; CC, art. 188), as peculiaridades do regime de invalidades do direito societário impõem que tal regra seja excepcionada com mais frequência e intensidade do que também o é para os atos jurídicos civis. A mitigação à regra da retroatividade da sentença desconstitutiva é uma das mais contundentes provas da especialidade do regime de nulidades do direito societário, que, informado pelos imperativos de certeza e segurança, tem na recusa à retroatividade pura e absoluta um de seus mais fortes pilares. Assim, não só é possível, mas até mesmo desejável, que o julgador module o alcance da invalidação, levando em conta o (i) pedido e (ii) as circunstâncias do caso concreto. Para afastar o subjetivismo dessa atividade, procuramos estabelecer alguns critérios decisionais que possam servir de guia para o julgador.

Analisamos o tema das deliberações e dos atos conexos, afirmando que, também diversamente do que entende a doutrina prevalente, não se pode sustentar que a desconstituição de uma deliberação gere, automaticamente, a invalidação de outro ato que dela seja dependente e contra o qual não foi dirigida pretensão desconstitutiva. Apesar de termos reconhecido que no plano do direito material de fato existem relações de dependência e/ou prejudicialidade que fazem com que a invalidação de uma deliberação impacte, de alguma maneira, no ato que lhe é dependente - o que, em nosso sentir, deve ser mais propriamente visto como perda de um fator de eficácia: a validade da deliberação funciona como condição de permanência da eficácia do ato que dela depende, de tal sorte que a sua desconstituição atua como condição resolutiva da eficácia do ato - sob a ótica do processo não é possível sustentar que anulação que não tenha sido determinada pelo dispositivo sentencial esteja contida nos limites objetivos do provimento; quando muito, é um efeito refratário, atribuível não à sentença, mas à supressão, no plano do direito material, do suporte jurídico do ato subsequente. Em razão disso, não é possível dizer que eventual invalidade ou ineficácia derivada torne-se imutável pela coisa julgada; ou seja, o vício derivado poderá ser objeto de discussão judicial em novo processo, sem que se possa invocar a objeção de coisa julgada para trancar esse processo (função negativa da coisa julgada). Será possível, apenas, invocar-se a função positiva da coisa julgada, ou seja, alegar que a invalidação da primeira deliberação é uma premissa assentada e fora de 
discussão. Mas não se poderá impedir o debate a respeito da validade do segundo ato, discussão essa que versará sobre a existência de dependência entre o ato e a deliberação já desconstituída. Para que haja a invalidação do ato subsequente, é necessário que seja formulado pedido nesse sentido e que a sentença o acolha. Cogitamos, por fim, de alternativas para que os atos subsequentes sejam desconstituídos pela eficácia direta do provimento (e não apenas reputados ineficazes por uma eficácia reflexa).

Ainda no que diz respeito aos limites objetivos, negou-se que haja, na anulação de deliberação, uma eficácia inibitória, que pró́ba a sociedade de emitir novas deliberações com conteúdo idêntico ao da invalidada. Caso queira obter essa tutela, o autor da demanda deve formular pedido expresso nesse sentido.

Concluímos que, em razão da natureza incindivel que a deliberação ostenta, ela não é passível de ser anulada ou reputada válida para uns e não para outros, sobretudo aqueles que estão ligados por uma mesma relação jurídica base. A sentença que a desconstitui, por isso, vai além dos limites subjetivos do processo e projeta efeitos na esfera de muitas outras pessoas que não as partes, aspectos que demonstram a insuficiência do art. 472 do CPC para reger situações como essa. Dissemos que, a despeito da ausência de regra expressa que derrogue parcialmente o art. 472 do CPC, referido dispositivo pode ser interpretado de modo que a coisa julgada na impugnação de deliberação assemblear seja erga omnes. Expusemos, por fim, quais são as ferramentas que nosso sistema coloca à disposição de terceiros para que, em contrapartida à expansão da coisa julgada, (i) tenham informação efetiva, (ii) possuam ferramentas de reação e (iii) protejam-se de atos de conluio e disposição do processo e do direito material.

Apesar de sabidamente moderna, a legislação brasileira do anonimato é lacônica a respeito das deliberações inválidas. E embora boa parte dos problemas processuais que surjam nesse terreno possa ser resolvida mediante a instituição de regras simples (que tratem, por exemplo, de competência e conexão), enquanto isso não for percebido pelo legislador os intérpretes do direito devem, sem descuidar do texto legal, construir esse regime. Esperamos que este trabalho possa, de alguma forma, contribuir para esse debate. 


\section{REFERÊNCIAS BIBLIOGRÁFICAS}

ABBUD, André de Albuquerque Cavalcanti. Execução específica dos acordos de acionistas. São Paulo, Quartier Latin, 2006.

ABDO, Helena Najjar. O abuso do processo. São Paulo, RT, 2007.

ADAMEK, Marcelo Vieira von. "Ação de acertamento de deliberação assemblear". In:

BRUSCHI, Gilberto Gomes; e outros (coords.). Direito processual empresarial. São Paulo, Elsevier, 2012.

; e outro. "Affectio societatis' e conceito de 'fim social"”. In: FRANÇA,

Erasmo Valladão Azevedo e Novaes. Temas de Direito Societário, Falimentar e Teoria da Empresa. São Paulo, Malheiros, 2009.

; e outro. "Algumas notas sobre o exercício absusivo da ação de invalidação de

deliberação assemblear". In: YARSHELL, Flávio Luiz; e PEREIRA, Guilherme

Setoguti J. (coords.). Processo societário. São Paulo, Quartier Latin, 2012.

. Responsabilidade civil dos administradores de S/A e as ações correlatas. São

Paulo, Saraiva, 2009.

ALCALA DIAZ, Angeles. La impugnacion de acuerdos del consejo de administracion de sociedades anónimas. Madrid, Civitas, 1998.

ALLORIO, Enrico. El ordenamiento judicial en el prisma de la declaración judicial. Trad.

Santiago Sentís Melendo. Buenos Aires, Ejea, 1958.

. La cosa giudicata rispeto ai terzi. Milano, Giuffrè, 1992.

ALVARO DE OLIVEIRA, Carlos Alberto. Alienação da coisa litigiosa. $2^{\mathrm{a}}$ ed., Rio de Janeiro, Forense, 1986.

. "Coisa julgada. Respeito que merece. Interpretação da sentença. Princípios pertinentes.” Revista Forense, n. 383. Rio de Janeiro, 2006.

. Do formalismo no processo civil. $3^{\text {a }}$ ed., São Paulo, Saraiva, 2009.

AMERICANO, Jorge. Comentários ao Código de Processo Civil do Brasil, v. I. São Paulo, Saraiva, 1958.

AMORIM FILHO, Agnelo. "As ações constitutivas e os direitos potestativos". Revista Forense, v. 216. Rio de Janeiro, 1966.

"Critério científico para distinguir a prescrição da decadência e para identificar as ações imprescritíveis”. RT, v. 744. São Paulo, out. 1997. 
ARAGÃO, Egas Moniz de. Comentários ao Código de Processo Civil, v. II. $9^{\mathrm{a}}$ ed., Rio de Janeiro, Forense, 1998. . Sentença e coisa julgada. Rio de Janeiro, Aide, 1992.

ARAGÃO, Paulo Cézar. "Aspectos processuais da legislação societária”. RT, v. 641, São Paulo, mar. 1989.

ARENHART, Sérgio Cruz Arenhart, e outro. Comentários ao Código de Processo Civil, v. 5, t. I. São Paulo, RT, 2000.

ARIETA, Giovanni. I provvedimenti d'urgenza ex Art. 700 C.P.C. Padova, Cedam, 1985. ARMANI, Elena Ricci. "Le delibere di rigetto adottate dalla maggioranza assembleare in conflito d'interessi”. Rivista del diritto commerciale, v. 95, n. 1-2. Padova, 1997.

ARRUDA ALVIM, José Manoel de. "A posição dos sócios e associados em relação a ações movidas contra as sociedades e associações de que façam parte". In: YARSHELL, Flávio Luiz; e PEREIRA, Guilherme Setoguti J. (coords.). Processo societário, São Paulo, Quartier Latin, 2012.

. “Ação declaratória de nulidade de cláusula contratual”. RePro, n. 76. São Paulo, 1994.

. Código de Processo Civil Comentado, v. I. São Paulo, RT, 1975.

. Código de Processo Civil Comentado, v. V. São Paulo, RT, 1979.

. Manual de direito processual civil, v. 2. $6^{\text {a }}$ ed., São Paulo, RT, 1997.

. Manual de direito processual civil. 13ª ed., São Paulo, RT, 2010.

ASCARELLI, Tullio. Appunti di diritto commerciali - società e associazoni commerciali.

$3^{\text {a }}$ ed., Roma, Foro italiano, 1936.

. “Inesistenza e nullità". In: Problemi giuridici, t. I. Milano, Giuffrè, 1959.

. 'L'interesse sociale dell'art. 2441 Cod. Civile. La teoria dei diritti individuali

e il sistema dei vizi delle deliberazioni assembleari”. In: Problemi giuridici, t. II. Milano, Giuffre, 1959.

. "Os vícios de constituição das sociedades anônimas e a prescrição". In:

Problemas das sociedades anônimas e direito comparado. $2^{\mathrm{a}}$ ed., São Paulo, Saraiva, 1969.

. "Vícios das deliberações assembleais - direitos individuais dos acionistas -

prescrição". In: Problemas das sociedades anônimas e direito comparado. São Paulo, Saraiva, 1945. 
ASCENSÃO, José de Oliveira. Direito civil: teoria geral, v. II. $3^{\text {a }}$ ed., São Paulo, Saraiva, 2010.

ATTARDI, Aldo. Diritto processuale civile, v. I. $2^{\text {a }}$ ed., Milano, Cedam, 1997.

ÁVILA, Humberto. Segurança jurídica. 2a ed., São Paulo, Malheiros, 2012.

AZEVEDO, Antônio Junqueira. Negócio jurídico. $4^{\mathrm{a}}$ ed., São Paulo, Saraiva, 2010. . "Princípios do Novo Direito Contratual e Desregulamentação do Mercado -

Direito de exclusividade nas relações contratuais de fornecimento - Função Social do contrato e responsabilidade aquiliana do terceiro que contribui para inadimplemento contratual”. $R T$, n. 750, abr./1998.

AZEVEDO, Álvaro Villaça. Código Civil Comentado, v. II. São Paulo, Atlas, 2003.

BADARÓ, Gustavo Henrique Righi Ivahy. Correlação entre acusação e sentença. São Paulo, RT, 2000.

BADINE JÚNIOR, Hamid Charaf. Efeitos do negócio jurídico nulo. São Paulo, Saraiva, 2010 .

BANDEIRA DE MELLO, Celso Antonio. "Segurança jurídica, boa-fé e confiança legítima”. Revista trimestral de direito público, n. 51/52. São Paulo, 2009.

BARBI, Celso Agrícola Barbi. Comentários ao Código de Processo Civil, v. 1, t. 1. Rio de Janeiro, Forense, 1975.

BARBI FILHO, Celso. "Acordo de acionistas: panorama do instituto no direito brasileiro e proposta para a reforma de sua disciplina legal". Revista Forense, v. 354. São Paulo, 2001.

BARBOSA MOREIRA, José Carlos. "A eficácia preclusiva da coisa julgada material no sistema do processo civil brasileiro". In: Temas de direito processual, Primeira série. $2^{\mathrm{a}}$ ed., São Paulo, Saraiva, 1988.

. “Aspectos da 'execução' em matéria de obrigação de emitir declaração de vontade”. In: Temas de direito processual, Sexta série. São Paulo, Saraiva, 1997. . "Coisa julgada: extensão subjetiva. Litispendência. Ação de nulidade de patente". In: Direito processual civil. Rio de Janeiro, Borsoi, 1971.

. "Coisa julgada e declaração". In: Temas de direito processual, Primeira série. $2^{\mathrm{a}}$ ed., São Paulo, Saraiva, 1988.

Comentários ao Código de Processo Civil, v. V. 15ª ed., Rio de Janeiro, Forense, 2009. 
- "Conteúdo e efeitos da sentença: variações sobre o tema". In: Temas de direito processual, Quarta série. São Paulo, Saraiva, 1989.

. “Correlação entre o pedido e a sentença”. RePro, n. 83. São Paulo, jul./set. 1996.

- "Eficácia da sentença de interdição por alienação mental”. In: Temas de direito processual, Quarta série. São Paulo, Saraiva, 1989.

. Litisconsórcio unitário. Rio de Janeiro, Forense, 1972.

. "Intervenção litisconsorcial voluntária". In: Direito processual civil. Rio de Janeiro, Borsoi, 1971.

. "Notas sobre el contenido, los efectos y la inmutabilidad de la sentencia". In:

Temas de direito processual, Quinta série. São Paulo, Saraiva, 1994.

. O novo processo civil brasileiro. $25^{\mathrm{a}}$ ed., Rio de Janeiro, Forense, 2007.

- “O problema da 'divisão do trabalho' entre juiz e partes: aspectos

terminológicos". In: Temas de direito processual, Quarta série. Rio de Janeiro, Saraiva, 1989.

- "Os limites objetivos da coisa julgada no sistema do novo Código de

Processo Civil”. In: Temas de direito processual, Primeira série. $2^{\mathrm{a}}$ ed., São Paulo, Saraiva, 1988.

. "Questões novas e velhas em matéria de classificação das sentenças". In:

Temas de direito processual, Oitava série. São Paulo, Saraiva, 2004.

. "Reconhecimento do pedido". In: Direito processual civil. Rio de Janeiro, Borsoi, 1971.

. "Reflexões críticas sobre uma teoria de condenação civil". In: Temas de direito processual, Primeira série. $2^{\text {a }}$ ed., São Paulo, Saraiva, 1988.

. "Reformas processuais e poderes do juiz". In: Temas de direito processual, Oitava série. Rio de Janeiro, Saraiva, 2004.

. "Regras de experiência e conceitos juridicamente indeterminados". In: Temas de direito processual, Segunda série. $2^{a}$ ed., São Paulo, Saraiva, 1988.

. “Sentença executiva?”. In MORAES, Maurício Zanoide de; e YARSHELL,

Flávio Luiz (orgs.). Estudos em homenagem à Professora Ada Pellegrini Grinover. São Paulo, DPJ, 2005.

- "Solidariedade ativa: efeitos da sentença e coisa julgada na ação de cobrança proposta por um único credor". Revista do Advogado, n. 84. São Paulo, dez./2005. 
- "Tendências na execução de sentenças e ordens judiciais". In: Temas de direito processual, Quarta série. São Paulo, Saraiva, 1989.

BARROSO, Luís Roberto. O controle de constitucionalidade no direito brasileiro. São Paulo, Saraiva, 2004.


Paulo, Saraiva, 1997.

BATALHA, Wilson de Souza Campos. Direito processual societário. Rio de Janeiro, Forense, 1985.

. Sociedades anônimas e mercado de capitais, v. II. Rio de Janeiro, Forense, 1973.

BEDAQUE, José Roberto dos Santos; e outro. Causa de pedir e pedido no processo civil (questões polêmicas) (coords.). São Paulo, RT, 2002.

In: MARCATO, Antonio Carlos (coord.) Código de Processo Civil interpretado. São Paulo, Atlas, 2004.

. Direito e processo. $5^{\text {a }}$ ed., São Paulo, Malheiros, 2009.

. Efetividade do processo e técnica processual. $3^{\mathrm{a}}$ ed., São Paulo, Malheiros, 2010.

. "Os elementos objetivos da demanda examinados à luz do contraditório". In:

BEDAQUE, José Roberto dos Santos; e CRUZ E TUCCI, José Rogério (coords.). Causa de pedir e pedido no processo civil: questões polêmicas. São Paulo, RT, 2002.

"Prorrogação legal da competência: aspectos teóricos e práticos". Revista do Advogado, n. 88. São Paulo, nov. 2006.

. Tutela cautelar e tutela antecipada: tutelas sumárias de urgência (tentativa de sistematização). $5^{\mathrm{a}}$ ed, São Paulo, Malheiros, 2009.

BESSO, Chiara. La sentenza civile inesistente. Torino, Giappichelli, 1996.

BETTI, Emilio. Interpretación de la ley y de los actos jurídicos, Madrid, Editorial revista de derecho privado, 1975.

Teoría general del negocio jurídico. Trad. A. Martin Perez. $2^{\mathrm{a}}$ ed. Madrid.

Editorial revista de derecho privado. S.d.

D. 42.1 .63 - Trattato dei limiti soggettivi della cosa giudicata in diritto romano. Macerata, Bianchini, 1922.

BITTENCOURT, Lúcio Bittencourt. O controle jurisdicional da constitucionalidade das leis, Rio de Janeiro, Forense, 1948. 
BONÍCIO, Marcelo José Magalhães. Capítulos de sentença e efeitos dos recursos. São Paulo, RCS, 2006.

; e outros. Comentários à execução civil - título judicial e extrajudicial (artigo por artigo). São Paulo, Saraiva, 2007. ; e outro. "Litisconsórcio unitário: aspectos materiais e processuais" (inédito).

BORBA, José Edwaldo Tavares. Direito societário. $5^{a}$ ed., Rio de Janeiro, Renovar, 1999. BOTELHO DE MESQUITA, José Ignacio. “A coisa julgada no Código do Consumidor”. In: CRUZ E TUCCI, José Rogério (coord.). Processo civil - evolução, 20 anos e vigência. São Paulo, Saraiva, 1995. . Da ação civil. São Paulo, RT, 1975.

- "Sentença e coisa julgada". In: Teses, estudos e pareceres de direito processual civil, v. 2. São Paulo, RT, 2005.

BRAGA, Paula Sarno; e outros. Curso de direito processual civil, v. 2. $6^{\text {a }}$ ed., Salvador, Jus Podivm, 2011.

BRANDÃO LOPES, Mauro. A cisão no direito societário. São Paulo, RT, 1980.

BULGARELLI, Waldírio. "Anulação de assembléia geral de sociedade anônima assembléias gerais posteriores - abuso de minoria”. RT, v. 514. São Paulo, 1978. . Comentários à Lei das S.A., v. 4. São Paulo, Saraiva, 1978. . “Deliberar não deliberar é deliberar?”. In: Questões de direito societário. São Paulo, RT, 1983.

. "Questão referente a livros societários e documentos relativos à presença e às deliberações das assembléias gerais”. RDM, n. 114. São Paulo, 1999.

Regime jurídico da proteção às minorias das S/A. Rio de Janeiro, Renovar, 1998.

BULHÕES PEDREIRA, José Luiz. "Acordo de acionistas sobre controle de grupo de sociedades". Revista de direito bancário, do mercado de capitais e da arbitragem, $\mathrm{n}$. 15. São Paulo, 2002.

"Deliberação de sócios quotistas de transformar limitada em S.A.". In: BULHÕES PEDREIRA, José Luiz; e LAMY FILHO, Alfredo. A Lei das S/A. Rio de Janeiro, Renovar, 1989.

. "Regime especial de invalidade dos atos societários". In: BULHÕES PEDREIRA, José Luiz; e LAMY FILHO, Alfredo. A Lei das S/A, v. II. $2^{\mathrm{a}}$ ed., Rio de Janeiro, Renovar, 1996. 
; e Outro. "Acordo de acionistas sobre exercício do direito de voto". In: BULHÕES PEDREIRA, José Luiz; e LAMY FILHO, Alfredo. A Lei das S/A, v. II. Rio de Janeiro, Renovar, 1992.

BÜLOW, Oskar. La teoría de las excepciones procesales y los presupuestos procesales. Trad. Miguel Angel Rosas Lichtschein. Buenos Aires, El foro, s.d.

BUSTAMANTE, Thomas da Rosa de. "A Lei 9.868/99 e a Possibilidade de Restrição dos Efeitos da Declaração de Inconstitucionalidade. Inaplicabilidade na Fiscalização de Normas de Direito Tributário". Revista dialética de direito tributário, n. 59. São Paulo, 2000 .

BUZAID, Alfredo. A ação declaratória no direito brasileiro. São Paulo, Saraiva, 1943. . Considerações sobre o mandado de segurança coletivo. São Paulo, Saraiva, 1992. Do agravo de petição. $2^{\text {a }}$ ed., São Paulo, Saraiva, 1956.

CABRAL, Antonio do Passo. Nulidades no processo moderno. $2^{\mathrm{a}}$ ed., Rio de Janeiro, Forense, 2010.

CAETANO, Marcello. Manual de direito administrativo, v. I. 10 a ed., Coimbra, Almedina, 2001.

CALAMANDREI, Piero. Instituciones de derecho procesal civil, v. I. Trad. Santiago Sentís Melendo. Buenos Aires, El foro, 1996. Introducción al estudio sistemático de las providencias cautelares. Trad. Marino Ayerra Merín. Buenos Aires, El foro, 1996. . "Verità e verosimiglianza nel processo civile". In: Studi sul processo civile, v. 6. Padova, Cedam, 1957.

CALMON DE PASSOS, J. J. "Esboço de uma teoria das nulidades". RePro, n. 56. São Paulo, 1989.

. Esboço de uma teoria das nulidades aplicadas às nulidades processuais. Rio de Janeiro, Forense, 2009.

. Comentários ao Código de Processo Civil, v. III. Rio de Janeiro, Forense, 1973.

CÂMARA, Alexandre Freitas Câmara, "A admissão do assistente qualificado no processo civil - Algumas considerações sobre o adquirente de direito litigioso e sua intervenção". In: WAMBIER, Teresa Arruda Alvim; e outros (coords.). O terceiro no processo civil 
brasileiro e assuntos correlatos - Estudos em homenagem ao Professor Athos Gusmão Carneiro. São Paulo, RT, 2010.

CÂMARA LEAL, Antônio Luís da. Da prescrição e da decadência. $3^{\mathrm{a}}$ ed., Rio de Janeiro, Forense, 1978.

CAMPOS, Ronaldo Cunha. Limites objetivos da coisa julgada. Rio de Janeiro, Aide, 1988.

CANDIAN, Aurelio. Nullità e annullabilità di delibere di assemblea delle società per azione. Milano, Giuffrè, 1942.

CAPPELLETTI, Mauro. O controle judicial de constitucionalidade das leis no direito comparado. Trad. Aroldo Plínio Gonçalves. $2^{\mathrm{a}}$ ed., Porto Alegre, Sergio Antonio Fabris, 1999.

CAPONI, Remo. "La tutela sommaria nel processo societario in prospettiva europea". Rivista trimestrale di diritto e procedura civile, v. 58, n. 4. Milano, dez. 2004. . L'eficcacia del giudicato civile nel tempo. Milano, Giuffrè, 1991.

CARDOSO, Patrícia. "Oponibilidade dos efeitos dos contratos: determinante da responsabilidade civil do terceiro que coopera com o devedor na violação do pacto contratual”. Revista trimestral de direito civil, v. 20. Rio de Janeiro, out./dez. 2004.

CARMONA, Carlos Alberto. Arbitragem e processo: um comentário à Lei 9.307/96. $3^{\text {a }}$ ed., São Paulo, Atlas, 2009.

CARNEIRO, Athos Gusmão. Intervenção de terceiros. 16 ${ }^{\mathrm{a}}$ ed., São Paulo, Saraiva, 2006.

CARNEIRO DA FRADA, Manuel A. Renovação de deliberações sociais. Coimbra, Coimbra, 1987.

CARNELUTTI, Francesco. "Eccesso di potere nelle deliberazioni dell'assemblea delle anonime". Rivista del diritto commerciali e del diritto generale delle obbligazioni, v. 29. Milano, 1926.

Instituciones del proceso civil, vv.. I/III. Trad. Santiago Sentís Melendo. Buenos Aires, El foro, 1997.

. Sistema di diritto processuale civile, v. I. Padova, Cedam, 1936.

. Teoría general del derecho. $3^{\mathrm{a}}$ ed. Trad. Francisco Javier Osset. Madrid, Editorial revista de derecho privado, s.d.

CARRAZZA, Roque Antonio. "Segurança jurídica e eficácia temporal das alterações jurisprudenciais". In: FERRAZ JÚNIOR, Tércio Sampaio; CARRAZZA, Roque Antonio; e NERY JUNIOR, Nelson. Efeito ex nunc e as decisões do STJ. $2^{\mathrm{a}}$ ed., Barueri, Manole, 2009. 
CARREIRA ALVIM, J. E. "Intervenção de terceiros na arbitragem”. In: MARTINS, Pedro Batista; e GARCEZ, José Maria Rossani (coords.). Reflexões sobre arbitragem. São Paulo, LTR, 2002.

. Tratado geral da arbitragem. Belo Horizonte, Mandamentos, 2000.

CARVALHO, Milton Paulo de. Do pedido no processo civil. Porto Alegre, Sergio Antonio Fabris, 1992.

CARVALHO DE MENDONÇA, J. X. Tratado de direito commercial brasileiro, v. III, livro 2. $3^{\text {a }}$ ed., Rio de Janeiro, Freitas Bastos, 1938.

CARVALHOSA, Modesto. Acordo de acionistas. São Paulo, Saraiva, 2011. . Comentários à Lei de Sociedades Anônimas, v. 1. $6^{\mathrm{a}}$ ed., São Paulo, Saraiva, 2011.

. Comentários à Lei de Sociedades Anônimas, v. 3. $5^{\text {a }}$ ed., São Paulo, Saraiva, 2011.

. Comentários à Lei de Sociedades Anônimas, v. 4, t. II. $3^{\mathrm{a}}$ ed., São Paulo, Saraiva, 2009.

CAVALCANTI, Themistocles. Do controle da constitucionalidade, $1^{\mathrm{a}}$ ed., Rio de Janeiro, Forense, 1966.

CAVALlONE, Bruno. "Interventi”. In: Processo civile e società commerciali - atti del XX Convegno Nazionale. Milano, Giuffrè, 1995.

CHIOVENDA, Giuseppe. "Azione di mero accertamento". In: Saggi di diritto processuale civile, v. 3. Milano, Giuffrè, 1993.

. "Azioni e sentenze di mero accertamento". In: Saggi di diritto processuale civile, v. 3. Milano, Giuffrè, 1993.

Instituições de direito processual civil, v. I. Trad. J. Guimarães Menegale. $2^{\mathrm{a}}$ ed., São Paulo, Saraiva, 1965.

"L’azione nel sistema dei diritti". In: Saggi di diritto processuale civile, v. 1. Milano, Giuffrè, 1993.

. Principii di diritto processuale civile. Napoli, Jovene, 1980.

. "Sul litisconsorzio necessario". In: Saggi di diritto processuale civile, v. 2. Milano, Giuffrè, 1993.

. "Sulla cosa giudicata". In: Saggi di diritto processuale civile, v. 2. Milano, Giuffrè, 1993. 
CINTRA, Antônio Carlos de Araújo, e Outros. "Atuação por via processual dos direitos decorrentes da nova lei das sociedades anônimas" (palestra proferida na AASP). In: A nova Lei das Sociedades Anônimas. São Paulo, AASP, 1978.

. Comentários ao Código de Processo Civil, v. IV. $3^{\mathrm{a}}$ ed., Rio de Janeiro, Forense, 2008.

Do litisconsórcio. Tese de doutorado apresentada à FADUSP. São Paulo, 1968.

. "Estudo sobre a substituição processual no direito brasileiro". $R T$, v. 809. São

Paulo, mar. 2003.

. Teoria geral do processo; e outros. $18^{\mathrm{a}}$ ed., São Paulo, Malheiros, 2005.

CLÈVE, Clèmerson Merlin. "Declaração de inconstitucionalidade de dispositivo normativo em sede de juízo abstrato e efeitos sobre os atos singulares praticados sob a sua égide”. Cadernos de direito constitucional e ciência política, n. 19. São Paulo, 1997.

COELHO, Fábio Ulhoa. Curso de direito comercial, v. 2. $14^{\mathrm{a}}$ ed., São Paulo, Saraiva, 2010.

. Princípios do direito comercial. São Paulo, Saraiva, 2012.

COGLIOLO, Pietro. Trattato teorico e pratico della eccezione di cosa giudicata, v. I. Torino, Fratelli Bocca, 1883.

COMOGLIO, Luigi Paolo; e outros. Lezioni sul processo civile, v. 1. $5^{\mathrm{a}}$ ed., Bologna, Il Mulino, 2011.

COMPARATO, Fábio Konder. "A natureza da sociedade anônima e a questão da derrogabilidade das regras legais de quorum nas assembleias gerais e reuniões do conselho de administração". In: Novos ensaios e pareceres de direito empresarial. Rio de Janeiro, Forense, 1981.

. "Controle conjunto, abuso no exercício do voto acionário e alienação indireta de controle empresarial”. In: Direito empresarial - estudos e pareceres. São Paulo, Saraiva, 1990.

."Da imprescritibilidade da ação direta de nulidade de norma estatutária". In: Novos ensaios e pareceres de direito empresarial. Rio de Janeiro, Forense, 1981.

"Eleição de diretores em companhia aberta. Validade e eficácia de reuniões do conselho de administração de sociedade anônima. 'Quorum' deliberativo em 
assembléias gerais de companhia aberta". In: Direito empresarial - estudos e pareceres. São Paulo, Saraiva, 1990.

- "Notas sobre parte e legitimação nos negócios jurídicos". In: Ensaios e pareceres de direito empresarial. Rio de Janeiro, Forense, 1978.

. O poder de controle na sociedade anônima, $3^{\mathrm{a}}$ ed. Rio de Janeiro, Forense, 1983.

- "Validade e eficácia de acordos de acionistas. Execução específica de suas obrigações". In: Novos ensaios e pareceres de direito empresarial. Rio de Janeiro, Forense, 1981.

CORDEIRO, António Menezes. Direito das sociedades, v. I. $3^{\text {a }}$ ed., Coimbra, Almedina, 2011.

. S.A.: assembleia geral e deliberações sociais. Coimbra, Almedina, 2009.

CORRÊA, Fábio Peixinho Gomes. O objeto litigioso no processo civil. São Paulo, Quartier Latin, 2009.

COSTA, Judith Hofmeister Martins. "A proteção da legítima confiança nas relações obrigacionais entre a Administração e os particulares". Revista da Faculdade de Direito da Universidade Federal do Rio Grande do Sul, n. 22. Porto Alegre, 2002.

COUTO E SILVA, Clóvis. A obrigação como processo. Rio de Janeiro, FGV, 2006.

COUTURE, Eduardo J. Fundamentos del derecho procesal civil. $4^{\mathrm{a}}$ ed., Buenos Aires, BDEF, 2010.

COVIELLO, Nicolas. Doctrina general del derecho civil. $4^{\mathrm{a}}$ ed. Buenos Aires. El foro. s.d.

CREDIE, Ricardo Arcoverde. Adjudicação compulsória. 5ª ed., São Paulo, RT, 1991.

CRUZ E TUCCI, José Rogério. A causa petendi no processo civil. $3^{\mathrm{a}}$ ed., São Paulo, RT, 2009.

- "A denominada situação substancial como objeto do processo na obra de Fazzalari”. In: Scritti in onore di Elio Fazzalari, v. 2. Milano, Giuffrè, 1993. . A motivação da sentença no processo civil. São Paulo, Saraiva, 1987. ; e outro. Constituição de 1988 e processo. São Paulo, Saraiva, 1989. ; e outro. Causa de pedir e pedido no processo civil (questões polêmicas) (coords.). São Paulo, RT, 2002.

. "Impugnação judicial da deliberação de assembleia societária e projeções da coisa julgada". In: YARSHELL, Flávio Luiz; e PEREIRA, Guilherme Setoguti J. (coords.). Processo societário. São Paulo, Quartier Latin, 2012. 
. Limites subjetivos da eficácia da sentença e da coisa julgada civil. São Paulo, RT, 2006.

CUNHA, Paulo Olavo. Direito das sociedades comerciais. $4^{\mathrm{a}}$ ed., Coimbra, Almedina, 2010.

DALl'AGNOL JUNIOR, Antonio Janyr. Comentários ao Código de Processo Civil, v. III. Porto Alegre, Lejus, 1985.

DI MAJO, Adolfo. La tutela civile dei diritti, v. 3. $2^{\text {a }}$ ed., Milano, Giuffrè, 1993.

DI PIETRO, Maria Sylvia Zanella. "Os princípios da proteção à confiança, da segurança jurídica e da boa-fé na anulação do ato administrativo". Fórum administrativo, n. 100. Belo Horizonte, 2009.

DIDIER JR., Fredie. Curso de direito processual civil, v. 1. 11ª ed., Salvador, Jus Podivm, 2009.

; e outros. Curso de direito processual civil, v. 2. $6^{\mathrm{a}}$ ed., Salvador, Jus Podivm, 2011.

DINAMARCO, Cândido Rangel. "100 anos de Liebman”. In: Fundamentos do processo civil moderno, t. I. $6^{\text {a }}$ ed., São Paulo, Malheiros, 2010.

. A instrumentalidade do processo. $13^{\mathrm{a}}$ ed., São Paulo, Malheiros, 2008.

. A reforma da reforma. São Paulo, Malheiros, 2002.

. Capítulos de sentença. $4^{\mathrm{a}}$ ed., São Paulo, Malheiros, 2009.

. "Controle difuso de constitucionalidade: eficácia da decisão". In: Processo civil empresarial. São Paulo, Malheiros, 2010.

. "Cumulação de pedidos em matéria tributária, litisconsórcio necessário e concurso eletivo de foros”. In: Processo civil empresarial. São Paulo, Malheiros, 2010. . Direito processual civil. São Paulo, Bushatsky, 1975.

. Execução civil. $7^{\mathrm{a}}$ ed., São Paulo, Malheiros, 2000.

. Instituições de direito processual civil, v. III. $6^{\text {a }}$ ed., São Paulo, Malheiros, 2010

- Instituições de direito processual civil, vv. I e II. 6a ed., São Paulo, Malheiros, 2009.

. Instituições de direito processual civil, v. IV. $3^{\text {a }}$ ed., São Paulo, Malheiros, 2009.

. Intervenção de terceiros. $5^{\mathrm{a}}$ ed., São Paulo, Malheiros, 2009.

. Litisconsórcio. $8^{\text {a }}$ ed., São Paulo, Malheiros, 2009. 
. "Modulação dos efeitos da declaração de inconstitucionalidade". In: Processo civil empresarial. São Paulo, Malheiros, 2010.

- "Momento de eficácia da sentença constitutiva". In: Fundamentos do processo civil moderno, t. I. $6^{\text {a }}$ ed., São Paulo, Malheiros, 2010.

. "O conceito de mérito em processo civil". In: Fundamentos do processo civil moderno, t. I. 6ª ed., São Paulo, Malheiros, 2010.

. "O regime jurídico das medidas urgentes". In: Nova era do processo civil. $2^{\mathrm{a}}$ ed., São Paulo, Malheiros, 2007.

. "Os institutos fundamentais do direito processual”. In: Fundamentos do processo civil moderno, t. I. $6^{\text {a }}$ ed., São Paulo, Malheiros, 2010.

- "Sentença substitutiva da vontade do devedor e execução por obrigações específicas". In: Fundamentos do processo civil moderno, t. I. $6^{\text {a }}$ ed., São Paulo, Malheiros, 2010.

DONATI, Antigono. L'invalidità della deliberazione di assemblea delle società anonime. Milano, Giuffrè, 1937.

DUARTE, Teófilo de Castro. O abuso do direito e as deliberações sociais. $2^{\mathrm{a}}$ ed., Coimbra, Coimbra, 1955.

EIZIRIK, Nelson. A Lei das S/A comentada, vv. I e III. São Paulo, Quartier Latin, 2011. ."Interpretação dos $\S \S 8^{\circ}$ e $9^{\circ}$ do art. 118 da Lei das S/A”. RDM, n. 139. São Paulo, 2005.

ENRIQUES, Luca, e outro. "Spunti in tema di rimedi risarcitori contro i'invalidità delle deliberazioni assembleari”. Rivista del diritto commerciali e del dirito generale delle obbligazioni, v. 104. Vallardi, 2006.

ENNECCERUS, Ludwig; e outros. Tratado de derecho civil, t. I, v. II. Trad. Blas Pérez Gonzáles e José Alguer. 39ª ed. Barcelona, Bosch, 1944.

ESTELLITA, Guilherme. Da cousa julgada - fundamento jurídico e extensão aos terceiros. Rio de Janeiro, 1936.

. Do litisconsórcio no direito brasileiro. Rio de Janeiro, Freitas Bastos, 1955.

FADEL, Sergio Sahione. Código de Processo Civil comentado, v. I. $7^{\mathrm{a}}$ ed., Rio de Janeiro, Forense, 1988.

FAZZALARI, Elio. Istituzioni di diritto processuale. $5^{\mathrm{a}}$ ed., Padova, Cedam, 1989.

FERNANDES, Scarance Antonio. Prejudicialidade. São Paulo, RT, 1988. 
FERRANDO, Jose Vicente Soria. La legitimación ativa para la impugnación de acuerdos de la junta general de la sociedade anónima. Alicante, Universidad de Alicante, 1982.

FERRARI, Regina Maria Macedo Nery. Efeitos da declaração de inconstitucionalidade. $5^{\text {a }}$ ed., São Paulo, RT, 2004.

FERRAZ, Sérgio. Assistência litisconsorcial no direito brasileiro. São Paulo, RT, 1979.

FERRAZ JÚNIOR, Tércio Sampaio. "Irretroatividade e jurisprudência judicial”. In: FERRAZ JÚNIOR, Tércio Sampaio; CARRAZZA, Roque Antonio; e NERY JUNIOR, Nelson. Efeito ex nunc e as decisões do STJ. $2^{\mathrm{a}}$ ed., Barueri, Manole, 2009.

FERREIRA, Waldemar. Tratado de direito comercial, vv. 3 e 4. São Paulo, Saraiva, 1961.

FERRI, Corrado. "Le impugnazioni di delibere assembleari - profili processuali”. Rivista trimestrale di diritto processuale civile, v. 59, n. 1. Milano, 2005. ; e outros. Lezioni sul processo civile, v. 1. $5^{\text {a }}$ ed.. Bologna, Il Mulino, 2011. . Profili dell'accertamento costitutivo. Padova, Cedam, 1970.

FIGUEIRA DE MELO, Luiz Carlos; e outro. "Princípio da segurança jurídica e o fato consumado no direito administrativo", Revista do curso de direito da Universidade Federal de Uberlândia, v. 31. Uberlândia, 2002.

FILOCAMO, Fabio. “I c.d. diritti individuali dell' azionista, i poteri degli amministratori e la non impugnabilità delle delibere consiliari da parte del socio". Rivista del diritto commerciale e del diritto generale delle obbligazioni, v. 98, n. 1. Padova, 2000.

FONSECA, Elena Zucconi Galli. "La compromettibilità delle impugnative di delibere assembleari dopo la riforma". Rivista trimestrale di diritto e procedura civile, v. 59, n. 2. Milano, 2005.

FONSECA, Priscila Corrêa da. Suspensão de deliberações sociais. São Paulo, Saraiva, 1986.

FORNACIARI JÚNIOR, Clito. Reconhecimento jurídico do pedido. São Paulo, RT, 1977.

FRANÇA, Erasmo Valladão Azevedo e Novaes; e outro. "Affectio societatis' e conceito de 'fim social'”. In: Temas de Direito Societário, Falimentar e Teoria da Empresa, in Temas de direito societário, falimentar e teoria da empresa. São Paulo, Malheiros, 2009.

; e outro. "Algumas notas sobre o exercício absusivo da ação de invalidação de deliberação assemblear”. In: YARSHELL, Flávio Luiz; e PEREIRA, Guilherme Setoguti J. (coords.). Processo societário. São Paulo, Quartier Latin, 2012. 
."Apontamentos sobre a invalidade das deliberações conexas das companhias". In: Temas de direito societário, falimentar e teoria da empresa. São Paulo, Malheiros, 2009.

. Conflito de interesses nas assembléias de S.A. São Paulo, Malheiros, 1993.

- "Ilegitimidade de parte e falta de interesse processual da companhia para requerer a anulação das próprias deliberações sociais”. In: Temas de direito societário, falimentar e teoria da empresa. São Paulo, Malheiros, 2009.

. Invalidade das deliberações de assembléia das S/A. São Paulo, Malheiros,

1998.

- "Lineamentos da reforma do direito societário italiano em matéria de invalidade das deliberações assembleares”. In: Temas de direito societário, falimentar e teoria da empresa. São Paulo, Malheiros, 2009.

FURTADO, Jorge Henrique da Cruz Pinto. Curso de direito das sociedades, $5^{\text {a }}$ ed., Coimbra, Almedina, 2004.

. Deliberações de sociedades comerciais. Coimbra, Almedina, 2005.

GALGANO, Francesco. La società per azioni - Trattato di diritto commerciale e di diritto pubblico dell'economia, v. $7^{\circ}$. Padova, Antonio Milani, 1984.

GIERKE, Julius Von. Derecho comercial y de la navegación, v. I. Trad. Juan Semon. Buenos Aires, Tipografica Editora Argentina, 1957.

GOLDSCHMIDT, James. Derecho procesal civil. Trad. Leonardo Priesto Castro. $2^{\mathrm{a}}$ ed., Barcelona, Labor, 1936.

GOMES, Fábio Luiz; e outro. Teoria geral do processo civil. $5^{\mathrm{a}}$ ed., São Paulo, RT, 2009.

GRADI, Marco; e outra. “A intervenção de terceiros no procedimento arbitral no direito português e no direito italiano”. Revista brasileira de arbitragem, n. 28, São Paulo, jul./out. 2003.

GRAU, Eros. "Parecer - acordo de acionistas". Direito público: Revista da Procuradoria Geral do Estado de Minas, v. 1, n. 2. Belo Horizonte, 2009.

GRECO, Leonardo. Instituições de processo civil, v. 1. Rio de Janeiro, Forense, 2009. . O processo de execução, v. 1. Rio de Janeiro, Renovar, 1999.

GRECO FILHO, Vicente. Da intervenção de terceiros. 2a ed., São Paulo, Saraiva, 1986. . Direito processual civil brasileiro, v. 2. 17 ed., São Paulo, Saraiva, 2006.

GOMES, Orlando. Introdução ao direito civil. 14a ed., Rio de Janeiro, Forense, 1999. . Contratos. 13 ${ }^{\mathrm{a}}$ ed., Rio de Janeiro, Forense, 1994. 
GOMES DA CRUZ, José Raimundo. Pluralidade de partes e intervenção de terceiros. São Paulo, RT, 1991.

GOMES DE MATTOS. "Princípio do fato consumado no direito administrativo". RDA, v. 220. Rio de Janeiro, abr./jun. 2000.

GRINOVER, Ada Pellegrini. "A tutela coletiva dos investidores no mercado de valores mobiliários: questões processuais". In: YARSHELL, Flávio Luiz; e PEREIRA, Guilherme Setoguti J. (coords). Processo societário. São Paulo, Quartier Latin, 2012.

. "Ações coletivas ibero-americanas: novas questões sobre a legitimação e a coisa julgada”. Revista Forense, n. 361. Rio de Janeiro, maio./jun. 2002.

. "Coisa julgada e terceiros". Revista Magister de direito civil e processual civil, n. 12. Porto Alegre, mai./jun. 2006.

. "Coisa julgada erga omnes, secundum eventum litis e secundum probationem". RePro, n. 126. São Paulo, ago./2005.

. "Considerações sobre os limites objetivos e a eficácia preclusiva da coisa julgada". Revista do Advogado, n. 65. São Paulo, 2001.

. Direito processual civil. São Paulo, Bushatsky, 1974.

. O processo em sua unidade, v. II. Rio de Janeiro, Forense, 1984.

- "Realização de assembléia sob o regime da execução provisória e posterior anulação". In: NERY JUNIOR, Nelson; SANTOS, Ernane Fidélis dos; WAMBIER, Luiz Rodrigues; e WAMBIER, Teresa Arruda Alvim (coords.). Execução civil: Estudos em homenagem ao Professor Humberto Theodoro Júnior. São Paulo, RT, 2007. ; e outros. Teoria geral do processo. $18^{\mathrm{a}}$ ed., São Paulo, Malheiros, 2005.

. "Tutela jurisdicional nas obrigações de fazer e não fazer". RePro, n. 79. São Paulo, jul./set. 1995

GUERRA, Marcelo Lima. Direitos fundamentais e a proteção do credor na execução civil. São Paulo, RT, 2003.

GUERRA FILHO, Willis Santiago. "Efficacia ultra partes della sentenza, litisconsorzio necessario e principio del contraditorio". In: Processo civile e società commerciali - atti del XX Convegno Nazionale. Milano, Giuffrè, 1995.

"Fenomenologia em direito processual: apontamentos para um estudo sobre a relativização dos limites subjetivos da coisa julgada em conexão com o litisconsórcio necessário de uma perspectiva filosófica fenomenológica”. Revista autônoma de processo, n. 4. Curitiba, 2008. 
GUERREIRO, José Alexandre Tavares; e outro. Das sociedades anônimas no direito brasileiro, vv. 1 e 2. São Paulo, Bushatsky, 1979.

.Execução específica do acordo de acionistas”. RDM, v. 41. São Paulo, Malheiros, 1981.

GUERRIERI, Gianluca. La nulità delle deliberazioni assembleari di società per azioni. Milano, Giuffrè, 2009.

GUILLÉN, Víctor Fairen Guillén. El processo en la Ley de Sociedades Anónimas. Barcelona, Bosch, 1953.

GUSMÃO, Manoel Aureliano de. Coisa julgada no civel, no crime e no direito internacional, $2^{\mathrm{a}}$ ed. São Paulo, Saraiva, 1922.

HEINITZ, Ernesto. I limiti oggetivi della cosa giudicata. Padova, Cedam, 1937.

HÖRSTER, Heinrich Ewald. A Parte Geral do Código Civil Português. Almedina, Coimbra, 2009.

IMPAGNATIELLO, Gianpaolo. "La provvisoria esecutorietà delle sentenze costitutive". Rivista trimestrale di diritto e procedura civile, v. 46, n. 1. Milano, mar. 1992.

JAEGER, Pier Giusto. L’interesse sociale. Milano, Giuffrè, 1972.

JAUERNIG, Othmar. Direito processual civil. Trad. F. Silveira Ramos. Almedina, Coimbra, 2002.

KIPP, Theodor; e outros. Tratado de derecho civil, t. I, v. II. Trad. Blas Pérez Gonzáles e José Alguer. 39ª ed., Barcelona, Bosch, 1944.

KOMATSU, Roque. Da invalidade no processo civil. São Paulo, RT, 1989.

KONDER, Carlos Nelson. Contratos conexos. Rio de Janeiro, Renovar, 2006.

KÜBLER, Friedrich. Derecho de sociedades. Trad. Michèle Klein, $5^{\mathrm{a}}$ ed. Madrid, Fundación Cultural del Notariado, 2001.

LACERDA. Galeno. Comentários ao Código de Processo Civil, v. VIII, t. I. $2^{\mathrm{a}}$ ed. Rio de Janeiro, Forense, 1981. Despacho saneador. $3^{\text {a }}$ ed., Porto Alegre, Fabris, 1990.

LAMY FILHO, Alfredo; e outro. "Acordo de acionistas sobre exercício do direito de voto". In: BULHÕES PEDREIRA, José Luiz; e LAMY FILHO, Alfredo. A Lei das S/A, v. II. Rio de Janeiro, Renovar, 1992. . "Mudança do objeto social e incorporação de subsidiária". In: BULHÕES PEDREIRA, José Luiz; e LAMY FILHO, Alfredo. A Lei das S/A, Rio de Janeiro, Renovar, 1992. 
LEÃES, Luiz Gastão Paes de Barros. Comentários à Lei das Sociedades Anônimas, v. II. São Paulo, Saraiva, 1980.

"Diretoria de conselho de administração na sociedade anônima". In: Direito comercial - textos e pretextos. São Paulo, Bushatsky, 1976.

."Vícios em assembléia geral ordinária". In: Estudos e pareceres sobre sociedades anônimas, São Paulo, RT, 1989.

LEBRE DE FREITAS, José. Introdução ao processo civil, $2^{\mathrm{a}}$ ed., Coimbra, Coimbra, 2009.

LEITE, Clarisse Frechiani Lara. Prejudicialidade no processo civil. São Paulo, Saraiva, 2008

LENER, Raffaele. "Invalidità delle delibere assembleari di società per azioni”. Rivista del diritto commerciale e del diritto generale delle obbligazioni, v. 102, n. 1. Padova, 2004.

LEONEL, Ricardo de Barros. Causa de pedir e pedido - o direito superveniente. São Paulo, Método, 2006.

. Manual do processo coletivo, $2^{\mathrm{a}}$ ed. São Paulo, RT, 2011.

. "Objeto litigioso no processo e o princípio do duplo grau de jurisdição". In:

BEDAQUE, José Roberto dos Santos; e CRUZ E TUCCI, José Rogério (coords.).

Causa de pedir e pedido no processo civil (questões polêmicas). São Paulo, RT, 2002.

LIEBMAN, Enrico Tullio. "A coisa julgada nas questões de estado". In: Eficácia e autoridade da sentença e outros escritos sobre a coisa julgada. Trad. Alfredo Buzaid, Benvindo Aires e Ada Pellegrini Grinover. 4ª ed., Rio de Janeiro, Forense, 2007.

. "Ações concorrentes". In: Eficácia e autoridade da sentença e outros escritos sobre a coisa julgada. Trad. Alfredo Buzaid, Benvindo Aires e Ada Pellegrini Grinover. $4^{\mathrm{a}}$ ed., Rio de Janeiro, Forense, 2007.

"Ainda sobre a sentença e a coisa julgada". In: Eficácia e autoridade da sentença e outros escritos sobre a coisa julgada. Trad. Alfredo Buzaid, Benvindo Aires e Ada Pellegrini Grinover. 4ª ed., Rio de Janeiro, Forense, 2007.

. "Eficácia e autoridade da sentença". In: Eficácia e autoridade da sentença e outros escritos sobre a coisa julgada. Trad. Alfredo Buzaid, Benvindo Aires e Ada Pellegrini Grinover. $4^{\mathrm{a}}$ ed., Rio de Janeiro, Forense, 2007.

. "Execução e ação executiva". In: Estudos sobre o processo civil brasileiro.

São Paulo, Bestbook, 2004. 
“Limites à coisa julgada nas questões de estado". In: Eficácia e autoridade da sentença e outros escritos sobre a coisa julgada. Trad. Alfredo Buzaid, Benvindo Aires e Ada Pellegrini Grinover. $4^{\mathrm{a}}$ ed., Rio de Janeiro, Forense, 2007.

. Manual de direito processual civil, v. 1. Trad. Cândido Rangel Dinamarco. $3^{\text {a }}$ ed., São Paulo, Malheiros, 2005.

"O despacho saneador e o julgamento do mérito". In: Estudos sobre o processo civil brasileiro. São Paulo, Bestbook, 2004.

. "Pluralidade de partes legítimas à impugnação de um único ato". In: Eficácia

e autoridade da sentença e outros escritos sobre a coisa julgada. Trad. Alfredo Buzaid,

Benvindo Aires e Ada Pellegrini Grinover. $4^{\mathrm{a}}$ ed., Rio de Janeiro, Forense, 2007.

Processo de execução. Trad. Joaquim Munhoz de Mello. $4^{\mathrm{a}}$ ed., São Paulo, Saraiva, 1980.

LIMA, Alcides de Mendonça. Comentários ao Código de Processo Civil, v. VI, t. II. $3^{\mathrm{a}}$ ed., Rio de Janeiro, Forense, 1979.

. Direito processual civil. São Paulo, Bushatsky, 1977.

LIMA LOPES, José Reinaldo de. "Regla y compás, o metodología para un trabajo jurídico sensato”. In: COURTIS, Christian (org.). Observar la ley. Madrid, Trotta, 2006.

LOBO DA COSTA, Moacyr. Assistência. São Paulo, Saraiva, 1968.

LOBO XAVIER, Vasco da Gama. Anulação de deliberação social e deliberações conexas. Coimbra, Almedina, 1998.

"Invalidade e ineficácia das deliberações sociais no direito português, constituído e constituendo; confronto com o direito espanhol". Boletim da Faculdade de Direito, v. 61. Coimbra, 1985.

LOLLI, Alessandro. I limiti soggettivi del giudicato amministrativo - stabilità del giudicato e difesa del terzo nel processo amministrativo. Milano, Giuffrè, 2002.

LOPES, Bruno Vasconcelos Carrilho. Limites objetivos e eficácia preclusiva da coisa julgada. Tese de doutorado apresentada à FADUSP. São Paulo, 2010.

, "Notas sobre a litis contestatio e a sua sobrevivência no processo civil canônico”. RePro, n. 187. São Paulo, set./2010.

LOPES, João Batista. Ação declaratória. 6ª ed., São Paulo, RT, 2009.

. Condomínio. $3^{\mathrm{a}}$ ed., São Paulo, RT, 1990.

. “Tutela antecipada nas ações declaratórias”. RT, v. 806. São Paulo, RT, 2002.

LÓPEZ, Sonia Calaza. La coza juzgada. Madrid, La ley, 2009. 
LUCON, Paulo Henrique dos Santos. In: MARCATO, Antonio Carlos (coord.). Código de Processo Civil interpretado. $3^{\mathrm{a}}$ ed., São Paulo, Atlas, 2008. . Eficácia das decisões e execução provisória. São Paulo, RT, 2000. . Embargos à execução. $2^{\mathrm{a}}$ ed., São Paulo, Saraiva, 2001. . Tutela coletiva (coord.). São Paulo, Atlas, 2006.

LUGO, Andrea. Manuale di diritto processuale civile. 12a ed., Milano, Giuffrè, 1996.

LUISO, Francesco Paolo. Diritto processuale civile, v. IV. Milano, Giuffrè, 1997.

MAIA DA CUNHA, Fernando Antonio; e outro. "A arbitragem e os limites à atuação do Judiciário nos litígios societários". In: YARSHELL, Flávio Luiz; e PEREIRA, Guilherme Setoguti J. (coords). Processo societário. São Paulo, Quartier Latin, 2012.

MAISANO, Aldo. L'eccesso di potere nelle deliberazioni assembleari di società per azioni. Milano, Giuffrè 1968.

MALLET, Estêvão. "Breves notas sobre a interpretação das decisões judiciais". Revista do Tribunal Regional do Trabalho - $9^{a}$ Região, n. 60. Curitiba, jan./jun. 2008.

MANCUSO, Rodolfo de Camargo. “Ação civil pública para tutela dos interesses dos titulares de valores mobiliários”. RT, v. 650. São Paulo, 1989.

MANDRIOLI, Crisanto. Diritto processuale civile, v. II. $19^{\mathrm{a}}$ ed., Torino, Giappichelli, 2007 Diritto processuale civile, v. III. $7^{\text {a }}$ ed., Torino, Giappichelli, 1989.

MARCATO, Antonio Carlos (coord.). Código de Processo Civil interpretado. $3^{\text {a }}$ ed., São Paulo, Atlas, 2008.

MARDER, Alexandre Salgado. Das invalidades no processo civil. São Paulo, Malheiros, 2009.

MARINO, Francisco Paulo de Crescenzo. São Paulo, Saraiva, 2009.

MARINONI, Luiz Guilherme Marinoni. “A tutela antecipatória nas ações declaratória e constitutiva”. RT, v. 741. São Paulo, 1997. ; e outro. Comentários ao Código de Processo Civil, v. 5, t. I. São Paulo, RT, 2000. Teoria geral do processo. $4^{\mathrm{a}}$ ed., São Paulo, RT, 2010.

MARQUES, José Frederico. Manual de direito processual civil, vv. 1 e 2. Campinas, Bookseller, 1997.

MARTINS, Fran. Comentários à Lei das S.A., v. 1. $3^{\mathrm{a}}$ ed., Rio de Janeiro, Forense, 1989. 
MARTINS, Ives Gandra da Silva; e outro. Comentários à Constituição do Brasil, $4^{\mathrm{o}}$ v., t. III. São Paulo, Saraiva, 1997.

MARTINS, Raphael Manhães. "O princípio da confiança legítima e o enunciado n. 362 da IV Jornada de Direito Civil”. Revista CEJ, n. 40. Brasília, 2008.

MASSARMORMILE, Andrea Pisani. "Invalidità delle delibere assembleari: stabilità ed effetti”. Rivista del diritto commercial e del diritto generale delle obbligazioni, v. 102, n.1. Padova, 2004.

MEDINA, José Miguel Garcia; e outra. O dogma da coisa julgada: hipóteses de relativização. São Paulo, RT, 2003.

MELENDO, Santiago Sentís. La prueba - los grandes temas del derecho probatório. Buenos Aires, Ejea, s.d.

MELLO, Marcos Bernardes de. Teoria do fato jurídico - Plano da validade. $10^{\mathrm{a}}$ ed., São Paulo, Saraiva, 2010.

MENCHINI, Sergio. I limiti oggettivi del giudicato civile. Milano, Giuffrè, 1992. . Il giudicato civile. Torino, UTET, 1988. . "Il giudizio sommario per le controversie societarie, finanziarie e bancarie". In: Studi di diritto processuale civile in onore di Giuseppe Tarzia, t. II. Milano, Giuffrè, 2005 .

MEO, Giorgio. Gli effetti dell'invalidità delle deliberazioni assembleari. Milano, Giuffrè, 1998.

MILAN, Maria Encarnación D’Avila. Litisconsorcio necessario - concepto y tratamento procesal. Barcelona, Bosch, 1975.

MIRANDA, Gilson Delgado; e outra. Recursos no processo civil. São Paulo, Atlas, 2000.

MOITINHO DE ALMEIDA, L. P. Anulação e suspensão de deliberações sociais. $4^{\mathrm{a}}$ ed. Coimbra, Coimbra, 2003.

MONTELEONE, Girolamo. I limitti soggettivi del giudicato civile. Padova, Cedam, 1978. MONTESANO, Luigi. La tutela giurisdizionale dei diritti. $2^{\mathrm{a}}$ ed., Torino, UTET, 1994. "Limiti oggetivi di giudicati su negozi invalidi". Rivista di diritto processuale, v. 46, n. 1. Padova, jan./mar. 1991.

MORAES, Maurício Zanoide de; e outro (coords). Estudos em homenagem à Professora Ada Pellegrini Grinover. São Paulo, DPJ, 2005.

MOREIRA PINTO, Junior Alexandre. Conteúdos e efeitos das decisões judiciais. São Paulo, Atlas, 2008. 
NERY JUNIOR, Nelson. "Boa-fé objetiva e segurança jurídica”; In: FERRAZ JÚNIOR, Tércio Sampaio; CARRAZZA, Roque Antonio; e NERY JUNIOR, Nelson. Efeito ex nunc e as decisões do STJ. $2^{\mathrm{a}}$ ed., Barueri, Manole, 2009.

NEVES, Celso. Contribuição ao estudo da coisa julgada civil. São Paulo, RT, 1970.

NOGUEIRA, Antônio de Pádua Soubhie. Execução provisória da sentença. São Paulo, RT, 2005.

OLIVEIRA, Rafael; e outros. Curso de direito processual civil, v. 2. $6^{\mathrm{a}}$ ed., Salvador, Jus Podivm, 2011.

OLIVEIRA LIMA, Paulo Roberto de. Contribuição à teoria da coisa julgada. São Paulo, RT, 1997.

PACÍFICO, Luiz Eduardo Boaventura. Ações concorrentes. Tese de doutorado apresentada à FADUSP. São Paulo, 2009.

PAGNI, Ilaria. Le azioni di impugnativa negoziale - contributo allo studio della tutela costitutiva. Milano, Giuffrè, 1998.

PARÁ FILHO, Tomás. Estudo sobre a sentença constitutiva. Dissertação de concurso à cadeira de Direito Judiciário Civil da FADUSP. São Paulo, 1973.

PENTEADO, Luciano de Camargo. Efeitos contratuais perante terceiros. São Paulo, Quartier Latin, 2007.

PEREIRA, Caio Mário da Silva. Instituições de direito processual civil, v. 1. $23^{\mathrm{a}}$ ed. Rio de Janeiro, Forense, 2009.

PEREIRA, Guilherme Setoguti J.; e outro. "Antecipação de tutela nos contratos de segurosaúde”. In: CARNEIRO, Luiz Augusto Ferreira (org). Planos de saúde: aspectos jurídicos e econômicos. Rio de Janeiro, Gen-Forense, 2012.

. "Cumprimento de acordo de acionistas em arbitragem”. In: YARSHELL, Flávio Luiz; e PEREIRA, Guilherme Setoguti J. (coords). Processo societário. São Paulo, Quartier Latin, 2012.

. É possível a chamada relativização da coisa julgada material? Trabalho de conclusão de curso apresentado à FADUSP. São Paulo, 2002.

; e outro (coords). Processo societário. São Paulo, Quartier Latin, 2012.

. "Verdade e finalidade da prova". RePro, n. 213. São Paulo, nov./2012.

PEREIRA, Luiz Fernando. Medidas urgentes no direito societário. São Paulo, RT, 2002.

. "Tutela antecipada nas ações declaratórias e constitutivas". $R T$, v. 805. São

Paulo, 2002. 
PEREIRA CALÇAS, Manoel de Queiroz. "A reforma da Lei das Sociedades por Ações”. Revista do instituto de pesquisas e estudos, n. 25. Bauru, abr.jun. 1999.

- "Protesto judicial contra alienação de bens, ações e quotas em conflitos societários”. In: YARSHELL, Flávio Luiz; e PEREIRA, Guilherme Setoguti J. (coords.) Processo societário. São Paulo, Quartier Latin, 2012.

PESUCCI, Stefania Pacchi. "Impugnazione di delibere assembleari: legittimazione ed interesse di agire". Rivista del diritto commerciale e del diritto generale delle obbligazioni, v. 88, n. 1. Padova, 1990.

PIMENTEL, Wellington Moreira. Comentários ao Código de Processo Civil, v. III. $2^{\text {a }}$ ed., São Paulo, RT, 1979.

PISANI, Andrea Proto. “Appunti sul giudicato civile e sui limi oggettivi”. Rivista di diritto processuale civile, v. 45, n. 2. Padova, abr./jun. 1990.

. "Appunti sul litisconzorzio necessario e sugli interventi". Rivista di diritto processuale, v. 49, n. 2. Padova, abr./jun. 1994.

. "Appunti sulla tutela c.d. costitutiva". Rivista di diritto processuale, v. 46, n.

1. Padova, 1991.

. "Appunti sulla tutela di mero accertamento". Rivista trimestrale di diritto e procedura civile, v. 33, n. 2. Milano, 1979.

. "I lineamenti del nuovo processo societario". Rivista di diritto civile, v. 49, n.

5, Padova, set./out 2003.

. Lezioni di diritto processuale civile. $5^{\mathrm{a}}$ ed., Napoli, Jovene, 2006.

PIZZOL, Patrícia Miranda; e outro. Recursos no processo civil, São Paulo, Atlas, 2000.

PONTES DE MIRANDA, Francisco Cavalcanti. Comentários ao Código de Processo Civil, t. II. Rio de Janeiro, Forense, 1973.

. Comentários ao Código de Processo Civil, t. VI. Rio de Janeiro, Forense, 1975.

. Tratado da ação rescisória das sentenças e de outras decisões. $5^{\mathrm{a}}$ ed., Rio de Janeiro, Forense, 1986.

. Tratado das ações, t. I. São Paulo, RT, 1970.

. Tratado de direito privado, t. IV. $4^{\mathrm{a}}$ ed., São Paulo, RT, 1983.

. Tratado de direito privado, tt. L e LI. $3^{\text {a }}$ ed., São Paulo, RT, 1984.

PORTO, Sérgio Gilberto. Coisa julgada civil. 4ª ed., São Paulo, RT, 2011. 
PUGLIESE, Giovanni. Giudicato civile (diritto vigente). In: Enciclopedia del diritto, 18. Milano, Giuffrè, 1968.

RÁO, Vicente. Ato jurídico. $4^{\mathrm{a}}$ ed., São Paulo, RT, 1997.

REDENTI, Enrico. Il giudizio civile con pluralità di parti. Milano, Giuffrè, 1960.

REZENDE FILHO, Gabriel de. Curso de direito processual civil, v. I. São Paulo, Saraiva, 1952.

RICCI, Edoardo. "Gli effetti delle sentenze sulle impugnazioni di deliberazioni assembleari”. In: Processo civile e società commerciali - atti del XX Convegno Nazionale. Milano, Giuffrè, 1995.

- "Sugli effetti del rigetto dell'impugnazione di delibera assembleare di S.P.A.”. Rivista di diritto processuale, v. 50, n. 1. Padova, 1995.

ROCCO, Alfredo. La sentencia civil. Trad. Mariano Ovejero. Buenos Aires, El foro, s.d. Le società commerciali in rapporto al giudizio civile. Torino, Fratelli Bocca, 1898.

ROCCO, Ugo. L'autorità della cosa giudicata e suoi limiti soggettivi. Roma, Athenaum, 1916.

ROCHA LIMA, Tiago Asfor. "A legitimidade ativa e passiva nas ações de responsabilidade civil contra o administrador e o controlador na Lei das S/A". In: YARSHELL, Flávio Luiz; e PEREIRA, Guilherme Setoguti J. (coords.). Processo societário. São Paulo, Quartier Latin, 2012.

RODRIGUES, Marcelo Abelha. Elementos de direito processual civil, v. I, $2^{\mathrm{a}}$ ed. São Paulo, RT, 2000.

RODRIGUES, Silvio. Dos vícios do consentimento. São Paulo, Saraiva, 1982.

ROMANO-PAVONI, Giuseppe. Le deliberazioni delle assemblee delle società. Milano, Giuffrè, 1951.

ROSENBERG, Leo. Tratado de derecho procesal civil, t. II. Trad. Angela Romera Vera. Lima, Ara, 2007.

SALAMACHA, José Eli. "Fraude à execução - proteção do credor e do adquirente de boafé”. In: NERY JUNIOR, Nelson; SANTOS, Ernane Fidélis dos; WAMBIER, Luiz Rodrigues; e WAMBIER, Teresa Arruda Alvim (coords.). Execução civil - estudos em homenagem ao Professor Humberto Theodoro Jr. São Paulo, RT, 2007.

SALOMÃO, Jorge. Da coisa julgadas nas ações de estado. Rio de Janeiro, Freitas Bastos, 1966. 
SALOMÃO FILHO, Calixto. O novo direito societário brasileiro. $3^{\mathrm{a}}$ ed., São Paulo, Malheiros, 2006.

SANTOS, Andrés De La Oliva Santos. Objeto del processo y cosa juzgada en el processo civil. Navarra, Aranzadi, 2005.

SANNA, Valentino. "L'inesistenza delle deliberazioni assembleari e delle decisioni assembleari: un problema ancora aperto". Rivista di diritto civile, v. 53, n. 2. Padova, 2007.

SANTOS, Caio Augusto Silva dos. "Os efeitos das decisões no controle concentrado de constitucionalidade". RT, n. 831. São Paulo, 2005.

SANTOS, Moacyr Amaral. Comentários ao Código de Processo Civil, v. IV. Rio de Janeiro, Forense, 1977.

. Primeiras linhas de direito processual civil, v. I, 25ª ed. São Paulo, Saraiva, 2007

Primeiras linhas de direito processual civil, v. 3. 22a ed., São Paulo, Saraiva, 2008

SASSANI, Bruno. "Sulla riforma del processo societario". In: Studi di diritto processuale civile in onore di Giuseppe Tarzia, t. II. Milano, Giuffrè, 2005.

SATTA, Salvatore. Direito processual civil. Trad. Luiz Autuori. $7^{\mathrm{a}}$ ed., Rio de Janeiro, Borsoi, 1973.

"La responsabilità per lesione di interessi legitimi", Rivista del diritto commerciale, v. 61-I. Padova, 1963.

SCARPINELLA BUENO, Cassio; e outra (coords.). Aspectos polêmicos da nova execução, São Paulo, RT, 2008.

. Curso sistematizado de direito processual civil, vv. 1 e v. 2, tt. I e II. São Paulo, Saraiva, 2007. . Impactos processuais do direito civil (coord.). São Paulo, Saraiva, 2008. . Partes e terceiros no processo civil brasileiro. São Paulo, Saraiva, 2003.

SCHWAB, Karl Heinz. El objeto litigioso en el processo civil. Trad. Tomas A. Banzhaf. Buenos Aires, Ejea, 1968.

SERPA LOPES, Miguel Maria de. Curso de direito civil, v. I. $9^{\text {a }}$ ed., Rio de Janeiro, Freitas Bastos, 1996. . Curso de direito civil, v. III. $4^{\mathrm{a}}$ ed., Rio de Janeiro, Freitas Bastos, 1991. 
SHÖNKE, Adolf. Derecho procesal civil. Trad. Prieto Castro. $5^{\text {a }}$ ed. Barcelona, Bosch, 1950.

SHUENQUENER DE ARAÚJO, Valter. O princípio da proteção da confiança. Niterói, Impetus, 2009.

SICA, Heitor Vitor Mendonça. “A nova liquidação de sentença e suas velhas questões”. In: SCARPINELlA BUENO, Cássio; e WAMBIER, Teresa Arruda Alvim (coords). Aspectos polêmicos da nova execução, São Paulo, RT, 2008.

. "Contribuição ao estudo da teoria das nulidades: comparação entre o sistema de invalidades no novo Código Civil e no direito processual civil”. In: SCARPINELLA BUENO, Cassio (coord). Impactos processuais do direito civil. São Paulo, Saraiva, 2008. O direito de defesa no processo civil brasileiro. São Paulo, Atlas, 2011. ; e outro. "Litisconsórcio unitário: aspectos materiais e processuais" (inédito).

SILVA, José Afonso. Ação popular constitucional. 2a ed., São Paulo, RT, 2007.

SILVA, Ovídio Baptista da. A ação cautelar inominada no direito brasileiro. $3^{\text {a }}$ ed., Rio de Janeiro, Forense, 1991.

“Eficácias da sentença e coisa julgada". In: Sentença e coisa julgada. $2^{\mathrm{a}}$ ed., Porto Alegre, Fabris, 1998. ; e outro. Teoria geral do processo civil. $5^{\text {a }}$ ed., São Paulo, RT, 2009.

SILVA, Paula Costa e. Acto e processo. Coimbra, Coimbra, 2003. ; e outro. "A intervenção de terceiros no procedimento arbitral no direito português e no direito italiano". Revista brasileira de arbitragem, n. 28. São Paulo, jul./out. 2003.

SIQUEIRA CASTRO, Carlos Roberto, "Da declaração de inconstitucionalidade e seus efeitos". Revista da Procuradoria-Geral da República, n. 8. Rio de Janeiro, 1996.

TALAMINI, Eduardo. Coisa julgada e sua revisão. São Paulo, RT, 2005. ."Legitimidade, interesse, possibilidade jurídica e coisa julgada nas ações de impugnação de deliberações societárias”. In: YARSHELL, Flávio Luiz; e PEREIRA, Guilherme Setoguti J. (coords.). Processo societário. São Paulo, Quartier Latin, 2012. . Novos aspectos da jurisdição constitucional brasileira: repercussão geral, força vinculante, modulação dos efeitos do controle de constitucionalidade e alargamento do objeto do controle direto. Tese de livre-docência apresentada à FADUSP. São Paulo, 2008. 
Tutela relativa aos deveres de fazer e de não fazer. São Paulo, RT, 2001.

TARUFFO, Michele; e outros. Lezioni sul processo civile, v. 1. $5^{\text {a }}$ ed., Bologna, Il Mulino, 2011.

TARZIA, Giuseppe. "Interrogativi sul nuovo processo societario". Rivista di diritto processuale. v. 58, n. 3. Padova, jul./set. 2003.

TEIXEIRA, Egberto Lacerda, e outro. Das sociedades anônimas no direito brasileiro, vv. 1 e 2. São Paulo, Bushatsky, 1979.

TEPEDINO, Ricardo. In: LAMY FILHO, Alfredo; e BULHÕES PEDREIRA, José Luiz (coords.). Direito das companhias, v. I. Rio de Janeiro, Forense, 2009.

TERRUSI, Francesco. L'invalidità delle delibere assembleari della SPA. Milano, Giuffrè, 2007.

TESHEINER, José Maria Rosa. Coisa litigiosa! Porto Alegre, Corag, 1973. Elementos para uma teoria geral do processo. São Paulo, Saraiva, 1993.

TESLLER, Marga Inge Barth. "O fato consumado e a demora na prestação jurisprudencial”. Revista CEJ, n. 27. Brasília, dez. 2004.

THEODORO JÚNIOR, Humberto. “Antecipação de tutela em ações declaratórias e constitutivas”. RT, v. 763. São Paulo, 1999.

. “Arbitragem e terceiros - litisconsórcio fora do pacto arbitral - outras intervenções de terceiros”. Revista de direito bancário, v. 14. São Paulo, out. 2001.

. Curso de direito processual civil, v. 1. 50ª ed., Rio de Janeiro, Forense, 2008. - "Execução de Sentença - Iniciativa do Devedor - Interpretação de Sentença”, Revista Jurídica, n. 299. Porto Alegre, set. 2002.

. Processo cautelar. 10ª ed., São Paulo, Leud, 1988.

. "Prova - princípio da verdade real - poderes do juiz - ônus da prova e sua

eventual inversão - provas ilícitas - prova e coisa julgada nas ações relativas à paternidade (DNA)”. Revista de direito privado, n. 17. São Paulo, jan./mar. 2004.

TISCINI, Roberta. "Il procedimento di cognizione nelle liti societarie". Rivista trimestrale di diritto e procedura civile, v. 58, n. 1. Milano, mar. 2003.

TOLEDO, Paulo Fernando Campos Salles de. "A tutela jurisdicional do mercado de valores mobiliários”. RT, v. 667. São Paulo, 1991.

TOMMASEO, Ferruccio. I provvedimenti d'urgenza - struttura i limiti della tutela anticipatoria. Padova, Cedam, 1983. 
TORNAGHI, Hélio. Comentários ao Código de Processo Civil, v. I. 2ª ed., São Paulo, RT, 1986.

TRIMARCHI, Pietro. Invalidità delle deliberazioni di assemblea di società per azioni. Milano, Giuffrè, 1958.

TRIUNFANTE, Armando Manuel. A tutela das minorias nas sociedades anônimas direitos individuais. Coimbra, Coimbra, 2004.

TROCKER, Nicolò. Processo civile e Costituzione. Milano, Giuffrè, 1974.

TUCCI, Rogério Lauria; e outro. Constituição de 1988 e processo. São Paulo, Saraiva, 1989.

Do julgamento conforme o estado do processo. $2^{\mathrm{a}}$ ed., São Paulo, Saraiva, 1982.

VALVERDE, Trajano de Miranda. Sociedades por ações, v. III. $3^{\mathrm{a}}$ ed, Rio de Janeiro, Forense, 1959.

VASELLI, Mario. Deliberazioni nulle e annullabili delle società per azioni. Padova, Cedam, 1947.

VAZ, Anderson Rosa; e outro. "Princípio da segurança jurídica e o fato consumado no direito administrativo". Revista do curso de direito da Universidade Federal de Uberlândia, v. 31. Uberlândia, 2002.

VENOSA, Silvio de Salvo. Direito civil - parte geral. $4^{\text {a }}$ ed., São Paulo, Atlas, 2004.

VENTURA RIBEIRO, Renato. Direito de voto nas sociedades anônimas. São Paulo, Quartier Latin, 2009.

VERDI, Giovanni. Profili del processo civile, v. 1. $4^{\text {a }}$ ed., Napoli, Jovene, 1994. . Profili del processo civile, v. 2. Napoli, Jovene, 1996.

VIDIGAL, Luis Eulálio de Bueno. Comentários ao Código de Processo Civil, v. VI. São Paulo, RT, 1974. . Da ação rescisória dos julgados. São Paulo, Saraiva, 1948. . Da execução direta das obrigações de prestar declaração de vontade. São Paulo, RT, 1940.

VILELA, Marcelo Dias Gonçalves Vilela. Arbitragem no direito societário. Belo Horizonte, Mandamentos, 2004.

VILLATA, Stefano A. Impugnazioni di delibere assembleari e cosa giudicata. Milano, Giuffrè, 2006. 
VIVANTE, Cesare. Trattato di diritto comerciale, v. II. $5^{\text {a }}$ ed., Milano, Francesco Vallardi, 1929.

VOLPINO, Diego. "Cognizione e decisione nel procedimento societario". Rivista trimestrale di diritto e procedura civile, v. 61, n. 1. Milano, mar. 2007.

VON TUHR, Andreas. Derecho civil. Trad. Tito Ravá, v. II. Madrid, Marcial Pons, 2006.

WACH, Adolf. Manual de derecho procesal civil. Trad. Tomas Banzhaf, v. II. Buenos Aires, Ejea, 1977.

WAMBIER, Teresa Arruda Alvim (coord). Aspectos polêmicos da antecipação de tutela. São Paulo, RT, 1997.

. Nulidades do processo e da sentença. $6^{\text {a }}$ ed., São Paulo, RT, 2007.

; e outro. O dogma da coisa julgada: hipóteses de relativização. São Paulo, RT, 2003.

WARDE JR, Walfrido Jorge; e outro. “A arbitragem e os limites à atuação do Judiciário nos litígios societários". In: YARSHELL, Flávio Luiz; e PEREIRA, Guilherme Setoguti J. (coords). Processo societário. São Paulo, Quartier Latin, 2012. . (coord.). Fusão, cisão, incorporação e temas correlatos. São Paulo, Quartier Latin, 2009

- "Qual o modelo de governança corporativa que exsurge da disciplina das reorganizações societárias no Brasil”. In: WARDE JR., Walfrido Jorge (coord.). Fusão, cisão, incorporação e temas correlatos. São Paulo, Quartier Latin, 2009.

- Responsabilidade dos sócios - a crise da limitação e a teoria da desconsideração da personalidade jurídica. Belo Horizonte, Del Rey, 2007.

WATANABE, Kazuo. Da cognição no processo civil. São Paulo, RT, 1987.

. "Relação entre demanda coletiva e demandas individuais". In: GRINOVER, Ada Pellegrini; MENDES, Aluisio Gonçalves de Castro; e WATANABE, Kazuo (coords.). Direito processual coletivo e o anteprojeto de Código Brasileiro de Processos Coletivos. São Paulo, RT, 2007.

WOLFF, Martin; e outros. Tratado de derecho civil, t. I, v. II. Trad. Blas Pérez Gonzáles e José Alguer. 39ª ed. Barcelona, Bosch, 1944.

WÜRDINGER, H. German company Law. London, Oyez House. 1975.

YARSHELL, Flávio Luiz. Ação rescisória - juízos rescindente e rescisório. São Paulo, Malheiros, 2005. 
Antecipação da prova sem o requisito da urgência e direito autônomo à prova. São Paulo, Malheiros, 2009.

. "Antecipação de tutela específica nas obrigações de declaração de vontade, no sistema do CPC". In: WAMBIER, Teresa Arruda Alvim (coord). Aspectos polêmicos da antecipação de tutela. São Paulo, RT, 1997.

. "Brevíssimas reflexões a propósito da legitimidade passiva nas ações civis públicas envolvendo atividades sujeitos à regulação". In: LUCON, Paulo Henrique dos Santos (coord.). Tutela coletiva. São Paulo, Atlas, 2006.

; e outro (coords). Estudos em homenagem à Professora Ada Pellegrini Grinover. São Paulo, DPJ, 2005.

. “Simulação e processo de execução". In: WAMBIER, Teresa Arruda Alvim (coord.). Processo de execução e assuntos afins. São Paulo, RT, 1998.

. "Antecipação de tutela nos contratos de seguro-saúde"; e outro. In:

CARNEIRO, Luiz Augusto Ferreira (org). Planos de saúde: aspectos jurídicos e econômicos. Rio de Janeiro, Gen-Forense, 2012.

. Tutela jurisdicional. $2^{\mathrm{a}}$ ed., São Paulo, DPJ, 2006.

. Tutela jurisdicional específica nas obrigações de declaração de vontade. São Paulo, Malheiros, 1993.

. "Tutela jurisdicional meramente declaratória”. RePro, n. 76. São Paulo, RT, 1994.

ZACLIS, Lionel. Proteção coletiva dos investidores no mercado de capitais. São Paulo, RT, 2007.

ZANZUCCHI, Marco Tullio. Diritto processuale civile, I, 6 ${ }^{\text {a }}$ ed. Milano, Giuffrè 1964.

ZAVASCKI, Teori Albino. Antecipação da tutela. São Paulo, Saraiva, 1997.

Comentários ao Código de Processo Civil, v. VIII, $2^{\mathrm{a}}$ ed.. São Paulo, RT, 2003.

ZORZI, Andrea, e outro. "Spunti in tema di rimedi risarcitori contro i'invalidità delle deliberazioni assembleari”. Rivista del diritto commerciali e del dirito generale delle obbligazioni, v. 104. Padova, 2006.

ZUFELATO, Camilo. Coisa julgada coletiva. São Paulo, Saraiva, 2011. 